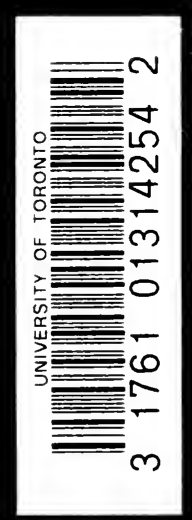




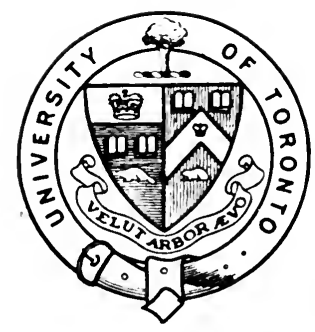

Presented to the

UNIVERSITY OF TORONTO LIBRARY

by the

ONTARIO LEGISLATIVE LIBRARY

1980 


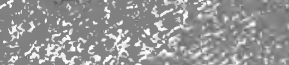

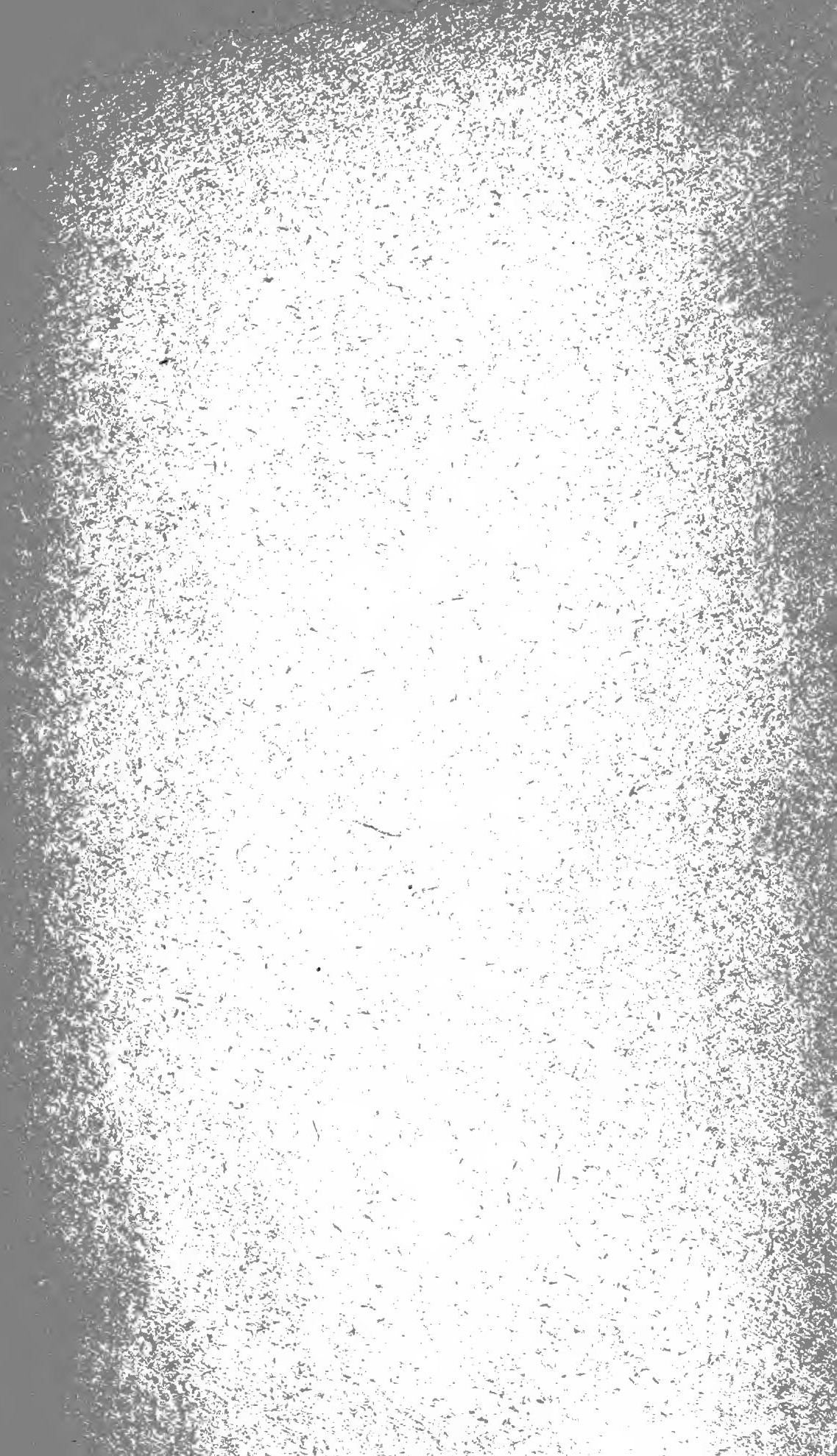




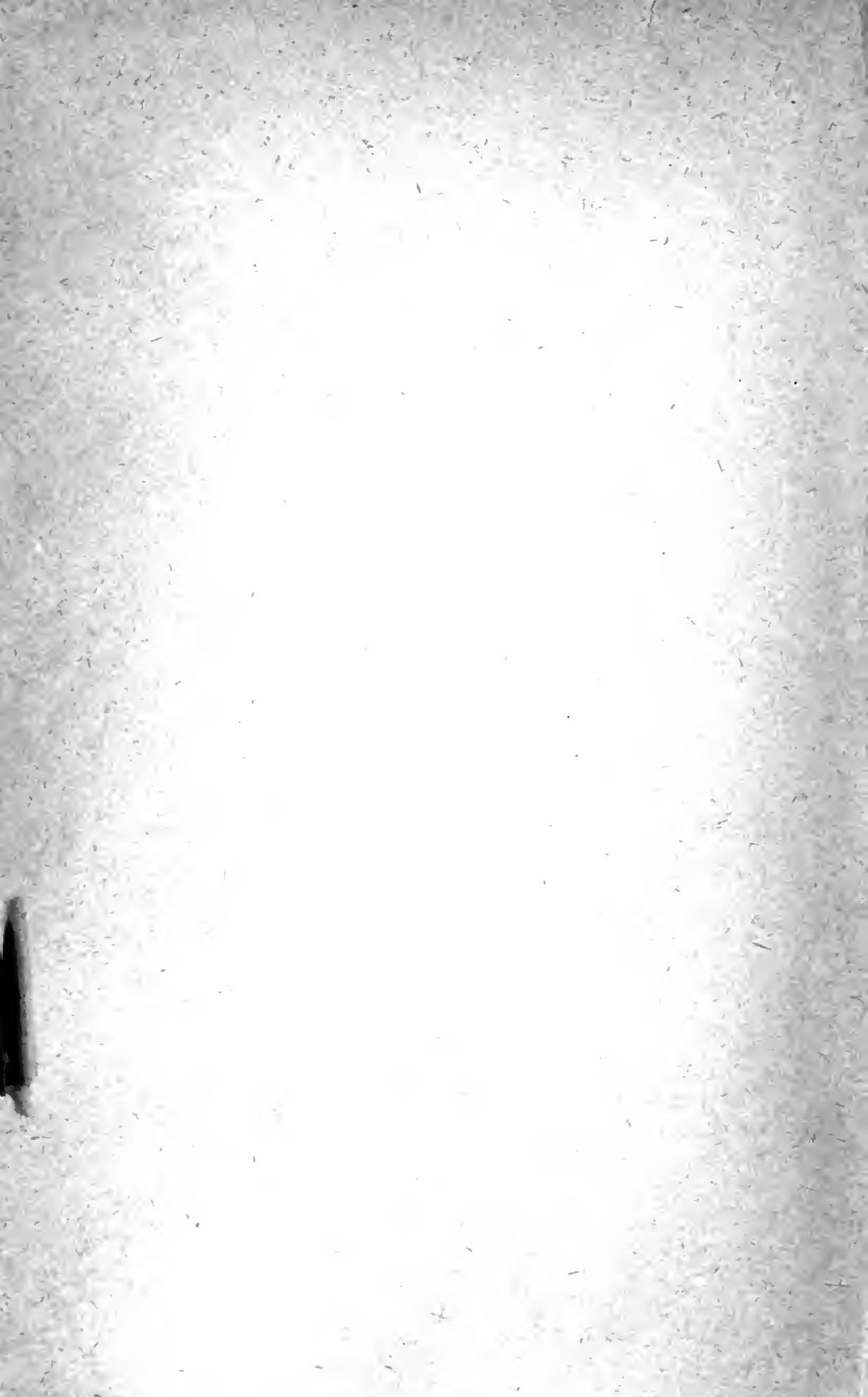




\section{LECTURES}

ON

EUROPEAN HISTORY 


\section{BY THE SAME AUTHOR.}

HISTORICAL INTRODUCTIONS TO THE ROLLS SERIES. Collected and Edited by ARTHUR HAsSALL, M.A., Student, Tutor, and sometime Censor of Christ Church. 8vo. I2s. $6 d$. net.

VISITATION CHARGES DELIVERED TO THE CLERGY AND CHURCHWARDENS OF THE DIOCESES OF CHESTER AND OXFORD. Edited by E. E. Holmes, Honorary Canon of Christ Church, and Vicar of Sonning, formerly Domestic Chaplain to the Bishop of Oxford. 8vo. 7s. 6d. net.

ORDINATION ADDRESSES. Edited by E. E. Holmes, Honorary Canon of Christ Church and Vicar of Sonning, formerly Domestic Chaplain to the Bishop of Oxford. With Photogravure Portrait. Crown 8vo. 3s. $6 d$. net.

THE EARLY PLANTAGENETS. With 2 Maps. Fcap. 8vo. 2s. 6d. (Epochs of Modern History.)

LONGMANS, GREEN, \& CO., 39 Paternoster Row, London New York and Bombay. 
32406

\section{ECTURES ON EURO- PEAN HISTORY. By}

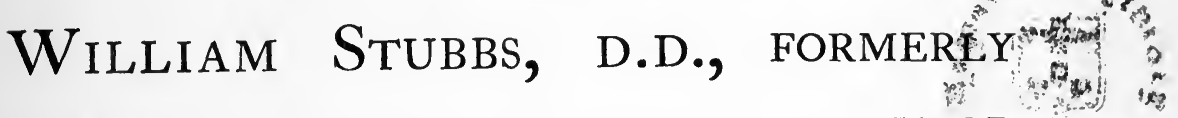
BISHOP OF OXFORD AND REGIUS PROFESSOR OF MODERN HISTORY IN THE UNIVERSITY

OF OXFORD

Genthis

ARTHUR HASSALL, M.A.

STUDENT, TUTOR, AND SOMETIME CENSOR OF CHRIST CHURCH OXFORD

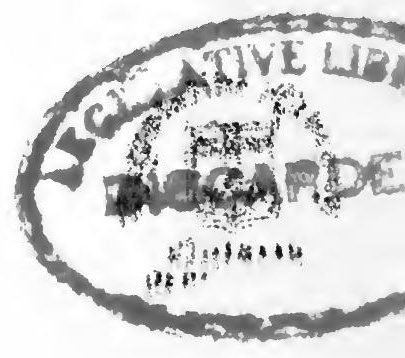

LONGMANS, GREEN, AND CO.

39 PATERNOSTER ROW, LONDON NEW YORK AND BOMBAY 1904 


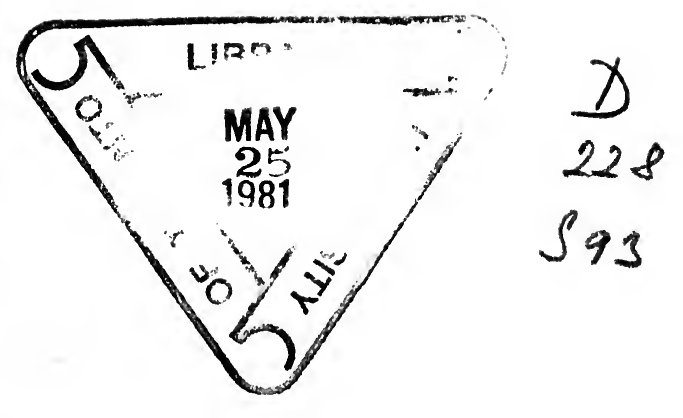

AVAILABLE

No. B9900189 


\section{PREFATORY NOTE}

These Lectures were first delivered between 1860 and 1870 by

Bishop Stubbs, when Regius Professor of Modern History in the University of Oxford.

The responsibility for publishing them rests entirely with myself.

I have, however, no doubt whatever that the world would be very considerably the loser if these Lectures were not published; for, while principally known as a Constitutional Historian, Bishop Stubbs had an immense knowledge of European History, and this is apparent in every page of the present volume.

Though numerous publications bearing on the period of which these Lectures treat have appeared in England and abroad, it may well be doubted whether any so well-reasoned an account of the years from 1519 to 1648 has yet been written.

These three Lectures form one historical drama, in which the reign of Charles V. is the first, the period from his death to the beginning of the seventeenth century the second, and the Thirty Years' War is the third act. In the reign of Charles V. is witnessed the growth of the Reformation ; in the intervening period the growth of the anti-Reformation; in the Thirty Years' War the conflict between the two.

While the period may in one sense be regarded as a struggle between the dynastic policy of the Hapsburgs on the one hand, and that of the Valois and Bourbons on the other, there were deeper issues at stake. Throughout the years from 1519 to 1648 there are two distinct ideas in progress, which, writes Bishop Stubbs, ' may be regarded as giving a unity to the long period. The Reformation is one, the claims of the House of Austria is the other.' From these claims were developed, as it were, the underplot of the conflict between the dynastic policy of the Hapsburgs and that 
of the Valois and Bourbons, distinct from, and yet constantly complicating, the conflict of the creeds. Within the Empire also the two ideas are sufficiently distinct, and it would be false simplicity to identify the claims of the Hapsburgs with those of the New Catholicism.

Bishop Stubbs refused to regard the Thirty Years' War as a struggle; waged by the dynastic policy of Austria against the spirit of the German people-a point of view dear to Prussian historians. 'We cannot say,' he writes, 'that the Saxon and Brandenburger regarded the struggle as one of truth and enlightenment against darkness and error.'

The historical student will find in these Lectures a judicial and masterly exposition of the immense issues placed before Europe in the sixteenth and the first half of the seventeenth century. Bishop Stubbs's weighty reasoning and conclusions will commend themselves to all who have studied, or wish to study, one of the most important periods of European History.

As editor I have confined myself mainly to the task of deleting colloquialisms, of adding a few notes when absolutely necessary, and of inserting some genealogical tables. Though I have no doubt that, had he prepared these Lectures for publication himself, Bishop Stubbs would have made certain other changes, I have thought it best to publish these Lectures in almost the exact shape in which they were delivered.

A. H. 


\section{CONTENTS}

I

THE EMPEROR CHARLES V.

LECTURE

I. Spain at the beginning of the Sixteeenth Century -

II. The Character of Charles V.'s Rule in Spain and the

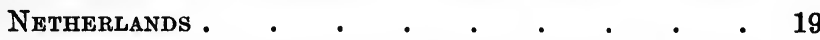

III. The Constitution of the Empire in the Sixteenth

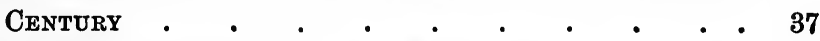

IV. The Rivalry of the Houses of, Hapsburg and Valois down to the Peace of Cambrai, 1529 . $\quad$ - 49

V. The Reformation to the Diet of Augsburg, 1530 . 61

VI. The Wars of Charles V. from 1529 to the Truce of

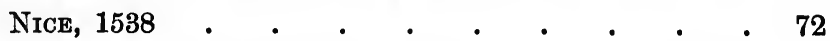

VII. From the Truce of Nice to the Peace of Crespy,

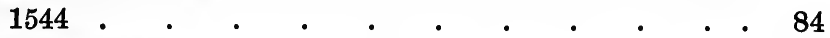

VIII. The Reformation from the Diet of Augsburg, 1530, TO THE INTERIM, 1548 . 5 .

IX. Charles V.'s Relations with Maurice of Saxony and Henry II. of France . . . . . . . 108

X. General Review of Charles V.'s Reign • • $\quad 120$

XI. The Character of Charles V. . . . . . . . 132

\section{II}

THE POLITICAL HISTORY OF EUROPE FROM THE RESIGNATION OF CHARLES $V$.

I. Europe at the Resignation of Charles V. • . . 145

II. General Survey of the Period 1558-1618 • • 156

III. The Reigns of Ferdinand I. and Maximilian II., 1558-

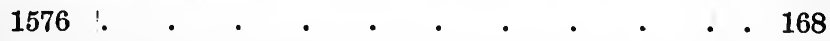

IV. The French Civil Wars of Religion from the Death of Henry II. to the Accession of Henry III., 1559-

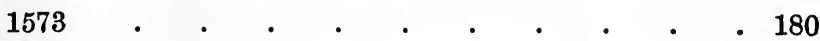

V. Philip II. and the Netherlands to the Outbreak of

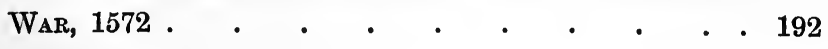


viii

LECTURE

PAG

VI. The War in the Netherlands to the Death of William THE Silent, 1584 •

VII. The later Years of the Reign of Phirip II., 15841598 . $\quad . \quad . \quad . \quad . \quad . \quad . \quad . \quad . \quad . \quad .217$

VIII. From the Accession of Henry III. of France to the

Peace of Vervins, 1573-1598 • . . . . . . 229

IX. Henry IV.'s Place in the History of Europe . • . 241

X. Germany under Rudolf II. and Matthias, 1576-1619 . 253

XI. Spain and France in the early Years of the Seven-

teenth Century • • • • • • . • • • • 265

\section{III}

THE POLITICAL HISTORY OF EUROPE DURING THE THIRTY YEARS' WAR

I. Europe at the Opening of the Thirty Years' War . 277

II. The Bohemian Struggle • • . . . . • . 288

III. The Development of the War • . . . . . 298

IV. The Intervention of Denmark: Wallenstein's Successes 310

V. The Swedish Intervention • • • . . . . . 321

VI. The Victories and Death of Gustavus Adolphus . . 332

VII. The War from the Battle of LÜtzen, 1632, to the

Death of Wallenstein, 1634 . . . . . . 343

VIII. The Intervention of France in the War. . . . 353

IX. Nine Years of War, 1637-1645 • • • • • . 365

X. The closing Scenes of the War, 1646-1648 . . . 375

\section{TWO SUPPLEMENTARY LECTURES}

I. Survey of the Reigns of Louis XIII. and Philip IV. . 387

II. The Peace of Westphalia . . . . . . . . . 398

\section{PEDIGREES}

The House of Hapsburg

The Houses of Valois and Bourbon . . , . . 409

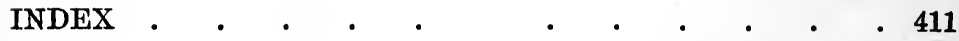




\title{
LECTURES ON EUROPEAN HISTORY
}

\author{
$1519-1648$ \\ THE EMPEROR CHARLES V
}

\section{LECTURE I}

SPAIN AT THE BEGINNING OF THE SIXTEENTH CENTURY

The student of the later period of Modern History-of Modern History definitely so called, as opposed to Medieval History-has in some respects a great advantage over the student of the first or medieval portion. The period of time which he has to study is very much shorter; the geographical area over which, as we study it here, the interest extends is much narrower; there is much more unity in the dramatic portions of it, because there is a far more decided connexion of the several parts than is wont to reveal itself to the ordinary student of the history of the Middle Ages : that is, the history of modern Europe, through the introduction of the idea or doctrine of the balance of power, has a single string or centre of interest round which almost all the foreign history, and much of the internal history of the nations, gathers or may be grouped. Important as the internal history is, and the details of wars, they are not the whole of the history, as in the earlier times. And this grouping of interest has a further effect: that it actually thins the numbers and actually individualises for us the several persons and characters of the great actors in the drama. In the earlier ages we have large number of local or national heroes whose greatness is a matter of tradition by historians, rather than an inference from recorded exploits; fewer of general and all-engrossing interest. Now, however, the unity of the drama has helped to fix the eyes of the nations upon one another, and to give to the leading men in one a leading interest in the rest: not only is their influence more 
widely felt, but their greatness is more widely appreciated, often it is even exaggerated in a way that is quite foreign to the tone of medieval story. And thus, although modern history presents us far fewer men for whom transcendent greatness is claimed than the Middle Ages do-and this I say without any disrespect for the modern period, because it would not be fair to expect of three centuries the same harvest of great men that we find in the ten preceding (and we scrutinise their claims to greatness more carefully the fewer they are and the closer we see them)-it does furnish us with a larger number about whom the world in general busies itself and whose lives have, for their interest rather than for the greatness of the characters, been thought worthy to be written and rewritten times without number.

Another point : the principles which in modern history men have fought and struggled for in war and politics are more akin to principles and ideas of the present day than those of the earlier times; they themselves, independent of the dramatic unity that $I$ have spoken of, are more directly and closely interesting. Religion, and the growth of political freedom in its modern acceptation, catch the attention of superficial readers far more in the later than in the earlier : and, more books being read, far more are written.

It is not true, as sometimes we see it stated, that modern history is the history of principles and ideas, medieval the history of facts: but it is true that in modern history ideas and principles assume a garb in which they seem more akin to the controversies touching ideas and principles which prevail at the present day. The sixteenth century, as a century of ideas, real, grand, and numerous, is not to be compared with the thirteenth: the ideas are not so pure, not so living, nor so refined ; the men are not so earnest, so single-hearted, so loveable by far. Much doubtless has been gained in strength of purpose, and much in material progress ; but compare the one set of men with the other as men, and the ideas as ideas, and the advantage is wonderfully in favour of the semi-barbarous age, above that of the Renaissance and the Reformation.

But, although the sixteenth century could not have been what it was unless the thirteenth had been what it was, the form which the modern ideas took in the sixteenth appeals directly to the sympathies of the nineteenth, the interest is nearer, and is therefore more appreciable than that of the more remote. The study of the former period thus is more extensive both in fact and principle, that of the latter more intense, if I may use the word, in fact, though not necessarily so in principle: not necessarily so because we have quite sufficient documentary remains of much earlier times to enable us to form a very just judgment as to the principles, the men who 
contested them, and their direct connexion with later developments. Still, as a fact, we have far more books to read, about a far smaller number of men and incidents.

The causes I have specified have this twofold effect; although the chief actors are fewer, much more has been written about them, and that has been written from many sides, with more prejudice and antipathy, as we might expect. The student comes to the reading of a large number of books, the writers of which view matters from diametrically opposite standing points and with the uttermost bitterness of party feeling. The element of religion by itself is enough to account for much of this, for the struggle between Romanism and Protestantism, which begins in the sixteenth century in its modern form, rages now as bitterly as it ever did : nor is political rancour very much behind it, although the points actually contested in the seventeenth century may be now regarded as antiquated. Nay, the interest of extinct party burns as briskly as ever ; the merits and demerits of Anne Boleyn or of Mary Queen of Scots are contested by men who have no sympathy with the religion of either, as furiously as the most vital questions of the present day. And this I am inclined to regard as the great drawback of the study. We all come to the examination of a period of history which above all demands, for judgment between its varied and contradictory versions, the coolest and most impartial treatment, with our minds made up on some of the most important principles concerned in it, and as to the characters of some of the principal actors. Every man who comes up to matriculate at Oxford has made up his mind on the great political questions of the day-I do not venture to guess how long he will maintain that decisive attitude-and also on those of the last three centuries. I find no fault with this; I should not myself have the slightest respect for a coldblooded boy who had determined to reserve his opinion until he was perfectly informed: such a creature would, I am convinced, be far too bad for earth, would be perfectly intolerable, for he would be intolerant to both sides. According as home politics, his father's house, his native town, or his public school, have affected him-and somehow the three influences will pull the same way, whichever way it be-he comes or ought to come up a decided Radical or a decided Tory : and it is very well that he does : if he does not he must be either a prig or an idiot, a fool on either showing. It is a good thing that you should come up with that interest, although it may need, what assuredly it will get, some tempering and some informing; you have to learn here to be perspicacious, critical, and cool, instead of blind partisans. But the real difficulty remains: you come to the study of these things with a strong prejudice, in favour of or against Henry VIII. or 
Charles I. or Oliver Cromwell, or William III., and, in a less degree, for or against Charles V., or Henry IV., Lewis XIV., or Napoleon Buonaparte.

I allege these things, however, not as a discouragement or as a hindrance to the study, but as a reason for a particular mode of treatment. It is of all things most important for you to learn to form a critical and historical judgment upon matters about which you are or may be strongly interested: for your own sakes you should learn how important it is to attack and defend in controversy, only with tried weapons; and how fatal to a good cause (and we on each side believe our own cause to be a good one) it is to undervalue the strength of the opposite side, or to use any plan, to rely upon any basis, that is not well tested, thoroughly explored, and a reality realised by the combatants themselves. Let me just say further that it is possible to study medieval history without much knowledge of modern controversy : I do not think it is well, because it robs the principles and the men of a vitality of interest which they certainly deserve; but it is possible. On the other hand, it is quite impossible to read modern history without some knowledge of medieval ; the very ordinary terms of the language of history are unintelligible, or, what is almost as bad, are interpreted as meaning what, after all the changes and chances of the history that you are travelling through, they have come to mean, something very different indeed from what they meant at the beginning of the period.

Now the result of all this is, that to study any, even the most limited portion, of modern as opposed to medieval history, in a perfect way-that is, to read it straightforward, accumulating all that is in print about each particular as we proceed, or even all that is at hand in our less recondite books of history-demands an amount of application which cannot be exhibited in the form of lectures. If I were to bring down here, and go over with you, the mass of material heaped up on many of the single points that we must go through-the divorce of Henry VIII. from Catherine of Aragon for instance-we might spend, not to say a term but a year, upon one of them. In a private lecture with one or two men who have nothing else to do, this might be done; and it is not a bad thing sometimes, by way of pattern, to work out single points with minuteness : but in a mixed lecture it would be useless to attempt it, useless to argue the possibility of so reading any considerable portion of history. What is the alternative? Either simply to prescribe a choice of books which you should study by yourselves, or to attempt. such general views of the period as may help you to form an idea of the bearing of one of the minutiæ upon another; of the relations of the different parts of the drama, of its actors, their strength and 
weakness; the events, their immediate and their prospective bearing. Now to give you a mere list of books which you will not have time to read, even if you were to desire to do it, does not seem to me to be worth while devoting a term's lectures to. I shall therefore, if all is well, in the course of the lectures before us, attempt, on an analytic rather than a synthetic plan, to portion out the interest of the whole reign of Charles V.- -taking the subjects one by one, not adhering to the chronological sequence, or running in and out, each summer and winter, to the different scenes of his wars and intrigues, on the plan of Thucydides: but, attempting in each head, and in each separate scene of his great influence, to get some idea of the results of his reign, and of the bearing of those results, in that particular department, on the general history of Europe. It is no longer the history of Germany that we devote ourselves to, for Europe has now begun to have a general history: the great principles of religious and political liberty have taken their modern dress.

To trace the political elements and their working, in each of the many and dissimilar states that Charles governed, will be a task in itself : to examine how far his wars and alliances were matters of principle, policy, or experiment, will bring us into direct contact with everything that is going on in Europe inside and outside of his own dominions, that has historical importance: to endeavour to arrange these topics so as to give a consecutive series to the years of his active life, and to trace through them the developments, changes, or ossification of his own political views, will be a further flight. And, if we succeed in doing anything like this we shall not have failed to get a general view of the place of his reign in history, and of his own personal character and place in it. I shall try to do this, under the firm conviction that a more consecutive study would be impossible with means and opportunities limited as ours are by the nature of the matter and the case. Some parts of this programme will take us much more into detail than others, and some will take us more into the precedent medieval history : but I shall try to avoid repetition or irrelevant discussions; and in particular I shall not attempt the details of wars and battles. That must be understood from the first; it is impossible to get a clear notion of the general bearings of history, if time be spent on these minutix. Of course I am speaking only of lecture purposes: pedigrees, and exact chronology, and plans of battles have an interest of their own, and are very worthy objects of special study: I advise you by no means to neglect them: but in a general lecture it is the results rather than the details that are of importance, and from what I have said you must understand that you are not to expect them from me.

Now the greatest part of the interest of Charles V.'s reign is based

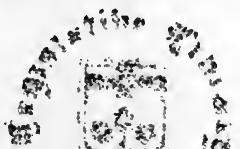


on this : that his dominions, actual or virtual, cover the whole of that part of Europe in which the problems of modern political life have been in the process of working out, with the exception of England and France. Germany, Spain, Italy, and the Netherlands have been the arena of all sorts of modern struggles : in Germany, for instance, the Reformation, the balance between Roman and Protestant influences, and the most determinate actual struggle between the material forces of the two. In Spain the unfettered working of absolutism with every favourable condition of successful development, resulting in what we now see-a series of revolutions of which it is impossible to see the summation. In the Netherlands the most energetic working out of freedom both in politics and religion that the world perhaps has ever seen, under circumstances the most apparently overwhelming, and with the greatest odds against success : a struggle in which the political energy of the race itself seems, although victorious, to have been exhausted. In Italy you have, on the other hand, the entire failure of liberty under circumstances that might have seemed the most favourable, the extinction of a light that had burned for ages and kindled other lamps far and wide in other countries, but which was powerless or reduced to absolute impotence at home; an impotence from which, after all the revolutions, after the demolition of all the old tyrannies, after the emancipation of all forces capable of struggling, it is even now questionable whether anything but misgovernment or mismanagement in our time is likely to follow. ${ }^{1}$ Our own times are seeing in Spain and Italy the harvest of which the reign of Charles V. in those countries was the seedtime. We can only hope that the worst is over.

These are great questions, how far the remote responsibility of a mistaken policy extends; and whether one man's influence is ever of so far range and so penetrating as to make him guilty of the evils which centuries after his death have sprung from the schemes he originated. As a rule, and it is one that applies to all human responsibility as well as to history, a man is not regarded as guilty of the consequences of his actions which he could not foresee, but only of those which he might and ought to have seen. Otherwise the apportionment of political responsibility would be not merely impossible, but unattemptable, and we must content ourselves with running back once for all to the fall of Adam. It is in the last degree absurd for writers of the present day who hate the house of Austria, to bestow their retrospective curse on Rudolf of Hapsburg. It is scarcely less absurd to ascribe to Charles V., in

- Bishop Stubbs would certainly have modified this sentence had he read the Lecture during the last twenty-five years of his life. 
any of the countries that he governed, evils which he must have been scarcely Iess than a god if he could have foreseen. And I mention this here because both English and German history is very much written from this standpoint; and it strikes me as not merely unjust but as showing an ignorance of the plainest aphorisms of common sense, an ignorance that should disqualify a man from even claiming the name of an historian, to make an historical character responsible for evils and crimes which have resulted from his actions by processes which he could not foresee; whilst, on the other hand, crimes and evils which not only were foreseen but actually purposely perpetrated are accounted excusable for good results which have followed them, although those good results were such as it would have demanded the spirit of prophecy to anticipate in the remotest degree. It is very unsafe to read any history backwards, but most especially unsafe to attempt so to read a history in which all our beliefs and prejudices are concerned.

You will, I hope, gather from this prefatory advice that I am not going to attempt any original research in this course; I do not think that we shall be able to go into original matter at all. A term's lectures cannot be made to contain a searching investigation into a history the superficial survey of which fills twelve books of Robertson's history of Charles V. I may as well, however, tell you in what order I propose to treat the subject. In the first place we shall take an outline of the history, during this reign, of the constitutional and internal affairs of the states which are less immediately connected with the great struggle between the Empire and France. These are Spain and the Netherlands. They are removed from the great struggle locally, for no part of them witnessed the great campaigns of the reign, nor were the points at issue between the combatants points related directly to those countries. Charles had difficulties of title in Spain and difficulties of title in the Netherlands, but Francis I. and Henry II. had no standing-ground in either : both countries furnished Charles with supplies of men and money and both did it unwillingly; both had a struggle with him, and, in each, constitutional law had the worst of that struggle. But there is not that unity about their interest in the great drama that there would be if they were contiguous and consolidated. Charles quarrels with Francis, not so much as King of Spain or of the Netherlands, as in his character of Emperor and King of Naples. If it can be shown that Charles had any design of universal dominion, or even of a despotic position, politically speaking, in Europe, any uniform plan of progress towards a general European dictatorship, then I think it would be fair to believe that he acted on a political principle in the repressive measures which he took in each of his states, and an element of 
unity, of political interest would be supplied, which does not show itself at first. But I question whether that can be shown, and the discussion of its possibility belongs rather to the last lecture of the course than to the first. I shall then endeavour, in what may be regarded as the second and third lectures, to take a continuous, a brief, but I hope adequate view of Charles's administration in the two countries in which he was first called to bear personal rule. A fourth lecture will take us back to the empire and to the several internal interests comprised in the geographical area of Germany. We shall thus have, I hope, clear to our minds the personce of the great drama in which the actors are states, kingdoms, bishoprics, with their several influences, quite as much as kings, pontiffs, and republics. We shall thus be able to approach the great action of the period. This is, I need hardly tell you, twofold: Charles in his rivalry with Francis, and Charles in his struggle with the Reformation. And in these we shall have to go a good deal into detail, for our friend Robertson is weak in dates, as I shall have occasion to mention again.

Charles's wars with Francis are a regular seesaw. The Pope is generally the person who pulls the ups and downs. The whole reign is a continuous struggle in this respect, although it may be divided into several acts. Not to include the earliest events which fall rather under Maximilian and Ferdinand than under Charles, the first act lasts from Francis's first attack on Charles in Navarre, Bouillon, and the Milanese, to the peace of Cambray in 1529, during which the Medicean Popes Leo X. and Clement VII. take bcth sides alternately, and the welfare of Europe, so far as their influence can effect, depends on the rise and fall of a single Florentine family. The second act reaches from the war of Savoy and death of Francesco Maria Sforza in 1535 to the truce of Nice in 1538: the third from the renewal of war in 1541 to the peace of Crespy in 1544 : the fourth from the attack by Henry II. on the three bishoprics in 1552 to the end of the reign, when it was still proceeding, although languishing. In the third the interest of the Farnese house, in Parma and Piacenza, takes the place which the house of Medici in Florence occupies in the earlier: the interest of the latter is closely bound up with that of the Reformation. In all this long struggle, and it was a diplomatic struggle during all the intervals of peace, Charles was acting on the defensive : his invasions of France were intended to cripple Francis, not to establish his own dominion, or even in reality to dismember the kingdom of his rival. So much cannot be said of the motives of Henry VIII., when he consented, as he did once or twice, to make a diversion in favour of Charles by invading France. The wars which Francis and his son Henry undertook 
were wars of aggression. The only ones in which there was even an appearance of defence were those which related to the Milanese, and there the claim of Francis was an invasion of the empire as well as of the rights of the family which reigned there under the empire. I do not say this here in defence of Charles, but simply as a help to the recollection of the string of events.

Well, the other struggle of Charles, that with the German reformers, may be divided also into four acts : the first from the beginning of his reign to the Diet of Augsburg, in which the famous Confession was promulgated : this is a period partly of doctrinal discussion and partly of legal decrees and counter decrees, and lasts from 1519 to 1530 . The second is a period of intrigue and political action not breaking into war, and lasts from the promulgation of the Confession to the war of Smalkald, 1530-1546. The third is a period of war, the Smalkaldic war, to the Interim 1546-1548; and the fourth is the great struggle, in which Maurice of Saxony is the principal figure, which ends with the pacification of Passau in 1552. In this also the Popes attempt to keep the seesaw going; to prevent the reformers from beating the Emperor, lest they should take on themselves the remodelling of the whole Church; and to prevent the Emperor from beating the reformers, lest, so strengthened, he should undertake the entire subjugation of Italy and the uprooting of Medici and Farnese alike.

The Council of Trent in its relations to these three powers is of great importance now ; but into the religious history I do not propose to go even so far as to discriminate the parties existing in the council itself. In my view and as to the present subject its importance lies in its being the lever by which the Emperor works on the Protestants and the Pope works on the Emperor. When the Pope wishes to help the Emperor he calls the council, when he wishes to thwart him he dismisses it. He himself-indeed we may on this point speak of the occupants of St. Peter's chair as one man-has been forced into holding the council; the idea of its being strong and effective is hateful to the Court of Rome, at all events during the life of Charles. The Pope fears it because there is always the chance that with the Emperor to pull the strings it may revive the doctrines of the Council of Basel, and even the idea of responsibility of the Vicar of St. Peter himself. He hates the Protestants but will thwart the Emperor at the risk of benefiting them. $\mathrm{He}$ hates the Emperor, but will countenance the council for a time if it will cut the ground from under their feet. To do them justice, the Protestants disclaim consistently the papal authority and the idea that a council held at Trent under Charles's influence can be anything but a one-sided assembly, can be anything like that free 
assembly which, if the divisions of Christendcm prevent its being œcumenic, may yet be Teutonic and national, afford free discussion, and a compromise that will secure liberty.

The point in which the two great struggles of the period touch is the possibility of Francis or Henry II. affording substantial assistance to the Protestants : and this point is, so long as Francis lives, a mere question of intrigue. The early Protestants distrusted him, and rather shunned than courted an alliance with him, although the Smalkaldic league did announce its existence and its willingness to receive new members both to him and to Henry VIII. But the Protestant confederation under Maurice of Saxony, in 1552, was a very different thing from the Smalkaldic league of 1546, and the Protestants had not, in the case of Henry II., the same conviction of incurable ill faith that they had in the case of his father. It is then only in the campaign of $\mathbf{1 5 5 2}$ that this point works overtly. But it cannot be overlooked that Charles's fears were constantly aroused by the suspicion of such a combination and that existing intrigues gave strong grounds for such a suspicion. The pacification of Passau put an end to Charles's personal work in Germany, and the failure to recover Metz broke his spirit and determined him to give up the personal struggle. The two events thus produce the climax or dénouement of the drama; and are, in their turn, the climaxes of the two long struggles which have been wearing away his energy for forty years. The two struggles go on side by side, or in alternate acts, until 1552 : then France and the Protestants join; the pacification of Passau ends one, the discomfiture at Metz the other: the hardy, wiry athlete feels that fortune has exhausted her favours: he plays the game bravely to the last: then he accepts the rod, and makes way for younger combatants. Well, I sketch this thus briefly, because I shall want you to keep it before you, as we go through a quantity of details that are distracting in their sameness and constant recurrence; campaigns in the Milanese and Piedmont, in the Netherlands and in Luxemburg; diets at Augsburg and Speyer and Worms ; edicts and interims and recesses ; promises of councils and sessions and postponements; now a Medici married and done for, now a Farnese equally well disposed of; now a siege of Milan, now a seizure of a pass or province; now an alliance with Rome, now with Venice, now with Henry VIII. Again, in all this there is a perennial warfare with the infidel in three quarters; on the Spanish coast, on the Neapolitan coast, and in Hungary and Transylvania: a warfare which knows no peace and seldom even a truce, but which is brisk when Francis and Solyman are working together, brisker when peace with Francis gives Charles the chance of attacking the robber nests at Tunis 
and Algiers, and which only lulls, if even then, when Solyman is far away in Persia, or when his domestic misunderstandings, like Henry VIII.'s, demand all his attention at home. This, although it has a great interest in many: ways, we shall be able to go into only very cursorily.

I shall, before the term ends, give a lecture, if I can manage it, on the character of Charles and some estimate of his policy in its intention and in its results. And now I must say a word about Robertson. There can be no doubt that Robertson's work is a very interesting one, that in its view of the historic sequence of cause and effect it is in the main a sound one, and that in the antiquarian or constitutional portion of it, although behind the requisitions of this age, a wonderful work for the time in which he lived. I do not propose in this course to deal directly with Robertson's book, because that would involve us in a great deal of discussion of extraneous questions, some of which are antiquated as well as extraneous, and in a number of picturesquely drawn details which require abridgment rather than explanation. Although much of Robertson's introductory matter may be regarded as superseded by Hallam's work on the Middle Ages, it will always retain the great charm of lucid order and conscientious research. Much of what is wrong in it may be corrected by a study of medieval history, and scarcely any of it can be taken with entire confidence in detail. But there it is, readable, orderly, and well thought out. The notes are very valuable whether as illustrating Hallam or as a substitute for him. But in the body of the book itself there are faults which I am sure you will find, if you have not already found, serious. In the first place there is an attempt at continuous detail which is puzzling, when the string of real unity is wanting. A life of Charles written on Robertson's plan would have been far more readable and rememberable than a history of the reign, in which we are constantly losing sight of the chief actor. It would be extremely difficult, on opening any chapter of Robertson, to see where Charles was at the moment of narration; and, in the case of a king who pulled the strings of government so exclusively himself, this ought to be ascertainable. But, further, the meagreness of chronological data in Robertson is an intolerable deficiency. And this I say, not because I want you to spend the best energies of your minds in learning them, but because you ought to be aware how altogether impossible it is to carry on two or three contemporaneous strings of narration without definite dates: it is absolutely impossible to estimate the importance of the Reformation movement without knowing the exact attitude of the varying policy of the Popes or Venetians, or Kings of France and England, as the two struggles proceed: often mistaking a day or a week may alter 
the whole sequence of cause and consequence, and render our whole conception of a crisis one great misapprehension. This evil you cannot remedy in the study of Robertson, without recourse to outof-the-way books; some help however in this, I trust, I may be able to give you.

I wish that I could add that I hoped to give aid of a more valuable kind in another department in which Robertson fails us. Thus. When Robertson wrote, the German scholars had not bestowed so much labour as they ought to have done on their own history; and the writer had therefore to go for his information either to the Latin historians of the seventeenth century who wrote" whilst popular prejudices were high and access to original documents difficult, or to French writers of his own time, whose views are uniformly French as opposed to German and everything else. I do not think that there were any good German histories written then, or that Robertson could have read German if there had been. The German literary and historical life dates from a later period; and you will find that Robertson is quoted as an authority by German writers of his own day in a way which a modern German historian would blush to own. This being so, Robertson is on one side very French, and on the other very Protestant; and so, in both struggles, arguing like a Scot Protestant in religion, French in political affinity, he takes a view of Charles which is too one-sided, too consistently one-sided to impose on any one as true. I believe him to have been quite conscientious; and I do not know any case in which his details of facts have been at all warped by the bias which he took from his authorities, but the truth is as I have stated: of course I shall have to return again and again to this point. And once more, I think that he treats Charles too much as a political machine, and too little as a man with strong passions and a powerful will, with great opportunities for gratifying the one and displaying the other.

Having said this, I have said the worst of Robertson. His Protestant prejudices must of course, throughout the work, be allowed for; I do not know that they ever lead him into misstatements. Many parts of his work have been very critically handled, both by Dr. Dunham in his history of Spain, and by Prescott and later writers on the Dutch and Spanish transactions; but I think that very little really can be said against his accuracy. The great want of the book, the want of unity and distinctness, I shall try in this course of lectures to help you to supply. If at times I seem to be running too much into details of this kind, please to remember that I do it with a deliberate intention of helping you to work out the reality of his story: if at times you miss a general view that might make contemporary lines of narration more easily tenable in 
the memory, please also to remember that $I$ have in this lecture given you my idea of the plot of the period, the acts of the drama, and the steps that lead up to the final catastrophe, if catastrophe is not too harsh a word for the quiet conclusion of a reign, a retirement from active life that has been vouchsafed to few men who have ever made so great a name in the world.

Our work begins with the history of Spain. We take it first, not because it was that one of his dominions which Charles was able to administer for himself the earliest, but because the interest of it is rather more remote from the general line of European history during the early years of Charles's misgovernment and Spain's misery, and the long expanse of peace and good, or comparatively good government which followed. Although this is the case, to a marked degree, if we compare this reign with the following one, we must not forget that it was from Spain and the Spanish colonies that Charles was furnished with much of the wealth which enabled him to do what he did in Europe. Not that he was ever rich, but that without Spain not even the liberal support of the Netherlands provinces would have saved him from being very poor: as poor, considering the extent of his territory, as his grandfather Maximilian, who had very little, and his great-grandfather Frederick III., who never had anything at all. But the interest of Spanish history is out of all proportion to the place it occupies in the general history, or that we can afford to give it in this course of lectures. It is full of political interest and of the working of well-traced causes to their effects. In some respects it reads like a leaf taken out of the history of England three centuries earlier, so many of the ingredients are the same. In some respects it reads like the closing scene of some great drama, after which there is a lull, to be broken by quite different sounds.

Ferdinand and Isabella, like most strong and politic princes, left to their successor an almost immediate harvest of troubles. Ferdinand did indeed live to reap some of his own. These troubles are partly internal and partly external; within the borders of Spain itself the infringement of the ancient constitutions of the different kingdoms, and on the border the annexation of Navarre. The latter, however, as things went then, between strong kings and weak, is of less importance and may be set aside for the present. But the constitutions of Spain are very interesting and demand strict attention. Nor can it be said that to study them at this time is to study them in their decay: for although they were near their end, there was no lack of vitality in them, nor a lack of appreciation of principles such as educated Englishmen at least regard as sound. 
Each of the kingdoms of Spain had a constitution and a national assembly of its own. In Castile and Leon the states had been long consolidated, and under the same principles, but Castile was contrasted very much with Aragon, and Aragon with its two subkingdoms of Catalonia and Valencia. Each of these states had Cortes and all were jealous of one another. Robertson, as you may have noticed, describes both constitutions as feudal, and as derived by direct succession from the Goths, the Suevi, and the Vandals: but this is not the case; from the Vandals Spain inherits nothing but the derivation of the name Andalusia, for the Vandals were driven out of Spain into Africa as early as the fifth century; and the Suevi lost their own nationality in the general mass of the Visigothic kingdom, helping perhaps in some small way to deepen the tinge of Teutonism in the Spanish institutions. For the historic institutions of Spain are fundamentally Teutonic, and that is perhaps all that Robertson in his use of the word 'feudal' meant to convey. But it is not correct to call them feudal without drawing a distinction. Castile had institutions which in some parts resembled feudal ones: Aragon had been feudalised under the influence of historical feudalism. But each has a history and a law of development that distinguishes it from the ordinary feudal constitution. The truth would seem to be this: the Visigothic royal race and common law were Teutonic : they were fast degenerating and sinking into the normal condition of Southern nations, when the invasion of the Moors in the eighth century braced them up to action, and proved a sort of regeneration to them; it brought out all their noble qualities and threw them back on their ancient original usages.

The formation of the kingdom of Castile was the result of a series of encroachments on the Moorish kingdoms : the history of Aragon is of the same sort but with other circumstances. Both kingdoms lived for seven hundred years in a chronic crusade. In Castile every new acquisition required consolidation : it was either granted feudally to a nobleman with a castle, or it was colonised by a privileged community, or occupied with a new city. The strength of these advancing outposts was the stay of the kingdom, and the strength had to be sustained by making those who had the work of defence sharers in the work of administration. On Teutonic principles the power of the king was to be limited by a national assembly, and that national assembly consisted of the three estates, the clergy, the nobles, and the commons. These formed the Cortes of Castile, and to these by rights were referred the making of new laws and the imposing of taxes and the working of the politics of the state. But at an early date the clergy had gained for themselves immunity from taxation; the nobles had received their estates on 
the feudal condition of service; and consequently the voice on taxation came to belong to the commons only; and to them very frequently, by their representatives, the name of Cortes belongs. But the commons were not summoned as in England, two knights from every shire, and two burgesses from every town : there was no distinction between the ancient element of landownership in the country and the modern one of privileged franchise in the towns: the communities, whether rural or urban, had their privilege of being represented bestowed on them by royal grant, and it was within the power of the king to call up only the representatives of the communities that he knew to be liberally disposed, and by their voices to exact a supply from his whole people. The communities, having neither a basis in the common law of the land, nor a support in the sympathy of the lords and clergy (and in England we know they had all three), were, although not wanting in independence, very much at the mercy of their rulers, were apt to be jealous about small things, knowing that they must yield in great ones : but were, as regards their own constitutional privileges and ancient rights, thoroughly conservative in spirit. Ferdinand and Isabella, it seems, had, by a sort of tacit compromise, kept well with them for years: they were not to ask much influence and they would not be troubled with much taxation.

In Aragon matters were different. There in Aragon proper there were four estates, or four ingredients in the Cortes: (1) The prelates ; (2) the 'ricos hombres,' or barons ; (3) the 'infanzones,' or lesser tenants in chief; and (4) the representatives of the royal boroughs. And all three on feudal principles, just as it was in England in the reign of Henry II., with the addition of the representatives of the towns. Here as in Castile there was no representation of the land, or of the country as country. The 'infanzones,' the landowners, who in England were represented by the knights of the shire, in Aragon appear in person ; there are very few of them, so largely is the land in the hands of great feudatories. There is no representation except of the towns in demesne which owe their political existence to privilege. An almost exact parallel existed in Scotland before 1428. The system in both Aragon and Castile is without a backbone. The Cortes of Valencia and of Catalonia were more or less feudal and of the same sort, but they were not divided into four estates, simply into three. The three provinces were jealous of one another and of Castile, and required management which should carefully avoid the infraction of their prejudices, even more carefully, perhaps, than their substantial rights.

On this heterogeneous mass of political jealousies, which the strength and repressive policy of Ferdinand and Isabella had been 
long smothering, the early 'prentice hand of Charles had to be tried : he came to the work fettered with a foreign education and foreign, greedy, and selfish advisers, and the first years of his reign were, as might be expected, both unsuccessful and inglorious. When I speak of the policy of Ferdinand and Isabella as repressive, I do not mean that it was ever unconstitutionally so. But they had found Spain in a state of anarchy, and they reduced it to a state of sound organisation, and that by policy as much as by force. Their wealth and economy enabled them to keep the purse strings out of the hand of the Cortes : the Cortes accordingly enjoyed the utmost consideration; they were regularly summoned, the popular element was not weakened: the laws were accepted and passed by them: but for all that the sovereigns were the strong party: and there was no room for uneasy spirits.

Charles V. was born in 1500, heir of the houses of Austria, Burgundy, Castile, and Aragon: in 1504 Queen Isabella of Castile died, leaving the regency of Castile to her husband Ferdinand, until her grandson Charles should be twenty; passing over her daughter Johanna, who became queen regnant, as of weak mind, and her son-inlaw Philip as a foreigner. The immediate result illustrates what I said as to the sensitive conservatism of the constitutionalists of Spain. The will of Queen Isabella at once sets Aragon against Castile, Philip and Johanna against Ferdinand, and the rights of the Cortes against the will of the prince. In brief, Philip, at the instigation of the minority of uneasy nobles, refused to recognise Ferdinand's right to the regency : he ordered the old king to quit Castile and retire into Aragon, and denounced all that had been done by him since the queen's death as unlawful. Ferdinand insisted on his right and refused to treat of resigning it until Philip and Johanna, who were already reigning in the Netherlands, presented themselves in person. The constant underhand politics of Philip, who seems to have had very little merit besides his beauty, provoked Ferdinand to dismember the inheritance: he would marry again and settle Naples on the issue of his new wife. Robertson, you may remark, is wrong in saying that he offered to marry Johanna, the reputed but doubted daughter of Henry IV. and half-sister of his queen. Although there was such a report at the time, it seems to be without foundation, but he did marry Germaine of Foix, and this brought Philip to a dissembled agreement. By the treaty of Salamanca (Nov. 24, 1505), Ferdinand, Johanna, and Philip were to reign jointly in Castile : but on Philip's part this was only a trick; for, as soon as he was able to make his way to Spain, he annulled the treaty and proceeded to measures against his father-in-law which could only end in war. With this before his eyes Ferdinand consented to resign the regency. 
Fortunately for the peace of Spain, and of Europe generally, for both England and France were at this moment on the side of Ferdinand, Philip died about five months (Sept. 25, 1506) after his arrival in Spain; as soon as he had time to receive the homages of Castile. By his death the kingdom was left without a government, and the nobles accordingly took measures for appointing a regency. After some difficulty, and a good deal of opposition on the part of the minority, Ferdinand was restored to his office in 1507, and continued to govern all Spain with his former sagacity for nine years more. By his second wife he had no children, and, on his death in 1516, Charles became entitled to the prospective crowns of Aragon and Naples as well as Castile, subject to the life of his mother, who, continuing unfit to govern, remained a rallying-point for disaffection, and lived nearly to the end of the reign of her son. So firm seems to have been the settlement of the family inheritance on Johanna, that no attempt was made to disturb it, although, on the ordinary rules of feudal heritage, her sisters Catherine of England and Maria of Portugal might have had some claim. Singularly these two princesses had complicated matters, Catherine by marrying her first husband's brother; and Maria by marrying her deceased sister's husband. But against the succession of Charles not a word was said; Johanna was the eldest daughter and Charles was her eldest son. His brother Ferdinand had been brought up in Spain, and a party might easily have been made up for him; but, until Charles offended the Spaniards, no one thought of anything but submission, and happily the time during which Spain had to complain of being misgoverned by him was soon over.

Charles was now sixteen; old enough, if he had been ordinarily mature, for kings have a sort of political precociousness, to have reigned, or to have begun at least to reign, wisely. But Charles was far from precocious; his mind was slow, and its growth steady; and as we cannot suppose the wisdom which he showed a very few years later to have come upon him by accumulation, we are forced to allow that his first series of false steps were owing to false and interested advisers. Anyhow we see bow much he needed experience. The court that Philip had left at Brussels was not likely to be a very farsighted one; the Flemings had a great eye to their own interests, but had not yet bred a politician whose views were more than patriotic; and the French were in every respect worse. Yet by selfish, hard-headed, sharp-practising Flemings, or avaricious and unprincipled Frenchmen, Charles was surrounded; by such he was urged on to snatch at every apparent advantage, and from such only at this time could he choose his ministers. Before his grandfather's death he had sent Adrian, dean of Louvain, a worthy but ignorant

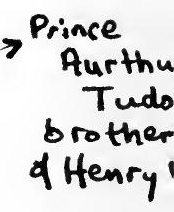


man, to take the regency as soon as the throne should be vacant; and his assumption of the title of King at once, without regard to his mother's rights as 'reyna propietaria' was a second false step. Both of these were particularly grievous to the higher-principled Spaniards, who saw the risk to Spain of being governed from a foreign court by foreign ministers, for the use and behoof of foreigners, with foreign purposes in politics and foreign principles. At the highest or lowest estimate we take of Spanish patriotism such expectations were reasonable enough: and these two steps made them seem imminent. Not the English under Stephen or Henry III. hated and dreaded foreigners more than the Spaniards. The French they could not tolerate, the Flemings scarcely. Yet here, as soon as, nay before the throne was vacant, when, moreover, the vacancy was a mere demise from father to daughter, this Flemish boy of sixteen, who has no right to the crown as long as his mother lives, calls himself king; and, although he has no right to interfere at all until at the age of twenty he may take the regency under the will of his grandmother, he sends a Flemish clergyman, who does not even know Spanish, only a dean, moreover, in dignity (that is next to nothing), and expects that he shall be received as the regent, to the exclusion of the great and wealthy, pious and learned Ximenes, whom Ferdinand had appointed to the office. But something might be said on the other side. Ximenes was appointed by Ferdinand, but Ferdinand was, in Castile, only the representative of his daughter Johanna; how could a regent nominate another regent? Ximenes, like a patriot and an honest man, made the best of things. He was eighty years old and had no earthly prizes to gain. He determined to do the best he could for Spain, and this could be only by doing all he could for Charles : so he proclaimed him king, and accepted Adrian of Utrecht as his nominee in the regency. Charles thereupon confirmed him as regent, and for a year and a half he exercised the authority.

But the elements of disquiet were already loosed. Aragon would not acknowledge Charles as king: Castile would not recognise Ximenes as regent. He had to form and work out his own policy. He began by revoking the lavish grants that had been made by Ferdinand and Isabella in their emergencies out of the royal demesne. These grants were unconstitutional ; they were contrary to the common sense and common law of every nation of Europe: in many the kings were sworn not to diminish the hereditary demesne. In all, the diminution of the demesne meant, unmistakably, repeated petitions for feudal aids, or debt, or irresponsible taxation. Again we have a parallel with the earlier history of England : the first measure of Henry II., when he had secured the English 
throne and saw the necessity of beginning a period of retrenchment, as well as reform in all departments of the state, was to recall into the exchequer the endowments by which his mother and king Stephen had provided for the new class of nobility which they had created for a defence for themselves; so to diminish taxation and get rid of unpopular favouritism. Ximenes alienated the Castilian nobles, but with the savings he created a force which kept them in awe. His management of the wars in Navarre and Africa, which Ferdinand had left on his hands, was not less effective, although the results were dissimilar: his efforts were only partially successful against Horuc Barbarossa, while against Francis I. he not only beld Navarre, but, by dismantling the fortresses, made it for ever untenable by an invader.

\section{LECTURE II}

THE CHARACTER OF CHARLES V.'S RULE IN SPAIN AND THE NETHERLANDS

When, then, in 1517, Charles arrived in Spain (which he did as soon as he could after concluding the war with France by the peace of Noyon, August 1516), he found matters not indeed as favourable as they might have been, but as favourable as could fairly be expected. Ximenes had kept at bay the nobles who were eager for an anarchy, in which their privileges might be increased; he had kept under the rivalry between the Flemish emissaries of Charles and the native Castilians, and prevented it from breaking into open animosity, and he had done his utmost to defend the borders. $\mathrm{He}$ deserved better of Charles than to be treated with neglect and contempt : but, although he lived long enough to taste the bitterness of ingratitude, he died before he saw the misery of a civil war. Charles landed at Villa Viciosa, September 19, 1517: before he met the Cardinal, he wrote him a letter of dismissal which may have had some effect on his health: he died on November 8 of the same year, leaving his country to be a prey to the inexperience of the boy king, the shameless avarice of the Flemings, the selfish and impolitic jealousies of the nobles and commons, and the senseless rivalries of the different provincial governments.

Spain, it would seem, was quite prepared to salute the rising sun. Ximenes's rule had been too strong to be popular, and the Flemings had not had time to show their true colours. Charles immediately began the business of his inauguration, and, in close connexion with that, the negotiation for supplies. He was crowned at Valladolid on 
February 7, 1518, in the presence of the Cortes, who, before they separated, bestowed on him the unparalleled gift of six hundred thousand ducats. Thence he went to Saragossa to meet the Cortes of Aragon. These were less accommodating: they were not to be bound by the action of Castile, nor would they forsake the cause of Johanna. Charles was not their king : the justiza was the lawful regent, in his name the Cortes should be called or not at all. It was not until a very great deal of patience had been shown by Charles, and much persuasion exercised, that they allowed him to be received as joint sovereign of Aragon with Johanna, and bestowed two hundred thousand ducats, which, however, they strictly appropriated to the payments of the debts of the crown. From Aragon Charles went to Catalonia, where he had the same difficulties to contend with, and was detained many months at Barcelona before he overcame them. He ought next to have proceeded to Valencia, but, by this time, his patience was exhausted; he had received the news of his election as Emperor, in succession to his grandfather Maximilian, and was anxious to leave for Germany. He sent therefore Cardinal Adrian to treat with the Valencians; he thus offended that nation. A religious tumult and plague complicated matters more: the nobility refused to do homage unless Charles appeared in person to receive it, and he foolishly allowed the trades of Valencia to form a hermandad or league against the nobles. This league broke out into revolution. Charles was compelled to withdraw his sanction, and thus incurred the deadly enmity of every class of society in the jealous little kingdom. So much then for the jealousies between kingdom and kingdom and class and class.

The Flemings had not waited long before they tried the patience of the Spaniards. They began by getting the money, so liberally voted by Castile, into their own pockets and transmitting it to Flanders. So Charles was soon as poor as ever. They followed up this by engrossing the great offices that Ximenes had vacated. Chièvres, a Fleming, was prime minister; Adrian of Louvain was the Cardinal in the King's confidence: Sauvage, a Frenchman, became Chancellor; and William de Croy, nephew of Chièvres, Archbishop of Toledo. These measures had so far provoked the Castilians that within six months of the coronation they had instructed their deputies to insist that no more foreigners should be appointed to civil or ecclesiastical dignities in Castile. All this helped to increase Charles's difficulties in the other kingdoms also. Each nation wished him to reside among themselves; all were jealous of strangers and afraid of Charles's departure to Germany. Thither, however, he was determined to go; money he must have before he could go: money he was not likely to obtain 
without management, and, by a piece of mismanagement, which exhibits the policy of his advisers, as at once insincere and contemptible, he summoned the Cortes of Castile to meet at Compostella, where he would have them at his mercy, instead of at Valladolid. In spite of all remonstrances, and shutting his ears to all complaints against the Flemings, he brought the Cortes to Compostella, where the pertinacious opposition of the deputies of Toledo led him to order them to quit the assembly and to return home. This so unconstitutional proceeding was followed by the arrest of two of the Toledan magistrates; and this led the other great cities to refuse any accommodation. The Cortes, unmanageable at Compostella, were removed to Coruna, where the few deputies left made Charles a fresh grant, and after appointing regents he was able in 1520 (May 22) to sail to England on his way to the Netherlands and Germany.

Such is the short outline of Charles's first attempt at government in Spain. He left Spain a prey to the calamities that his wretched tactics had brought upon it-a condition in which it continued until his return in July 1522. The events of this year of Charles's absence are detailed by Robertson at a length which is due perhaps as much to their romantic interest as to their real importance, although that importance is great; for they are worthy of being carefully compared, not so much with the English events of the seventeenth century, as with the earlier struggles of the commons and barons in this country in the thirteenth. You get the same demands for economy and that the King shall live within his income; the same curious expedients to avoid taxation; the same detestation of foreign favouritism; the same combinations and oppositions. Unfortunately you do not get the same result : in England the event was the limitation of royal action by constitutional restraints; in Spain it is the gradual extinction, by mutual counteraction, of the elements of constitutional life. No doubt, somewhat of this was owing to statecraft, which Charles soon began to learn, but more of it was due to the irreconcilable differences of the different classes of society, which rendered them available against one another, and to that incurable wrongheadedness which was and seems to be still the great characteristic of Spanish politicians.

The events of 1521-1522 arrange themselves under the three heads of Castile, where Adrian had been left as regent; Aragon, which was put under Don John de Lanuza; and Valencia, which was entrusted to the Conde de Melito. In Castile the string of the story seems to be this: the offence given by Charles-(1) in calling the Castilian Cortes so far from Castile, (2) in overcoming the opposition of the great towns by means scarcely short of violence, 
(3) by coercing the other deputies into a grant, and (4) by leaving the country without one grievance remedied and under the sway of the Flemish Cardinal-caused immediately an outbreak. The leader of this outbreak was, at Toledo, Don John de Padilla, and his better half, Doña Maria de Pacheco, both nobles. But it was not confined to Toledo: Segovia was the scene of another revolt: the people there rose and murdered their deputy Tordesillas, who had voted for the grant to Charles : and both Toledo and Segovia levied forces to resist the regent. On Adrian's taking measures to repress the revolt, other cities rose in support of these two. Medina del Campo in particular, refusing to give up the magazine of artillery to Antonio de Fonseca, Adrian's general, was burned, partly by accident, during the time of the great fair. The cruelty imputed to Fonseca, and the loss of goods and merchandise, roused the people of Valladolid, where Adrian held his court; he lost his courage, if ever he had any, and emboldened the revolters by making an apology to them, thus losing all hold on the authority committed to him and opening the way to general anarchy. Don John de Padilla had now assumed the general leadership : he called together, at Avila, a sort of convention of the deputies of the fifteen cities of Castile which-on the pattern of the hermandad or brotherhood which, under the form of a voluntary association, had, during the early years of the reign of Ferdinand and Isabella, superseded the Cortes in the management of the internal affairs of the country-assumed the name of 'Junta,' and drew up a programme of political reform. They declared Adrian, as a foreigner, deposed from the regency; they seized poor Queen Johanna, declared that she was competent to govern, and that they should conduct the government in her name : they, by their forces, relieved Segovia from the siege which Adrian's general had engaged in, and arrested the council of government at Valladolid, though sparing the person of the Cardinal. Up to this point their conduct, although revolutionary, had been moderate and, to a certain degree, capable of justification. Henceforth they seem to put themselves more and more in the wrong.

Charles, on hearing of the revolt, conscious of his own folly, and a little wiser perhaps than he had been, issued letters to the cities of Castile, offering to renounce the subsidy, and promising redress of complaints against foreigners, associating the Admiral and Constable with the Cardinal in the government, and calling on the leaders of the ' Junta' to restore law and respect to authority. But the letters were scorned by the rebels : they were, according to the usual programme of revolution, persuaded that these promises were intended to gain time, or to entrap the unwary : they were not to be so caught.

The next thing to do was to prepare for a political reformation, 
to draw up a series of articles, which if Charles should accept, they would accept him. These articles briefly may be arranged under seven heads :-(1) The King shall live in Spain. (2) All the favours, offices, privileges, and opportunities bestowed on foreigners shall be reversed and abolished for ever. (3) All new taxes shall be abolished, the subsidy renounced, alienated demesnes resumed : the nobles shall be taxed, and a committee appointed to examine the administration of the royal estates. (4) The constitution of the Cortes shall be altered so that every city shall return three members, one for the clergy, one for the lower nobles, and one for the commons: these shall be assembled every three years. (5) The administration is to be improved in several obvious ways. (6) All privileges of the nobles prejudicial to the commons shall be revoked. (7) A general amnesty to the Junta and its servants. With these demands they sent to Charles envoys, who, afraid of the threats which were whispered to them, did not venture to present their credentials. The Junta, hearing this, prepared for war. But they had got to the length of their tether. The nobles, seeing themselves now the object of attack, declared themselves on the King's side, joined the regents and defeated the Junta, recovered the possession of Queen Johanna, and, after some military operations, took Padilla prisoner at Villalar and put him to death as a traitor. Doña Maria, like a heroine, conducted the defence of Toledo against the regents ; but the clergy, finding that the intrusive archbishop was dead, rose against her; she fled and the Castilian revolt collapsed. The revolutionists had thrown themselves against the rock of nobility and perished. The revolt in Valencia, the continuation of the one which had begun before Charles's departure, ended in the same way. The trades Junta or Germanada (Hermandad) compelled the nobles to take arms in self-defence; the Castilian nobles, after the victory of Villalar, were able to help their brethren, and so the authority of the regent was restored. Aragon did not break into open insurrection, so, before Charles (July 16, 1522) landed in Asturias, matters were advanced far enough to make clemency politic.

Charles had grown much in experience in the years of his absence. He came to live among his people, won all hearts by refusing to shed blood, and in reality secured Spain from anything like a breach of the peace or political tumult during the remainder of his reign. From 1522 to 1529, Charles made Spain his headquarters, and during that time Spain by herself has no history. The eyes of all the world were on France and Italy, and, save that Charles's wars involved the heavy taxation of his Spanish subjects, it would seem from the silence of the historians that there is nothing to record. In 1526 he married the daughter of Manuel of Portugal, Isabella, who, on 
several occasions, acted as his representative during his absence from Spain. In particular she ruled from 1529 to 1533 , and, after the Tunis expedition, 1535 and 1536. She died in 1539. Charles's visits to Spain after the Tunis expedition in 1535 , were (1) from October 1536 to June 1538, (2) again after the Algerine expedition in 1541 and 1542. In 1543 he left the country under Philip, his acknowledged successor, and did not return until after his abdication, in $\mathbf{1 5 5 6 .}$

During all these years there are but two interruptions to the monotonous details of peace within the borders of Spain. One is the revolt of the Moriscoes, the children of the Moors, who had been Christianised by force, and were now by the violence of the Inquisition driven to rebellion. Charles would not or dared not allow them to return to their own religion : he tried to compel them to conformity, drove some thousands into Barbary, and by force or persuasion brought the great body of them to submit. But the peace was as hollow as their professions of Christianity; and the harsh policy laid up great store of troubles for Philip. The other event is in our view more important, for it is the end of the struggle which we have been trying to piece into a connected outline. In 1538 Charles was bitterly in want of supplies from the Castilians, and he assembled the Cortes at Toledo to ask for them. The proposition he made was for a tax on provisions-an excise, as Robertson calls it. The nobles took umbrage at this attempt to break down their immunity from taxation and found occasion to speak their mind to Charles, requesting him to live in Spain like a Spaniard and not involve himself in foreign wars. Charles, whose wars were not of his own seeking, and who had just lost, in the Empress Isabella, his wisest counsellor, was both hurt and indignant, he dismissed the Cortes in great confusion, and never again summoned the nobles to take a share in the public business. From this time the Cortes consisted of thirty-six members, two deputies from eighteen communities : unaided by the landed interest, they lost all independence and sank into complete insignificance for several centuries.

With this event the political life of Spain ends, until the days of revolution, and it seems to have ended likewise Charles's earlier devotion to his Spanish kingdom. The few other incidents which affect Spain during the period must be considered in their connexion with the general current of European affairs : and the result of Charles's administration I shall attempt to estimate broadly in the final lectures.

Although Spain claims the earliest place in a review of the dominions as well as of the reign of Charles V., the Netherlands come hardly second to Spain in any respect, and in some they 
come decidedly before it. Charles was their ruler before he ruled Spain, he was born in the Netherlands, and doubtless was happier and more at home there than anywhere else : from the Netherlands also he drew largely the sinews of war. But further it was in the Netherlands that his great ability for government was chiefly shown, and, unhappily we must add, the great fault of his character had its freest working and produced its speediest consequences. Yet the history of the Netherlands occupies but a small part in the ordinary histories of the reign. It is, however, most important to obtain a clear notion of the relations of Charles to his territory, how he got it, what were its divisions and political affinities, and what were its constitutional rights and machinery.

Under the title of the Netherlands we will comprise the whole of the modern kingdoms of Holland and Belgium with a rectified frontier towards France; the province of Artois, the southernmost province of Charles's dominions, having been at the treaty of the Pyrenees in 1659 surrendered to Lewis XIV.; and the province of Liège, which is now part of Belgium, being a semi-independent state immediately subject to the empire. The names of the states comprised in this geographical extent are Flanders and Artois, which belonged to the kingdom of France, and for which their rulers were feudally vassals except for a small portion of Flanders which was imperial; the duchy of Brabant, the county of Hainault, the county of Namur, all imperial: these form the modern kingdom of Belgium with the addition of Liège: what is now Holland consisted of the county of Holland; the duchy of Guelders, which was in dispute with Cleves until 1543 ; the bishopric of Utrecht, acquired by Charles in 1527; and the provinces of West Friesland, Gröningen, and other smaller territories dependent on the county of Holland or on the duchy of Guelders. In these lands four languages are spoken-French, Dutch, or Low German, Walloon, and ordinary High German. The whole of them except Flanders and Artois were part of the ancient Lotharingian kingdom, and afterwards of the imperial duchy of Lower Lorraine which finally settled down into the duchy of Brabant, the other provinces being separated from it, either by the institution of new marches for the defence of the frontier, or by division among different branches of the same house, or by the many other causes which affect for disruption a population of different languages and in debatable situation. The Low Countries, Lower Lorraine, i.e. what is now modern Holland and Belgium, come but little into the history of the body of the Empire from the eleventh century downwards: the interests of Flanders and Hainault are early bound up with France ; and those of Holland are remote from that of Germany. The whole 
of Lotharingia was, always has been, a land debated if not properly debatable; the cause of countless quarrels and the field of thousands of battles. Each of these little territories has through the Middle Ages a government and a dynasty of its own; a reigning house alternately gathering and dividing territory in different combinations, and when it becomes extinct supplied, like the rest of the empire, by a new nomination from the Emperor.

Little attached to the Empire or to France and of comparatively little influence in Europe, these provinces contained an industrious and thriving population who were perhaps much more at one than their rulers. Little basis of union as there was amongst them, there was no very strong attraction towards any neighbouring centres. Hence when in the fifteenth century, in one way or another, by different titles, deaths, marriages, and usurpations, the larger portion had fallen to the house of Burgundy, which was itself a junior branch of the royal house of France, the people seem to have combined well enough under the Burgundian dominion: I do not mean that they became peaceful subjects, for they were quite the reverse, but quite able and ready to act as a nation. And the result of the sway of Burgundy which was inherited by Philip the Handsome, father of Charles V., was up to a certain point to increase that sense of unity and nationality; until the religious questions and the struggles supervening on them broke up the territory into two parts, which have only been united once for fifteen uneasy years since, to separate more definitely than ever. The secret of this combining was partly in the policy of the Burgundian rulers, partly in the circumstances of the ruled. Charles the Bold instituted a supreme tribunal of judicature for the whole of his Netherlands provinces in the great council of Mechlin: Maximilian associated them again for imperial purposes in the circle of Burgundy; and in the assembly of the States General they had an organisation which, although not much in itself, was a symbol and practicable basis for common action. But the influence of the cities of the Netherlands was a more powerful one towards cohesion: so entirely was political influence coming to be engrossed by the cities, and so warily were the politics of the shrewd and money-making burghers administered.

The growth of the Netherlands towns is not characterised by any features peculiar to them : they were centres of population gathered as in England round some castle capable of defending them, or some shrine of special sanctity, or some natural situation affording opportunities for trade. They grew in population and independence under the patronage of their feudal lords and bought new privileges from their necessities. The lords were more than ordinarily necessitous, and the privileges they parted with were more than commonly great. 
So the cities of Flanders especially grew to a condition of wealth and independence little inferior to the Italian cities whose government was more ostentatiously republican. Into any analysis of these privileges we cannot go : as in Spain, they varied in every case, being the result of distinct grants of privileges, not of any national act or compact between the king and his people. The period of growth was, moreover, far from peaceful; the privileges of the citizens were incompatible with the views of the counts and dukes; and the claims of the latter, although they might in form be legal, were irksome to the spirit of independence among the burghers. Hence there was a fellow feeling between the cities which, with all their jealousies, prevented them from imitating the fatal feuds of North Italy. Neither was the Pope near at hand to create a chronic division of Guelf and Ghibelline.

Each of the provinces had its own provincial assembly, its estates, of clergy, nobility, and commons, but the power of the clergy was weakened by the smallness of the number of the bishops; and the nobility was also a small and decreasing body exposed for centuries to the aggression of the commons, by whom they were expelled from all real share in the government of the towns and even from the right of citizenship. In the estates, the cities which appeared there by their representatives were all-powerful, and they were for the most part liberal towards their ruler. As the extent of his territory increased, their liability to heavy demands decreased without any decrease in their power of money-making. It was in their provincial assemblies, the estates of Flanders, of Holland, and of Brabant, that the chief political power besides that of the prince resided, not in the States General, which were only a small council of ambassadors rather than representatives from the several provincial estates. It will be seen thus that the bond of unity in the territory, slight as it really was, was threefold: dynastic union, organisation under the council of Mechlin and in the States General, but chiefly in the preponderant influence of one element in the national life diffused pretty equally through the whole and as yet not broken up by jealousy or religious antagonism.

The influence of the cities and the tendency of the territory to consolidate had been going on in an increasing ratio since the death of Charles the Bold in 1477. That great prince, whatever were his real views and purposes, was not of a nature likely to allow any development of liberty: his policy was repressive, and his death caused a reaction such as might be expected: for his successors were first a weak girl, then a poor king with only half a title and no principle, then a vain fool, then a regency. From Mary of Burgundy the provinces, in their assembly at Ghent, extorted a Great Privilege 
or Magna Carta for each of her states: in this she allows that the provincial estates alone have the right of taxation and that war shall not be undertaken without their consent. With these additions to their own peculiar privileges the cities enjoyed an amount of freedom unsurpassed by any state except England, and perhaps with more means of realising and vindicating it than even England herself at the time can be said to have possessed.

Under Maximilian, who married Mary, the history of the country is a series of squabbles out of which that erratic hero comes with very little credit; and we have no occasion to go into them. They end with the recognition of his son Philip in 1494, who, as his father had done, repudiated the great privileges and other charters extorted from Mary. The policy of Maximilian, using the burghers against the nobles and then addressing himself to the elimination of an independent spirit by a ruthless exercise of power, had reduced for the time the people to servility. But with the accession of Charles in 1506 a better feeling sprang up. He was born and brought up a Fleming, and the cities were personally attached to him. The extent of his present and possible influence was to them the extension of their own commerce and political power; his Spanish and American possessions were an inviting field for their personal selfish purposes ; and Charles, particularly in his early days, and generally throughout his life, played in this respect into their hands. His favourite friends and ministers were Flemings or Netherlanders, and his sagacity saw many ends served in promoting the commercial views of the most industrious and attached of his subjects. That these were not always wisely promoted, considering the extent and various constitutions of his other states, we cannot much wonder at. Charles was naturally inclined to support his early friends : as I have remarked already, his capacity was by no means precocious, and his early acts must be charged on his advisers rather than himself. From his sixth year to his sixteenth he was brought up in Flanders as the nominal ruler, his grandfather Maximilian being the nominal regent. William of Chièvres, Lord of Croy, was his governor, and Adrian Florenz, Canon of Louvain, his tutor.

The government of the country was committed by Maximilian to his daughter Margaret, duchess of Savoy, who held it from the year 1507 to the year 1530. It was by her that the interests of the Empire and the Netherlands were represented at the Congress which ended in the league of Cambrai in 1508; she continued, after Charles had left Flanders for Spain, to exercise authority in his name, and in all the political transactions of the remaining years of her life her name is constantly appearing. It is she who negotiates 
for the release of Francis I. after the battle of Pavia: and it is she who breaks the alliance between England and France in 1528 and the next year settles the peace of Cambrai by which the feudal rights of France over Flanders are extinguished. Her politic management of the states, the way in which she moved them to grants of money and rewarded them by encouragement of trade, is the theme of great praises among the historians, yet she was unable to defend the coast against the French cruisers or to remedy the evils produced by the famine and destruction of the fisheries in 1524. It was under her government, moreover, that Charles was enabled to round off his dominions in the north by the acquisition of the territory which had been for many centuries ruled by the bishops of Utrecht as the temporal prince.

Philip of Burgundy, a bastard brother of Charles the Bold, was appointed Bishop of Utrecht in 1516: he showed himself more desirous of assisting the aggrandisement of the family heritage than of maintaining his own official position. He let his people become Protestant, and his temporal authority be made subservient to the family schemes. On his death in 1524 his successor found the people half Protestant, and himself politically powerless against the attacks of Charles of Egmont, the claimant of the duchy of Guelders. In fact, the province was split into two parties, the Protestants supporting the duke, and the Catholics with their bishop appealing for help to the Empire. The price of this help was the surrender of the temporal sovereignty. The old bishopric is thrown into the county of Holland, and henceforth the prelate is a spiritual lord only.

This must have been almost the last negotiation in which Margaret was employed. Her successor in the government was Mary of Austria, sister of Charles and widow of King Lewis of Hungary. She reigned from 1531 to 1555 , when, on the resignation of the Netherlands by Charles to Philip, she vacated her office and retired to Spain. The two great events of her government are the quarrel of Charles V. with his native city, Ghent, and the termination of the struggle with the Duke of Guelders for supremacy in North Holland and Friesland. And these events, with the religious phenomena which manifested themselves throughout the territory, and the repression which met every attempt at reform or change, comprise nearly all that will call for remark now, as touching the Netherlands especially, without falling into the general stream of European history.

The ten years that preceded the death of Margaret had been years of war; admirably as she held the reins of government, she had not been able to avert the usual evils. The Netherlands them- 
selves had not been the battlefield of the principal campaigns between Charles and Francis; but the coasts were exposed to depredation; the states had to be asked continually for supplies, and, in the chronic war with Guelders, the provinces had an open and festering wound. The origin of this war reaches some way back into the preceding century. Duke Arnold of Guelders, in 1472, had surrendered all his rights to Charles the Bold, to the disinheritance of his undutiful son Adolf. Adolf, on the death of Charles, had taken advantage of the weakness of Mary to reclaim his rights and attempted also to force himself on the infant heiress as her husband. Happily for her, for he was a monster of wickedness, he got himself killed in 1477; but he left a son, Charles of Egmont, who, a child at the time, was destined to be a terrible thorn in the side of the house of Burgundy. During his minority Maximilian, by the help of family jealousies, got Guelders into his own hands and was recognised by the people as their duke. At his court the young Charles was educated, and in several of Maximilian's campaigns he fought by his side. But, partly by a desire of recovering his inheritance and partly by the persuasions of France, he was induced in $\mathbf{1 4 9 2}$ to throw himself into the arms of the discontented states of Guelders. He received oaths of allegiance from them, and Maximilian was too busy to interfere. The Emperor Frederick claimed Guelders as a lapsed fief; Maximilian claimed it as the representative of Charles the Bold : still Charles of Egmont held it and fought for it until his death. In 1523 he lost his hold on Friesland : in 1528, after a brave struggle, he had to yield the ground he had won in the bishopric of Utrecht. For ten years longer he struggled by intrigue against the rising fortunes of Austria; but his intrigues disgusted his people. An attempt to induce the states to throw themselves into the arms of France brought on his ruin. They compelled him to resign his duchy to the son of the Duke of Cleves and retire on a pension. William of Cleves, who succeeded his father in that duchy the following year, endeavoured in vain to prevail on the Emperor to recognise him as Duke of Guelders and sought a French alliance; but the result was unfortunate for him; after four years of war, the details of which will come into our general survey, he was obliged to throw himself on the mercy of Charles. The Emperor contented himself with exacting the surrender of Guelders and Zutphen, and soon after, thinking it politic to separate William permanently from the French alliance, gave him, as wife, his niece, the daughter of Ferdinand of Austria. From 1543 Guelders was united with the dominions of Charles.

It was in the war in which Charles of Egmont ruined himself that the other great event of the reign had its origin. In 1535 on 
the outbreak of war between Charles and Francis after the break-up of the peace of Cambrai, great sums of money had been asked of the states by Mary, in her brother's name, towards an invasion of France. Twelve hundred thousand florins was the amount required; and a third part of this was to be procured from the county of Flanders. The States General agreed to the grant, the representatives of Flanders amongst them; but the war itself, and still more the cost of it, was very unpopular; nowhere more so than in Ghent, both from old traditionary causes and because of the injury which war was likely to inflict on the commerce of the city. And the power and privileges of Ghent were very great. One of the claims put forward on her behalf was that she should be liable to no taxation which had not received her special assent through her own deputies. When the proposal had come before the states of Flanders, Ghent refused to accede, but was outvoted, and called on, of course, to pay her share. The burghers protested against this. Their privilege should not be infringed; if the Emperor demanded their services they would march against the French in person, but the money was unfairly levied and should not be paid. If the character of Ghent stood higher in point of honesty and loyalty, we might be tempted to admire the spirit of the burghers; but, remembering how extraordinary was the privilege that was claimed and how frequent had been the struggles between the city and its sovereign, we are obliged to withhold any fervent admiration. The maintenance of such a privilege, were it authentic, could mean nothing more or less than that the policy of Charles must be directed by the men of Ghent or the supplies stopped.

The Queen tried in vain the usual means of persuasion, and at last, provoked beyond endurance, ordered the arrest of all the citizens of Ghent who could be found within the limits of the jurisdiction she was able to exercise. This only made the grievance more intolerable. The burghers of Ghent did not throw off their allegiance openly, but began to intrigue on all sides with the enemies of the Emperor. They tried to get up a league of the Netherland cities, to join first of all in a remonstrance to Charles, and obtained from Queen Mary a respite from the payment until they were able to lay the circumstances before him. He was in Spain, and with some reluctance granted the envoys an interview; but their remonstrance he declined to listen to, and sent them back to the court of Mechlin, the supreme judicial council of his Netherland estates. There, their cause was heard, and, as was to be expected, they were condemned to pay. All scruple about obedience ended here; the men of Ghent openly rebelled, arrested the imperial officers, and placed their city in a condition of defence. 
And they now looked for some fruit of their intrigues. They felt that they could look for help to no more likely quarter than France, and although the truce of Nice had been made but a year before (for the legal proceedings had now occupied two years and drifted on to the summer of 1539), although the truce of Nice had so recently put a stop to a war in which both parties were exhausted, they did not scruple to invite Francis I. to attempt the annexation of Picardy, Flanders, and Artois to France. They offered him their services to secure the conquest and form it into a provision for the Duke of Orleans, whom, as well as his father, Charles had long tantalised, by neither bestowing nor refusing the coveted duchy of Milan. But Francis either saw through the blind selfishness of the Ghenters and realised that their design was simply a mad attempt at revenge; or had hopes of a more sanguine character from the friendship of Charles. He not only refused the treasonable proposal, but informed Charles of it. His principal adviser in this policy was the Constable, Duke of Montmorency. Charles snatched at the opportunity which Francis's good offices opened. He asked for a passage across France, and received permission to take that short cut from Spain to the Netherlands. Received with great honour by the young princes, on his crossing the frontier, and by Francis himself at Bourges, he advanced to Paris, where he spent New Year's day 1540, and thence to the Netherlands.

Once arrived there he took speedy measures for punishing the rebels and asserting his authority. He brought up from three different quarters all the force he could collect, in Spain, Germany, and the Netherlands. The burghers saw that they had no chance. On February 24 his birthday, coronation day, and anniversary of Pavia, as he approached the city they opened the gates to him and entreated forgiveness. He entered as if in triumph; declared that the city of Ghent had forfeited for ever all privileges and possessions and every sign of independent administration. Twenty-six of the chief citizens were put to death, others banished; and, by abolishing the ancient constitution, he reduced the place to the condition of a town in demesne of which he appointed the magistrates, for which he made laws, and which he could tax and talliage at his pleasure. He began, moreover, the building of a citadel which would prevent future outbreaks; imposed a fine of 150,000 florins to pay for it, and an annual tax of 6,000 to pay the garrison. He continued in the Netherlands until the autumn; now settling the affairs of government; now conducting the delusive negotiations with Francis I.; and now looking towards Germany to watch for an opportunity of putting a stop to the religious movement that threatened the unity of the Empire. 
He left in October for Germany. In 1543 the war with France brought him again into the Netherlands, but his proceedings then were merely a part of the general war which I shall sketch in a further lecture. Nor need I attempt now to fix the dates of the ten visits which he mentions as paid by him to this part of his possessions, in the speech which he made at his abdication. Most of these were in the latter years of his reign, when the pressure of business kept him rushing about Germany, and not unfrequently crossing the border.

The next point of interest is the ecclesiastical condition of the Netherlands under Charles VI. You are probably aware of the great importance of this question in its bearing on the revolt of Holland and the subsequent establishment of the republic of the Seven United Provinces. Of course the causes which led to open war under PhilipII. in his earliest years must have been working during the reign of his father; and the knowledge of their working, slight as it may be (for the working was a good deal below the surface, and violently repressed as soon as it rose above it), is a necessary part of the knowledge requisite for the understanding of the reign of Charles. I hope you will not ascribe it to mere professional zeal, if I say that one of the great openings for the Reformation was made by the absence in some countries of Europe of adequate episcopal superintendence. It may have been quite one of the subordinate causes, but you will find it the rule: where the dicceses are large and the bishops few and powerful, there their temptation to secular business is the greater, the machinery of the Church is found to be loose and ill-adjusted, religion lifeless; and consequently, whether you regard the Reformation as a good or as an evil, the way for renunciation of the dominant religion is opened.

In Ireland, in Italy, in Spain, and in France, where the dioceses were small and well organised, the Reformation made comparatively small way. In Germany, Switzerland, Scotland, England, and Scandinavia, where the bishops were few and secular in their ideas or comparatively so, the Reformation made great way. But in no case was the inadequacy of episcopal superintendence more conspicuous than in the Netherlands; nowhere was there so strong political dislike to the influence of the clergy : and the result appears in the spread of Protestantism on the one hand, and in the united resistance to the new organisation which Philip II. thrust on the Church, against the will of both clergy and laity, on the other. In the Netherlands, take them altogether, four bishops had spiritual jurisdiction : the Bishop of Utrecht in the north in what is now Holland; and in what is now Belgium and French Flanders, the Bishops of Cambrai, Tournay, and Arras. The Bishop of Utrecht was 
canonically subject to the Archbishop of Cologne; the other three to the Archbishop of Rheims. That is, the fountain-heads of the two jurisdictions were external to the states, were subjects of another power, and every derivation from a power external to the states had to be guarded against, and was guarded against jealously. It was one of the privileges of the province of Brabant, that the sovereign should swear to take no measures for the exaltation of the clerical estate. The management of Church interests lay in the hands of the chapters of the collegiate churches, which abounded in the provinces ; an institution which had originated in ancient Lorraine and had its largest development in these lands. Further, the Bishop of Utrecht, under whom the northern Netherlands were, was, like his superior at Cologne, a prince of the Empire, and added in that double character, the working of which in this direction I have often had occasion to remark, the other inducements to religious insubordination and reaction which are peculiar to that arrangement of Church and State.

Under such circumstances we are not surprised to find first an early influx of Protestantism or heresy, arising doubtless from inadequate ecclesiastical superintendence; and secondly, a failure of the ordinary methods of repression by the Church courts and by increased religious action on the part of the Catholic clergy; nor is it to be regarded as monstrous that, for the supply of the latter, the organisation which in Spain had been found so efficacious for repression of concealed Mahometanism and Judaism should be introduced to put down Protestantism. Charles V., I grieve to say, as early as the year 1522 introduced the Inquisition into the Netherlands ; and notwithstanding the mildness of his own character and the popularity of the 'governantes' who ruled under him, an enormous number of persons were put to death during the forty years that followed. Charles was only twenty-two when the deed was done, of which we cannot in the least degree suppose that he could anticipate the consequences: this measure must therefore to some degree be laid to the account of his ecclesiastical advisers: but the subsequent acts of the institution, introduced by him half unconsciously, were well known to him in the years of his maturest judgment, and he must be regarded as responsible for all the persecutions that took place during his reign. Even these, cruel as they were, did not satisfy Philip II., his successor. He determined to strengthen the Inquisition by founding a strong and new church machinery, of three new archbishoprics with a proper number of suffragans to each, and by uniting, in a way in which they were nowhere else united, the ordinary machinery of the dioceses with the extraordinary machinery of the Inquisition. That measure lost him half the Netherlands ; the Catholic population objected to 
the innovation, and to the strengthening of the clerical element; the Protestant or struggling heretical population, against the additional weight and authority given to their persecutors. Philip, then, brought about a result which Charles's personal popularity would perhaps have been insufficient much longer to avert, if he had lived.

It is not an uncommon statement that the Reformation in the Netherlands was more akin to the corresponding movement in France than in Germany. If this merely means that the Dutch republics, which successfully vindicated their freedom, both religious and political, against Philip II., adopted Calvinism and not Lutheranism as their established religion, it is true: no doubt the great leaders in the revolt were Calvinist; the movement itself was in hearty sympathy with that in France against the Roman policy of the kings sprung from Francis I. ; and it may be maintained perhaps with as much show of reason that Calvinism, which generally is found in union with republicanism, except in Scotland, where during the religious struggle the government was in a very abnormal state, led to republicanism, as that republicanism led to Calvinism. But if it be meant that the Reformation in Holland and the Netherlands was owing to Calvinistic propagandism, I think it is a mistake; for it ignores the earlier condition of the religion of the country and the persecutions of the early years of Charles V., persecutions in full force when Calvin was scarcely more than a child.

A reading of the Church history of Flanders and Hainault, from the thirteenth century downwards, would show that in these countries there had been, for the three centuries before the Reformation, a great deal of religious energy or fanatical energy existing, either opposed to the teaching of the Church, or in some cases supplementing it, originating in other causes, but finding room to work in the absence or laxity of episcopal jurisdiction, and in the jealousy between the Church and State, in the several provinces to which I have just referred. Nowhere do we read more of the Beghards and Beguins than in the Netherlands; and whether we regard the Beghards and Beguins as being, as they often were, dangerous fanatical associations, or as being, what they are still where they exist, pious fraternities voluntarily originated and maintained without vows, we see in them the result of the laxity I refer to. Nowhere were the Flagellants guilty of greater excesses; or the Dancing Heretics, or the Brethren of the Free Spirit; all societies of a partly mystic, partly political, partly fanatic character, such as in the age of the Reformation was chiefly manifested by the Anabaptists. Of the good side of this sort of phenomenon, I may say that it was in Holland that the Brethren of the Common Life 
originated, founded by Gerhard Groote at Deventer in the fourteenth century; amongst whom were Thomas à Kempis and a whole school of pious mystics of the most Catholic tenets; and in which society there was a great zeal not merely for spiritual religion but for learning and for popular education, in which phase their representative man is the great Erasmus. All these, bad or good, show that long before the sixteenth century religious matters were being stirred pretty deeply, and that in Holland and Flanders, as in every other country in Europe, there must have been peculiar and local causes of revolt against Rome, which combined with and flowed on in augmentation of the great general causes of Reformation.

It is probable that the sort of tenets secretly held from Lollard times among the neglected people were akin to the Huguenot opinions of France, and that this led later to the adoption of Calvinism. But it must have been the movements of the German reformers that led Charles V. to introduce the Inquisition. Once introduced it did not rest. The first inquisitor was Francis Van der Hulst, to whom in 1523 Pope Adrian gave the commission of Inquisitor-General of the Netherlands ; a long string of names of men known only as persecutors follows down to the end of the reign. Unhappily the stringency of the instructions given them by the Emperor shows that he had too much sympathy with their work: heretics and protectors of heresy are to be inquired for, proceeded against, and chastised; everybody infected or vehemently suspected was liable to have secret information collected to overwhelm him. The inquisitors could compel evidence, even punishing the contumacious with death. They could direct the local civil officers to arrest and detain their victims; and in 1550 their authority was extended so far that it was to have its full powers notwithstanding all privileges or charters to the contrary. This is what I called the fatal stain on the reputation of Charles : not that he was a persecutor, for the age was a persecuting age and each side persecuted as it got the chance; not that he introduced the Spanish Inquisition into the Netherlands: he was accustomed to its working in Spain, he was not the inventor or first promoter of it, and he might fairly think that what was justifiable there was justifiable here; but the energy which he threw into the work, that led him not merely to tolerate, but to sympathise with, to encourage and urge the monstrous exertion of power in its most inquisitorial, its most secret, its most indefensible form, and in the destruction of thousands and tens of thousands of people, against the due operation of the laws; people and laws which alike he was sworn to defend. 


\section{LECTURE III}

\section{THE CONSTITUTION OF THE EMPIRE IN THE SIXTEENTH}

CENTURY

IN order to understand the circumstances which led to the election by the Germans of Charles, Duke of Burgundy and King of Spain, as Emperor of the Romans, it is necessary to give a glance at least at the constitution and political character of the Empire at this time. The imperial dignity was now a very different thing from what it had been in the hands of Frederick Barbarossa, much more from what it was under Charles the Great. The Karling Empire had comprised the entire Frank heritage, to which the title of Empire was an honourable but little more than honorary appurtenance : it included then, France, Germany, the intervening territory afterwards Lorraine, Burgundy, Switzerland, the Netherlands and much besides, with Italy down as far as Campania, and Spain as far as the Ebro. That Empire came utterly to an end at the peace of Verdun, A.D. 843: thenceforward France was emancipated: and the imperial title carried with it only certain power in Italy, with such rights in Germany and Lotharingia as its holder by right or by conquest was able to make for himself and enforce. From the decay of the Lotharingian kingdom and its gradual absorption in the German one, the German king began to claim a right to the title of Emperor, which, however, it required the journey to Rome and the acquiescence of the Pope and people to realise. From the reign of Otto I. (crowned 962) to that of Frederick II. every German king had been either crowned emperor, or had only been prevented by untoward circumstances from claiming to be so. And after the interregnum the same rule may be laid down; every king of the Germans was prospective emperor, though only a minority of the number actually wore the imperial crown. Every reign from Frederick II. to Maximilian's saw some material diminution in the powers and prerogatives of the emperor: Frederick III. retained very little indeed besides the insignia of the rank, the power of accepting or rejecting the elections of the spiritual prelates, the right of escheat and forfeiture where it could be vindicated, and a few others of legal rather than constitutional importance.

During the early period the crown had fallen to the head of one of the great nations, the Saxons, Bavarians, Swabians, Franconians, or Lotharingians, who made up the German people: and whilst this was the rule, the succession was as a matter of fact hereditary, 
although the ceremony of election was always gone through; generally the father obtained the election of his son in his own lifetime. The rival houses showed a constant jealousy of this hereditary succession and once or twice interrupted it ; the Saxons in particular, after the extinction of their own line, made constant attempts to interrupt the Franconian and Swabian succession, but until the extinction of the Hohenstaufen this was the practice: the great prince who was also emperor was generally strong enough to settle who should succeed him. Thus gradually, instead of the full Diet of the five nations, the elective ceremony was brought into the hands of seven electors, the Archbishops of Mentz, Cologne, and Trèves, the Duke of Saxony, the only representative of the national systems; the Count Palatine, representing the imperial household or feudal system : the Margrave of Brandenburg, and the King of Bohemia, the former of whom ruled a mixed, and the latter a non-German population. This, with some disputed votes and two additions, was the body which from the thirteenth century to the end of the imperial system in the present elected the Emperor.

With the extinction of the house of Hohenstaufen coincides in point of time the entire break-up of the great feudal dukedoms of the early Empire. Saxony had been broken in pieces under Frederick Barbarossa, Swabia was under Frederick II. : Austria had been cut out of the body of Bavaria : there were no longer any great princes who could afford to accept and maintain the dignity so impoverished as it had become: and there were a vast number that were jealous of the election of a member of any other house than their own. There was a difficulty in getting an emperor; but there was a greater difficulty in doing without one; so utterly paralysed was German influence in Europe without a recognised head, and so many titles depended upon the recognition which by law could be bestowed only by the emperor. It was under the pressure of all sorts of evils of anarchy, and after a succession of phantom emperors, that Rudolf of Hapsburg, the founder of the Austrian house, was elected King of the Germans : and from the time of his election the imperial authority, instead of being made to support itself by the power and dignity of its wearer, was made a means of enriching and aggrandising the particular house that got hold of it. Rudolf himself founded the Austrian heritage out of the marriages and escheats which his position as king enabled him to make use of ; and treading in his steps the houses of Luxemburg and Bavaria accumulated electorates and duchies among their own members. From these three houses during the thirteenth, fourteenth, and fifteenth centuries the emperors were chosen: the Luxemburgs had the longest tenure; and they united with the Hapsburgs in the mar- 
riage of Albert II. with Elizabeth of Luxemburg. Since that marriage, with one unhappy exception, Austria has furnished the emperor : the succession has not been strictly hereditary, because the ceremony of election has been gone through regularly: but wherever the hereditary principle has been departed from it has been by the arrangement of the reigning family itself.

The impoverishment of the imperial dignity reached its climax in Frederick III. : he had a very small share of a younger brother's portion of Austria proper; but as he was not the head of his house all the accumulations of the earlier dukes and of the Luxemburgers were held by others whom he was too weak, as well as too honest and too idle perhaps, to despoil. From his time accordingly the only change must be for the better, and with Maximilian the tide turned. He not only, by marriages and escheats, built up a family heritage in Germany, but by similar means made for his descendants a position in Europe which they have never entirely lost, and founded moreover a policy which they have never yet entirely forsaken: nay more, by his internal reforms he placed the imperial dignity in a really dignified position, and put an end to the anarchy of the Middle Ages of Germany. His great reforms-the establishment of the public peace, which had never been realised since the reign of Frederick II. ; his institution of the administration of the Empire in circles for the prevention and abolition of private wars, and the Imperial Chamber and Aulic Council as supreme tribunals of appeal, although they were not original, but part of the inherited policy of Albert II., who in his short reign had attempted to carry them outwere reforms of importance enough to entitle the prince who enforced them to the name of a benefactor. Maximilian was far too erratic for a statesman, but many a reputation has been won by a steadier man with one tenth of the statesmanship that he showed in these matters.

It is the fashion to ridicule the Empire under the house of Austria, as a phantom of a great power, the mere shadow of a great name: but this is very unfair. There can be no doubt as to the strength of the princes that bore the imperial title from Charles V. to Francis II. They were of the first rank of European sovereigns, although they did not wield that supremacy which since the days of Charles the Great no emperor had wielded. It was not that the imperial dignity greatly strengthened the house of Austria, but most certainly the house of Austria maintained the imperial dignity and made it a force in Europe which throughout the Middle Ages it was not. It may be said that the imperial dignity was made to subserve Austrian interests, instead of Austrian interests being made to subserve it ; but, so long as human nature lasts, is it likely 
that it should be otherwise? To suppose that it could be is to close the eyes to the fact of the existence of a variety of other powers in Germany, which would acquiesce in Austrian aggrandisement, but not in the increase of the power of a supreme institution which would depress them. Austria might increase in power, but to increase the pressure of imperial supremacy that would diminish their independence was not to be suffered. Austria therefore wisely used all her power in strengthening her position on the border lands, and exercised little imperial authority in those North German regions where her destined rival was advancing by every conceivable art into power and strength, but power and strength far too small, even to the middle of the eighteenth century, to arouse the jealousy of the imperial family.

It is no small credit then to Maximilian to have drawn the lines of such a power as this, and to have created for his descendants a position which he had never enjoyed himself. It was for his son that he secured the succession of the Netherlands, for his grandsons that he secured Spain, Naples, and the Indies, Hungary and Bohemia. Frederick III., who had spent his time in studying astronomy and devising heraldic titles and mottos, unwittingly came near to being a prophet: his device for the family flag, A.E.I.O.U.-Alles erdreich ist Oesterreich unterthan, Austrice est imperare orbi universo-meaningless in his own case, for he had scarcely a house over his head-was not so far from a true symbol under Charles V., his great-grandson. Even under Maximilian coming events only cast their shadows before. In spite of his great marriage, he secured for himself only the proper Austrian heritage, without Bohemia or Hungary as Sigismund and Albert II. had possessed them. He was therefore a poor man throughout his life; he was somewhat unscrupulous as a politician, but, as a man, wonderfully amusing and taking, one whom it is far better to smile at than to condemn : a man in whom there was much that was morally bad, but in whom also there was far more good than there is in the general run of kings.

Maximilian died, while Charles was getting into his first difficulties in Spain, on January 12, 1519; he had never been crowned Emperor, but had borne the title of Emperor-elect; nor had he obtained the election of a King of the Romans as his presumptive successor. He had left many difficulties for the successor; amongst them the Italian question; the French claims, that is, on Milan; the religious question, the excitement of Luther being now in its first phase; and, if the successor were an Austrian, the maintenance of the rights of the house to the kingdoms of Hungary and Bohemia: altogether not an easy or comfortable legacy, nor one which Maxi- 
milian, had he lived, would have had much chance of arranging successfully notwithstanding the qualifications which he believed himself to possess for the office of pope or even of canonisation as a saint. The interregnum after Maximilian's death lasted for five months, and the omission of the electors to provide him with a successor before his death had the result of making the election more a matter of debate than it had been for some generations. Frederick III. had taken months to consider whether he would accept a crown for which there was no competition; now the three greatest princes in the world competed with one another: surely Maximilian had not lived in vain.

Of course the natural successor to Maximilian was his grandson Charles ; but Charles was so well provided for elsowhere, and had already so much on his hands, that it might be questioned whether, at the age of nineteen, he was qualified to undertake more. But notwithstanding this, it is not likely that the electors would have looked or thought of looking elsewhere, if it had not been that their attention was arrested by the claims of the French king. Where could they get a worthier prince than they would find across the Rhine, in Francis I., King of France and Duke of Milan?-a man, in his own belief and that of his countrymen, whose brilliancy and splendid achievements were so extraordinary that they absolutely cancelled all his baseness, his vile life of sin, his utter want of honour and faith, his engrossing selfishness and unscrupulous contempt for anything like moral principle! Among the worst kings of France, Francis, with Philip the Fair, occupies the unenviable primacy; and Philip the Fair and Francis I. are the two kings of France who most distinctly entertained designs on Germany. There is no need to go into the argument of Robertson as to the pleas of the candidates. The proceedings of the electors are scarcely likely to have been affected by them. Francis, however, and Charles did offer themselves as candidates, and Henry VIII. of England, not to be behind in the race, sounded the electors by an embassy, but found no encouragement.

On Mid-Lent Sunday the Rhine electors, that is to say the Count Palatine and the three archbishops, met at Ober-Wesel and bound themselves over to mutual defence: Charles and Francis sent a series of embassies, and procured recommendations among their friends, and forces to back up their claims. Amongst these Leo X. supported Francis, and forbade the electors to disregard the constitution of Clement IV. according to which it was unlawful for the same person to be King of Naples and Emperor of the Romans. As it was on this very point that the enmity between the Popes and Frederick II. sprang up, it will be interesting to remark the 
permanence of the Roman policy in the matter, and the contrast or parallel, as you may pleass to take it, between the state of things in the thirteenth and that in the sixteenth century. Francis also asked for a testimonial from the Swiss, who, however, contented themselves with reporting his request to the electors and praying them to choose none but a German.

But it is time for us to ask who were the electors. At the head of them in reputation if not in rank was Frederick, Duke of Saxony, surnamed the Wise ; the friend and counsellor of Maximilian, and the founder of the University of Wittenberg. He is a grave and prudent man, the most influential man in Germany, and perhaps, except in wealth, the fittest to become Emperor. But his dominions are not great, the duchy of Saxony is a very small part of the whole nation, and Frederick has business enough of his own : moreover, he is getting on towards sixty and not likely to live long. The three archbishop electors are (1) Albert of Brandenburg, brother of the reigning Margrave Joachim, Archbishop of Mentz; he is also Archbishop of Magdeburg and Bishop of Halberstadt, thus occupying a leading position in North Germany, and is a thorough German as against Pope and Frenchman; (2) the Archbishop of Cologne, Hermann of Wied, who owed his position to the support of Maximilian; and (3) the Archbishop of Trèves, Richard von Greiffenklau, a supporter, as the Archbishops of Trèves have before been, of the French against the national interests of Germany. The other electors are Joachim of Brandenburg, who was said to be bribed by Francis ; the Count Palatine, Lewis V., who was acting as Vicar of the Empire during the vacancy; and the King of Bohemia, who appeared by deputy.

The assembly was called at Frankfort on June 17, 1519. The determination was come to, apparently, either by way of declaring the independence of the electors, or possibly in the hope of its being accepted, to offer the crown to the Duke of Saxony. He, however, refused it. The Archbishop of Mentz then proposed Charles, the Archbishop of Trèves suggested Francis. The Duke of Saxony spoke next, urgently pressing the election of Charles. The others acquiesced, the Elector of Trèves alone ungraciously. Joachim of Brandenburg weighed Francis's money against Charles's artillery, and determined that discretion was the better part of valour. The Count Palatine, whatever he may have thought, voted for Charles. According to different German authorities, scarcely any of the electors come away with quite clean hands, but these aspersions are probably to be taken for very little: Francis was great at promising money and may have hoped to secure Albert of Mentz by bribing his brother Joachim; and if the Elector Palatine were open, as was said, to the same influence, these three votes with that of Trèves 
would have given him a numerical majority. But I cannot believe that the electors were either so dishonest as to listen to Francis, or so foolish as to believe him. That he actually gave money no one can believe; he was likely enough to promise it, but the Germans were very unlikely indeed to accept his promises. On the whole the candidateship of Francis I. is one of the most impudent pieces of effrontery that come into history. It is satisfactory to know how determinedly it was scouted, and that the Pope's prohibition of Charles's election, far from weighing in favour of Francis, called forth an indignant and impassioned repudiation from the Archbishop of Mentz. The Papal representatives thereupon, agreeably to the instructions of Leo X., turned round, adopted Charles as their candidate, and offered a dispensation for holding the kingdom of Naples with the Empire notwithstanding the constitution of Clement IV.

The election of Charles was thus outwardly unanimous, and the adhesion of the Papal envoys gave completeness to the title so created. The result of the election was reported to him in Spain, and had no small share in producing the difficulties with the several Cortes of the kingdoms which we have seen prevented him from leaving that country before May 1520, nearly a year after the election. On his way to the Netherlands he took the opportunity of securing the friendship of Henry VIII. and Cardinal Wolsey, and he stayed in the neighbourhood, until he had seen that the interview of Henry and Francis at the Field of the Cloth of Gold was likely to have no permanent effect. That done he proceeded to Aix-la-Chapelle, where he was crowned King of Germany on October 23, 1520, and thence to Cologne.

The history of Germany from the death of Maximilian to the arrival of Charles, and indeed during the whole of Charles's reign, is simply the history of the Reformation, and in connection with the Reformation I shall try to sketch it. But there are a few minor points necessary to the understanding of the personncl of the Reformation history which it will be advisable to examine now, and, as nearly as we can, we may do it in the order in which they arise.

The organisation of the Empire was at this time arranged variously for various purposes. For the election of an Emperor and some other high business there was the organisation of the seven electors : for national deliberation and legislation and for the voting of general taxation throughout the German kingdom-I should say the German portion of the Empire-there was the Imperial Diet; for the preservation of peace between the sereral states there was the organisation of the circles, and for the arbitration between the princes or states in the way of appeal there were the Imperia] Chamber and the Aulic Council. 
Of the electoral system I have said as much, perhaps, as is necessary. The constitution of the Diet is probably more important ; it is also far more intricate, and marked historically by more modifications, many of which it is difficult to fix to certain dates. The word 'diet' means simply a day's journey in medieval Latin; thence it has the meaning of a day's work : and thence the work of that particular day which is set for the assembling of the estates and the despatch of important business. From the use of it to mark the occasion, it has come, like our word 'parliament,' to be transferred to the assembly itself. The Diet, then, is simply the Assembly of the States of Imperial Germany, and its constituents might be arranged under the three heads of clergy, nobles, and commons: but practically and from time immemorial this common plan had been superseded for a more complex one. There were three primary divisions: (1) the electors, (2) the princes, and (3) the towns. Of the princes there were two divisions or benches, one ecclesias. tical and one secular. These benches were again divided into (1) those princes who voted sigillatim, that is with an independent vote each ; and (2) those who voted curiatim, or in distinct colleges, as they were called, each cluster having a vote. The colleges of counts, of which there were only two at this time, those of Swabia and Wetterau, to which in the seventeenth century two more, Franconia (1640) and Westphalia (1655), were added, voted with the secular princes; the colleges of prelates voted in the same way with the ecclesiastical princes. The theory was that these inferior states had lost their full privileges by neglect; but it was an ancient neglect, for the counts had ceased to possess votes in the Diet as early as the end of the thirteenth century. The third division, that of the imperial cities, was divided into two benches, each voting curiatim, with a collective vote; this was the case since 1474 , one bench contained the Swabian cities under Ratisbon; the other the Rhenish under Cologne. The barons, 'Freiherren,' were not entitled to representation in the Diet, but for some purposes were counted as an estate and as such arranged in three circles for their own business, the Swabian, the Franconian, and the Rhenish. This, however, is by the way.

In theory this Diet had a right to examine and deliberate on every department of the imperial business; certainly no imperial taxation could be voted without the co-operation of the assembled states; but practically the machinery was unwieldy, a great deal of the business that might have been arranged in it was despatched by the provincial assemblies in the several states, and although we shall during the reign of Charles see it in very active working for many purposes, after the Reformation it sank into a sort 
of congress of ambassadors, very few of the constituents of it taking the trouble to appear.

The organisation of the circles was based on local convenience, not either on rank or on political association; it had originated in the voluntary leagues of the cities and princes formed during the latter half of the fourteenth century, when, under Charles IV. and his successor Wenzel, the central power was unable to secure any respect for authority. These leagues had been recognised by Albert II. as public organisms and arranged in circles; and Maximilian, following the policy of Albert in this as in other points, had divided the whole of Germany and the Netherlands in the same way, into ten circles, those of Franconia, Bavaria, Swabia, Westphalia, Upper Rhine, Lower Rhine, Upper Saxony and Lower Saxony, Austria and Burgundy, the last containing the imperial, afterwards the Spanish, dominions in the Netherlands. Each of these circles had civil and military directors; the offices being filled by the principal potentates, lay and spiritual, within the circle. To these directors belonged the right of convoking the estates of the circle. Each circle contributed a distinct quota of taxation, and a contingent in men and horses for military purposes. The force for which the whole system was liable was 4,000 horse and 20,000 foot ; the money varied according to exigency. A good deal of this, however, was mere theory and not likely to be called for in practice. The idea was to provide men and money to take the emperor to Rome; as a matter of fact, after the institution of circles, no emperor ever was crowned at Rome. The maintenance of peace was, however, the original purpose of the device, and for the enforcement of peace amongst powers too weak to resist the pressure it would seem to have been effective.

Of the courts of appeal, the Aulic Council and Imperial Chamber, I need not give the details : it is sufficient for our purpose to mention that as supreme tribunals of appeal they were both outward and visible signs of an imperial jurisdiction and corporate unity, and by the settling of questions which might have led to war they were useful-the Aulic Council at Vienna for the Empire and Italy, the Imperial Chamber at Speyer for Germany. It was the business of the circles to carry out the decisions of the Imperial Chamber. Neither, however, was strong enough to put down the practice of private war between princes who were rich and strong enough to wage it as states, not as mere robbers or pirates.

Such was the machinery at the head of which Charles V. found himself : complicated enough to begin with and now doubly complicated by the religious question. Although the machinery was in. fluential in certain directions, still each state, each prince, prelate, and 
imperial town possessed the right of managing, without any real check from either Emperor or Diet, all its internal affairs, its courts of justice, its commercial regulations, its internal taxation and legislation, and its foreign alliances. The actual independent exercise of such rights was, of course, qualified by the power of the possessor; but I believe that by the time of Charles V. either by grant from the emperors, or by usurpation or prescriptive exercise, every community under prince, prelate, or burgomaster had got hold of them, and exercised them whenever its neighbours would suffer it.

It is almost to be wondered that during the long period of weak emperors who reigned from Frederick II. to Charles V. Germany had not separated into a few really strong states, which would have overcome and consolidated all the weaker communities and rid themselves altogether of the slight incumbrance of the Empire. One obstacle, however, to this was the elective character of the Empire, which each state strong enough to be ambitious coveted for itself. Another was the importance and weight given to the ecclesiastical states and to the imperial cities by emperors who had everything to gain by their friendship and nothing to fear from the increase of their power. A third was the custom of dividing the heritages, and, instead of consolidating, splitting up the family territories into new principalities. This rule prevailed over all Germany, although it was not uniformly carried out. It was not until 1545 that the Bavarian inheritance was made indivisible, nor till 1621 the Austrian. Würtemberg had established the rule in 1482 , but all the rest of the princely houses had thrown away their personal unity, if not also their political strength, by this practice of division. So long as merely political interests were concerned, the families, however divided, might pull together; but the religious question was now about to set brother against brother and to make the house organisation untenable. Accordingly, from the Reformation the practice was on the decrease, but the houses of Saxony, Brandenburg, and the Palatinate, the three most Protestant of the electorates, retained it and much weakened their religious interest thereby.

If we were now going merely into the history of Germany, I should be very glad to follow into detail the broad statements that I have made: but it is the reign of Charles in its European aspects rather than its particular ones that is our chief theme, and to detail a quantity of genealogical particulars would be to throw the greater features of the period into the shade. As, however, this lecture is in its nature something of an introductory one, I may sketch, geographically, an outline of the states. Of the ecclesiastical ones at first little need be said; they had not up to this time fallen into a dynastic groove, although the succession was the bone of contention 
to the greater houses at each vacancy : a little later, 1583-1761, Cologne was held by an unbroken series of Bavarian princes. Magdeburg was held from 1513 to 1631 by princes of Brandenburg, but long before the latter date the character of archbishop had become secularised. The ecclesiastical electors very frequently held other bishoprics in commendam. Worms and Speyer, for instance, very seldom had bishops of their own; and in this way the more powerful prelates accumulated to themselves a plurality of votes in the Diet. Of the lay electorates, Brandenburg had branches both in North and South Germany ; beginning as counts of Hohenzollern, made burggraves of Nuremberg by Frederick Barbarossa ; princes of the Empire by Charles IV., electors of Brandenburg by Sigismund, they had both carefully conserved their successive acquisitions and tried on all hands to increase them. They had the electoral branch in Brandenburg itself ; the margraves of Anspach, Culmbach, and Baireuth, in Franconia, and the neighbouring lands ; and the high mastership of the Teutonic Order fell in 1511 to Albert of Brandenburg, who recovered the independence of the Prussian possessions of the Order from Poland in 1521, and in 1524 took his seat among the ecclesiastical princes in the Diet, adding thus a new territory to the Empire; which by careful plying of his interests in Poland as well as Germany he succeeded in 1525 in obtaining as an hereditary duchy for himself.

Of these different branches, the Prussian and Franconian very early accepted the Reformation; the electoral house continued Catholic until 1539. Saxony had followed the plan of division, but without the acquisitive instincts of Brandenburg, and was in 1464 broken up into the two houses, the Ernestine and Albertine, which still exist. The electorate was taken from the Ernestine house and given to the Albertine in the person of Maurice in 1548: both went on dividing and subdividing; both lines being generally Protestant until Frederick Augustus the Strong, Duke of Saxony and King of Poland, joined the Roman Church at the end of the seventeenth century. The same was the ease with Brunswick: Lüneburg became Protestant early; Wolfenbüttel comparatively late. The Palatinate also; the electorate was Protestant from 1545 to 1685, when it fell to the line of Neuburg, which had clung, with some intervals of Protestantism, to the Roman Church. Hesse continued one until the death of the famous landgrave Philip, 1561; and remained Protestant after its division between Cassel, Philippsthal, Darmstadt, and others in the next generation. Würtemberg and Bavaria made themselves indivisible; the former being Protestant from the beginning of the Reformation; Bavaria continuously Catholic. The Austrian house, I need hardly say, was never affected 
by the tenets of the reformers: of the minor states I shall say, perhaps, more than enough in discussing the Reformation.

Well, Charles V. soon discovered that if he was to retain any power in Germany, he must do it by deputy; the Spaniards would not endure his permanent settlement in a foreign country; nor would the wars which he was always engaged in suffer him to sit down quietly in his most peaceful state, be it Spain or Germany, whilst his people were being taxed at home and fighting for him abroad. Accordingly, as soon as he had perfected his own imperial title by receiving the crown at the hands of Pope Clement VII. at Bologna in 1530, he made preparations for devolving the management of Germany on Ferdinand his brother, to whom he had made over his hereditary dominions in Austria proper. In January 1531 in spite of the opposition of the Elector of Saxony, who declared the election unconstitutional, Ferdinand was elected at Cologne (Jan. 5) and on the thirteenth of the same month crowned at Aix-laChapelle.

But Charles did not, I think, find the arrangement a very useful one; for Ferdinand was not only a less prudent tactician and a more zealous Catholic than himself, both circumstances calculated to render his relations with the princes difficult; but, by his rights over Bohemia and Hungary, he had involved himself in quarrels, not merely with the Turk, against whom Charles was always ready to fight, but with the native population, of whom the Emperor as Emperor had no cognisance. Ferdinand thus had business of his own and more than enough to manage. Charles, instead of being able to leave Germany to itself, was continually obliged to visit it or to conduct the business of it in person : and towards the end of his life he no doubt thought that his brother had shown incapacity enough to warrant him in proposing to set him aside in favour of his son Philip. But the electoral body by that time had learned Ferdinand's character, and also knew enough of Philip to dislike him; nor on any theory could they consent to be subject again to the dominion of a prince so strong or with so great foreign attractions as Charles. The more continuous and dated history of these transactions we shall take in the sequel of the Reformation history. We ought by this time to bave a fair notion of the balance of interests in Germany itself as well as in Spain and the Netherlands. 


\section{LECTURE IV}

THE RIVALRY OF THE HOUSES OF HAPSBURG AND VALOIS

DOWN TO THE PEACE OF CAMBRAI, 1529

THE review which we have taken in the previous lectures of the dominions of Charles, his titles to them, and the different elements of political life which were actively stirring in each, has been sufficient to prove to us that the condition of European affairs most favourable to a prince at the head of such an accumulation of opposing influences must be peace. Peace was necessary for carrying on the commerce of the Netherlands and for the furtherance of the great designs of the Spanish discoverers in the Western world ; peace was necessary to the very existence of German unity, and most necessary for Italy, distracted at all times with disturbances within her own area, and most liable to be made the battlefield of her rival plunderers. The great cloud of Ottoman conquest still impended over Eastern Europe. Peace as a guarantee of united action against the Turks, such a crusade as \#̈neas Sylvius had spent his art and energy and very earnest labours to achieve, seemed needful if Europe was to continue to be Christian. Yet the whole of the reign was occupied with war, scarcely a year in which it was not being waged actually, or being prepared for and intrigued for by warrior and politician alike. Charles was probably himself inclined to peace for the reasons I have stated, but he was kept at war all his life and worn to death with it: in fact, the very extent of his dominions laid him open to attack on every side, and the variety of the titles by which he held them exposed him to the claims, just or unjust, of every pretender who could get the French to take up his cause. For it was of course the rivalry between Francis I. and Charles V. that created the occasion of war, and that gives the dramatic or romantic as contrasted with the political interest to the history of the period.

Low as Francis I. stands as a man and a politician, a cooler and wiser and better-principled ruler might have felt fears for France from the rapid increase of the power of the Burgundian or Austrian house. For on all sides now France was bounded by the territories of Charles ; along the northern frontier ran the Netherlands, until they joined the ecclesiastical electorates and Lorraine on the east. Lorraine was German. Switzerland was German indeed, but very anti-Burgundian and anti-Austrian, and so did afford a loophole for Francis, the net being everywhere else around him, and

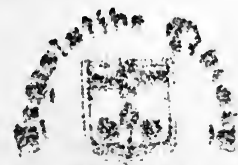


further on Savoy was open to him for a road into Italy; then came the Mediterranean and then the Pyrenees. Whichever way he turned, immediately or over a little low hedge like Switzerland or Savoy, he saw his rival keeping the look-out upon him. Yet Francis's true interest was peace also: if his rival had a great territory he had a compact one, one that had moreover, since the extinction of political life by Lewis XI., been not a hard one to rule; a country whose vast resources a statesman, if France ever had a statesman, would have done his best to develop : a country, moreover, on which his rival had no ostensible claim. But Francis also had claims on foreign possessions which he was earnest to vindicate; and he stood at the head of a nation that saw in him the very impersonation of its own qualities, gay, unscrupulous, ambitious, ruthless, false, and above all things believing in and devoted to the acquisition of glory in war.

Francis succeeded to the crown of France in 1515. At this date the state of affairs was this. The descent of Charles VIII. of France into Italy in 1494, to wrest the Milanese from Gian Galeazzo Sforza and to assert his own right to Naples, may be regarded as the beginning of modern as distinct from medieval history. It was the challenge which produced the first general war in Europe within historical times. Not that the war became general on the instant, it did not so until the whole power of Europe was divided between Charles and Francis, but it set the work going and gave utterance to the claims which perpetuated it. France had a quarrel with Naples, and a quarrel with Spain, and a quarrel with Burgundy, and a quarrel with Maximilian; but so long as Naples was under Alfonso, Spain under Ferdinand, Burgundy under Philip, and Germany under Maximilian, France could take her enemies in detail : it did not produce a general war until Charles V. united the possessions and the quarrels of Naples, Spain, Burgundy, and the Empire. With Germany France had never had a serious war since the earliest times, since the rivalry of the perishing Karlings and the rising Ottos: under the Hohenstaufen there had been close peace, and since the Hohenstaufen no German emperor had been a prince strong enough to fight with France single-handed, or to engage the princes of the Empire on his side. Nor until the consolidation of the Burgundian heritage had France been bounded by a distinct German limit on the east: for the Duke of Burgundy was a French prince. When Albert I. was offered the kingdom of France by Boniface VIII. on Philip's deposition, he replied that there was an agreement between the Karlings and the Capetians not to interfere with one another, and if he possessed much outside of France he possessed also a large stake in France to keep him 
true to his allegiance: he was a close relation and a powerful bulwark to the King of France in Flanders and Belgium and Burgundy and Franche-Comté ; that is, if he chose to be.

We know that under Charles the Bold Burgundy began to assert for herself a quasi-independence, and that it was in serious contemplation at one time that the ancient title should be revived and he should be acknowledged by Frederick III. as King of Burgundy. But, however this might have affected matters, the effect of having this great band of territory between them kept France and Germany at peace. If France was in danger from Burgundy, Germany was no less so and was so drawn to France: if Burgundy was friendly to France, so much the less fear of an alarm on the side of Germany. So with different names it had been since the time of the Crusades, the two countries were divided by states which were independent of either and which by war or peace kept the two asunder. Now all this was altered. Burgundy, in the shape of Charles V., had become a rival, and all round, the territory that had been kept off by the debateable lands before came nearer; and beyond his own borders the King of France saw nothing but Hapsburgs, Burgundians, Spaniards : they covered all the land, and a quarrel on one side was a quarrel on all. Thus it was that the invasion of Naples by Charles VIII. lighted the flame of a general war.

The war of Charles VIII. had come to an end, and in the twenty years that separate it from the accession of Francis I. many other wars had been fought, and many combinations of the European powers had been formed and broken; of these the most famous is the one which followed the league of Cambrai in 1508, formed by the Pope, Maximilian, Ferdinand, and Lewis XII. against Venice; the allies, having plundered the Republic, had quarrelled, and, in 1513, Venice and France united against the rest. The arms of the Spaniards and Germans were generally successful, and in $\mathbf{1 5 1 6}$ the war was lingering on against the wishes probably of all concerned. Francis I. was anxious at the moment for peace to secure his acquisitions in Lombardy, won by the victory of Marignano (September 1515) and the cession of Maximilian Sforza. Charles was anxious for peace to enable him to visit Spain, which he had just inherited, though by no means with a fair prospect of acquiescence on the part of his subjects ; and Maximilian also was quite willing. So this part of the drama, which is, indeed, but introductory to our proper business, comes to an end in August 1516, when the treaty of Noyon settled the quarrels between Spain and France, and that of Brussels the struggle between the Emperor and the French and Venetians.

By the treaty of Noyon, Francis, on the understanding that Charles should marry his daughter, gave up his claims on Naples. 
By that of Brussels, Verona was given up by the Emperor to the allies, Venice and the French, and Francis thus retained Milan and Genoa, being, with his allies the Venetians, and the friendship of the Pope, supreme in Lombardy. From 1516 to 1521 we get five years of peace, but they were pregnant with new wars : they were occupied by Charles in Spain from 1517 to 1520 ; and during 1519 and 1520 he was busy securing his election to the Empire, and arranging his affairs after the election, as we have seen. Thus he had no time for open war. The gap is filled up with intrigue. All the rival claims and quarrels founded on them still subsisted: Naples, Milan, Burgundy, and Navarre. The French still coveted Naples, to which Francis had claims under the will of the last of the Angevin line, the heir of King René; the Emperor coveted Milan as an escheat, and hated the sight of the French in Italy; Charles had a right to the Duchy of Burgundy, which Lewis XI. had seized as an escheated male fief, and had never let go; Navarre was still held by Spain, in spite of the undertaking made at Noyon that Henri d'Albret should be restored. Accordingly we are not prepared to find that the peace of Noyon was kept very long. Within three months a new treaty was arranged between Maximilian, Charles, and Henry VIII. of England (October 1516), by which each was bound to defend the other in case of invasion. The Pope and the Swiss were to be taken into the league, but the latter disappointed the confederates by making a perpetual peace with France about the same time.

It is here that England comes on the stage: another power as compact as the kingdom of Francis, and as ubiquitous by her naval power as the kingdom of Charles, but, unlike the two, almost impregnable against attack; like the two, ambitious and aggressive. The intrigues of England at this point are attributed generally to the ambition of Wolsey, who was alternately bribed by both parties, either with hard cash or with promises of aid in his views on the Papacy. Into a refutation of this idea, this is not the occasion to go; but I may say that the result of modern investigations has been to alter the balance of opinion against Wolsey, to show that he was an able minister, but minister to an able king, and that his character for honesty of purpose and patriotism is on a par with that of far more renowned statesmen. ${ }^{1}$ It was a period of intrigue, but the intrigues were not woven by Wolsey for his own selfish ambition, but used by him for the advancement of England, and for the averting of the two great evils, a too powerful France, which would be fatal to English independence, and a too powerful Emperor, which would be fatal to all independence in Europe. The internal causes of the English

\footnotetext{
' For the latest results of the latest investigations, see Mr. Pollard's Henry VIII.
} 
intrigues at this time are beyond our present subject: both the great rivals courted Henry, and he endeavoured, doubtless with statesmanlike selfishness, to hold the balance between them.

From the treaty of Noyon onwards an outward tendency towards the consolidation of peace continued to show itself. In October 1518 a general treaty was agreed on between Charles, Francis, Henry, and Maximilian, for the defence of Christendom against the Turks, and for the maintenance of peace against all invasion. By this treaty Henry was bound to help the party which was first invaded; and henceforth all depended on who should be first to proclaim war. The death of Maximilian and the election to the Empire changed the state of aftairs only so far as to delay any approaching break-up for a short time. In 1520 we find Charles and Francis both eager to draw Henry VIII. into a close alliance. Wolsey plans the meeting of Henry and Francis at the Field of the Cloth of Gold : Charles hears of this before it comes off, and, to get the first word, visits England in person. In May 1520 Charles visited his uncle at London; in June Henry visited Francis at Ardres; and in July he met Charles again at Gravelines. The result of these interviews was to throw Henry's sympathies entirely on the Imperial side. Leo X. now began to lcok the same way: he had the views of the Papacy and the views of the Medici to carry out, he had also the natural Italian desire to drive the French out of Lombardy. Since the election of Charles V. he had changed his views more than once : then he acquiesced in the retention of the kingdom of Naples, although a German sovereign in South Italy was at least as dangerous as a French one in North; then he had made a league with Francis for the conquest and partition of Naples; now he proposed to Charles a league for the conquest of the Milanese and the expulsion of the French. He also saw that war was coming on, and was glad to take his chance with the strongest.

But before the intrigues came to a head-and I can acquit neither party, for they did not drift into war as we do, but made preparations for it and then waited until an occasion of quarrel came-before the intrigues came to a head, Francis by his dishonesty and underhand dealing brought the whole of Europe down upon him: the death of William of Chièvres, lord of Croy, Charles's most mature and pacific adviser, in May 1521, almost exactly coincides with his first attacks upon Charles, and certainly removed Charles's last objection to accept the challenge. The war begins, but at first not overtly : Francis sends L'Esparre and Bonnivet into Navarre at the head of the forces of Henri d'Albret, which he has himself supplied, and with instructions to carry the war into Castile. At the same time, encouraged by his support, Robert de la Marck, Iord of Sedan 
and Bouillon, ${ }^{1}$ proclaims war against the Emperor. Charles very naturally complains. Henry is told that he should, according to the treaty of 1518 , attack the first aggressor, or at all events act as mediator. He gets together a congress at Calais, at which Wolsey represents him (August 1521). ${ }^{2}$ There each side puts forth all the old claims; but the news from Spain scatters negotiation to the winds. Bonnivet has taken Fontarabia. Francis refuses to restore it: there is now no hindrance to the war; and the combination is now Charles, Henry, and the Pope against Francis. In October hostilities begin on the Netherland border: in November Milan is taken; the French under Lautrec are driven out of Lombardy by Colonna and the Marquis of Pescara: in December Leo X. dies and Charles sees his old tutor, Adrian of Utrecht, on the papal throne.

But Europe was only beginning to learn what a general war means: neither party had his preparations yet available; and the year 1522 saw a languishing war both in Picardy and in Lombardy ; the advantage was on the side of Charles; Genoa recovered her independence by the expulsion of the French; Lautrec was compelled by the mutiny of the Swiss mercenaries to retire into France ; and Cremona remained the only Italian city in the hands of Francis. In the meantime (May 1522) Charles again visited England and drew the cords of the alliance closer by a new treaty, this time engaging himself to Henry's daughter Mary, as he had done at Noyon to Francis's daughter Louise; but both Charles and Francis were short of money, Henry had to apply to his parliament to raise it; and the influence of Adrian VI. was felt to be pacific instead of the reverse, as that of Leo X. had been. The business of Spain called Charles from the scene of action as soon as he had assured himself of the active co-operation of England. It was even possible that the struggle might languish on: the troubles in Spain gave Charles more work than he could manage. At all events men held their hands somewhat; the crash had yet to come.

Again Francis cut the ground from under his own feet by his quarrel with the Duke of Bourbon, Constable of France : he drove from his side the most able of his friends and furnished his enemy with a general in the first rank of the soldiers of that day, beloved by the French people, and henceforth by the natural result of hatred and desperation, an unwearied enemy and stirrer-up of enmities and deviser of evils for the perfidious king. I need not repeat the story how Louise of Savoy, the mother, and a worthy one, of

1 Bouillon, the duchy of Godfrey, was mortgaged by him to the church of Liège, which retained it until 1484, when Robert de la Marck forced them to mortgage it to him and tried to make himself duke. The title of duke was accorded to Robert IV. in 1552.

2 Treaty of Bruges between Henry and Charles, August 1521. 
Francis I., loved Charles of Bourbon: how he refused her, and she thereupon raised an unrighteous claim to the lands of the duchy of Bourbon which Charles had received with his wife; how Francis, knowing his mother to be what she was, and Charles to be what he was, allowed the wicked woman to have her way, sequestrated through the perverted machinery of the law courts the estates in dispute, and goaded the Constable into treason and flight. This was early in 1523, just as Francis was making up his mind to descend in person into Italy and attempt to renew his early triumphs.

The effect of Bourbon's flight was to postpone this design. Bonnivet was sent instead of his master: Bonnivet, the more complaisant lover of Louise, and the deadly enemy of Bourbon. Yet the air of the year was not good for action: Bonnivet found Pescara unprepared and overran the Milanese. He might have taken Milan, but he too was languid and failed to do so. His successes were very small ; but it was a great thing that Francis was able to show fight at all. Robertson sums up the year as on the whole glorious to Francis, but it is only by shutting his eyes to the intensity of the shame of the French king. Francis counts the alienation of Bourbon as a triumph, and attributes the confusion of the designs of his enemies to his own intrigues : but apparently he forgets that he has provoked a general war, in which all men are against him, and has given a just ground of quarrel ; that the storm is as yet only brewing. The one great success is the defeat or failure of the English invasion of Picardy : the greatest piece of good fortune to Francis is the death of the Pope Adrian VI. in September 1523, and the election of an Italian as his successor. This at once gave him an improved position in Italy; an Italian Pope might turn against the Germans; a German Pope would always be hostile to France : and on the side of England also Wolsey, disappointed of the Papacy, would be less ardently imperial.

But the march of events from this point becomes more rapid; the year 1524 is very eventful, nor, although the influences on which he calculated did not altogether fail him, was the result more favourable to Francis. There were three campaigns, if we may call them campaigns, succeeding one another rapidly: the attempt of Bonnivet to recover the Milanese, the invasion of Provence by Bourbon and Pescara, and the second invasion of Lombardy by Francis himself which ends in the siege of Pavia. Clement VII. refused indeed to be accessory to the attack on Francis; he was afraid that the imperial power, which whilst at a distance appeared less dangerous than the French, was growing too great for the safety of Italy, but the change in his position had not yet affected that of the other 
Italian states. Bonnivet found himself without allies and with a very insufficient army, in a territory now altogether hoștile. He was compelled to retreat, his own mismanagement being almost as conclusive against him as the tactics of his opponents. It was in a battle fought with Pescara during this retreat that the French experienced the loss of their best and bravest champion, Bayard, the knight without fear and without reproach. He fell on April 30, 1524, a date which enables us to remember the close of Bonnivet's second series of Italian disasters.

It would have been well if Charles had been satisfied and willing to make peace, but the acquisition of a general of such power and local influence as Bourbon, and probably also the counsels of the Constable himself anxious to make a bold stroke for his promised kingdom of Provence, led him to adopt a policy of aggression, the unfortunate result of which turned for the moment the tide that seemed flowing in his favour. In July 1524 he despatched Bourbon and Pescara into Provence with orders to take Marseilles. But the design was more easily drawn up than carried out. The Marseillais conducted their defence with admirable spirit of endurance and self-sacrifice : for forty days they held out unsuccoured; then Francis was enabled to bring up a large force in time to save the town. The siege began on August 7. The forces of Bourbon and Pescara, insufficient in themselves and disabled further by the divided counsel of their leaders, neither of whom had willingly undertaken the expedition, were obliged to draw off in disgrace: in September they had to retire into Italy after the sole exploit of the capture of Aix, which of course they had to leave defenceless when they retired.

Francis lost no time in making reprisals : notwithstanding the lateness of the season, he crossed the Alps. It was a race between him and Pescara which should first reach Milan. Pescara, who had returned by the coast whilst Francis crossed Mont Cenis, beat him by incredible exertions, but only by a day. That day showed him that he could not defend Milan in its present state and with his present force. He left the city by one gate whilst Francis entered at the other (October 1524). The tables were completely turned, and Francis found that the powers were ready enough to salute the rising sun. Henry VIII. had already cooled towards Charles ; Clement VII. was ready for open hostility.

It is curious, in the midst of all these complications, to learn with how small a force Charles was prepared to hold the ground against his energetic rival. His whole army, Robertson tells us, was not more than 16,000 men: most of them, it is true, faithful and trained Spaniards; but yet very disproportionate to both the extent of his dominions and the great and compact force that Francis was 
able to marshal against him. With 16,000 men, Bourbon, Pescara, and Lannoy, the viceroy of Naples, who was Charles's representative in Italy, had to hold the world, we may say, against Francis. Fortunately Francis's want of generalship was in their favour. Whilst Bourbon hastened into Germany to levy men on his own account, and Lannoy mortgaged the revenue of Naples to obtain mercenaries for the defence of that kingdom, Francis had nothing to do but overwhelm Pescara with his scanty force. But Francis did nothing of the kind : he insisted on besieging Pavia ; he invested it on October 28, a fortnight after he had taken Milan; and for nearly four months Antonio de Leyva defended it against him. Not content with thus wasting time he detached 6,000 men under the Duke of Albany to Naples, and so left himself with a diminished force, whilst the imperialists were straining every nerve to increase their own. On February 24, 1525, Charles's birthday, he attacked the army of Pescara, which was approaching Pavia in a faint hope of raising the siege or throwing provisions into the city. There he was beaten and taken prisoner; the strength of his position failed him in a moment; in a fortnight after there was not a French soldier in Lombardy; Milan surrendered without a stroke, and the fortune of Charles rose higher than ever, rose indeed high enough to excuse in a young man of twenty-five any amount of exultation and presumption.

I may as well remark here that Robertson's strictures on Charles's conduct at this juncture, and on his character generally, seem to me to be not only eminently unfair, but extraordinarily superficial. The imputation of an unbounded ambition and unscrupulous insincerity is one of the most regrettable features of historywriting. If Charles was unboundedly ambitious, why on earth did he throughout his life content himself with simply labouring all he could to secure the territory that he possessed? He was by right and title master of half of Europe ; was it a sign of unbounded ambition that he did not choose to resign the rights and dominions that he had inherited from his father? or that he did his best to establish the dominion which he held, and held for the most part without any competitor who had even the shadow of a claim? That he should regard Francis as a bitter enemy, and that he should be anxious to disable him from disturbing his authority in every country that bordered on his dominions, was a policy of caution, not of ambition. The whole of Charles's wars were really defensive wars ; his political sins and errors in the treatment of his own subjects, both as touching religion and as touching constitutional liberty, were sins and errors of defence, not of aggression; the securing, as he thought it, not the increasing of his power. We may ask, in what war did Charles ever engage without either being provoked into it 
by intrigue or acting simply on the defensive? What territcry did he ever seize that was not either his own by right or absolutely necessary to the securing of his right? An ambitious policy must be aggressive: Charles's policy was never aggressive; he made no attempt on little Portugal; Bohemia and Hungary were safe from his aggression; the Milanese he recovered not for himself but for the Sforza as against the French. In all his wars he acts like a man who knows that he has as wide dominions as he can manage, and who, whilst he will not listen to the proposal to diminish them, certainly makes no attempt to enlarge them. Nor does his insincerity rest on any better basis than wanton imputation, although I cannot say that his character in this respect was a whit better than the average political morality of his day. Anyhow, I think, having got the hold on Francis that he now had, he was in the right to take advantage of it and to show that such an adversary merited no generosity at his hand. Francis had no claim for anything but hostility from Charles. Charles at his worst. is an angel of light beside Francis.

The captivity of Francis lasted for eleven months, until Jan. 14, 1526 (treaty of Madrid). He was liberated Feb. 21, and returned March 17, 1526. During this pericd, mark first the alteration of the balance of opinion. England and Italy both saw that it would be a mistake to suffer France to be overwhelmed. Henry VIII., therefore, drew off from the Emperor, and, on the pretence that he had failed to fulfil the treaty of Bruges, by which each was bound to deliver up usurpers to those whose rights they had usurped, renounced his alliance, and concluded one with the mother of Francis, who was acting as regent during his captivity (Aug. 25, 1525). Clement VII., on the other hand, miscalculated Italian opinion and bought peace from Lannoy, paying for it in hard cash ; a payment which enabled Lannoy to quiet his mercenaries, although Charles refused to ratify the treaty. Morone, the Chancellor of Milan, the chief minister of Sforza, in whose favour Charles had been fighting, was afraid now of the imperial preponderance; he proposed to Pescara, who was offended by the transfer of the royal prisoners to Spain, a treason which should give Italy its independence and give Naples to Pescara as an independent kingdom. Pescara, however, showed himself to be above the bribe, and Morone drew down absolute forfeiture on his unlucky master. But Morone did not lose his power of intrigue, and the Pope, the Venetians, and the disinherited Sforza, with the aid of Henry VIII. as patron of the Holy League, formed no inconsiderable basis for a confederation against Charles: this was formally arranged immediately after Francis's liberation, in the treaty of Cognac, March 22, 1526. 
Whilst these intrigues were working Charles was endeavouring to get what he could out of the French king. Francis, though loth to yield, was able to comfort himself with the reflexion that promises and treaties made under compulsion were not binding. We need not, I think, trouble ourselves about the tedious negotiations. The end was the treaty of Madrid, by which Francis was released on condition of surrendering the Burgundian duchy with its dependencies to Charles in full sovereignty, and renouncing all pretensions to any part of Italy, Milan, Genoa, or Naples. He was to marry the Emperor's sister, to give up all claims of suzerainty over the Flemish provinces ; to restore the Constable of Bourbon to his possessions; to obtain the resignation of Henri d'Albret of his rights in Navarre, and to leave two of his sons as hostages with Charles for the fulfilment of the treaty. Francis, before signing, executed a secret document, formally disavowing any intention to keep the conditions : an act which simply puts him out of the pale of historical toleration : no more entire and accomplished scoundrel ever left himself without excuse. Scarcely less wicked, however, was the policy of Clement VII., who, as soon as the Holy League was agreed on, absolved him of his oath and set him free to co-operate with the designs of the confederation for the restoration of Sforza and the conquest of Naples.

Francis's intention to avoid the surrender of Burgundy was early discovered by Charles. Embassies went to and fro, Charles insisting and Francis offering money, but no agreement was come to: the war in Italy, however, continued without Francis's aid, and the Emperor had enough to do to break the strength of the league alone. Bourbon had succeeded Pescara in the command of the imperial forces in Italy, and he was able to compel Sforza to surrender Milan, and took possession of the duchy which Charles was to bestow on him as duke. Thus the Sforza branch of the conspiracy was broken. Clement VII. was next detached; and this by intrigue; Hugh de Moncada, the imperial envoy, persuaded the Colonnas to take up arms and besiege the Pope; then offered his services as mediator, and, as one condition of restoration, persuaded the Pope to recall his forces : this for the moment reduced the league to inactivity. The second great crisis of the war was brought on by the conduct of Bourbon, who indeed was in this matter hardly a free agent; for he was a desperate outlawed man, knowing that he had been deceived and victimised on all hands, and that a desperate death was his only release. He had brought down, at the end of 1526, a large force of Germans whom he was put to his wits' end to pay: men whom Lutheranism had so far touched as to make them careless of all religion, and unbridled in their appetite for plunder. Nor were they all Germans; they were, like the medieval 
mercenaries, the offscouring of the earth. To satisfy these men with plunder, he was compelled to march southwards; and as Clement had, as soon as he got his forces back to Rome, expelled the Colonnas and joined in the French attack on Naples, he directed the march on Rome, where I need hardly tell you he perished in the assault, seeking death, and leaving the capital of Christendom to sack and outrage (May 7, 1527). The news of the capture of Rome and the imprisonment of the Pope roused the whole of Europe. Henry and Francis became now close friends: the Florentines expelled the Medici; the Venetians shamelessly seized Ravenna from their friend and ally the Pope; Francis prepared for war in Lombardy and an invasion of Naples. When the measures of Henry and Francis were taken, and the mask of negotiation thrown off, their heralds formally denounced war against Charles and presented their defiance. Charles accepted that of Henry ; Francis he declared a renegade and faithless. This produced a challenge from Francis, which Charles accepted for single combat; but the duel never took place.

Meanwhile the imperial forces remained unmanageable and losing time at Rome: both the Pope and their own generals equally anxious to get rid of them. After six months of imprisonment and negotiation, Clement, in December 1527, escaped in disguise from Rome; and, the bird being flown, the armies were at last free to depart, war being now openly proclaimed. The year 1528 is full of the brilliant exploits of Lautrec, who in this last year of his life amply redeemed all his former failures. Under him the French forces reconquered Lombardy, and almost conquered Naples. With the assistance of Filippino Doria he blockaded the capital, and defeated the Spanish fleet. But the success of the French in Naples, like that of the Germans in Rome, was short-lived. It expired at the death of Lautrec by plague, Aug. 15, 1528. Nor were his exploits in Lombardy more permanent in effect. The Count of St. Pol sacked Pavia in the same month of August, but the troops were entirely demoralised. Filippino Doria rapidly changed sides at the persuasion of his uncle Andrea, and joined the Emperor, relieved Naples and then seized Genoa, where he restored the republic, so long in abeyance under French protection or domination.

These reverses convinced Francis that it was time to submit to the exigencies of his bad luck. His sons must even be ransomed: his manœuvres, intrigues, and forces had all been wasted; only he had gained time and the chance that he might in freedom make better terms than he had been able to do in captivity. His mother Louise, and her sister-in-law Margaret of Savoy, were the mediators; and by their efforts the peace of Cambrai was negotiated, to which- 
after a short campaign in Lombardy in 1529, in which A. de Leyva took the Count of St. Pol, the French general, and destroyed his army-Francis agreed. This treaty was settled on August 3. Two million crowns were paid for the release of the hostages; Francis gave up his rights over Flanders and Artois and renounced all claims on Italy; he undertook also to complete the negotiation for marriage with Queen Eleanor of Portugal. The Emperor, on his part, gave up his designs on Burgundy. So peace was made for the time; and the treaty of Barcelona, between Charles and the Pope (June 29, 1529), made shortly before that of Cambrai, restored the Medici to Florence, and abolished the papal rights over Naples, completed the general pacification.

\section{LECTURE V}

THE REFORMATION TO THE DIET OF AUGSBURG, 1530

Among all the events which give the sixteenth century its peculiar character in history none is more important than that movement, or series of movements, which goes under the name of Reformation. It is, indeed, this, with the accumulation of power in the Hapsburg family, which makes the distinctive mark between the medieval and the modern; but the influence of the Hapsburgs broke up gradually and was wasted after the death of Charles $V$. by division between the Spanish and German branches; that of the Reformation has gone on, for good or for evil, gradually gathering into itself a variety of other elements, dynastic, local, national, and political, until it has underlain, more or less near to the surface, almost every struggle since the century in which it originated. If there had been no Reformation there would have been perhaps no [French] Revolution-at all events not a revolution in which the defiance of God was as clearly and loudly proclaimed as was the overthrow of all the laws of human society; and without the Reformation the schism between North and South Germany, exhibited in the wars of the seventeenth, eighteenth, and nineteenth centuries, would have taken some other way of developing. I say this without any reflection on the tenets of the reformers. I do not say that their doctrines led the way to either of these sets of consequences : there were other causes at work, but the religious one was a good colourable cause, and it mixed with, and gave its colour to, many others which had little in common with, in particular, the cause of liberty, as it is called.

The yoke of the Church of Rome was in many respects a heavy 
yoke at the beginning of the century: an escape from it was freedom, even if it were an escape ending in the still bitterer thraldom of Puritanism. Puritanism of your own choice was regarded as greater freedom than Roman laxity if such were your father's choice for you. And so traditionally Puritanism in religion has been connected with freedom in politics; not that they have anything in common save chance resistance to one authority, an authority which the politician would destroy to substitute a more voluntary keeping of law and a greater share of individual responsibility in the subject, but which the Puritan would destroy to set up a more grinding religious tyranny of his own. I intend in this course to steer clear of the religious part of the Reformation history: as clear as I can. But it will be necessary, before we can estimate its political importance, to mention some of its causes and some of the reasons which made it an expression of the religious as well as of the political tendencies of the age. And in Germany itself, I think, it was a more religious movement than it was in England, or in any part of Europe where it was finally successful ; for there it began in religious questions, and was taken up only later by politicians. It cannot be said that, independent of political support, the Reformation has triumphed in any nation. In England its success was certainly political rather than religious. In France it was political as well as religious, and in France it was beaten. In Germany it was political after having been first religious, and in North Germany at least it succeeded. In Spain and Italy, where it was mainly a matter of religion, learning, and cultivation, it was thoroughly stamped out.

The religious movement of the Reformation was occasioned by a revolt against the doctrinal teaching of the Roman Church; the political movement by a desire amongst princes and nobles to appropriate to themselves the extensive wealth and territorial property and jurisdictions which had accumulated in the hands of churchmen. In England this took the form of the plunder of the monasteries and the greater churches; but as the bishops and clergy had no great territorial jurisdictions, they did not afford the same inducements to secularisation that the great German churches did; and there can be little doubt that, humanly speaking, it was to this, the absence of this temptation to greedy princes, that we owe the maintenance of Church discipline and organisation here; if we had had archbishops like Mentz, Cologne, Trèves, and Magdeburg in the sixteenth century, we should have had none at all in the nineteenth. Now, curiously enough, the great endowments, immunities, and jurisdictions of the German churches had been heaped on them for the very purpose the fulfilment of which was the real ground of offence against them in the eyes of sixteenth-century politicians. Some of them, no doubt, 
had been purchased by ambitious prelates, or were the voluntary offerings of too superstitious sovereigns; but the larger portion were the deliberate gift of kings and emperors who were anxious (1) to prevent private wars among the vassals of the Empire, (2) to retain in their own hands the nomination to the temporal government of some extensive portion of their dominions ; and (3) to prevent the accumulation of too wide stretches of territory in the hands of one man or of one family. The jurisdiction of the never-dying Church corporation could never be gathered in by marriage or escheat into the neighbouring lay principality; and so long as the ecclesiastical principalities were widely scattered between the territories of the jealous princes, a very great difficulty was interposed against the prevalence of private wars. Thus the secular character of the bishoprics had its good side as well as its bad; and even the bad, bad as it is, may be exaggerated ; although the prelates were themselves ministers, judges, sovereign princes, politicians, and, in some few instances, warriors, yet the spiritual welfare of the people was not wholly neglected, as might be expected. Every prince bishop had his staff of suffragans, or curate bishops, who did the spiritual work for him, and the spiritual work of the lower clergy must be freely allowed for when we are estimating by a modern standard the overengrossing secularity of the higher clergy, the canons of the chapters, and the heads of the great monastic communities.

In reading any history of the Reformation written by a German, or drawn, as most of our own are, from German sources, it seems to us curious that the German mind contrives to confound so thoroughly these two elements: it almost looks as if the writers thought the Reformation was called for as much by the faults of the episcopal system as by the Roman depravations of doctrine: it certainly looks like a consciousness that without the more vulgar, the more popular, the more easily understood cry, the religious movement would have failed to become popular amongst the classes who were then the arbiters of change. I believe that this is a mistake on their part: I believe that the ecclesiastical territories were better and not worse governed than the secular principalities, that there was less taxation and less war, more education, commerce, and care taken in the development of resources. It is impossible to blame the present holders of unpopular jurisdictions for their administration of a system which has come down to them from many generations, unless they can be shown to have refused improvement. On a broad political view the true objection is not to the existence of ecclesiastical jurisdictions or principalities, but to the subdivision of a national unity into irresponsible jurisdictions and principalities at all. Religiously regarded, the system has scarcely a redeeming feature. 
Well, the desire of increasing territory and exercising the rights of independent princes to prey upon one another was, I am convinced, the political cause of the German Reformation. And, curiously enough, in Germany as in England, the example was set in that direction by the party which afterwards was to lose so largely by it. It was Wolsey's dissolution of the minor monasteries to support his new foundation which is now Christ Church that set the inviting bait before the hungry courtiers and the greedy King; and so in Germany it was the purchase and secularisation of the bishopric of Utrecht by Charles V. which opened the eyes of the electors and other princes to the prospect of being able to round off and increase their own possessions by similar dealings. The full fruit of this does not appear until the following century, and the entire secularisation of these territories was deferred until the Revolution in which the ancient Empire itself collapsed.

Into the history of the religious movement I shall not go minutely, but I must state one or two things which it seems to me are generally overlooked or misstated. And in the first place about the invention of printing. It is often argued that the invention of printing was an important contribution to the cause of reformation, because it multiplied books and placed the means of reading and forming a judgment within the reach of all of those who had been neglected and mistaught and were now able to detect the errors and ignorances of their misleaders. This is an exaggeration-great as the power of the press became in its earliest days, it could not educate as fast as it could print, nor could the invention of printing, scarcely fifty years before-Luther began to preach, have produced any such change in the minds and powers of the people amongst whom his first successes lay. But in one way it certainly did affect the question, and that so as to put the two parties on an equality. It multiplied books and facilitated the acquisition of knowledge, but it also made the means of knowledge too common to be precious. Whilst books were scarce, books were very precious; and a man of learning was, not the man who knew how to find what he wanted in a great library, but the man who had read every book he could lay hold on and studied it and had its stores at his command. The very scarceness of books made them more greedily, more carefully studied. The learned man of the fifteenth century was a very prodigy of learning ; the learned man of the sixteenth was not the man who had his knowledge in his head, but who could refer to books. If the Roman Church had had in the early part of the sixteenth century a few such theologians as she had at the Council of Basel, she might, for the learned half of the world, have turned back the tide of the Reformation. As it was, her clergy, and even her students, were ignorant under the 
overwhelming pressure of the regenerated literature; and the adversaries were more learned, for they were the aggressors and had taken care to polish their controversial armour and look well to the weapons of defence as well as of attack. The great weak point of the Roman theologians was the neglect of the study of the Holy Scriptures.

But again the Renaissance, the restoration of learning, is sometimes alleged as a contributing cause of the Reformation, because it restored the studies of the Greek language and the New Testament in the original tongue, and in general awoke the minds of mankind to new truths. Now this is only true within a limit. It certainly opened the Greek Testament and other Greek treasures to the learned; but it was not by the learned that the Reformation was popularised nor was it popular among them, the people who did work out the Reformation were not learned in these ways. Erasmus, the typical man of the Renaissance, never left the Church of Rome. Rather I should say that the Renaissance was in its essence a pagan revival, and had little else to do with the Reformation than that it opened men's minds-that is, the minds of men who were liable to its influences- to the existence of strange forms of thought; it helped by shaking, by being one of the subordinate causes of the shaking of the fabric of society. Nowhere was the influence of the Renaissance more deeply felt than at Rome : yet was Rome enlightened by it? Nay, truly she was heathenised, and it was her heathenising that gave umbrage to the reformers and that gave them, moreover, much of their vantage-ground against her. No : although there is much in German Protestantism which is painful to an historically inclined mind, I do not think that its source was either in the printing press of Mentz or in the opened sluices of Greek and Latin paganism. During the whole of the fourteenth and fifteenth centuries, there had been an acknowledgment of the need of reformation in the Church, in her practices, and very especially in her discipline. There were unquestionably men ardently bent on reformation in these respects who were as firmly as ever attached to her dogmatic teaching; there were others whom the urgent necessity of reformation in one point led to believe in an equal necessity for reformation in another, men who in some cases, like that of Wiclif, remained in the Church criticising and rejecting the authoritative dogmas as well as the delinquent discipline; and others, like the Lollards, who went out of the Church rather than be partakers of what they thought her abominations. But in both sorts of men we should, I think, give credit to the best and most learned for a true zeal for righteousness.

The great cry in the fifteenth century was for reformation by a general council : the great schism of the West, the spectacle of two, 
three, or four rival Popes, had broken up the perfectness of the idea of unity in the Western Church: the Court of Rome had lost its supremacy, and that supremacy must be regained. It was not that reformation was objectionable, but reformation without a general council was impossible, and a general council carried to its legitimate results could not but end. in the depression of the See of Rome. That could not be thought of for an instant. And, besides this desire of reformation, there were already in different countries of Europe, although unconnected, so far as we can see, with one another, societies of men who were persuaded that they had purer and clearer views of divine truth than the Roman Church taught or suffered to be propounded to the faithful. And all these, if it were simply in the way of negation, had something in common. Such were the Waldenses of the Swiss mountains, the mystics of Germany, the Lollards in England, the Hussites in Bohemia : all of different race, of different tenets, different history, and different motives for reformation, but all at one in the rejection of the dogmatic pressure of Rome. These men had little to do with the actual machinery of the Reformation. The Lollard movement in England was a criminal one in the eyes of those who set the stone of reformation rolling: the Hussite movement in Bohemia was anti-German as well as anti-Roman; there is the utmost difficulty in establishing any actual string of connexion between the Vaudois and any reformed party ; but they were more remotely helping-causes to change. They were monuments of the existence of schools of thought and dogma which survived notwithstanding the hostility of Rome; nay, such was the Greek Church itself. All these, the negative characteristics of the Reformation gradually absorbed; and whilst they unite on the ground of common antipathy to Rome, each of them loses its individuality gradually, and is lost in the general stream of the Reformed or Protestant Churches.

Yet, when all things are considered-and I maintain that the sincerest Protestant is quite at liberty to form his own idea of the wisdom or necessity of a reformation, and of the acts of each influential reformer-nay, that he should do so as a duty, on the best information within his reach-when all these things are considered and even the lowest estimate of the motive causes is adopted, still the change is a very wonderful and historically a most important one. The accumulation at one point of time of so many various influences in one direction; the contemporaneous fruitbearing of a quantity of growths that had been advancing with no mutual acquaintance for ages; the co-operation in the same work of the mistakes and vices of Popes; the lusts, avarices, and ambitions of princes; the learning of the one side, and the ignorance of the 
other: the almost accidental appearance of some of the most powerful causes, occasions, or influences ; the divorce, for instance, of Catharine of Aragon, or the pecuniary distresses of Leo X., and the common tendency of these to the break-up of Roman powerthe coincidence of all these things makes a problem which philosophy cannot account for. We can but say with humility, 'It was so, for the time was come.'

But we must now try to form an idea of the chronological sequence of the events of the German Reformation. The opening scenes of the German Reformation are familiar to us all, I suppose: the pecuniary exigencies of Leo X., and his issue of indulgences as a means of raising money towards the rebuilding of St. Peter's ; the judicial blindness which seems to have fallen upon both the Roman Court and its servants in Germany; the barefaced imposture of Tetzel and the Dominicans, to whom the sale of the indulgences was entrusted; the grief of the religious of all sentiments in Germany ; the intense indignation of men like Martin Luther. As to the early history of Luther I shall say nothing, but simply warn you against receiving as historical much of the mythical detail which three centuries of German Protestantism have evolved out of its own consciousness touching their great national hero. For Luther is no less, and, with all his faults, is lowered rather than raised by posthumous adulation. There is no occasion even to regard him as a deep student until his indignation was roused by the impudence and impiety of the Dominicans : their outcry awoke him, friar as he was himself, and made him search to the very root of the matter. As for the dates of his life, he was born in 1483; entered the University of Erfurt in 1501 ; became an Austin friar and was ordained; in 1508 became professor of philosophy in the newly founded University of Wittenberg on the nomination of Frederick the Wise, Elector of Saxony, who stood his friend as long as he himself lived; in 1510 visited Rome and saw it in the heyday of its wickedness under Julius II. ; there also he perhaps picked up some of the cultivation of the Renaissance, as we are told that on his return he devoted himself to the demolition of the scholastic method.

Both as a teacher and as a priest he had acquired considerable influence when the sale of indulgences was proclaimed: as a scholar he knew the history of these inventions and how altogether baseless was the idea which the vendors of them attempted to spread amongst the people; as a confessor also he knew the deadly mischief they were doing to men's souls. His nailing to the door of the great church at Wittenberg his ninety-five theses was the first overt act of the German Reformation; this was done on August 31, 
1517. Maximilian, you must remember, was yet King of Germany. Frederick the Wise, Luther's patron, was Maximilian's confidential friend. Albert of Brandenburg, the Archbishop of Mentz, and, as being also Archbishop of Magdeburg, Luther's ecclesiastical superior, was a man of fair and grave mind, and far from severe, always intent on the mean, and accused by both parties in after years of a leaning to compromise; a man who, so far as Luther had yet gone, must have had more sympathy with him than with Tetzel, although it was owing to his debt to the Pope, for his pall, that the sale of indulgences was introduced into Germany. Leo and he had agreed to go shares. Nor could there fail to be much feeling in Germany, so heavily taxed already for ecclesiastical and papal purposes, on a question of money.

Tetzel was not wanting in courage: within a month after the promulgation of Luther's theses he attacked Luther at Frankfort. In January the next year (1518) the two friars had a disputation on indulgences at Frankfort-on-the-Oder. The Dominican Order took up the question. Prierias, Hochstraten, and Eck wrote against Luther, who, finding that the controversy was extending to matters of doctrinal importance, wrote to the Pope his willingness to submit, if on due examination of his opinions he should be convicted of error. The Dominican interest was strong at Rome, and the Pope was urged to summon Luther thither for trial. Leo, who cared far more about the money than the doctrine of the indulgences, after some hesitation complied, and after issuing the summons was confirmed in his determination by a letter which Maximilian had been persuaded to write in which he described the threatened division or schism in Germany. Luther was summoned to appear within sixty days at Rome; but the Elector, fearful of losing his professor and of bringing discredit on his university in case he should be convicted, forbade him to leave Germany, insisting that the offence, if it were an offence, should be tried by the competent authorities on the spot. With this demand Leo complied, and ordered Luther to appear at Augsburg before Cardinal Cajetan. In October 1518 Luther attended the Cardinal, who was himself a Dominican and a very learned sch lastic: it was unfortunate that he should be made judge in a cause in which the interests of his order and even those of scholasticism itself were involved. Luther was treated by him as guilty, and ordered to recant. He replied by an appeal to the Pope when better informed. Leo, without taking the trouble to inform himself, published an edict (November 9, 1518) requiring all Christians to believe that he could remit the penalty of all sins : Luther replied (November 28) by appealing to a general council.

Cajetan having failed, the divine and scholar, Leo chose a new 
sort of legate, Charles von Miltitz, a Saxon instead of a Rcman, a knight instead of a friar, and a canonist instead of a scholastic; and with him sent to the Elector the golden rose. Miltitz, in 1519 and 1520 , had several arguments with Luther, and on one occasion even prevailed on him to submit so far as to promise to be silent if his adversaries would let him. alone. But his adversaries were not so accommodating. Eck on the Papal side, and Carlstadt on the side of Luther, would have a disputation on free-will at Leipzig, July 1519 ; and when they had done Luther and Eck had a discussion on the power of the Pope. Neither convinced the other, but Luther so offended Eck that he posted off to Rome and there persuaded Leo, without regarding the mediation of Charles von Miltitz, to publish a bull of condemnation of the tenets of Luther. This was done June 15, 1520. Maximilian had died a year ago, and although Frederick the Wise was staunch to Luther he had not much to hope from the new Emperor-elect. Yet Luther was bold enough to challenge both Church and State. He burned the bull and a copy of the canon law with it (December 10, 1520), and three weeks after, January 4, 1521, was excommunicated by a second bull.

Leo did not confine himself to spiritual sentences; he urged the Emperor Charles, who was still in Germany, to punish the refractory friar, who, having gained notoriety and gathered friends, the chief of whom was the learned Philip Melanchthon, was teaching heresy with more popularity than ever. Charles was very much attached to Frederick, and determined that Luther should have fair play: but he could not refuse the Papal request. He summoned Luther therefore to Worms ; and before the Diet, which also was a national or provincial council of the German nation, Luther argued his own cause on April 17 and 18, 1521. Charles had promised him a safe-conduct, and this promise he was determined not to break; Luther was suffered to depart before the sentence was pronounced; but when it was pronounced it was conclusive against him. The Emperor and the princes declared him and his proselytes to be enemies of the Empire and to be treated as such. And Frederick, fearful of something worse happening to him, carried him off to his castle on the Wartburg and kept him quietly there for ten months; he returned to Wittenberg in March 1522. Leo X. by that time was dead, and, we may charitably suppose, had learned the true value of an indulgence.

Adrian VI. was a better and wiser man; but he could not afford to spare Luther: he sent to the princes praying that the sentence of outlawry against the reformer might be duly executed; and he would promise a remedy of the evils which had caused him to be tolerated. The princes replied by demanding a freer council, and presenting a hundred gravamina, waiting for the redress of these 
before they would trouble themselves about Luther. So he had rest during the life of Adrian. Clement VII., who succeeded in November 1523, was a different man. He was a Medici, an Italian, and a kinsman of Leo X.; he was ready to insist on the punishment of Luther. Cardinal Campeggio, in a Diet at Worms in 1524, and the Emperor also, by his minister, urged that it should be done. The princes were willing to use Luther as a tool : they were ready to sacrifice him if he must be sacrificed, but until they were obliged to do so they would keep him as a pledge for the future reforms. When the reforms were settled Luther might go. He had really but a small number of powerful friends; the Duke of Saxony was as yet only a protector, not a proselyte: his chief followers were among the learned in the universities and the burghers in the free towns. Still he profited by the determination of the Diet for reform : all questions besides that of a council were postponed to the next Diet at Speyer : the legate, with a number of prelates, adjourned to Ratisbon and there prevailed on them to undertake to carry out the sentence in their own dominions.

But now a storm had arisen on which neither Luther nor his adversaries had calculated, and which served at least to gain timethe Peasants' War of 1525. Luther's enemies laid the blame of this insurrection on the new religious teaching, unfairly, for Luther both preached and wrote laboriously against the madness of the people. Whilst this continued nothing was done with regard to religion. The Peasants' War ended at the battle of Mülhausen in 1525. It was not until 1526 that the Diet of Speyer assembled. By this time two great events had changed the prospects of the reformers. Frederick of Saxony died in 1525, and Luther, instead of a mild protector such as he had had in him, gained in his successor, John the Constant, an enthusiastic supporter. By John's endeavours, Philip the Magnanimous, landgrave of Hesse, was brought over; George of Brandenburg-Anspach, finding that his subjects in Franconia were eagerly receiving the new doctrines, visited Luther privately and came away a convert; so that at the Diet the reforming party was not unrepresented in the highest benches. But a second point was this : the controversy with Rome had now developed far beyond the question of indulgences or even that of the power of the Pope himself. Luther had begun to study the books of Holy Scripture deeply, and had translated and published them one after another. Other schools of reform had sprung up prepared to go to much greater lengths than Luther : on the Sacrament of the Lord's Supper there was a division between the Swiss and Germans; nay, there was a schism within the Lutheran body, if it can be called a body, itself. But this is not a question for us now. 
The first Diet of Speyer met in 1526 : Ferdinand of Austria presiding as his brother's representative. It went off in every way like the former ones. The Emperor insisted verbally on the execution of the sentence of Worms, but also that all contention on the subject of religion should cease. $\mathrm{He}$, however, took no measures to carry out either one command or the other. The princes, as usual, prayed for a free council, and urged that, until that should be held and the points in debate decided, all should be allowed to think and manage the religious affairs of their estates as they thought fit. These wishes were embodied in a petition to the Emperor, who was now (1527) actually at war with the Pope.

Again the secular quarrels gave the reformers a respite from persecution, and they now began to form themselves into something like a party organisation. The German states had always conceived themselves at liberty to form voluntary associations, leagues, or confederacies, for the carrying into effect of designs not proscribed by law, or which the law, as administered in Germany, was unable to carry into effect for itself. Such leagues were those of the fourteenth century between local clusters of states for the purpose of enforcing peace: such was the Vehmgericht, more or less, in Westphalia : and out of these voluntary associations Albert II. first, and Maximilian after him, had created the system of jurisdiction by means of circles, which had done so much since the century began to consolidate and pacify Germany. Some such association had been created by the princes for the putting down of the Peasants' War in 1525; that had suggested to the more papal of the princes a similar confederacy against the reformers; and this fact, or the suspicion of it, had moved the reformers to adopt the same plan. In May 1527 the Elector of Saxony, John the Constant, and the landgrave of Hesse, Philip the Magnanimous, joined in a league for mutual defence; and they were soon joined by some of the free towns. John the Constant further held a visitation of his dominions, in which Luther and Melanchthon took part; and finding the ignorance of priests and people beyond what they had imagined, Luther undertook the composition of Catechisms for them : new forms of worship were introduced into Saxony, and the Elector took advantage of the absence of the Emperor and his quarrel with the Pope to make proselytes in every quarter. But of course this state of things could not continue long. The day of grace drew to a close when Charles signed the peace of Barcelona in 1529 and embarked for Italy to receive the imperial crown. Preparatory to this peace the second Diet of Speyer was held in the spring of 1529. In that assembly the resolution of the Diet of 1526 was rescinded: instead of leaving each prince free to manage his own religious affairs, the Diet determined to enforce uniformity; 
and prohibited as unlawful all changes in the worship of the Church, until the council so often asked for should be at last held and should decide. This was a reversal of the policy of the former Diets, and was probably a concession to imperial pressure. It fell heavily on the newly formed association; and John of Saxony and George of Brandenburg publicly remonstrated against it. Their remonstrance took the juridical form of a protest, which was handed in to the legate and Ferdinand on April 19, 1529; and the title of protest earned for the remonstrants the title which has since become common to all the reformed communities of Protestants. The protestants on this occasion were John of Saxony, George of Brandenburg, Ernest and Philip of Lüneburg, Philip of Hesse, and Wolfgang of Anhalt: all, you observe, except Brandenburg, the strength of which lay in Franconia about Nuremberg, all North German States under the influence of the Saxon Elector, and perhaps scarcely less under the influence of the old Saxon spirit; strong in personal piety, and also strongly opposed to an imperial policy. The fourteen imperial towns which joined them were chiefly in South Germany, where indeed free towns abounded more: the chief was Nuremberg, but Strassburg, Ulm, and Constance were also of great importance; nor had the others as yet sunk into that torpor, commercial and political, into which they afterwards subsided.

But a mere protest did not, however well supported, carry with it the effect of law. The Emperor himself was coming shortly into Gerrnany, and for him a declaration of the tenets of the reformers must be prepared. Luther drew up the basis in seventeen articles : which were rearranged by Melanchthon in scholarlike form in twenty-eight: and these, known as the Confession of Augsburg, were presented to Charles at the Diet there on June 25, 1530. With the presentation of the Confession and the consequent formation of the Smalkaldic league, which was in reality but the organisation of the earlier league of 1526 , with extended purposes, the first phase of the German Reformation ends.

\section{LECTURE VI}

WARS OF CHARLES V. FROM 1529 TO THE TRUCE OF NICE, 1538

We have now brought down the history of Charles, in a sort of outline, to the peace of Cambrai, and, anticipating a little, the process of the German Reformation to the second Diet of Speyer, the date at which it becomes a political as well as a religious movement. 
Hitherto, with the exception of the campaign at Pavia, the main interest has lain outside of Italy, although it was in Italy and by Italians that the strings of politics were in a great measure pulled. Charles himself had been occupied chiefly in Spain, somewhat in the Netherlands, somewhat in Germany. Now, however, we have to take him to Italy. We can no longer object to run our heads into the wonderful cobweb of Italian politics, and we must go there awhile to note the springs of the changes that were now about to take place. For a change of partners and pieces is coming on. Bourbon and Wolsey are disappearing : the connexion of Charles V. with Henry VIII. is broken, and a close league between England and France has now succeeded : the Reformation and the opposition to it are changing their character, or the character of their weapons of warfare; and we look for the beginning of a new period during which the successes of the Emperor will no longer be as decided or continuous as they have hitherto been. From 1522 to 1529 Charles had been in Spain; in August 1529, after signing the treaty of Barcelona with the Pope, he embarked on board the fleet of Andrea Doria, and landed at Genoa on the 12th of the same month. I propose now to take a review of the state of Italy, territorially rather than politically, from the beginning of the century, so as to enable us, in some measure, to unravel some of the leading complications which in the earlier lectures we have had to take for granted.

The kingdom of Naples has, throughout medieval history, a more puzzling series of revolutions than any other state in Europe, Hungary excepted. For our present purpose, however, it is only necessary to remember that Sicily had, since the thirteenth century, belonged to the royal house of Aragon, whilst Naples had been held by princes of the two lines of Anjou, French in origin and by alliance. In the middle of the fifteenth century, Alfonso of Aragon had got possession of the mainland as well as of the island, and henceforth the Angevin kings, of whom René, father of our Queen Margaret of Anjou, is the best known to us, had been titular only. Alfonso had left Naples to an illegitimate son: Sicily and Aragon going to his brother, John, father of Ferdinand the Catholic. The illegitimate dynasty was ruined by Charles VIII.'s invasion of Italy, one object of which was to vindicate his right to Naples, as testamentary heir of the Angevin race of kings : but the French influence was short-lived: Ferdinand of Aragon stepped in and ousted both competitors, proclaimed himself the successor of his uncle Alfonso, and, supported by the victories of Gonzalvo of Cordova, the last Spanish hero of the medieval type, maintained himself from 1501 onwards in Naples, and left the kingdom to his grandson Charles in 1516. From the date of Ferdinand's conquest, Naples was governed by 
viceroys. Gonzalvo of Cordova was the first ; Don John of Aragon, Count of Ribagorsa, the second. Don Raimond de Cardona was viceroy at Charles's accession; he died in 1522. Charles de Lannoy, a Fleming by birth, was the next viceroy; he, as we have seen, was Charles's general in Lombardy after the death of Bourbon, and he it was who had the task of repulsing the attacks on Naples which followed the peace of Madrid ; he died, however, in 1527. His successors were Hugo de Moncada, who fell in the attack of Filippino Doria on Naples in 1528; Philibert, Prince of Orange; Pompeo Colonna, 1529 ; Pedro de Toledo, marquis of Villafranca, whose viceroyalty lasted until 1553. These viceroys had their authority fettered by what was termed the Collateral Council of two, three, or four regents, as they were called, one of whom attended on the King in person to advise him on Italian subjects. In lieu of a single regent in attendance, Philip II. in 1558 instituted an Italian council. The effect of this machinery was to withdraw the several departments of government from native hands to Spanish ones, and so to prevent the cordial union of the countries. But the assembly of the estates, the nobility and commons, on the strictest feudal model, continued to be called, and by it only taxation could be decreed.

Proceeding northward we come on the Papal dominions. Since the century opened we have seen four very conspicuous Popes, Alexander VI., Julius II., Leo X., and Clement VII. : and we may trace in them the development of a new and altogether secular policy on the part of the heads of the Church ; the determined purpose to found in their own families, not merely a noble and wealthy house within, but a territorial principality outside the States of the Church. Alexander VI. had done this for Cæsar Borgia, and Julius II. for his nephew Francesco Maria della Rovere, out of the duchy of Urbino. Paul III., later on, did the same for the Farnese out of Parma and Piacenza. Leo X. and Clement VII. devoted their political influence to establishing the sovereignty of their own kinsfolk, the Medici, in Florence. At the end of the century the Papal policy changed, and Urbino (1631) and Ferrara (1597) also were added to the estates of the See.

As we advance northwards we come on the territories of the republics, many of which still existed. Florence itself at this time was in name a republic ; nay, for the two or three years of its revolt from the Medici, from the capture of Rome to the peace of Barcelona, it had resumed its democratic institutions. Siena and Lucca were still republics; the latter retained the character until the eighteenth century. The rest of Tuscany was dependent either on Florence or, in the form of feudal vassalage, on the Empire. North 
of Tuscany were the ancient duchy (a marquisate until 1457) of Modena, possessed by the house of Este, the marquisate of Mantua, created out of a republic by the Gonzagas, the duchy of Milan, also created out of a republic, and containing or ruling Parma and Piacenza also, which, however, from 1521 to 1534 belonged to the Popes, and the Venetian estates, which, themselves republican, had achieved their present extent by absorbing their neighbours, whether republican or feudal, to an unprecedented extent. Beyond the territory of Milan were Montferrat and Piedmont, both ancient fiefs and not republican; along the coast was the state of Genoa, republican in form, but divided between two aristocratic factions, one French (Fregosi) and the other imperial (Adorni)and from time to time actually under the protection, that is, in the possession, of France. That dependence ceased in 1528 by the return of the Dorias, and its emancipation was an article of the treaty of Cambrai. Genoa, I may remark, had been from the time of the crusades attached to France, the rival city of Pisa being imperial or English as the case might be.

So was Italy cut up: it inherited in the fullest measure the traditions of ancient hatred. Every little prince was by hereditary politics a Guelf or a Ghibelline. Though the last of that great historic quarrel had been heard of in Germany only 300 years ago, it had subsisted all along in Italy, and in every republic there were two parties, Guelf and Ghibelline, Imperial and Papal, or German and French. All these complications it is impossible to keep in mind, greatly as it is required for the understanding of Italian history: for, especially in the cities and in the more contested fiefs, the parties changed sides more than once. Besides the French and German political affinity, there was a strong hatred of any foreign interference at all. Intrigue was used against intrigue; the art of Italian diplomacy was to weary out one foreign party by means of the other ; the fault of it was that, when both foreign parties were worn out, the Italians themselves fell to struggling and called them in again.

Political interest centres in three of the strong powers, the duchy of Milan, the republic of Venice, and the house of the Medici at Florence. The interests of the Papacy do not change, although with the change of hands its modes of action and the particular families that it favours change. The empire and the kingdom remain opposed to the independence of the republics, and jealous of the assumptions of the princes, but willing to tolerate the former so long as their own party is in the ascendant, and glad to win over and attach the latter by marriages, or by cheap grants of privileges which the grantee must employ and exhaust his energies in securing for himself. 
We have not now to examine how matters had got into this state; the circumstances from which it arose were, however, common to Italy and Germany. The Italian republics were really nothing nore elevated in origin or idea than the imperial free towns of Germany, and, like the free towns, they had flourished by means of trade, and decayed when, in place of trade, they took up politics; but otherwise their history was distinct. The German towns were imperial in feeling as opposed to the aggressions of the great feudatories; in Italy the nobles and princes were more imperial than the towns; the latter were the aggressive and perhaps also the more purely national ingredient. But the internal struggles of the Italian republics, their incessant changes of democratic forms, the minutiæ of their organisation, are little more worthy of examination than the vagaries of a parish vestry. As the struggles of a nation they are respectable, but in general the further removed they are from extraneous influences, the more bitter their internal quarrels, the more engrossingly powerful their suicidal mania. One great advantage of the study of the present period of history is that you need not load your memory with these petty details. The duchy of Milan was the great bait for the French in Italy; the supremacy in Florence was the great end and aim of the Medicean Popes; the humiliation of Venice was really a great object with all the sovereigns, and had been openly attempted by the league of Cambrai.

Up to this time we have seen how these influences have worked. The Milanese has been the battlefield and bone of contention between Charles and Francis, the house of Sforza being the shuttlecock: it was this that brought Francis into Italy for his triumph at Marignano; for this he fought and was taken at Pavia. Here was the last struggle before the peace of Cambrai. For the Medicean ascendency Leo X. had favoured first Francis and then Charles in the competition for the imperial crown. Florence was lost to the Medici when Clement VII. played the double game that drew down Bourbon upon Rome, and was now to be recovered for them by Charles himself as an article of the treaty of Barcelona. This was the first thing to be done in Italy, when Charles made his appearance there in 1529. His object, however, was nothing less than the pacific action of Italy and the obtaining from the Pope a promise to hold a council that might pacify Germany also.

He left in Spain as regent his wife Isabella of Portugal, whom he had married in 1526, and he now intended to receive the imperial crown. He landed at Genoa on August 12, 1529, and his presence alone seems to have inspired confidence; he conducted himself with the same solid moderation which he had shown latterly in Spain and Germany. Whatever harsh or cruel work had to be done, was 
ever done by the subordinates; in the face of the Emperor-elect were always to be found clemency and sincerity. On November 5 he entered Bologna, where he was to be crowned; and there he summoned the princes and representatives of the States, which had all, with the exception of Florence and Venice, sent to meet him with addresses of congratulation. And everyone seemed to get what he wanted. Francesco Maria Sforza was reinvested with Milan (December 23), and received a niece of Charles as wife. The Duke of Modena was confirmed (March 1530) in the possession of Modena, Ferrara, and Reggio ; the Marquis of Mantua (March 1530) was raised to the rank of a duke. Venice made peace on December 23 on condition of restoring the places which were unlawfully seized during the war, and the same day concluded with Charles and the princes of Savoy, Milan, Montferrat, and Mantua a league for the entire pacification of Italy. Only Florence, which had been besieged since the end of October, held out. At last, after six months spent in Italy, Charles received the crown of Lombardy at Bologna from Pope Clement on February 22, and on the 24th of the same month, his birthday and the anniversary of the battle of Pavia, the crown of the Holy Roman Empire. Charles was the last crowned Emperor, and he was not crowned at Rome.

Florence was still holding out at the time, and held out until August 12, 1580 : the imperial general, Philibert of Orange, having been killed in a sortie on the 3rd of the same month. Charles immediately restored it, according to the treaty of Barcelona, to Alexander de' Medici. He had, however, before this time left Italy to attend the Diet summoned at Augsburg for April 8, but at which he actually arrived on June 13. Sismondi regards this visit of Charles as accomplishing the evil destiny of Italy; and in some respects it did so, but it was a case in which the destiny was a less evil than the suspense from which it delivered Italy; for, for sixand-thirty years, since the invasion by Charles VIII., the unhappy country had been the battlefield of foreign armies, had been ravaged, sacked, and plundered indiscriminately by friend and foe. The subjugation of Italy to German influence dates from this time, and from the league of Bologna concluded in 1532 for the peace of Italy. The question of the evil or good of this is one that we shall answer according to our own political prejudices. If it be a bad thing for one nation to be ruled by another, one race by another, not for its own good but for the good of the ruler, and against its own will, and by means that only constant political intrigue and insubordination in the subject people can justify, then it was a bad thing for Italy to lie at the mercy of Austria. But if it is a necessity to the world that nations which cannot govern themselves, which, when they are 
left alone, turn their weapons against their own throats, which are constantly inviting foreigners to arbitrate in their quarrels, which are as constantly, by their intrigues, fomenting wars between stronger powers-if it is a necessity that such a race should in the end fall under a foreign yoke, Italy richly deserved what she got, and so far it was for the good of the world. She exchanged the shadow of liberty for the substance of peace.

Well, in the spring of 1530 Charles left Italy for Germany, and there busied himself for some time with the religious quarrels, the aspect of which was becoming threatening. In 1532 the urgent necessity for a council to unite Christendom in reform of doctrine and to defend it against the impending conquest by the Turks, brought him again into Italy and to Bologna; and in the second interview with Clement (at Mantua, November 8, 1532) the league for the defence of Italy was reconstituted. All the states except Venice were included; an organised confederacy, with definite contributions and contingents, was formed, and at the head of it was placed a Spanish General, Antonio de Leyva. The business of the council the Pope temporised about. The league was arranged on February 24, 1533, and Charles immediately afterwards sailed for Spain, taking with him the Spanish troops, whose presence was offensive to the Italians and whose place was to be filled by the forces of the new confederation. (He landed at Barcelona in April 1533.) He left Italy, for the first time for nearly forty years, at peace. And nominally the peace between Charles and Francis did continue until 1536. In reality Francis was employed during the whole of that time in undermining the influence of Charles amongst his neighbours, and preparing for another war. He had already, in 1525 , opened a secret negotiation with the Sultan Solyman; in 1534, alarmed by Charles's naval preparations in the Mediteranean he concluded a treaty of commerce and mutual defence with the great enemy of Christendom. In $\mathbf{1 5 3 2}$ he had made another alliance with the Smalkaldic League at Esslingen; in 1533 he entered into the closest relations with the Pope, and even accepted as a wife for his son, afterwards Henri II., Catherine de' Medici, niece of the Pope and of a house as famous for its sudden rise to sovereignty as it was remarkable for the meanness of its origin and the brilliant versatility of its politics. He was also now drawing more closely to England than any French sovereign had done before, and aiding Henry VIII. in his plan of getting rid of Catherine of Aragon. Of these negotiations, that which was most dangerous to Charles was the one with the Pope, and to frustrate this he offered to marry Catherine de' Medici to the Duke of Milan, to the disparagement of his own niece; but Francis was too quick for him, the marriage was arranged so as care 
fully to avoid giving the Emperor a reasonable ground of offence, and to keep him still more in good humour he was allowed to manage the business of the English divorce in his own way. This was, however, soon taken out of his hands by the resolution of Henry; and the imperial influence exhausted itself in those fulminations against him and his people which recoiled on the Papacy itself and ended in the English Reformation.

Matters crept on towards a warlike solution. Francis was gaining time, and Charles always benefited by peace; besides, he had other enemies to meet, and the defence of Christendom rested solely on him. The death of Clement and the succession of Paul III., Alessandro Farnese, a strong imperialist, also had the effect of changing the tactics of the players. This event took place in September 1534. The general history of the period is diversified by the expedition of Charles to Tunis and the revolt and extermination of the Anabaptists in North Germany, both incidents which belong to another part of our scheme. The new storm rises again in Milan but breaks in a new, though still an Italian quarter. Charles had by this time returned from Tunis, September 1535, and was staying in Sicily and Naples enjoying his triumph, and received everywhere by his barons with the greatest magnificence. He was thus employed when the news reached him that the Duke of Milan was dead, and that Francis had seized Savoy and expelled Duke Charles, the Emperor's brother-in-law. The news of Sforza's death was to him simply the news of an escheated fief; but it was speedily followed by a demand from Francis of the investiture of the duchy for the Duke of Orleans, one of the vague promises which, both before and afterwards, the Emperor held out, or suffered Francis to believe that he did, in order to gain time.

In the matter of the Duke of Savoy, Francis appears in the new character of a bully. The Duke was not a very wise man, but he was wise enough to know how to give way when there was no chance of success in resistance. And accordingly, when Francis, who wished to pick a quarrel that would justify him in annexing Savoy, demanded a passage through his territories, he immediately allowed it. Francis - who, by the by, was nephew of the Duke, Louise of Savoy, his mother, being the Duke's half-sister-then insisted that all the demands which he had on Savoy, either as King of France or as son of the Duchess Louise, should be satisfied. The Duke could not undertake to do this, and his dutiful nephew thereupon drove him out of Savoy, plundered him of all that he had, and occupied his fortresses. Francis's errand to Italy was, however, originally intended for the chastisement of Francesco Maria Sforza, who had assassinated Merveille or Maraviglia, an envoy of Francis, with 
whom he had been transacting treason, and who he feared might betray him to Charles. Francis had seized Savoy on his way to avenge this breach of international law, when he heard of the death of Sforza (October 1535). On this he withdrew his army, retaining, however, the strongholds of Savoy, and betook himself to negotiation. The Duke of Savoy, who had married a daughter of the King of Portugal, threw himself on his brother-in-law's protection, the revolt of the Genoese, which had been prompted or connived at by Francis, leaving him quite landless. Francis acted foolishly in this. He had intended war, and might have taken Milan, if he had proceeded at once on the news of the Duke's death : by opening a negotiation with the Emperor he simply gave him all the advantages of delay; he could not hope to overreach him in negotiation or to baffle him in intrigue.

Charles was prompt to take all the advantage afforded by Francis's hesitation; he played him with promises and half-engagements until he had got together supplies for the war. These supplies the Neapolitan kingdom afforded. Taking advantage of his personal popularity, he called a Parliament (January 8, 1586) at Naples and asked for a subsidy. The request was most liberally answered. The Neapolitan barons saw the imminence of danger to their coasts from both Francis and his friend Solyman: it was better to give their money to Charles for defence than to be plundered of it by the corsairs. They voted a million and a half of ducats, three-fourths to be paid by the nobles and the remainder by the towns. So well furnished with money, Charles proceeded on March 22 to Rome: he had already ordered levies of troops in Germany, and, peace being still maintained, provoked the fears and suspicions of Francis. Early in April he reached Rome, and there, in an assembly held by the Pope and cardinals, he declared his grievances against Francis in the most vehement terms. He ended by professing himself ready to meet Francis in single combat.

Robertson makes, on this speech, which doubtless was intemperate and imprudent, some characteristically unfair comments. The idea of the single combat had been broached by Francis himself before the outbreak of war in 1528, and should not therefore be regarded as an insane whim of Charles : in other points Francis had deeply injured the Emperor, he had taken advantage of his exigencies, even when he was at peace with him, he had broken faith continually, and never for a moment stopped the most selfish and unscrupulous intrigues with the Sultan on the one side and the discontented princes of Germany on the other. Francis could have heard nothing from Charles that he did not deserve, although Charles's conduot touching Milan had been far from immaculate towards him. 
The Emperor's appeal seems, however, to have startled all parties. The Pope earnestly pleaded for peace; and Charles himself condescended to make such an apclogy for his language about Francis, as induced him to continue his negotiations. Nevertheless he must have considered his speech equivalent to a declaration of war, for the King of France still continued in occupation of Piedmont, and Charles, having got together an army of 40,000 men, proceeded northwards. He designed, we are told, no less a scheme than the conquest of France; not content with carrying out the attack on Provence, which he had seen fail under Bourbon, he planned an invasion of the north also from the side of Flanders. The campaign of Provence he reserved for himself.

Francis's army of Piedmont retreated before him; the Marquis of Saluzzo, a Savoyard by allegiance, to whom Francis had entrusted the Piedmontese fortresses, turned against him and betrayed his trust to Charles; but for the siege of Fossano, which detained him a month, he would have taken Francis unprepared. He reached the Var, which divides Piedmont from Provence; his army under Antonio de Leyva, his fleet under Andrea Doria: with fifty thousand men he crossed the river on July 25 and proceeded towards Marseilles. But Marseilles a second time proved impregnable: after a fortnight's hard work, to his intense mortification, he was compelled to raise the siege, and to return with the loss of half his army.

Francis, or rather Montmorency his general, had devastated the country before him so that he could not advance, and had skilfully avoided any risk of a general engagement. The siege was raised on September 11. As scon as he reached Genoa, unable to face the Italians after so great a reverse, he embarked for Spain in October. This was the greatest reverse that had ever befallen Charles: and he had lost his best general, Antonio de Leyva, as well as the prestige of all his former successes.

The invasion of Picardy by the Count Henry of Nassau was not so prosperous as to counterbalance the misfortunes of the imperial army in the south : the nobles armed, and the fortresses held out. The Count had to retreat like his master. Montmorency, the general personally opposed to Charles, gained the chief glory of the struggle, which Francis would have risked by a battle; the same cautious policy, however, probably threw away the chance of overwhelming the enemy on his retreat. Francis's triumph was saddened by the loss of his son, the Dauphin, who died on August 12, and whose death he did not hesitate to accuse Charles of causing, although others attributed it to the machinations of Catherine de' Medici, anxious to make a way for her husband to his father's 
throne. Neither story, probably, is in the least entitled to belief. So the year 1536 ends in the thorough discomfiture of Charles.

Francis began the new year with a proceeding which may be compared for absurd unreality with Charles's escapade at Rome, and which was probably modelled on Philip Augustus's mock trial and forfeiture of John of England, which resulted in the restoration of Normandy and Anjou to France. He appeared with his court and officers in the Parliament of Paris, and preferred a charge of treason against Charles of Austria. Charles, according to his showing, had broken the treaty of Cambrai ; the treaty of Cambrai, by that act, was annulled, and the rights and duties of each revived as they were before it was agreed on; therefore the suzerainty of France over Flanders and Artois revived, and Charles became again a vassal. As a vassal, he was ordered to appear and answer the charges of Francis : the summons was served by the proclamation of a herald on the frontier of Picardy. Charles of course did not attend; the Parliament pronounced him contumacious, and his French provinces forfeit.

In order to give effect to the sentence, Francis marched towards Picardy and gained some few places on his march; but he was obliged to leave the conduct of the war to his son Henry, who lost all that his father had gained. He was just about to risk a battle with the Flemish army, in order to relieve Térouanne, which had been besieged, when a truce was announced. Queen Mary of Hungary the governante of the Netherlands, and Queen Eleanor of France, both sisters of the Emperor, arranged this truce or armistice between them; it established for ten months peace between France and the Netherlands, beginning from July 30 .

It must be taken as a proof that at last the force of both parties was abating, their resources becoming exhausted; for, although the war continued a little longer in Piedmont, the truce of the Netherlands was but an anticipation of the truce of Nice which followed in the next year. The truces began indeed before the end of the year 1537 , but were prolonged until June $1538,{ }^{1}$ when, by the mediation of the Pope, the two sovereigns met him at Nice and concluded a truce for ten years. Paul III. did not allow them to meet one another, although they were both for some days in the town : nor did the arrangement go further than the temporary character of a truce implies. It involved no permanent change of position of either of the parties, simply the abstaining from warfare against one another. It was in a manner a necessity for Charles. What with the efforts made by Solyman to help Francis, the devastation of the

${ }^{1}$ League of Venice, Pope, Charles, and Ferdinand, against the Turks, 1538. 
coast of Naples and Spain by Hayraddin Barbarossa, and the pertinacious attacks on Hungary, great part of which was in possession of the Turks: what with the rapidly increasing power of the Protestant princes in Germany ; the importance of the Council, which could not be much longer delayed; the difficulties in Flanders, which shortly after culminated in the revolt of Ghent; and the general unwillingness of the Cortes, the States General, the Diet, and the Parliament in the several constitutionally governed kingdoms which owned his sway, he must have required rest and opportunity for preparing for the defence and conservation of Christendom. $\mathrm{He}$ was indeed sick of governing; and from this time, it is believed, entertained the design, which he carried out many years later, of retiring from active life and leaving his kingdoms to Philip as soon as he should be old enough to manage them.

The truce of Nice settled nothing: it did not even obtain for the Duke of Savoy the restoration of his fortresses. It did not settle the question of the Milanese or set aside the verdict of the Parliament of Paris. It was merely the concession to the Papal mediation of an armistice, which for the moment was welcome to both parties, which either might transgress as soon as he felt himself strong enough, and which left all the former causes of animosity unextinguished. For Francis, then, it was a piece of good luck; he had no other formidable enemies to fear; at peace with Charles, he was at peace with or safe from attack from all the world. With Charles it was far different; to him peace with France meant only an opening for work in other quarters, war with the Turks and Algerines, war in Hungary and the Mediterranean; quarrels with his own Cortes or estates; the incalculable weariness of the religious struggle now threatening in Germany, and beginning to threaten in the Low Countries also. Nay, in Naples and Spain the doctrines of the reformers were gaining ground to an extent that endangered the orthodoxy of the most Catholic nations.

It was not that in these countries the evangelical sentiments had allied themselves, as in Germany, with independence in politics; but they had unsettled the faith of many in certain doctrines preached commonly in the Roman Church, which were not as yet, as they were a few years later by the Council of Trent, formally determined to be of the substance of the faith. Protestant views, or views which at a later period were marked as Protestant, made themselves acceptable in the highest quarters of the Church; men like Pole and Contarini were both doctrinally and politically allied on many points with the reformers: Charles himself had listened gladly to the preaching of Bernard Ochino, who shortly afterwards became a Protestant and subsequently a Unitarian; and some of his 
favourite chaplains, Carranza for example, figured afterwards as victims of Papal persecution. But although these men were prepared to go certain lengths towards reform, they were not prepared to cut themselves loose from the Church. The German and English Protestants had convinced themselves of the falseness of the Papal claims to supremacy in doctrine as well as in politics: the Italian reformers, with some brilliant exceptions, chose to forfeit their convictions of the need of reform, rather than risk the supremacy of the Chair of St. Peter. And out of much the same series of causes which produced this result arose the Society of the Jesuits, which, more than any other like institution that ever was founded, was created for the reformation of the Church, and yet ended in the most determined maintenance of all the most flagrant abuses.

The attempts to introduce the Inquisition into Naples, which were made during Charles's reign, were perhaps owing rather to the zeal of his viceroy Pedro de Toledo than to his own inclination for persecution. The history of the reform movement in Naples is, however, complicated and puzzling : nor has it been yet written with much pretence to fairness. The persons who were affected by it were not persons who otherwise exerted much influence in Europe, and their names are perhaps as well known now as they were in their own days. Peter Martyr, Bernardo Ochino, Aonio Paleario, Vittoria Colonna, are the most famous names of Italian reform: but they have not left a considerable mark either on theology or on political history. Nor can we, with any regard to the proportion of our discussions now, turn out of the way to review them. These and some of the Spanish divines, Valdes in particular, were much more in accord with Luther than with Pole and Contarini. The Neapolitans resisted the attempt to introduce the Inquisition, and successfully : nor was it established in Naples during Charles's life. Unfortunately, without recourse to the Inquisition, the ordinary process by the canon law and the assistance of the secular arm afforded too many opportunities for indefensible and irresponsible cruelty.

\section{LECTURE VII}

FROM THE TRUCE OF NICE TO THE PEACE OF CRESPY, 1544

WE take up the string of history again at the truce of Nice, which, having been negotiated from the month of June 1538 to the end of the year, was finally ratified for ten years by the Emperor, February 1, 1539. The ten years ultimately turned out to be about three: 
another war follows in 1541, which also lasts for three years, and is concluded by the peace of Crespy in 1544 .

The truce of Nice had scarcely one of the elements of a sound peace ; it scarcely even called itself a peace; it was the result of no great success on either side; it was not the voluntary or spontaneous act of either sovereign; it settled no disputed question; it was brought about by the Pope for purposes alien to the war which it was intended to close, and between princes whom he so much distrusted that, during the negotiations for it, he did not suffer them to have one interview with each other. Notwithstanding this, circumstances, in themselves of minor importance, seemed, after it was concluded, to make its permanence at least probable.

A few days after Charles's departure from Nice, he was forced by stress of weather to put in to the coast of Provence, where Francis met him and offered him hospitality. The two great princes, who had been more or less at war for twenty years, and who had not only fought against one another, but brought mutual accusations, such as seemed to make their personal enmity irreconcilable, met and were, or pretended to be, pleased with one another. It really appeared that war might be coming to an end. Botb princes were now experienced and sobered down. Charles was indeed only thirty-eight years old now, but he had been accustomed for twenty years to the most intricate and laborious sorts of public business. He had lived such a life as is calculated to make a man old before his time. You must have observed how very little any other name than his own comes into the history of his counsels. Doubtless he had faithful ministers, as he had skilful and valiant generals. But none rises to such eminence as to eclipse his master : there is no Wolsey, or Cromwell, or Strafford in Charles's train. Whatever is done, he must have the doing of it: and henceforth, wherever there is a war, he will have a leading part in it. We may be sure that he, for one, longed for peace; although it must be a peace which would be as laborious as war, for the consolidation of perfect peace in Christendom must be the signal for an onslaught upon the Turks. But, although he may have longed for it, it is impossible to say that he expected it; pressed by the Pope into the truce of Nice, he was willing to use that truce as a breathing time; but he must have known that, from the first attempt to trample out the smouldering ashes of the late war, a new flame would, as it did, actually arise: he knew the hatred of Francis, and, although he would temporise even to a degree that was hardly honest, he could not forgive, or sincerely reconcile himself with, an enemy whom he most entirely distrusted.

The three years of the truce are diversified with some very 
memorable transactions: the subversion of the Cortes in Castile, the chastisement of Ghent, and the expedition to Algiers. These events, which belong to other portions of our subject, are not without their bearing upon this. The quarrel with the Cortes was caused by the want of supplies to pay the wages of the soldiers employed in the late war; and the exhaustion of the imperial resources, by the unhappy expedition to Algiers, was no doubt one of the arguments that induced Francis to begin a new war. But the revolt of Ghent is the one that more immediately connects the two acts of the drama. This occurred, as you will remember, in 1539, owing to the refusal of the people of Ghent to pay the contribution voted by the estates of Flanders in 1536. Charles's behaviour to the Ghent envoys, who visited him in Spain, is a singular instance of his occasional want of tact. There was no doubt that the privilege claimed by Ghent, of not being liable to taxation which had not been roted by its own representatives, was destructive of all government; had it been general, it must have precluded the possibility of any taxation except local and unanimous taxation, and taxation so transacted must necessarily lead to the loss, by the powers taxed, of all opportunities of joint action in politics, and all chance of obtaining redress of grievances. But, though Charles saw this, Ghent, though a single city, had the riches and the proportions of an independent state. Ghent was very dear to Charles, and he should have treated the representatives with respect; instead of doing this, he remitted the discussion of their charter to the Council of the Netherlands at Mechlin, from which under the circumstances they could barely expect such justice as they desired. They did not wait for it, but applied to Francis for help; if he would join them in an attack on Charles, they would assist him to recover the French provinces which were still in Charles's hands, Artois and Picardy, the homage of which had been given up by Francis at the peace of Cambrai, but which the Parliament of Paris in $1587 \mathrm{had}$ declared to be forfeited to the French crown in consequence of Charles's treason. This offer was a very welcome one to Francis, and, as later events have shown, the acceptance and carrying out of it would have resulted well. The population of these territories is more French than Fleming or Walloon, and now they are firmly consolidated with France. But Francis had set his heart on Milan, and Charles had played him with Milan for a bait. The interview of the monarchs in Provence had been the beginning of a series of civilities, and the Emperor had no donbt allowed Francis to believe that he would, on the arrival of a settled peace, invest Charles Duke of Orleans with the Duchy of Milan, as a fief of the Empire. Francis, accordingly, not only refused the proposals of the men of Ghent, but 
reported them in detail to Charles. The Constable de Montmorency was the adviser of this policy, and afterwards suffered for it.

Charles saw the peril of his situation and was ready for all risks. $\mathrm{He}$ trusted, it seems probable, more to Francis's regard for the ordinary code of honour than to any good feeling on his part ; somewhat also to his own power of intrigue.

Contrary to the entreaties of his Spanish council, he determined to ask leave to cross France on his way to Flanders; he instructed Granvelle to hold out hopes to Francis about the Milanese, but to avoid any express engagement. Francis listened and was deceived, partly perhaps by his own wishes, partly no doubt by the Emperor's finesse. Charles was allowed to land at Bayonne, was met by Francis himself at Bourges, and went by Orleans to Paris, which he entered on New Year's Day, 1540. Six days he spent there, during which Francis was sorely tempted to seek a short cut out of his difficulties, but his dread of outlawry by all Europe was too great, and he suffered the great bird to escape from the net. Charles knew his man, and that, whatever he might be willing to do underhand or with reservation, he dared not do it openly. I do not say this to Francis's discredit: his character is too low to lose at all by being credited with some respect for the appearance of honour; he should have the benefit of the fact. Charles was in his power, and he neither imprisoned nor poisoned him ; as to binding him with conditions, he knew how little likely compulsory agreements were to be observed; and he was conscious that the history of the peace of Madrid was too fresh in all men's recollections to allow him to claim the benefit of any such negotiations, even were Charles liable to such coercion.

Putting the most favourable construction possible on this finesse of Charles, we cannot acquit him of very disingenuous behaviour, or of an unfair treatment of an enemy, on whose generosity he seemed to be throwing himself. Charles was not the man to break a treaty, but he was quite the man to sail as near the wind as was safe. He did not lie to Francis, but suffered Francis to be lied to by others, and to deceive himself. $\mathrm{He}$ never dreamed of surrendering either the Milanese or Flanders, but if the French King would deceive himself, why e'en let him. So he made his way to Ghent and punished the burghers. When Francis applied to him to fulfil the understood promise to the Duke of Orleans, and Charles found that he must return a downright answer, he declared that he would give up neither Flanders nor Milan; Francis might do what he liked. Francis prepared for war.

The rest of the year Charles spent in the Netherlands; in April 1541 he was at a Diet at Ratisbon, in which some of the disputa- 
tions of Melanchthon and Eck were carried on, and in which he put the Duke of Cleves to the ban of the Empire. This was, you remember, Duke William, brother of the unlucky Anne of Cleves, and claimant, on the cession of Charles of Egmont, of the duchy of Guelders. Charles had rejected the Duke's claim in favour of his own : and the Duke had thrown himself into the arms of Francis, and was now outlawed by the Empire. The Emperor, after the Diet, went down into Italy, where he met the Pope at Lucca ; from Italy to Majorca, thence to Algiers ; thence, after the failure of the expedition, back to Spain. That disaster was the signal for a new attack on the part of Francis. This breach of faith on his part is neither to be wondered at, nor very severely blamed, except in so far as it really sacrificed the good of Europe and Christendom generally to the desire of revenge. We have no reason to suppose that Francis was amenable to the higher motives; he saw his opportunity and took it ; nor is Charles much to be pitied; he had indeed avoided a breach of treaty, but he had really deceived his rival; he had wasted an enormous force, which might have recovered Hungary from Solyman, in a vain attempt on an untenable acquisition, which he had failed even to acquire; he had done this in a way that is little short of foolhardiness, contrary to the entreaties of the Pope, and contrary to the advice of his own generals and admirals. Still Francis could not look for much sympathy in Europe in an attack, itself made in breach of truce, upon a monarch who had suffered so heavily for the defence, as he thought it, the common defence, of Europe. The German Protestants would have nothing to say to him ; Henry VIII. was rapidly cooling towards him, and as many obstacles to a renewal of relations with Charles were being gradually removed he was resuming his ancient position with respect to them both. The Scots were as usual a thorn in Henry's side, and the Scots were as usual emboldened by their alliance with Francis.

The casus belli occurred in July 1541 ; but the very occasion of it showed that peace would have been otherwise possible no longer. Francis had concluded the truce of Nice without leave from his most potent ally, Solyman, and, by doing so, had left Charles and his brother Ferdinand at liberty to use their arms against the Turks, had made in fact the great opportunity which the Algerine expedition had wasted. Solyman had sulked in consequence, and Francis had to request humbly a new alliance : into this he wished to draw the Venetians also; and for this end he accredited two envoys, neither of them a subject of his own-Antonio Rinçon, a Spanish exile who had been his ambassador at Constantinople, and Cæsar Fregoso, a Genoese. They were to go by Venice to Constantinople. The Marquis del Guasto, who was governor of the Milanese, regardless 
of their sacred character, or rather perhaps refusing to recognise it, arrested them and had them assassinated. Their papers revealed the negotiation, betrayed the treachery of Francis, and left him no choice but to begin war or wait until Charles should attack him. He did not hesitate; although the Lutherans of Germany would not listen to him, the Kings of Denmark and Sweden were ready to join in an attack which would relieve the fears of their co-religionists.

Francis I. and Christian III. proclaimed war against Charles in the spring of $\mathbf{1 5 4 2}$. There was no mistake as to the spirit and vigour with which this was undertaken. Francis levied five armies, and attacked the Emperor in five different points: Artois, Brabant, Luxemburg, Piedmont, and Roussillon. The Dauphin was sent into Navarre ; the Duke of Orleans to Luxemburg ; the Duke of Vendôme to Flanders ; Van Rossem, marshal of Guelders, to Brabant; the fifth army, under Annebaut, into Piedmont. Four of the five armies represent the four great claims of France on Charles, for the Milanese, Navarre, Flanders, and Burgundy; the fifth, the quarrel of the Duke of Guelders. The campaign, or the five campaigns, were not brilliant. Charles was greater in defence than in attack, and the force of Francis was 'wasted by being so divided. The story is simple: the Dauphin was successful in Roussillon and besieged Perpignan; the Duke of Orleans overran Luxemburg and captured every fortress except Thionville-but, this done, he left his acquisitions and hastened to join his brother, in fear of an attack by the Emperor on the army of Navarre. That attack was never made; Perpignan, under the Duke of Alva, was proof against a siege, and these two branches of the great design ended in a not inglorious failure; a result more brilliant than useful. The expeditions to the Netherlands were delayed. The Piedmont one ended in the acquisition of a few towns and fortresses.

It was, however, high time for Charles to be on the spot. Ferdinand held a Diet at Nuremberg early in 1543 , which entreated the Emperor to return from Spain and repel the attack of the Duke of Cleves and the French. The fleet of Solyman was plundering the coast of Italy, and Francis appeared to be stronger than ever, beating up everywhere friends for himself and enemies for Charles. Thus urged, the Emperor left Spain, which he placed under the management of his son Philip, the estates of Aragon and Valencia recognising him as heir and designate successor; sailed to Genoa; saw the Pope at Busseto in Lombardy, between Piacenza and Cremona, and then met the Diet of the Empire at Speyer. Thence he hastened to the north. The Duke of Cleves was the first enemy to be demolished, and he was effectually demolished. He had won (March 24, 1543) a battle at Sittard, which had turned his brain ; for, 
although he was at the time in treaty with Charles through his ambassadors, and the Protestant powers had done their best to procure a reconciliation, he repudiated all mediation and defied the Emperor. The poor Duke soon found out his mistake; Charles besieged in August and took his strongholds, and reduced him to the condition of a suppliant. Charles was not a vindictive enemy, and the Duke, from the position of his dominions, might become a valuable friend. $\mathrm{He}$ was, at the intercession of the Duke of Brunswick and Elector of Cologne, restored to Cleves, but compelled to renounce the Duchy of Guelders, the league with France and Denmark, and the Protestant religion. This done, Charles gave him as a wife, instead of the Princess of Navarre whom Francis had promised him, his own niece, the daughter of King Ferdinand.

The importance of the Duke in this affair is well worth noting. It might have been fatal to Charles's hold on the Netherlands to leave a neighbour, whose dominions were so critically situated, bound by any tie at all to his great enemy. But the war of 1543 is not confined to Cleves. Francis knew the weak point of Germany, and a second time seized Luxemburg; whilst towards the Netherlands he occupied and fortified Landrecy, which gave him the command of Hainault. Charles preferred the latter battlefield. His forces, assisted by the English contingent, which Henry, who had finally broken with both the French and Scots, had supplied, besieged Landrecy. He himself hastened to join them: Francis marched in the same direction; and it seemed not impossible that at last a general engagement might decide the long-standing rivalry. But the world was disappointed. Francis manœuvred; Charles was cautious, the season was advanced; the troops were wearied and winter was approaching; it was a very busy time in Germany, and accordingly Charles retired into winter quarters.

If the war of 1542 was uneventful, and that of 1543 disappointing, no such charge can be brought against that of 1544, in which, as if for a last effort against one another, both parties put forth their utmost strength and skill. Charles made the utmost exertions to disarm the allies of Francis, by concluding separate treaties with them. The intrigues of France and Scotland provoked Henry VIII. into at last sincerely determining to help the Emperor ; and Francis, finding that the friendship of Solyman did him more harm than good, sent Barbarossa about his business. The Germans were prevailed on by the concessions made at Speyer in April to support Charles with a force of 20,000 foot and 4,000 horse. In this, which was Charles's last campaign against Francis, in which both put, or seemed to put, forth all their strength against each other, and in which the allies on both sides showed an unusually 
sincere purpose of fulfilling their obligations, almost everything turned out exactly the contrary of what was to have been expected. It would almost seem that Charles had at last got the power of crushing his rival; he had obtained active support from the Germans, who were more apt to retard than to promote his designs in a general way ; and he had arranged a definite plan with Henry VIII., who had so often contented himself with holding the balance between the two, and doing no more. According to this latter arrangement, the allies were to concentrate their attacks upon Paris itself, each at the head of an army of 25,000 men; they were, moreover, to march direct upon Paris, not wasting time on the fortresses between the border and the capital. Henry was further to disable the Scots from bringing any assistance to Francis by an invasion of that unhappy country, which it was supposed, without the material aid that Francis could not afford to supply, must lie at the invader's mercy.

Matters were so far advanced before the end of 1543. Charles delayed the opening of the campaign until the summer, in the meantime securing the co-operation of the Diet with the force already stated. Francis, however, in that quarter which was open to his attack, did not hesitate to take the initiative, and this led to one of the most famous battles which marked the whole struggle, the battle of Cerisoles in Piedmont. The Marquis del Guasto, Charles's general in Italy and Governor of Milan, had, the year before, seized and fortified Carignan, in the forfeited territory of the Duke of Savoy. The Count of Enghien, whom Francis had placed at the head of his army in Savoy, determined to besiege Carignan as a step to the entire occupation of Piedmont. The Marquis advanced from Milan to the rescue, and offered battle. Enghien had been forbidden by Francis to risk one. Ready as both were for the struggle, neither would begin it: Enghien restrained by his master's orders, the imperial general by his wish to take the defensive. At last, after a strong and earnest appeal from Enghien delivered by Monluc, Francis sent him orders to engage. The battle really came off on April 14, and the result was the decisive victory of the French. The actual advantages gained by this were rather negative than positive. Del Guasto was disabled from joining his master in the invasion of France from the south-east, but the capture of Carignan and a few other Piedmontese towns was the sum of the positive gains.

It was not before June that Charles felt himself strong enough to take the field. He then advanced from Speyer, where he had remained since the Diet, to Metz, and awaited the action of Henry VIII., whose fleet and army, under the Earl of Hertford and Lord Lisle, took Edinburgh and Leith, and devastated the south of 
Scotland early in the year. Charles's army now amounted to fifty thousand men, twice the number with which his treaty with Henry bound him to attack Paris ; but he advanced slowly, and gave time to Francis to place every available obstacle in his way. $\mathrm{He}$ first retook Luxemburg and the other fortresses of the duchy, and then invaded Champagne. Henry, in July, crossed over to Picardy to fulfil, or rather to shirk, his part of the arrangement with Charles. In singular forgetfulness of the agreement they had made not to waste time on the fortresses, both Henry and Charles devoted themselves, late in the year as it was, to that very point. Henry stayed before Boulogne for seven weeks, and only succeeded in taking it a week before the final peace was made. Charles, who had lost, a fortnight before, Luxemburg, and also had stopped to retake Commercy, Vaucouleurs, and the other places seized by the French in 1543, adopted the same plan when he had actually entered Champagne. Francis removed all supplies out of his way, not scrupling to devastate the most fertile province of France, if he could by so doing starve out the enemy. Ligny, which Charles took after the capture of Commercy, was an off-lying piece of Luxemburg surrounded by the territories of Lorraine; the first place in Champagne which he besieged was St. Dizier, which commanded the passage of the Marne, and was defended for five weeks by the Count of Sancerre. This loss of time and force, for the army before St. Dizier had suffered greatly by disease, was unquestionably the ruin of the campaign and the salvation of France. Even whilst France seemed most defenceless, Charles had learned his own weakness, and was negotiating for peace.

It is frightful to read that, with the greatest prince of Europe actually en route to attack the capital, Francis's time was occupied and the unity of his council disturbed by the quarrels between two wretched women, the mistresses of his son the Dauphin and himself. The negotiations hung fire in consequence; and Charles, feeling himself unfettered, put an end to them by surprising Epernay and Château-Thierry, and advancing within two days' march of Paris. The panic that followed this hasty movement brought the duchesses to their senses : the Dauphin threw a force into Charles's way by garrisoning strongly both Meaux and La Ferté. And the Emperor, seeing himself at last seriously opposed, turned northwards to Soissons. He felt, no doubt, that now he had done all he could safely attempt. Henry would not fulfil his part of the agreement until Boulogne and Montreuil were taken.

Charles and Francis suddenly arranged peace. This was settled and signed at Crespy, near Meaux, on September 18, 1544 . The terms consented to by Charles in this treaty are only less astonishing 
than the apathy shown by Francis during the invasion: the result of the war bearing no proportion whatever to the greatness of the forces employed and the energy exhibited, or the success really gained by the invasion. It would almost appear certain that Charles could have made good his retreat into the Netherlands without a struggle: it would almost seem as if his march on Paris was really intended only to compel Francis to peace ; yet the peace, when it was agreed on, was scarcely less advantageous to France than it must have been if victory had declared for Francis.

In the complicated web of wars and peaces, we are liable to lose sight of the real causes of the several detached struggles, and to take too general a view of a contest which had its origin far deeper than any contested claims to the towns on the Somme or even the sovereignty of the Milanese. But when it becomes necessary for the adversaries to take breath, we are obliged to see that the minor points must be at least formally and temporarily settled. The treaty of Crespy, as the closing act of the wars between Charles and Francis, has to be looked at somewhat minutely; for it has its own bearings as to these particular points, as well as its place in the strategic or politic programme of Charles. The former are these :

(1) All places taken since the truce of Nice are to be restored. This, I conceive, would leave the Emperor in possession of Luxemburg, in which he had done no more than retake his own strongholds, which had been taken by Francis after the conclusion of the truce. It involved, however, the severance of the alliance with Henry VIII., who was not likely to give up Boulogne after a week's possession of it.

(2) The two princes are to unite for the maintenance of the Catholic religion: Francis is to contribute 600 cavalry and 10,000 infantry towards Charles's war with Turkey; Francis thus throws over Solyman as Charles threw over Henry, a treatment which shows that the one was regarded only as a little more tolerable and less dangerous than the other.

(3) Francis renounces all claims whatever on Naples, Flanders, Artois, and Guelders also as ally of William of Cleves : Charles, on the other side, renounces the towns on the Somme, the old bone of contention between the Dukes of Burgundy and France a century before this, and likewise the duchy of Burgundy and county of Charolois, the claims on which had now become a matter of respectable antiquity. Francis, moreover, gives up the defence of Navarre and undertakes the restoration of Savoy to its displaced ruler.

All this is right and fair : the remainder of the treaty is the astounding part. Charles, by this, promises to Francis that he will give either his daughter, or his niece the daughter of Ferdinand, in 
marriage to the Duke of Orleans. If he gives the daughter he will give with her the entire succession to the Netherlands, as an independent state from the date of his own death; if he gives the niece, she shall have the Milanese in the same way: and, by a further arrangement, if the Milanese is given, Charles is to retain Burgundy; if the Netherlands are given, he is to retain the Milanese without claim from Francis. Within four months Charles is to state which of the young ladies the Duke is to have.

Such are the provisions of the treaty. That Charles should consent to the alienation in permanence of so large a part of the inheritance of Philip as either the Netherlands or the Milanese, whilst he himself had the upper hand, is extremely strange; nor can it be explained on any theory, except the absolute necessity of peace. How and why that peace had, within two years from the opening of the war, and whilst he had so much still on his side, become such an imperative necessity, requires a careful study of the state of affairs in Germany and Italy to understand. Robertson is, I think, right in his belief that the action of Pope Paul III. is traceable in this: that Charles was partly wearied and partly exasperated by the Pope, and really saw, in an alliance with Francis, a way to settle the religious question, which must be settled before Europe could be at peace. With all his dislike and jealousy of the Pope he saw that he must be satisfied, and in this matter the political interests of Francis, looked at with the eye of a statesman, were identical with his own. If he offended the Pope, he threw him and what remained of independence in Italy into the arms of Francis ; if he made peace with Francis, a solid peace, or one that lcoked fairly solid, he might yet have time to put down the Protestants, to attack the Turks, and to reduce the Pope to political insignificance.

The extirpation of Protestantism was made the subject of a separate article with Francis, but the extirpation of Protestantism was as valuable to Charles, as involving the securing of peace in Germany and his own consequent supremacy in Italy, as it was because he was a bigoted Catholic, and one who, as we saw, sympathised with the cruelties of the Inquisition. It was then, I think, a real and great concession on the part of Charles, to secure Francis as a friend : a concession which, when the occasion was past, it would not be hard to repudiate on some ground to be found among the many complicated agreements of the treaty. At all events, however, at first, he showed the intention of keeping it, and, within the four months specified, promised definitely his niece and the Milanese to the Duke of Orleans.

The treaty was not approved of by the Dauphin, who considered that Francis sacrificed too much: but, if we consider how often the 
renunciations made by the King had been repudiated and renewed, and how lightly any obligation sat upon the father, we shall be surprised to see that the son, with his eyes opened by their common mistress, could have given him credit for even such a little quantum of sincerity. But, all things considered, we must allow something to the already failing health of Charles: he was a martyr to the gout; and although he had acted with great speed and decision in several matters, and although in the war in Germany which soon followed he displayed perhaps to a greater extent than at any period of his life his skill and promptness in execution, we may quite believe that he was weary of the labours which had tasked his energies for so many years. He had long contemplated resignation as possible; he persuaded himself to believe that, disabled as he was, he would only hold power until Philip was old enough to succeed him. Philip was now seventeen, and at seventeen Charles had been King of Spain and ruler of the Netherlands.

The main provision of the peace of Crespy came to nothing: within a year after the signing of it (September 8, 1545) the Duke of Orleans died, and Charles considered himself freed altogether from any further obligation. The two years succeeding the peace were occupied, by Francis in war with England, which ended in June 1546; by Charles in fruitless negotiations about the Council of Trent and preparations for the Smalkaldic war, the first year of which, with the increasing chances of Charles, Francis watched with anxiety. Charles was wise in his suspicions of the Pope, whose conduct was dictated rather by regard to the interests of the Farnese than by a regard for religion. The Emperor was fighting the Protestants in defence of the Pope's spiritual authority, the Pope was intriguing against the Emperor in defence of the temporal possessions of his own family. Francis was watching his time, making new friends and looking up old ones. Before the crisis came, however, he died on March 31, 1547. Henry VIII. had preceded him by a couple of months, dying January 28 . Luther had died a year before. Charles saw himself the last left of the chief players in the great game of war, and he had the chief part of his work still to do.

We ought not, perhaps, to bid good-bye to Francis without one more word of execration. A contrast between Charles and him is the correct thing in this place. But I cannot see that such a contrast can seriously affect our notion of Francis's character and place in history. The lowest estimate may be taken of Charles; but it does not help Francis to rise one instant in our opinion. Charles may or may not have been prosaic and unchivalrous: but that does not make Francis poetic, or his sham chivalry anything more than a sham. Charles may have been a sincere bigot, but it is 
no help to Francis that he was an insincere one. If you had to choose between two persecutors, you would, I imagine, prefer the honest one to the dishonest one. Charles was a bigot; Francis does not therefore become an enlightened man : nay, his superstition is more contemptible than the other's narrowness. For want of faith, for unparalleled selfishness in a ruler ; for utter heartlessness as a man and a king; for incapacity as a ruler at home unredeemed by any brilliant successes in wars, which he never suffered to be interrupted by a sound peace; for a degree of laches incompatible with personal honour ; with a reputation for the grossest ingratitude to his best servants, and for any unscrupulous tyranny exercised on behalf of the basest favourites, Francis occupies among the Kings of France a bad pre-eminence; deserves a condemnation which the splendour of his court, the magnificence of his buildings, the charm of his manner, the patronage of art for which he is famous, the general air of chivalry which, like our Edward III.-a prince whom he strongly resembles in everything except power and success-he tried to throw over his dishonourable and abandoned life; not one of these, nor all of them together, serves to do more than gild his infamy. All that is bad about him is too substantial and effective; all that seems good or noble is sham, and a sorry sham, a very ragged covering to the mismanagement, misrule, and tyranny that make him the fit representative, as he was the father, of the worst dynasty that ever reigned in Europe since the rotten empire of Rome fell to pieces-the dynasty of Henry II. and his sons; or, if you please, that of Catherine de' Medici.

\section{LECTURE VIII}

THE REFORMATION FROM THE DIET OF AUGSBURG, 1530, TO THE INTERIM, 1548

The history of the Reformation in Germany falls into three epcchs, which we describe as the period of argument, the period of intrigue, and the period of war. The first reaches from the year 1517 to the second presentation of the Confession of Augsburg; the second from the formation of the league of Smalkald to the outbreak of the Smalkaldic war; the third from the Smalkaldic war to the peace of religion, which shortly preceded Charles's resignation. At the risk of seeming to give a disproportionate amount of discussion to the subject, we must devote two more lectures, one to the second, and one to the third phase. We have traced the movement up to 
the date of the Augsburg Confession, which was presented to Charles on June 25, 1530, a few months after his coronation as Emperor, and whilst he was still, as indeed he was always, only not so hopefully as now, earnestly pressing on the arrangements for the peace of Christendom, preparatory to a general attack on the Turks. At this time but five princes of the Empire and two imperial cities had committed themselves on the side of reform; the names attached to the Confession when it was presented are those of the Elector of Saxony, Margrave George of Brandenburg, Ernest duke of Lüneburg, Philip landgrave of Hesse, Wolfgang duke of Anhalt; and the towns of Nuremberg and Reutlingen, a place in the south of Swabia; but before the end of the Diet four more towns added their names; and the example was quickly followed.

To begin, however, with the Diet of Augsburg itself. Charles, before he was crowned at Bologna, made (January 21, 1530) the summoning of a Diet his first business. According to the Golden Bull of Charles IV., this first Diet ought to have been at Nuremberg. Charles, however, summoned it at Augsburg, which, amongst other advantages, had this, that it was the residence of his faithful bankers the Fuggers. For the Diet was not called only for the purpose of settling the religious dispute ; there was the demand for supplies for the never-ending Turkish war, and Charles, moreover, was desirous, by procuring the election of his brother Ferdinand as King of the Romans, to rid his own shoulders of the pressure of imperial business. And the religious question was now quickly ceasing to be a merely domestic one. The Lutheran opinions had taken deep root in Denmark as early as they had in Germany, and the questions were there, as in Germany, complicated by the overweening secular claims of the prelacy. Three kings-Christian II., a bully and a tyrant, Frederick I., and Christian III.-successively devoted themselves to the task of promoting the Gospel and humbling the bishops. In Sweden, Gustavus Vasa, who had learned Lutheran doctrine whilst in exile at Lübeck, brought teachers from Germany, had the Holy Scriptures translated, and in 1527 obtained from his States the recognition of the reformed religion as that of the State.

Although in France the movement against the Church and clergy was not so successful as among the Scandinavian nations, it yet found support largely among the nobility and people; nay, it had its proselytes within the circle of the royal house. But the kings of the house of Angoulême never really favoured it ; Francis, his son, and his grandsons, with perhaps the single exception of Charles IX., were men singularly devoid of principle and were attached to the Church simply by reason of habit with a dash of superstition. A religious man in those days must have taken one side or the other:

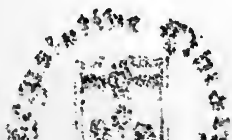


an irreligious man then, as now, simply adhered to the side on which his own interests seemed to lie, and Francis and his sons found that on the side of Rome. England was rapidly tending towards a change: therefore France and Scotland must continue and wax more exceeding Catholic. In Germany Charles was politically inclined to be merciful, though, as a strong Catholic of those days, he was religiously bound to persecute; and Francis would have a becoming policy marked out for him by Charles's changes: he could vindicate his own crthodoxy by persecuting at home, and, having laid up a stock of merits thereby, could afford, without loss of character or risk of his salvation, to support Charles's heretical subjects in their opposition to his authority.

Thus the Protestants were by no means likely to be helpless in a struggle if the Emperor should provoke one. But Charles had no wish to do so ; he wanted the schism to be closed; and as yet only two ways approved themselves to him, the two ways that had been tried and proved failures already, argument first and a sentence of the Diet to follow. He did not want to go to extremities. Saxony and Brandenburg and Hesse were rich States; he could not afford to lose their contributions; nor could he afford to dispense with the help of an old friend like George of Brandenburg. A campaign against the Turks was a much better way of defending the faith than the burning of heretics. On June 15, 1530, Charles came to Augsburg, and the first sign he found of the spirit of the Protestants was the refusal of George of Brandenburg, in the name of the other princes, to attend the Corpus Christi festival on the following day; he would rather, he said, part with his head than forsake the Gospel. On the 20th, the Diet opened; on the 25th, the Confession was presented; and Charles determined on hearing the confutation: this was drawn up by Faber, Eck, and Cochlæus, and read on August 3. The reformers were ordered to submit at once, but they determined on answering this. Melanchthon drew up his apology for the Confession and offered it to Charles (September 22). He refused to receive it. The end of the Diet was the publication (November 19) of a decree against the Reformation: passed in the absence of the Elector of Saxony and his friends : reviving the Diet of Worms with new sanctions; insisting that the princes should return to the old religion within so many months or be declared enemies of the Empire; and finally repeating the often made and broken promise of a Council, this time to be held within six months.

This done, Charles issued summonses for a Diet at Cologne in December, at which the election of Ferdinand was to be transacted. The Elector of Saxony protested against this as an infringement of the Golden Bull, though what his arguments were is not very clear; 
but he sent his son with his excuses to Charles and himself called together the Protestant princes at Smalkald on December 22. There he formed with them the league of Smalkald, contrary to Luther's wishes, who desired the struggle to be conducted on strictly legal. principles; the lawyers, however, convinced him that combination was recognised by the Constitution, and he acquiesced. Philip of Hesse wished to include the Swiss in the league, but they were considered by the strict Lutherans ineligible, their view of the Eucharist being irreconcilable with that of the Saxon reformers. This league was more completely organised and defined for defence for six years on March 29, 1531. In the meantime the election at Cologne went on, and on January 5, 1531, Ferdinand became, in spite of the protests of John of Saxony, King of the Rcmans. Ferdinand was as faithful a Catholic as, and a more unscrupulous one than, Charles; and the confederates having, as I think, taken their first wrong step in opposing his election, added another, by canvassing for support among the foreign states hostile to or only formally at peace with the Emperor. Neither Henry VIII., however, nor Francis I. showed any inclination to join the league of Smalkald as yet. Henry was too sound a Catholic, and Francis was not ready to renew the war; his interest, moreover, lay rather in the favour of Pope Clement VII.

But Charles had for the present played out his hand; the very existence of his hereditary dominions in Germany was imperilled by the Turkish invasions which year after year poured through Hungary, his brother Ferdinand's kingdom, into Austria. He had already resigned to Ferdinand the Austrian patrimony, but he could not, the leading and most victorious prince in Europe, suffer the loss and disgrace to continue. In spite of the extent of his dominions he was always poor: in Germany he was pcorer than elsewhere, he must have peace and he must have money. So having failed to frighten the Protestants into submission, and to bribe the Pope into concession, he found that his best, indeed his only, policy was peace. $\mathrm{He}$ began to negotiate, and in the following year peace was made; the Archbishop Albert of Mentz and the Count Palatine Louis were the mediators. The representatives of the two parties met at Schweinfurt in April 1532, and again at Nuremberg on June 3. On July 23 Charles proclaimed peace throughout Germany, and immediately went off to meet the Turks, who retired before him, as we saw, without a battle. On August 16, within a month of the peace, John the Constant died, leaving his electorate to his son, John Frederick the Magnanimous, one of the best and most unfortunate princes of the century.

By the terms of this peace of Nuremberg the Protestant princes recognised Ferdinand and undertook to vote money for the war: 
Charles on his part annulled the edicts of Worms and Augsburg, and, as had been done at the first Diet of Speyer, put it in the power of each State to regulate its own religious affairs, until the Council, which, as usual, was to be held in six months. For some years matters went on quietly so far as the relations of Charles to the Protestants are concerned. He had other work to do, and they enjoyed a comparative quiet. But the period was not uneventful. In the first place the movement in England, some of the principal actors in which were inclined to Lutheranism, although the mainspring was a very different influence indeed, went on apace. The supremacy of the Pope was repudiated ; Catharine of Aragon, the Emperor's aunt, was divorced, and her daughter bastardised; Cranmer, a friend of the German reformers, was now Archbishop of Canterbury; the Bible was translated, and men like Fox and Latimer were on the highway to promotion. Henry even sent over an envoy to the league of Smalkald in 1535, and Francis was desirous of intriguing with them as Charles's enemies. But the reforming spirit had got ahead in France likewise, and the cruel way in which it was there repressed was repellent to the Germans : they in their turn declined to listen to Francis's dishonest and unprincipled invitations. Neither France nor England was anxious, it seemed, to do more than make use of them for its own designs; neither was willing to adopt the Augsburg Confession, as its supporters desired. Cromwell, who was the leading man in England, in spite of his Protestant leanings, was a time-serving rogue, and eventually came to grief in consequence.

Nor was the Pope at this time able to do much. Clement VII., intriguing on the one side with Francis against Charles and with Charles against Henry, had so mismanaged matters that no one trusted him. He lost the obedience of England, and risked that which remained of Germany. Nor was it likely that Charles would sacrifice the Protestants to him before the result of the ever future Council should be seen. He died, however, in 1534, and Paul III., his successor, had nothing better than the same promise to move the Emperor with. Clement would have called an Italian Council willingly, and Paul did in fact promise to call one at Mantua in $\mathbf{1 5 3 5}$ and the next year issued the formal summons. But the Germans had from the beginning demanded a free Council on their own soil, and such the Roman Pontiffs never had called voluntarily, and now, since the example of the Council of Basel, had determined that they never would. The promise of Paul III. had the effect of stirring up the princes to a greater effort: in 1535 the league of Smalkald was renewed; and in 1537, after the summoning of the Council, they drew up a new series of articles, far more strongly expressed than those of which the Confession of Augsburg consisted, to be presented to 
the bishops when they should meet. But the idea of a Council blew over for the time.

It was just now that the terrible outbreak of the Anabaptists in Münster took place: an event which, although it in some respects resembles the Peasant War of $\mathbf{1 5 2 5}$, must be carefully distinguished from it. In the Peasant War, as in every insurrection of the kind, there was, no doubt, an element of religious enthusiasm, for which the Lutherans at the time were taken to task unjustly; but the Anabaptists, although their tenets were repudiated by the reformers, were a sect of religionists distinctly, and based their claims on misinterpretations of the Scriptures, much as a sound Romanist would consider that the Lutherans themselves did. No doubt, the general break-up of the blind confidence in the ancient forms of faith contributed largely to the growth of such sects, even where it did not originate them ; the ancient rule of authority, rightly or wrongly, was broken down, and out of the gap went the madman and the criminal, as well as the innocent who had been captives. The wickednesses of the Anabaptists cannot be laid more justly on one than on the other of the two parties, the one of which had set at naught authority, whilst the other had strained it beyond endurance. But the coincidence of these exaggerated forms of tenet and monstrosities of practice with extreme Puritan views is too common in history to allow us to separate the Anabaptist excesses altogether from the doctrinal movement of the German Reformation. Those excesses called for, and received, the severest punishments, and an unhappy frequency of persecution was thus inaugurated. In fact, the repression of the Anabaptists was the first step in Germany towards the attempts later made to extinguish heresy by sword and fire. It must not be forgotten that Charles had lived for years in Spain, in constant view of the acts of the Inquisition, and had early introduced it into the Netherlands, and only been prevented by the resolution of the people from doing the same in Naples. But the Inquisition was a force too unmanageable and irresponsible to be introduced into Germany ; nor hitherto had any attempt been made to imitate its proceedings. The reformers lived in a constant state of alarm, but up to this time blood was not shed for religion.

So we come down to the year 1541, when disputations were renewed, this time between Eck and Melanchthon; and the revival of the talk about a Council which ended the next year by Pope Paul's proposal that Trent should be the place of meeting. Trent was geographically in Germany, but it was much nearer to Italy than to Saxony, and, lying in the midst of the Austrian estates, although itself under a prince bishop, could not be regarded as a safe place for the Emperor's enemies or those whom he might incline 
to treat as such. During these years Charles was obliged by the exigencies of his wars to keep good terms with the Protestants, who in the great Diet of Speyer in 1544 laid him under the greatest obligations (March 24) by a grant of men and money. The King of the Romans accepted the place as fitting, and the Pope gave notice of the Council throughout Christendom. In 1545, at a Diet at Worms, Charles attempted to win the Protestants to attend the Council; but in vain of course. Ferdinand had no better argument than the duty of submission to the decrees of the Council as soon as they should appear, and such advice was but mockery in the ears of the princes. And the princes were not in a mood to submit; their influence and numbers were increasing. In 1544 Frederick the Wise, the Count Palatine who had defended Vienna against the Turks in 1529, succeeded to the electorate, and he was kncwn to have reforming tendencies. In 1545, although he had not joined the Smalkaldic League, he abolished the ritual of the Mass in his dominions. Since 1540 Hermann von Wied, Archbishop of Cologne, had been an earnest reformer and had employed Bucer to preach the new doctrines in his electorate. Three of the electoral body were now openly Protestant; the Archbishop of Mentz continued averse to persecution. Joachim, since 1535 Elector of Brandenburg, although he did not join the league of Smalkald, and remained faithful to the Emperor, became in 1539 a Lutheran so far as to swamp three bishoprics.

Nearly all North Germany was now subject to Protestant rulers. It was not probable either that these would submit blindly to the decrees of a Council in which they were not represented, decrees which were not yet conceived; or that when the decrees were conceived and published they would be accepted by men against whose cherished beliefs they were framed. Nor was it to be expected that Charles would suffer the defection of half the Empire from the Roman faith without a struggle. It was clear that, as soon as the Council should publish a decree, submission or war must follow; both sides were prepared for such an arbitrament. Charles, released from immediate pressure by the peace of Crespy in September 1544, was for the moment at peace and able to bring a force into Germany. The league of Smalkald was armed and ready for resistance. On January 7, 1546, the Council of Trent held its first sitting; on February 18, Martin Luther died at Eisleben. The first decrees of Trent were laid before the Diet at Ratisbon in April and there rejected by the Protestants : the princes refused to recognise the Council as that for which they had prayed and waited so long.

The war was not long delayed. In this war it is worth while attending particularly to the attitude of the princes. We are not to 
suppose that the taking up Lutheran views, or even the introduction of them by some of the princes into their dominions as the State religion, is the same thing as to join the league of Smalkald or to go to war against the Emperor. We have to distinguish between the Protestant States: (1) Those which were prepared for rebellion and self-defence in resistance to the Emperor ; (2) those which were averse to war and did not regard the religious cause as sufficient to warrant them in taking up arms, and so remained neutral; (3) those which, whilst upholding the Protestant religion, were fighting on the side of Charles, either on account of some private and personal quarrel with the leaders of the league, or because they believed the assertion, which Charles was never weary of making, that he took up arms to bring his rebel subjects to order; not to oppress Protestantism, but for a merely secular purpose. It is hard to see how anyone who was not wilfully blind could accept Charles's statement that such was the cause of the war, for his own persecutions in the Netherlands and in Spain were sufficiently notorious ; but it was on this understanding that Maurice of Saxony and the princes of Brandenburg, Joachim the Elector, John of Brandenburg-Anspach, and Albert of Brandenburg-Culmbach and Baireuth, continued faithful to Charles. The Elector Palatine remained Protestant and neutral ; the brunt of the struggle was borne by John Frederick the Magnanimous of Saxony, Philip also the Magnanimous of Hesse, the Duke of Würtemberg, Ulric VI., and the free cities.

The influence of the Brunswick dukes was paralysed by a division, the history of which explains the attitude taken by the Brandenburgers in the Smalkaldic war. The Duke of Wolfenbüttel, Henry, was a bigoted Catholic ; Ernest of Lüneburg was one of the original presenters of the Augsburg Confession. In the year 1542, Duke Henry, by an attempt to enforce on the citizens of Goslar the restitution of the ecclesiastical property which they had seized, drew down on himself the anger of the Elector of Saxony and Philip of Hesse, who deprived him of his dominions. In 1545 he returned with a force supplied by France and attempted to recover them, but he was defeated in this and compelled to surrender himself and his sons to the Magnanimous landgrave. Albert and John of Brandenburg as well as the Elector Joachim, offended at this harsh treatment of their kinsman, joined the Emperor instead of the league, to which by religion they were before inclined. The defection of Maurice of Saxony is traceable to a similar want of tact on the part of John Frederick, giving an excuse for the ambition and jealousy of his kinsman which ended in his own downfall and the transference of the electoral dignity to the younger branch.

This division among the Protestants was promoted, of course, by 
the Emperor's declaration that his purposes were solely directed to the restoration of order, in the secular sense, throughout Germany. But there were further difficulties in the Protestant camp arising from the opposing views of Philip of Hesse, who was a politic and energetic man, very unscrupulous as to the means he adopted for his righteous ends; and those of John Frederick the Magnanimous of Saxony, who was a brave good man, but very innocent of policy and obstinate to a fault. They did not indeed quarrel, but the elector's conscience fettered Philip's political genius and was indeed for the time fatal to the good cause. One of the first signs of the struggle approaching was the deposition by the Pope of Hermann of Cologne; he was displaced by the Pope (July 7, 1546), and, the Emperor having consented to enforce the sentence, he solved the difficulty by resigning the see which he had held for thirty-two years in February 1547. This is, however, to anticipate a little. Well, the Protestant princes, after being tried by Charles singly and collectively, refused, at Ratisbon in April 1546, to accept the decrees of the Council of Trent. In June (19th) the Emperor made a secret agreement with Maurice of Saxony to give him the electoral hat if he would join in displacing his cousin John Frederick; he also concluded an alliance with the Pope, who was to send forthwith a large force into Germany; he stirred up the Brandenburgers to attempt the deliverance of Henry of Brunswick, and summoned his own forces from Spain and the Netherlands.

The state of peace ended formally, I believe, on July 15, when the league of Smalkald published the reasons for taking up arms. The following day Philip of Hesse moved his force southward to attack the Emperor, who was at Ratisbon, as usual behindhand with his preparations, with about 8,000 infantry, to resist Philip, who came against him with 50,000. Not a whit, however, frightened by the superiority of his force, Charles, on the receipt of the manifesto of the league, put the elector and Philip (July 20) under the ban of the Empire. He had no right to do this without trial or summons at least before the Diet, but he dispensed with this, as perhaps he was justified in doing by the open attitude of war assumed by the confederates. They, in retaliation, proclaimed war against him by a herald and renounced their allegiance, treating him as a pretender to the Empire and calling him Charles of Ghent (August 11). Charles refused to receive the proclamation, and threatened to hang any more such heralds that might come to him. He had by this time moved from Ratisbon to Landshut, where the Papal force joined him after a passage through the Tyrol, where they might easily have been cut off if the elector and landgrave had been as prompt as their captain Schertel. Finding himself followed by the enemy, he removed to 
Ingolstadt, where he fortified a very strong camp, from which all the insults and assaults of the leaguers failed to draw him. Whilst at Ingolstadt he received the succours from the Netherlands which they had failed to intercept. He then extended his lines, occupied Donauwerth and Nördlingen (September), and waited until the confederates should quarrel.

It was now time for Maurice of Saxony to play his game. His innocent and magnanimous cousin, ignorant of the secret treaty, had actually left him to govern Saxony as his deputy. To him Charles directed the letters of proscription against John Frederick. $\mathrm{He}$ took the advice of his states, which agreed with him that he must obey the Empercr, and, after proposing to his cousin that he should give up his part of Saxony to him, took up arms and defeated the little band of men left to protect the electorate. With the aid of Hungarian auxiliaries, supplied by Ferdinand, he occupied the whole electorate excepting the fortified towns of Wittenberg, Gotha, and Eisenach. The news of this struck consternation into the leaguers, whose headquarters were at Ulm : John Frederick wished to return northwards, but the rest proposed to treat with Charles. He of course would be content with nothing short of absolute and unconditional submission. John Frederick in consequence put an end to the campaign, and, leaving nine thousand men to defend the cities of Swabia, returned home to meet his treacherous cousin. The imperial forces thus set free immediately took possession of the cities within their reach, and amongst them the great fortress of Ulm. The Count Palatine was obliged to renounce his neutrality; the Duke of Würtemberg to submit to an enormous fine, and Strasburg, Augsburg, and Frankfort to renounce the league.

Such were the successes of Charles's quiet and deliberate tactics. The enormous superiority of the leaguers in point of force was counterbalanced by a defensive attitude and prudent delay; whilst the diversion in Saxony not only dispersed the great force of John Frederick and Philip, but actually gave the Emperor the opportunity of repairing his finances by the fines he could impose on the cities and princes who were left alone, unable to resist him. The return of John Frederick turned the fortune of war in Saxony. He quickly recovered all that he had lost, took prisoner Albert of Brandenburg whom Charles sent to the aid of Maurice; harried Maurice in turn out of his own dominions, and closed the year 1546 in triumph.

The gradual improvement in Charles's prospects was, as usual, calling forth the fears of his rival Francis and of his never very zealous friend the Pope; and the year 1547 would have undoubtedly witnessed some very serious modifications in the state of parties, had not the deaths of Henry VIII. and Francis I. robbed 
the Protestants of any hope of a diversion in their favour. Charles did not hesitate for a moment, on receiving the news of Francis's death, to march towards Saxony and make a bold stroke to end the war. He had but 16,000 men with him, but they with the benefit of his caution and experience were enough, he thought, to defeat and reduce the elector, whose usual imprudence and ill-luck he counted upon. John Frederick determined, after separating his force and changing his plans more than once, to contest the passage of the Elbe at Mühlberg. There the great battle was fought on April 24. John Frederick showed incapacity as well as magnanimity. The Saxon force was thoroughly beaten, Charles losing only fifty men as against the elector's 1,200; and John Frederick himself, with Ernest of Brunswick, son of Duke Philip of Grubenhagen (not, you observe, the hero of the Augsburg Confession, who had died in 1546), was taken prisoner.

It is not to be wondered at that so great a success should have provoked Charles to exult in an unseemly way over his prisoner. John Frederick had indeed brought upon himself, partly by imprudence and partly by vanity, all that he had to suffer. The Emperor at first threatened the extremest measures against him and by that means frightened the Electress Sybilla of Cleves into surrendering Wittenberg: he went so far as to bestow all his estates upon Maurice, but he spared his life, holding out, however, no hope of release from imprisonment. John, who was greater in adversity. than in prosperity, and whose firmness was greatly exercised in patient endurance of imprisonment, bore his fate with equanimity.

The formidable confederacy was now thoroughly disabled; only Philip of Hesse remained, and he was by this time as penitent as could be wished. Charles got him into his power on June 17. He had taken Wittenberg; and whilst bestowing Saxony on Maurice, he had reserved Gotha and its little territory as a future provision for the imprisoned elector: and he had liberated Ernest of Brunswick in exchange for Albert of Brandenburg. The friends of Philip, his son-in-law Maurice and the Brandenburg princes, interceded for him. In faith in their undertaking he presented himself before Charles and submitted to the most abject terms : he renounced the league, acknowledged the jurisdiction of the imperial chamber, consented to pay a fine, to release Duke Henry of Brunswick, and to do and suffer whatever the Emperor wished. With the greatest difficulty he avoided having to receive the decrees of the Council of Trent. He condescended, as a matter of form, to ask pardon on his knees. But when the time came for him to return home, Charles consigned him to captivity, declaring that he had bound himself by no other promise than to spare him perpetual imprisonment. The document 
which he had signed, according to the tradition of the Germans, read ewige for einige. Philip supposed that he should be spared all imprisonment, the Emperor read it only as sparing him imprisonment for life. By this very disingenuous pettifogging act, Charles disgraced his great and deserved triumph.

He had now the two great leaders of the league in his hands, and all the inferior ones had submitted. But the end was not yet. The Pope was, as usual, alarmed at the imperial suceess, and suspected that, if the Council of Trent continued to sit, Charles's influence would be found greater in it than his own; nor was it his interest that the Emperor should be all-powerful in Germany. $\mathrm{He}$ connived at, therefore, if he did not actually suggest, a division in the Council : half the prelates, for fear of the plague, seceded to Bologna and reconstituted themselves there as the veritable Council. Until that schism was healed the business of the reformation could not proceed. It became, therefore, Charles's object to reunite the two divisions, in order to pacify Germany by reforms whilst his successes were still fresh: it became the Pope's aim to hinder this reunion, lest under the Emperor's influence the reforms should go further than was convenient to himself, and Charles's power in Germany increase to a degree incompatible with any independent spirit in Germany, such as had been so often, from the time of Henry IV. downwards, the salvation of the Apostolic See. The influence of the family interests was also still strong with Paul III. The Emperor had refused to give Parma and Piacenza to his son Pietro Ludovico, and he was half inclined to go to war.

Charles again saw that no time must be lost. He summoned the Diet to Augsburg, and during a sitting of some months prepared the minds of the princes. Among the other business transacted in this session were the release of the landgrave: the investiture of Maurice with the electorate of Saxony; the reform in the imperial chamber, which was loudly called for and had been indeed one of the stated causes of the war of Smalkald; but the most important was the obtaining a consent to receive the Tridentine decrees. By intrigue of one sort or another, Charles persuaded the states to give a conditional consent: they would receive the decrees, but not without terms. Maurice was bought by the electorate: Joachim of Brandenburg followed Maurice's line; the Elector Palatine Charles frightened into consent, but the cities would have a provision made for their teachers being heard before the Council of Trent, and for the decision of all points by Holy Scripture and primitive tradition. Charles pretended to accept this as an explicit promise to obey, and forwarded to the Pope, as the wish of the Diet, a petition for the reunion of the Council. But the Bologna division 
proved obstinate, and, the Pope declining to coerce them, Charles took on himself to provide a cure for the spiritual evils of Germany. After protesting by his ambassadors against the conduct of the council (January 1548), he propounded what was called the Interim, because it was intended as a provisional arrangement for the interval before the Council should determine on reformation, on May 15, 1548, at Augsburg.

This document or declaration of the Emperor, which may be compared with some of Henry VIII.'s manifestoes in England, was a summary of Christian teaching drawn up by two Catholic divines, Julius Pflug and Michael Sidonius, and one nominally Protestant, John Agricola. Unfortunately for its character as a compromise, it contained nothing but Roman doctrine; two points of practice only being temporarily conceded to the Protestants : the retention by the married clergy of their wives, and the giving of the cup to the laity in the districts where it had been customary. Unpalatable as it was to the whole party, it was accepted by the Diet in which it was promulgated. The Archbishop of Mentz rose immediately on hearing it, and in the name of the assembly approved it, without their authority indeed, but uncontradicted. Charles pretended to receive this unauthorised assent as satisfactory and dissolved the Diet. Both parties were equally outraged, yet Charles declared that he would enforce the Interim on them alike. John Frederick gained dignity by refusing, and Philip lost it by promising adhesion. The Electors Palatine and of Brandenburg, with Maurice of Saxony, reluctantly received it ; but the Margrave John refused, pleading the Emperor's promise to his Protestant allies. The Spanish forces took the cities one by one, and compelled submission in them, Charles abolishing at the same time their ancient constitutions. Hollow as the peace was, Charles pretended to believe it, and, seeing only peace in Germany, departed to the Netherlands with his prisoners.

\section{LECTURE IX}

CHARLES V.'S RELATIONS WITH MAURICE OF SAXONY AND HENRY II. OF FRANCE

The Interim was propounded by Charles on May 15, 1548. Two years of uneasy quiet followed it, during which the Protestants were discussing among themselves how to avoid any decided action that would either commit them to the objectionable formula, or draw down upon them the vengeance of the Emperor, who was for the 
time irresistible. Charles had survived his rivals, and his chief enemies were in his own prisons. He had extinguished political life in Spain, and had nearly done the same in Germany, partly by dividing the Protestants against one another, partly by breaking down the constitutions of the free cities which refused to receive the Interim, and imposing on them a new municipal system and new Catholic magistrates. Helived during this time in Belgium, making a royal progress in company with his son Philip, and, during the intervals of gout, bending his politic mind to the compassing of two ends : the greater one, the recalling of the Council of the Church to Trent; the smaller, the substitution of Philip for Ferdinand as his successor in the Empire.

It is possible that the next two years might, but for the gout, have been the quietest years of Charles's life. But his two sets of negotiations gave him employment and sowed the seeds of difficulties which, in spite of the gout, were to put him to as great trouble and exertion as he had ever had before. The negotiation with the electors for the substitution of Philip had no effect except to offend Ferdinand and cause a sort of political alliance, or rather resumption of friendly relations, between him and Maurice of Saxcny, which bore fruit later. The negotiations for the re-summoning of the Council and closing of the schism of Bologna were hampered by the difficulties touching Parma and Piacenza, which were claimed by the Pope as the property of the See of Rome, by his grandson Ottavio Farnese as his duchy, the investiture of which, either from Emperor or Pope, he insisted in vain on receiving, and by the Emperor as overlord of Milan. So long as the Emperor refused to recognise either the Pope or his grandson in the possession of Parma and Piacenza, so long Paul III. declined to recall the Council to Trent; so long Charles could make no use of the pretended consent of the Protestant princes to receive the decrees; 'and there was no chance of permanent peace in Germany. Several cities, Hamburg, Bremen, Lübeck, Magdeburg, refused to receive the Interim altogether, and the states which received it were already quarrelling about the extent to be allowed to the class of questions that were called adiaphora, which the divines were anxious to make as definite and the politicians as large as possible.

This state of uncertainty ended with the death of Paul III. on November 10, 1549 : accelerated, as his contemporaries believed, by the conduct of Ottavio Farnese, who had seized Parma, then held by a Papal garrison, and offered to hold it of the Emperor. The election of the Cardinal del Monte, who had acted as Paul's representative in the Council of Trent, and who became Pope, as Julius III., on February 8,1550 , puts an end to the complication of the Farnese 
rights, with the other obstacles to the Council ; although Parma and Piacenza continued not only now but long afterwards, nay, almost to the present day, to act as an open wound in Europe. To sum them up briefly and put them out of the way, Ottavio Farnese got from Julius III., in the beginning of his reign, a recognition as duke. Julius repented very soon of having thrown away what might have been kept to the Holy See. Ottavio placed himself under the protection of Henry II. of France, with whose forces he fought a campaign against the Papal and imperial forces, the King and Emperor being still at peace. After the peace of Passau, Charles secured Ottavio in possession of the duchy, and in 1556 Philip II., in order to draw him off from France, gave him the town of Piacenza, the castle of which was, however, retained by him as overlord until 1585 .

The accession of a new Pope inspired Charles with renewed hopes of the Council. He plied Julius with constant requests, and, not content with that, took the business of Germany again in hand, summoned the Diet to Augsburg for June 25, left the Netherlands at the end of May; met the Diet in July 1550, and laid before it a proposition to renew the promise made in 1548 to receive the decrees, and another to force the Interim on Magdeburg by a regular siege.

The conduct of the siege was committed to Maurice of Saxony, who becomes for the remaining years of his life the chief man in Germany. We have traced his career hitherto as that of a thoroughly selfish and unscrupulous man; he was a sound Protestant, but had stood aloof from the league of Smalkald, had ruined the Protestant cause by the attack upon Saxony in the Smalkaldic war; had risen to the electoral dignity by an act of treason to the head of his family, and had urged with the whole force of his authority, and with the insinuating power of his dissimulation and address, the hateful Interim upon the unwilling people. His action now might well astonish the faithful, if any of them retained any belief in his sincerity. Possibly some few were aware of the depth of his schemes, and to a certain extent took part in his design; but it would seem certain that his purpose, even at the moment he undertcok the siege of Magdeburg, was hostile to the Emperor. Either he intended to create for himself an independent dominion or to turn the tables on Charles. That he had determined to revenge himself for the long-continued detention of his father-inlaw the landgrave Philip, who had consented to receive the Interim, and whose imprisonment was a disgrace to Charles, as it was an insult to Maurice; that his selfish ambition was so great that it would shrink from nothing by which an increase of power might be seized or purchased, although it does not follow that he had formed 
any definite design of founding a new dominion since he had supplanted his cousin ; that he and Germany in general had a real ground of complaint and even of armed resistance against the Emperor, on account of the forcible abrogation of the constitution of the free towns and the high-handed way in which the Diet had been treated ever since the battle of Mühlberg ; and that, moreover, his alliance with Ferdinand somewhat countenanced the idea that in resisting Charles whose plan to substitute Philip was unquestionably dangerous to Germany - all this, I think, may be regarded as certain. But although these reasons or some of them may justify resistance, and others palliate the treason of rebellion, it could only have been a very deep-laid scheme of revenge that induced him to dissemble so long and so craftily. If he was merely waiting for his opportunity, we may admire his adroitness and rapidity in seizing it; but the voice of history generally accuses him of deliberately and expressly deceiving Charles, of studiously lulling his suspicions, and, having done so, of sparing no weapon of political warfare against him.

$\mathrm{He}$ is a wonderful man, Maurice, I am afraid we must allow ita wonderful scoundrel. Scoundrel or not, he undertook the siege of Magdeburg, confiding the personal management of it to George of Mecklenburg, a Protestant of his own stamp, who had the command of a host of mercenaries trained under the wretched Henry of Brunswick, whose history we discussed in the last lecture. The siege was not a very brisk one. Magdeburg was a strong place ; and Maurice's plans wanted time to ripen. Negotiations alternated with attacks and sorties, in one of the last of which George of Mecklenburg was taken prisoner.

Whilst the siege, which lasted from November 1550 to November 1551, was in progress, Charles was urging the Council on Julius III., who, not having a family interest to maintain, had only the usual Papal obstacles to prevent his concurrence. The month that the siege of Magdeburg began, he recalled the Council to Trent, and on May 1, 1551, it met. One of its first acts was to accord safeconduct to the representatives of the Protestant doctrines, whom Charles was strongly urging all the princes to send from Germany. In conformity with his command a large number of divines were selected to attend the Council, and some of them actually reached Trent: but the King of France protested against the holding of the assembly under imperial influence ; and Charles at the same time, by forcibly ejecting the Protestant ministers in Swabia and Augsburg itself, afforded great reason for suspicion that there would not be fair play. Philip Melanchthon, who had agreed to attend and present the Confession of the Saxon Churches, got as far as Nuremberg and there thought better of it, for he went no further. Charles 
himself, who at all events was thoroughly in earnest about this, and of whom it is too much to say that he was insincere in his desire of religious peace, betook himself to Innsbruck, two days' journey from Trent, and there watched the proceedings. So entire was his security that he retained only a small guard about him and sent away the little army that he had always so much difficulty in paying, partly to fight against the Turks in Hungary, partly to support Julius III. in the little war of Parma.

Well, the Council drew its slow length along from the eleventh to the sixteenth session: and the siege of Magdeburg proceeded almost as slowly until it surrendered on November 9, 1551. Before it surrendered, Maurice had made a league with Henry II. against Charles, and the surrender was the signal for renewed and reunited action on the part of the Protestants. All along, to the very last moment before he proclaimed war, Maurice took the most elaborate measures to deceive the Emperor. Of course his treaty with Henry II., as well as his abortive negotiation with England for help, was kept profoundly secret. But if Charles had not entertained some suspicions, Maurice's zeal must have overdone the thing. It is wonderful how he got both parties to believe him, prevailed on the Magdeburgers to elect him their burggrave, whilst the merit of his victory was urged on Charles as a ground for entire trust in him; prevailed on Ferdinand by the zeal with which he supported his right to the succession, and through Ferdinand blinded the eyes of Charles; and prevailed on the Protestants to confide the entire management of their affairs to him, although he had so often betrayed them. The mercenaries who had helped to besiege Magdeburg were taken into the pay of Mecklenburg, lest Maurice should be suspected of keeping too large a force, and Melanchthon was sent to Trent, for fear he should be thought likely to act up to his own pronounced views as to the decrees, the only point on which the Emperor had mistrusted him, and on which he was obliged to make a show of firmness for fear of alienating the Protestants. Charles, perhaps, believed that this also was a trick of Maurice, intended to betray the reformers once again. But if Maurice was so cunning a man, and yet had resort to such elaborate artifice to outreach Charles, we cannot but conclude that, though in this case unquestionably hoodwinked, Charles was no mean adept in the same art.

At length the plan was ripe. Henry II. was ready for war. He had renewed his alliance with the Turks, and was ready to do what his father had never been able openly to do, to assist the Protestants of Germany in the field. The league between him and Maurice was renewed at Chambord on January 5, 1552; and as soon as the spring opened war began. Maurice secretly moved into 
Thuringia. To the last he had kept up the deception, and pretended to Charles's envoys that he was going to visit their master at Innsbruck; instead of going to Innsbruck he joined the forces which he had collected under William of Hesse and the Duke of Mecklenburg, and hastened by forced marches into South Germany. As he began his march he published his complaints and demands on the Emperor. Three reasons were given for rebellion: the safety of the Protestant religion, the unconstitutional behaviour of Charles to the Diet and the free cities, and the imprisonment of the landgrave Philip. All of them were reasonable grounds, and moderately stated. Unfortunately, one of his allies, Albert of Brandenburg, who had got a little force of his own together to seek adventures and found a principality, thought it necessary to issue another manifesto, in which the same principles were stated in offensive and exaggerated language.

Coincidently with Maurice's action, Henry II., on March 15, began his own movement. He also proclaimed war on Charles, and announced himself the defender of the liberties of Germany and of its captive princes. This was a poor reason for an orthodox tyrant like Henry to give, but as usual matters were in an uneasy condition, and swords had been drawn already, both in the Low Countries and on the Italian frontier, on the old pretexts. The Constable Montmorency commanded, and led his army into Lorraine. He took the imperial cities Toul and Verdun, and on April $10 \mathrm{Metz}$ also. On the 18th Henry joined the army in person and overran Lorraine, levying contributions through Alsace also, and even from Strassburg itself.

Maurice on his part lost no time; after his proclamation he marched towards Augsburg. Everywhere he was received as a deliverer, restored the displaced magistrates to the free towns, and the churches to their Protestant ministers. The garrison of Augsburg fled at his approach; and Charles saw him at a distance of two days' journey from Innsbruck, where he was absolutely defenceless. Charles's fortune had hitherto never failed him, and very confidently he must have trusted it when he ventured to stay at Innsbruck. $\mathrm{He}$ besought his brother Ferdinand to mediate, and porhaps trusted that Maurice would not go to extremes with him. But Maurice's masterpiece was now in hand. He did not refuse to negotiate, far from it ; he left his army under the Duke of Mecklenburg and met King Ferdinand at Linz on the Danube. Whether he prevailed on Ferdinand to let him give Charles a lesson in diplomacy I cannot say, but the two, finding that they could not arrange matters at once, agreed to meet again at Passan on May 26, on which day a truce was to begin for the purpose of negotiating, to last until June 10. 
Until May 26 Maurice was free to gain any advantage he could; after that his hands would be tied. He determined to make one bold stroke for the highest stake, and seize the Emperor himself. He took the command of his army again on May 9, and hurried them on towards the Tyrol. On the 18 th they arrived at the border, routed the little force that Charles had placed at Güssen and Ruten, and seized Ehrenburg by storm, or rather by panic. If it had not been for the mutiny of a body of mercenaries at Ehrenburg, he would have taken Charles in his bed. As it was, the delay gave time for the news to reach Innsbruck; the Emperor was carried off in a litter into Carinthia, where it was impossible for an army to follow him, and rested at Villach. Before he left Innsbruck he set the Magnanimous elector free; but the poor fellow did not know what to do with himself, and, thinking Maurice a more dangerous friend than Charles, posted off to Villach with him. Maurice, finding that the bird was flown, returned to the army in Bavaria, where Albert of Brandenburg was doing mischief to both sides; and then went on to Passau to keep his engagement with King Ferdinand.

At Passau a congress of the powers of Germany was held, from May 26 to August 2. Charles was utterly impotent for present resistance. The Council of Trent had collapsed on the news of Maurice's march southwards, and on April 28 adjourned for two years, not to meet again for ten. Henry was threatening not merely the imperial dominions but the Empire itself, and had inflicted a wound from which, as a matter of fact, it never recovered. The three bishoprics Toul, Verdun, and Metz, were permanently lost to the Empire, and Lorraine, Alsace, and Strassburg were going too. The war of 1870 was the revanche for 1552 . Ferdinand himself saw that the succession which he was waiting for would not be worth having, unless Charles were brought to reason. The congress comprised representatives of nearly all the German princes. Maurice acted for the Protestants, Ferdinand, moving to and fro between Passau and Villach, for the Emperor. The immediate demands of the former were: the release of the landgrave; religious peace and liberty, and the redress of civil grievances, the despotic aggressions of Charles and the iniquities of the Imperial Chamber. The whole assembly of the princes, Catholic and Protestant, joined in begging Charles to satisfy Maurice and stay the civil war. Ferdinand was as anxious for peace as any of them; and Charles, when he saw that to prolong the struggle at present would be to give up the Netherlands to Henry, and Naples to Solyman, was ready to yield if he could save his dignity. Even as it was, he was the gainer by delay, and if he could have prolonged this, he might have managed to divide the allies: but Maurice was too wide-awake for that, and 
chose to yield somewhat, rather than to risk the loss of the advantage he had so cleverly won. Now that the great point was within reach, he saw clearly that Charles might do him much harm yet, and that the only sound peace would be one that Charles could be compelled to keep.

The principal articles of the treaty were: the release of the landgrave of Hesse; the holding within six months of a Diet which should provide means for settling religious disputes henceforward; the abstinence in the meantime on both sides from interference with each other in religious matters ; the admission of Protestants to be members of the Imperial Chamber ; the provision that, in case the future Diet should fail to provide machinery for the settlement of religious questions, the article of this treaty shall continue in force by which the security of the Protestants is provided for; both parties forgive each other the injuries done in the war; and the unruly Albert Alcibiades may, if he likes, be included within the settlement. The question of Charles's unconstitutional dealings with the cities was to be referred to the proposed Diet.

I shall spare you any reflexions on reflexions, such as Robertson favours us with, on this collapse of the design which he imputes to Charles of establishing a despotic government in Germany. If all is well, we can consider some of them in the last lecture, when I shall hope to give you my idea of the character and policy of the Emperor. But now we must follow up the other half of the struggle. The treaty of Passau pacified the Protestants, and they had shown their regard for their generous protector and avenger Henry of France, by omitting any mention of him in the treaty. Albert of Brandenburg, who had done them more harm than good, was provided with an escape, but nothing was done for Henry.

Charles saw the mischief that the alliance between France and the Protestants had done him ; saw that the wound given to his power inside Germany was curable: time might give him another chance; but if Germany were ever to be defensible on the side of Lorraine, the three bishoprics must be speedily recovered. As soon as the treaty of Passau was concluded, he set out at once towards Lorraine. Maurice he sent to Hungary to fight for Ferdinand; Albert of Brandenburg, who declined to join in the peace and was ravaging the Catholic states still with 20,000 men, he thought a more endurable evil than the retention of Metz, Verdun, and Toul by the French, and on the whole wisely. By Augsburg, where his army met him, and where he divided the churches of the city between the Protestants and the Catholics, he proceeded, on September 1, towards Lorraine. On October 22, he began the siege of Metz. Metz was 
defended by Henry of Guise, who brought to the task a great deal of spirit, and skill far beyond the then undeveloped science of military defence. His bravery and earnestness created in the very inhabitants of the town, which had until that year been German, a perfect furore of independence. He had with him the very flower of the French nobility and army, whilst with Charles were a magnificent force of 50,000 men and uninterrupted communications.

The siege of Metz was, no doubt, the thing that broke the spirit and heart of Charles. For fifty-six days he persisted in continuing it, in spite of gout, of intolerable weather, and of terrible pestilence in the army. It is easy to condemn him for cruelty and waste of the lives of the thousands who perished in that awful time: but it should not be forgotten that Metz had been torn from the Empire by a wanton, unprovoked aggression, and that the holder of it had the key of Germany in his hands. It was not a mere retaliation by war, but the expulsion of a foreign invader from the imperial territory, that Charles had undertaken. We know that he failed, lost his army, and was obliged to retire on January 1, 1553, into the Netherlands, the French exulting in the thought that they had at last seen the demolition of the power which had overcome them so often.

The same time saw several mishaps in Italy : the expulsion of the imperial garrison from Siena, and an alarming show of hostility on the Neapolitan coast by the Turks. But these events are not of great interest as touching the string of Charles's history. Siena was recovered in the year 1555, and annexed in 1557 to the Medicean state in Tuscany, which had also acquired Piombino from Charles by mortgage, and which was raised by the Pope in 1570 to the title of Grand Duchy of Tuscany. Another Italian republic thus tasted death, and, if it were worth while going into particulars, tasted it by the same means so many before had done, a preference of French intrigue for the risk of imperial oppression. The republics insisted on being republics, the Empire insisted on regarding them as imperial free towns; trying to become independent by French aid, they lost both characters, missed being republics, and ceased to be free.

The break-up of the siege of Metz is the last great event of Charles's life, but it is not the end of his political intrigues, nor even of his active military career. Notwithstanding the gout, he thought of marrying again, and not only thought of but actually fought another campaign. But his disappointments and ill-health were telling upon him; the defeat at Metz brought all his failures home to him, and, although we must not exaggerate his failures as those writers do who make capital by ascribing to him superhuman designs, 
we cannot doubt that, both at Villach and at Metz, personal humiliation had come to him as intolerable to bear as the breakdown of great projects. His conduct of affairs in 1553 was enough, however, to show that the French had counted too certainly on his declining power. Early in the year he sent an army into Picardy, took and destroyed Térouanne (June 10), which was in some respects to France what Metz was to Germany, and took also Hesdin by storm. This provoked Henry, who led an army in the direction of the Netherlands, thus rousing up Charles in person from the retreat at Brussels, where he had buried himself since his return from Metz. But, as usual when both princes were in the same campaign, a general engagement was avoided. Henry, it seems, was at this very time trying to draw on Maurice again into alliance and aspiring to the Empire, which he calculated would soon be vacant.

In Germany matters were proceeding rapidly towards a determination for the time of the religious crisis. The Diet promised by the treaty of Passau was not yet called, but the Protestants were in no hurry about that, having secured liberty for themselves during the interval; and Charles and Ferdinand were too busy to set about it on the Catholic side. Maurice of Saxony had returned from Hungary ; and Albert Alcibiades, having made his peace with Charles and joined in the siege of Metz, had again rushed into his robber warfare and attacked the Franconian cities, Bamberg and Würzburg bishoprics, and the Nürnbergers. Albert Alcibiades was not a man to make friends; he had persecuted the Catholics, and refused to combine with the Protestants ; there was scarcely a state in the Empire that he had not outraged, and, now that there was time and leisure, all men joined against him. I cannot think, notwithstanding Carlyle's admiration of him (and he was a true Hohenzollern), that there was much good in him ever; at all events now there was none. He was little better than a robber chieftain, a sort of Arab or Bohemian, as the modern phrase is, fighting about everywhere on a pretence of religion. He roused all the princes against him. Maurice was put at the head of the army of the allies, and Albert Alcibiades was thoroughly beaten in the battle of Sievershausen, near Lüneburg, June 9, 1553. There Maurice himself fell, but Albert Alcibiades never lifted up his head again. He was put under the ban of the Empire in May 1554; he fled to France, and, failing of help there, to Baden, where he died in 1557.

Germany, in this action at Sievershausen, lost her two most brilliant men; for whatever was the moral character of Albert Alcibiades, of his extraordinary ability there can be no doubt; either in military capacity, or in political intrigue. The way in which be was able for so long a time to stand practically outlawed against all 
Germany proves it if nothing else did. Carlyle calls him a 'failure of a Fritz;' that is, an abortive attempt at a Frederick the Great. This is unfair; Albert at the lowest estimate was in character as much above Frederick the Great as he was in success beneath him. If success is the criterion of character, William I. of Prussia is above Frederick the Great himself, Philip Augustus a greater man than St. Louis, and so on. In truth, Albert was very like the original Alcibiades, able and somewhat taking, but desperately unprincipled and picturesquely adventurous, and that seems to be all. But for Maurice we must say more: we read with astonishment that he was only thirty-two when he died; he had done so much good and so much harm already. Perhaps his youth, coupled with his wonderful ability, may be the fairest key to the difficulties of any consistent view of his conduct and character. $\mathrm{He}$ was clearly immensely ambitious and perfectly conscious of his great ability. His perfidy to his cousin John Frederick may not be defended, but may partially be accounted for, I think, by his natural contempt for the narrowness and obstinacy, amounting to pigheadedness, of that heroic and virtuous prince. No doubt John Frederick was magnanimous; no doubt Philip of Hesse was magnanimous too ; I do not see anything they had in common, except that they were both Protestants, and both had to endure imprisonment. In other matters the similarity did not go far.

John was a good man, Philip a bad one; John a religious Protestant, Philip an irreligious one; John a patient prisoner, Philip an impatient one; John would not accept the Interim to deliver himself from prison, Philip did accept it and did not escape any the sooner ; John was content with one wife at a time, Philip used his Protestant liberty by having two. I suppose the Germans called Philip magnanimous for fear he should be jealous of John Frederick.

But it was Maurice that I was speaking of. If he-conscious of his own ability, seeing the way open to his ambition and despising his worthy cousin ; warranted in his adhesion to the Emperor not merely by interest, but by the example of other princes of far higher rank, the Count Palatine and Elector of Brandenburg-made by one act of faithlessness to John his way to the electorate, and by one act of faithlessness to Charles the pacification of Germany; why, he did, certainly, what no thoroughly conscientious man would do, but what any young prince of his power and opportunities would be very strongly tempted to do. He died too soon for us to conceive at all what he might have come to: but I should think it extremely probable that he would have been Emperor if he had outlived Charles, and that as Emperor he might have given a new history to Germany. 
It is astonishing to see how, notwithstanding his treatment of John Frederick, the whole of the Germans trusted him.

The battle of Sievershausen closes the history of Germany for the year 1553. Charles continued in the Netherlands, negotiating the marriage of Philip with Mary of England, and preparing for another campaign which Henry was provoking him to. The promised Diet was still postponed; it was summoned for August 1553; then for November 1554 ; it was not got together finally until March 1555. By that time Charles's active career was over. The history of 1554 consists of the attack by Henry II. on the Netherlands, in which he took Marienburg, Bouvines, and Dinant; but which fell, as a campaign, into a merely maranding expedition. It is redeemed by the events of the siege of Renti, where the Emperor took personal share for the last time in the actual labours of war. The Duke of Guise, who was besieging, was compelled by Charles to raise the siege and retire into France. In Italy there was the siege and surrender of Siena. The next year began with an attempt of Cardinal Pole to negotiate a peace between Charles and Henry, which failed; the attempt to surprise and betray Metz, which also failed; and Ferdinand's first essay to get the princes to Augsburg to the Diet which was to settle the questions that had been troubling Germany for nearly forty years, and whose work was really the fit termination of the reign of Charles.

This Diet began, or at least the first attempts at it were made, on February 5. Then, in a very thin meeting, Ferdinand stated his view; the Council was for the present hopeless, he had nothing better to propose than a revival of the plan of disputation and conference between the best men on both sides. This alarmed the Protestants, who saw all they had struggled for again risked; and they were further startled by the appearance of Cardinal Morone as Papal legate at the Diet. It is possible that a secession might have followed, but peace was saved by two things, the death of Julius III. and the political interests of Ferdinand. Julius III. died on March 5, and his successor, Marcellus II., on April 30. Cardinal Morone left Augsburg on the death of the Pope whose commission he had received. Paul IV., who succeeded Marcellus, was \& determined enemy of Charles V.: it was morally certain that there could be no effective operation in religious matters between them; and Charles's aversion to beginning a new struggle with the Papacy may have been one reason for hastening his resignation. Ferdinand's interests were greatly dependent on the support of the Protestant princes. Charles was moving heaven and earth to obtain the imperial succession for Philip, and had offered to buy off his brother's claims, and take any means whatever to reconcile the 
hostility of the princes. But they knew too much of Philip, and indeed Charles himself was learning that he had shown far too much consideration for an ungrateful son. The princes stood by Ferdinand, and Ferdinand could not help giving in to the desires of the Protestants, which they would, as soon as he was left to himself, be perfectly able to enforce upon him. He saw, too, that the formation of a league between Saxony, Brandenburg, and Hesse, by which they added to their ancient treaty of erbverbriiderung, or mutual right of succession and cross-remainder, an article binding them to support the Augsburg Confession, would put an end to the imperial power in the North altogether if it were ever to be ranged against it.

The negotiations dragged on until September 25, when the Recess of Augsburg was drawn up and published, for the peace of religion. By this it was provided that all states which had adhered to the Confession of Augsburg should be free from interference of any kind from Ferdinand, nor should Catholic ecclesiastical jurisdictions be exercised in them: and that war should no more be undertaken for causes of religion; that all church revenues seized and appropriated before the treaty of Passau should be retained by their holders; that every state should be at liberty to establish its own form of religion, and those of its subjects who reject that form should be at liberty to emigrate; and that any Catholic prelate changing his religion shall cease to hold the dignity which entitled him to his place in the Empire.

Such, I said, is the last act of the reign of Charles. A month after the issue of the Recess, Charles resigned the Netherlands to Philip as the first part of his abdication of his whole estates and functions. On February 5, 1556, he resigned Spain also to Philip, and on September 7 of the same year he sent the imperial ornaments to Ferdinand with the act of renunciation of the Empire. The last year of Charles's nominal reign belongs to that of Philip and Ferdinand; the latter of whom had exercised any imperial functions that could be exercised in Germany since the treaty of Passau. I shall say a word or two about the abdication in the last lecture, whilst contemplating the reign and character of Charles in a general review.

\section{LECTURE X}

\section{GENERAL REVIEW OF CHARLES V.'S REIGN}

As the head of the Empire, as the inheritor of many great names and dignities, and as the actual possessor of widely extended territories exposed to the aggression of the Mahometan states Charles V. 
was marked out as the defender of Christendom. And amidst the varied and complex questions of the politics of his reign, complications in which we lose sight for years of any individuality of character in the principal actor, it is refreshing to see him from time to time distinctly buckling on his armour and setting out on his crusades. It is curious to remark how in this respect he repeats the policy of the earlier emperors, in particular of Sigismund; and how closely bound up with the desire of repelling the Turks is the urgent demand for a Council to reconcile all the Churches, to reform the relations between the Papal See and the national Churches, to reform and purify religion itself. It was not thought likely that a divided Christendom would succeed in an attack on the Turk, or that an unsatisfied population would subscribe liberally the funds needed for such an enterprise.

On reviewing the relations of the European states at this date, the internecine quarrel of Francis and Charles, the divisions produced by the Reformation, and the amount of intrigue that was winding its way into the general politics of Europe; and on the other hand, the long reign and immense power and prestige of the Sultan Solyman (1520-1566); it does seem an extraordinary thing that Europe continued to be Christian. It was on Charles alone that the defence of Christendom rested; and if his successes were not brilliant, the reality and efficiency of his defence are rather to be admired than to be depreciated. The march of Solyman was stopped, although there might be no great victory; he was not suffered to reach the heart of the West, although the selfish dissensions of the princes and the divided heart of the people suffered a territory far too large to be spared to fall into his hands. Although these matters have not in the ordinary text-books the importance they deserve, we will devote a morning to the exhibition of them.

Not only were Charles's Spanish dominions exposed to the constant attacks of the maritime powers of North Africa, who for the most part were independent of the Turk, and his Neapolitan dominions in the same way threatened from the sea, but the whole of Eastern Germany lay open to attacks which a strong government in Hungary and Bohemia was requisite to ward off. In defence of Spain, Charles made his expedition to Tunis ; in defence of Italy the one to Algiers; his defence of Germany brings us into direct relation with these two kingdoms, which the inertness, or rather perhaps the honesty, of Frederick III. had suffered to slip out of the hands of the Austrian family. Albert II. had been King of Hungary and Bohemia as well as King of the Romans and Duke of Austria. His little posthumous son Ladislas had succeeded to both as soon as he was born; and on his death at 
the age of eighteen in 1458, each kingdom, irrespective of the claims of Frederick III., had chosen for itself a king alien to the royal houses of Europe. Matthias Corvinus was King of Hungary from 1458 to 1490 ; George Podiebrad of Bohemia from 1458 to 1471. They were reunited, however, on the deaths of these two great princes, by another Ladislas, a son of Casimir IV. of Poland by Elizabeth, daughter of Albert II.

Ladislas after a short quarrel with Maxmilian, who compelled him to surrender the share of Austria proper which he had received with his two kingdoms and to secure the succession on the failure of his own family to the house of Austria, was for the rest of his life employed in the struggle with the Turks. In this he was by no means successful. He was not well supported by Maximilian, who indeed had much else to do; nor by his own subjects, who were too ready to turn their arms against one another. In 1516 he died, leaving his kingdoms to his son Lewis, a boy of ten, whose minority as usual opened the way to civil disturbances, and these to new attacks by the Turks.

When Lewis was fourteen, the Ottoman succession fell to Solyman the Magnificent. The thrones of Europe were now filled by the strongest men who ever contemporaneously occupied them. There may have been greater sovereigns than Charles, Henry, Francis, and Solyman; but there never were so many great ones together, of so well-consolidated dominion, so great ability, or so long tenure of power. And of the four not one had any particular love of peace: each had a taste for war and an engrossing thirst for power. But Solyman had to make his way by aggression; the others had but to hold their own, or to fight for what they thought they had a claim to. Solyman's first steps to conquest must be made in Hungary, the second in the Mediterranean. Hungary, a prey to dissension and with a child king, was a tempting bait; the destruction of the settlement of the Knights of St. John at Rhodes was an absolute requisite for the obtaining that command of the Mediterranean which could secure Egypt, the conquest of his father Selim, and the supremacy in North Africa on which he had set his heart. There is much nobility about Solyman in his earlier history, and his chivalrous and merciful character reminds one of Saladin; but, like so many Eastern heroes, he outlived his virtues, and fell, under female influence, into a dishonoured old age. But his early successes were conspicuous. In $\mathbf{1 5 2 1}$ he took Belgrade and overran Eastern Hungary and Croatia. In 1522, after a long siege borne with unparalleled heroism and endurance, he wrested Rhodes from the Hospitallers and so opened the Mediterranean to his .own fleet. Cyprus still remained in the hands of Venice, but Venice was not yet 
involved in hostility to the Turk; her mercantile interests were still predominant, and she was more enriched by peace than war.

In the destruction of Rhodes, Solyman cleared out of his way the greatest and foremost hindrance to Ottoman conquest. For two hundred years and more, since the last effort of the Crusaders had ended in the loss of Acre, the Hospitallers had been the great defence of Christendom by sea ; their exploits are amongst the most wonderful in all history, but they are forgotten for the want of a nationality that can claim them as its own. In 1530 they settled in Malta, which Charles V. gave them as King of Sicily : there they established themselves in nearly their former glory, and Solyman lived long enough to endure at their hands not merely reprisals for the treatment they had received from him, but a victorious resistance to another siege as carefully planned and as elaborately carried out as the siege of Rhodes had been.

In 1525 the captivity of Francis I. had opened to Solyman another way towards influence in the West. Francis negotiated with him preparatory to an alliance which was to bring him down on Germany itself. But Hungary still lay in the way to Germany ; and to subdue Hungary Solyman first bent his energies. $\mathrm{He}$ marched in 1526 on the young King Lewis, who was defeated and killed in the battle of Mohacs (August 29). Solyman took and burned Buda, the Hungarian capital. The death of Lewis left the succession to his two kingdoms open. Ferdinand, his brother-in-law, to whom by the treaty between Ladislas and Maximilian the kingdoms were secured, entered at once upon Bohemia; but the Hungarians, a prey, as usual, to domestic quarrels, refused to receive him, and elected John Zapolski, voivode of Transylvania, who condescended to apply for the support of Solyman. This was readily accorded, and for ten years he was maintained by Eastern aid in half the kingdom. In 1536 he made peace with Ferdinand on condition of being allowed to retain his possessions for life; and he died in 1541.

Both during his life and after his death, John Zapolski's alliance opened the way for Solyman into Hungary: in 1529, as his ally, he advanced and again took Buda, crossed into Austria, and besieged Vienna. From Vienna, which was defended by Frederick, the Count Palatine of the Rhine and afterwards Elector, he was compelled to retreat (October 14) with great loss, whilst Charles was in Italy on the business of his coronation; but he made a second attempt in 1532. Charles on that occasion met him with an army of 120,000 men, but the two hosts parted without a battle. Solyman, it is said, distrusted the good fortune of Charles; and to Charles men and 
arms were too precious to be wasted in conflict when the desired object was effected in Solyman's compulsory retreat.

Leaving John Zapolski to fight Ferdinand by himself, Solyman next devoted his attention to the Mediterranean; or rather, having views upon the East and the Persian Empire in particular, he gave a commission of admiral to Hayraddin Barbarossa, the famous corsair of Algiers; who not only ravaged the Christian territories bordering on the Mediterranean, but, anxious to found a strong kingdom for himself, expelled Muley Hassan, King of Tunis, and made that city the headquarters of the fleet and army with which he threatened both Spain and Italy. Muley Hassan, in his distress, had recourse to Charles; and Charles, proud of his success against Solyman, undertook the expedition to Tunis, which ycu have so well described by Robertson. For this expedition Charles brought together forces and ships from all parts of his dominions; the fleet was under Andrea Doria; the army Charles himself commanded, with the Infante Lewis of Portugal and the Duke of Alva. The expedition was successful in spite of great losses and expenses. He took the Goletta, with Barbarossa's fleet, and drove him himself out of Tunis to Algiers. Muley Hassan was restored, surrendering the Goletta as the payment for the help he had received. The dates of the Emperor's movements are: July 16,1535, he sailed from Cagliari : August 6, he reinstated Muley Hassan; August 17, sailed for Sicily; August 20, landed at Trapani ; September 12, he was back at Palermo. The great corsair was far from being annihilated: for several years, however, the struggle was carried on by sea ; constant flights and pursuits, but no great battle.

In 1536 Hungary was pacified by the treaty between John Zapolski and Ferdinand, and Solyman had there no pretext for interference; but in 1540, on John Zapolski's death, on the pretext of defending the rights of his widow and child, the Sultan took up arms against Ferdinand for the conquest of Hungary. In this quarrel the Hungarian element was represented by George Martinuzzi, Bishop of Waradin, whom John Zapolski had left guardian to his infant son. The widow would gladly bave fulfilled the arrangement with Ferdinand, but Solyman and Martinuzzi objected, and the former prepared to sustain his objection with an immense army. Ferdinand was weak enough to offer to pay tribute on condition of being allowed to hold Hungary ; but, happily for the credit of the Empire, Solyman refused the offer. He then brought up his army, drove the Germans from before Buda, took possession of the capital and the little King, and annexed Hungary to his own Turkish Empire. Martinuzzi he rewarded with the regency of Transylvania, which had belonged to John as voivode, and which Solyman generously left for a portion to 
the little King Stephen; there, under the name of John Sigismund, and as the patron of the Socinians, he ruled until his death in 1571.

This conduct is the greatest blot on the public fame of Solyman; and it was crowned by the murder of the German prisoners. Buda became a Turkish city; the churches even were turned into mosques.

And now we have to set against this unscrupulous act of Solyman an equally singular mistake on the part of Charles, or at least a measure which its ill success qualifies for the character of a blunder. His pertinacity and his pride were both involved in the hunting of Barbarossa out of the Mediterranean; and in the interval of peace with France that followed the truce of Nice, and the league of Pope, Charles, and Ferdinand against the Turks (which the Venetians also joined 1538-1540), after great preparation and the liberal contributions of all his kingdoms, he in 1541 sailed from Majorca to Algiers. The expedition was most unfortunate : a terrible storm dispersed and wrecked the armament; one short skirmish, in which no success was achieved, was the sole act of hostility that took place. The destruction of the fleet and army by the storms put an end to hope : after a series of unparalleled disasters, distresses, and personal hardships, which the Emperor shared with the meanest of his soldiers, the remains of the army were got away from the hostile coast, and, after a tedious voyage, returned to Spain, landing on December 5, 1541.

I do not quite see how this expedition can be justified when the condition of Ferdinand in Hungary was what it was; but it is possible that Charles considered the defence of Hungary to be safe in his brother's hands during the winter months when the Turks were pretty sure to be quiet, and that the Algerine expedition was fixed for this unfortunate time of the year in consequence. But it was every way most disastrous, for it invited Francis I. to a renewal of the war, it destroyed the Emperor's prestige, and, to a lamentable degree, wasted his resources.

Solyman now renewed, and drew closer, his relations with Francis, and the Venetians also entered the league. In 1543, and again in 1544, Solyman, having quite paralysed all action on the part of poor Ferdinand, invaded Austria again, and ravaged Silesia and Moravia. In 1545 he turned his attention to Italy, and by the agency of Barbarossa, threatened, and even ravaged, the coasts from Nice to Messina. The same year he made peace with Ferdinand on the condition of receiving a tribute of 50,000 crowns annually, and that each should retain what he held in Hungary. The peace of Crespy in September 1544 had, in fact, robbed him of the open alliance of Francis. As they had never been able to act in concert, this made no practical difference; nor did the coolness last long, for, shortly before his 
death, in preparation for a renewal of war, Francis was urgent in entreating Solyman to strengthen his grasp on Hungary. The attitude of hostility was not materially altered by the peace, but, during the Smalkaldic war, Ferdinand was too weak to take the aggressive, and Solyman was growing old, weary of the sameness of the war, and busied with designs in the East.

Nor were Martinuzzi and the young ruler of Transylvania getting on well with the Turkish pashas whom the Sultan had left to be their allies and defenders. In 1551 Martinuzzi offered his services to Ferdinand; the Queen and the little King received two duchies in Silesia in exchange for their rights in Transylvania; Martinuzzi a cardinal's hat and the government of Transylvania. Castaldo, Ferdinand's minister, and Martinuzzi were to join their forces to carry on the war; but the jealousy of Castaldo and the conscious superiority of Martinuzzi prevented any cordial co-operation. Ferdinand was persuaded of the treason of the bishop, and was prevailed on to allow him to be assassinated. The Turks, rejoicing in the removal of such a formidable minister, proposed to renew, and to throw more energy into, the war. Solyman, in conformity with his part of protector, declared that he would avenge the murder.

Again the war is carried into the Mediterranean; Dragut, the successor of Hayraddin Barbarossa, ravaged the coast of Calabria. Mehemet, beglerbeg of Roumelia, restored the Queen and Prince of Transylvania. Ferdinand's mismanagement and poverty combined caused his forces to mutiny, and his subjects to rebel. The treaty of Passau (August 2, 1552) enabled Ferdinand at length to bring Maurice of Saxony with 20,000 men against the Turks, but the success of Maurice was not equal to his fame; he also was hampered with Castaldo, as Martinuzzi had been, and could effect nothing permanent. Nor is it worth while to attempt to trace the further steps of the struggle: the war of Austria with Turkey continues for a century and a half with little intermission and with various success, the battle of Lepanto (1571) itself scarcely shows the turn of the tide.

The defence of the Mediterranean during this long struggle rested partly on the Sicilian viceroy, partly on the imperial admiral, Andrea Doria, partly on the Knights Hospitallers, now established at Malta. As I feel some remorse for the cursory way in which we have treated these great men, we will, at the risk of some repetition, have a word about them, and close the lecture with a remark or two about the progress of the Spanish arms in the new Western world.

Don Pedro de Toledo, who was Charles's viceroy at Naples from 1532 to 1553 , was a man after Charles's own heart: he was a good 
general, an able administrator, a reformer of the law, a persecutor of the Protestants. And, although from time to time the greatest efforts were used, even by persons like the Marquis del Guasto, to supplant him, he retained his master's good will until he died at Florence of the malaria fever, caught in the expedition of that year for the recovery of Siena. On his vigilance depended the defence of the Italian coasts, as on Andrea Doria the command of the open sea. The first great alarm from the Turks during his viceroyalty was that of 1537. Don Pedro, on the news of this, organised a general defence; summoned the whole regular force of the kingdom, and chose for encampment a central point in Lower Apulia, whence succour might easily be sent to any threatened point; armed the citizens of Naples, and trusted the defence of their city to them in company with a handful of trained soldiers; and, calling a parliament of the barons, engaged them in like manner to give their own services and those of their vassals.

Solyman's expedition was partly under Barbarossa, who was burning to avenge the loss of Tunis ; partly under Solyman himself, with the Pasha Lussibeo as admiral. The former landed in the province of Otranto, and plundered there; the latter took Castrio and Urgento, and enslaved and carried off the inhabitants; but the approach of the viceroy's army, and the news that Andrea Doria was taking reprisals in the Levant, sent the Turks back in a hurry to their own regions; and Pedro took advantage of the patriotic furore thus created to rebuild the castles and other fortifications on the coast, and at the same time prevailed on Charles to furnish supplies for the building of a chain of watch-towers round the coast, which, by beacon-fires and other ante-telegraphic contrivances, could at once spread the alarm of a threatened invasion, and summon the defenders to the spot. The next great alarm was, however, in 1541, when Barbarossa sacked Reggio and threatened Rome itself. It was on this occasion that he joined the fleet of Francis at Marseilles and besieged Nice. The fleet of Andrea Doria again frightened him away. In 1544 Barbarossa ravaged the islands of Ischia and Procida, and purposed a landing at Pozzuoli. But the viceroy was ready to meet him, and he did not venture to approach.

The war of 1552, in which for the first time the French were able to afford armed aid to the Protestants, was also the occasion on which Solyman seemed most likely to lend effective aid to the French. And this time the attack was no doubt caused partly by the discontent prevalent in Naples, consequent on the attempt of Charles and his viceroy to introduce the Inquisition, and partly directed by the King of France at the suggestion of the Prince of Salerno, who had rebelled against Charles and fled to Henry. 
Again Don Pedro had recourse to the good will of the barons, and 300,000 ducats were raised for the payment of a force of 30,000 men to be used in a sudden emergency. On July 15, 1552, the enemy really came: it was a great fleet of 150 galleys under Dragut, the successor of Barbarossa, and Sinam Pasha, anchored at Procida, within sight of Naples. There, however, they stayed for a month and then sailed away without waiting for the French fleet which was to have acted in concert with them: according to one story, they were bribed by the Viceroy, according to another they were dissatisfied with the French. After their departure the French arrived at Genoa with the Prince of Salerno, but their friends were by that time in the Levant and would not return. Thus the greatest storm blew over, and although Dragut continued annually for a long time to give alarm and even to plunder the coasts of Sicily and Naples, nothing like an invasion or attempt at conquest was made. The incitements of the French had failed to produce their former effect, and the frequent betrayal of Turkish interests by them for their own ends wearied out the patience of their allies.

The later expeditions were rather piratical than warlike; and, indeed, from the beginning of the career of Hassan and Hayraddin, the piratical was no small element in the naval expeditions of the Sultan. This comes out more distinctly in his dealings with the Maltese knights, whose settlement at Malta by Charles in 1530 had exposed them to constant aggression from Barbarossa and his imitators. The gift of Charles to the Order was one which brought them great labour and little profit, and rid Charles of considerable responsibility. It comprised not only Malta and Gozo, the adjacent island, but the city of Tripoli on the mainland of Africa, which was, indeed, nearly all that remained of the conquests of Cardinal Ximenes, under whose administration it had been acquired for Spain in 1510. Of this splendid endowment, Malta was a barren island, producing a revenue of 41 ducats per annum; Gozo was fertile, but without a harbour. Tripoli was a well-fortified city, but in a situation indefensible against the arms of modern warfare. It was a very poor exchange to the knights for the rich island of Rhodes, which they had defended to the last, and which ought to have been defended by the joint fleets of all Europe, and might have been but for the guilty ambition of Francis $I$.

The Hospitallers, however, were eager to get an independent home, which would rid them of the restraints of their Papal allies and render them less of a tool in the hands of Clement VII. They accepted the gift, and after an unhappy attempt to get a better settlement at Modon, in the Peloponnesus, set themselves to conduct the defence of Europe from this unpromising standing-ground. Under

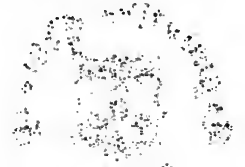


their management Malta became fertile; and fortified by their skill it became practically impregnable. As soon as they had settled in their occupation they threw down the challenge to the Turk : in 1531, their fleet, in conjunction with that of Andrea Doria, took Coron, in the Peloponnesus, with Patras and some other less important places, and strongly fortified the first. In 1532, Coron was besieged by one of Solyman's corsairs and relieved by the two fleets after a general engagement with the Turks, in which the Christians were victorious.

In the Tunis expedition of 1535 the knights fought side by side with Charles and drew down the vengeance of both Barbarossa and his patron on the Order. Tripoli was the most accessible of their possessions, and Tripoli was attacked by Sinam, the Devildriver, who had built a fortress called Alchaide, near Tripoli, to watch for a favourable opportunity. He was not, however, successful; he was himself defeated by the garrison, and a detachment of the fleet from Malta destroyed his castle.

The Algerine expedition of Charles for a time drew off the vengeance of Solyman; but on the death of Barbarossa, shortly after, he promoted another corsair, named Dragut, to the command of his fleet, and Dragut set his heart on acquiring Tripoli. His first acquisition was Mehedia, a fortress which had advantages that Tripoli wanted, a strong situation as well as fortifications almost unassailable: it had been a sort of petty republic until Dragut seized it, being one of the old dependencies of Tunis, which, after the break-up of the power of Tunis, had not been thought worth appropriating by the Sultan. From Mehedia, Dragut pillaged the opposite coasts and watched for Tripoli. The knights, on the other hand, watched Mehedia, and in 1550, in conjunction with the viceroy of Sicily and Don Garcia, son of Pedro Toledo, they took it, after a very brave, nay savage, resistance. Dragut persuaded Solyman to make an expedition against Malta. In July 1551, just a year before the similar expedition to Naples, Dragut and the Devildriver made a descent on the island and ravaged Gozo; having thus distracted the attention of the knights, Dragut turned on Tripoli. Unfortunately the garrison had quarrelled among themselves, and one party declared the place untenable. With this insubordinate crew, the governor saw nothing better to do than to capitulate. Whilst negotiating, he was, contrary to the laws of all nations, seized; by the Devildriver, and the rebellious faction eoncluded the surrender. The following year the Maltese fleet, under Leo Strozzi, made an unfortunate descent on Barbary ; and from that time for many years. the knights played the part of crusading corsairs.

The great ineffective siege of Malta by Solyman falls some years

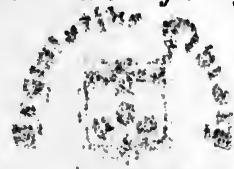


after the death of Charles; in 1565 the whole power of the Turkish Empire was brought against the little rock, and was driven off with a loss of 25,000 men. Charles had used the services of the knights without showing them much gratitude; he had, perhaps, hardly appreciated their value; and after they had fortified Malta he coolly proposed to them to emigrate to Mehedia. This they refused to do, at the risk of offending Charles.

I have said, perhaps, too much about the knights, but they are very interesting people, and there is a picturesqueness as well as utility about their proceedings which is inviting. Anyhow, no view of Charles's measures for the defence of Europe can be complete without attention to them; although practically independent in their action, they were nominally his vassals, and must have been always an important element in his calculations of the expense and necessity of a crusade. Their existence was one long crusade-a link between the present age and that of Frederick Barbarossa and Richard Cœur-de-Lion, which an historian, if not a politician also, may grieve to see finally and completely broken.

The knights lost Malta in 1798. We took it from the French in 1800 , and although the restoration of it to the Order was provided for by the peace of Amiens in 1802 we have continued to hold it ever since, justifying ourselves by the weakness of the Order and our own necessities, a plea as strong, perhaps, as any by which the modern sovereigns of a great part of Europe can maintain their own position in great portions of their territories.

Into the career of Andrea Doria I cannot, in conformity with the plan I have adopted of avoiding personal details and devoting our attention to political events, now attempt to go. I may, however, say that from 1528 to 1560 he not only maintained the possession of Genoa against the French and their faction in the republic, but commanded the imperial fleet against the Turks. His interests were one with those of Charles, who trusted to him without misgiving and without jealousy. In relation to Genoa, the chief events of his long domination as the chief citizen although not the presiding magistrate of the republic were the attempt of the Fieschi in $\mathbf{1 5 4 7}$ to seize the city on behalf of the French, and the loss of Corsica to the united fleets of France and Turkey in 1553. Andrea was then eighty-four, but he took the command or direction rather of the expedition which was intended to recover it, and kept up the struggle against France for several years with varying success. In 1559 he saw the island restored, by the treaty of Cateau-Cambrésis, to his native city; he died in 1560, aged ninety-two.

It would be pleasant if we could add to these defenders of Christendom the name of the rich and powerful republic of Venice; 
but with the exception of the league of Pope and Emperor against the Turks in 1538, in which the Venetians joined, we read of little done by them in the way of crusade; and this show of hostility was terminated by a peace between Venice and Solyman in October 1540. The interests of the Venetians were purely selfish, whether their momentary policy was a merely commercial one or a design of territorial and political aggrandisement. The peculiarity of their situation and their history, and the great strength of their internal organisation, seem to set them quite by themselves; they are dependent on no alliances, constantly inviting but as constantly escaping attack, ever growing richer and more powerful and more self-contained. Their policy with respect to Turkey, although, looked at from the modern point of view, it was prudent and enlightened, was, according to the medieval idea, ungenerous and treasonable to Christendom. It must be allowed, however, that, although a high-spirited and really chivalrous nation would not have entered into the relations with the Turks into which Venice had entered, it was a different thing to accept the necessity of maintaining and increasing them. Nor had Venice begun her career as a chivalrous state; her beginning was mercantile, and as Genoa had been to the Byzantine Empire, Venice, partly perhaps by defence against the aggression of Genoa, was to the Ottoman. It was no small contribution to civilisation that resulted from the Venetian policy; whether it was enough to justify neutrality in the perpetual crusade may well be doubted.

Before leaving the subject we may hurl a last stone at Francis and the French policy which invited the Turks into Europe, to the destruction of the Church and Empire of Christendom. Were it for this alone, his memory is stamped with eternal infamy. The wretch who was murdering the Protestants at home and intriguing with them abroad added yet this, that he invited into Hungary and Naples and the coasts of the Mediterranean generally the forces of a prince who, whilst he was no doubt as good a Christian as Francis and far more noble and honest in every way, stood at the head of a system which men believed to be Antichrist, and maintained an army and fleet every act of which was full of relentless barbarity and wanton cruelty. The sin of Francis is unpardonable, and in any comparison between him and Charles it is enough to decide the inclination of the scale, however scanty the estimate of Charles's merits, and the overvalue set upon Francis's brilliancy and ability. Nor has his conduct the catchpenny excuse of enlighten. ment. Francis was as ignorant and bigoted as any man of his age : he was purely selfish, wanton, and revengeful, and for the gratification of these instincts he sacrificed the welfare of Europe. 
I cannot, in the last place, pass over altogether unmentioned the exploits of Hernando Cortez and Francisco Pizarro. I can only, however, mention them to show that I have not unintentionally omitted them. But in truth the plan of the lecture has not been such as to involve any reference to them. The Spanish colonies in the New World had begun under Ferdinand and Isabella, and a consideration of the policy by which they were managed belongs to the earlier period. The conquests of Peru and Mexico fall within Charles's reign; but they introduce no new elements into the government or political condition of Spain; and their other results on her social condition really fall outside of Charles's life altogether and belong to the later history. Charles's relations to both the great conquerors were generally those of respect and gratitude. He is accused of neglecting Cortez, because he did not place him in the government of the country which he had conquered. But this was not neglect : it was a part of the policy which had been pursued, with far less reason, in the case of Columbus; nor can it be said that Cortez suffered, for, although he was not made civil governor, he remained Captain-General of Mexico. But the truth of the matter is that the visits of Cortez to Charles were ill-timed. One was in 1529, whilst the negotiations for the peace of Cambrai were pending, and the interests of all Europe were on the Emperor's mind. The other was in 1541, when he joined the unhappy expedition to Algiers, and Charles was overwhelmed with vexation and chagrin. The subsequent neglect into which he fell may be as easily accounted for. Charles was never actively ungrateful; he perhaps thought that Cortez had received his reward. Pizarro did not. live long enough to have to complain. The money that Mexico and Peru poured into Spain had scarcely begun to flow in such abundance as to affect political history.

\section{LECTURE XI}

\section{THE CHARACTER OF CHARLES V.}

WE have now to attempt some estimate of the character of Charles V., of the distinguishing features of his policy, and of the actual results of his reign on the history of Europe. We must first, I think, beg the question that he had a character, and that he was not, as Robertson makes him, a mere machine on whose wooden framework you can calculate exactly the mechanical effects of every blow of fortune. I shall not ask you yet to beg the question that he had a consistent policy. 
As for the general result, we know that there must have been one unless the whole theory of cause and consequence is a mistake. $\mathrm{He}$ had, then, a character, some traits of which were doubtless inherited, some points of which were brought out more prominently than others by his education, and still more by his being called on at so early an age to rule without a guardian so enormous an extent of dominion. I will try not to analyse the characters that other people have written of him, but to say what seems to me, from the careful reading of his life, to be the most reasonable view of his character.

I think, then, first, that we cannot deny him the character of a great sovereign and a great man. Doubtless there are degrees of greatness, and there is a difference between the greatness that is backed by thorough goodness and the greatness that achieves success : a difference between the man who makes himself great and the man who shows his power only by maintaining an inherited position. But to say this is not to deny greatness to the latter if the difficulty of sustaining the position increases as the exaltation of the position increases. I mean to say that only a great sovereign could have kept together the empire that Charles V. did keep together for forty years. This I claim for Charles to begin with: power and force of character that entitle him to be called Great. Greatness may be shown in several ways; the end may be sought by different means. One king is great in directing everything himself ; another in organising the work of his servants ; a third in choosing servants who will organise, direct, and do everything obedient to the impulse of a will that has but to indicate its direction and to be obeyed. Of these there can be no doubt that the last is the highest degree. I think that Charles can only be said to have had it in a measure; and this was perhaps his misfortune rather than his fault. He had no minister whose greatness in the least degree encroaches on the greatness of his master. He had ministers and advisers, and good ones, who did his will and managed the details of his work for him carefully ; but he had no minister who ruled him or directed his policy; he had none who had a policy at all likely to run counter to his own ; he never betrayed or was betrayed by any of them; not one has left anything like a great name behind him. We conclude that he had not the material of great ministers to choose from, but that he found good and able administrators. His generals and admirals were well chosen; and his other subordinates hardly come at all into history. $\mathrm{He}$ chose his viceroys of Naples and his queens governantes for the Netherlands well; none ever thought of treason or rebellion. Even his brother Ferdinand, placed in a position of all positions the most trying, and certainly attached to him by no tender fraternal affectionfor during their youth they could scarcely ever have met-was faith- 
ful to him throughout, even when sorely tempted at the end of the reign by Charles's mancuvres in favour of Philip. This gives one the notion of a very businesslike, commanding, and overseeing mind.

But again; success may be won either by force or by policy, or by a persistency which partakes of both and has something besides of its own. Charles had this last, and with it considerable energy. Some of his rapid effects are as fine as anything one reads of in medieval history; he had great power of deceiving other people without committing himself ; that is a great gift of policy. The way in which he played Francis from time to time with different baits is amusing enough and a sign of great power in its way; but neither of these can account for his success. There was a certain persistent steady defensiveness about him that is more distinctive than either his force or his craft. I should roughly describe this as wiriness : Charles's character is altogether wiry; not deficient in muscular force, not deficient in grace and agility, but pre-eminently tough and wiry.

Further, in social life it would seem that he was a good friend and kind master; he was never betrayed by a servant; never, from the time he came to maturity of character, did he disgrace or abandon a minister; he was not intolerant to an unsuccessful general. He trusted and was trusted by his own people; he was not vindictive as an enemy; he was not wasteful of the lives of his people, except as every warrior or king with a warlike policy must necessarily be. But Charles's policy was not intrinsically warlike; he kept up no great standing army, his wars were generally defensive, and poverty as well as humanity compelled him to be economical of his fighting material.

He was, although a reserved man, kind and genial: he was a faithful husband and had a very good wife. His appetites were strong but under considerable restraint; his morality compared with that of his contemporaries is pure; his illegitimate children were born either long before his marriage or long after his widowhood; andino vile connexion was ever flaunted before the world. The children were indeed the result of what in the case of kings was a sort of legalised concubinage; but Charles was not an adulterer nor a slave of women, nor a taker of other men's wives. He was not a drunkard, as, considering Flemish habits, he might have been. If, like many men who have led hard lives, he was a heavy feeder, one can hardly wonder, but even this was only a peculiarity of his latter years, and may have been attributed to him without much cause by people who were set to watch whatever he did, and had little else to do than to count the number of the different 
dishes at his dinner. He was certainly a sincere Catholic; a strict observer of the letter of all covenants ; for even in the famous case of Philip of Hesse he took care, if the story is true, to have the letter of the law on his side; there was, I am inclined to think, more wiriness than tenderness about his conscience in such matters.

The articles of impeachment against him generally are ambition, dishonest policy, and persecuting cruelty. As for the last, I said so much whilst speaking of his administration of the Netherlands that I need not dwell on it now. It is too true, Charles was not only a man of a persecuting age, but sympathised and organised persecution and urged on the already too willing inquisitors. $\mathrm{He}$ is guilty on the face of the matter. He did not persecute in Germany, partly because he could not, partly because his position would have been endangered if he had made the attempt; that he persecuted the Calvinists because their views were political, and spared the Lutherans because they were not pronounced heretics, as Motley says, can hardly be true. The Inquisition was established in the Netherlands before Calvinism had got any real power or displayed any dangerous political tenets ; and the measures which he took to force the Interim on the Swabians were not less than persecuting, though blood might not be shed or the fires lighted for religious causes alone. I think he was a sincere persecutor, and that his professions of tolerance were transparently insincere, were merely a political device intended to bring about the result they actually effected-the division of the Protestant princes of Germany. From this fearful accusation there is no escape : the persecution might be allowed for, but the strong and urgent sympathy with the persecutors can never be extenuated.

We should be glad to know that he repented ; and some historians, arguing from the line which his favourite priests took after his death, have imagined that it was so, and that the reaction was such as to incline him in some measure to receive Protestant tenets. But I believe this is a mistake and that to the last his instructions to Philip were to go on as he had begun. To his memory this accusation is doubly fatal : doubly, because we lose all pleasure, contemplating it, in defending the defensible parts of his character; and because it has drawn down on him the vengeance of the bitterest of all critics and placed him guilty before a tribunal that knows no mercy. But grant it all, and try to look at the other two articles of impeachment: he was ambitious; he was ambitious of glory in war, and of extensive dominion; he was deceitful, he had no chivalry; he was tricky, cunning, unscrupulous in the means he took to gain his ends; he played on the weakness of men, both his friends and his enemies. 
Take them singly. He was ambitious: was there anything wonderful in that? At the age at which a boy leaves a public school, he was a King of three years' standing in the wealthiest realms of Europe, and elected Emperor, titular ruler of the world and defender of the Church. He was, as I remarked once or twice, slow in coming to maturity. His early administration of Spain was that of an ignorant, hot-headed boy, easily led, fond of his old friends, shy of new ones; ungrateful to one certainly to whom he owed a great debt, but whom he had never seen, of the nature of whose obligations he was ignorant, and whom he knew to be hostile to the friends whom he trusted. Then, if ever, we might look on it as likely that he would be ambitious. The most able, intelligent, and fortunate warrior of his time, with a vast empire, and a great multitude of princes to make fortunes for by war, would there have been anything strange if this power and fortune had led him to entertain views incompatible with the peace of Europe? Power, youth, skill, and opportunity, are no small helps, no small spurs to ambition. Yet did Charles ever engage in war that was not in its nature defensive? Did he ever claim an acquisition that was not his own by legal right as Emperor or as heir of his forefathers? He held fast what he had received, but he did not increase his European dominions, the real field for his hypothetical ambition, by conquest at least, by a single acre. He was ambitious of glory in war? Truly; yet he was the most cautious of all tacticians. Even where he seems, as in the campaign of Mühlberg, to have neglected advice and to have risked too much, the result justified his calculations to a degree that convinces us that he knew what he was about better than his counsellors ; and so great were his skill and foresight in this respect that, knowing his habitual caution, we may confidently acquit him of rashness. He was a most cautious tactician; a most econcmical general ; most averse, from first to last, to risk anything in battle. I repeat, his warfare was forced on him, and was in its whole spirit defensive. He kept no great army, he was too poor. On all sides he had enemies, who never ceased to attack him; his own safety was peace, but it was no peace to suffer himself to be beaten. This charge of ambition is a vulgar and unmeaning accusation. No man can be blamed for an ambition which consists in holding fast that to lose which would stamp him as a mean and unintelligent coward.

And now for his unscrupulous craft, his deceitfulness, and what Motley calls his want of chivalry - the way in which he laid snares for men and took advantage of their weakness, and deceived them in intention whilst he spoke the truth in words. I think the defence in this point is this : First, he never deceived his friends or any that trusted in him; he did not forsake his allies or sacrifice their interests 
to save his own. Secondly, he did not break his plighted word, nor incur the stain of personal dishonour. What is the meaning of chivalry? Is it not the gloss put by fine manners on vice and selfishness and contempt for the rights of men? Edward III. was chivalrous; he thought nothing of risking the lives of 10,000 men on an enterprise which could bring no good to any mortal man but himself ; involved Europe in a war in which he had not the shadow of a right, and brought more misery on England than any other man before or since. Francis I. was chivalrous, a man who spared no woman in his lust, or man in his revenge; whose futile ambition never let him rest, whose unscrupulous lying wore out every shred of honour, who never scrupled to desert an ally, or purchase a moment's ease and luxury by the sacrifice of a friend. George IV. would, no doubt, have been chivalrous if he had lived a few hundred years before his time. $\mathrm{He}$ was behind his age in this as in some other points of more importance. The chivalry of such men is unworthy of the name; true chivalry has indeed existed, but not in many cases in which the world has regarded it. But as a system, as a rule of society or a prevailing influence, it never existed but in the Romance writers. Happily in all ages there have been true knights of God without fear and without reproach, sacrificing themselves for others, self-denying, bearing death sooner than wrong another; but I doubt whether the majority of them would be what is called chivalrous. About Charles V. there was no pretension: he falls very far below the real thing; but his dignity, his reserve, and his self-respect set him far above the sham.

But he was tricky? Yes, he took full advantage of all that delay and concealment and tact and management could do for him : as with his force, so with his policy. He was determined to hold fast, and he did hold fast. His enemies are the evidence against him: the French, and the Protestants of Germany. These last he did not deceive, they were far too wary to let him, although by his policy he divided them and made them fight his battles. I do not call him ingenuous; he was most artfully politic : but, first, was not the age politic? What were Charles's sins in this matter compared with those of Francis, of Clement VII., of Henry VIII. ? Was not the whole policy of the Italians based on this principle, and carried out without faith to friend or mercy to a foe? I would not defend dishonesty, but Charles may fairly be defended by a comparison with the men of his own time. His treatment of Philip of Hesse may be paralleled by Maurice's treatment of himself; it is very far outrun by Maurice's treatment of his magnanimous cousin; and beside that there is absolutely nothing against Charles but his dealings with Francis I, What could he do with a man so false 
as to defy all open obligations; who would justify himself by private renunciation of a treaty which he was going to sign; who would betray his closest friend; who stood throughout his reign-and this mark is a matter on which the conscience of the age was very tender, whilst Francis's unscrupulousness showed that he had no such conscience-who stood in lifelong alliance with the Turk, the pirate and plunderer of the West, the enemy of God's Church and Empire? Charles had no weapon but cunning against a man so false; and as it is against Francis that his policy is chiefly demanded, that cunning has given a colour to the policy which perhaps, judged by the standard of the age and the morality of its great men, it hardly deserves.

But I have not undertaken to prove Charles to have been a good man, or within the highest ranks of greatness. I should only like so far to clear him from the censures of incompetent and insincere judges. The cry of ambition is a mere cuckoo cry; the charge of deceitfulness I admit in so far as to allow that his policy with regard to enemies whom force and honour could not bind was disingenuous in itself and artful, but not dishonest beyond the diplomatic dishonesty of that age and of many since. I think the Prussian policy of 1866 was immeasurably falser, immeasurably more dishonest.

Take now our second point. I have maintained that a wiry pertinacity was the distinctive feature of Charles's character, and that the maintenance rather than the extension of his dominion was the aim of his reign, the end of his ambition and his contrivances. Had he, in conformity with this character, and as conducive to this end, a settled plan of despotism; a conscious intention to destroy liberty of religion, and the remains of political freedom and constitutional independence which continued to exist in his wide and varied dominions? Had he this despotic plan? Was it disappointment at its failure that drove him to abdication? If he had it, was it a plan of mere despotic power, or an imperial design for complete and united organisation?

Of the facts upon which such a theory might be based there is no doubt. It is certain that Charles V. did in Spain reduce the Cortes to insignificance; that in the Netherlands he acted, with regard to Ghent, with justifiable severity but with unconstitutional vindictiveness, a swiftness to take the opportunity of abolishing the dangerous privileges of his native city, that looks almost as if he had been waiting and watching for it. It is true also that he tampered with the Diet in Germany, and that, in his efforts to force the Interim on the princes and cities, he broke through charters and abolished constitutional liberties. And, further, it is true that his contem- 
poraries gave him credit for a design to make himself absolute in Germany, and in Italy to reduce the Papacy to insignificance. This last, as it is the widest, and the hardest to prove and to disprove, is also the most popular view.

In all these respects he has to pay for the sins of many generations that went before and came after him. It is regarded as Austrian policy ; he is the exponent if not the father of it. Austrian policy is supposed to have grown by a combination of successful diplomacy abroad and repression of constitutional life at home; Prussian policy, by the similar combination of unscrupulous violence abroad and the silence of discontent at home, by maintenance of the forms without the life of constitutional government.

I am willing to grant, to begin with, that Charles's policy was repressive : certainly in Spain and the Netherlands; more or less so in Germany and Italy. The question becomes one of degree; was his idea of repression a fixed and conscious design of absolutism; or was it the pursuit of hereditary policy; or are these instances only cases of momentary treatment, the only way in which at the moment he saw he could meet his difficulties? I grant that his policy was repressive, but it might be that, without his having a settled purpose to destroy liberty. Was his repressive policy defensive or aggressive? You will be prepared for my first answer. I believe it was defensive; but I think we may go further, and say that, beginning on the defensive, he did towards the end of his life see that the struggle was becoming one on both sides for existence, and that he had begun to entertain designs which, whether he saw it or not, would, supposing them to be successful, end in absolutism. There are many factors in this discussion : there is first his own mind, which we cannot penetrate; his own servants could not, and he has left behind him no confession, only the results of his work. His own mind was slow in coming to maturity; but when it was matured, when, I think, he was twenty-two or twenty-four, he had the mature mind of an old man. He was a long time young: ceasing to be young, he was old all at once. In every way, in policy, in business, and in warlike skill, he gained and had little to gain from experience; the only mistress to whom he bowed was disappointment.

I do not think, then, that we are justified in attributing to him a conscious origination of a design of despotism, when for at least twenty years of his reign there is no sign of it. All that was repressive in these earlier years was an inherited policy, both in Spain and in the Netherlands.

In Spain Charles cannot be exactly said to have broken down the constitution: here, as in many other matters, we can trace his 
observance of the letter of the law whilst he transgressed it in its spirit. He acted with great art, according to Robertson, in this: in 1521 he used the nobility to overwhelm the towns, and in $\mathbf{1 5 3 9}$ he put an end to the power of the towns in the Cortes, by summoning only a limited number, and those in many cases crown nominees. It is not, however, true that Charles in 1521 availed himself of the aid of the nobles to crush the independence of the commons. Spain was at that time in a state of revolution, provoked, no doubt, by the impolicy of Charles and his favourites. The nobles and clergy were engaged in it as well as the commons; but the revolutionary junta, by its proposition to tax the nobles, threw them into opposition, and placed them at once at the disposal of the regents. The commons were beaten, and for nearly twenty years performed their duty of voting supplies, with murmurs perhaps, but without resistance. In 1539 they refused supplies, and Charles, in the exercise of his power of summoning only those communities whom he would to the Cortes, reduced their constitutional power to a cipher.

But there is no conceivable unity between his policy, or rather the policy of the nobles, in 1521 and his conduct to the Cortes in 1539. It is an indispensable duty of all constitutional parliaments to keep the administration of the country afloat. If the king is bound to consult his parliament, the parliament also has its duties not to refuse supplies until there is reason. That is how the parliament of Charles I. began to get wrong; and it is how the Cortes of Castile incurred their fate. Do not mistake me: I do not mean that a national assembly has not a right to refuse money, but it has not the right to refuse it unreasonably, either as an attack on the king, as was the case in England, or as a means of increasing its own independence, as was the case in Castile. English law in the circumstances compels the king to submit, even where he is iniquitously treated : Castilian law, without any pressure, placed Charles's remedy in his own hands. The expedient had been tried under the earlier kings; the Cortes had rarely attempted to thwart Ferdinand and Isabella. Anyhow, the system on which it was constituted, based on privilege and limited by royal will, broke down when it came into direct opposition with the persistent and strong will of Charles.

In the Netherlands, the same year (1539), was the affair of Ghent. But at Ghent, whatever may have been the original right of the case, and granting that there could have been a privilege so destructive of all constitutional right as that a single city should have the power of refusing to pay a tax levied and assessed in an assembly in which it was represented-Ghent, even if right to begin with, was unquestionably guilty of the worst and most deliberate treason. 
Charles's revenge on Ghent was perhaps impolitic, but it was not unprovoked, and it was not undeserved. After all, the line taken by the burghers of Ghent was an hereditary one, and Charles's repressive policy towards them was hereditary too. It was the most turbulent town in the Netherlands, and had given more trouble than any other to his ancestors.

But are we called on to believe that Charles in this same year, 1539 , was so besotted with a design of absolutism as to strike two such blows intentionally? Surely he would have made certain of one before he attacked the other: as it was he submitted for the time to be thwarted by the Cortes; and his design in the Netherlands went no further than the destruction of the liberties of Ghent.

His conduct in Germany is at first sight a more plausible ground for the assertion of this design; but even this, when it is looked at closely, fails. Even here, where more than anywhere else he breaks the spirit of constitutional law, breaks through the charters of the imperial towns, and forces on the Diet the acceptance of the Interim, he does not infringe any written law. The Diet did accept the Interim, and the towns refusing to receive it refused to obey what, by an unworthy procedure, had become the law of Germany. But surely Charles's end in this business was not to set up a new system; it was simply to settle the religious question which was dividing Germany and paralysing the imperial jurisdiction; obliging him to intrigue with the Pope, and disabling him from the defence of Europe. To put down Protestantism is one thing, to destroy the constitutional status of the members of the Empire is another. If the former could not be done without the latter, Charles no doubt was willing to humble the princes; but also a great number even of the Protestant princes were on his side; and the constitution of the league of Smalkald was such that he might fairly deem it necessary, both for religion and for the sake of the unity of the Empire, to break it down.

I do not now unsay anything I have said before: in the main quarrel I do not see how Charles could have sat down and let the Elector John Frederick and Philip of Hesse have their own way. Having once taken up arms, the constitutional law was in abeyance: and, that being so, the system of which the ill-treatment of the Swabian towns was a part became a vexatious necessity. The Interim must be adopted. It is curious that in each of his states the town element is the one which complains of being unconstitutionally dealt with. Having said thus much, I must add that whilst these events to my mind afford no convincing proof of any fixed purpose of destroying liberty, such as is ascribed to Richard II. in the madness of his last years, and to Charles I. and Strafford by 
those who would justify their own iniquities by charging contemplated iniquities on those who could not contradict them, there is no doubt that Charles was being forced into a path in which the formation of such a design would soon have become needful to him. Separate as we may the political and the religious sides of the great quarrel, and to some extent they were separable during the life of Charles, there can be no doubt that they must in the end become one. Political liberty is absolutely inconsistent with religious compulsion. Charles was finding it so, and Philip, advancing with accelerated speed along the groove in which his father had placed him, found it so to his ruin, at least in the Netherlands, where the determination to force the Catholic doctrine on the Protestant people cost him seven of his fairest provinces; seven of the most attached and most anciently loyal of all his states.

In Germany, it was as much, perhaps, the weakness as the will of Ferdinand that prevented him from attempting the same course; but it must not be forgotten that Charles had failed to set the machine going in that direction there. Germany was too strong for him, and there can be no doubt it would have been too strong for Philip had he, as his father wished, succeeded to the Empire.

That this was so, I think, Charles realised; I think so sagacious a man could not fail to do so. Whether it was that he saw that failure must attend the scheme, or that he felt his own attempt to stay the Reformation had been abortive, or that he knew himself to be worn out, and retired accordingly to have time to think about death, may be questioned. There are some to whom the possession of power seems so sweet a thing that they cannot understand how a man can by his voluntary act bring himself to renounce it: but are there not some to whom, however dear power may have been, responsibility is so heavy a weight that they are glad to renounce the one that they may relieve themselves of the other? Charles had stood at the head of Christendom for forty years : at such a height above all other princes, both in power and fortune and character, that nothing but national vanity can account for the comparison between him and Henry VIII. or between him and Francis I. $\mathrm{He}$ was a pious man, according to his light, and recognised a responsibility to God, which after the darkness of his heart he had tried to fulfil by persecuting where he could persecute, and humiliating whenever it was possible, the enemies of the faith. He was responsible to man in a sort of way; to keep up the high name that he had inherited, that through him the estate which he had tried to govern should take no damage. $\mathrm{He}$ felt himself weak and breaking: perfect rest did not restore him, although it may well have belonged 
his life for a year or so. He was bound, we may believe that he believed, both to God and to his own fame, to resign a kingdom which he was losing the power to manage. I dare say that disappointment mingled with the thought, but I can well believe that he spoke the truth when he declared his weariness, and his longing for rest, and that this was a long-looked-for and welcome end of his labours.

In what I have said as to the second question I have answered the third. If Charles did not consciously conceive and elaborate a plan of despotic government, he left an inheritance of it to his successor in Spain and in the Netherlands. But can it be said that this was an innovation in the policy of Europe? Lewis XI. had reduced the constitutional government of France to absolutism. Henry VIII. through his parliament governed his people as absolutely as Francis did his without one. The social liberty may have been greater, but the political liberty was quite on a par. Henry forced on England, not indeed Protestantism, but a renunciation of the Papal supremacy, which must end in Protestantism, and a destruction of the monasteries, which had been for nearly a thousand years the pride and glory of England. Edward VI. advanced in the same direction, forced absolute Protestantism on the people, made their old religious rites penal, destroyed learning in the universities, prepared the way for an abject submission of Parliament to the royal power, not the less abject that Philip and Mary found means to turn it in a diametrically opposite direction, whilst Elizabeth changed the direction again and by tact and endurance brought some good at least out of the wretched state of things she succeeded to.

Charles was not the inventor or the successful organiser of 'paternal government:' the merit of it or the guilt of it does not lie at his door. The general result of the reign, however, means not only what he succeeded in doing, but what he failed in preventing. He failed in preventing the Reformation and he failed in circum. scribing the pernicious influence of France. He succeeded in impressing upon Spain and on certain parts of the Netherlands, and possibly of Germany, and of Italy too, a decided hostility to the Reformation; giving the Jesuits a standing-ground from which working they recovered within a century after his death a very large portion of what had seemed lost for ever to the Church of Rome. The result of his reign includes, further, the unintentional issue of the means he took to promote his views; in Germany, the determinate change of the whole of the North with respect to the Papacy, a result which a more temperate support of the unreformed doctrine would not have risked; for North Germany had always 
been papal, and anti-imperial; it continued anti-imperial, and now ceased to be papal. The feeling was intensified which opposed the North to the South, and although for a time and at times the princes of North and South have worked together, there has been no love lost between the people, least of all when the old schism was widened by the difference of religion.

Although within Germany this was the case, it can hardly be denied that Charles greatly magnified the imperial office and the position of the Emperors of the Austrian house in Europe. The very fact that so great a sovereign had worn the imperial crown added importance to that crown, the real power of which depended so very much upon prestige. The permanent acquisition by Ferdinand of the crowns of Hungary and Bohemia was also a result of Charles's greatness; and that acquisition formed from the time of his death, and does still, the great support of the very existence of the house of Austria; it formed, until the final stoppage of Turkish aggression, its great plea for the respect of Europe, and the respect of Europe was a necessary ingredient of the imperial influence. There is not one of his dominions that is not greater and richer and stronger at his death than at the beginning of his reign, however that advance may have been made, through him or in opposition to him. $\mathrm{He}$ leaves, then, a very great mark, and a great many very definite marks, in Europe. His empire across the Atlantic we have had barely time to glance at, but I conceive there also he made a mark for ever. We part with him, then, with some little liking, and some considerable respect, and a great deal of pity ; and we cannot spare him from very deep blame; we cannot shut our eyes to very great guilt. But we cannot doubt his greatness, his force and tenacity of mind, his great ability in war and government; his earnest faith in the religion he had been educated in; we cannot but think that he might have been a better man, if he had not been so great a prince, with so much power for good and evil. 


\section{THE POLITICAL HISTORY OF EUROPE FROM}

THE RESIGNATION OF CHARLES V.

\section{LECTURE I}

EULOPE AT THE RESIGNATION OF CHARLES V.

THE reign of the Emperor Charles V. is not a mere period of eventful years. Its history is the history of a series of causes and consequences, of designs and evolutions and disappointments, that have a dramatic and historic unity of the highest interest. Wide as were his dominions, and various as were his titles to the obedience of his subjects; infinitely diversified as were the border nations with whose hostility he had to struggle all his life; very various as were the interests which he had to consult in the Netherlands and Germany and Italy; the persistence of his policy, the uniform character of his proceedings, and especially the precedent and following history of the house of Austria, which he consolidated in power and in a manner for the time impersonated, gave his reign this unity. The continuous struggle with the French, wherever the dominions of Francis touched or the claims of Francis could be asserted against his own; the perpetual crusade against the Turks, in Hungary, in the Mediterranean, and on the exposed coasts of Spain, Italy, and Africa; the as constant rivalry of the Popes, sometimes inspired by Italian patriotism, more frequently by personal or family ambition; and the equally perplexing difficulties that attended the rise of Protestantism in Germany : these four threads weave in and out, and form the web, whilst they give the colour, of the whole of the history of the reign. Throughout the greatest part of it also the actors are the same: Charles and Francis and Henry VIII. and Solyman and Luther begin their active careers together. Charles does indeed survive his enemies, excepting Solyman, by a dozen years; but as long as he lives and reigns the policy of those enemies is maintained by their successors; and, curiously enough, the deaths of these successors, of Mary of England, of Henry II. of France, and Paul IV., synchronise within a few months with his 
own, so that the field is left open to new actors when he, the great figure of the earlier drama, is withdrawn.

How great he was and how great the effect of his policy, mainly defensive as it was, must appear from the events that followed. The coincidence may be mainly accidental, but it is marked. How different might have been the success of the Reformation in England and the Netherlands, and the combinations of parties in France, if he had lived and reigned twelve years longer, we can only conjecture; but we do know that the collapse of the Roman reaction in England, and the outbreak of revolt in the Netherlands, and the wars of religion in France, followed speedily upon his death. In all those things Philip played a conspicuous part: the part which would have fallen to the lot of Charles, and which Charles would doubtless have played differently from the way in which Philip played it. But, for all that, the results might have been the same; we can only reckon safely on the probability that the means and workers would have been different.

The dramatic unity of the reign of Charles may thus be regarded as a different thing from the historical or political completeness of the period embraced by his reign. The former will mean the series of campaigns against the French and of struggles with the reformers which succeeded one another from the year 1520 to the year 1552: they end in the peace of Passau and the discomfiture of Metz-two events that end the personal interest of Charles's reign, although some few years still intervene before his abdication. Those two events are the climax of the series that has given the personal interest to the preceding thirty years. Charles quits the stage, and he quits it in a great measure disappointed. But the struggles which have caused or have been caused by that series of designs do not cease yet; the peace of Passau and the retreat from Metz are not the closing events of either series considered in itself. It is a coincidence worth remarking, how, although neither the retirement from Germany nor the subsequent resignation of the Emperor ends those two series, they are brought to an end at his death. The recess of Augsburg is nearly contemporaneous with his resignation of the Netherlands; the peace of Cateau-Cambrésis is an almost immediate consequence of his death.

I propose in this lecture to complete our sketch of the period covered by Charles's life. The last term's lectures brought us down to the resignation; but the view I shall now take will involve some little recurrence to earlier events of importance which led to his resignation.

The two strings of events which hang loose at the pacification of Passau and the retreat from Metz are, of course, the proceedings 
with the Protestants in Germany and the war with France. We must trace the sequel of these struggles. The peace of Passau provided for the settlement of all disputes touching religion in a Diet to be held as soon as circumstances would permit. That Diet was not held until the year 1555. It was delayed partly by the war with the Turks, for which Maurice of Saxony was detached almost directly after the pacification; by the struggles of Albert Alcibiades and the death of Maurice, and by the still continued attempts of Charles to procure the election to the imperial throne for Philip to the detriment of Ferdinand, who had been since 1531 King of the Romans. This unhappy project of Charles, which unquestionably paved the way for his great humiliation in 1552, although it never alienated from him the personal attachment and even veneration of Ferdinand; had the effect of placing their political interests in decided opposition. Ferdinand and his son Maximilian, who was now able to take an important share in politics, were never treacherous to Charles, but they saw no harm in counteracting a project which was in itself perhaps impracticable, but which was certainly detestable to the whole German people. Even the princes who were most hostile to the Reformation were enemies to the design of any further union between Germany and Spain, many of them personally hostile to Philip. But the great result of it was the identifying of Ferdinand and Maximilian with the interests of Germany, and the preparation that it gave them for ruling the Empire witt. a view to true German objects. And the first and most pressing of these objects in the minds of all Germans was peace and the compromise of the religious struggle. The religious struggle in Germany, the Germans had always insisted, should be put an end to by Germans, on German soil, and on national principles. Various as were the degrees of enthusiasm in the religious champions on each side, early as the struggle had begun, and rapidly as the events had succeeded one another, neither of the two parties was hardened so far as to suppose that its own safety depended on the extinction of the other. The Council of Trent had not yet quenched the hopes of reform within the Catholic Church itself, nor the machinations of the Jesuits set the moral instincts of the Protestants in array against the system which they so unscrupulously and so successfully supported.

The ecclesiastical party, then, which was constitutionally so strong in Germany, was at this moment not politically strong nor religiously very much in earnest. If it was ecclesiastical it was still German; and the retrospect of the struggle of the preceding thirty-five years was such as to render the most enthusiastic likely to be content with a safe tenure of their own dominions, with a liberty of persecuting their 
own subjects, but without any idea of forcing unmitigated Romanism upon the states which had now renounced it. A Protestant, even a divided, Germany seemed to them, moreover, better than a perpetual union with Spain, involving the constant participation by Germany in wars in which she had no interest, and the constant humiliation of her independence before Spanish soldiers or by Spanish gold.

We are not to suppose that either Catholics or Protestants intended to fulfil the pacification of Passau, otherwise than by getting their own way. The Emperor knew that the gain of time by delay was always a benefit to him ; the ecclesiastical princes felt that their power in the Diet was constitutionally supreme if they were united; the Protestant princes were determined that no constitutional rights should stand in the way of their obtaining fresh territory or securing religious toleration for their own views. But when they were brought together, as always is the case, they saw that compromise, hateful as it might be, was yet necessary; that they must at all events be content to waive some of their demands in order to secure the others; and that those others might, if they temporised wisely, be easily erected into a platform from which those now waived might be successfully revindicated. They must have peace, that Ferdinand and Maximilian saw, and the Protestants saw it likewise.

On February 5, 1555, Ferdinand, having got a few members of the Dist together at Augsburg for the purpose of arranging a permanent peace, addressed them in a sort of opening speech. In this, although he professed an earnest desire of peace, and acknowledged the difficulty of supposing that it could come from Trent, he did not abate any of the Roman claims ; and his only substantive proposition was that the system of disputations, under which the first struggles of the Reformation had been conducted, should be renewed. It was well known that the only result of the former disputations had been to strengthen both sides in their first opinions, and to leave the Emperor and ecclesiastical princes self-justified in their opposition to change; but the Protestants were alarmed by the proposition, more especially as it showed no sign of change in the imperial policy, and it coincided in time with the reconciliation of England to the Papacy, and the growth of the Jesuits. The Protestants had lost their great and irrefragable champions; Rome had trained new athletes, and the prestige of success was now with her. Although the result of disputations might not then change the faith of any, it might be such as to seem to justify the other party in their pertinacity. Cardinal Morone was coming to Augsburg to conduct the proceedings against the Protestants, and Cardinal Morone was not likely to fail either from want of ability or from superabundance of scruples. Accordingly they took measures for mutual defence, and in a con- 
ference at Naumburg, held on March 6, the Electors of Saxony and Brandenburg and the Landgrave of Hesse, renewed their close alliance of 'Erbverbrïderung,' binding themselves to maintain the Confession of Augsburg in their own dominions.

The Diet met at Augsburg formally on March 7, and its deliberations terminated in the publication of a recess on September 25. External events doubtless contributed as much to the actual result as internal intrigue, much more than the plan of disputation, of which in point of fact we hear no more. The death of Julius III. and the recall of Morone a few days after his arrival, and the election, after the three weeks' reign of Marcellus, of Cardinal Caraffa as Paul IV., must have affected the proceedings as they affected everything else that was going on in Europe. I shall speak of this directly. The two great points on which the pacification in religion turned were, first, whether the ecclesiastical princes should be at liberty to accept the Confession of Augsburg, and so alienate their dominions in perpetuity from the Roman Church; and secondly, whether the princes that remained Catholic should be allowed to compel their subjects to renounce Protestantism. The Protestants insisted that the Reformation should be allowed to extend itself by the adhesion of the ecclesiastical states; the Catholics that they should be allowed to enforce their own religion within their own states. On some points there was no difference of opinion, because a change was hopeless; the states that had embraced the Reformation might be allowed, because they could not be hindered, to retain it. And no interference by one state with the religion of another was likely to be tolerated, so far had matters gone since even the days of the Interim.

But here were two strong and real points in question, and on these the compromise turns. As to the first, the Protestants, we are told, did not wish to secularise the spiritual principalities, but merely to have the right of being elected to them. The point was vigorously contested; in the end the Protestants had to yield. They would not enact their own discomfiture, but left the decision to Ferdinand: he decided that a spiritual prince embracing Protestantism should forfeit his dominions. This is the Ecclesiastical Reservation of which we shall hear so much. As to the second, were the spiritual princes to be allowed to persecute the Protestants? For that they as sturdily held out, and were by the same means obliged to yield; they also agreed to leave the settlement to be made by a declaration of Ferdinand that they would not force the Catholic religion on their subjects. So the peace of Augsburg was secured, which kept Germany in some sort of internal harmony for thirty years. The recess which embodied it was published on September 25, exactly a month before Charles's 
resignation at Brussels. With it ends the religious history of the reign and life of Charles so far as they affect Germany.

What little remains to be said of the intervening events may be as well said when we discuss the character and reign of Ferdinand. Charles's reign over Germany continued for nearly a year after his resignation at Brussels; and during that time he seems to have intrigued again for the succession of Philip, this time negotiating with Ferdinand himself, whom he hoped to persuade by offering him some fresh provision in Italy or the Netherlands. But Ferdinand, for the first time in his life perhaps, was feeling his strength, realising how greatly he had served Germany and attached the Germans to himself. He rejected the proposal, and Charles, anxious to leave for Spain, at last executed his act of resignation, August 27, 1556. The unprecedented nature of this act occasioned some delay in the completion of Ferdinand's title; but all difficulties were eventually got over, and on February 24, 1558, the day of St. Matthias, the birthday and lucky day of Charles V., the claims of his successor were at last admitted ; and he was recognised at Frankfort as Emperor on March 12, 1558.

Here, then, we close the German history of Charles. He did not continue here, as in his hereditary dominions, to exercise direct or indirect supervision; or to fan the flames of religious persecution as long as he lived. We might almost date his abdication from the peace of Passau.

We turn now to the French war, the other series of events the interest of which is conterminous with Charles's life. The discomfiture at Metz, in 1552 and 1558, broke the spirit and heart of Charles, but they did not destroy his power, and he was able to make still some brave strokes for victory. The campaigns on the Netherlands border in $\mathbf{1 5 5 3}$ in which Térouanne and Hesdin were taken; the failure of Henry to revenge the injury or to recover the towns ; and the marriage of Philip with Mary of England, did much to restore the power and rehabilitate the prestige of Charles ; in an especial degree the English marriage, for it placed at his disposal an influence of very considerable importance, which had been often used against him and never heartily exerted on his side, and the forces of a country still in a flourishing condition, notwithstanding the anarchy and extravagance of the reign of Edward VI. This is worth observing. Charles had, since the death of Henry VIII., meddled but little with England; under the profligate statesmen of the Reformation her hostility was as little to be feared as her friendship was to be desired. There had been negotiations from time to time; Edward had been commended by his father to the imperial patronage, and negotiations respecting the Reformation and toleration 
in the Netherlands had been carried on with more or less of sincerity on either side; but the position and treatment of Mary, and the aid afforded in money to the German Protestants by England, were enough to prevent cordiality, and Charles waited patiently for the exhaustion of the country under its scandalous administration, thinking that the hostility of Scotland was the safest guarantee of at least the negative aid of England in any dispute between himseli and France. But now all this was altered. England was recovering herself under the prudent management of the old ministers of Henry VIII. and by the successful mediation of Pole was being brought to renounce the new doctrines. The marriage of Philip and Mary took place on July 25, and the English nation was absolved, in the person of its parliament, by Cardinal Pole on November 30, 1554.

The next year Pole tried his hand at making peace between Charles and Henry and spent some time in Flanders in negotiating; but he was unsuccessful, and all existing arrangements were broken up by the death of Julius III. and of his successor Pope Marcellus. The new Pope, Paul IV., whose curious career and very extraordinary character are so well drawn out by Ranke, lost no time in showing which side he intended to take in the great struggle. He was a Neapolitan, of a house hereditarily attached to the French, and hating the Spanish rule; he was an Italian, and detested the Empire; he was an old man and could remember the days when Italy was free from a foreign yoke, free to prey upon her own vitals as ever. He was, moreover, at this time under the influence of his ambitious and unprincipled nephews, who were bent not more on driving the Spaniards out of Italy than on making for themselves a territorial principality on the pattern set by the Farnesi and the Medici. Urged by such motives he lost no time in drawing near to Henry II.

The war languished during the early part of 1555 , and the autumn witnessed the resignation of Charles: a measure which, although it had been long determined on, may not improbably have been hastened by the Emperor's knowledge of the designs of Caraffa. The time was spent by Paul and Henry in negotiation. They agreed to form a new alliance; the object was to be the conquest of Naples and the expulsion of the Spaniards from Italy. The Guises, who were Henry's chief advisers in this negotiation, had some pretensions to the Neapolitan throne, and one of them, the Cardinal of Lorraine, had a design on the Papacy. The Duke of Montmorency, who, as usual, was opposed to a war with Charles, took the other side, but the pertinacity of Paul overbore all opposition, and the league was signed on December 15,1555 . It seems strange to learn that, during this negotiation with Paul IV., Henry was also 
negotiating a peace, or rather a truce, with Charles and Philip. So it was, however; both parties were exhausted and tired of .war, as the dilatory character of the campaigns of the year had shown; both were disinclined to give way. The simple expedient was a truce of years, during which each of the contracting powers should continue to hold such of the disputed territories as he was in possession of at the moment. And such a truce was made to last for five years : a truce manifestly advantageous to Henry, who thus retained his conquests in Savoy, and the three bishoprics ; but, as it seems to us, diametrically opposed to the obligations he had just incurred to the Pope.

The truce of Vaucelles was concluded on February 5, 1556. The Pope, although thunderstruck, as he well might be, at this deliberate perfidy, was equal to the occasion. He immediately opened negotiations, of which both parties were glad to take temporary advantage, for the recalling of the Council of Trent and putting down of heresy; underhand, he urged Henry to fulfil his obligations to him against Philip, whilst his nephews mustered allies all through Europe, negotiating, as Francis I. had done, at the same time with the Turks and with the Protestants. The underhand negotiations were those which ultimately prevailed, the public ones serving to gain time. Yet even for this purpose the impetuous nature of the old Pope refused to be patient. He could not help throwing off the mask; before the middle of the year he had begun to take open measures, displaced all the Spanish partisans in Rome, deprived the Colonnas of their duchy of Palliano, seized and imprisoned the Spanish envoy. Next he instituted a fiscal process against Charles and Philip as having forfeited the kingdom of Naples, and threatened them with excommunication and the absolution of their subjects from allegiance. And this was the overt beginning of war.

Provoked beyond endurance by the insults heaped on his master, and alarmed by the machinations of the French party within the kingdom of Naples, the Duke of Alva, the viceroy of the kingdom, took advantage of this last measure and marched into the States of the Church. He might have found them an easy conquest; but neither he nor Philip was disposed as yet for extreme measures. Both were superstitious if not religious. Philip would endure a good deal rather than risk the temporal and spiritual penalties of a permanent breach with the Pope. Alva remembered that the conquest of Rome had been, as a rule, fatal to the conquerors. It was in September that he entered the Papal States. His success, moderate as he made it, was sufficient to compel the Pope to terms and a succession of truces postponed the outbreak of the realities of war until the January of the following year, 1557. 
By this time Henry had made up his mind to fulfil his engagements, and the Duke of Guise appeared in Italy as the ally of Paul with 20,000 men. He advanced to Rome, Philip still persevering in the policy of conciliation towards the Pope. In April the Duke of Guise entered the kingdom of Naples. In Passion week he pillaged Compli and advanced to Civitella. But it was one thing to adopt a conciliatory line of policy and another to endure invasion. When the Neapolitan frontier was crossed, the war became one between Henry and Philip. The Duke of Alva, strengthened by the almost unanimous assistance of the inhabitants, presented an insurmountable obstacle to the further progress of the Duke of Guise. The Colonnas, in another quarter, beat the Orsini and entirely destroyed the Pope's auxiliary force of Swiss and German mercenaries. The distress of the Duke of Guise began to be pressing : his good fortune seemed for once to have forsaken him, when the necessity of peace and an excuse for returning home were afforded by the news of the battle of St. Quentin.

The battle of St. Quentin was the first great result of the marriage of Philip and Mary. $\mathrm{He}$ had at last persuaded her and the English people to declare war against France, a measure never very unpopular here, although now perhaps more so than usual; and at this time scarcely needing the excuse which was found in an invasion of Yorkshire by some English exiles, who had taken refuge in France. England declared war against France on June 7, 1557. This alliance determined Philip to open his attack on France on the side of the Netherlands. Henry had exhausted bimself by sending the Duke of Guise and his army to Naples; here then his frontier would be hardest to defend, and the English succour most readily and economically available.

Mary did not find it an easy task to raise an army ; the persecutions had not propitiated the people towards Philip, although he publicly and ostentatiously urged his wife to tolerance; nor was the parliament likely to supply funds. The Queen appropriated to the expedition the sum of $140,000 l$. which had been granted to pay the debts of the crown, and sent the Earl of Pembroke with 7,000 men into the Netherlands.

Philip's army already amounted to 50,000 men; his general was Emmanuel Philibert, Duke of Savoy. Philip himself took up his quarters at Cambray. The Duke, without waiting for his English contingent, having first given an alarm on the side of Champagne, turned aside into Picardy and besieged St. Quentin. St. Quentin was a strong post, but its fortifications were out of repair and its garrison had been detached for the expected attack on Champagne. It must have been taken directly had not the famous Gaspard 
Coligni, Admiral of France, thrown himself with a small force into the town, and summoned the Constable Duke of Montmorency to its relief. The attempt to reach St. Quentin involved the Constable in a general engagement with the army of Philip. The Duke of Saroy and the Count Egmont won a splendid victory on August 10.

The army of Montmorency included a great part of the nobility of France, and the result of the struggle was, as Mr. Froude observes; not unlike that of Agincourt, where the army was similarly constituted. Montmorency and a vast number of princes and nobles were taken prisoners; the defence of the place was rendered hopeless, and seventeen days after the battle it was taken by storm, Coligni himself being among the captives. The English force was present at the sack, although it had not arrived in time to take part in the battle of St. Quentin. It was in honour of this great victory, won on St. Laurence's day, August 10, that Philip built his great church, monastery, and palace of the Escurial, in the shape of a gridiron.

The seventeen days spent in the siege of St. Quentin lost France to Philip. The defence by Coligni saved it. Had the Duke of Savoy marched immediately on Paris after the battle, he must have taken it : the time was lost; and although the ultimate event was perhaps as fortunate, the splendour of the achievement was so far forth wasted. The news of the battle caused a cessation of hostilities in Italy and brought the Duke of Guise back to France. In Italy, as we have seen, the Duke had no real success. He was himself in such distress that he had to entreat the Papal succours ; the news of St. Quentin was a ready excuse for his return to France. He left Pope Paul IV. in the lurch.

Paul was still breathing forth threatening and slaughter. The news of the part taken by Mary in the war with France set loose his old antipathy to Pole ; and in depriving him of the legation, notwithstanding his brilliant services to the Papacy, he satisfied himself for the injury done to his cause by the altered policy of the Queen. Even when he knew that he was to be deserted by Guise, he maintained the same attitude of inflexible hostility until he saw the Duke of Alva at the gates of Rome the second time. Then suddenly he yielded and made peace. Alva visited him as a suppliant rather than as a conqueror, and received the boon which he could have extorted, and indeed was extorting, as a favour.

On September 17th, Paul made his peace with Philip, and on the most advantageous terms. Alva restored all the acquisitions he had made in the States of the Church. Paul had to turn his energies in a new direction: he had been utterly beaten by his enemy, who yet left him no pretext for renewing the strife. Guise left Rome the 
day that Alva entered it. Philip, by giving up the city of Piacenza to the Duke of Parma and Siena to the Duke of Florence, gained two important friends in the north and centre of Italy, and, having disabled the Pope, left the peninsula at peace.

Thus ends the chief share of Italy in the complications of European politics for some centuries. Naples continued in the closest connexion Spanish until the extinction of the Spanish Hapsburgs. The Popes continued powerless against Spanish influences; Italy ceased to be the battlefield of France, Germany, and Spain.

The power of France in Italy came to an end at the peace of Cambrai in 1529 ; this pacification by Philip prevented its ever being revived.

Such was the result of the battle of St. Quentin in the remoter field of action. At home its effects could not be expected to end here. Yet they might, so far as Philip was concerned; instead of pressing on Henry at the moment of success, he waited until he saw the next move. He busied himself during the autumn with making himself master of the fortresses of Ham and Catelet, and let the next stroke come from the Duke of Guise.

The Duke, ready to avenge the honour of his country against her ancient foe, surprised and seized Calais on January 8, 1558; and the capture of Guines and Hammes speedily followed. In May he took Thionville, the most important post on the side of Luxembourg that remained after the capture of Metz: he then ordered Marshal de Termes to invade Flanders, intending to join him before he could be met by the Duke of Savoy or Count Egmont. De Termes took Dunkirk, but here the successes of the French ended; the Marshal was met by Egmont, and completely routed at Gravelines on July 13. This altered the Duke's scheme of aggression; he had to bring up all possible resources to save Picardy, and so far he succeeded ; but the battle of Gravelines was the last important action of the war. T'wo great armies continued opposed to one another on the frontier, about twelve miles apart, and there were occasional skirmishes, but nothing to be called a battle.

With the autumn negotiations succeeded; and within a month of the death of the Emperor Charles, which occurred on September 21, 1558, proposals of peace were entertained in earnest. These were transacted at Cercamps, beginning on October 15, and terminated by the peace or treaty of Cateau-Cambrésis, on April 3, 1559. One great alteration of circumstances that contributed to this Peace was doubtless the death of the Emperor ; another, scarcely less efficacious, was the death of Queen Mary, which occurred on November 16. Her successor, Elizabeth, must, as Philip well knew, 
be treated with quite a different regimen from Mary, if the union in politics between England and Spain was to continue.

With these two great personages, very much of the prescriptive system of politics in Europe died out. The Reformation was triumphant in England, and all but triumphant in Germany. The two Catholic countries, the most Christian King and the most Catholic King, could scarcely afford to destroy one another's influence in the face of an enemy, the religious movement against Rome, which was becoming so very formidable. Henceforth we have to regard complications of a new character, and influences of a nature alien to earlier history, alternately bringing near and driving apart the interests of the great Powers. These we shall have to study in our later lectures. For the present it is enough to say that the peace of Cateau-Cambrésis was brought about by the management of Antony Perrenot, afterwards better known as the great Cardinal Granvelle, assisted by the Prince of Orange and the Duke of Alva on the part of Philip, and by the Constable Montmorency on behalf of France. England and France made peace at the same time. By the peace with Spain, France gave up her hold on Savoy and Montferrat, and quitted Italy altogether. By the peace with England she recovered Calais for eight years certain, and in perpetuity in case the terms of the treaty should in any point be infringed by Elizabeth.

With this treaty we may consider that the period of Charles V. ends. In the next lecture, I shall take $a$, sort of view of the period after Charles. Then we must attempt a new field, and devote ourselves to the politics of an entirely new school and set of actors.

\section{LECTURE II}

GENERAL SURVEY OF THE PERIOD 1558-1618

The period that now lies before us is one of great interest, although not of that concentrated interest that belongs to the reign of Charles V. If we were to look for a single string on which the largest number of significant events should be arranged, we should probably describe it as the period of reaction against the reformation; the period of the great preparation by the Catholic sovereigns for the struggle which culminated in the Thirty Years' War : the period of the Counter-Reformation as Ranke describes a part of it. But to regard it so would not be quite fair either to the aspect of the religions during a great part of it, or to the many other scarcely less 
important issues that were worked out during the sixty years. The wars of religion in France and the vindication of liberty in the Netherlands are really rather the working out than the preparation for the struggle with Roman influences: and the designs and disappointments of Philip II., of Henry IV., and Elizabeth had many other sorts of interests and influences gathered up in them, over and above those of religion.

And as with the current of events, so with the characters of the actors. Three stand out in bold relief, three of whom opinions are very much diversified and about whom many books have been written : Philip II. of Spain, Elizabeth of England, and Henry IV. of France; and yet it would be unfair to regard them as the only, though they may be the most prominent, workers. A set of actors of lower power has in all except power quite as great interest. Maximilian II. of Germany is, to a careful student of men, a far more interesting person than Henry IV. Mary Stuart is at least as curious and well-worn a subject as Elizabeth Tudor. No doubt in this aspect the interest clusters round the policy of Philip II. $\mathrm{He}$ pulls the strings of political history in France and England as well as in Spain and the Netherlands during the forty years of his reign, and after him to a certain extent we regard Henry IV. as the great politician; but attention must not be given to these two to the neglect of others. This makes it somewhat difficult to allot our several lectures beforehand to several particular periods or national histories. Yet the period does contain several well-defined subperiods : the wars of religion in France, 1559 to 1589 ; the struggle of the Netherlands for independence, covering nearly the same period (1559-1609). So long continued the unsettled state of English politics occasioned by the existence of Mary Queen of Scots.

The year 1588 may be regarded as marking the collapse of the whole of Philip's designs in Northern Europe, and forms in many respects a useful and convenient landmark. But we shall not be able, I fear, to bind ourselves to such landmarks. It will perhaps be the best plan to begin with a survey of each of the principal countries, and, having taken in outline all that is peculiar in the history of each, to proceed to consider separately the events in which they have a common interest, and so complete our view by tracing the general current of political events. In this way we shall be able to give a certain number of lectures to Germany, and a certain number to France; to group around Philip II. most of the events of Spanish, Italian, and Netherland history, and whilst avoiding any minute inquiries into English history - and indeed we shall not be able to go into any minute questions of history at all-see the part 
actually played in Europe by Elizabeth, and attempted by James I. On the death of Philip we can take Henry IV. for our chief, because he was the most prominent actor. The first thirty years of the sixty have a wider and more eventful interest, however, and to them we shall have to give the larger share of attention. With Philip II., Spain and the Netherlands lose much of their importance, and France and Germany accumulate new sources of interest.

We may begin with a glance at the personnel of the new period, merely naming, however, the great names, leaving their characters and history to be later developed: simply the names and dates. The years 1558 and 1559, as I have several times observed, cleared the board. Charles V. died in September, Queen Mary and Cardinal Pole in November 1558; Pope Paul IV. in August, and Henry II. of France in July 1559. They were succeeded by a set of princes whose recognised policy was, as their predecessors' policy should have been, peace and the development, the restoration, of the exhausted resources of their dominions. The period, then, does not contain great wars, but mainly civil wars ; mainly religious wars ; the strings often pulled from without, but not much overt hostility between princes and nations.

In personal character there are great changes. Philip, a thorough Spaniard and a religious bigot, takes the place of Charles, a cosmopolitan statesman, and if a persecutor, a persecutor only where persecution is politically safe. The strong and concentrated authority of Francis I. and Henry II. in France comes to an end; the reins of government fall to women and children or to the divided and hostile factions of Guise and Bourbon. In England the Reformation is supreme, the Catholic reaction is nowhere. In Germany Ferdinand and Maximilian initiate a policy as much in advance of that of Charles V. as that of Philip was behind it.

Well, the reign of Philip lasts until 1598; that of Elizabeth to 1603 ; the sons of Henry and Catherine de Médicis rule or misrule France to 1589 ; Francis II., 1559 to December 1560; Charles IX. from 1560 to 1574 ; Henry III., 1574 to 1589 . Then follows Henry IV., 1589 to 1610 ; then Louis XIII., a minor, during the remainder of the period to which we are now looking, under the influence for the greater part of the period of his mother, Marie de Médicis. Philip III. succeeds Philip II. in 1598 and reigns until 1621. James I., succeeding Elizabeth, reigns until 1625. In the Empire we have four reigns : Ferdinand I., 1559 to.1564; Maximilian II., 1564 to 1576 ; Rudolf II., 1576 to 1612 ; Matthias, 1612 to 1619 ; then Ferdinand II.

A large number of Popes, ten in fact, some of them of very small importance, fills the space between Paul IV. and Gregory XV. Of these, those to be remembered are Pius IV. (John de' Medici), 
1559 to 1566 ; Pius V. (Michael Ghislieri), 1566 to 1572 ; Gregory XIII. (Hugo Buoncompagno), 1572 to 1585 ; Sixtus V. (Felix Peretti), 1585 to 1590 ; Urban VII., 1590 ; Gregory XIV., 1590 ; Innocent IX., 1591 ; Clement VIII. (Hippolito Aldobrandini), 1592 to 1605 ; Leo XI. (Alexander de' Medici), 1605 ; Paul V. (Camillo Borghese), 1605 to 1621 .

Two Kings of Denmark filled the throne during the whole period: Frederick II., 1559 to 1588 ; Christian IV., 1588 to 1648 . Sweden was governed during it by Eric XIV., 1560 to 1568; John III., 1568 to 1592 ; Sigisniund, 1592 to 1604 ; Charles IX., 1604 to 1611 ; Gustavus Adolphus, 1611 to 1633.

Many of these names have their own significance; but as regards personal and political interest they come far below the Guises and Condés in France, and the several electors and other princes of Germany, whose dates may be given now. The Dukes of Guise who successively headed the Catholic party in France are Francis, the defender of Metz and conqueror of Calais, who was shot in $\mathbf{1 5 6 3}$ at the siege of Orleans. His son Henry, the captain of the League, was assassinated by Henry III. in 1588. The Guises were a branch of the house of Lorraine: Claude, the father of Duke Francis, being the son of Duke René II., the grandson by his mother Yolanthe of King René, and nephew of our Queen Margaret of Anjou. This Claude, besides Duke Francis, had a son of his own name who became Duke of Aumale and died in 1573 :-Francis's second son was Charles, Duke of Mayenne, another hero of the League, who survived until 1611. The Duchy of Lorraine was feudally subject to the Empire; but the estates of the Guise branches lay within the borders of France, and, whilst the main stock remained princes of the Empire, the Guises were thoroughly French. Mary of Guise, mother of Mary Queen of Scots, was a sister of Duke Francis, and this alliance gave him an influence over Francis II. which he was careful not to lose: but the position of the Guises was owing at least as much to their ability as generals and politicians as to their wealth and connexions.

The Bourbon princes, who with Henry, King of Navarre, headed the Protestant party, were the descendants of Charles, Duke of Vendôme, brother of Antony, King of Navarre, the father of Henry. The first Prince of Condé was Louis, son of Duke Charles; he became a Protestant from hatred of the Guises in 1560, and was killed at Jarnac in 1569. His eldest son, Henry, bore the title from 1569 to 1588, when he was poisoned. His son Henry II., was a posthumous child; his history belongs to the reign of Louis XIII. Francis, Prince of Conti, was a younger son of Louis of Condé; he died in 1614. The Cardinal of Bourbon, Charles, the prime minister 
of Henry III. and the head of the royalist Catholics, was also a son of Louis, and brother of Henry and Francis of Conti; he died in 1594.

This little pedigree will, I hope, be of some use in enabling you to distinguish between persons who, bearing the same titles and supporting for the most part the same principles, are still of very distinct character, and should not by any means be confounded. Especially a close succession of Cardinals of Bourbon and Cardinals of Lorraine, besides other Cardinals of the same houses but with different titles, is extremely likely to lead to confusion. These, however, as they have no particular dates to distinguish them, we must learn to identify, if it be necessary, as we proceed.

Turning next to Spain. Philip II. was, as we know, the only legitimate son of Charles V. He was married four times : first, to his cousin, Maria of Portugal, the mother of the unlucky Infante Carlos ; secondly, to his cousin, Queen Mary of England ; thirdly, to Elizabeth of France, daughter of Henry II., whom he married in accordance with the treaty of Cateau-Cambrésis in 1559, and who left him two daughters ; fourthly to his own niece, Anna Maria, the daughter of Maximilian II., in 1570, by whom he had Philip III., his successor.

Philip, like his father, administered both the Netherlands and Naples by viceroys, retaining Spain only under his immediate direction. In Naples his viceroys were (1) Don Parafan de Rivera, Duke of Alcalá, who ruled from 1559 to 1571 ; (2) Antony Perrenot, Cardinal Granvelle, 1571 to 1575 ; (3) Iñigo López de Mendoza, Marquis of Mondejar, 1575 to 1579 ; (4) Juan de Zuñiga, 1579 to 1582 ; (5) Pedro Giron, Duke of Ossuna, 1582 to 1586 ; (6) Don Juan de Zuñiga, Count of Miranda, 1586 to 1595 ; (7) Don Henriquez Guzman, Count of Olivarez, 1595 to 1599. None of these, except Cardinal Granvelle, had more than a local reputation. King Philip, being an excellent man of business, directed their proceedings, from Spain, with the assistance of his Council of Italy, resident in Spain, and by the advice of his confidential favourites.

The Netherlands were a more difficult post and required the exercise of an authority more nearly approaching the character of irresponsibility. Hence they had been governed under Charles V. first by his aunt and afterwards by his sister. Queen Mary of Hungary resigned her office when the Emperor resigned his; and Emmanuel Philibert, Duke of Savoy, the general of the Spanish forces at St. Quentin, was for a short time governor or Stadtholder; but Philip was resident more or less continuously in the Netherlands during Emmanuel's tenure of office; and, as by the treaty of CateauCambrésis he recovered the duchy of Savoy, Philip, on his final 
departure to Spain, placed his half-sister, Margaret of Parma, wife of Octavio Farnese, Duke of Parma, the young lady of whom Charles had made so much political capital among the small princes of Italy, in the vacant seat. Margaret's mother was a Flemish lady, and her education in and acquaintance with the Netherlands made her a very fit person for the office, but her life was a burden to her during the eight years she exercised it. Cardinal Granvelle was left as her chief minister, and, hampered by his interference, she failed, as well she might, to reconcile the conflicting interests. She resigned in 1567. Her successor was Ferdinand Alvarez de Toledo, the great Duke of Alva, Philip's most able minister and the deadly enemy of William of Orange. He ruled from 1567 to 1573 . After him the viceroys were Don Luiz de Requesens y Cuniga, 1573 to 1576 ; Don John of Austria, 1576 to 1578 ; Alexander Farnese, Duke of Parma, 1578 to 1592 ; Peter Ernest, Count of Mansfeld, 1592 to 1594 ; the Archduke Ernest, 1594; Peter Henriquez d'Azevedo, 1595 ; the Archduke Albert of Austria, 1596, who by the treaty of Vervins in 1598 married the Infanta Clara Isabella, daughter of Philip, and by the same treaty became sovereign of the Netherlands. Albert died in 1621, his wife in 1633.

The complications of government after the division of the seven United Provinces will come upon us later; the dates, however, may now be put down. William of Orange was elected Stadtholder after the union of Utrecht in 1578; he was killed in 1584. His second son Maurice succeeded him and ruled until 1625. Maurice was grandson of the Elector Maurice of Saxony, whose name he bore; his mother Anne, however, was no credit to him, resembling her grandfather, the Landgrave Philip the Magnanimous, in her temper and morals.

The origin of the house of Nassau-Orange is this :-Paternally it is descended from the Counts of Nassau whose territories lie, or did until 1866, along the right bank of the Rhine from Mentz to Coblenz; but the estates and titles of the Netherlands branch came on the female side. The principality of Orange lies in the Rhone country, far away from either Nassau or the Netherlands, and had been held by semi-independent nobles since the twelfth century. In 1393 it had come through an heiress to John of Chalon, from whom descended Philibert of Chalon, the general who succeeded the Constable of Bourbon after the sack of Rome in 1527. Philibert's sister Claude married Henry of Nassau; her son, René of Nassau, succeeded Philibert in 1530; and on his death in 1544 he bequeathed all to his cousin, William the Great and the Silent. He was without any hereditary right, and the principality was claimed by the Duke of Longueville as representing the ancient princes ; but by the treaty of Cateau-Cambrésis William obtained recognition. The eldest son of William, Philip William, had been brought up in Spain and as 
a Catholic; he accordingly, notwithstanding his father's attitude towards the Spaniards, was allowed to retain the principality until his death in 1618. Maurice succeeded his brother, and the principality continued in the family until 1673, when Louis XIV. confiscated it: William III., however, made his claim to it, and it was not until several years after his death that it was finally and formally made part of France. Louis XIV., in this proceeding, relied legally on an act of homage done by the Prince of Orange to the crown of France in 1475; otherwise there was no question but that the homage belonged to the kingdom of Arles: and Louis XII. had in fact recognised the prince as an independent sovereign. So much for Orange.

William's importance in the Netherlands depended territorially on the fact of his being lord of Breda, in Brabant-inherited from a marriage early in the thirteenth century which had first brought the house of Nassau into the Low Countries. I may as well mention here that the title Stadtholder, by which the chief magistrates of the house of Orange in Holland were generally known, merely means lieutenant, in German Statthalter, and has nothing to do with the German Stadt, a city. As the person whose place he was supposed to fill was the ancient ' Count,' the name answers exactly to the title Viscount, or Vicecount, Vicecomes, the Latin word for the English 'sheriff.'

We will now go to Germany, in which country the personnel of the period before us demands strict and exact attention, alike from the eminence of the persons, their number, and the intricacy of their mutual connexions. The Emperor Ferdinand I. was the only brother of Charles V. ; his marriage with the heiress of Bohemia and Hungary gave him a portion of his title to both those kingdoms, a portion that had, however, to be supplemented by the acceptance of one people and by the maintenance with the strong hand of his hold upon the other. Ferdinand by this marriage was father of fifteen children, from whom all the later Hapsburg princes spring. Maximilian, his eldest son, was Emperor after him. Charles, another of his sons, was father of the Emperor Ferdinand II., who succeded in 1619 on the extinction of the direct line of Maximilian. His daughters were all put out at interest by Charles among the North German and Italian princes; one of them married Duke Albert of Bavaria, and another William of Cleves, the dangerous adversary of Charles, who was brought into order by this alliance in 1546.

Maximilian, who succeeded his father in 1564, married his cousin Mary, daughter of the Emperor Charles, who brought him fifteen children also. Of these Rudolf II. and Matthias were Emperors 
after him; Albert and Ernest were successively governors of the Netherlands. Anne was married to her uncle Philip; and set the first example of the incestuous marriages which have been, down to the present day, one of the moral banes of the royal families of Spain and Naples. Elizabeth, another daughter, was married to Charles IX. of France. Neither Rudolf II. nor Matthias left any children; the close intermarriages, prolific enough in the first generation, seen to have been barren in the second. Philip III. is the only grandson of Maximilian II., and that in the female line. The imperial crown falls, on the death of Matthias, to Ferdinand of Carinthia ; and the struggle for that of Bohemia brings about the Thirty Years' War.

Descending in the scale of nobility to the electoral houses: Maurice, Elector of Saxony, fell at Sievershausen in 1553. His only child was a daughter, who married William of Orange; the electorate fell to his brother, Augustus the Pious, who reigned from 1553 to 1586. His son Christian I., who forsook Lutheranism for Calvinism, died in 1591. Christian II., his eldest son, returned to Lutheranism; he died in 1611 ; and his brother John George I. ruled from that year to 1656. Of these the Elector Augustus, brother of Maurice, makes far the greatest figure in the history of our period.

In the Palatinate we have Frederick III., elector from 1559 to 1576, the first Calvinist prince in Germany. His son Lewis VI., 1576 to 1583 , became a Lutheran; his son Frederick IV., 1583 to 1610, returned to Calvinism, his son Frederick V., the husband of Elizabeth Stewart, the Winter King of Bohemia and ancestor of our own royal family, reigned from 1610 to 1632 . The electorate of Brandenburg was held by Joachim II., 1535 to 1571 ; John George, 1571 to 1598 ; Joachim Frederick, 1598 to 1608 ; John Sigismund, 1608 to 1619 ; son succeeding father, John Sigismund in 1614 deserted Lutheranism to become a Calvinist; and the royal house of Prussia continued Calvinist until the project of union was carried out by Frederick William III. in 1817. The importance of these religious changes we shall see exemplified as we proceed.

The fourth lay electorate was the kingdom of Bohemia. Of the other princes who in dignity came nearest to the electors, the most memorable are those of Bavaria, Brunswick, and Würtemberg. In Bavaria three dukes rule during the whole period: Albert III. the Magnanimous, son-in-law of the Emperor Ferdinand, 1550 to 1579. William II., his eldest son, succeeded him, 1579 to 1596. Ernest, the third son, was Archbishop of Cologne and Bishop of Münster and Hildesheim, 1583 to 1612. Maximilian in 1596 succeeded his father William as Duke of Bavaria and reigned until 1651 ; he obtained the electorate, which the Winter King Frederick 
had forfeited, in 1623. His younger brother Ferdinand was Archbishop of Cologne from 1612 to 1650 .

The house of Bavaria was consistently and faithfully Catholic; and the retention of the electorate of Cologne, with other enormous episcopal commendams, by the younger sons of the dukes was no doubt one of the great influences of the Counter-Reformation in Northern Germany. I have just mentioned their tenure of that great see from 1583; they kept it until 1761. The only elector before 1583 whom we need notice is Gebhard Truchsess, who was chosen in 1577, and married Agnes of Mansfeld in 1581, becoming a Protestant the same year, and, according to the recess of Augsburg, forfeiting his principality by that act. He fell into obscurity after his expulsion, and the year of his death is uncertain. The Electors of Mentz are not men of much note in history and it will be enough to name them as we have occasion; and the same must be said of the Archbishops of Trèves and the Dukes of Wïrtemberg and Brunswick.

I need hardly repeat that the knowledge of dates is in one sense an absolute requisite to the knowledge of history. It is of course impossible to retain in the memory more than the main landmarks of time permanently ; the process of cause and consequence is far more easy to be remembered, and when that current of events has been well impressed on the mind, it is useless to attempt, as it is impossible to succeed in the attempt, to retain all the minutia of the chronology in the memory. To know how and why Ferdinand I. succeeded Charles V. is more important than to know that he succeeded him on a particular day of the month. But although history once learned may be remembered without a great array of dates and pedigrees, it cannot be learned without them; nor can the student succeed in getting general impressions correctly, without the line-upon-line process of chronological training. I give you these dates that you may know whether, when I speak of an Elector of Saxony in 1610, I speak of father or son, of a young man or an old, of a Lutheran or of a Calvinist, of an imperialist or an opponent of Austria. You cannot learn the current of history without identifying the actors, and you cannot identify the actors without dates and pedigrees. I give you in this lecture the dates and pedigrees for the course that we may not have to interrupt the thread of events to discuss them, and it will be as well if you can so write them out as to keep them before you during the later lectures.

I do not know that of the Italian princes any are of sufficient note in the history to make it necessary to call especial attention to their dates, except perhaps those of Savoy and Tuscany. In Savoy Emmanuel Philibert reigned from 1553 to 1580 ; his son Charles 
Emmanuel, son-in-law of Philip II., reigned from 1580 to 1630 . In Tuscany, Cosmo, the first Grand Duke, known as Duke of Florence from 1537 to 1569, was declared Grand Duke by Pius V. in 1569 ; be lived until 1574. His son Francesco Maria, son-in-law of the Emperor Ferdinand, 1574-1587, was followed by his brother Ferdinand, 1587-1609; Cosmo II., 1609 to 1621, was son of Ferdinand. The branch of the Medicean house from which Catherine sprang was considerably remote from this of Cosmo, whose line only came into the front rank on the extinction of the more brilliant but less fortunate branches. One of the other Italian principalities was Urbino, held by the house of De la Rovere from the time of Julius II. to its extinction in 1631. Parma was governed by Octavio Farnese, the husband of Margaret, vice-queen of the Netherlands, 1547-1586 ; Alessandro, their son, himself viceroy of the Netherlands, 1586-1592 ; and Ranuzzo, his son, 1592-1622. If we come across any Dukes of Ferrara, or Mantua, we can name them as they occur.

Having devoted so much time to figures, we may as well proceed now to the apportionment of the nine lectures that are before us to their proper subjects; and it may perhaps be the simplest plan to give two to Germany, three to France, and four to Spain, that is, the dominions of Philip II., for, of the actual drama of the history of Philip, little except the wire-pulling lies within the peninsula itself ; far more in the Netherlands, and no small portion outside the limit of his proper dominions. In the first of these I propose to discuss the reigns of Ferdinand I. and Maximilian II., to examine the religious condition of Germany for the twenty years that succeeded the Augsburg Recess and the Peace of Religion, and to form some estimate of the character and policy of those two sovereigns, who seem to me to be amongst the most German of all the German Emperors. We shall see in that lecture how the obligations of the great religious compromise were observed on both sides and how the Catholic reaction had the way made for it partly by the unprincipled conduct of the Protestant princes, partly by the divisions among the Protestant theologians: two influences which the systematic toleration of Maximilian II. suffered to develop far more than was consistent with right and which were only partly counterbalanced by corresponding failures from honest policy on the side of the Catholics. We shall thus see our way to the apprcaching reconquest of great part of the Empire by the Roman Church, hardened and sharpened by the definitions of the Tridentine Council.

In the second lecture we shall sketch the history of the civil wars of religion in France from the death of Henry II. to the accession of Henry III. ; and trace the different principles which actuated the 
Guises, the Bourbons, Catherine de Médicis, and the fourth party, which may be regarded as represented by the Montmorencys and as originating what afterwards became the party of the Politiques. We shall see how Catherine, a woman without principle, and with only that sort of governmental skill that depends on the power of creating and using intrigue, passed through the phases of tolerating, of patronising, and of persecuting the Protestants; how the rivalry of the Guises made her tolerant, and jealousy of the Bourbons intolerant; how, on the death of Guise, she took up his programme, and even succeeded to his relations with Philip II., but how throughout the period the action is determined by two independent currents of influence: the balance of intrigue at home and the varying relations of Spain and England, Scotland and the Netherlands. The campaigns of the struggle are four: the first in 1562 and 1563, which ends with the convention of Amboise; the second in 1567, ending in the peace of Longjumeau; the third in 1569, ending in the Edict of St. Germain ; and the fourth in 1572, ending at the election of Henry of Anjou as King of Poland.

The next three lectures I shall give to Philip II. of Spain; and as the history of the Netherlands is almost the entire history of his reign, we shall dwell most at length on the history of the Netherlands. The first of these will embrace the story of the struggle from the commencement of Philip's reign to the outbreak of the war of liberation produced by the proceedings of the Duke of Alva. We shall have occasion to remark the persistency of Philip's policy, and the invariable singleness of his aim; a policy and aim from which he is not for a moment diverted, although he sometimes consents to tack, and has no great objection to a change of servants. The extent of Charles's influence in the Low Countries may be estimated by the fact that it takes twelve years of misgovernment to provoke the Netherlanders into open war and revolution. The fundamental error of his policy is shown by the fact that Philip's was but the natural development of it, although modified doubtless by the character and principles of those who had to carry it out. If Charles had lived, the result might have been very different; we cannot forget that Orange, Egmont, and Hoorn, the great enemies of Philip, had been the great friends and pupils of his father. But the truth is the same: the loss of the Netherlands resulted from the policy which Charles initiated; which Philip entered into with enthusiasm and determination; which Granvelle enforced as an obedient servant and adroit administrator, which Margaret strove as a woman and as a Netherlander to temper, which Alva carried to its worst as a cruel persecutor, a ruthless judge, and a valiant soldier.

In the next lecture, the seventh, we shall take the war in the 
Netherlands down to the time of William the Silent in 1584 ; and, in connection with it, have to remark how gradually it assumes the dimensions of a European interest: how it affects the relations of Spain, France, and England ; and how the balance of difficulties throws the Prince of Orange now into the hands of one, now into the arms of the other, of the two hereditary foes. I shall not anticipate if I remark now, how, although this war had its motive cause in religious questions and was by foreign nations viewed very much as a religious war, it was, to those who fought through it, very much more decidedly a constitutional war. The Spaniards doubtless fought it as a religious one, but by adding to the religious pressure every sort of unconstitutional pressure also ; by the institution of new tribunals, by the imposition of new and impossible taxes, by breaking down old customs and privileges, they had arrayed in defence against themselves every element of national life. This is apparent in the long continuance of the influence of William of Orange even in those states which did not put themselves directly under his authority: by the extent of the insurrection; by the fact that Catholics as well as Protestants combined in it; and that the restoration of Spanish dominion in the portions which it did eventually recover was nothing less than a reconquest. In William of Orange the Netherlands lost their tie of unity, they lost the one Protestant who had any idea of the meaning of toleration and the one adviser who might, with time to help him, have ousted Philip and the Spaniards altogether.

Another lecture must serve to complete the reign of Philip, and to take in such particulars of the Netherlands history after the death of the Prince of Orange as are politically important; the few other interesting circumstances of Philip's history, a summary estimate of his character and of the political life of Spain under his rule. This will be the eighth lecture.

We shall then have to turn back to France and bring up the details from the beginning of Henry III.'s reign to the end of that of Henry IV., dividing the period into two lectures : the ninth from 1573 to 1598 when Philip and Henry made peace with one another, and the tenth the remainder of the reign of Henry. In these two lectures I shall have to apologise again for the number of dates and divisions. In truth the French wars are capable of much more definite treatment in this respect than the long Netherlands struggle, in which year after year you have the same string of battles, intrigues, and sieges, without any formal or real break. In the second of the two lectures we shall be able to point out the tendency of Henry's characteristic policy and to attempt some estimate of his character, if not of his place in European history. Philip II., Henry IV., and William of Orange are indeed a trio of characters 
well worth an amount of study far greater than we can bestow on them in this course. Two lectures will remain. In one I shall take the history of Germany under Rudolf II. and Matthias, more especially with a view to the religious complications that produced the Thirty Years' War. In the other the continuation of the history of Spain after the death of Philip II. down to the same period; and a slight sketch of the early years of Lewis XIII. The Thirty Years' War is the natural terminus to a course beginning with the resignation of Charles V.; and without going into the actual circumstances that produced the war, we shall be able, I trust, to view the causes that were at work, and that had been working during the sixty years that preceded it, to bring war out of those circumstances. Such a course lies through some of the most promising fields of modern study; if I can but trace a line by following which you may watch the developments of the history, I shall be glad and you ought to be satisfied.

\section{LECTURE III}

THE REIGNS OF FERDINAND I. AND MAXIMILIAN II. 1558-1576

Ferdinand I. had gone through a long and arduous apprenticeship, before he arrived at the united form and substance of imperial power. His hold on Bohemia and Hungary had brought him face to face with an amount of religious and political discontent, which, at that time, was without parallel in Europe, and had, at the same time, thrown him on his own resources and on the support of the princes of Germany. As his brother Charles was neither able nor perhaps especially anxious to make sacrifices to strengthen him-a fact which comes out strongly when we consider how much might have been done for Hungary, and against the infidel who supported rebellion and division there, by the treasures and forces that were wasted in the Tunisian and Algerine expeditions-he was obliged to make for himself friends of the German princes, in a way in which Charles in his later years refused or neglected to do.

The design of Charles to obtain the imperial succession for Philip worked in the same direction. Ferdinand's interest was obviously to counteract such a design; and that of the whole body of the princes, Catholic as well as Protestant, was the same. They had a common interest in thwarting this particular plan. Ferdinand was sincerely attached to his brother personally; so long as Charles was Emperor, Ferdinand's power and influence in Germany were at his brother's service : his power of management did much to defeat 
the Smalkaldic League, and it was attachment to him that drew off the Protestant leaders, whose desertion left John Frederick and Philip of Hesse to fight the battle alone. It is true that the events of 1552 placed him on the opposite side to his friend Maurice; but his whole conduct seems to point to the fact that he tacitly connived at what he might with a little exertion have prevented: and regarded the threatened seizure of Charles at Innsbruck as a feint intended to teach the Emperor a lesson of moderation. I dare not say that he was a confederate with Maurice on the occasion, but the result showed that his own position in Germany was improved rather than depreciated by the ignominious humiliation of his brother : a humiliation, you may remember, which did him, and was perhaps intended to do him, no great harm.

The conference at Passau and the deliberations at Augsburg show us Ferdinand as a mediator: a mediator in a contest in which his German instincts had to be balanced with his Catholic principles, and in which it may be fairly said of him that his conclusion was not an unsound one. It was a compromise, but it was a compromise which maintained the peace of Germany for thirty years. As he grew more and more German as years advanced, showing more and more tact in his dealings with the Germans, and identifying the interests of Germany with his own, in a way in which they had not been identified by any sovereign for many centuries-as, we may add, he grew more and more accustomed to act on the advice of his son Maximilian and less and less on that of Charles, his nominal superior-it is no wonder that he gained the affections of the people and the confidence of the princes. Nor can it be said that this confidence and affection were altogether undeserved. Towards the Germans at least he was blameless. The cruel restrictive measures used against the Protestants in Bohemia and Hungary did not affect the body of the Empire: nor did his unconstitutional conduct in those countries tend to make him unpopular outside of them. To himself, and to the statesmen of his day, heresy and rebellion would appear excuse enough for severity, and even for political bad faith within his own dominions. Outside of his own dominions he kept faith, and recognised the necessity of a toleration which, no doubt, he detested.

The one great sin of his career is his permission of the assassination of Martinuzzi : an act which it is vain to excuse, but the relative enormity of which ought to be settled by a comparison with the similar assassinations in France under the rule of the house of Angoulême. Take him altogether, he was a very good specimen of a king, and the Germans had come to regard him as for them a very good one. All of them, whether or not they liked his religion and 
his way of maintaining it, were ready to accept him as Charles's successor; not merely as an escape from Philip, but on his own merits. They had had him for twenty-six years as King of the Romans; they were glad enough to have him as Emperor. His maintenance of his hold on his right was very determined : not even in Italy would he yield to Philip an inch of ground that was not his own: Charles's last project, of placing Philip as Imperial Vicar at the head of Italy, was rejected with calm decision, and Ferdinand entered on all that remained of the imperial dignity in its integrity.

We have traced the history of the transaction up to the date of Charles's resignation, September 7, 1556. But two years nearly intervened before Ferdinand became full Emperor elect. We might have expected that the elected King of the Romans, as in both earlier and later times, would have succeeded at once without more than an honorary ceremonial ; but the resignation of an emperor was a proceeding on which the notaries had not counted, and a new process had to be arranged and carried out: perhaps the electors were willing to make it an occasion of securing the peace of the Church ; at all events a new capitulation, or settlement of rights, was exacted from Ferdinand in which the peace of religion was included. The Pope, indeed, refused to recognise him, to receive his ambassador, or to crown him ; but the Germans determined that all this might be easily dispensed with. Although he did not reconcile himself with Paul IV., he allowed a verbal victory to Pius IV., his successor, professing the ancient obedience of the Emperor to the Pope : but even this was retrenched by Maximilian, who substituted obsequium for obedientia. On the whole the conduct of Paul IV. may be regarded as loosening the hold of the Papacy on the Emperors, who never afterwards sought coronation at Rome. In the Electoral College itself the delay was a matter of form rather than of reluctance : the title of Ferdinand was recognised on the 15th, and himself acknowledged as Emperor on February 24, 1558.

The transactions of the intervening year and a half were not important; they consist mainly of negotiations for the maintenance of the religious peace settled at Augsburg, and of the obtaining of subsidies for the Hungarian war. The year 1557 was marked by a religious conference held at Worms to determine the differences amongst the Protestants. The great quarrels were touching Justification and the Holy Eucharist. On the former the opinions of Osiander, of Melanchthon and Flacius Illyricus were opposed, in points too minute and abstruse for us now to enter on, but not the less vehemently contested. On the latter the opinions of Luther and Zwingli were in hopeless opposition. The conference came to nothing, owing to the obstinate intolerance of the party of Flacius, 
supported by the Dukes of Saxony of the Ernestine branch. The recognition of any schools of Protestantism other than those which acknowledged the Confession of Augsburg as entitled to the benefits of the religious peace was thus hindered, and the force of the tide of reformation broken. Philip saw in the result of this conference the turn of the tide. 'Their strife,' he said, 'is our peace.' The wiser heads among the Protestants knew this: the princes of South Germany, under the Count Palatine and Duke of Würtemberg, in a meeting at Frankfort this same year, had recommended the divines to agree among themselves before they engaged with the Papal champions: and again in 1558, a similar assembly at the same place contented itself with adhesion to the Confession of Augsburg, without condemning the non-Lutheran views on the Eucharist. But the evil was too deeply rooted.

It may be said that most of the interest of Ferdinand's reign is ecclesiastical. Such was the business of the Diet of Augsburg in 1559, where the Emperor, having laid before the princes the failure of the conference at Worms, pressed them to give their aid towards the reassembling of the Council of Trent, and received the usual demand in answer, for a fair, German, impartial, and non-pontifical council. The rest of the business consisted of mutual recriminations as to the maintenance of the peace; and the only result was the imperial confirmation of the Recess of Augsburg. Again, in 1561 (January 10) the Protestant princes held a great conference at Naumburg, which lasted for three weeks; in which the various Protestant differences were discussed with much tolerance, and the Papal invitation to Trent respectfully shirked, by a reference to the Emperor as already in possession of the views of the princes. The council was itself revived the following year and sat until December 1563 ; but it produced no more effect in Germany than in England; the generation that might have been impressed by it had passed away.

This short résumé includes nearly all the acts of Ferdinand's reign that historians have cared to dwell upon. Two others are worth notice. The first is the election of Maximilian as King of the Romans, November 24, 1562, unanimously agreed on, and followed by his coronation on the 30th. He had been two months before accepted as King in Bohemia, and in September 1563 was crowned King of Hungary. The other is the disturbance produced by the conduct of William Grumbach, a Franconian knight, who, having in 1558 procured the assassination of the Bishop of Würzburg, in 1563 attempted to seize and massacre the chapter of the cathedral. The quarrel seems to have originated in some of the plundering raids of Albert Alcibiades. The canons paid Grumbach a ransom 
and undertook to stop legal proceedings against him. Ferdinand quashed the agreement, but the matter did not end until 1568, when, after provoking a more serious conflict, the culprit was punished.

With these exceptions, the secular history of the reign contains little that is of importance. There is no war ; there is no great intermixture of European politics in the German ones. The country, wanting only peace and national principles of government for its development, grows with extreme rapidity in wealth and commercial enterprise. The government is economical, and the people, except on religious matters, are united. The growth of Protestant opinions is rapid in the South as well as in the North of Germany, and not only Bavaria, but Austria also seems to be accepting, so far as the cities and people are concerned, the doctrines of the Reformation. The Catholic reaction has not yet set in, and the existing Catholic powers are lukewarm in their adhesion to the Italian Popes. The current, then, would have been too strong for Ferdinand had he chosen to stem it; as it was, he was during the last year of his life negotiating with Pius IV. for permission to the Austrian clergy to marry and to administer the communion in both kinds. He died at Vienna on July 25, 1564, regretted by the whole of Germany.

Maximilian II. succeeded without opposition or delay. No prince ever ascended the imperial throne of whom more was hoped than of Maximilian. He was known to be accomplished, eloquent, and an able politician; his tolerance was so great that it was believed that he was at heart a Lutheran; his policy was thoroughly German; he had been indeed his father's principal adviser for years; and his sympathy with Germany was strengthened and equalled by his antipathy to Spain. $\mathrm{He}$ was ostentatiously anti-Spanish: he would have no Spaniard about his court or household whilst King of the Romans : and his relations with the Protestant princes were of the closest and most friendly sort.

It is difficult to read the character of Maximilian as written by Ranke, or even as caricatured by the Prusso-German historians, without seeing that he wanted but two things in order to be a perfect sovereign. If his toleration had been more certainly than it was based on conviction-if it were quite clear that he believed toleration to be right and wise, because no man has the right to constrain another's opinions, and because conversions proceeding from such restraint are absolutely bad and injurious to the cause that uses them-we might have beheld in him a man far in advance of his age. I cannot say that it strikes me that such was his view ; I rather think that he regarded Lutheranism as more likely to be true than Romanism, but did not regard the religious question 
religiously. He refused to persecute the Protestants because he did not believe in the Roman system which they renounced, but he continued a Romanist because he did not believe in the Protestant dogmas which were set before him as substitutes for the Roman creed.

If this be so, much as we may admire his sound sense and wise impartiality, we cannot give him the first rank of praise, which belongs to a man of strong faith and calm sense of justice. Be it remembered, however, that he was the first European prince of any religion who refused to persecute; who declined the invitation of Pope Pius to attack the Protestants, and declined the request of the Protestant princes that he would expel the Jesuits. And he was an Austrian prince. Truly the Prussian advocate has to go far to look for arguments when he charges it as a fault on Maximilian that he allowed the growth in Austria of a Protestantism which exposed his subjects to cruel persecution under his successor.

The other fault, which I fear was fatal to Maximilian's greatness, was the inability to carry into effect what be saw to be wise, right, and necessary - a weakness which was less apparent before he came to the throne and during the first years of his reign, but which appears prominently after his reapproachment to Philip, and is exemplified in other points, especially by his way of carrying on the Turkish war, and by his failure to compel the observance of the Ecclesiastical Reservation in the first half, and of the Declaration of Toleration in the second half, of his reign. The reign divides in half at 1570, when he gave his daughter Anna to Philip as his fourth wife, and when the Catholic reaction or Counter-Reformation in Germany began to set in.

The history of Maximilian's reign, like that of his father's, is chiefly internal and religious. There is no great war or even rebellion; and a singular abstinence from interference in France or Italy : the religious wars in France, in which Philip was so deeply interested, did not stir the atmosphere of Maximilian. He has to watch against the Turks and to put down Grumbach. Perhaps no ruler could come up to the expectations entertained of Maximilian : certainly it cannot be right to regard him as a failure because he disappointed them. Compared with what he was himself, his career was less brilliant than it might have been; but compared with the sovereigns of his time he is to a certain point truly great.

The three events of Maximilian's reign which are not directly connected with religion are (1) the Turkish war, (2) the war of Gotha, and (3) the election to the kingdom of Poland, about which he was preparing to go to war during the last year of his life. With the Turks, I need hardly say, the war was chronic: even if settled for a time by an occasional truce, it was kept up, under false names 
on the Hungarian and Transylvanian frontier, and whenever it lulled it was liable to be revived by the old Transylvanian quarrel, which had been the bane of the earlier days of Ferdinand. John Sigismund Zapolski, prince of Transylvania, son of that John Zapolski who had been elected Hing of Hungary in opposition to Ferdinand, was still alive and flourishing under the protection of Solyman. From the year 1563, when Maximilian was elected King of Hungary, John Sigismund set himself up as his rival, and was only saved from summary humiliation by the intervention of the Sultan Solyman, with whom the Emperor was negotiating for peace. From 1563 to 1570 an intermittent struggle between Maximilian and the Transylvanian prince continued. In this the Turkish intervention was the most powerful ingredient. Maximilian made himself ready for a war, and in a Diet at Augsburg in March 1566 obtained a subsidy for the purpose, greater than had ever been granted to any Emperor before. Unfortunately, the religious disputes, and particularly the protection of Grumbach by John Frederick of Gotha, indisposed the princes to join him ; but the Italian princes joined in it as a crusade, and French and English volunteered to assist.

Solyman had taken the initative and in person arrived in Hungary. In the month of May he was besieging Szigeth, which was defended by Count Nicolas Zriny, Maximilian's chief Hungarian counsellor. Maximilian himself was in command of three several armies and encamped at Raab. Whilst there, he was secretly informed of the death of Solyman (August 30, 1566). Unfortunately, he refused to credit the story, which was one of a sort by which both early and late the crusaders had been deceived and drawn out of strong positions to fall victims to a crafty foe. Had he advanced on Szigeth he might have overwhelmed the whole Ottoman force. The Turkish generals, by concealing the death of the Emperor from their own army, maintained their order, and confirmed the doubts of Maximilian. Sziget was taken without an attempt at rescue; Zriny fell in the defence, the Turks retreated victorious : Maximilian retired inglorious. The next year he had to condescend to purchase peace, to give up his claims to the towns taken by Solyman and his army after his death, and to pay the tribute of 30,000 ducats. $\mathrm{He}$ quailed before the long successes of this pertinacious enemy. In 1570 he made peace with the prince of Transylvania. The truce with the Turks, which was for eight years, had the effect of preventing him from joining the league between Philip, the Pope, and Venice, which won in 1571 the great battle of Lepanto.

The war of Gotha fell out in the year 1567. The wretched Grumbach, under the ban of the Empire, a robber and a murderer, was defended by the Ernestine dukes, who were suspected by the rival 
princes, both Protestant and Catholic, of a design to make use of him as a pretext for war in which they might recover the electorate their father had lost. In the Diet of 1566 it had been determined that they should be compelled to surrender Grumbach : the army was placed under the command of Augustus, the elector whose dignity and whose life were supposed to be threatened, and he besieged Gotha on Christmas Eve 1566. The struggle terminated on April 13, when Gotha was taken, and John Frederick surrendered himself a prisoner. Grumbach was also given up and put to death shortly after. John Frederick expiated his obstinacy by twenty-eight years of imprisonment. He died in 1595. This little struggle may be regarded as the wind-up of the business which Albert Alcibiades had started, or taken in connexion with the quarrel between the elder John Frederick and Maurice. It was no doubt affected by religious feelings and animosities as well as by personal antipathies, but it cannot be regarded as a breach of the religious peace, the questions of which did not enter into it. In this matter Maximilian himself scarcely appears at all ; but the result was the confirmation of permanent peace, which was further strengthened by the truce made with the Turks in 1568 and with Transylvania in 1570. The prince of Transylvania died in 1571.

Maximilian was by this time able to look about him. In 1570 he had got over his dislike to Philip, and given him his daughter, Philip's own niece, as a wife. He begins from this moment to contemplate a return to the hereditary policy of his family. Having obtained for his son Rudolf the election to Hungary in 1572, he looked about for a provision for his other sons. The same year the throne of Poland became vacant and there was no candidate with paramount claims to election. Maximilian determined to put forward his son the Archduke Ernest. After several months of negotiation, the Duke of Anjou, afterwards Henry III. of France, was chosen (April 1578) and crowned in February 1574. But he held the crown only a few months. The death of his brother Charles IX. brought him back to France in June 1574 ; and the Polish throne was declared vacant.

Thirteen months of intrigue followed, and Maximilian was again disappointed by seeing preferred to his own son Stephen Bathory, voivode of Transylvania, the successor of John Sigismund Zapolski, who had been his prisoner and was now his vassal. Maximilian had, however, a strong party in Poland, and considered the effort worth making. $\mathrm{He}$ accordingly obtained the election to Bohemia, and that of King of the Romans for Rudolf (October 27, 1575), and then prepared for war. Thus employed he was seized by the fatal attack of which he died. In this attempt on Poland there can 
be little doubt that Maximilian acted on the advice of Philip or of the Papal legate Commendone.

Far more interesting than these scraps of secular history are the religious politics of Germany, of which the reign of Maximilian may be regarded as the turning point. We have seen the rapid and steady progress of Lutheranism during the last reign; the other forms of heresy now forced their way up to toleration. The Elector Palatine vindicated the position of Calvinism in the Diet of 1566. Although the Ecclesiastical Reservation and Declaration of Toleration were not verbally renounced, they were observed only as it was convenient to observe them. During the first six years of Maximilian's reign the Ecclesiastical Reservation was constantly tampered with; during the last six the Declaration of Toleration was continually infringed and the efforts of the Jesuits encouraged. From 1561 onwards Protestants and married men were elected constantly to the bishoprics of the North. They were not yet secularised. Neither party was quite ready for that, but the Protestants claimed a right to be elected to them and interpreted the Ecclesiastical Reservation as applying only to cases of conversion.

When such a Protestant candidate was elected he had recourse to an evasion of the law of the Church provided by the avarice and ambition of the elder prelates. The confirmation of the title by the Holy See was requisite to the completeness of his position, and this he could never obtain: it was not likely that the Pope would regard such a pretender as anything but a pretender. But the Emperor could bestow the regalia ; and it had been usual, on the ground of the expensive character of a journey to Rome, and the taxes of the Papal chancery, for the Emperor to grant an indult, by which the bishop elect could receive his revenues and delay his pilgrimage for confirmation. This plan was easily adapted to the change of circumstances. If the Protestant claimant could obtain an indult -and, the elective process being complete, it was no part of the imperial business to inquire into the orthodoxy of the candidate-the indult was capable of indefinite extension, and the journey to Rome was not taken; the revenues were constantly received, as long as the elect continued to be elect : that is, as long as he lived.

In this way several of the great prelacies became permanently detached from the Church. The archbishopric of Magdeburg was continuously held by Protestant margraves of Brandenburg. Sigismund of Brandenburg had become a Protestant when archbishop, and was not removed. His successor, Joachim Frederick, who had been elected Bishop of Havelberg at the age of seven, and was chosen to Magdeburg in 1566, when he was twenty, in 1570 determined to efface the last vestiges of Catholicism in the diocese. Yet he claimed 
the spiritual primacy among the princes of the Empire, being a married man into the bargain. Pius V. urged his deposition, but Maximilian did not see his way to it. It is observable that, on his accession to the electorate of Brandenburg in 1598, his son Christian William was chosen to succeed him at Magdeburg; nor did the house of Hohenzollern ever relax their hold on the see, which was ultimately secured to them by the treaty of Westphalia.

Much the same was done in Bremen. Duke Henry of SaxeLauenburg, a Lutheran of seventeen, became archbishop in 1567 and added Osnabrück in 1574 and Paderborn in 1577. Eberhard of Lübeck was confirmed by both Pope and Emperor and attended the Diets without opposition from 1561 to 1586. Hermann of Minden did the same; Julius of Brunswick was Bishop of Halberstadt; and at Osnabrück the canons, being divided, elected a Protestant and Catholic bishop alternately without any fault being found other than that the Protestant was suspected of being a Catholic and vice versa.

The natural conclusion to be drawn from this state of affairs is that the zeal for religion in the Catholic powers was subordinate to their political principles, and that the Protestant morality which gained such ends by such subterfuges can be defended only by alleging the supineness of their adversaries. Perhaps it is the safest to argue that really the Roman Church was paralysed in North Germany : nine-tenths of the people were Protestant, and there was no champion for the Ecclesiastical Reservation to be found. The acts were done, however, and the faith, in which they were defended, was bad faith : the laxity of the Emperor cannot excuse the dishonesty of the princes. If the Protestants ignored the Ecclesiastical Reservation wherever they could, we cannot wonder that the Catholics ignored the Declaration of Toleration when and where they had the power to persecute ; or that Maximilian, after the year 1570, when his reaction towards Spain succeeded to his former jealousy, thought it as allowable to connive at the breach of the one obligation as at the breach of the other.

Such things provoked and made possible the Counter-Reformation, the Catholic reaction. This Catholic reaction dates in its earliest form from the conclusion of the Council of Trent in 1563, the accession of Pius V. in 1566, and from the reconciliation of Maximilian with Philip in 1570. Pius IV., through Cardinal Morone, had at once gained the Papal ends in the Council and cut off all hope of healing the schism in the Church. Ferdinand had agreed to the resummoning of the Council with the idea of reforming the Papacy and of extending the powers of councils, and at the same time the liberty of the clergy. Pius IV. had mastered the intelligence of the Emperor and brought him to conclusions diametrically opposed 
to those which he had derived from Maximilian, and which were in fact the hereditary views of the German Cæsars. But he was not a Pope zealous for religion, nor likely to gain much hold on Maximilian. The attitude of calm aversion, in which the Empire and the Papacy stood at the beginning of the reign, continued. Paul IV. could canvass the Protestant princes against Charles : neither Ferdinand nor Maximilian cared for the Papal interests as Papal : the latter saw clearly the difference between the Papal and the Catholic Church.

But Pius IV. had his eyes open, and he saw that the Catholic princes might be induced to adopt measures which Maximilian could not be tempted to. In particular the Bavarian house, although liberal, was faithfully Catholic. Albert V., Duke of Bavaria, began the Catholic reaction in Germany. And he was aided by circumstances. You will remember how large was the class of noble vassals feudally subject to the princes. These nobles had very largely taken up Protestantism : so largely in the spiritual electorates that their rulers found it impossible to persecute in the teeth of the imperial declaration; and very largely in Bavaria, where they were jealous of the superiority of the Duke. The Duke was poor; they insisted on the grant of religious privileges in exchange for the subsidies he required. He was stern; they were pertinacious : he chose to regard their organised opposition as a conspiracy, and degraded, and deprived of their seats in the states, all nobles who were compromised. Once the master, he maintained his position : he would not admit the Papal grant of the cup to the laity for which he had petitioned; he forced the confession of Trent on the professors of his University, and turned the Jesuit missionaries loose upon his subjects; those who would not comply were banished, and Maximilian declined to interfere.

Under the brisk pressure of Pius V. (1566-1572) the work went on apace. One remarkable phase of it we see at Treves, where the elector was able to force Catholicism and dependence at once upon his people. There was a revival also at Mentz and in the obedience of Fulda; all Protestants were turned out of office, and their preachers were expelled the state. Everywhere the Catholic rulers persecuted; everywhere the Protestant rulers plundered. The Catholics evicted the contumacious; the Protestants confiscated Church property and secularised the monastic estates. But war did not break out. Maximilian was content to let things take their course.

I have several times mentioned the year 1570 as the date at which Maximilian's relations to Philip on the one side, and to the Protestants on the other, began to change. Philip had no son, and Maximilian was not without hopes that the inheritance might be reunited in him or one of his children. At the same time the 
change in the Emperor's mind cannot be ascribed altogether to policy. He was converted from Lutheranism, it is said : but it seems to me, as I have said, that his Lutheran proclivities were never the result of conviction; and it would be truer to say that he was brought, as he grew older, to see the fairer side of Romanism and the worst features of the Lutheran plunderers, who, without the convictions or the provocations of their fathers, thought of nothing but dividing the spoil. The divisions of the Protestant teachers were also repulsive to him, and the influence of his own family was decidedly towards the old religion. He retained his love of toleration and stood alone between the two parties. Thus he was situated, when Philip made his overtures to him, and they were at once accepted. Philip's influence henceforth affected Maximilian perniciously. His policy became less German, his action less impartial. He made no attempt, as indeed it was hardly to be expected that he should, to modify Philip's policy in the Netherlands. Now he ceased even to remonstrate. ${ }^{1}$ He allowed his daughter to contract a marriage which was incestuous, notwithstanding the Papal absolutions. From this date, then, the Catholic princes acted in disregard of the imperial declaration, as complete as that of theProtestants had been to their rights.

The state of things was already crying when in 1575 Maximilian applied to the electoral college for the election of his son Rudolf as King of the Romans. The three spiritual electors were Catholic, the three temporal ones were Protestant. The latter proposed that in the 'Wahlcapitulation' to be exacted from Rudolf he should be required to observe not merely the religious peace which his father had promised at his election but the Declaration of Toleration also. The spiritual ones demurred : they would have no new capitulation insisted on without the consent of a Diet; they denied the very existence of the imperial declaration. On both points they were silenced. But the Protestant electors were divided. The Palatine was hampered with foreign alliances, the Duke of Saxony was persuaded by Maximilian to give up the point, and nothing was done.

The next year, when the Elector Palatine in a Diet at Ratisbon made a like proposal, the jealousy of the Elector of Saxony caused it to fall through. On this occasion the question arose of getting rid of the Ecclesiastical Reservation and opening the bishoprics to both religions. It was proposed that they should be made subservient to the war against the Turks, and that Protestants in possession of them should be obliged to do military service in the Emperor's armies. This proposal was defeated by the opposition of the counts, 
who had begun to see, in the extinction or secularisation of the ecclesiastical principalities, the aggrandisement of the temporal princes and the loss of their own position of comparative independence.

The four colleges of counts, being consulted, unanimously refused to join in the proposition. They would, Protestant as most of them still were, rather see the ecclesiastical principalities continue in the hands of the Catholics exclusively, and maintain the Ecclesiastical Reservation, than risk their falling into the hands of the princes. They were divided against the princes on political grounds, and amongst themselves on religious ones. There was no unity in Protestantism, to meet the unity of the Catholic body now recovering its strength.

Maximilian died, happily for himself, before the evil reached the climax. His successor was a man of very different views and of a very different mould. He was bound by no promise to observe the declaration, he had no scruples about the legality of the Catholic reaction. Maximilian died on October 12, 1576. He did not do all that he might have done : he did somewhat and suffered to be done much that had better not have been done; but, take him altogether, there have been in any age few princes nearly so great and good.

\section{LECTURE IV}

THE FRENCH CIVIL WARS OF RELIGION FROM THE DEATH OF HENRY II. TO THE ACCESSION OF HENRY III.

The portion of French history which corresponds with the period embraced in the last lecture is of a very different character from that of Germany. Instead of being governed by the best of her kings, instead of taking breath after the great labours and exhaustion of the two preceding reigns, instead of enjoying a peace which the rest of Europe was content with and glad to use as a period of development and as a period of forbearance, France had one continuous term of discord; a term which lasts nearly twenty years longer than the space which we can hope to discuss in this lecture. These years were filled with political intrigue and civil war. They were restless, miserable years, of spasmodic torture to the people. The rulers were of the most selfish and abandoned of mankind ; the misgovernment, extravagance, and tyranny of the most heartless sort.

It is hopeless to attempt to carry in the memory more than a general outline of the course of events : as for the minutia, it may 
be enough for an ordinary memory to confess that it has known them, and not to pretend to be able to rearrange them at any distance of time, from the first reading. I should call the period dreary, were it not that it is lighted up from time to time by the brilliant exploits, or rather the brilliant qualities, of some of the actors in it, and has been illustrated by historians, and obfuscated by writers of romance, in a way that makes the persons at least familiar to most who have any knowledge of light literature. It is, moreover, at certain points, closely connected with the history of Mary Stuart and Elizabeth, and their history lends to this something of the interest which our own domestic quarrels and national sympathies have given to theirs. I shall attempt some sort of a survey of it on the following plan.

The period of the reigns of Francis II. and Charles IX. does not reach quite to the origin of the league which was formed in 1577. This period divides into two: from 1559 to 1570 is the period of intrigue, chiefly political, and of war, in which the religious interest is very much leavened with the political. The period from 1570 to 1577 is of a character in which the religious questions take precedence of the political. The first half, then, contains a reign and a half, and three religious wars; the second, the remainder of Charles IX. and the beginning of Henry III. and a period of religious discord the limits of which are not easy chronologically to define. Look first for a moment at the political source of grievance. Francis I. left two millions of francs in his treasury; the debts of the crown amounted at the death of Henry II. to forty-two millions with an annual deficit of two millions and a half. To meet this there was no legal or constitutional system of finance. The taxes were not granted in a constitutional assembly, nor was the imposition of them regulated by any idea of public economy or national usefulness. For a century the kings had been accustomed to impose taxes by ordinance, or in an occasional assembly of notables : and the royal power was so great that they were able to do it with hardly a remonstrance from the suffering people. They used every possible shift for raising money : the increase of the customs imposts and the sale of the royal domain were plans which any financier of the age would have regarded as justifiable; but the creation of loans and the invention of new offices of judicature and tribunals, by the sale of the appointments of which the King could make money out of his people, was a stroke of financial skill, borrowed probably from the Court of Rome, where the art had been long studied and its rules elaborated.

What Francis I. did on a small scale Henry II. did on a large one. He doubled at one stroke the prices of all offices and extended the system of loans and lotteries. There was none to interfere. Francis I. 
had bidden the Parliament of Paris to cease to trouble itself with politics, and besides its strength was broken for all purposes by the institution of provincial parliaments by Lewis XI. Matters were ripe, it might seem, for revolution. Yet what followed was not what we should call revolution. There was no rising of class against class; the religious movement gave the struggle a character quite different from political revolution. The divisions were headed, if even they were not as a matter of fact originated, by princes, rival members of the royal family or their closest connexions. Personal intrigue thus comes in as well as religious to modify the political crisis; and in such quarrels the forces are consumed which might in a clearer atmosphere have produced a general disruption of society.

The death of Henry II. left the kingdom in this state, and the supreme power a bone of contention to three or four parties of intriguers. Francis II., who succeeded him, was of age to govern, and therefore the actual miseries of a disputed regency were for the time avoided; but he was incapable of ruling, and the management of the King rather than that of the kingdom became the stake. The parties which might play for it were (1) Catherine de Médicis, the Queen mother, whose objects were chiefly personal, and secondly the benefit of her other children, and revenge on those who had wronged or slighted her during her husband's reign; (2) the Bourbon princes, Antony, King of Navarre, and Louis, prince of Condé, the first princes of the blood royal, who were firstly Protestants and secondly ambitious of exercising the power which the princes of the blood had usually exercised under weak sovereigns. These were supported by a strong party among the nobles, of which the Chatillons, the Admiral Coligny, and Dandelot, were the heads; (3) the Guises, Francis, the Duke, the defender of Metz and captor of Calais, the most accomplished and popular man in France, and his brother Charles of Lorraine, the Cardinal Archbishop of Rheims : both of them princes of a sovereign house and uncles of the young Queen Mary of Scotland whose influence over her husband was supposed to be unbounded. Of these the Duke of Guise was involved in the religious designs of Philip II. ; and the Cardinal also, although, in order to govern the French Church independently of the Pope, he would probably have accepted Protestantism had he seen his way to it. The Cardinal was a very able minister and took great part in the negotiations of 1556 . (4) A fourth party may be regarded as composed of the Constable of Montmorency and other faithful servants of Francis and Henry, who had not the personal objects of Catherine de Médicis and were personally obnoxious to her, nor the Spanish engagements of the Guises, and were opposed religiously to the 
Bourbons and Châtillons, with the latter of whom they were, however, closely connected by marriage.

The ascendency of Mary Stuart over her husband Francis II. determined the struggle for power during the eighteen months of the reign in favour of the Guises : the Queen Mother, seeing no help for it, threw herself on the same side. But the Bourbons were not to be brought over. Submission in their case meant no doubt extinction of both family and religion, and neither they themselves nor the French people, who were to a large extent Protestant, were prepared to suffer this. But the Guises had to walk warily at first. They attempted to reconcile the chiefs of the rival parties. Catherine was brought into alliance by the disgrace of the Constable Montmorency and of the Duchess of Valentinois, Diana of Poictiers, who had been the chief advisers of her husband. The King of Navarre was propitiated with compliments and left to manage his less manageable brother Condé. The Duke and Cardinal were free to try their hand at administration, and they fell into difficulties which would perhaps have been too much for even more experienced heads. Amongst their measures of finance the resumption of the alienated lands of the crown was not likely to make them popular; they were obliged, moreover, to give up the tax instituted by Francis I. for the support of his army of 50,000 infantry; they forbade the carrying of firearms: they bid for the support of the nobles by increasing the number of Knights of St. Michael ; they instituted some law reforms ; and this is all that is said of their administration; so little of history of a constitutional kind is contributed by an arbitrary government such as that of France had now become.

But the uneventfulness of such periods is delusive: the great springs of action are covered, but when a little accident opens them they burst out in a flood. The incident that in a constitutional state would create but a nine days' wonder, in an absolute one is the cause or the vent of a revolution. The murder of the President Minard, a sound Catholic, by a Scottish madman, had the effect of hastening the condemnation to death of Anne du Bourg, a lawyer convicted of Calvinism : and the execution of du Bourg produced a conspiracy among the Protestants which ended in war. Of the two former events I need not speak, except perhaps to remark that the execution of du Bourg, when so many more important persons were allowed with impunity to support Calvinism, and so large a portion of the people were infected by it, probably shows that the government were feeling their way towards a general persecution. Anyhow, so the Protestants understood it. They formed a secret confederacy under the supposed presidency of Condé, but really under an adventurer named Renaudie, with the object of seizing the King and 
the Guises when at Amboise on March 15, 1560, and of compelling the King to appoint Condé lieutenant-general of the kingdom. The conspiracy was betrayed. The minor confederates were punished. Condé cleared himself, and the Duke did not find himself strong enough to use violence. The insurgents who, with help from England and Navarre, had risen were put down with great ease and punished with terrible severity. Olivier, the Chancellor, died of grief at the cruelty of the executions, and Hôpital, his successor, was made to seal an edict by which the bishops were authorised to decide on and declare heresies and power was given to the subordinate judges to punish without appeal.

The conspiracy of Amboise had strengthened the Guises and prepared the way for more stringent persecutions. They seem to have conceived the idea of bringing all the heads of the Huguenot faction together and overwhelming them, as was later done in the St. Bartholomew massacre. After an assembly of notables, in which Coligny and his friends pleaded earnestly for tolerance, a meeting of the estates was called at Orleans in October : thither the King was brought, and the King of Navarre and the Prince of Conde summoned. Against the wishes of their friends, they obeyed: as soon as they reached Orleans Condé was arrested and the King put under guard. A hurried trial of the Prince followed, and he was condemned to death. A plan was said to have been laid for implicating and even assassinating his brother. What might have been done we cannot say, the illness and death of Francis producing a total change of circumstances; but when the King's state was hopeless the Guises tried to persuade Catherine to assent to the execution of Condé. She, on consideration, saw that the death of Condé would leave the King of Navarre untouched, and that the King's death would make him the chief man in the kingdom; knowing, moreover, that the Guises had no love of her and were but trying to use her, whereas her policy was to save the Bourbons to be a counterbalance to the Guises, on the advice of Hôpital, the Chancellor, she refused to agree. But she made her capital out of it ; . by threats of the execution of Condé she prevailed on King Antony to give up his claims to the regency on Francis's death; and the dying King prevailed on him to be reconciled with the Guises. It was his last act; he died on December 5, 1560. His reign saw the outbreak of the troubles and jealousies which created the miseries of the next two reigns ; but, as I have said, they were only the vents for the powerful forces that were at work through the land : that misgovernment and religious persecution and discord had arrayed against one another and against all authority.

The death of Francis produced, as had been foreseen, an entire 
change of relations. The hold of the Guises on the government determined at once. Catherine became regent, Antony of Navarre received the reward of his compliance, the lieutenant-generalship of the kingdom. The boy king Charles IX. remained under his mother's care. An immediate change of policy followed the change of government. The estates, meeting at Orleans a few days after the King's death, passed an edict more favourable to the Protestants, and to meet this reaction the Duke of Guise, the Constable, and the Marshal St. André formed themselves into a little political alliance which was called the New Triumvirate. The release of Condé took place in March 1561. In May the estates, under the pressure of the triumvirate, renewed the severe edict against the Huguenots; the Queen answered with an ordinance of toleration, or at least of a more tolerant character. In September, in consequence of the petition of the Protestants, a religious disputation was held at Poissy, the only results of which were the conversion of the King of Navarre to the Roman Church, and the provocation of the Calvinists to open resistance to the government.

Catherine was evidently incompetent to govern. As the triumvirate increased in strength, she drew towards Condé and the Protestants, but she failed to prevent the outbreak at last of civil war. The massacre by the Duke of Guise's retinue of some Protestants at Vassy on March 1, 1562, although unpremeditated, served as a watchword of insurrection. The triumvirs got possession of the King and Queen ; Condé had no other resource than to put himself at the head of the rebels.

The details of the war I shall not attempt. Suffice it to say that the Huguenots obtained nearly all the strongholds of Western France; that the King of Navarre, being sent to besiege Rouen for the King, was killed there on October 15, 1562; and that in the battle of Dreux, on December 19, Condé was defeated and taken prisoner by the Duke of Guise: Marshal St. André being killed in the same engagement. Guise, in his haste to finish the war, besieged Orleans in the February of the next year, and was there killed, February 18, 1563. His death ended the war.

The Constable and Condé made peace in March, and the Edict of Amboise, which was issued the same month, was most favourable to the Huguenots. The possession of Havre by the English induced the Queen to grant whatever was asked. On condition of laying down their arms, the Huguenots have liberty of conscience fully granted; and to the Prince of Condé is further promised the same position in the royal councils that the King of Navarre had enjoyed. The force of the kingdom thus united was devoted to the recovery of Havre, which was taken July 18, 1563. Queen Catherine was now 
supreme, having got rid of her enemies and the most dangerous of her friends; she declared King Charles IX. of age, and henceforth enjoyed, without a rival, complete supremacy over him and his kingdom.

The state of peace lasted for four years, from 1563 to 1567 . Catherine's diplomatic skill was tasked to the utmost to preserve it so long. Her political ability was that of the old school of Italian politics ; powerful in intrigue and in the creation of entanglements and combinations of party against party, clique against clique: powerless against the strong convictions, and pertinacious action on high principle, which marked the leaders of the Huguenot party and their rising opponents. Her court was the most immoral and unprincipled assembly of profligates that ever disgraced Christendom. Her sons were allowed to become early initiated in every sort of licentiousness and iniquity. She continued to rule through their weakness.

The four years of peace-for with England also peace was concluded in 1564-were chiefly employed in a progress of the King and his mother through the various provinces. The year 1564 is marked by the edict of Roussillon, which prohibits meetings of the Protestants within ten leagues of the court; by increased financial difficulty; and by the commencement of the building of the Tuileries.

Catherine's personal dislike to the Prince of Condé was driving her further from the policy of toleration which she had adopted, out of political craft only, whilst the Guises were dangerous. Philip II. had not yet meddled with France; once only, in 1562, he had attempted to succour the Catholics in the civil war, on the side of the Netherlands, but the Flemish nobles had declined the expedition, and, instead of an army, the Duchess of Parma, the governante, raised and remitted to Catherine a sum of 50,000 crowns. Now, however, we begin to trace the combined working of the Catholic powers towards the extinction of the new religion.

The royal progress brought the court, in May 1565, to Bayonne, where a solemn interview was held between Catherine, her daughter the Queen of Spain, Charles IX., the Queen of Navarre, and her son Henry. In the train of Queen Elizabeth, the Duke of Alva was present. He held frequent conversations with Catherine, and argued out with her the question of the policy of tolerance. He seems to have overcome her scruples or to have refuted her arguments: the tendency that she had already shown to abandon the defence of the Huguenots was strengthened, and, although there is no reason to believe that the massacre of St. Bartholomew was, as afterwards was said, contrived on this occasion, there is no doubt that a design was 
formed by which the French government was to co-operate with Philip for the destruction of heresy in the Netherlands.

It was these negotiations with Alva that led ultimately to the second civil war which broke out two years later. The Queen's toleration of the Huguenots produced the first of these wars; her capricious treatment of them, and her generally threatening attitude towards them, produced the second. Her quarrel with Condé was not reconciled, and he with his friends began to make arrangements for mutual defence. The Catholics of Guienne and Languedoc, on the other hand, formed a confederation for religion in 1563 , renewed in 1568 ; a crusade authorised by the parliament of Toulouse; but no overt action of hostility took place as yet.

In 1566, at Moulins, Charles issued an ordinance of 86 articles for the reform of the law, and confirmed the restrictive edict of Roussillon. At this meeting of the states the Queen attempted a reconciliation between the Constable and the Cardinal of Lorraine, and also between the Guises and Coligny. She partially succeeded, and also made Conde the confidant of her pretended jealousy of Spanish interference. Her idea was to raise a force to guard against the Duke of Alva, and, when raised, to turn it against the Protestants. Her policy, however, was not equal to the occasion. The Prince and Admiral, finding that they were being cajoled, formed a design to seize the King at Monceaux, and the failure of this project almost compelled them to take up arms. It is impossible to do more than note the main string of the story. The plots of the Guises against Coligny, the plan of surrendering the Queen of Navarre and her son to Philip, and the countless intrigues that arose on the extraordinary complication of personal and political and religious partisanship, interesting as they are as matters of detail, are out of place in an attempt to summarise the politics of Europe.

The failure of the plot of Monceaux occurred in September 1567. Alva's proceedings in the Low Countries, the arrest of Counts Egmont and Horn, the same month, showed that there must be no delay and that there would be no sparing. Succours from the Palatinate arrived, and Condé went to war. On September 28, the Huguenots surprised and ruined Orleans; in October the prince marched on Paris. The Constable of Montmorency was sent out against him and in the battle of St. Denis on November 10, stopped his progress, but was himself mortally wounded. Condé, finding Paris on its guard, marched into Lorraine to meet a second body of German auxiliaries, and on his return besieged Chartres. Before he had taken it, however, he concluded the peace of Longjumeau, against the advice of Coligny. This peace ended the second civil war, but it was itself of short duration; it lasted six months, and 
was called 'la petite paix,' or ' la paix fourrée,' the forced peace. It simply confirmed the convention of Amboise, which had concluded the first war, provided for the restoration of the places captured, and threw the expense of the war on the government. It was satisfactory to neither party.

The six months were used by both as a time of preparation for renewed hostilities. The court determined this time not to be surprised. The Huguenots had promises of help from England: Catherine was more assured of the goodwill of the Duke of Alva. She determined to seize the Prince of Condé and Coligny, and make short work of them. Marshal Tavannes had orders to arrest them at Nojars, in Burgundy, in September 1568. As usual the plan got wind, and Condé hastened to La Rochelle, where he was joined by the Queen. of Navarre; then the third war may be said to begin. The whole force of the Protestant confederacy met there, and with it the Prince marched on Soissons. The winter was lost in pretended negotiations. In March 1569 the Duke of Anjou, under the tutelage of Marshal Tavannes, led the royal army against Condé. On March 13, the battle of Jarnac was fought; the Huguenots were beaten; Condé was wounded and directly after assassinated. Coligny remained at the head of the Protestant party, he and the Cardinal of Lorraine being the only survivors of the great band of rival statesmen who had competed for influence under Henry II. and Francis II.

Ordinarily the death of Condé might have been expected to end the war : but the spirit of Coligny, the fervent support of the Queen of Navarre, and the arrival of Wolfgang, Duke of Zweibrücken, with the German helpers on the south of the Loire, kept up the contest. The young Prince of Condé, now seventeen, and the young prince of Béarn, afterwards Henry IV., who was a year his junior, were accepted as heads of the party. The latter fought his first battle under Coligny at Roche-Abeille, in Limousin, in June. In July, Coligny, at the head of the whole Protestant force, besieged Poictiers. Poictiers was defended by the young Duke of Guise, Henry, who at the age of nineteen comes on the stage at the same time with the other three Henries with whose lot his own fate was so deeply involved. Henry of Guise was successful against Coligny, as his father had been at Metz against Charles V. He compelled him to withdraw his forces in September after great loss; and the downfall of the Protestant cause seemed to be sealed by the defeat at Moncontour, October 3. The Admiral was again beaten by the Duke of Anjou and Tavannes, and with a loss of 12,000 men. The war did not end here. The Duke of Anjou lost the benefit of his victory by staying to besiege St.-Jean-d'Angély. Then came winter. Coligny made great exertions, and in the early part of $\mathbf{1 5 7 0}$ 
appeared with an army in Burgundy, whither he had gone to meet the German auxiliaries, leaving the Princes of Béarn and Conde to do what they could in Gascony and Languedoc. At Arnay-le-Duc, Coligny was met by Marshal Cossé with a royalist army thrice as great as his own; but he first beat him and then outmanœuvred him and made good his retreat.

There was no great battle this year; peace was come to, owing apparently to the exhaustion of the parties. Catherine was deserted by her Italian and Spanish allies : the Germans would not serve the Huguenots without pay. The peace of St. Germain, called the paix boiteuse (Biron) or Malassise (de Mesme), from the personal defect of one, and the name of the estate of another of the negotiators, was arranged on August 8. This was very favourable to the Huguenots. Their chiefs were restored to their places; four strongholds were left in their hands for two years : La Rochelle, the port for England ; La Charité, the passage of the Loire; Montauban, commanding the frontier of Languedoc and Quercy; and Coignac, that of the Angoumois. The preaching of Calvinism was sanctioned in two towns of each province. Coligny was persuaded that he was to command a French army to be sent to relieve the Protestants in the Netherlands. As usual no one was satisfied; but Charles got time by the peace to conclude his own marriage with Elizabeth of Austria, the daughter of Maximilian II., and to arrange for a similar alliance between his sister Margaret and Henry of Navarre.

The peace of St. Germain ends the first phase of the religious wars. During this the Huguenots had lost four battles: Dreux, Jarnac, St. Denis, and Moncontour. The Duke of Guise, the King of Navarre, the Constable of Montmorency, and the Prince of Condé had fallen in battle or by assassination. A new race of heroes was springing up, even less amenable to the policy of Catherine than their fathers. But the marriage of Charles was what seemed for the time the most threatening influence to her continuance in power. The King was beginning to find that he had a will of his own; that this will delighted in thwarting or complicating his mother's sch 3 mes ; and that in his young wife he had a prudent, an honest, and a virtuous adviser. But the mother was not to be shaken off : for the remainder of Charles's reign his own line alternates between compliance and opposition; compliance induced perhaps by his dread of poison, his knowledge of his mother's unscrupulous character, and of her devotion to the interests of her favourite son, the heir presumptive; and opposition weakened by his own ill-health and his distrust of all around him.

One of the changes in the royal mind was manifested in a disposition to draw nearer to the Protestants. Charles was jealous of 
his brother Henry of Anjou and of the glory he had acquired by his share in the battle of Moncontour. He took into his head, therefore, to favour Coligny; and the Admiral, whose vanity throughout his career was the point on which the court played in order to deceive him, pleased with the idea of gaining influence over the King, listened to his overtures. It is not impossible that Charles was sincere in this, but Coligny should have remembered the power which Catherine had so often exercised over her children; and the unforgetting, unrelenting hatred of the Guises. Under this temporary influence Charles thought of undertaking the patronage of the Flemish Protestants, who had just driven Philip to extremities by their iconoclastic outbreak, and made a peace with England that rejoiced the hearts of the Huguenots. Even the Queen of Navarre, under this phase of circumstances, was prevailed on to consent to the marriage of her son with the Princess Marguerite, and to attend the court at Blois (April 11, 1571). The marriage of the Duke of Anjou with Elizabeth of England was supposed to be seriously entertained, and war against Philip was regarded as a certainty. So the year 1571 passed away, and in 1572 the marriage of Henry and Margaret was to settle all disputes in the royal house, and to be the surest gage of religious toleration and safety to the Protestants.

The Queen of Navarre came in June to Paris to be present on the occasion, and whilst there died (June 10), with the usual suspicion of poison. Her son thus became King of Navarre. Her death did not prevent, or much delay, the marriage, which took place on August 18. During the week of festivities that followed, the great massacre of St. Bartholomew took place, about which so much that is contradictory has been written. This massacre was-I can only now allege facts of which there is no dispute-devised by the Guises, and assented to by the court, probably thoroughly approved by Catherine, and under her influence actually participated in by Charles. There is no doubt that the Guises took the opportunity of the festivities to compass the murder of Coligny and his chief adherents : there is grave suspicion that the King of Navarre, whose wife's lover the Duke of Guise was, was destined by both the Guises and Catherine to the same fate, from which, indeed, he was saved only by the personal interference of King Charles himself. It is less certain that the massacre was intended, either by Catherine or by the Guises, to overwhelm the crowds of inferior Protestants, who really fell, as victims to the hatred of the citizens of Paris and the towns which imitated their zeal, to the number of 50,000. The part that Charles played in it, revolting as it is, may very well be ascribed to excitement purposely encouraged by his mother, and to a revulsion of feeling against Coligny. If he consented to his death, pressed 
upon him by Catherine as a religious and political necessity, he showed by the effort he made to save Henry that he was not lost to all right feeling; what followed resulted from a panic of orthodoxy, hereditary cruelty, and a mind overborne with diseased imaginations. The degrees of guilt may be variously estimated; I think that the first belongs to the Guises, the second to Catherine; the third to the Parisian mob, which since 1563 had become violently Catholic; the next to Charles, and last, though scarcely least, to those European powers that approved and applauded the crime. We can hardly accuse the Pope or Philip of contriving it, but both may be well regarded as accomplices after the act.

The massacre of St. Bartholomew was the first act of the fourth civil war. One of the strongholds of the Protestants, La Charité, was surprised during the excitement that followed; the King of Navarre was prevailed on to abjure Protestantism; the chiefs of the party who survived were panic-stricken. The young Prince of Condé was the only one who retained his head, and maintained the spirits of the Huguenots. Some of the most faithful even countenanced submission. But La Rochelle held out and became a city of refuge to the whole party, the object of attack to the whole military force at the disposal of the court. For eight months it was besieged by Henry of Anjou, and its siege is the fourth civil war. It was ended on June 24, 1573 : the Duke was formally admitted into the town, but the terms of the surrender left it in the hands of its brave defenders. A peace followed immediately, by which the edicts of pacification were renewed and all things remained as they were before the massacre.

Henry of Anjou had been elected King of Poland, and one of the great influences that never wavered against the Protestants was thus diverted for a time. He started in September 1573 to take possession of his throne; and intrigue for a short period takes the place of violence. His departure was followed by the formation of a new party called that of the Politiques, headed by the Montmorencys and the Duke of Alençon, the younger of the King's brothers. The Duke was an ill-conditioned and ambitious fool. The principles of the party were moderate : it was a coalition, on the basis earlier adopted by Catherine during the rivalry of the Guises and Bourbons ; but the object of the Duke probably was to supplant his brother Henry in the succession. The machinations of these politicians, and the prospect of favour that they seemed to be showing to Huguenots, produced an alarm of a renewal of war, and of reprisals on the part of the Protestants for the St. Bartholomew cruelties. In order to guard against any such outbreak, Charles and his mother arrested both the Duke of Alençon and the King of Navarre, and committed them to close custody. 
Catherine prepared to take advantage of the alarm to execute judicially the remaining chiefs of the Huguenots ; amongst them the Count of Montgomery, the accidental murderer of Henry II., suffered death. This was the last cruelty of what has been called the reign of blood. Charles had been ill for a long time; and, in his agonies of pain and remorse, threw out hints of past horrors and of disappointed good intentions, the truth of which can never now be arrived at. Of him also it was suspected that he was poisoned by Catherine to make way for Henry of Anjou. He died on May 30, 1574, having declared the King of Poland his heir, and Catherine the regent until his brother should return.

We will leave to another lecture the events that follow and that belong more naturally to the wars of the League than to what went before. I fear that in this abstract, for it is little more, of a period of great interest, I have dwelt too long on names and dates. But if I have, I have tried at least to show how those names and dates illustrate the history of the great parties. It is not easy either to detect, or to remember when detected, all the underhand workings of policy, especially when the underhand workers were such people as Philip II. and Elizabeth. But we may, I think, conclude that Philip's movements with regard to England, and Elizabeth's towards Philip, depended very much on the varying state of the Netherlands : and that Catherine's attitude towards the Huguenots varied according to her objects of negotiation from time to time with Elizabeth and Philip. Spain and England were not at war, but the French politics were affected very much as they might have been if they had been at war. They were known to be rivals, but rivals who were kept at peace by mistrust of their power to control their own subjects and by common hatred of a third party that must step in to reap advantage from their open hostilities. The time was to come when all this would change, and the hands of the real wire-pullers be seen. But by that time the attitude of France also was to change.

\section{LECTURE V}

PHILIP II. AND THE NETHERLANDS TO THE OUTBREAK OF WAR

THe history of Philip II. has been written so often, on so large a scale, and from so many different points, and the result has been the examination of every part of it in such detail, that it would be impossible in a single course of lectures even to review it with any degree of fulness. It may be further said that the process of this 
examination is far from being exhausted. Every year the archives of Brussels or Simancas are made to pour forth a new abundance of matter respecting it, tending to perplex the memory if not to confound the judgment of those who have made the period their particular study. It is as well, then, that in this course what we have set ourselves to do is not to give an exhaustive résumé of the facts thus multiplied upon us, but to attempt to trace such a continuous series of causes and consequences as bears on the general political history of Europe and illustrates this great King's part in the common life of the society of Christendom.

As for Philip himself, I believe that his character has represented itself in substantially the same features to all who have studied it. The views of opposing parties differ as to the merits of it, but not as to the qualities or actions by which both alike must estimate those merits. He was a man of enormous industry and exactness; doing much work, and expecting much work from all who served him. $\mathrm{He}$ was to the last degree bigoted as a Roman Catholic, and this bigotry underlies the whole of his policy, excuses his thousand deceptions and his innumerable cruelties. His morality is not above that of the decent princes of the age, of any way of thinking; he is out of the region of religious controversy, impartial, severe, and fairly honest; his firmness is fully entitled to the name of obstinacy, and his severity to that of cruelty; his statecraft to that of cunning; but it is evident that according as you regard his religious bigotry as a merit or as a fault the general estimate of his character must be coloured. He was, in a word, his father over again, but without his good points and with his bad points exaggerated to a great extent. Although we may not regard him as successful in the main points to which his policy was directed, we cannot deny him the title of an able ruler. $\mathrm{He}$ did in fact rule his people; and thus his reign is distinctly contrasted with the corresponding periods in France and Germany, where the governing power retained its place either by intrigue or by carefully balancing against one another the forces which singly were able to overthrow it, or where it contented itself with the possession without the exercise of authority.

We may say of Catherine de Médicis that she would have ruled if she could, and of Maximilian that he could if he would. Philip both could and would and did : ruled with a single straightforward dominant will, not like a woman, not like Elizabeth of England whose success and prosperity are in so strong contrast to his disappointment, but like a strong hard-headed, hard-handed man, who knew the value of power, and drank the draught of what came to him to the very dregs : who by his own action kept the machine of state going, held the reins in his own hands, and attended himself 
to every single, even the minutest, article of the harness. He thought nothing well done in which he had not directed and seen to the carrying out of the lowest details. He is not a man to be despised.

The interest of the part of Philip's reign which corresponds with the periods of French and German history discussed in the last two lectures belongs, if not wholly, almost wholly to the Netherlands. I propose, then, to gather up first the few indications of important action in European politics, and the few interesting points relating to him in other fields of work, which occur during these years, and then to sketch the string of events in the revolt of the Netherlands down to the year 1576. In this review we are not perplexed by much personal history of Philip himself, for he spent the whole of his reign in Spain after his arrival there on August 29,1559. Philip's attempt to retain his hold on England by marrying Elizabeth was over by this time; the treaty of Cateau-Cambrésis had engaged him to the daughter of Henry II. of France, and with France he continued on peaceful if not on cordial terms, until the wars of the League. He was not able to interfere much except diplomatically. His influence, first with the Guises, and, after the death of Duke Francis, with Catherine, was used simply, it would appear, in the direction of religious persecution. He could not help the Catholics in arms without producing a union between the revolted Flemings and the Huguenots, which he wished to avoid; nor could he conscientiously make use of the Huguenots to demolish the power, if any still remained, of the house of Valois. They were his father's enemies and his own. If religious sympathy prevented him from taking the opportunity of overwhelming them, political principle urged him to prevent their aggrandisement; and this seems to have been the key of his policy towards England so long as the conduct of Elizabeth and her ministers rendered it possible.

Philip supported Elizabeth as a counterbalance to the power of France, but more especially because he knew that the acquisition of the English crown by Mary Stuart would be to throw the kingdom under the influence of the house of Valois. Strong Catholic as he was, he discouraged the rising of the Irish against English rule, his remonstrances with Elizabeth as to the Reformation were dictated by a sincere policy as well as by religious conviction; and from the time of the Netherlands outbreak it was most necessary to Philip to prevent her from lending help to the insurgents. Again, as a Catholic he was hurt by her interference with Scotland; whilst his fear of French influence prevented him from boldly interfering in defence of the English Catholics. Elizabeth's conduct in the first religious war in 1562-3 even did not exhaust his patience. It was not until his endurance had been tried to the utmost by the 
unwarrantable piracies of the English adventurers, and his religious principles roused by the remonstrances of the Popes and the general combination of the Catholic powers, that he even assumed an attitude of hostility. That hostility took the form of intrigue for years before it gave way to open war ; and this does not occur in the period on which we are now employed. Philip's slowness of action is nowhere better exemplified than in his behaviour towards England, and we cannot doubt that the attempt to balance religious and political considerations, as well as to avoid the expense and danger of open war, made his relations with Elizabeth, and his own views regarding her, unsettled and uneasy.

In Spain itself the history of these eighteen years is not a varied one. Philip was at home : his domestic government was not uneasy except in the department of the Inquisition and the troubles which the severities of the Inquisition brought about. The revolt of the Moriscoes, 1567 to 1570 , was the only serious attempt to shake his authority : this was produced partly by the action of the Inquisition, partly by the leaven of national independence not yet extinct. It was conducted with great cruelty on both sides. The persecution of the Spanish Protestants by the Inquisition was not less effective; they were entirely crushed. The miseries produced by this persecution were incalculable: the agency of the Holy Office being made to subserve all purposes of public and private enmity. The greatest victim, Bartholomew Carranza, Archbishop of Toledo, was sacrificed to the personal enmity of Valdes, the Archbishop of Seville and Grand Inquisitor. Carranza, who had been the friend of Charles and the confessor of Philip II., was arrested by the Inquisition in 1559; sent to Rome on appeal and imprisoned there for seventeen years; condemned as a heretic by Gregory XIII. ; and after his release sank a victim to the severity of his penance and the agony of his mind. He was by no means a Protestant; not a word could be said against his orthodoxy; but he was a tolerant Christian, and this tolerance was handle enough for the Inquisitor who had determined to destroy him.

The episode of Don Carlos, which occurs in 1568, need not be more than mentioned. Philip's only son, he was a hopeless madman; and his death, harsh as it seems, at his father's commands, was perhaps the safest both for Philip and the realms that he might any day have been called upon to rule. Romance and pity are alike wasted on him.

The history of Philip's Italian possessions is uneventful. They enjoyed peace, in common with Italy in general, from everything but the Turkish depredations. In relation to these the most important matters are the raising of the siege of Malta in 1565, when Spanish 
succours, tardily but effectively supplied, compelled Solyman to withdraw his forces; and the league between Venice, the Pope, and Philip in 1571, which had its crowning success in the battle of Lepanto won by Don John of Austria. It was time something should be done; for not only were the Turks permanently encroaching on Hungary, as we have seen; but the Venetians had in 1571 lost Cyprus, the last important relic of the dominion of the Crusaders : it had been held by the Latins since it was conquered by Richard I. of England in 1191.

All these incidents, detached as they are, although in themselves interesting enough, strike us as inferior in lasting importance to the affairs of the Netherlands; the development of whose history contains so much more of political element, and the results of which have been so pregnant of consequences for all Europe. It is in the Netherlands, and in his transactions with France and England in connexion with the Netherlands, that Philip's policy is most conspicuously exemplified and his share in the general political system of Europe most clearly seen. No doubt he had an eye on everything of importance that went on in Europe; but so much of his action was secret that its effects can only be guessed at. Here he had to act, and all his characteristic qualities are brought out. The Netherlands were that part of Charles V.'s dominions which were most attached to him personally; which had been most wisely administered under him; and to which his visits, although not the longest, were the most numerous. Ten times he visited the Netherlands, as he said in the resignation speech. The revolt and punishment of Ghent in 1539 had been the only event opposed to the general tenour of wise government; and the persecution of the Protestants, carried on by the machinery of the Inquisition with much cruelty, though no doubt enormously exaggerated by Protestant writers, had been perhaps the sole defect in his policy. The country was for the most part happy and contented under him : commerce flourished largely; his favourite ministers were Netherlanders, and their influence and that of their families were used consistently in favour of order. The Prince of Orange, the most popular man in the Netherlands, was brought up at his court, and the receptacle of as much of his confidence as he gave to any man; and Count Egmont was the general of his armies.

From the time of Charles's resignation the internal condition of the country began to deteriorate, and before his death the troubles that were coming had given clear indications of the future. In the first place Philip did not take care to make himself acceptable to the Flemings; he was a Spaniard by education and temper, just as his father was a Netherlander. He was haughty and reserved; he did 
not like the people and they did not like him. It is wonderful how great influence personal dislike has in giving effect to causes that might have worked on in silence and quietness without it, and kindling with a little spark a great fire of consequences. The provinces were predisposed to put an adverse interpretation on every measure that should even seem to be originated by such a person. It is a curious proof of the strength and prominence of Philip's repulsive traits that this should be the feeling with regard to him in both Germany and the Netherlands. The Germans, who had scarcely seen him, would not have a word to say to him as Emperor; the Flemings, knowing him, and before they had real cause disliking him, were ready to do everything in their power to thwart him. $\mathrm{He}$ was unbending and they were intolerant. Can we wonder at the result?

I need not now go at any length into the inherent sources of difficulty in the condition of the Netherland states. They were twofold: the political independence of the towns and the weak organisation of the Church. The burgher spirit had grown very strong under the weak and capricious rule of the native sovereigns, whose poverty had sold to the cities the privileges which their weakness forbade them to refuse, to elude, or to break through by force. The Church was weak for want of a head: the provinces were under three bishops owning obedience to different metropolitans, the metropolitans were not subjects of the sovereign of the states; the chapters of the collegiate churches exercised most of the ecclesiastical jurisdiction, and the constitutions, of : the states were distinctly opposed to the growth of spiritual authority as well as of ecclesiastical influence in secular matters. The cohesion of the states was slight : they were only united by the accident of inheritance; each had a distinct constitution and provincial assembly. The Great Court of Judicature, the Great Council of Mechlin, and the Assembly of the States General, which was but a congress of ambassadors from the several provinces, were all the common organisation besides their personal union under the Burgundian house and its successor, the Austrian. Little cohesion, great individual independence; no complete religious organism: here was field enough for the growth of political liberty and religious dissidence: the proper field for Calvinism in its worst as well as in its most plausible phases.

Before Philip left for Spain in $\mathbf{1 5 5 9}$ he had managed to rouse every one of these sources of disaffection. He had kept the Spanish troops in the country after the termination of the war with France, as if either he did not trust his subjects, or disliked being left to their protection. $\mathrm{He}$ had renewed the edicts against the Protestants, and there were whispers that he had even concluded an agreement with Henry II. 
for the utter destruction of Protestantism. He had given to the Duchess of Parma, whom he appointed as governante, a close council of three, over and above the three Councils of Finance, of Justice, and of State (war and peace) to which the Flemings were accustomed; and the chief man of this council was a foreigner, Granvelle, a native of Franche-Comté, an ecclesiastic, bishop of Arras, and a much abler man than either of his colleagues, Berlaymont and Viglius. Granvelle, they suspected, was to be their real ruler. And to crown all, he had obtained from the Pope, not the modest church organisation of six new bishops in addition to the existing three for which his father had petitioned, but one of three archbishops and fourteen bishops to be provided for out of the property of the collegiate churches and monasteries, which had until now been the chief organisation of the kind. He thus offended the parties that were opposed to the Church altogether, and alienated those churchmen and their families who were in possession, very often by hereditary or family arrangement, of these important positions. The bull for the new constitution arrived just before he left for Spain. He had moreover shown distrust and dislike of the Prince of Orange, which, however well warranted, and I think that there was cause for it, he would have been much wiser if he had been content to conceal. The Duchess Margaret must have seen early that she had no easy task; the more clearly as she was united by long acquaintance and sympathy with the people she had to rule.

Notwithstanding the representations made by the nobles to Philip before his departure, the Spanish troops were retained in the Netherlands until January 1561. The Prince of Orange and the Count of Egmont were systematically outvoted in the Council of the State, Granvelle was all-powerful and offensive to all. It was indeed found impossible to carry the episcopal scheme everywhere into effect, but Granvelle was made Archbishop of Mechlin and a Cardinal, and a wide and deep impression went forth that this was a prelude to the introduction of the whole machinery of the Spanish Inquisition. In July 1561, the Prince of Orange and Egmont made a complaint to Philip of their exclusion from all important business, and from this moment the murmurs of the national party are to be distinctly heard. But it was not until 1562 that anything like an open quarrel was thought of. In that year Philip ordered a force of 2,000 men to be sent into France to assist the Guises in the first civil war. The nobles objected; Granvelle insisted. Margaret, unable to decide, called a chapter of the Golden Fleece, who were to be her counsellors in the last resort and in the greatest emergencies. By their advice Montigny, a faithful Catholic noble, was sent to lay the state of affairs before Philip. 
Philip deliberated as usual a long time before he answered. In the meanwhile, the Prince of Orange and Count Egmont attempted to form a party against Granvelle: they failed in this, but the result was an open and irreconcilable quarrel between the minister and these two, the most powerful men in the country. It is to be remembered that the Prince was still a Catholic, and that the persecutions of the heretics, according to the edicts confirmed by Philip before his departure, were still being carried on, leaving not a moment for political or religious rancour to cool.

Philip's answer to Montigny's mission was a promise to visit the Netherlands in person: privately he instructed the Duchess to endeavour to sow discord between Orange and Egmont, which might easily, it seemed, be done, Egmont being a faithful, Orange a suspected, Catholic. The answer of Philip was as far as possible from being satisfactory. In March 1563, Orange, Egmont, and Count Horn, another very powerful noble who had but lately returned from the Spanish court, made in common a very strong remonstrance to Philip against Granvelle: again the answer was the promise of a visit. The three remonstrants thereon drew up a third complaint and retired from the council.

From this moment the Duchess seems to have turned against the minister. In August she wrote to entreat his removal. The King, by the advice of Alva, refused to suffer it. Again and again she implored Philip, as he desired to retain the sovereignty of the Netherlands, to remove the greatest stumbling-block. At last he yielded, and in April 1564 suffered Granvelle to go into Burgundy on a visit to his mother, from which he never returned to the Netherlands. There can be no doubt that Granvelle was an able and faithful minister, and without fault towards his master, who continued his confidence in him and constantly employed him in matters of supreme importance, but no more in the region which, by his master's orders, he had gone so far to ruin.

On the departure of Granvelle, the three nobles returned to their seats in the council; but their influence was still restricted. Viglius and Barlaimont maintained the policy of Granvelle; the executions under the edicts continued; and it must be added that the departments of business entrusted to the Flemish lords were so mismanaged that the element of financial difficulty seemed in a fair way of being added to the other troubles. It was now that Philip ordered the reception of the decrees of the Council of Trent and stirred up another alarm of the coming of the Inquisition. The lords now saw no remedy but in a visit of Philip in person, and Egmont was sent to Spain to beg him to come, as he had so often promised. Egmont's mission was no more successful than Montigny's. Philip 
consulted his theologians and came to the conclusion that he could not as a Christian relax the edicts ; and, instead of relaxing them, wrote from Segovia, in October 1565, an important despatch to Margaret, insisting on the rigid execution of them. This despatch caused no overt act of disobedience on the part of Orange; but it did cause the formation of a league among the nobles, which ended in rebellion.

It may be observed that this despatch of Segovia followed immediately after the interview of Catherine de Médicis with the Duke of Alva at Bayonne, from the date of which the persecution of the Huguenots waxed fiercer; that in that interview it was commonly suspected that an arrangement had been made for joint action against the Protestants, and that the Segovia despatch no doubt appeared to the Flemings to be the first-fruits of the new alliance. Be this as it may, the twenty confederates formed their League in November 1565 at the house of the Count of Calemburg at Brussels, drew up a programme of grievances under the name of the Compromise, and bound themselves by oath to one another to resist the introduction of the Inquisition. The Prince of Orange shortly after announced to the Duchess that he would resign the government of Holland, of which province he was Stadtholder, rather than execute the edicts. A few months after this, he became a Lutheran, but he did not join the league of the confederates, the chief of whom were the lords of Brederode and St. Aldegonde, and Lewis of Nassau, the Prince's brother. Of these Brederode was an unprincipled, versatile, restless partisan; St. Aldegonde a severe religionist; Lewis an accomplished soldier. The confederacy contained both Catholics and Protestants, and was altogether an organisation of constitutional rather than of religious defence. They came in a body to Brussels in April 1566 and presented their petition to the Duchess. On this occasion they earned the well-known sobriquet of 'les Gueux,' or 'the beggars.'

For a time milder counsels began to prevail. The Duchess was not inclined to severity, and Orange, Egmont, and Horn had become her chief counsellors: she could not refuse to execute the edicts. She even prevailed on Philip, in consideration of the dangers of the times, to make some slight concessions, to promise that the Inquisition should be abolished, and the persecution carried on by the bishops only. But unfortunately neither party trusted the other; and the heretics, including Lutherans, Calvinists, Anabaptists, and all sorts of sectarians, took advantage of the temporary relaxation of the edicts to run to excess and riot. Public preachings began everywhere and could not be stopped by ordinary authority. On August 14, the cathedral of Antwerp was sacked and the images 
destroyed by the heretics; other places followed the example: a religious or a fanatical revolution was imminent, and the Duchess was only prevented from flight by the threats of the Prince of Orange and Egmont. On August 23, she was obliged to grant the demands of the confederates, and allow public preachings and freedom of worship; they in turn swearing to assist her in putting down the disorders.

But the outrages at Antwerp had produced a reaction already. The Catholic members retired from the confederacy, and Margaret took advantage of it to prepare for defence in case of an open rebellion, such as under the advice of Brederode was now imminent. Just at this juncture a letter was discovered from Alava, the Spanish minister at Paris, to Margaret, stating that Philip was assembling a force with which he would come to take vengeance on Orange, Egmont, and Hoorn. This seems to have proved to the Prince of Orange that his position, careful as he had been not to entangle himself, was no longer tenable. In a conference of nobles at Dendermonde, he declared that the time was come for preparation : if Philip should attempt to enter the Netherlands in arms, he must be resisted in arms. Egmont refused to listen to this ; but the other malcontents took their measures immediately. Lewis of Nassau made his levies in Germany, Brederode prepared his ultimatum; the Duchess went on garrisoning the towns and increasing her force. This produced the outbreak. The town of Valenciennes refused to receive the garrison, and was besieged. Brederode sent in his petition, and Margaret with a high hand refused it: then the insurgents everywhere took arms.

I shall not, in conformity with my usual plan, go into any details of this little struggle. It lasted three months (February to April 1567), just as long as the siege of Valenciennes, which ended as soon as the Duchess had obtained leave from Philip to bombard the town. During the time, Antwerp was the scene of a violent tumult, the mob insisting on, and the Prince of Orange exerting the utmost energy to prevent, the admission of the insurgents. The Prince succeeded and saved the city from revolutionary pillage, but he had implicated himself now too deeply to be forgiven. After the taking of Valenciennes the Duchess proposed an oath to be taken by him to serve King Philip without restriction or limitation, against every one, whom he might command. Orange refused to take it, and left the country, retiring to Germany. After his departure the provinces one by one quietly submitted, Holland last of all, Brederode also had to fly, and the great migration of the Protestants from the Netherlands, which brought the wool trade to England, began.

It is impossible to say whether, supported by the Catholic 
reaction which was everywhere setting in and aided by the emigration, the pacification produced by the policy of Margaret might not have been a lasting one. The ostensible reason why it failed was the mission of the Duke of Alva, who was sent by Philip with a commission of practical supremacy, although he left to Margaret the title of regent, this same month of April. Alva was a brave and consummate warrior, a very hard-headed, merciless man : a man of high principle and great experience, the most unrelenting and the most dangerous enemy of the new religions. He arrived at Brusse's in August 1567; and Margaret knew herself to be superseded. Fy a deliberate act of cunning he drew Counts Egmont and Horn to Brussels early in September and arrested them after sitting in council with them and making a show of friendship and confidence. In vain Margaret remonstrated and threatened to resign. Alva did not care: he had begun his reign of terror. He instituted a fifth council, the Council of Troubles, or, as it was commonly called, the Council of Blood. By the end of October the whole of the Netherlands were quiet-quiet in stupefaction at the vastness of the cruelties designed and begun under his orders. $\mathrm{He}$ summoned the Prince of Orange to Brussels to share the fate of his friends. Margaret would no longer witness the wretchedness of her people; the people lamented her rule, with all its severity, as mild and gentle in comparison with Alva's. In October she was allowed to resign, and Alva became supreme in title as well as in fact. His administration lasted until 1573, and its character is uniform throughout.

The events of the year 1568 are most important. The beginning of the year is marked by the horrid edict of condemnation issued against the whole people on February 16, as guilty of treason and under sentence of the Inquisition. Persecution had never ceased; now extermination began. The remonstrances of Maximilian were answered with supreme contempt. Even Catherine stood aghast and declined the assistance of Alva in the French troubles. At last the Prince of Orange determined that the time was come. Under Lewis of Nassau, Hoogstraten, and Cocqueville, three Protestant armies entered the Netherlands and obtained some short successes; at Heiligerlee Lewis beat the Count of Aremberg, the Governor of the province of Groningen; but the other two were defeated. Nor was Lewis able to resist the arms of Alva when he found himself at liberty to march against him. This was not until he had completed his proceedings against Egmont and Horn. They were tried, to the disgrace of Spain and civilisation, condemned, and beheaded; even Granvelle interceded for them in vain. The sentence was carried out on June 5. Then Alva marched into Friesland against Lewis and utterly destroyed his army, July 21. Another army was hastily 
brought together by the Prince himself, who, having published a statement of his grievances, on August 31 entered the Netherlands in arms. But Alva was more than a match for him; avoiding a general engagement, he harassed him with skirmishes and constant feigned attacks, until the Germans, of whom the army was composed, became homesick and disappointed, and the Prince had with some difficulty to retreat, with the loss of all his prestige and 8,000 unhappy victims. This for the time paralysed the action of the liberators, and two years or three passed without anything important being attempted.

From 1568 to 1572 the Netherlands were prostrate under the feet of Alva. William was almost beggared by the expedition of 1568 ; and the German powers were not anxious to sacrifice themselves or their men for a mismanaged, helpless cause. The year 1569 is marked by the quarrel of Alva with Queen Elizabeth, which produced a sort of state of war between the English and the Spaniards, without declaration, and principally carried on in piratic naval expeditions. The Prince of Orange, observing this, devoted what money he could raise to the fitting out of privateers, who shortly were to do good service. The same year Alva sowed the seed of disaffection on quite a new ground. He summoned all the provincial estates to Brussels and produced a new budget March 30: by this he imposed a tax of a hundredth penny on all property to be paid once ; a twentieth on the transfer of all real property for ever; and a tenth penny on all merchandise and personal property everytime it changed hands. The twentieth penny was, of course, destructive of all trade. Viglius headed the opposition in council, but the measure was passed. The province of Utrecht refused to pay, and was condemned to forfeit all her charters, and the magistrates and inhabitants sentenced to the penalties of treason. But Philip would not back his minister in carrying out the sentence.

The states refused after 1569 to pay the taxes, and in the end they were commuted for a payment of 2,000,000 gulden for two years. Alva had overshot the mark. In 1570 he issued an amnesty, but it contained so many exceptions that it failed in any degree to satisfy the people. The same year Montigny, who had been in prison in Spain since 1566, was assassinated in prison under a sentence of the Council of Blood, under the superintendence of the King. The inundations of Holland, and the attempt of $D_{\theta}$ Ruyter to seize the castle of Lowestein, which he blew up rather than surrender, perishing himself in the ruins, complete the memorabilia of the year.

1571 is marked by the negotiations of the Prince of Orange with Charles IX. ; now under the influence of Coligny ; by the Ridolfi plot 
for the assassination of Queen Elizabeth, in which Alva did his best to prevent the execution of Philip's schemes, and by the battle of Lepanto.

In 1572 Alava visited Brussels and reported to Philip against Alva's administration. But Alva had already resigned, and the Duke of Medina-Celi received his commission as viceroy (September 1571). Alva held office only until his successor should arrive. He did arrive in June 1572; but by that time the difficulties were so great, owing to the condition of war and finance, that the government could not be transferred, nor was Alva willing to make way for him. Their views were incompatible, and the uneasy relation between the two Dukes continued until the middle of 1573 , when Medina-Celi retired and left Alva master of the field. But before Medina-Celi's arrival the atmosphere had changed, and a brisk war was being carried on which ended in the emancipation of Holland. The discussion of this war must be put off to another lecture in which I shall hope to complete our survey, or our attempt at a chronological review, of the reign of Philip II. You will find in Prescott and Motley elaborate details of the period which we have now run through in outline: both are learned historians, but Prescott's fairness is as much superior to Motley's as the language in which he records his impressions. Without being a philosophic historian, he is invaluable as far as he goes.

\section{LECTURE VI}

THE WAR IN THE NETHERLANDS TO THE DEATH OF WILLIAM THE SILENT, 1584

We shall proceed in this lecture with the sequel of the history of the Netherlands, which we left under Alva and Medina-Celi in 1572. We have failed to see in the proceedings of Philip himself towards the provinces any policy other than that of repression. The extinction of heresy at any cost was the object which he had set before himself, and which he had persuaded himself was a duty imperative upon him and a justification of all the cruelties through which the end was to be obtained. A failure of success in this point was enough to ensure the dismissal of his most valued ministers; he had thrown over the astute and careful management of Granvelle, the comparatively mild and temporising administration of the Duchess of Parma, and was now ready to recall Alva, whose measures, going straight to the mark, seemed to be ensuring their own defeat. 
To his opponents, great as was the use made of the religious grievance, it was not the whole of the grievance. The destruction of the ancient guarantees of independence; the iniquitous system introduced instead of the regular process of law; the constant influence of foreign adventurers or native statesmen hardened in Spanish principles; the cruel work of destruction of trade and commerce produced by the taxation of Alva; the accumulation of new expedients of tyranny upon the old ones which had banished Orange and reduced the political feelings of the provinces to a paralytic numbness, had proved too much even for the paralysed energies of those who remained to submit to them. They brought together Catholic and Protestant upon one ground, hostility internecine and perpetual to the foreign tyrant.

I remarked, I think, that Margaret's policy might possibly have succeeded; that when Alva undertook the government the Prince of Orange was not yet in arms ; that the reaction in favour of Roman doctrine had set in throughout the Continent, and that in the Netherlands it might have been successful if it had not been pressed beyond the limits which were reached in France and Germany. A very large portion of the countries in which these things were going on is now the most Catholic country in Europe. The Netherlands themselves were at that time not more Protestant than the Austrian dominions in Germany. The Austrian dominions in Germany are now nearly purely Catholic: and both might have been treated alike. But Philip hated compromise, and Alva was too able a minister to let well alone. His financial budget produced the storm, which kindled into a great war, which lasted from 1572 to 1609 and ended by making Holland Protestant and Belgium Catholic.

Very large as is the proportionate importance which we have to give to this war in this course of lectures, it is not greater than the subject demands. During great part of its continuance it is the only war that can be said to be going on in Europe; it is not broken by a peace during the whole of the thirty-seven years, and it has connected with it every great name known in Europe. Nor can its political importance be less than the highest: it is the first war of liberation and the pattern and precedent of all succeeding revolutions. The principles on which it was worked out, and even the religious formula of its chief actors, have mingled with the elements of all of those revolutions. The Thirty Years' War, the war of the English rebellion, the revolution of 1688, the war of American independence, everything republican, looks to this war as part of the throes of its origin. And the importance of the result has shed a glory over the men and a brilliancy over their exploits which are, perhaps, a little out of proportion to the reality. The interest is in the principle that 
was at stake and in the mightiness of the result, not in the details of the wars, or, to some extent, in the character of the actors. It is only the extravagance of partisanship that can elevate the Princes of Orange to the rank of heroes. Egmont and Horn are victims, most basely and ungratefully treated, but they are not martyrs. The very length of the war at once stamps the battles and sieges of which it is composed as petty and inconclusive: if they had been so great as to deserve all the elaboration with which they are written, they would have been decisive. As it is, they illustrate the obstinacy of the parties rather than the grandeur of their achievements. We cannot attempt even to detail them with the minuteness of which the French civil wars are capable; those wars are short and distinct in their field and effect: this is without a break and can only be divided or arranged according to the dates of the entry and exit of the chief actors in it. To divide it by the death of Orange or the death of Philip, or the change of governors, is not really to mark eras, but to form a convenient mnemonic artifice. But the period has to be read and studied, otherwise we cannot understand the play of European politics.

War may be said to begin with the capture of Brill by the privateer fleet which the Prince of Orange had been labouring to create, and had placed under the command of William de la Marck. These privateers had been sheltered in the English ports, during the time that Elizabeth and Alva had been hostile: now the Duke and Queen were drawing together and the Flemish privateers were ordered to quit the English coast. On April 1, 1572, de la Marck took Brill; and, although the people were spared, the pirates showed their nature by plundering the churches. The fleet which Alva sent to displace them was repulsed; and, by the advice of Treslong, a Flemish noble and admiral, the people of Brill took an oath of allegiance to the Prince of Orange as Stadtholder or lieutenant of the King. This is the first step towards the vindication of political independence in the country.

The capture of Brill was followed by a revolution at Flushing: undeterred by the fate of Rotterdam, which had been sacked by Bossu, Alva's admiral, for refusing him admission, the people of Flushing received Treslong, hanged Pacheco, Alva's engineer, and accepted as governor of Walcheren a nominee of the Prince. The example of Brill and Flushing was followed all through Holland and Zeeland. Everywhere the Prince was recognised as Stadtholder, and as Stadtholder for King Philip: the states claimed only their ancient rights, and it was against Alva, not against Philip, that they would be understood to rebel.

In May a bold stroke was made in the south. Lewis of Nassau 
took Mons. Alva was overwhelmed with indignation and astonishment. Next the insurgents captured a Spanish fleet. In June Alva summoned the States of Holland, and, in hopes of gaining a subsidy, offered to abolish the tenth penny: but the states would not come at his call ; they met at Dordrecht, in obedience to the summons of the Prince of Orange, and recognised him as the Stadtholder, promising to do their utmost to procure his appointment as Protector of all the Netherlands. It was now time for the Prince to come forward: he entered the Netherlands July 7, with his German army, and advanced to meet Alva who was besieging Mons. He had hoped for aid from France, but instead of it received the news of St. Bartholomew. This was a thunderbolt. $\mathrm{He}$ was obliged to retreat, leaving Lewis to his fate. Mons was surrendered by capitulation; Lewis got off scot-free, but the people were sacrificed. Alva and the Blood Council had a sweet and full revenge. The Prince of Orange disbanded his army and retired into Holland. The city of Mechlin shared the fate of Mons; it had recognised the Prince and, by way of example, was sacked by Alva.

The rest of the year was spent in a struggle for the places in Holland which had not yet received the Stadtholder. The insurgents failed to take Tergoes; Alva's force sacked Zutphen. Treason helped to complicate the disasters of the Orange party; town after town forsook the Prince after the tide turned. Don Frederick of Toledo, Alva's son, outwent his father in savage cruelty. By the winter matters began to look hopeless and the Prince to rise in dignity to the occasion. He summoned the States of Holland to Haarlem and laid before them his plans. Holland might be defended, further conquest was at present not to be looked for. Alva and Toledo were on their way. Haarlem was the bulwark of Holland; every nerve must be strained to save it.

The siege of Haarlem began on December 10. Every expedient was used for the capture, and every expedient for the defence; battles were fought on land, on water, and on ice; but no terms of compromise were offered. Expedition after expedition failed to relieve the city. On July 12, 1573, Haarlem was starved into surrender. Alva came in person to preside over the punishments; 2,300 prisoners were executed.

The next town to be besieged was Alkmaar, which, after seven week's siege, was saved by a threat of the Prince to cut the dykes and let in the sea. This was in October. The same month the patriots won a naval fight near Horn, and took prisoner Admiral Bossu. This is nearly the last event of Alva's command. He had got rid of Medina-Celi ; in November 1573, Don Luiz de Requesens, Grand Commander of St. James, arrived to supersede him, and on 
December 18 he departed. His administration demands no further comment. He was, as a ruler, all that the revolutionists of Germany and Italy have charged the Kings of Spain, the Emperors, and the Popes with being. He died in 1582. He had, early in the year, made close alliance with Elizabeth; and, since the massacre of St. Bartholomew, had been playing on the excited feelings of Charles IX. He was as successful as he wished to be in his plans for preventing any succour reaching Holland from either France or England.

The administration of Requesens lasted from December 1573 to March 1576, and was terminated by his death. He was a brave and moderate man, but not equal to the task he had undertaken; nor was he welcome to a nation longing for peace and financially beggared. But he came with promises of gentle dealing, and was an angel of light after Alva. His first task was to relieve Middelburg, which was besieged by Boisot; in this he failed. Middelburg capitulated to the Prince of Orange in February 1574. The next was to repel Lewis of Nassau, who was bringing the auxiliaries from Germany: this was committed to Don Sancho d'Avila, and was carried out successfully. Avila beat Lewis at Mook on the Meuse, April 14; and Lewis is supposed to have perished in the battle; he was never heard of again.

The history of the year is diversified by a mutiny among the Spanish troops, who seized Antwerp and compelled the magistrates to pay the wages due by the government. Leyden had been besieged in the end of 1573, and had been left only on the alarm of Count Lewis's approach. The siege was renewed in 1574 and lasted until October 3, when it was relieved by Admiral Boisot. The details of it are a repetition of those of Haarlem; the result happier. As in that case also the history of the siege is the history of the war.

From the arrival of Requesens we trace the revival of the third party in the Netherlands, which for a long time occupies as leading a place as Philip or the Prince of Orange: the national party, which would gladly have seen the country governed as it had been under Charles V.; but desired toleration and the expulsion of the Spaniards more than revolution or political independence. To this party Orange was not a national leader, as he was to the Hollanders and Zeelanders, but an able leader of opposition, to whom they might incline as much as they pleased, but were nowise bound to follow. This party was strong in the administration of Requesens ; it contained, indeed, all the native statesmen who were not yet bound hand and foot by Philip or maddened by religious bigotry. To humour these, Requesens, early in 1574, made some propositions for the abolition of the Council of Blood, but his proposals were contingent on the grant of subsidies, and, this failing, were withdrawn. 
From this time, however, the regular sessions of the Blood Council ceased, and the institution itself fell into abeyance.

Another result of the change of governor seems to have been the commencement of negotiations, at first secret, but later formal and recognised, between William of Orange and the governor himself. These were carried on through St. Aldegonde first, afterwards through Champagny, the brother of Granvelle, and Dr. Leoninus, a professor of Louvain. But the points reserved by Requesens as indiscussablethe King's authority and the religious toleration-made any reconciliation on such a basis impossible. In the meantime William's influence on his own government was jeopardied by the jealousies of the states, and he was obliged to remonstrate against their treatment so strongly that in November they vested in him, under the title of regent or governor, absolute authority. This dictatorship, for such it practically was, is a second decided step towards the casting off the allegiance to Philip.

One more attempt to negotiate was made by Maximilian this winter, and one result of it and of the secret deliberations was a conference at Breda, held in the spring of 1575 , between the States of Holland and Zeeland and a commission from the governor. These conferences lasted from March to July. The removal of the Spanish troops and the summoning of the States General were the text of Orange and his supporters; submission to the King and restoration of the Catholic religion that of the commissioners. The commissioners were willing to dismiss the troops; they were willing to promise that the Spanish Inquisition should not be introduced; but religious freedom was not to be heard of ; the German system of repression must be adopted if the Spanish were discarded; the heretics might sell their property and emigrate. The states were willing that even this compromise should be settled by the States General. The final disruption took place on the question of guarantees. William refused to place four strongholds of the provinces in the hands of the commission as security for compliance with the sentence of the States General ; the only security offered by the other party being the signature of Philip and Maximilian. So this attempt at peace ended. Hostilities were resumed by Requesens immediately and with some success. In July Ondewater was taken and sacked; in August, Schoonhoven. In September, by a very bold expedient, he marched his troops through the shallows from the isle of Tholen to Duiveland and Schouwen; took the isle of Schouwen, and besieged Zierikzee. This siege lasted until June 1576.

One other remarkable event of the year was the marriage of the Prince of Orange to Charlotte of Bourbon during the life of his 
former wife, Anna of Saxony, whose temper and bad habits had driven her mad. This was in June 1575. The marriage, of course, grievously offended her German relations, and injured the Protestant cause, and when the siege of Zierikzee threatened to cut off communications between the different parts of his provinces, he determined to risk all : to cast away the allegiance hitherto professed to Philip, and demand admission into the Empire as a German State, The latter part of the project was abortive, but on October 1, 1595. Holland and Zeeland renounced their allegiance. Negotiations were forthwith opened with both England and France. As for England, Elizabeth was willing to accept the sovereignty, but not the expense of a struggle. As to France, the proposition could not be made to the Duke of Alençon at the moment, owing to his position with regard to the court; he was just now heading the Huguenots; and Henry III. and Catherine could not in decency make the proposal of Orange a mere expedient for getting rid of him. Matters were in this state when Requesens died suddenly, March 5, 1576, and the supreme government, not having been otherwise provided for, fell into the hands of the Council of State, most of whose members belonged to the national or anti-Spanish party. The long hesitation of Philip as to the appointment of a new governor had the effect of prolonging their tenure, not of strengthening their hold of power.

The action of the year is rapid and important. Zierikzee, after a vain attempt to relieve it, in which Admiral Boisot perished, surrendered in June and was followed by a revolt of the Spanish troops all over the Netherlands. The cruelties perpetrated by these wretches were very terrible; but they had so much of a good result that a Congress of the States met, and in November at Ghent made a treaty with William of Orange, the fifteen Catholic States, and the two Protestant ones, by which the whole body pledged themselves to the expulsion of the Spaniards. The edicts against the Protestants were suspended; the prince was continued in his government, prisoners were released without ransom; and an early meeting of the old States General determined on, which would settle the religious question on the basis of toleration.

There are many difficulties and obscurities connected with this subject, and indeed the events of the year are confusing, all real authority being in abeyance; but in particular we must guard against supposing that this Congress of Ghent was a constitutional assembly of the States General; it was only the best substitute that could be got. We ask in vain what had become of the renunciation of allegiance by Holland and Zeeland, and what real power the council had in the convention. Morally, the importance of the pacification of Ghent is greater than it is legally. It expresses, no 
doubt, the deliberate wishes of the nation, but it has not the element of permanency. The events of $\mathbf{1 5 7 6}$ are certainly revolutionary.

Immediately after the pacification the arrival of Don John of Austria, son of Charles V., as governor in the place of Requesens, was made known. He arrived at Luxemburg on November 3. Don John was a very able, brilliant person, with some very good, some very admirable qualities; but in many respects he was the very reverse of William of Orange, and those respects were perhaps of the most importance in such a matter as lay before him. He was vain, impulsive, rash, and without any plan of operations, or policy either of his own or marked out for him by Philip: he had nothing but genius unassisted to oppose to the able and wary and elaborate policy of his opponent, who had perhaps no less genius than himself, of a nature far more germane to the occasion.

The Congress of Ghent, under the advice of William, lost no time in accosting Don John: deputies met him at Luxemburg on December 6, and presented to him eight articles of demand. The chief are: the removal of the Spanish force; the release of all prisoners ; the maintenance of the pacification as containing nothing that did not tend to the furtherance of the Catholic religion; an amnesty; a convocation of the States General; and an oath to maintain the liberties and privileges of the provinces. If he agreed to this, they were ready to receive him as governor, to maintain the religion and authority of Philip, and to renounce all foreign alliances. John returned no direct answer, but fenced merely. The Spanish troops might go, but they must go by sea; he wanted them, in fact, to invade England; he would be glad of peace, but he must know more about the pacification of Ghent before he signed it; he was glad to hear that the States were so well disposed to the King and the faith; he would govern as had been done under his imperial father, Charles V.

To meet this undecided dealing a new expedient was devised, or rather, perhaps, imitated from the other side of the frontier. The year before was the year of the formation of the League in France. January 1577 saw the formation of the Union of Brussels on a like basis : the formation of a league to expel the Spanish soldiers and to maintain the Catholic religion and constitutions of the Netherlands, a confederation of individuals of all ranks and orders, membership being entered by signing of the name, and, curiously enough, by men of all religions. It was on this point that, like the Compromise confederacy in the days of Margaret of Parma, it was destined to split.

From this time there is a sort of triangular struggle to be observed : Don John the governor, withput council, without troops,

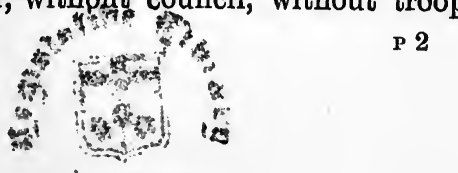


and without policy; the Prince of Orange; and the States General, or the national government as left by Requesens but really under the influence of William, ruling in their name. The States had not yet accepted Don John as governor. A month's negotiations satisfied Don John that it was useless to struggle: he must surrender all and hope for new chances from a new beginning. His heart was not in the struggle; his object was to attack and conquer England, release the Queen of Scots, and share the throne with her. But he did not mistrust Philip, and Philip's enemies thought that he had sent him to the Netherlands to ruin himself. On February 17 he yielded all, and by the Perpetual Edict accepted the pacification of Ghent, conceding all the demands of the States. Philip, a few weeks after, confirmed the Edict.

This measure threatened to rob William of Orange of his vantageground. He acted as a politician, and as a crafty one. Although the Perpetual Edict confirmed the pacification, wherein was his great success ; although he had sunk, in the negotiations for obtaining it, the renunciation of his allegiance to Philip, he saw in this a subtle way of turning Don John's weapon against himself, and set himself in earnest to break through the understanding between Don John and the States. In vain Don John negotiated. William was, by his silence or his disingenuousness, a master at negotiation; he had been tutored by Charles V. Unfortunately for himself, Don John gave occasion to the States to disown him. The troops were removed; Don John was received at Brussels as governor; but he saw himself still powerless. The Duke of Aerschot was commanderin-chief of the army, and he was in constant and close communication with the Prince. Don John saw that he must make a stroke for himself. Taking advantage of a visit of Margaret of Valois to Namur, undertaken with the intention of making the way easy for the Duke of Alençon, he seized the citadel and garrisoned it with his own men. A like attempt at Antwerp failed, and threw the citadel there into the power of Orange's party, ostensibly the officers of the government.

These acts caused a breach between Don John and the States which drove them into more open co-operation with the Prince of Orange. They wrote in August 1577 to Philip, begging that the governor might be removed. He himself was anxious to go ; his life was made a burden to him by the real or pretended plots of the Orange party. So great was the change of circumstances now, that Orange was invited to Brussels, and visited the States there in September. He put an end to all negotiations with Don John by insisting on terms which he could not accept; he was, in fact, treated as a rebel. He retired to Luxemburg, and the States set 
to work to find themselves a new sovereign. Elizabeth, as usual, trifled, and satisfied herself with damaging the chances of Alençon. The States turned for a saviour to quite a new quarter. The Archduke Matthias, son of Maximilian II. and brother of the Emperor, jumped at the offer, ran away from Vienna, and was met by the Prince of Orange at Antwerp. On December 7 the States deposed Don John, and on the 10th signed a new Act of Union, 'the New or Nearer Union of Brussels,' the last confederation of all the Netherlands. This constitution was accepted by the Archduke, and on January 18, 1578, he was inaugurated at Brussels. Orange was made lieutenant-general.

Don John prepared to assert his position in arms. At Luxemburg he collected a brave little army with which he declared his purpose (January 25). He had with him Ottavio Gonzaga and Alexander Farnese. The States army sent to meet him was under De Goignies, a soldier of Charles V. They met at Gemblours, not far from Namur, January 30,1578 , and the result of the battle was a brilliant victory of the conqueror of Lepanto. It was his last success. He overran Flanders afterwards, taking the cities one by one; and he at last succeeded in getting remittances from Spain; but his chances of governing the Netherlands were gone. His design on England was betrayed to Philip, and his secretary, Escovedo, assassinated. He saw himself without a friend and without a prospect in life.

On the other hand, the States and their supporters were for the moment paralysed. The Archduke sank at once into insignificance ; he was nothing by himself, and had brought nothing with him. To France they must look for aid. Alençon was ready to help them. William negotiated terms with him. The armies were again collected, but the religious difficulty was already dividing the national party, and before they could settle their quarrels Don John was dead. He died on October 1, a victim, not perhaps, of poison, but certainly of Philip's heartbreaking and unscrupulous selfishness. He appointed on his deathbed Alexander Farnese, the son of the Duchess Margaret of Parma, as his successor.

Matters were already assuming the appearance of anarchy, and the death of Don John seems to have removed the chief external help to cohesion between the provinces. As might have been expected, the anti-Spanish party had split on the question of religion; William of Orange, in the name of the Archduke, had devised a plan of religious peace and general toleration; the national party as a body could not support it, and it met with the bitterest opposition from the Catholics. And there were Protestants also, men of Antwerp and Ghent, who would not be satisfied with toleration, 
but demanded the forcible prohibition of the ancient worship. The national party, represented by Champagny, protested against the peace from one side; the demagogues of Ghent, strengthened by the presence of a large force of Germans under John Casimir, from the other. Alexander saw that his policy was to keep quiet and to watch for every chance of detaching man, party, city, and province from either the Prince of Orange or the States. Poor Archduke Matthias no party seemed much to think of consulting at all.

In December 1578 William succeeded in forcing the religious peace and the departure of Casimir and his army on Ghent. The following month a great step was taken towards the dismemberment of the Netherlands. The Walloon provinces were won over on ecclesiastical grounds to desert the cause of the States, by the exertions of the famous John Sarrasin, prior of St. Vaast. They formed themselves into a league, standing aloof from the other States, and were gradually prepared for reconciliation with the Spanish Government. On the other hand, Groningen and Friesland had attached themselves to the Prince of Orange, and formed, with Holland, Zeeland, Overyssel, Utrecht, and Guelders, the league of Utrecht, the actual foundation act of the future republic, January 28, 1579. It was a league to act together in all political matters, offensive and defensive, to secure religious freedom by conforming to the peace propounded by the Archduke; perfect religious liberty being thereby secured, and not the simple ignoring toleration that was struggled for in France. The supremacy of the King was still recognised ; Matthias was governor ; William Stadtholder of Holland and lieutenant-general.

The warlike proceedings of the year are confined to the siege of Maestricht by Alexander of Parma, from March to June, when it was taken, and the capture and recapture of Mechlin, first for the Spaniards, next for the States. During all the summer a conference was being held at Cologne for the purpose of inventing terms of peace, on which no two statesmen could be found to agree. In September the Walloon league reconciled itself altogether with the Spanish governor ; and the work of reaction against the government of the States began. This work of reaction was continued by absolute treachery. William was greater at devising constitutions than at maintaining them, and at making friends than at keeping them. The year 1580 saw Count Renneberg, the governor of Groningen, turn against him, and endeavour to carry his province with him ; and Count John of Nassau, the Prince's brother, weary of his task, resign the government of Gelderland. The treason of Renneberg produced an active struggle. Groningen was besieged by Philip of Hohenlohe, who failed to recover it, and was beaten in the 
field. The Prince again came to the conclusion that France must be the helper; the negotiations begun with the Duke of Alençon, now called of Anjou, must be completed. In vain the Archduke protested against the idea; the answer was that nothing was to be expected from Spain ; and the Empire, under Rudolf, would not stir a finger in their favour. A treaty was accordingly made with the Duke at Plessis-les-Tours in September 1580; and ratified by the convention of Bordeaux January 23, 1581 : to this treaty, although arranged by the prince, the States of Holland and Zeeland were no parties, nor of course the Walloon league.

In 1580 Philip claimed Portugal on the death of the Cardinal King Henry, and succeeded in making good that claim. He satisfied himself, as far as concerned the Netherlands, with setting a price on the head of William of Orange, 30,000 crowns to anyone who would deliver him up, dead or alive. The object was only too well answered.

The Declaration of the Independence of the United Provinces was made on July 26, 1581. The States of Holland and Zeeland would not accept the sovereignty of Anjou; they would no longer recognise their dependence on Philip ; they renounced his allegiance, and offered the sovereignty, with the dignity of Count, to the Prince. He now accepted the dignity provisionally, for he had not yet given up the hope of gathering in the rest of the provinces. The Netherlands were thus divided into three parts: the Walloon States under Philip; the United States under William; the Central States under Anjou. Anjou had presented himself in June, but had postponed his installation until the conclusion of his courtship in England. The Archduke, thinking there was no more work for him, took his departure in October. The Duke of Parma, who had only just received the confirmation of his appointment from Philip, proceeded in his gradual work by taking Tournay.

The courtship of Anjou came to an end with the year; and early in February 1582 he presented himself for installation. He was received with great ceremony and went through the process of election as Duke of Brabant at Antwerp, as Duke of Guelders and Friesland in July, and as Count of Flanders at Bruges in August. This was the theory of his sovereignty: he was to fill the place of the ancient provincial rulers, to confirm and observe the privileges and to govern with the aid of the States, just as had been done by Philip of Burgundy and Charles the Bold.

In March the first attempt was made to assassinate the Prince of Orange. He was severely wounded, but recovered rapidly. The alarm cost him his wife, Charlotte of Bourbon. The excitement of the event kindled the loyalty of Holland and Zeeland; they insisted on his accepting the sovereignty plenarily, and he com- 
plied. $\mathrm{He}$, as Count, would renew the Great Privilege granted by Mary of Burgundy, and rule as did the old national princes. The circumstance that this arrangement was never completed by his installation is perhaps one efficient cause why the government of the provinces ultimately took the form of a republic. He died before the installation could take place.

The military history of $\mathbf{1 5 8 2}$ is languid. Parma went on taking small towns, Oudenarde and others; there was no work in the field. But the lull did not last. 1583 was a very eventful year. At Christmas 1582 Anjou was persuaded by his French visitors that he was a puppet of Orange and a prisoner to the States. To vindicate his dignity he formed a plot to seize the principal cities still garrisoned by the States and hold them with French soldiery. The plot was discovered, but was not wholly resultless. He disgraced himself and betrayed the narrowness and wickedness of his nature, and the States were anxious to have done with him and send him away. But he declared himself the injured person, and procured the strong intercession and vehement promises of Henry III. and Catherine. More efficacious, however, than these was the influence of the Prince of Orange, whose last hope of help from without was vested in him, and who would fain use him still, though he could not trust him. By March he was reconciled, although the harm he had done was never remedied. On April 12, Orange married Mrs. Teligny, daughter of Coligny.

In June the Duke left for Paris and never returned. Although he had not divested himself of the sovereignty, the States seem to have considered themselves at liberty to seek a new master, and in August, at Middelburg, offered the post to the Prince. Brabant also offered to elect him Duke; but he would not accept either offer. He would not endure the reproach of selfish ambition; nor could he rid himself of his engagements to the Duke of Anjou. Nor would it have been easy to oppose himself alone to the rising power of Alexander of Parma, who was rapidly gathering in towns and even provinces. The governor of Guelders, the Prince's brother-in-law, betrayed his province to the Spaniards. The Prince of Chimay, governor of Flanders, did the same, and Ghent was saved only by the strong remonstrances of Orange. Bruges gave itself up in May 1584 .

But the end of two chief actors was near. Anjou was still purposing a return, when he died, as it appeared, by poison, June 10, at Château-Thierry. William was assassinated by Balthazar Gerard on July 10 at his own house at Delft; and with him a great part of the interest in the history of the Netherlands ends. I shall say little now of his character; something I may by and by ; now only this, that, 
taken at the lowest estimate, he was something very different from ordinary men, especially politicians ; and yet he was a politician, rather than a hero or a statesman. Taken at the higher estimate, he was a hero, almost a saint. He did a great work, and yet, had he been better or worse than he was, it might have been a greater. How this was we will consider in a future lecture; we have dwelt long on these details, because they cannot well be compressed. Henceforth we must content ourselves with a scantier outline and from a somewhat higher standing-point.

\section{LECTURE VII}

THE LATER YEARS OF THE REIGN OF PHILIP II., 1584-1598

IT will be necessary in this lecture to complete our view of the reign of Philip II., and as it, of course, contains elements of importance over and above the history of the Netherlands, to draw the latter into as small compass as possible. Very much of the personal and particular interest ends with the life of William of Orange; and the political history, although after that date it becomes even of more interest than before, does not involve us in so much minute detail.

The state of affairs in the autumn of 1584 was this: death had removed the Duke of Anjou and the Prince of Orange within a month of one another. With the death of the Duke the interest of France in the Netherlands determined; by that of the Prince, so immediately following, before he had time to provide a successor to the Duke, all cohesion between the States, save and except those bound together by the Union of Utrecht, appeared to be removed. Alexander of Parma, Philip's governor-general, was not slow in following up the system he had begun upon: as he had brought Bruges to submission in the summer he brought Ghent in the autumn (September 17), and every month saw the dominion of the States' government in the south seriously curtailed. The whole of Flanders, except Ostend and Sluys, followed.

On this success he commenced the siege of Antwerp, which was, indeed, no slight undertaking, and in which he, the greatest general of the age, employed and exhausted all the expedients of the rapidly developing art of war. The siege of Antwerp lasted until August 17, 1585. During the continuance of it, Brussels, Mechlin, and many other places of importance went over to the Spaniards.

The conquest or reconciliation of Antwerp very nearly completed 
the subjugation of the south, and the authority of the States was becoming gradually confined to the provinces united by the Union of Utrecht, of which Holland and Zeeland had shown a disposition to accept isolation under the sovereign rule of William of Orange. The United Provinces had lost in him the great symbol of their union. Holland and Zeeland had elected in his place as Stadtholder his second son, Maurice; and the other States placed a confidence in him more warranted by his capacity than by his years, and justified by his future exploits rather than by the apparent necessity of the trust. But he simply had their confidence. Although they renewed the Union of Utrecht and chose governors attached to the Orange policy, they remained under their own magistrates and the direction of the States. They wanted not only a successor to William, but a successor to the Duke of Anjou, whose lieutenant-general William had been.

Compelled to seek such a successor abroad, they betook themselves again to England, and this time with apparently more success. The treaty with Elizabeth was made on August 17, 1585. Elizabeth promised to assist the States with men and money, and Brill, Flushing, and Rammekens, were put in her hands as guarantees for the payment of the debt. Sir Philip Sidney was made governor of these towns; the Earl of Leicester captain-general of the forces. The States eagerly welcomed Leicester, who arrived on December 10, 1585. He was made governor-general by the United Provinces, at the Hague, February 1, 1586, Maurice having previously been elected governor, admiral, and captain-general of Holland, Zeeland, and Friesland. I need hardly explain the causes of Leicester's failure, and the actual mischief his incapacity did to the cause he was sent to promote. He showed himself undeserving of the confidence of the States, by aiming, as Anjou had done, at the sovereignty; his behaviour was offensive, his policy weak; his management tyrannical, extravagant, and ineffective.

Alexander of Parma continued to enlarge and consolidate his acquisitions. In December 1586, Leicester quitted the country, and returned to England to press the execution of Mary Queen of Scots. The government he left, by one act, in the hands of the Council of State, reserving to himself, by another, large portions of patronage and jurisdiction. It did not require this to sicken the Netherlands of the wretch. Parma was all the while gaining strength, yet Leicester had attempted to undermine the authority of Maurice, who was the only person exercising sound government in the whole of the provinces. They complained to Elizabeth, who sent back her favourite in June 1587. But this did not turn the luck. Alexander took Sluys in August, and rested awhile from his labours. Leicester 
spent the time in intrigue and conspiracy; the States discovered his treacherous designs, complained again to Elizabeth, and procured his recall in December 1587.

There was now no longer any pretence of peace between England and Spain. Mary Queen of Scots had been beheaded in February 1587 , and the fleets of the two powers were burning and plundering at sea. Philip's design of conquering England and bringing it back by force to the Catholic religion was a part of the programme of his alliance with the League now attempting revolution in France. Yet, even whilst the Spanish Armada was on its way to England, Elizabeth attempted to negotiate a peace for herself and her Netherland towns with the Duke of Parma, the relations of each with Spain remaining unchanged. This expedient was not entirely new. The governante of the Netherlands had been at war with Francis I. whilst Charles V. was at peace with him ; and Alva had had relations with Elizabeth herself not by any means parallel with those of Philip. This proposal, however, considering Elizabeth's relations with the States, was too absurd, and it came to nothing. During the excitement about the Armada, Alexander had no time for active proceedings against Maurice; and in September 1588 Leicester's death relieved all parties from apprehensions of his return. The towns which he had alienated from the common interest returned to allegiance, with the exception of Gertruydenberg, where the garrison had been thoroughly corrupted, and, after great cruelties, gave up the place to the Spanish governor.

In 1589 the health of Parma failed, and the affairs of the provinces looked up. Breda was taken-a very good exchange for Gertruydenberg-and Nimeguen seriously threatened. The French wars, moreover, now again distracted the attention of Parma. Maurice was growing in ability and in the confidence of the States; in 1591 he was elected governor of Guelderland. The north-western provinces also showed signs of shaking off the Spanish yoke; Nimeguen was at last won, October 22, 1591. In May 1592 Maurice pushed his conquests in Overyssel and took Steenwyck and the strongly fortified town of Corwærden. In December 1592 the Duke of Parma died, and Ernest of Mansfeld, who had been long acting as his lieutenant, succeeded him. His government lasted two years, during which Maurice, who since the failure of Farnese had taken rank as the greatest warrior of the time, took Gertruydenberg after a three months' siege, and isolated Groningen by occupying and fortifying the frontier. On January 30, 1594, the Archduke Ernest arrived as successor to Mansfeld, but his period of rule is in itself uneventful and lasted but a few months to February 1595. It witnessed, however, another great triumph of Maurice, the capture of 
Groningen, which he took on July 24, 1594. This success completed the territory afterwards known as the Seven United Provinces, with the exception of a few border towns. Maurice had now recovered nearly everything that his father had lost since the Union of Utrecht.

The next governor, Pedro Henriquez d'Azovedo, Count of Fuentes, did nothing but quarrel with the Flemings. Maurice strengthened his position, to some extent, by an alliance with Henry IV., which, however, roused the jealousy of Queen Elizabeth, who was anxious to maintain an influence on the Netherlands, although she would make no sacrifice or exertion to help them. But Fuentes was recalled in 1596, and Philip, now grown old, seems to have determined to submit to circumstances and endure the idea of a permanent loss of the northern provinces. Not that he would endure a peace or a recognition of independence: that was not to come yet for many years; but if by the sacrifice of a part the remainder could be retained, or if, by devoting more time and pains for the consolidation of the remaining portion, a standing-ground could be formed from whence at some future period the other parts might be reconquered, he would be content. On the recall, therefore, of Fuentes he appointed as governor the Archduke Albert of Austria, Archbishop of Toledo, and lately viceroy of Portugal. He arrived February 29, 1596. The French war was now raging, and Albert had little time for anything else. He succeeded, however, in taking Hulst from Maurice in 1596. Maurice, on the other hand, in 1597 was very successful, and threatened Brabant with conquest. The alliance between England and France strengthened Maurice still more. The States did their best to prevent a peace between Henry and Philip in 1598, and resisted every attempt made by Philip, through the Emperor and the Kings of Denmark and Poland, to make some sort of terms. But they did not succeed in hindering the peace of Vervins; they consoled themselves with a close alliance with Elizabeth.

Philip's last transaction with regard to the Netherlands was, curiously enough, an act that might at an earlier date have kept them altogether for his house. He consented to part with them. $\mathrm{He}$ arranged a marriage between the Archduke Albert and his daughter Isabella: Isabella was to have the Netherlands in full sovereignty, the feudal suzerainty alone being reserved to the Kings of Spain. All difficulties were got over; the Archduke was relieved from his archbishopric and all clerical obligations, and the marriage contract was signed shortly before the death of Philip : it was completed in the spring of $\mathbf{1 5 9 9 .}$

Here for the present we must close our sketch of the Netherlands 
history. Henceforth the war, although continuous, is rather a war of aggression than of liberation: no great changes of attitude or frontier took place after the death of Philip, although Maurice went on for twenty years and more startling the world with brilliant exploits. Up to the year 1584, the history of the Netherlands is the history of Philip II. From that date we see more clearly than before the working out of the other designs over which that astute and prudent, slow and sure monarch had brooded so many years.

In 1580, the King of Portugal died, and Philip found himself involved in a new interest which certainly did relieve for some time the pressure of his power on the Netherlands. The vacancy in the Portuguese throne had been looked for with anxiety since the death or disappearance of Dom Sebastian in Africa in 1578. There were five candidates for the succession: Antonio, prior of Crato, son of Luis, brother of Joam III., but reputed illegitimate; Joam, Duke of Braganza ; Rainucci, Duke of Parma ; Emanuel Philibert of Savoy ; and Philip, King of Spain. Philip was the son of the eldest sister of Henriquez, the Duke of Savoy of a younger sister; the other three were descended maternally from a younger brother. On English principles these three claims would be better than Philip's: but, mere consanguinity considered, he came the nearest to the late King. What advantage, however, he had in that way he lost by the operation of a law of Portugal, by which any princess who married a foreign prince forfeited her right to the throne. In this disability the Prince of Parma and the Duke of Savoy shared. The Duke of Braganza's claim thus became supreme, and might fairly have been admitted but for the strength and intrigue of Philip. Henriquez had seen the justice of that claim, but he dared not openly oppose Philip; he appointed three regents who were to decide. Antonio, the prior of Crato, on the news of his uncle's death, betook himself to Lisbon without waiting for the decision of the regents; threw himself into the arms of the deputies of the third estate, who claimed, certainly without authority, the right of determining the succession, and declared himself King. Philip proclaimed war forthwith and sent in an army under Alva. The struggle was short. Lisbon, army, and navy fell into Philip's hands, and he was proclaimed King of Portugal, as Philip I. Antonio made a good fight for his crown, and was supported in some measure by the intrigues of Elizabeth, as well as by a fleet under Sir Francis Drake; he held out in the Azores for some little time, but was gradually edged out by Philip, who, by spending two years in Portugal, propitiated the people and obtained the full allegiance of both the kingdom and the colonies. On returning to Spain he left the Archduke Albert as viceroy, who governed well and temperately. 
Antonio, however, was not dead, but likely to give further trouble. He applied first to the French Court and afterwards to the English. Here in England he arrived in 1589, after the event of the Armada, and consequently met with a good deal of encouragement. The Queen declined to invade Portugal on his behalf, but she was persuaded by the Earl of Essex to furnish him with an armament: a fleet of 120 vessels and 20,000 men under Drake and Norris, under the idea that on the news of his arrival the people would rise and welcome him. As precisely the reverse appeared to be the feelings of the natives wherever the fleet attempted to land, the leaders of the expedition, with some little loss of glory and credit, returned home. The whole expedition was discreditable and only to be excused on the ground of the long-standing hostility of Elizabeth to Philip and its similarity to some of the marauding speculations he had encouraged in Ireland. This is Antonio's last stroke for the crown; but three several false Sebastians played the rôle of pretenders from time to time and gave Philip no small trouble between 1585 and 1594.

The relations of Spain and England during the two long reigns are extremely complicated and tedious ; and, although it is necessary to mention them again as I have done several times already, they would be better studied in connexion with the domestic history of our own, country. Both Elizabeth and Philip were anxious throughout to avoid open war. Anything like personal or national friendship was impossible. The English hated the Spaniards as persecutors, and the Spaniards hated the English as heretics; nor is there any reason to believe that Elizabeth and Philip personally were exempt from the feelings with which their subjects respectively regarded each other. Yet both hated the French, and, as the French were nearer to both than either was to the other, it was by their relations to France that their public conduct, their political attitude, their alliances, war and peace, had to be guided. Under the guise of peace, therefore, each would do the other as much harm as possible, provided it did not result to the good of the third foe.

Philip might be regarded as the natural protector of the English Catholics; as his father's son, and as the most powerful Catholic sovereign, during the abeyance, for such it was, of the Empire, and as having been once their King and done his best to secure the restoration of their religion. Yet, in consequence of the fact that the Catholic intrigues in England hinged on the fortunes of Mary Queen of Scots, he stood aloof from them : contenting himself with occasional remonstrance as to the heretical conduct of the Queen, or her hard usage of the Catholic party, but not until late in his reign intermeddling with their intrigues. This outward relation 
continued even after he had allowed himself to be drawn into the Ridolfi plot, in 1569, and whilst the English ships were plundering his fleets in all quarters of the world. No doubt the excommunication of Elizabeth by Pius V. in 1570 rendered it difficult for Philip to retain friendly communications with her. But in 1572 we find her expelling the Netherland refugees at the request of Alva; relations were drawn closer still in 1573 , after the massacre of St. Bartholomew; they languished during Elizabeth's flirtations with Alençon: it was not until 1584 that the discovery of Throgmorton's plot, and the share of the Spanish ambassador in it, that Philip's representative was removed from the English Court. By that time Elizabeth was hand and glove with the Netherland liberators: and although she did them little good, as we have seen, they certainly drew on her the determined vengeance of Philip.

Since 1569 Philip had taken up, though coldly, the cause of the imprisoned Queen of Scots : as his connexion with the Guises grew closer, his patronage of her became more ardent; although he would not approve Don John's design of conquering England and marrying her, he hoped to make of her a use that would bring England to his feet. Her execution accordingly was a blow which he did not expect ; as a Catholic prince, as a long-enduring friend of Elizabeth, and as the ally of the League, he determined that his vengeance should be signal. Hence the Armada in 1588, the result of seven or eight years of preparation; hence Elizabeth's retaliation in Galicia and Portugal the following year, and a state of war almost as desultory as the state of peace that preceded it, lasting to the end of Philip's reign, and chiefly signalised by marauding expeditions and attacks on the Spanish colonies in America. This war outlived both Philip and Elizabeth; giving the opportunity for occasional spurts of hostility and causing enormous suffering and bloodshed: it was terminated by James I. in 1604 .

It would perhaps be wrong to omit the sad episodes of the assassination of Escovedo, Don John's secretary, in 1578, which led not remotely to his master's death; and, consequent thereon, the disgrace of Antonio Perez, Philip's confidential minister, and his subsequent flight. The latter proves that, notwithstanding Philip's rigorous government, the constitutional spirit was not yet extinct in Spain. Antonio Perez was supposed by Philip to have learned too many of his master's secrets, in particular to have been indiscreet as to the circumstances of Escovedo's assassination. Philip was so slow and cautious that it sounds most improbable that he should have betrayed himself : but some reason of the sort there must have been, and Antonio must be sacrificed. Or it may have been that he had been the rival of Philip in the affections of the Princess of 
Eboli, ${ }^{1}$ the Catholic King's mistress. Anyhow a charge of malversation was laid against him: his conduct was made the subject of legal investigation, and he was sentenced to imprisonment, exile from court, and a fine. From the place of imprisonment he escaped and reached the frontier of Aragon, where he appealed to the justiza. This secured him by law a fair trial, but a fair trial Philip was determined that he should not have: he ordered him to be arrested; and the Aragonese at Saragossa rose against the act as an infringement of their constitution. Philip upon this gave information to the Inquisition that he was a heretic, and the Inquisition claimed and secured him. The justiza appealed and the people raged: the Inquisition was attacked, and Perez managed to make his escape. But the quarrel did not end there. Philip sent an armed force into Aragon to punish the rioters. The justiza, Don Juan de Lanuza, headed the people against the invasion; they deserted him on the approach of the soldiery, and he was seized and executed by Philip's order (1591). As for Perez, we hear no more of him.

I have said, I think, enough already about Philip's relations with France, down to the death of Henry III. in 1589. And his maintenance of the League in their opposition to Henry IV. belongs rather to the history of France than to that of Spain. His purpose was to place his daughter Isabella on the throne, to which as granddaughter of Henry II. she might, but for the established law of the French succession, have had a claim; or in default of that to procure for her the duchy of Brittany, the inheritance of Anne of Brittany, and heritable by his wife Elizabeth, or Isabella the daughter of Henry II. But the declaration by Henry IV. of his adhesion to the Roman Church put an end to the schemes of the League and to the chances of Philip and Isabella in 1594. Henry, released by this act from the pressure of civil war, devoted himself the next year to the humiliation of Spain: and this seems to have given the deathblow to Philip's hopes of carrying out the policy for which all his life he had been working and for which he had sacrificed his treasures and the liberties and lives of his peoples.

As the earlier war comes chiefly into French history, so this short portion of it belongs to the Netherlands. The Archduke Albert was Philip's general ; the battlefield the northern frontier. I have already mentioned the alliance between France, England, and Holland in 1596. In the year 1597 the Archduke captured Amiens; but Henry recovered it soon after: and early in 1598 peace was made at Vervins. By this Philip gave up, of course, all his demands on France and Brittany: with the towns which the Archduke had

1 Princess Eboli, wife of Ruy Gomez, Philip's confidential friend, who died in 1573. 
taken on the frontier during the late struggle. In return he was permitted to retain the county of Charolais, a part of the Burgundian heritage which was not yet quite lost sight of, subject to the suzerainty of France. His last act for the disposition of the Netherlands I need not now revert to. He died on September 13, 1598, at the age of seventy-one.

Few princes have ever lived for whom the voice of impartial history ventures to say so little. Philip II. was far the richest and most powerful monarch in Christendom at the beginning of his reign: and his political influence, owing to his relation to the imperial family and his connexion with England, gave him a position of paramount importance. He was better off than his father, for he was not hampered with the management of Germany, an unprofitable dominion, or with the obligations of the imperial office. He had no serious difficulty with the Papacy or great trouble with Italy during the whole of his reign, or at least from 1559 to 1598. In Spain he had merely the Moorish war, which, tedious as it was, was not dangerous or expensive. $\mathrm{He}$ engaged in no great war, or, excepting the Armada, in any great expedition. He received large revenues from America, and starved the government of the. Netherlands, yet he incurred no great expense in any undertaking except the building of the Escurial. He was not an extravagant or luxurious man. Yet he died exhausted and left his dominions on the decline. He was not a negligent ruler; the King's hand was everywhere in the business of the State; his letters were innumerable; he kept in his own hands all the strings of his policy ; but no success came of all his pains.

What is the secret? That he trusted himself too much and his servants too little, was too slow and prudent and cautious; that he took so long to ripen his plans that they betrayed rottenness before he executed them; that he was a selfish ruler, ruling for himself and not for his people, that he had too great power and not enough mental strength; all these may be true in a measure, but as reasons for his failure they are insufficient. He found Spain great and failed to keep her so ; he found the Netherlands strong and united and rich and likely to be contented with very few concessions : he lost half of them and beggared the other half. This was his failure. Is it religious bigotry that tempts an Englishman when he lays the whole failure to the charge of Philip's unbending determination to force the doctrines and discipline of the Roman Church on Christendom generally? I confess I can see no other key to his designs; and in this design $I$ think we cannot but see that, if he entertained it, there is contained the secret of his failure.

Do not misunderstand me. I do not say that this determination 
makes him worse than other kings. I can believe that there are minds to which it seems rather to excuse his sins. The age was an age of persecutors ; the Church herself, if we may judge by the acts of her representatives, Protestant as well as Catholic, had not learned the possibility or the wisdom of tolerance. If we blame Philip as a persecutor, we blame him not because he persecuted, but because he persecuted more relentlessly than any other prince, because, standing at the head of Christendom, he did not rise superior to the vulgar theory; because other princes persecuted in a moderate and more effectual way and so put him to shame. The German system of repression is a proof that, bad as it was, there was a better system than that of the Inquisition. The existence of Maximilian and William of Orange shows that the theory of persecution itself was not the only theory going.

Still, I say, it is not fair to blame him for not being before or for being behind his age. The moral guilt of the persecution lies heavily on him, as it does on Charles V., because of the enthusiasm with which they pressed the edicts. But we are speaking now of political folly rather than of moral guilt. It was the persecution that aroused the fears of the Netherlanders about the Inquisition : it was to maintain the persecution that the Spanish soldiery was kept in the country; that the constitutions of the several States were broken down; that the affection of every Netherlander in the land was alienated from him; that the churches he wished to protect were pillaged, and the doctrines he wished to eradicate were forced into premature popularity and hallowed with the devotion of countless martyrs. The object he desired to secure was rendered impossible by the means he used; yet he persisted; he directed the policy of Alva, whose administration accomplished the loss of the Provinces. $\mathrm{He}$ used then a policy that resulted in promoting the object which he intended to hinder; and he persisted in it when its actual result and tendency were clear enough; he sacrificed everything to it: and he lost, comparatively speaking, everything by it. He found that nothing but extermination could make an end of the heretics. So he adopted the policy of extermination, but it has never been shown in history yet that a king could annihilate a whole nation; much less a creed, or even a sect, that thrives on persecution and spreads the more because it is obliged to spread secretly. If this was not politically folly, I do not know how such a thing can be said to exist at all.

Philip's treatment of his Spanish subjects, his policy in England, and his policy in France, although modified, as we have seen, by other influences, were based on the same ruling desire. Next to the welfare of the Church came the welfare of his own house, without whose welfare the task that he had set himself could not of course 
be regarded as feasible: this principle modified his relations with France and England. But only so far; where he could persecute he did; where he could not, he urged the system on those who were likely to be influenced and fomented rebellion against those who would not be influenced by him. And all the while he saw the enemy that he wished to humble rising stronger and stronger, saw England, which he had known as a poor exhausted shattered little state, taking rank as in old times with the chief powers of Europe; saw on the throne of France a prince Catholic indeed in name, but so far from orthodox that his first Catholic act had been the Edict of Toleration of Protestantism; one, moreover, whose conformity was clearly political, and as clearly not religious; who further still had been Protestant and Catholic already twice alternately and might be again.

So I am obliged to sum up Philip's political career. It is no fancy estimate: seldom in the world's history has there been so singlehearted a king; seldom one whose policy tended so persistently to one manifest and invariable object. Setting this aside, Philip might have been a good king : except in this direction he was not tyrannical, violent, or false. In this he was all three.

We cannot help asking how his own people regarded him. There can be no doubt that the Spanish people admired-and loved him. $\mathrm{He}$ spent the whole of his life in Spain, his religious instinct was one with that of the great majority of his subjects. He spoke their language and adopted in some respects their habits. What the Netherlands were to Charles, Spain was to Philip ; and to a certain degree Spain had regarded Charles as the Netherlands did Philip. $\mathrm{He}$ drew his ministers from Spain as Charles had done from the Netherlands ; it was his own country, and the people were proud of their king, so rich and mighty and so faithful.

Setting aside, again, the religious question and the Inquisition as a part of it, Philip was not a bad king constitutionally. He did not quench the embers of national life which had been suffered to survive the crushing act of Charles V. in 1539. That act, as you will remember, had reduced the Cortes to practical insignificance, by fixing the number of towns represented in it at eighteen, and so placing the disposal of the votes at the royal command. But, as I have often had occasion to remark with regard to earlier history, the advice and influence of a constitutional assembly do not always correspond with their coercive power. A strong king will ask advice and listen to remonstrances where a weak one cannot afford to do either; the king who is above the need of jealousy will be able to use and willing to defer to national and constitutional safeguards. So Philip did. He did no harm to the Spanish constitution by using 
it and leaving it as he found it. The Cortes still had certain powers which, as he could manage the Cortes by fair means, he was not tempted to abridge by foul. The Cortes still had the exclusive right to grant supplies, and he only occasionally attempted to raise supplies without them. The Cortes were called very frequently indeed, and what the King asked for they granted. The nobles had ceased to sit in the Cortes, or at least to attend them regularly. Philip made no attempt to bring them back to their duty; he knew that it would have provoked rebellion, that the preservation of their immunities was a guarantee of their pacific conduct. They became mere grandees, mere courtiers; gamblers and intriguers; and as the absence of war gave them no chance of developing energies in a manly direction, they lost and lowered the old Spanish character by follies and extravagances that in another direction made way for the rapid decline of Spain.

But the Cortes, although powerless to resist, were able to advise and to remonstrate: they retained the right of granting supplies, but had lost that of seeing their complaints remedied before they granted them ; they retained the right of legislation, but they had lost the power of preventing the King from uttering ordinances that would have the force of laws. Their remonstrances remain on record to show that although the King had power to take the supplies, and to make the laws, he had not the will to provoke opposition by refusing to hear remonstrance. The voice, it is true, is feeble and faint, but still it is uttered; the word is spoken although the King is not forced to hear it. There is some moral weight in the utterances of a nation so governed.

Some of these remonstrances are interesting as illustrating the final struggles of the medieval ideal of administration, according to the spirit of which the King should live on his own estates, not by taxation, and every hardship of the people is ascribed to the extravagances of the Court. The Cortes of Valladolid in 1558 complain of the expense of the royal household ; the only matter in which Philip, acting on the plan of his Burgundian ancestors, was magnificent or lavish: they set before Philip both the ruinous cost and the bad example of the extravagance : without effect. Again and again, too, they complain of the alienation of domain lands of the crown, throwing the maintenance of government more and more on the contributions of the nation against the sale of titles and officesa plan in use in Spain as well as in France and Italy for the recruiting of an exhausted exchequer; against the imposition of taxes unauthorised by the Cortes themselves, as Philip's financial difficulties occasionally compelled him to do, and for which he pleaded necessity as his excuse : they urged on him the codification 
of the municipal law of Castile, the increase of the salaries of judges, the promotion according to the light they had of commerce and trade; the putting down of the luxury of coaches, and the maintenance of the national amusement of bull-fighting. Their most important recommendation, however, was that of forbidding the exportation of gold and silver.

Philip acted on their advice in the many sumptuary laws whicb mark his reign, running into the most minute particulars of dress and expenditure. We may laugh at such vestiges of ancient independence; but the nation that retains even these has not lost all, and the sovereign who suffers them to continue to exist is so far forth not quite a tyrant. Valeat quantum to redeem Philip II.

\section{LECTURE VIII}

FROM THE ACCESSION OF HENRY III. OF FRANCE TO THE PEACE OF VERVINS, 1573-1598

By the death of Charles IX. the family of Catherine de Médicis was reduced to two sons and a daughter : Henry, King of Poland ; Francis, Duke of Alençon; and Margaret, Queen of Navarre. Outside the immediate circle the King of Navarre stood next in succession, and after him the Cardinal of Bourbon and the Prince of Condé. Neither Henry nor Francis was married, and Charles IX. was the only one of the family who had any child. The Protestant succession became a lon'g step nearer by his death: and the prospect from that time constitited an element in the troublous complication of parties. Philip kept his eyes open on France since the feast of St. Bartholomew, 1572. It was indeed a stroke of luck on which he had not counted. Charles IX. and his advisers had not only rid the Catholic faith of some of its most dangerous foes, but had also brought on the French name an amount of odium which made it detestable throughout Europe, and whitewashed the cruel persecutions of Philip himself. He seems to havefelt from henceforth that France had incapacitated herself from troubling him, and had broken decisively and conclusively with Elizabeth. Accordingly he and Alva reconciled themselves with the Queen of England, and watched complacently to see what suicidal act the French would perpetrate next; not yet actively interfering, but ready to give a helping hand to any scheme that might destroy heresy or help the self-destruction of the house of Valois.

The new King hastened from Poland with unseemly hurry ; when he arrived in France he took matters much more easily. On 
September 5, three months after his brother's death, he met his mother, the King of Navarre, and the Duke of Alençon, whom she had released from confinement, at Pont Beauvoisin ; thence he proceeded to Lyons, and there, in council, determined, contrary to the advice of Maximilian and the Venetians, to prosecute the war against the Huguenots. Although this struggle seems as worthy of the name of a civil war as some of the others which preceded it, it is not numbered amongst them: partly, I suppose, because it had no great battle, or any defined beginning or ending. The government clearly was in a very helpless state : the Huguenots were in arms in the north and west and south, and Rochelle was the headquarters of a confederacy which could hardly be regarded as compatible with the health of a Catholic state. After a vain attempt to satisfy the malcontents in Languedoc, Henry went to Rheims and was crowned (February 1575), and immediately after married Louise of Vaudemont, to whom he was as faithful as the men of his family generally were to their wives.

The party of the Politiques as such had now discovered that their position was untenable. Francis of Alençon, seeing that line closed to him, declared himself on the side of the Huguenots. He was a prince of no principle, bad temper, and small capacity except for giving trouble; but he was heir to the throne, and chose to play the not uncommon rôle of heirs, the head of the opposition. Matters were in suspense, the Huguenots not moving except for defence, and the government not attacking. On September 15 Alençon fled from court to Dreux and was there joined by many of the nobles who were dissatisfied with the King or who favoured the Protestants. The King, as you probably all know, gave enough reason to everyone to find fault with him; his conduct and court were abominable and ignominiously licentious, and he had no principles except selfishness and bigotry.

At the same time the Prince of Conde brought into the country a body of German mercenaries whom he had hired, and prepared for war. Catherine averted the immediate outbreak by prevailing on the Duke of Montmorency, whom she released from the Bastile for the purpose, to negotiate an interview with Alençon, after which a truce for six months was made (November 22); but the truce lasted no longer than March. In that month John Casimir, the Palatine, arrived with 8,000 more Germans, and on hearing the news, Henry of Navarre made his escape from Court and declared himself a Calvinist. The Queen mother, seeing no chance of success in open war, now negotiated for peace. Alençon was bought over by the gift of Anjou, and henceforth bears the title. The Count Palatine was also to receive an endowment, and the edicts in favour of the Huguenots were to be confirmed for the fifth time (May 14, 1576). 
This pacification led directly to the formation of the League. The Guises and their adherents were intensely disgusted by it. The King, professedly the most Catholic of men, one of the contrivers of the St. Bartholomew massacre, had yielded the demands of the heretics without a blow. The League dates from the formation of a confederation at Péronne in consequence of this disgust. The Holy Union was immediately patronised, if not devised, by the Guises ; the King of Spain and the Pope were made protectors of it. Its purpose was declared to be the maintenance of the Catholic religion; its real object, probably even at this remote distance of time, was to keep the King of Navarre and the Prince of Condé out of the succession. The leaguers swear to grant to the provinces the rights they possessed in the time of Clovis; to proceed against all who refuse to accept the Union without acceptance of person, and to render faithful service and prompt obedience to a chief to be named.

The Huguenots, alarmed at the threatening proceeding, clamoured for the assembly of the States General. They met at Blois in November, with a result contrary to their hopes. The pacification was annulled, the League authorised, and the King made the head of it. War was determined on, and the Duke of Anjou, so lately the head of the Protestants, was nominated by the King to the command.

After some slight successes on the Duke's part, early in 1577, Queen Catherine again set to work to make peace. She took some of her young ladies to Nérac, the King of Navarre's seat, and seduced him into compliance. In October peace was made at Poictiers : the fifth war ended, and the sixth pacification was issued, not quite so favourable as the last, in consequence of the conquests of Anjou.

The history of 1578 is a record of court scandals. Towards the close of it, Anjou went off to the Netherlands, where we have traced his adventures already. In 1579, Queen Catherine took another journey to see Henry, and anything like an open war was avoided until the end of the year, when the Duke of Montmorency was ordered to demand of Henry some fresh guarantees, which he refused. Whether Henry was simply biding his time, or whether he really did fall a victim to the snares of Catherine and her young ladies, or whether he to a certain extent did both, enjoyed their society and waited for his opportunity, I dare not say; but from this point he became a changed man so far as war and business were concerned. He took the head of his party and welcomed the summons to war. $\mathrm{He}$ began by taking Cahors by surprise in May 1580, and the surprise extended through the whole of France. His promptness, bravery, and valour were at once conspicuous; the Huguenots had never had such a leader, and the Count was not. 
prepared to fight with him. Anjou was brought back from Brabant to pacify him.

The sixth war ended in November, against the wishes of Condé, who was under engagements with the Palatine and wanted to bring in a German force. This peace was favourable to the Protestants. I do not think it necessary to dwell on the details of these pacifications : besides the confirmation of toleration, in which they agree, they contain little more than arrangements as to the cautionary towns, the villes de sureté, or material guarantees left in the hands of each party, which arrangements differ according as fortune has favoured or frowned on the respective parties during the preceding campaign. From 1581 onwards, the Duke of Anjou was in the Netherlands; and thus one great hindrance to peace was removed. The Huguenots continued in a condition of uneasy watching; the Court, abandoned to scandals and penances alternately or in combination. So three years passed.

In 1584, the Duke of Anjou died (June 10), and the succession at once lay open to Henry of Navarre. The true object of the leaguers now was manifested. Henry must be set aside and a new candidate found. Ultimately, no doubt, the succession was to come to the Duke of Guise. Already the notion was being spread that the whole reign of the house of Hugh Capet was a long usurpation, and that the descendant of Charles the Great was the rightful sovereign. The Duke of Guise was such a descendant, although the directness of the descent might be questioned, as he was only a cadet of the house of Lorraine; but then primogeniture was not a main feature of the system of the Karlings. Still, until this could be arranged, a new candidate was found, the Cardinal of Bourbon, brother of King Antony of Navarre and uncle to King Henry. The Duke of Guise was declared chief of the League. Henry III. took the alarm. Catherine, whose powers of intrigue must now have been failing, leaned towards the Guise rather than to the Bourbon. The next year the Cardinal, having obtained the sanction of the Pope and Philip, pronounced himself heir presumptive (March 31, 1585) and published a programme of the reforms which he intended when he should be King. This drew together Henry III. and the King of Navarre. But the reconciliation was momentary. In July Henry III. pronounced against the Protestants again, and revoked all the edicts in their favour. And this rash act produced the eighth war : the war of the three Henries.

The year 1586 was occupied with constant skirmishes, conspiracies, and new combinations of parties. The principal combination was one called the League of the Sixteen, the sixteen 
quarters of Paris, composed of creatures of the Duke of Guise, and sworn to the destruction of Henry III.; but the conspiracy was betrayed and its execution prevented by the Duke of Epernon, one of the King's favourites. Its only result, and that not arrived at until the next year, was to throw Henry into the arms of the King of Navarre. In October the latter won a great victory at Coutras, in Guienne, over the Duke of Joyeuse; but the advantage was more than counterbalanced by the success of Guise against the German auxiliaries.

From the opening of 1588 events follow more rapidly. The King was only thirty-six years old, and it might have been thought that the Guises might have waited for some accident that would have simplified matters, or might have determined to turn their hostility against Henry of Navarre, who, indeed, was but two years younger than the King, and, like him, childless. But the immense popularity which the Duke of Guise had acquired in France, and especially in Paris, which by the conspiracy of the Sixteen was engaged altogether on the side of the League, seems to have inspired him and his family with the most ambitious designs and a rage for their early fulfilment. Although the war was still supposed to be proceeding, Henry of Navarre had returned to his mistress, and the Guises were devoting all their arts to make the King contemptible. His mind was kept in constant alarm by the threats of assassination; his feelings constantly outraged by the sermons, the pamphlets, the open insults of the leaguers. The Duchess of Montpensier, the Duke's sister, showed a pair of golden scissors with which she intended to clip the locks of the last of the Valois.

In February 1588 the heads of the League met at Nancy, and drew up a programme of eleven articles to be presented to the King. Amongst these was a demand for the reception in France of the decrees of Trent and the establishment of the Inquisition. This measure stung Henry III. into action. He forbade the Duke of Guise to come to Paris. Notwithstanding this, on May 9, he presented himself there, and the King began to tremble for his safety. An attempt made by him three days after to introduce a royalist force into the city produced an outbreak among the citizens which would, but for the presence of Guise, have ended in a general massacre. This was called the Day of the Barricades. The result was to throw the city at the feet of Guise, and to force Henry to flight. The next day, May 13, he retired from Paris to Chartres, and thence, without complying with the petitions of the Parisians for his return, to Rouen, where, on July 13, he made his peace with the League and issued a new edict of reunion which prohibited the succession of a Huguenot prince. 
Henry must have been driven very hard before he consented to this, for the King of Navarre's right of succession was to him an assurance of life : even the Sixteen would not assassinate him to put a Huguenot on the throne. But it is not clear that the edict was issued in ill faith. Henry was not wanting in cunning, but it is not likely that he had yet contemplated the coup de main which he executed in December: it is more probable that he was roused to extreme measures by the open contempt of Guise and the brutal threats of the Duke of Mayenne. He summoned the estates to Blois in September : the sittings continued until December; and on the 23rd of that month, Henry, by an organised conspiracy of forty-five bravos, assassinated the Duke of Guise and the Cardinal his brother, and imprisoned the Cardinal of Bourbon and other of the dangerous nobles.

There is little difficulty in apportioning the guilt of this proceeding. Guise deserved death as a traitor and revolutionist; Henry richly deserved all the evil that Guise had devised against him : the revolutionary scheme of the Duke was as unlawful as the assassination. Both were scoundrels: Guise a plausible one, Henry a pitiful one; Guise perished plausibly, Henry conspired pitifully.

The immediate consequence of the murder was to throw France into a frantic panic. The Duke was at once the favourite of the people and the defender of the Church. The people rose in arms, and the clergy preached excommunication and revolution. In the early days of this year (January 5, 1589), Catherine de Médicis died. Henry lost his most faithful counsellor in her: he had no army: the whole kingdom was against him, on the one side the League which he had failed to crush; on the other the Huguenots with whom he and the League were both at war. He preferred the lesser evil to the greater, and threw himself on the generosity of Henry of Navarre. The two Kings joined on April 30 at Tours (whither Henry had retired from Blois and summoned the Parliament of Paris), and marched together to besiege the capital.

In the meantime the leaguers had strengthened their position. They had lost their most popular chief, but the feelings that had exalted him to popularity still existed. The clergy of Paris had compelled the Parliament to swear to avenge the death of Guise. The oaths had been taken on compulsion, and by like compulsion the Sorbonne was made to approve the revolution. But the submission of the Parliament was not so prompt as to deceive the leaguers. On January 16, Bussy Leclerc, governor of the Bastille, arrested fifty members, with the president Achille de Harlai, a just and loyal man, at their head, and swore the remaining twenty-six to the League, on the crucifix. On February 10, the Duke of 
Mayenne arrived in Paris, and was declared lieutenant-general of the royal estate and crown of France.

Both parties were now ready for war, but the places which, without being for the League, had taken part with the King in the war against the Huguenots, now forsook him. In the north and east of France the League was all-powerful. Still the two kings advanced on Paris. On the 31st Henry took up his quarters at St. Cloud, on August 1 he was wounded with a poisoned dagger by Jacques Clément, and on the 2nd hedied. Of him, as of his brothers, little need be said beyond what comes out in their history : and the less the better. He was a clever, cruel, abandoned, handsome, pitiful creature ; the worst, perhaps, of his house, and, if so, the worst king of the worst family that ever reigned.

The death of Henry III. at once placed the kingdom in the condition of revolution. Henry IV. was with the army before Paris, and endeavoured to take advantage immediately of his position. $\mathrm{He}$ offered to swear to maintain the Catholic religion, and even to extend no further tolerance to the Protestants than had been secured by the edicts, so often changed, repealed, and re-enacted, of Henry III. The larger part of the nobles who were with the army readily acknowledged him : but the minions of the late King, the Duke of Epernon and others, refused and withdrew, reducing the army so much that Henry was unable to press the siege of Paris at once, and had to make a march into Normandy to join his English auxiliaries before he could renew it. The Duke of Mayenne hastened into the same province to meet him, but he was beaten at Arques, September 21. On Henry's return to the siege, however, in November, Mayenne was strong enough to embarrass him for the time, and he retired through a submissive country to Tours.

On November 21, Mayenne proclaimed, as King Charles X., the Cardinal of Bourbon, who was still a prisoner, as he had been since the assassination of Guise, and who spent the few remaining months of his life (until May 9, 1590) in the same captivity. He, poor man, had awakened from his dream of sovereignty, and acknowledged his nephew as King.

Early in 1590 the League was strengthened by the adhesion of the Papal legate, Cardinal Cajetan, who had been sent by Sixtus V. in the hope of converting Henry IV., but, contrary to his instructions, threw himself on to the party of Mayenne.

On March 14, Henry won the battle of Ivry and entirely demolished the army of the Duke of Mayenne, strengthened by auxiliaries from all the Catholic powers. In the night after this triumph he again (May 7) approached Paris and began a blockade. The Parisians themselves, embittered sufficiently to begin, were 
spirited to resistance by the Duchess of Montpensier, the Duke of Nemours, the legate, and the Spanish ambassador. The siege was not raised until August 30, when Henry had to go to meet the army of Alexander Farnese, which was advancing from the Netherlands. During these months the Parisians suffered the extremities of famine ; and terrible stories are told of cannibalism and other horrors. During this pressure and the ruin of the League which resulted from the defeat at Ivry the leaders were divided.

The death of the Cardinal of Bourbon threw the title to the crown again into dispute. Philip II. claimed it for his daughter Isabelle, the granddaughter of Henry II. The Duke of Lorraine claimed it for his son. The natural desire of the French Leaguers was for the young Duke of Guise, for whom a title might be contrived by a marriage with the Infanta Isabelle. This roused the jealousy of the Duke of Mayenne, who regarded himself as the elected chief of the kingdom and as the successor, so far as the League was concerned, to the merits and claims of his elder brother. The matter could not be decided whilst all parties were in arms.

Alexander of Parma, having relieved Paris, retired without a battle, harassed in the rear by Henry. In the south of France Lesdiguières cleared away the Duke of Savoy and his pretensions and took Grenoble. So the year 1590 ended; the affairs of Henry continuing to prosper, but neither party having yet a decided preponderance over the other. The struggle continued through the winter. In January Henry attempted to surprise Paris and the Lorrainers to surprise St. Denis, both in vain. A declaration of Gregory XIV. in March against Henry IV. was received with indignation in France, and helped rather to increase the dissensions in the League.

A new plan was now projected. The young Cardinal of Bourbon, brother to the Prince of Condé who died in 1587, was pitched on for a candidate. The Duke of Guise was the candidate of the Sixteen, deserting the interests of the Duke of Mayenne, who was conducting the struggle in the provinces. With this view they wrote to Philip II. proposing the marriage between the Duke and Isabelle; chance threw the letter into the hands of Henry IV., who very prudently transmitted it to Mayenne and roused him to action against the tyranny of the Sixteen. The King, without wasting his forces, awaited his time, sure that the conflicting views of the leaguers must tell in his favour, and in the meantime securing the places, such as Chartres and Rouen, on which Paris depended for provisions, and preparing for another siege.

In December 1591 the Duke of Mayenne returned to the capital, dismissed Bussy Le Clerc from the government of the Bastille, and 
hanged three of the leaders of the Sixteen. This, and the prompt action of the Parliament to restore order, had the effect of placing Paris, internally at least, in security for a time.

The events of the next year, 1592, were not favourable to Henry, and it is marked with no great success. He had not succeeded in taking Rouen, which the Marshal Biron besieged on November 11 in the preceding year. The siege continued until April 30, when the Duke of Parma compelled the King to retire. In the summer Henry took Epernay, but lost his great soldier, the Marshal Biron. $\mathrm{He}$ gained nothing but the glory of gallant exploits. The leaguers made head again in the south, in Languedoc especially, under the Joyeuses, the old favourites of Henry III., matched against Lesdiguières, the governor of Dauphiné. Both parties were exhausted, however, in the centres of life; neither being strong enough to procure or enforce supplies: England only slowly remitting money and men to Henry, and Philip fighting rather in his own interest than on behalf of the League. The Duke of Mayenne, aware of this, determined to put an end to the dissensions of the League, and summoned the States General to Paris on January 5, 1593, for the election of a king. They met on the 26th, and had a long sitting. Instead of strengthening the League, this assembly proved to be a long step towards the break-up. The Duke of Mayenne was finally disappointed.

The Duke of Feria, the Spanish ambassador, on April 2, demanded the abolition of the Salic law, and the crown of France for the Infanta ; and, although the proposal was received with a storm of indignation, Mayenne saw that his game was lost. He prevailed on the States to parley with the King. Several conferences took place between April 29 and May 17 : the representative of Henry being the Archbishop of Bourges, that of the League the Archbishop of Paris : on the conclusion of these Henry declared himself a Roman Catholic. Had he only the League to contend with, this event might have finished the war ; but the Spaniards, who wanted the crown for their Infanta, and to whom Henry as a Catholic was only a more formidable enemy than he had been as a Protestant, drew great part of the nobles of the League into continued hostility. They now proposed the marriage of the Duke of Guise with the Princess, the old plan of the Sixteen; and prevented a reconciliation between the King and Mayenne.

But whilst they were deliberating Henry was acting; and, what was quite as important, a reaction was setting in in Paris, now relieved from the tyranny of the Sixteen. Henry, on June 18, took Dreux, and so prevented the arrival of provisions at Paris from the side of Normandy. On July 23, he made a solemn recantation of 
all his heresies at St. Denis, great numbers of the Parisians attending on the occasion. Paris still held out, but the efforts of the leaguers were becoming spasmodic and disorganised. The land was thoroughly weary of war; city after city deserted the leaguers' party, and the foreign allies showed clearly that their own interest stood first with them. The war was still continued, however, with some vigour in Languedoc and Brittany.

Matters being thus, Henry determined to wait no longer for his coronation. On February 27, 1594, the ceremony took place at Chartres : the policy of this was soon apparent. Within a month Paris (March 22) received him as King; Rouen followed within a week; and shortly after the Duke of Guise submitted. The Parliament of Paris was recalled from Tours and reinstated: the clergy repented of the attitude they had taken towards Henry; and the University, freed from the fears of the Sixteen, declared its real sentiments. The Jesuits, the only religious body which refused to acknowledge the King, were compelled by a decree of the Parliament to quit Paris; Henry saw himself at last in undisputed possession of his hardly earned royalty, although frequent attempts at assassination showed him that the spirit which the League had conjured up was not yet exorcised.

Two difficulties, however, were yet in store for him : the hostility of Spain and the financial difficulties which he had to encounter as soon as the restoration of peace should make the payment of his debts and those of the State incumbent on him. These, sufficiently great already, were largely increased by the measures which procured his last successes. $\mathrm{He}$ had expended vast sums or vast promises in order to obtain the adhesion of the cities which had favoured the League: Paris itself had been, as he said, sold rather than surrendered to him. The rewards of successful intriguers and reconciled enemies came to an enormous sum, for the payment of which he had to look to a country desolated by war and exhausted by long misgovernment. Fortunately, in the year of the surrender of Paris, $\mathrm{D}^{\prime} \mathrm{O}$, the intendant of the finances, who had been a great rascal, died, and Henry was able to take counsel with Rosny, his great minister, whom I shall call henceforth by his better-known name of Sully, for the restoration of the public confidence. This, however, did not begin immediately. Nor was it until 1601 that the real reform commenced; but Sully had it ever in view, and only waited the restoration of peace to bring matters round. During these five years, unfortunately, extravagance and embezzlement, and consequently oppressive taxation, continued to be the order of the day. The war with Spain continued four years after the surrender of Paris. 
Nothing can, I think, show more clearly the exhausted condition of France than the present state of affairs. Henry was in peaceable possession of the central provinces, and the cities almost everywhere had joined him. But the authority of the leaders of the League was by no means extinct. The Duke of Mayenne was strong in Burgundy, of which he had been, and perhaps was still, the governor; and in Brittany the Duke of Mercœur, ambitious of becoming an independent prince, was still, by hook or by crook, bent on carrying out the plan, the hopes of whose success had first attached him to the League.

With Spain the relations of Henry were curious enough. As King of France he was not at war ; as King of Navarre and enemy of the League he was in irreconcilable contention. Philip had no idea of peace; he gathered into one organisation the relics of the League, and tried to revive the hopes of Mayenne. Henry at last, tired of intrigue and pretence at negotiation, declared war against Spain on February 17, 1595. The seat of the war was Burgundy. Philip perhaps had some idea of re-opening the old claims of his family; on that side, moreover, the opening was ready for him through Franche-Comté: in Burgundy, too, the Duke of Mayenne was strong. Against Mayenne himself Henry sent Charles de Biron, the young Marshal, who came to grief a few years afterwards ; against the Spanish general Valesco, the Constable of Castile, he entered the field himself. He won a victory at Fontaine Française with a very small force, and was enabled to traverse Burgundy entirely, bringing the whole province into allegiance. $\mathrm{He}$ then moved on to Lyons, where also he was received with joy. But these advantages were counterbalanced by the success of the Spanish general, Fuentes, on the Flemish border, where he took several important posts and perpetrated great ravages.

On September 17, 1595, Henry completed his reconciliation with the Church by receiving absolution from the Pope: immediately after he granted the Duke of Mayenne a truce for three months, which was followed in January 1596 by a peace or reconciliation. Henry generously took on himself the enormous load of debt under which the Duke was crushed, and exacted no other revenge from him than by taking him a very long quick walk which reduced the unhappy prince, who was very fat and short-winded, to a state of dissolution.

Even this did not produce a complete pacification. It was not until February 1596 that the King got hold of Marseilles : the Duke of Epernon maintained Provence in hostility, and the Duke of Mercœur held out still in Brittany. Henry did not, moreover, gain any signal advantage over the Spaniards, who went on taking town 
after town in Picardy. The fall of Calais in April and of Ardres in May 1596 was followed but not remedied by the recovery of La Fère. But in the following year Amiens was taken on March 11. At last Henry roused himself to action. ' $I$ have been playing the King of France long enough ; now it is time to act King of Navarre.' He marched forthwith into Picardy, and besieged Amiens. It did not yield, however, until after six months' siege, when Biron took it on September 25.

From this moment Henry's fortunes prospered. He found the Duke of Mayenne faithful : he was able to negotiate for peace with Philip II. One by one the elements of difficulty and disorder were got rid of. The Duke of Savoy, whose constant attempts on the eastern provinces were irritating if not dangerous, was thoroughly humiliated by Lesdiguières. In February 1598 the King saw himself at last at liberty to go into Brittany to bring the Duke of Mercœur to his senses. On Henry's approach the Duke prepared for submission : he offered his daughter and heiress as wife to Henry's elder son by Gabrielle of Estrées, and resigned the government of Brittany, taking his departure to Hungary to fight against the Turks. In this submission the whole machinery of the League came to an end. Mercœur, although only a leaguer for his own purposes, had encouraged and fostered every remaining spark of disaffection, and in his fall the League was finally extinguished.

After holding the estates of Brittany at Rennes, Henry proceeded to Nantes, where he issued his famous Edict in favour of the Huguenots on April 13,1598. The Edict of Nantes not only confirmed all the edicts of toleration issued by the former kings, but granted to the Protestants free admission to all places of trust, honour, and profit; the establishing of Chambers in the cities in which the Catholics and Protestants should be in equal numbers, and the opening of the Universities to Protestant as well as Catholic.

The treaty of Vervins, which was signed the next month, put an end to the war with Philip without any sacrifice of the territory or honour of France. The county of Charolais was secured to the King of Spain, but under the suzerainty of France; all the acquisitions made by the successive governors of the Netherlands in the north of France were surrendered to Henry. Philip's claim to the crown and to the duchy of Brittany collapsed at the same time, although his rights as well as those of Henry to Spanish Navarre were formally reserved. The county of Charolais remained in the hands of his posterity until it was seized by Lewis, Prince of Condé, for the debt due to him by Philip IV. The French historians represent the peace of Vervins as the first great blow at the power of the house of Hapsburg. It is perhaps the first peace in which they had resigned 
every advantage and come off content with the fact of the peace itself, and it was a blow inasmuch as it set France at liberty to prepare for a struggle in which the two old enemies would be more fairly matched. But it was in itself no real disparagement. The truer version of the matter seems to be that by the marriage of his daughter Isabella to the Archduke Albert, and by the resignation in their favour of all the remains of the Burgundian inheritance in the Netherlands, Burgundy, and Franche-Comté, Philip seemed to be consenting to the dismemberment of his patrimony. It was, indeed, more in semblance than in reality, as the divided estates fell again to Spain on the death of the Archduchess in 1633 ; but this was no part of the treaty of Vervins.

\section{LECTURE IX}

\section{HENRY IV.'S PLACE IN THE HISTORY OF EUROPE}

THE reign of Henry IV. may be divided into three portions : the first, his struggle for the crown against the efforts of the League, which may be regarded as practically terminated by his conforming to the Roman Church in 1593 ; the second, the period of the Spanish War and of the difficulties with the remainder of the influences that had been the strength of the League, which may be regarded as ending at the peace of Vervins in 1598; the third, the portion during which he was able to consolidate his power, to restore the exhausted finances of his kingdom, to carry out his scheme of religious toleration, and to develop his political views. This reaches to the time of his death, when he was busily preparing to throw Europe into a general war of religion which would have antedated the Thirty Years' War and might have altered the whole complexion of the history of Christendom from that day downwards. Two of these periods we have already considered so far as the chronological sequence of their political history is concerned. I propose in this lecture to sketch first my idea of the character of Henry IV., then to take the remainder of his reign, and then very briefly to touch on the history of France from the death of Henry to the close of the period that we have set ourselves.

Henry IV. is, or was before the Revolution, a national hero: he was a thorough Frenchman, with the good and bad qualities of the race well developed; he was a Frenchman of the old régime, without the debasement and ensavagement that successive struggles of blood and glory have produced in the Frenchman of the ordinary type of to-day. 
Taking the disagreeable parts of the character first, we must allow that there was a want of fixed principle in him: he was not the man to be the martyr of any cause, and, like the statesman of the present day, he had not the slightest difficulty in training his conscience to believe that the course most expedient for him at the moment was the one which his higher nature recommended to him, which the development of his own views showed him to be the right, nay, which, under a different form, was the course which he had always intended to hold. Whilst such a form of character is, as we shall, I think, all allow, one that is incapable of the highest sort of greatness, in which self-sacrifice is so large an element, it cannot be denied that for a king it is not by any means the lowest type; that, setting aside the moral condition of him who has it, it involves many very decided advantages to the nation that he governs and is not unfrequently found in connexion with a genuine love of the people and a purpose, mainly honest, of working for their good. Still it is a lack of principle, and as such a fault. Henry most certainly had it.

A second most serious fault was his relations with women, his utter incapacity for restraining his passions in that direction. This is a difficult subject to say much about, but it is as well that something should be said, and the thing done with. Henry IV. was not the slave of passion, but he was a thorough-going seeker of pleasure, to the destruction of his own honour, the disgrace of his court, and the misery of the objects of his pursuit; and, moreover, to the danger and loss of his own serious interests. I do not mean to say that when he saw his passions leading him into serious difficulties he could not restrain himself; but that his passions blinded him until he had got into those difficulties, and also as to the nature of the means by which he extricated himself. Now, it may seem hard to mention this against Henry IV., as a fault, a prince living in an age and country of licence practically unbridled, and in that royal position which is often regarded as an excuse for this special sort of wickedness. I do not suppose that he was in this respect worse than Francis I., or so bad as Henry III. wished himself to appear: certainly he was not like August the Strong, the father of 392 children. But these princes, even Francis I., did not let their vices interfere with their public interests : more at least than was common, when the king's mistress was almost a minister of state, and his lawful wife a nonentity. Henry IV. did let them so interfere, and puts himself, therefore, out of the region of such excuses. And unfortunately it must be added that the vices grew upon him as he grew old, and were in their full strength at the time of his assassination: so that he cannot claim the excuse of youth, if there be any truth in such an excuse. 
Of course, the original corrupting of his mind and morals is ascribed to Catherine de Médicis : and it is possible that the charge is a true one. But it is more likely that the poisoned atmosphere in which he lived after the death of his mother, his forced inactivity and want of employment, laid him open to temptation, and that Catherine, seeing the weak side of him, took care that temptation should not be wanting to sins which might render him unpopular, or indolent, or incapable of becoming a rival to her wretched offspring. The ladies of her court were skilled instruments of temptation : even those of the highest rank and birth, her own daughter first, were at once trained to the practice of vice, and educated in the art of political intrigue. With them she entangled, and manœuvred, and kept espionage, and made a captive of a very noble prey.

Such and so great were Henry's faults, and I do not apologise for introducing his morality into a lecture on political history, because unfortunately they are a part of his political history. $\mathrm{He}$ was not, as the remoter Bourbons, ruled by his mistresses; but he let the pursuit of pleasure draw him away from his regal duties, keep him the quiet captive of Catherine de Médicis when he should have been her watchful enemy, and down to the end of his life turn those into enemies who should have been his closest friends: he was worse and more foolish far in this way than his grandson Charles II., who in many respects strikingly resembles him, but whose lot fell on widely different days, different regions, and ways of men. Now for his good points. $\mathrm{He}$ had a true love of his people and a clear perception of all their best interests. To them he was a good king: the only good king since St. Louis. Good he might easily be in comparison with the race of Valois ; but it was more than comparatively good: he had the will and the power to see and determination to carry out what was good for the nation. The eleven years of his reign, 1598 to 1609 , mainly years of peace, were also a period of very hard work, and very good and sound work, of reform in every department. No doubt a great deal of the good of the reign is attributable to Sully. To him in most cases belonged the origination, and in very many cases the carrying out, of the reforms. But Henry was an active king and a clear-headed man; he has the merit of seeing without jealousy, and of carrying out with perseverance, the plans of his great minister. He found France in an abyss of misery and he left her capable of becoming what she became, for good or for evil, under Louis XIV., the arbiter of the whole of Europe; inclined, perhaps, to be the tyrant : but, even in his perversion and misapprehension of the real interests of Christendom, distinctly strong and great.

As a warrior, Henry, although inferior, doubtless, to Spinola and 
Maurice, and even to some of his own generals in the military art, was a very able strategist, a brilliant soldier, and a brave man. If we look at him as a politician, it is not quite so easy to estimate him, because there is doubt as to the originality of the plan attributed to him by Sully, or even of its real agreement with his actual designs. The idea of reducing European Christendom to a confederation of states, graduated and combined so as to prevent quarrels and to secure substantial justice by arbitration without recourse to war-of balancing Catholic against Protestant, German against French and Italian, and remodelling the map of Europe in accordance with an elaborate scheme of his own devising-may safely be dismissed as being either an imagination of his biographer, or more probably a fancy sketch that he may have talked over with him as a thing to be desired, but never to be compassed : it contains, indeed, no element of feasibility.

The scheme was to have fifteen great states : the Empire, France, Spain, Hungary, Great Britain, Lombardy, Bohemia, Poland, Sweden, Denmark, Venice, the Pope, Switzerland, the United Provinces, and the Italian commonwealth. To produce equality, Bavaria was to have the Empire; the Pope, Naples ; the Venetians, Sicily ; the Duke of Savoy, Milan with the title of King of Lombardy; the whole Netherlands were to be united; Franche-Comte, Alsace, and Trent to be given to the Swiss. These states were to elect a sort of confederate senate to decide international quarrels, and to join in the great design for extinguishing the Turks.

When I say that the plan had no element of feasibility I think I am justified by the course of events. Nearly three hundred years have passed away since it was broached and no approach has yet been made to it. The Duke of Savoy has indeed got Lombardy and much else. The experiment of uniting the whole Netherlands has failed signally. The house of Bavaria has attempted the Empire and failed to hold it. Bohemia has tried to set up as an independent state and failed. Hungary has found it impossible to subsist as a separate kingdom. Venice and Poland have ceased to exist as states, the Pope very nearly so. Two new powers not even mentioned in the scheme, Prussia and Russia, have overshadowed all Europe. Yet the times may still change and the Slav movement may yet give a separate existence to Bohemia, create an independent and a nonMagyar Hungary on the Adriatic.

Viewed, however, as a scheme for the dismemberment of the house of Austria, the creating an alliance of all the states of Europe against her, and rewarding the confederacy out of the plunder ; the grand project, whilst it loses its ideal beauty, loses also somewhat of its utopian character. Henry may have credited himself with ability 
to unite the European states against that house and manage the union; nor would he perhaps have had much difficulty in confederating a large majority of them; neither would the probability of failure strike him as a certainty. We who have seen the wonderful fight made by Austria in the last three centuries-especially in the struggle of Maria Theresa in the eighteenth, and that of Francis II. against Napoleon in the nineteenth-may affirm certainly that the toughness and vitality of the system, awkward and disjointed as it is, would have been proof against any confederation that Henry could have managed. That the destruction of the power of the Hapsburgs was really his great political object we cannot doubt : but I think we may very well doubt whether the ideal project was not quite subordinate in the King's mind to the desire of settling once for all the old rivalry between France and the Hapsburgs.

We all know how different a man's ideal aspirations are from his real objects in this life. We cannot afford to take a higher view of Henry IV. His genius may have imagined a plan of confederated Christendom as a speculation; but we know that the word 'speculation' has two meanings, and that the element of imagination enters into every dream of ambition. It would not be natural for a Frenchman to contemplate a war that was not for the benefit of France. Whether, if Henry had lived and succeeded in his plans for the humiliation of Austria, it would have been for the benefit of Europe, I cannot say; but from the fact that French ambition has brought infinitely more misery on Europe than all the repressive policy of Austria in all the years of her influence, I should argue that it was not; and I infer from the whole consideration that neither the grand project nor the instalment of it which he set himself in his last years to realise bears the mark of political genius. The former has not the feasibility that the true designs of genius surely must possess; it is not justified by the future, which it is the privilege of true genius to penetrate. The latter cannot, on the mere assertion of its planner, be judged of as actuated by higher motives, or likely to be justified by better results, than have prompted and followed the many attacks of France on Austria before and since.

To my mind, then, the Edict of Nantes and the administrative reforms by which Henry IV. laid the foundations of government in France anew are much greater proofs of genius, and much worthier as speaking of his true love and clear sight of the good of his people, than the entering on a general war that must have deluged Europe in blood, the coming of which he might have foreseen, but should have tried to avert and not to hasten. His death saved him from a great sin and averted from Europe a very great calamity.

Compare Henry IV. with the only sovereigns of the age capable of 
the comparison : Philip II., Elizabeth, and William of Orange. I place him above Philip, on a par with Elizabeth, and far below William the Silent. Both as a king and as a man, he comes below Maximilian in power and beauty, but far higher in actual work, and in the impression, and the character of the impression, he left on the world.

We must now turn to the history of 1598 to 1609. The Edict of Nantes was published in April, and the peace of Vervins on May 2 1598. On September 13, Philip died. The first event secured to Henry the affection of the Protestants, which had been endangered by his conversion; the second dispelled the Catholics' hopes of substituting another candidate on the throne with the aid of Spain; the last secured to Henry a relief from the pertinacious hostility of Philip, who, although recognising him as king, would not be likely, should the opportunity offer, to treat him any better for that reason. Becoming King of France, he took on him all the burden of Spanish and Austrian rivalry. It is characteristic that the first moments of peace should be devoted to the settlement of his love affairs. He had long wanted a divorce from his precious wife, Margaret of Valois, which she had resisted, fearing that he would marry his mistress and the mother of his children, Gabrielle d'Estrées, Duchess of Beaufort. In the year 1599, April 9, Gabrielle died; Margaret consented to the divorce, and it was completed in December. But, within three weeks after the Duchess's death, Henry had promised marriage to Mademoiselle d'Entragues. Sully tore up the contract which the King had signed: he signed another. His advisers saw the only thing to do was to get him a new wife; a marriage was negotiated for him, more quickly than he at all liked, with Marie de Médicis, daughter of Francis, Duke of Florence, and completed in December 1600. We may add that Margaret of Valois retained the title of Queen after her divorce; lived a perhaps much better life; and continued on much better terms with Henry than she had been on with him as her husband. She was a very brilliant and beautiful woman, the flower in every way of Catherine's family, but she was early initiated into the very inmost circles of vice. For her sins, if not for Henry's, Catherine is distinctly accountable.

A more memorable note of $\mathbf{1 5 9 9}$ is Sully's reform in the finance. $\mathrm{He}$ remitted the arrears of taxation, twenty millions of francs, as irrecoverable, and began on a new tack. He insisted on the King taking a personal cognisance of the management of the revenue; adopted a more economical method of collecting the taxes, reduced expenditure as much as possible, paid all the debts of the crown, and in imposing taxes did it with careful regard to the interests of commerce and the satisfaction of the payers.

The war of 1599 was with the Duke of Savoy, who had refused 
to surrender the marquisate of Saluces, which he had seized in the time of peace in the reign of Henry III. Henry in this war took from the Duke Bresse and other little territories, which by the peace of Lyons in 1601 he retained, leaving the disputed marquisate to the Duke. The following year (1602) we come to a crisis unexpected indeed : the conspiracy of the Marshal de Biron, one of Henry's ablest generals, who had conducted for him the war of Savoy. Sully had long suspected his ambition and tried by varied employment to keep him out of mischief. But Biron's influence and vanity were increased by the constant occupation of an ambassador. He became one of the most popular men in Europe, and it was consequently an object of distinct policy in the powers who hated Henry to win Biron to their designs.

Henry chose to ascribe Biron's vagaries to his vanity, and would not believe that so vain a man could be treacherous or dangerous. And had Biron been alone it might have been the safest policy. Had Henry been strong in the affections of his subjects, he might have defied the conspiracies of Spain and Savoy. But this was not so. The reforms that Sully initiated were only in their beginnings; the momentary hardships were felt, the lasting relief was a matter. of the future. Henry's extravagance, especially his habit of gambling, made him always poor; his unbridled lust alienated from him every honest noble who had a wife or a daughter whom he might covet. The new Queen, with her Italian retinue, was unpopular among the French, and her relations with her husband, such a man as he was, were not likely to make him respectable. The result was that in 1602 there was certainly a great mass of discontent and uneasiness in every class of society. This made the King suspicious and excitable. He knew not whom to trust, and he was possessed of little self-control : his most faithful advisers were alienated from him, and the newly roused suspicion could not distinguish between coldness and treachery.

There is no reason to doubt that the conspiracy of which the Marshal de Biron was the head and the victim, was very widely spread, and included some persons of the greatest rank and importance. Outside France it was supported by Spain and Savoy, the object of those powers being the actual division of Henry's dominions among themselves; Biron being promised the duchy of Burgundy as his reward. Of the details of the conspiracy, or the way in which it reached the ears of Henry, our information is not clear. It was, however, discovered. Biron was put to death. The Count of Auvergne, the natural son of Charles X., was pardoned at the entreaty of his half-sister, Madame d'Entragues. The Baron de Lux, the confidential friend of Biron, after the Marshal's death, 
laid before Henry the plan of the conspiracy and the names of the malcontents. These were too many and too powerful for Sully even to commit to paper; Henry's only policy was mercy and precaution. From this time he was more careful whom he trusted, and his hatred of Spain and of the whole house of Hapsburg became inveterate, their humiliation the great object of his life.

The year 1603 was that of Elizabeth's death; it is marked in French history as the year of the recall of the Jesuits, who, recovering their tenure of power through the influence of the King's confessor, never relaxed their hold on France to the time of their suppression in France in the year 1764. The accession of James $I$. afforded an opportunity for drawing closer the ties between the two rival nations : the old connexion of France with Scotland, and the new one with England on the ground of support to the Protestant interest in Europe, combined into a close alliance for the time. The two powers bound themselves to help the Netherlands against Spain: Henry being at peace, and James hastening in the following year to make peace with the common enemy.

The King's debts in $\mathbf{1 6 0 3}$ amounted to $\mathbf{3 3 0}$ millions of francs, on which all the financial reforms of Sully had as yet produced very little impression. In the year 1604 the embers left by the conspiracy of 1602 broke out again; again the King's love affairs complicate matters. The Count of Auvergne, pardoned in the former year, became the spy and tool of Spain. His half-sister of whom the King had grown weary, and whose claims he had bought off by appointing her father Marshal of France, entered into the plot. It was conducted, according to Hénault, by the father Archange, a bastard of Queen Margaret's and confessor to the discarded mistress : a detail which, if true, is extremely curious. Henry was not extreme in his dealings with the conspirators: Auvergne was imprisoned for life, the lady sent to a convent.

With this private outbreak are connected the difficulties with the Duke of Bouillon, who had been deeply involved in the Biron conspiracy, and the situation of whose territories made him a very convenient tool both to the Spaniards and to the Germans. He was, however, a Protestant and one of the leaders of the party. His discontent was owing rather to Henry's treatment of his old friends than to any complicity with Spain; and his object is said to have been the establishment of a Protestant republic in the south of France, on the plan of the United Provinces. But this is very conjectural ; it is more probable that he represented one distinct line of discontent, out of the many which combined in Biron's hands. In 1603 he had fled to Heidelberg, although pardoned by Henry; in 1604 he was pardoned at the instance of the Elector 
Palatine, and henceforth Henry kept him employed under his own eye.

In 1607 Henry united all his patrimonial estates with the crown. In 1608 he made an alliance, offensive and defensive, with Holland : in 1609 he helped the negotiation of the truce between Spain and the United Provinces. The rest of the history of these years comprises little else than a record of court scandals ; of administrative reforms ; and repeated conspiracies formed on a small scale against Henry, whose life was attempted seventeen times before he was assassinated. During this time, however, there is no reason to suppose that Henry neglected the great object for which he was working at the time of his death : preparing to isolate the house of Austria, by entering into close alliances with all her neighbours, and then, by a sudden and general war, to demolish her altogether.

The greatest of the scandals is perhaps that of the Princess of Condé, a lady of the house of Montmorency, whose marriage the King delayed until he was obliged to suffer it, and in pursuit of whom he drove her husband to carry her off into the Netherlands. The story is a common subject for magazine articles. It is one of the most damaging of all to Henry's character. It took place in 1609.

In 1610 Henry's military preparations were completed, and the conduct of the Emperor in the matter of the succession to the duchies of Cleves and Juliers gave him the opportunity he had been waiting for. The character of the opportunity belongs to the history of Germany, nor does it enter into French history at this time further. But Henry's preparations were noteworthy. $\mathrm{He}$ had ended his long enmity with the Duke of Savoy by the treaty of Brussol, April 25, 1610. By this he bound himself to conquer the duchy of Milan for the Duke, on the understanding that Savoy should be united to France: a curious anticipation, certainly, of the arrangement which resulted in our own day from the alliance of Victor Emmanuel and Lewis Napoleon against Austria in 1859. In February 1610 he made an agreement with the Count Palatine and the Elector of Brandenburg for the preservation of the succession of Cleves and Juliers. He had established the closest relations with England, and in Italy he was not without a strong party. His army was on the same scale with his alliances. His own army numbered 40,000 veterans, besides 6,000 Swiss and a body of 4,000 nobles. The treasure amassed for the war was $40,000,000$ francs. But the army of the whole confederation was expected to be not less than 300,000 infantry and 50,000 horse; the fleet, 120 vessels of war. The details are less known because of the collapse of the whole design almost before it was completed : but the first step was taken; the Archduke was asked for leave to cross his territory into the disputed 
duchies, and the leave could not be refused. Henry's army was to meet at Châlons in the middle of May. The Queen, Marie de Médicis, was to be crowned on the 13th, and directly after she was to be made regent, and Henry was to take the head of his forces.

On the day after the coronation Henry was stabbed in his coach by Francis Ravaillac. Who prompted the assassin was never known ; not is his history sufficiently clear to allow us to theorise. The guilt was variously laid to the Jesuits, to the Spanish court, to the family of d'Entragues; to his wife, Marie de Médicis, to the insanity or bigotry of Ravaillac himself. In support of the several theories it was said that Ravaillac had been lately at Brussels ; that he had two sons Jesuits; that he had been a servant in the family of the Marshal d'Entragues. The Duke of Bouillon in 1636 declared to Sir Robert Sidney, the English ambassador, his belief that the court of Spain was guiltless ; but he would not commit himself to any distinct supposition as to the real criminal. Sidney, therefore, suspected a collusion between the Queen and the Jesuits. Bouillon's acquittal of the Spaniards is more important than Sidney's suspicion of the Queen, for he was one of the judges who examined Ravaillac on the rack.

The repeated declarations of the assassin that the King was a heretic and extra ecclesiam, one who might therefore lawfully be killed, struck the Duke as singular and important; but nothing approaching a confession was extracted from him, and perhaps the most reasonable account is that he was a mad fanatic. The passion for assassination, as we know from the attempts made on the life of Queen Victoria, is infectious : seventeen attempts, as I said before, had been made on Henry IV.'s. The doctrine of the merit was a relic easily picked up of the days of the League and of the massacre of St. Bartholomew. Mysterious the matter can scarcely be called when it is capable of such a solution. It is in its political aspect a curious example of the way in which the house of Austria has been able to take advantage of her luck. The death of Henry, of which there is no ground whatever for accusing the Hapsburgs, was the luckiest thing that could have happened to them. Henry was prepared to strike a blow which could hardly have failed to paralyse Spain, and to wrest the Empire out of the hands of the Austrian family, if not to abolish it altogether.

Thus the great project of. Henry IV. perished in embryo: did not even reach the point of development at which it would be safe to define it. If it were really what Sully makes it and what I have described it, it was a utopian scheme; not impracticable, perhaps, but so far off practicability immediately that he who seriously entertained it can be regarded as little better than a visionary. 
Henry IV. may have been long-sighted enough to believe that what he saw in the distance of three centuries was near and within his grasp; to make him so, however, is not to exalt his genius. That he intended to humiliate Austria is clear : that he wished to establish religious freedom is possible, though, considering his relations with the Jesuits, less probable. What is certain is that by Ravaillac's blow all that he contemplated, and much else that might have been, and would have been far more for the good of France, came to an end. His successors were not able to maintain his policy; they sought for new alliances, and broke up at once the confederation he had formed : they employed new ministers, and threw into confusion the schemes over which he and Sully had watched so carefully. Still Henry had not reigned in vain ; and the light of his policy, after a long eclipse, was revived to make his descendant illustrious in the world's fashion.

Into the history of the next reign I do not propose to go further than to indicate the attitude that France, under her altered régime, was preparing to take in the general war that was at hand. The confusion and misgovernment of the early years of Lewis XIII. show that his father's difficulties must have been very great; and that it took a very strong man to hold down the conflicting parties which, all alike without principle and covetous of gain, were struggling for power. The regency was claimed immediately on her husband's death by Queen Mary; and for seven years she ruled France, in a way, through her chief minister, the Marshal d'Ancre, an Italian named Concini. The very fact of her regency gave offence to the Condés and the Protestant party who followed them. Her employment of an Italian minister and foreign servants offended the nobility of France, who were jealous in the extreme: she combined against herself both the parties which, without a common enemy, had been used to prey upon one another. By trying to humour these she lost instead of gaining strength; and her attempts to support her government by foreign alliances gave constant alarm to one or other. From the first she was obliged to give up any attempt to carry out Henry's scheme against Austria, and to get rid of the obligations he had entered into with the Duke of Savoy in the treaty of Brussol. In the next place, she must look for allies in Spain and throw over those whom Henry had made in Germany. But one act of his policy was carried out : a considerable force was sent into Juliers to assist the Duke of Neuburg and the Elector of Brandenburg.

In 1611 the Duke of Sully retired from the administration of finance, and the last remains of Henry's political system were obliterated. In 1612 the alliance with Spain was confirmed by a 
double marriage, Anne of Austria to Lewis XIII., Isabella of France to the Infante of Spain, afterwards Philip IV. In 1613 the intrigues and cabals of the princes began overtly to work. In 1614 Conde, the Duke of Vendôme, Henry IV.'s eldest illegitimate son, his brother the Grand Prior Alexander, the young Duke of Mayenne, the Dukes of Guise, Longueville, Rohan, Luxemburg, and others, at the instigation of the Duke of Bouillon, retired from the court, in disgust, as they said, at the Italian ministry. This secession very nearly assumed the dimensions of a civil war; and was actually terminated by a formal treaty of peace at St. Ménehould, ${ }^{1}$ the result of which was the King's declaring himself of age, and the summoning of the States General for the last time. No important business was transacted, although much was mooted. The next year, 1615, Condé again headed the malcontents ; demanded high office and was refused; then turned his indignation on the Concinis. Again the quarrel was healed by a formal peace, and again the peace (of Loudun) was ineffective. But the constant attacks on his mother's favourites ended in drawing the King into opposition.

The Queen, in 1616, had arrested and imprisoned Condé; the other princes left court and prepared for rebellion. The opening of the war was favourable to the court, but it came abruptly to an end in the fall of the Marshal d'Ancre, who was killed in attempting to resist Vitri, whom the King had sent to arrest him. He had been won to join in a conspiracy against his own prime minister by de Luynes, his own favourite, who became prime minister in Concini's place.

With her minister Marie de Médicis's power fell. Concini first, and after him de Luynes, both unprincipled men, governed France on the plan which Richelieu carried out to the full in the later years: the humiliation of the nobility and the protection of the Catholics. Condé was released in 1619 ; but the repressive policy pursued towards the Protestant party was gradually producing a feeling that was to end in war. In all these struggles and intrigues the only thing to note is general demoralisation; there were no great principles at stake; it was simply a struggle for power, money, and revenge. France was divided between the Queen and the princes. The King was incapable of anything great or noble. The nobles were educating themselves into a state in which they richly deserved a Richelieu.

${ }^{1}$ Condé to have Amboise and 450,000 livres; Mayenne, 300,000; Longueville a pension of 100,000 . 


\section{LECTURE X}

\section{GERMANY UNDER RUDOLF II. AND MATTHIAS, 1576-1619}

THE thrones of Maximilian II. were filled by two of his sons in succession : Rudolf II. reigned thirty-seven years and Matthias seven. Under them the imperial power suffered eclipse and the history of Germany itself went on with very little respect to them. Of Rudolf this is especially true; and even the history of the reign of Matthias is little else than a history of the Austrian states. The period is of importance as being the period of the Counter-Reformation, as Ranke calls it, through all Germany : but, except in religious questions, we find very little interference of Germany with the rest of Europe: nor does she take part in any war in which the general welfare of Europe was involved, save and except the defence of Hungary against the Turks. This abstention is owing to several reasons ; one is doubtless the assumption by Philip II. of his father's place as defender of the Catholic religion; the Emperor was thus cut out of that part of his work which had for centuries given him the largest share in the politics of Christendom: another was the comparative laxity with which Maximilian II. had held the reins of power, and the recovery by the princes of almost independent authority, largely increased by the religious peace and the doctrine 'cujus regio ejus religio.' In fact, under these two emperors the Aulic Council and the Imperial Chamber became nearly all the organisation for which Germany can be said to have been united. The diets were rather congresses of ambassadors than assemblies of estates of a united kingdom.

A further reason for the weakness of the Emperor was the distribution of the patrimony of Ferdinand. The Austrian house had so long depended on a single line, Maximilian being the only son of Frederick, Philip the only son of Maximilian, and Charles having early resigned to Ferdinand the whole hereditary dominions of the Hapsburgs, that we are apt to forget that the principle of primogeniture was not yet adopted, and that of the fifteen children of Ferdinand I. there were sure to be some who would object to the eldest brother taking all. The dominions of Ferdinand were accordingly divided at his death: Ferdinand took the Tyrol, and Charles took Carinthia and Styria. The extent of the imperial influence was thus limited: especially if the archdukes took different views of their duties. This is the last partition, however, of the Austrian states: Maximilian's dominions were not divided: but Rudolf succeeded to all. 
The Archduke of Tyrol died in 1595: Styria and Carinthia descended to Ferdinand, the son of Charles, who became Emperor in 1619. Both these governments were strongly Catholic, but with different results: Tyrol was never seriously affected by heresy; Styria and Carinthia at one time were almost entirely Protestant. Ferdinand and Charles both pursued a different line from Maximilian, and the repressive policy was maintained as a tradition in the Styrian house, to come out into effect in the Thirty Years' war. By this partition Rudolf's direct influence was confined to Austria proper and Bohemia: Hungary acknowledged him as King, but suffered little interference. The chief reason, however, of his insignificance we must find in his own character. Rudolf II. had been brought up in Spain as presumptive heir of Philip II., in the purest atmosphere of orthodoxy and etiquette. He was a man of intelligence and information, accomplished and a lover of learning. But he either had a taint of the old insanity or he had become a hypochondriac. After the first few years of his reign he lived the life of a recluse in the palace of Prague, in the midst of books, laboratories, museums, and mathematical instruments; he was never seen by his subjects; he took his exercise in cloistered galleries carefully fenced off from view; his associates were astronomers, grooms, and chemists; his pleasures were found in the possession of an immense stud of beautiful horses which he never mounted, and in the services of beautiful women, of whom a long string in rapid succession bore the reputation of being his mistresses: as, however, he never had any children, it is not improbable that his relations with these were merely platonic, or æsthetic. He never married: one of his fears being that, according to a horoscope drawn by Tycho Brahé, he would be killed by his son, or, another version, his fall would be due to a member of his own house.

The Emperor being thus employed, the Empire governed itself : Hungary conducted its own defence against the Turks, the archdukes governed the Austrian dominions as they pleased; in the politics of Europe it was uncertain that Rudolf's voice, if it were exerted, would be recognised. He was a devout and rigid Catholic, and whenever and wherever he chose to exercise any power it was in the direction of repression. From the beginning of his reign it was made evident that in this respect his line was distinctly opposed to his father's. The condition of things in Austria was curious: the nobles were Protestant and were allowed the ministration of Protestant ministers; the citizens and lower orders were supposed to be Catholic, they retained the churches and the Catholic priesthood and were forbidden to attend the preachings. Very early in 
Rudolf's reign, the Protestant preacher Opitz, who preached to the nobles of Vienna in their Landhaus, scandalised the city by his violence: he was forced to quit the city and territory. This was in 1578 , and is marked by Ranke as the beginning of the reaction in Austria.

The Emperor was not resisted and he proceeded to carry out the same line in the cities. The nobles, however, and the towns in alliance with them offered a passive resistance. The Archduke Charles was more successful still in Styria, and the ecclesiastical princes of Germany who had territories in or near Austria, the Archbishops of Cologne and Salzburg, followed the example. Bavaria had inaugurated the policy: Austria carried it out. But it is not to be forgotten that the nobles were still Protestant, and had a very great power in the provincial estates. The policy of repression, therefore, was consistent only with the most thorough economy : any demand for money would be met with a demand for religious liberty. Hence, perhaps, the peace policy pursued for the time by the archdukes. A Protestant reaction followed the death of the Archduke Charles in 1590, and the whole process had to be gone through again by his successor Ferdinand.

The policy of repression of which I have spoken so often was indeed a form of persecution, and it was the most effective sort of persecution. It consisted in the banishment of the Protestant ministers, the prohibition of the services, and the exile of the populations or individuals that had pertinaciously refused to hear the Church. It is strongly contrasted with the Spanish or inquisitorial process. No blood is shed : no fires lighted except to burn books : but first the preachers, then the proselytes are eliminated. Protestants are ineligible for municipal and government offices: the Protestant nobles, if not eliminated, are consistently snubbed. The charge of cruelty is avoided: the heretic principles are represented to the world without the prestige of martyrdom: the vacant lands are quickly filled up with new tenants whose interest it is to be Catholic and whose instinct is to hate those whom they have perhaps indirectly wronged. Surely this is far better every way than burning and cutting throats. But Rudolf was too lazy to carry out even this consistently : after the death of Charles the nobles got the upper hand. Ferdinand in 1597 had to begin the work: he undertook it against the remonstrance of Rudolf, but the Emperor, seeing his success, took courage and again headed the Counter-Reformation. It was the unpopularity that he gained in this later persecution from 1600 onwards that led to his being superseded by his brother Matthias in Bohemia and Hungary and even in Austria itself. But this is to anticipate. 
Before I go on to notice the affairs of the Empire, we will dismiss the Turkish wars. The chronic struggle went on languidly during Rudolf's first years : Amurath, the successor of Selim, being engaged in war with Persia. In this languid war Rudolf took no part, it was carried on from 1579 to 1583 by the nobles of Hungary. It was successful on their part. In 1583 the Emperor made a truce with Amurath for nine years: this was broken by the Turks. In 1587 Count Serin, Rudolf's general, won a splendid victory : but in general the defence devolved very much on the Prince of Transylvania, Sigismund Bathory, who allied himself closely with Rudolf, and obtained from him recognition as an independent sovereign: this status, however, he retained only three years : his vacillating character leading him first to exchange his territories for lands in Silesia and then to forfeit his dignities by treason. With his assistance, however, Rudolf made good way against the Turks.

The war began again on the expiration of the broken truce in 1592: the Hungarians gained a series of victories which brought down on them in 1596 the Sultan Mahomet in person. Against him Rudolf sent his brother the Archduke Maximilian. This war lasted for thirteen years: and it took at some points the appearance of a crusade: the French, under the Duke of Merceur, taking part in it. It was on the whole creditable but wearisome to the Hungarians, in consequence of whose discontent the Emperor in 1606 concluded a truce for twenty years with the Sultan: this was rcnewed by Matthias after he became Emperor, with great advantage to his people, the Turks employing themselves in the East and restoring to him the cities taken in the recent aggressions. It was in the same year, 1606, that Rudolf made with the Hungarians the famous Pacification of Vienna, by which he recognised their constitution and privileges and agreed to employ only native ministers in the government of their country. On the whole, the Hungarians had earned their rights, and their services had saved the reign of Rudolf from being altogether inglorious as regards the Turks, little as he had contributed to the result.

We will now turn to review the chief events in the history of the Empire itself. In the year 1577 the Lutheran princes and pastors drew up the Formula Concordiæ, an agreement as to doctrine which was to reconcile all conflicting schools within the Lutheran body, and which had the result of making the line harder and sharper than ever between the Lutherans and the Calvinists: Martin Chemnitz and David Chytræus drew it up: the Elector of Saxony and Duke Julius were its chief patrons; the Palatinate, under the influence of John Casimir, for Lewis VI. (1576 to 1583) was a Lutheran, bitterly opposed it. On the whole, it must have weakened the 
non-Catholic influence in Germany and indirectly helped the reaction.

In 1577 Salentin of Ysemburg, who had been Archbishop of Cologne for ten years and was not yet ordained, determined to marry and continue the paternal line of which he was the last representative. He accordingly resigned the see, and Gebhard Truchsess of Waldburg was elected in his place, in opposition to the Bavarian candidate. Gebhard was, no doubt, at the time involved with the Protestants, but the Pope confirmed his appointment and he conformed occasionally. Politically he attached himself to the Prince of Orange. In 1581, however, he fell in love with a lady of the house of Mansfeld, and, whether by compulsion of her brothers or by his own honest good will, I cannot say, married her, and immediately after this he joined the Protestant princes in the Diet (November 1582). He determined not to resign his see, directly in the teeth of the Ecclesiastical Reservation. He made his party among the counts and cities : John Casimir, the Count Palatine, took the command of his forces, and he prepared to resist the Emperor and all the Catholic princes. The Pope deposed him : the Emperor put him to the ban : the chapter elected a new archbishop. Against great odds he made fight for it for a year and more: in March 1584 he had to fly, and took refuge with the Prince of Orange at Delft. After William's death he returned to Germany, but made no more attempts to recover his see.

This event is of importance: it is the first breach of the religious peace that at all took the dimensions of a war: Gebhard during his prosperity had banished the Catholic priests from Westphalia: on his defeat, by way of reprisals, the Protestant canons of the chapter lost their stalls and revenues. The death of the Protestant bishop of Osnabrück, Bremen, and Paderborn, Henry of Saxe-Lauenburg, opened those sees to the Catholics; under the influence of the reaction caused by Gebhard's revolutionary proceedings. Altogether, the end of the struggle was decidedly in favour of the Roman Church. Gebhard has been made a hero of romance: one sympathises perhaps with his love affairs, and some people perhaps with his Protestantism: but he seems to have been a dishonest unprincipled man, and fared in the end as well as he deserved.

The Catholic cause was now winning back a very great part of what it had lost: the Jesuits of course being.the chief agents in the triumph. In 1584 Bishop Julius of Würzburg began the work of recovering his states to the Church : the bishop of Bamberg followed the example; within a very few years Franconia, or thegreatest part of it, was Catholic again: The cities, counts, knights even, whom the Jesuits found themselves able to influence, especially those who, 
having become Protestant in rivalry to the princes and having been disappointed of their booty, were now carrying on the opposition under the contrary colours, vied with one another in restoring the Catholic worship, and, where they could, getting rid of the non-Catholic population and their teachers. It was hoped that the princes themselves would soon begin to return: the first convert was made in 1590-James or Jacob, Margrave of Baden.

During all these movements we look in vain for a trace of Rudolf's existence. The agency of Philip through the Jesuits and the Papacy is far more apparent: doubtless Rudolf also was to some extent under Philip's influence. But with the exception of the episode of Mathias's adventures in the Netherlands, of which we have said enough already, the name of Philip does not come much into Rudolf's history. His hand was light, doubtless because he knew that he could get his own way with him when he wanted it.

In 1590 the question was raised in the Diet of Frankfort how the Spaniards should be expelled from the imperial territories, meaning of course the Netherlands: but the issue was a false one. The Netherlands had long ceased to be any way except technically a part of the Empire : and the discord between the Lutherans and Calvinists alone would have been enough to prevent any action being taken; as it was, nothing was done.

In 1592 a disputed election to the see of Strassburg, between John George of Brandenburg, a Protestant, and the Cardinal Charles of Lorraine, brought a struggle which lasted until 1604. The Emperor sent the Archduke Ferdinand to arbitrate, but the parties preferred to appeal to arms : soon tired of fighting, they referred the decision to a board of five princes, two Catholic and three Protestant, all in vain: at last in 1603 Henry IV. of France undertook to arbitrate. He decided in favour of the Cardinal, but made him pay 130,000 gulden to buy off his rival's claims.

It was during this turmoil that the confederacy of Heilbronn under the Elector Palatine was instituted in 1594; out of which some few years later the 'Union' of the Protestant princes grew. In 1595 men began to talk of electing a King of the Romans, but Rudolf distrusted his brothers and would have nothing to say to the proposal.

These little particulars bring the history down to the year 1600 , after which a sort of rousing appears to take place. The Archdukes in fact, seeing the contempt into which Rudolf has suffered the imperial house and dignity to fall, think it high time to provide for the family interests. Rudolf, on the other hand, careless of the use of power, clings to the possession of it. $\mathrm{He}$ also is roused to resist the action of his kinsfolk as directed against himself : both bid against one another for the support of the people they govern, and 
both are compelled to make concessions to the political and religious tendencies to which they are more or less opposed. The incident becomes more varied and rapid, and we begin to see more clearly the train of events that is leading to a general war in Germany: the struggling of the fires of liberty under the superincumbent mass of repression, and the progress of a struggle in which those fires are to break forth, here and there to be triumphant, here and there to be to all appearance completely extinguished.

The regular sequence of events which forms the later history of Rudolf's reign and his successors', and which led directly to the Thirty Years' War, may be regarded as beginning in 1597 with the reactionary measures of the Archduke Ferdinand. The league made at Heilbronn in 1594 was a political rather than a religious confederation to refuse pecuniary aid to the Emperor for the Turkish war until the grievances of the confederates were redressed; and, although it led not indirectly to the formation of a much more important confederation, it contained only the Elector Palatine of the great princes, the Duke of Würtemberg and three or four others of secondary rank.

The history of the life of Ferdinand II. would cover all that is really of political importance down to the year 1637 : forty out of the fifty years' history which must be read before we can understand the Thirty Years' War. The Catholic reformation of the Austrian states begins then under Ferdinand in 1597 in Styria. It was carried on with determination and severity, and it was very successful: the closing of the churches, the absolute prohibition of services, the option between conversion and exile, were the means. In 1603 Ferdinand had got an increase of 40,000 faithful. These proceedings had a twofold effect: they roused Rudolf to imitate them in his own states: they excited also the alarm of the Protestant princes and made them combine by way of precaution. In 1598 the confederates of Heilbronn renewed their league at Frankfort, adding to their numbers the princes of Brunswick, Hesse, Nassau, and even Brandenburg. Saxony still stood aloof, jealous as ever of the Elector Palatine. This league concluded in 1603 an alliance offensive and defensive with Henry IV. at Heidelberg; one of his first steps towards the carrying out of his great project against Austria.

But although these confederations were entered into for the purpose of controlling the imperial administration in Germany, and enforcing the respect due to the Protestant interest in the Diet, the imperial chamber, and the Aulic Council, they were only indirectly connected with the Protestantism of the Austrian States, where the right of the Emperor and archdukes to regulate religious matters was 
admitted. But the growth of the Catholic reaction in Austria and that of the Protestant opposition in Western Germany were large parts of the general arming of the two forces one against the other. The success of the Jesuits in Austria emboldened the Catholic princes in the Empire to follow the example, and Rudolf even attempted to effect in Bohemia the same changes that he had been able to carry out in his minor states.

The events which brought the two powers thus marshalling against each other into collision were first the affair of Aix-laChapelle, which had been put under the ban of the Empire in consequence of the successes obtained by the Protestants, many of them exiles from the Netherlands, in subverting the Catholic character of the town. This ban was executed by the Electors of Treves and Cologne in 1598 and the exercise of Protestantism prohibited. The second was the affair of Donauwerth, an imperial town within the duchy of Bavaria which at the peace of Augsburg had ranged itself on the Protestant side. At Donauwerth in 1605 the Catholics, fostered by the protection of Bavaria, attempted, not, like the Protestants of Aix-la-Chapelle, to get the government of the city into their hands, but simply to hold their processions in the teeth of the municipal law. The abbot of the Benedictine monastery determined to hold processions : the magistrates forbade it: the abbot obtained an injunction from the Aulic Council, which the magistrates could not resist: the people, offended by the procession, rose and insulted the monks: a new appeal was carried to the Aulic Council: the Aulic Council ordered a commission of inquiry ; and the commission was intrusted to Duke Maximilian of Bavaria. Another riot followed; Donauwerth was put to the ban as Aix-la-Chapelle had been, and Maximilian was ordered to carry it out. He followed his instructions too carefully; took possession of the town with his forces ; gave over the churches to the Catholics, deposed the magistrates, and abolished Protestantism.

This took place in 1607, and at the Diet of Ratisbon in 1608, January 12, it formed a topic of complaint. This Diet is a remarkable epoch: its president was the Archduke Ferdinand: the Emperor's demand, as usual, was for money for the Turkish war. But the policy of the Protestants was to refuse to enter upon any business whatever until Donauwerth was restored to its rights : until the Aulic Council was reformed and the peace of Augsburg positively confirmed. The Archduke, in the Emperor's name, was stiff in refusing or temporising with all these petitions. The princes carried out their resolution of abstention; and the Diet separated for the first time since there were Diets without coming to any decision.

The Princes directly after, at Aschhausen in Franconia (May 4), 
formed themselves into a new league, to last for ten years and to be under the presidency of the Elector Palatine. This league is known as the Protestant Union, and was concluded by the Elector Palatine and the Count Palatine of Neuburg; Joachim and Christian Ernest of Brandenburg; the Duke of Würtemberg and the Margrave of Baden. Their object was mutual defence against the imperial government.

Just at the same time, Rudolf's policy in Hungary and Austria brought about its natural result: and Tycho Brahe's prediction of the fall of the Emperor by one of his own house began to be fulfilled. His repressive measures had alienated the affections of the Austrian states, and his distrust of his own family had turned against him his brother Matthias, whose principles were politically opposed to his own, as was shown in the affair of the Netherlands many years before, and who scarcely needed the promptings of ambition to array him against a brother whom he saw to be ruining the fortunes of his house. The Hungarian, Austrian, and Moravian estates put their forces under the command of Matthias; he marched on Prague in May 1608, the same month that the Diet of Ratisbon broke up, and compelled Rudolf to resign the government of those three states. Matthias was crowned King of Hungary before the end of the year. Both brothers had in consequence to make large concessions to the Protestants : Matthias as a reward to the Hungarians and Austrians for their support, Rudolf to purchase the aid of the Bohemians and to allay the fears of the Protestants in the Empire; and these concessions provoked a counter-confederation among the Catholics under Maximilian of Bavaria; this was made on July 11, 1609, and is called the League, in opposition to the Union.

Rudolf, however, was not satisfied with merely obtaining the support of the Bohemians; he intended to take his revenge on Matthias. As his original quarrel with him had sprung in some measure from his design of procuring the succession to his dominions for the Archduke Ferdinand, he determined now to start the Archduke Leopold against him for the remainder of the family honours. And just at this time the decease of the last Duke of Juliers and Cleves (March 25, 1609), leaving the succession open to several competitors, gave him an opportunity of putting out a feeler in this direction. Of the claimants, the chief were the husbands of the four sisters of the last duke; the Elector of Brandenburg, who had had the succession made part of his marriage settlement; the Count Palatine of Neuburg, the Duke of Zweibriicken, and the Margrave Charles of Austria, son of the Archduke Ferdinand and Philippina Welser. Besides these the Saxon princes had claims depending on remoter marriage contracts and Erbverbrïderungen. 
The only two who were strong enough to assert their claims were Brandenburg and Neuburg: and these, after a brisk struggle, were induced by fear of an imperial sequestration to make peace at Dortmund, June 10,1609, and agree to administer the inheritance jointly. Rudolf determined, however, to secure the territory if possible, annulled the treaty of Dortmund, and sent the Archduke Leopold, brother of Ferdinand and Bishop of Passau, to take possession.

This was regarded by the Protestants and by Henry IV. as a bold stroke taken on behalf of Spain against the Netherlands. And here the French and German histories come together again after a long interval. It was on this unlawful seizure of Juliers and Cleves that Henry IV. was to take his first stand in his attack on Austria. The League of Heidelberg was renewed; the whole network of treaties against the Hapsburgs was strengthened, and the enormous army was raised, which he was going to visit when he was assassinated. He died and his plans collapsed, but the French force which was sent into the disputed territory was instrumental in expelling Leopold, and the war came to an end under the management of Maximilian of Bavaria, who obtained the evacuation of Alsace by the Union on condition of leaving the heirs of Juliers and Cleves to make their own arrangements.

The Emperor's project for Leopold in Bohemia was still more unsuccessful. He allowed him at the head of his army to enter Bohemia and produce a panic among the Protestants whom he had just propitiated. The states in their alarm sent for Matthias, who was even too ready to come. He arrived at Prague on March 20, 1611. In vain poor Rudolf tried by offering every sort of concession to recover the allegiance of his subjects. Matthias managed to outbid him : he was deposed: Matthias elected King in his room and crowned on May 23. Rudolf's dominions were now reduced to the four lordships which Matthias consented to settle on him. He was as poor as his ancestor Frederick III. whose astronomical tastes he had inherited. In his despair he threw himself on the princes, but they would have nothing to say to him, or rather what they had to say was cruel. Instead of being moved by his misery they reproached him with his past misgovernment and demanded redress of grievances which it was quite out of his power to take in hand now. They ended in requesting him to call together the electors and proceed to the choice of a King of the Romans. He consented, but contrived to put off the day : the electors, suspecting his policy, fixed it themselves for May 31, 1612. But before that time Rudolf had taken the last obstacle out of Matthias's way: he died simply brokenhearted, an old man although still under sixty, on January 20. 
Our contempt of Rudolf is not altogether unmixed with pity : he was one of the most unfit persons who ever reigned: his virtues and vices were those of a private man. His public character is almost a blank : his leading policy, the maintenance of the Catholic religion, he had not energy or perseverance to carry out steadily. $\mathrm{He}$ might reign safely whilst Philip II. could direct him : but against Henry IV. he was powerless ; and when a generation of weak princes followed the generation of the strong ones, in France, Spain, and England, Rudolf the eldest and the weakest of the weak was the first to go.

It is satisfactory to know that Matthias did not enjoy the fruits of disloyalty with any approach to comfort. He had risen on the wave of Protestant independence and so overwhelmed Rudolf; but the wave of Protestant independence was not the strong influence at this time. Ferdinand II. rose still more steadily on the wave of the Catholic reaction. Matthias, like Rudolf, had no son; he saw from the beginning of his reign a fate not altogether unlike Rudolf's in store for him. The electors met at the appointed time, but the election of Matthias was not the immediate result: the Catholic electors preferred the Archduke Albert of the Netherlands; the Protestant ones the grand master Maximilian-Matthias's younger brothers. But the two archdukes were faithful to the family interest; they declined to stand; and Matthias was elected at Frankfort on June 18, 1612. The capitulation which he signed on the occasion was more stringent than any that had preceded it. One article is politically important; it restrained the Emperor from employing the subsidies of the Diet for any purpose except that for which they were specifically granted: another enforced the reform of the Aulic Council and Imperial Chamber: another allowed the electors to choose a King of the Romans without the consent of the Emperor.

The reign of Matthias is a series of disappointments: having worked both Protestant and Catholic interests for his own advancement, he found himself trusted by neither party: as Emperor his policy was conservative : as an aspirant he had bound himself to the other party: he was brilliant, like his father, but not tolerant or patient: he prepared the way for his own failure. He could not get money for the war against the Turks : and had to make peace in 1615, losing Transylvania thereby, which had declared itself independent under Bethlen Gabor. He offended the Protestants by continuing the ban on Aix-la-Chapelle and even enforcing it after a settlement had, during the Interregnum, been effected. $\mathrm{He}$ had, moreover, in the interest of the Catholics of Cologne, ordered the demolition of the fortifications of Mülheim which were being erected 
by the heirs of Juliers. He seems to have determined to protect the Catholics and to manage the Protestants by intrigue. Not that they required much management, their own quarrels made them impotent. The Elector of Brandenburg and Count Palatine had agreed to settle the succession by a marriage of the Palatine with the Elector's daughter; but in the negotiations the Elector got drunk, struck at the Palatine, and quarrelled irreconcilably. The Elector, to obtain the help of the Dutch, turned Calvinist ; the Count, not to be beaten, turned Catholic and was helped by Spain. The struggle ended with the peace of Xanten in 1614, by which the inheritance was divided, the government being still administered jointly. In this Matthias took no part.

Shortly after this the Archduke Maximilian, seeing that the fate of his family was sealed unless provision were made for the continued union of the estates, proposed that all the archdukes should give up their claims to succession to Ferdinand of Styria : after some difficulties he prevailed with Matthias, the King of Spain, and the rest to accept him. Matthias himself proposed him as King of Bohemia, and he was crowned on June 29, 1617. He became King of Hungary a year after: and by the strength of his mind and persistency of his policy gradually edged Matthias out of power. Klesel, Bishop of Vienna, and confidential minister of Matthias, who had used his influence against his master's resignation, was carried off by Ferdinand and imprisoned.

He then turned against the Bohemian Protestants and provoked a rebellion, headed by Count Thurn, which ended in the election of Frederick, the Elector Palatine, as King of Bohemia. Matthias attempted in vain to enforce more prudent counsels, Ferdinand was all-powerful in the support of the Spanish court, and the Catholic interest was now strong in the possession of Maximilian of Bavaria. On the other hand, the Protestant Union was intriguing against Ferdinand: the Elector Palatine had already set his mind on Bohemia : the Empire was offered in turn to Maximilian of Bavaria and Charles Emmanuel of Savoy.

The sufferings of the Bohemian Protestants forced the Union to overt action. The Count of Mansfeld, under the orders of the Elector Palatine, on November 21, 1618, laid siege to Pilsen and took it after a stout struggle: and in a moment Bohemia was lost. The death on March 20,1619, of Matthias, who was striving to negotiate and had agreed to a conference at Egra, on April 14, put an end to all prospects of peace, and immediately the war began which desolated Germany for thirty years and the results of which produced a permanent change in the aspects of German history. 


\section{LECTURE XI}

SPAIN AND FRANCE IN THE EARLY YEARS OF THE SEVENTEENTH CENTURY

We have seen, in the last lecture but one, how Henry IV. used the position which Philip II.'s death had left open to him. It remains for us now to take up the strings that have been left loose at various parts of our discussion, and bring them down to the closing point of the period. Philip II. left but one son, Philip III., the son of his niece and fourth wife, Anne, daughter of Maximilian II. Philip III. was twenty-one years old when he began to reign : he reigned twentythree years, and during twenty of those twenty-three he had but one great minister, the Duke of Lerma ; and that great minister, one great favourite, Rodrigo Calderon. Philip III. was a fairly decent and clever man, but he had no energy or application or even the business qualities which were the great strength of his father's character. The history of Spain in his reign is a history of continuous decline, rapid and unbroken; although the spell of past power saved the kingdom from becoming, as it did a century later, absolutely powerless and contemptible.

Of the causes which led to this decline many theories have been given, and various degrees of importance have been ascribed to the causes adduced from different sides and standing-points. I shall not undertake to decide which was the greatest of these destructive influences; but amongst them these may be regarded as certainly powerful: the decay of national trade and commerce resulting from the possession of the American colonies and the large revenues derived from them; the exile or destruction of a large industrial population, the most industrious in Spain, the Moriscoes, who were persecuted into conversion and harassed into relapse under Philip II., and under Philip III. were actually driven from the country; the extinction of national independence by the abolition or disuse of constitutional forms of government; the forms, where they were retained at all, being a mere mockery of the political life which had before existed; the uncertainty and uneasiness of every relation of life produced by the secret, penetrating, unscrupulous, unrelenting action of the Inquisition. No doubt, all these were very efficient causes of national decline. I think we may add to them these : the want of any great or able minister, such as France had in Sully and afterwards in Richelieu, who could have remedied the evils consequent on the decay of trade and the influx of the revenues of 
the colonies, either by proper measures of political economy, or by a system of government in which men would have felt themselves secure and interested; or by a foreign policy which, even through war, should have maintained for a while the energies of the nation.

Philip II., as we have seen, did none of these things ; but he had power and he had qualities that deferred until his very last years the certain collapse of his affairs. None of his successors had even the kingly qualities which he possessed: had either his administrative capacity or his gift of choosing good ministers. Yet, with the cessation of the power, the wish and the old methods used to further the policy of Philip did not cease; the old position of orthodoxy and of the defence of the Church was maintained; the old grudge against France was retained; the old manœuvres to keep a hold on the Papacy; the old intrigues in England during the prevalence apparently of peace with the sovereign: all that was intriguing, all that was underhand and demoralising, all that tended to the sacrifice of the interests of the nation for the supposed interest of religion and exaltation of the house of Hapsburg, was retained : all that had given strength, or fibre, or even cohesion to the policy and manœuvres of Philip II. was taken away. The influence of Spain in Europe continues to live on the tradition of the influence of Charles V. and Philip II.

It is seen, moreover, how much of the power of Philip II. really was owing to the weakness of France during the whole of his reign. Such as he was, a man with no great quality, simply, we might say, the habit of being a king, of being a working and intriguing king, he had really no rival. What Henry II. might have been to him we cannot tell: probably not a more competent rival than Francis I. was to Charles V.: but what the sons of Henry II. were we know: adversaries too contemptible to be injured, or friends too much like adversaries to be helped. In Elizabeth of England and William of Orange he had met with characters which in themselves were more than a match for his own : but the policy of Eilizabeth was narrow, and, indeed, in many respects not unlike his own; William of Orange never had the field or appliances to show how he could have excelled him. In the Empire Ferdinand and Maximilian were able princes ; but exercised in Europe, probably from choice, an exceedingly small influence: and under Rudolf the Empire not merely was but was seen to be insignificant. Philip had succeeded to more than the position of Charles V., being less hampered with imperial difficulties and having nothing to dread from France.

Under such advantages the decline of Spain began; no wonder that when these were lost it continued and even accelerated. My idea is that Spain lost all the advantages that her colonial empire 
brought her by the want of an able and provident ministry ; and that, the advantage being lost, that which should have been to her wealth became an occasion of falling : that it would have been so first, but that the mischief was retarded by the practical supremacy of Philip II. in Europe, and when that was removed, when nothing was substituted for it, when the greatness of Spain was but a tradition of the past, it scarcely needed that the neighbouring nations should have great kings and ministers; the end must come.

Under Philip III. there is no great war. The desultory state of things with regard to England continued from 1598 to 1604, when peace was made. In the year 1599 there was a great alarm in England of a new armada, to avenge the attack on Cadiz by Essex in 1596. But it appears to have been a groundless one. Philip III. furnished the Irish rebels with money and with words of encouragement: the cause of the panic was simply the sailing of a squadron of eight vessels to the assistance of the Archduke Albert. In 1600 Queen Elizabeth and Philip III., at the urgent request of Henry IV., negotiated for peace. Elizabeth demanded on this occasion that the arrangements with respect to trade should be restored as they had been in 1568 before her coolness with Philip II. and the piratical war began. But the negotiations were altogether hindered by the demand for precedency on all occasions for the Spanish representatives. Elizabeth yielded in etiquette all that she could, but, no conference being possible, no peace was arranged. The state of war, whose determination was less important to England and Spain than that of the relative dignity of the ambassadors, could not have been very burdensome. Vexatious enough it was, and a hindrance to trade and a cloak to intrigue; but it was also a convenient outlet for uneasy spirits and a sop to the strong Protestant politicians of England and the Catholic bigots of Spain : and there was a strong party in England whose interests were bound upon the speculations which but for the state of war would have been called by their true name of piracy.

Again, in 1602 the Spanish court prepared to send a large army to Ireland, where Aguila, at the head of a small force, had the year before occupied and fortified Kinsale: that design was prevented by the surrender of Kinsale: and a plan of seizing the Isle of Wight was then undertaken, under Frederic Spinola; but it was defeated by the English fleets, which destroyed two Spanish squadrons, one on the coast of Portugal and the other in the channel. Elizabeth's death stopped this warfare, and peace followed. This peace was not maintained by James I. without considerable difficulty, owing to the strong sympathy felt by the people for the struggles of Maurice in the Netherlands and the traditional hatred of Spain felt by the 
puritan and pirate interests. That James was falling under Spanish influence was the cry: and although there was, no doubt, some reason in the cry, for the great bulk of Spanish power and its show remained whilst the real spirit was departed; and, as I have said, the intriguing machinery remained although the guiding hand was removed; there can be no doubt that its efficacy was owing to the national excitement and to the growth of other causes which ended in the revolution of the next reign. The peace or twelve years' truce between Spain and Holland in 1609 might have availed to allay any such fear, but the feeling that had been growing so long could not be at once allayed; and instead of being allayed it found other influences to run with it. The postponed Spanish marriage of Charles I. was very unpopular: you may remember how this feeling extended into the next reign : how in 1621 the English parliament compelled James I. to go to war with Spain: how on Charles's accession the Commons begrudged the supplies and laid the blame of the war on the Duke of Buckingham : how Charles was thus forced into illegal means for raising money: and the long miseries of England under Puritan faction and unconstitutional rule began.

The state of peace with France was not broken during the reign of Philip III. : no doubt, the death of Henry IV. prevented a breach that must have followed his projected attack on the Austrian family. The peace was cemented in 1612 by the marriage of the Prince of Asturias with Isabella of Bourbon, daughter of Henry IV., and of Lewis XIII. with the daughter of Philip III., famous afterwards as Anne of Austria.

This is perhaps the place for sketching the termination of the long struggle in the Netherlands, where the Archduke Albert, with the assistance of Spanish fleets, was maintaining as well as he could the attitude of resistance to the constant aggressions and aggressive policy of Maurice of Nassau. We left the two parties in 1598, Albert having been recently appointed governor and his wife Isabella sovereign of the remaining Spanish possessions. During the absence of Albert, the government was carried on by Cardinal Andreas of Austria; Mendoza, admiral and general of the Spanish forces, attempted to get into the northern provinces through Cleves and Westphalia, and, not succeeding in doing so, created great miseries in the undefended country through which he passed. Maurice, not averse to this, from the idea that the imperial government would be obliged to take the side of the Hollanders if their enemies should put themselves decidedly in the wrong within the boundaries of Germany, pressed Mendoza as hard as he could and made gigantic efforts to repel the attack which he expected from the Archduke; the whole power of Spain being now at liberty, released from the French war, to help 
him. These efforts produced a great deal of hardship among the Dutch, of which the Spanish government might have taken advantage had it not likewise been hampered with domestic difficulty, a league among the national party being formed to expel the foreign soldiery. This the Archduke, on his return in Sept. 1599, obviated by promising that as soon as the war was over all foreign troops should be removed. He then proposed terms of peace to the Seven United Provinces, but the states rejected them and the war was briskly resumed.

In June 1600 an important action occurred that diversifies the otherwise monotonous character of this most tedious struggle. Maurice invested Nieuport in Flanders with an enormous fleet of boats. The Archduke and his wife brought up a force to relieve the place, and in a battle on July 2 their troops gained a victory : but, the battle being renewed the same day, fortune had turned, the victory became a defeat, and Maurice beat them with a loss of 8,000 men. The inhabitants of Nieuport, however, defended the place so stoutly that in the end he had to retire without taking it. Another negotiation followed : and another campaign.

The event of 1601 was the opening of the siege of Ostend by Albert, which began on July 5, and lasted until Sept. 19, 1604, when it was taken by Ambrosio Spinola: in this siege there were employed troops and funds from all the states of Christendom: England, France, Holland, and Germany assisting in the defence; Spain, Italy, and Austria in the attack. During the siege some important actions were fought and divertissements attempted elsewhere: but all the interest is concentrated upon it. Maurice took Grave and Sluys, which he had besieged in order to draw off the attack from Ostend. In this war Maurice was opposed by the Marquis Spinola, who disputes with him the character of the greatest master of military science in the age.

The transactions of the following years are complicated by the exhaustion of both parties. The Archduke could get no money from Spain; and Spinola's troops were accordingly constantly in revolt, almost as difficult to manage as the enemy : Maurice was compelled by the states to be economical. The states were, however, finding that the English policy was the best and that the vulnerable points of Spain were her colonies and fleets: points which in future time they also were to find constituted their own strength and also their weakness. The rivalry of Dutch commerce and the foundation of Dutch colonies date from the difficulties of this struggle. The Spaniards were heartily weary of a war in which there was no way of avoiding loss, and in which all the expense they incurred seemed simply to be wasted. The English King was disposed to take the part 
of a pacificator: the dignity of the Archduke was not so great but that he could condescend to treat when Philip could not: the Portuguese, whose East India trade was being destroyed by the Dutch, importuned the royal ears with entreaties for peace. At last in 1608 the states at the Hague and the court at Brussels opened negotiations with one another.

The states had, however, grown up, we may say, in war; peace was a novelty they were not disposed to covet. The Archduke could remember his pleasant days in Portugal and would be glad of rest. Maurice was opposed to peace: the interests that had flourished at sea and on the destruction of the Spanish and Portuguese colonies resisted the idea : as did the Calvinistic religious interest. Barneveldt and the statesmen dreaded the ambition of Henry IV. The Archduke was ready to make sacrifices and gradually disarmed opposition.

A congress was agreed on at the Hague; Spinola headed the body that represented the Archduke: William of Nassau and Brederode the states. The negotiations hung fire a long time: the opposition of the policy of Maurice to that of Barneveldt dividing the states among themselves, and having the effect of rendering their attitude towards the Archduke insolent and exacting. Humiliating, however, as it was, he persevered : and at last, on April 9, 1609, a truce of twelve years was concluded: by the first article of which the Archduke for himself and for the King of Spain renounced all claims on the sovereignty of the United Provinces, and acknowledged their independence: the second article fixed the duration of the truce : the third determined that both parties should hold what they had, without cessation or restoration. The fourth provided for a general amnesty and full freedom of trade : the other articles referred to the regulation of commerce.

So the great struggle ended, and the work that William the Silent had laboured for was so far crowned with success. It is the glorious part of Dutch history, and of the life of Maurice, who was not so great a ruler as he was a captain. He never forgave Barneveldt the part he had taken in the negotiations; though it was not until 1618 that he succeeded in destroying him. The seeds sown in this rivalry bore fruit in the long party quarrels of the Dutch, with which the names of Grotius, and the de Witts later on, are inextricably involved.

The last memorable event of Philip III.'s reign was the disgrace of the Duke of Lerma produced by a court intrigue. He was succeeded as minister by his son, the Duke of Uzeda ; and the change, it is said, was no improvement. It matters little: such a particular is not worth remembering, and yet it is nearly all there is to be 
remembered of the last years of Philip III. He died March 31, 1621. He was a kind and good man, but utterly incapable and careless as a ruler; that is all that can be said for him.

We have now brought to a close our view of the events and characters and influences that form the public history of Europe during the sixty eventful years that intervene between the resignation of Charles V. and the outbreak of the Thirty Years' War. I have not thought it desirable for us to read these times with any special reference to the Thirty Years' War, because, as you know, I am averse to reading history backward and prefer to trace events in their development first, and to analyse results and trace them to their causes afterwards. I shall not then attempt now to anticipate reflexions which belong more properly to the period of that great war than to this intervening time. But some reflexions are in place at the end of a course even if it wants the element of unity which an anticipation of the Thirty Years' War might give it. We must not forget that when we speak of the period of the Thirty Years' War we mean much more than the war in Germany. We include in the term the great constitutional struggle in England and the administration of Richelieu in France: a period abounding in great men and in decisive struggles. Let us just see how the elements which were to contend in those struggles were now disposed to one another.

In Germany we have no difficulty in seeing: there the cloud of war first breaks and the forces at the end of the intervening period are most clearly and preparedly arrayed. In Germany ever since the Peace of Religion the two parties have been looking forward to a resumption of the strife. The Ecclesiastical Reservation and the imperial declaration have been alike a dead letter wherever the reigning prince or municipal governing body has been strong enough to override them. These transgressions have produced much quarrelling, much intrigue, much oppression and misery : neither party has thought of forbearance, and neither has understood the virtue and power of tolerance.

The balance of blame inclines, however, legally to the Protestant powers who had not only, like their Catholic neighbours, persecuted wherever they could, but have, by force and fraud of every kind, set aside the Ecclesiastical Reservation, on the understanding of which the imperial declaration issued. It is true the Protestants repudiated the reservation as the Catholics repudiated the declaration; but both had become the law of Germany and both should have been respected. The Protestants broke through both. Yet war on anything like a large scale was not produced by these trespasses. Under the shadow of a peace which neither party observed in terms, 
material peace was strong enough to maintain itself for nearly sixty years. And those sixty years witnessed the great change in Germany that made the Thirty Years' War a struggle for existence to the Protestants.

The preaching of the Jesuits, the repressive policy of the Austrian, Bavarian, and ecclesiastical princes, had changed South Germany from being, as it promised to be, the home of Protestantism, into a uniformly Catholic territory. It had consolidated the Protestants into a tolerably uniform mass of opposition. The Protestant Union under the Elector Palatine and the Catholic interest under Ferdinand II. were two bodies between which it was scarcely possible for waverers of either party to find standing-ground : they had no point of agreement or pacification, neither respect for the Empire, nor regard for the house of Austria, nor the spirit of German patriotism, nor the hatred of foreign interference; not one of the causes which during so large a part of the reign of Charles V. had maintained peace, and which had not entirely been extinguished under his successors, now continued to be effective. Germany was clearly divided; the attempt of Frederick on Bohemia was but the outlet of forces panting to be free.

Now if we look at France we see on a smaller scale something of the same sort. Only there the contest is not going to be between Catholic and Protestant only, but between the King and the princes: the ministers and the nobles: between an oligarchic and a despotic government. The Edict of Nantes has given peace to the Protestants, but it has also given them too much power and an organisation too independent to be safe. If Henry IV. had thought his Huguenot allies would have been safe without this political power, this recognised imperium in imperio, this distinct territory and towns and privileges, he would have doubtless granted no more than simple toleration. As neither party knew what toleration. meant, he was obliged to give them power and means to maintain their existence, power, and privileges which made them at once an object of alarm to the despotic system which Richelieu saw to be for the time necessary to France. The Protestants were themselves very jealous of any measure taken by Henry IV. to their disparagement: their jealousy was justified amply by the measures taken during the minority of Lewis XIII. : the reclamation of the Church lands in Béarn, the limitation of their assembling in council, and the positive denial of power to their chief representatives, the Condé princes.

In France, then, Catholic and Protestant were ready for a struggle when an opportunity should arise. The Jesuits in their strength overwhelmed opposition, and extinguished the opposing element; they, however, provoked the opposition where they were not all-powerful 
and intensified it by their constant aggression, until it became irrepressible and the struggle inevitable. In like manner with the nobles. We have seen how, during the reigns of the sons of Catherine, the nobles, the princes of the blood at the head of them, divided the government; how when a balance could be maintained amongst them peace was preserved, but the wavering of the balance produced almost an annual war. These annual wars, although they were connected with religion, cannot be called strictly religious, because a considerable part of the body that we generally regard as fighting the Protestant battle were really Catholics : but neither can we regard them as wars of personal intrigue, for as fast as one champion fell, and they fell in rapid succession, another took his place. It was a struggle of the princes for power; as against the crown and as against one another.

Well, the death of Henry III. and the war of the League against Henry IV. simplified matters very much: in the great question of religion and the royal title, the factions lost their importance; but on the restoration of peace they revived, and, next to Henry's love affairs and escape from assassination, they gave him more trouble than anything else that he had to encounter. When his adroit hand was removed, the factions sprang into more than former violence. Marie de Médicis had more principle or less power of intrigue than Catherine had had, and so the balance was harder to her to maintain : but what was needed was not now intrigue but policy: and for that purpose first Concini on a small scale, then Richelieu on a large one, adopted the same policy-the depression of the princes and nobles, the establishment in supremacy of the royal government independent of the territorial magnates. Such a reform ought to have been carried out into an alliance between the whole people and the King : but it was not: we may even doubt whether Richelieu ever entertained the idea : it was enough work for him to crush the factions, but it was the true policy: an alliance between the King and people which would concentrate administration in hands acceptable to both, and abolish feudal jurisdictions with everything that belonged to them. The time when this should be done was yet a long way off from France.

Now, if we turn to England, we may see, I think, that these contrasts and oppositions abroad were not without their echoes and reflexions here. True there was no great Catholic and great Protestant party opposed to one another, nor as yet any great constitutional faction-schism between the different orders of the state. But there were strong antipathies and strong sympathies, and there were causes which would give these their opportunity at a time not very distant, although those causes might be altogether

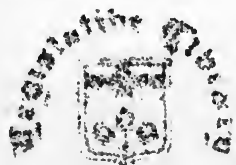


distinct from anything that was heard of at the time in Europe at large. In the first place there can be no doubt that the great body of the thinking people were possessed with a hatred of Spain and of the Roman Catholic religion; and a great desire to see the Netherlands emancipated and the power of Spain humbled in America, and the Protestants of Germany victorious.

On the other hand, James I., without loving Spain, had a great and natural horror of rebellion, such as even that of the United Provinces continued legally to be: and the court and the Church, and to a great extent the nobles also, were afraid of that composite system of puritanism and republicanism which was favoured by the Protestants of the Netherlands and Switzerland. The divines of the Caroline period were no Romanisers, but they would not, could not sympathise with either the religious or the political principles of the Continental Protestants. The synod of Dort proves this: the nearest approach ever made by the Church of England to the Calvinists.

When accordingly the Elector Palatine was chosen King of Bohemia, the court avoided, the people urged the assistance of the Protestants against the Emperor. The conservative party, we may say, sympathised with authority, the popular party with change. This opposition led unquestionably to an attitude of opposition between the court, clergy, and nobles on one side, and the middle classes in the towns on the other. The policy of the court to avoid interference would be amply justified on modern principles : on the principles of the day it was probably justified by necessity: the court could not without the people join the imperial side: they would not with the people join the opposition. No doubt, the approach of James I. to Philip III., the Spanish marriage proposed for Charles I., was an imprudent policy, in the then temper of the people : it may well be questioned whether, if it had come to maturity, it would have been more unfortunate for England than the marriage of Charles to Henrietta, and the French connexion that ruined the house of Stewart for ever. This jealousy,-these antipathies fostering the jealousy, the sympathies of puritanism with republican principles and with republican interests on the Continent,- - produced a wide division between a great part of the English nation and its rulers. That division widened into war, produced by other causes, but a war which would have been impossible but for these.

But in the midst of all these new influences, or new developments of the old ones, the old international jealousies still subsisted. France would persecute Protestantism at home, but would not, could not, act heartily in conjunction with Spain or Austria abroad. France could not join openly in the opposition to the 
Catholic powers: but she could take every advantage both of their necessities and of their misfortunes. Charles V. was never forgotten or forgiven until Lewis XIV. had revenged France on both Spain and Austria. 'I'his cannot be left out of consideration in all the complications with which the coming period is filled. These hatreds had become national; as the English hatred of France in the middle ages : they were not mere jealousies of kings, they were the accumulated memories, the inherited instincts of peoples. The dread of Spain did in England, during a large part of the seventeenth century, cast into the shade the hatred of France: but yet England and France were never found fighting on the same side abroad: and the result, as I have said, showed that French influence at home was more injurious than Spanish influence, at a period when Spanish influence was declining and French influence was increasing daily on the Continent generally, could possibly have been. The wars of William III. against Lewis XIV. were not indeed fought for English purposes: but they were on the old English model. In the war of the Spanish succession, England was again on the imperial side, so she was also in the Hungarian and imperial wars that followed the death of Charles VI. Germany, whether represented by a Hapsburg or not, by Catholic or Protestant, is, as against France, the immemorial and natural ally of England: at least historically.

What, however, no doubt contributed largely, perhaps most largely, to terminate the period of international peace that we have been studying in this term's lectures, was the fact that the generation of weak men was being succeeded by a generation of strong ones: men with strong convictions, strong wills, and strong powers of administration. The sixteenth century was a period of strong kings : no period probably has ever seen at one time on the thrones of Europe so many great kings as there were during the nearly forty years that Charles V., Henry VIII., Francis I., and the Sultan Solyman governed their States. Even Philip II. and Elizabeth and Henry IV. are small beside these: but it is not in Philip II., Elizabeth, or Henry IV. that our period comes to its natural close. It is in Philip III., and Lewis XIII., and James I.

The period that follows is rich in great men; but they are not great kings. Ferdinand II. is a strong-willed man; but the figures of the period are Richelieu and Cromwell and Wallenstein; Gustavus Adolphus comes in rather as a general than as a king, an adventurer rather than the ruler of a European state. Under such men, or even during the prevalence of influences that raised such men to the surface and head of affairs, there could not but be great struggles. They were men with wills and policies and power: 
determination, whether against one another, or for the carrying out of independent purposes, which could not fail to meet with obstacles which could not yield without gigantic efforts.

I do not know whether we can, in point of principle, strike a balance between the great men of the sixteenth century and those of the seventeenth. The best men of the sixteenth were men of impulse more than of principle : men like Maurice of Saxony, Philip of Hesse, Henry IV. of France in his earlier career (even Luther was a man who had a great purpose, but an uneducated and disproportionate zeal) ; men whose principles were not incompatible with thorough immorality and dishonesty in the most flagrant extremes, but whose character in popular estimation was redeemed by energy and spirit. The men of the seventeenth had deeper purposes, more matured and educated zeal ; impulses better trained, deeper seated, less easily roused, but more consistent, more proportionate, more thorough. Men like Cromwell and Strafford are not to be named with Maurice and John Frederick. William the Silent is perhaps an exception, as he is an exception to most generalisations: but very much of his glory depends on the contrast between him and contemporary statesmen. His convictions and purpose and statesmanship, great or strong in contrast with those of his neighbours, will hardly bear comparison with those of the heroes of the seventeenth century.

But we have had enough of him, and perhaps of all of them. The period is not a lively one; and very much of its interest depends on its evolution from what precedes, and its influence on the time that was coming. 


\section{THE POLITICAL HISTORY OF EUROPE DURING THE THIRTY YEARS' WAR}

\section{LECTURE I}

\section{EUROPE AT THE OPENING OF THE THIRTY YEARS' WAR}

The first thing to be done in this present course of lectures is to attempt to get a clear view of the condition of affairs at the beginning of the period on which we are going to work, the origin and direction of the political forces which by their conflict produce the action of the period, and, if we can, some definite notion of the character of the actors with whom the action begins. The subject of the course is not the Thirty Years' War only, but the political history of Europe during that war; of Europe, that is the Continent, for we shall not venture on anything touching England directly except in so far as our own country joins in the action or is affected by the influences that are at work on the Continent. But as in this, in the same way as I have done in the former courses on this line of history, I propose to give our chief attention to German history, our second to France and Spain, and to content myself with very general reviews of the other members of the European commonwealth. We are sure to find the 'Thirty Years' War turning up at every step of our course; it is the central action, the plot of our drama. I do not then intend to anticipate by attempting in this lecture any summary of the acts of the drama, or any general sketch either of the process of the war or its results upon Europe at large. Such a view will be appropriate to the last lecture : an introduction must be of a different sort.

But, as usual, with one general remark, a general caution, I must begin. It should not be difficult for an Englishman to take a fair and impartial view of this eventful period. An educated Englishman should be as far removed from the persecuting repressive instincts of seventeenth-century Jesuitism as from the hypocritical and rapacious intolerance of seventeenth-century Puritanism. If he is left to himself he naturally feels that he has little in common with either, and that, given the authentic materials, he can with little difficulty 
strike the fair balance between the two great parties who divided the world. He is able to say at once how much of the repulsive character that is common to both belongs to the age and to the nationality of the combatants, and, measuring the two parties side by side, to strike out of the comparison all the points that are common to the two. He is not likely to screen and extenuate the cruelties of one party and to exaggerate those of the other, nor to blacken the character of the one in points in which he sees that of the other to be indefensible. And he is not hampered by the necessity of coming to the conclusion that one side of the two was infallible and impeccable. But when I say this, I say it with an important drawback, if he had the materials before him for forming a complete judgment. Unfortunately, we have not the materials before us in a shape in which they can be made available for such a decision. What we have is the work for the most part of bitter partisans; a sort of material every particle of which, before it can safely be used, requires a testing which we are not in condition to give it.

Although there are some, and those honourable, exceptions among the accessible writers on the Thirty Years' War, there are very few who have not thought it a part of their duty as historians to support the Protestant cause against the Catholic; and this bias is strongly perceptible in English books written before the revival of historical study in Germany. In the writings of German authors, that is of those German authors whose works find their way to England, and considerably leaven the history-writing of modern Englishmen, there is, besides the religious prejudice, a strong political one. History has been largely taken up by those German scholars who incline most strongly to Prussian interests in politics, or by those who, not being actually Prussian, still place their hopes of the German future in the line in which Prussian politics are working.

Now, at the period at which the Thirty Years' War began, Prussia and the Hohenzollern family made but a very small figure in European politics, and it would have been a fruitless task to attempt to show that so early as that they had marked themselves out as the future regenerators of European society. Hence the effect of the bias is rather to the depreciation of the powers which governed before Prussia began the work, or whose interests ran counter to the Prussian interests, after the resurrection began. Of course Austria and the house of Hapsburg is the victim of all such lucubrations. Beginning with an imaginary Charles V., and an imaginary policy of universal empire and unflinching repression, the whole existence of the Austrian dynasty is represented as a sin against society. In so great a house there must have been diversities of character; but 
there is no diversity of treatment allowable; every Hapsburg is a tyrant. If strong, he is a strong tyrant: if weak, he is a petty tyrant; if repressive, he is a shameless tyrant; if liberal, he is false and subtle, but still a tyrant. In every act of the drama of European history it must be shown that Austria has been clearly and determinately in the wrong. As soon as Prussia begins to exist she must be shown to be invariably in the right; until then it is enough to prove that Austria is wrong.

And what have we to set on the other side? Why, simply this. Writers in the Catholic, imperial, or Austrian interest have very commonly written as if the defence of the faith were a shield that covered all wrong-doings, as if shortsightedness in policy, unscrupulousness in action, faithlessness in covenants, might all be excused, because the Catholic ends were so great and good as to justify all means. A cause that allows itself to use such arguments is extremely difficult to defend; we are not concerned to defend it; but worse than that, it renders the judgment of an impartial person even more difficult than it would be, were the writers on both sides working merely to blacken the character of their adversaries. Still, on the whole, an Austrian partisan could afford to give a more favourable account of his enemies than the Prussian could. He feels that the heresy of his antagonist is a sufficient cause to condemn him, and that granted, he is not bound to make out circumstantially that all his virtues are vices. As for his own side, it is covered by the shield of the faith ; it is not necessary to make out all vices to be virtues. Thus the Austrian's position is damaged by the very comparative fairness of his own story.

You will, I doubt not, think that, in much of what I shall say, I am taking too mild a view of Austrian policy. I do it intentionally; historical fairness compels us to pull to the Austrian side in spite of its faults. It does not follow, because I insist on a fair trial for such men as Ferdinand II. and Maximilian of Bavaria, that I am blind to the virtues of Gustavus Adolphus and Bernard of Saxe-Weimar. So far as I can read history at all, I can see that the balance of right and wrong, of virtue and vice, is not uniformly the same at every stage or in every person of a dynasty. There is no cause so good that it can justify by argument in detail every act of its defenders, any more than there is any so good that the crimes of its defenders disappear or become less of crimes because they were done in support of it.

In pursuance of this line of thought we may approach our first introductory question: What was the Germany of the Thirty Years' War? In it what was there besides the Empire and the imperial house? What were the grounds of the differences between the 
North and the South, between the princes, the prelates, the people, and the nominal sovereign? Germany at the beginning of the imperial history was an aggregate of four nations, the Franks, the Bavarians, the Alemannians, and the Saxons; of whom the Franks and Alemannians or Swabians soon lose their distinctive national identities, but the Saxons and Bavarians retain both strong identity and strong antagonism. In all the early struggles of the Empire, North and South are opposed. Whilst the imperial dynasty is Saxon, Bavaria and Swabia are anti-imperial; when the imperial dynasty is Swabian or Bavarian, North Germany is in opposition to the Empire. As the imperial dignity settled down permanently into the South German houses, the Bavarian, Austrian, and Luxemburg lines, Saxony, that is North Germany, became the seat of constant disaffection. Against the Hohenstaufen it was the great bulwark of Papal interests ; against the Luxemburgers and earlier Hapsburgers it was in armed independence. So long as the struggle between the Empire and the Papacy lasted, North Germany was enthusiastically Papal. As soon as Austria and the Papacy reconciled their differences and became, as for the most part of modern history has been the case, firm allies, North Germany took up with ardour the doctrines of the Reformation; her antipathy to a Southern Cæsar was great enough to overcome her ancient and as yet unshaken constancy to the Chair of St. Peter.

Of course this was not the only ground for the characteristic position and attitude of the two divisions. Early Saxony was faithfully Catholic not merely because it hated the Emperor and his antipopes, but because it had been brought to Christianity and civilisation under men and principles according to which Roman Papalism was an integral portion of religion: and modern Saxony was not enthusiastically Protestant only because the Empire was Catholic and Southern, but because Luther and his friends the Saxon electors were natives of the land and spoke directly to the hearts of the people, and quite as much because the prelates who had grown wealthy on the old Papal support offered a rich booty to men to whom the change of religion was the relaxing of all ties of honour, duty, and regard for right of property, and who saw in the downfall of the old system the readiest way to aggrandise themselves. The three influences, the Empire, the faith, and the plunder, all affected the North Germans in the same way. And so the South: whilst the Papacy was politically strong, the imperial influence, mainly South German, was in opposition; witness the fate of the Hohenstaufen and of Lewis of Bavaria. With the great schism of the West, and the termination of the Babylonish exile, begins the drawing together of the Empire and Papacy. When the Reformation begins, the North 
accepts it and the South rejects it. But here with a great difference. In the North, princes and people alike reject the Papal authority in religion. In the South the princes are faithful, but the people become Protestant; and this adds a distinct complication to the many other complications that we are obliged to consider as leading to the great crisis of the Thirty Years' War.

I confess that to my mind this attitude of opposition between North and South, Saxon and Bavarian, or, as it becomes later, Prussian and Austrian, is one of supreme importance : so important that I think it yet a problem whether any permanently united organisation of Germany can be formed. ${ }^{1}$ Second to it is the attitude of imperialism and anti-imperialism ; meaning by imperialism, however, only the supremacy of Austrian influence, that being the sole imperialism that belongs to our present period; then the rival forces of Catholicism and Protestantism. Again, as to this last: in South Germany Protestantism grew as rapidly as in North : as I said just now, in the North the princes and the people went together, in the South they went different ways. In Austria, Bavaria, Swabia, and Franconia, the people became Protestant, the princes continuing Catholic. At one time the middle nobles in South Germany were also Protestant, but that was not long; strong repressive measures soon brought them back or disabled them, and chiefly they were discouraged by finding that Protestantism and plunder would not be allowed to go on together as they were doing in the North.

But although German Protestantism quickly took root in the South, it was distinctly a Northern product, distinctly Northern in affinities ; that is, Lutheranism presented itself to the rulers of South Germany as the political programme of their enemies and rivals in the North. Scarcely less hateful was the aspect of Calvinism : Calvinism was not only uncatholic, but it was French, it was Dutch, it was republican. Bavaria and Austria saw not merely doctrinal but political and dynastic principles arrayed against them under the name of Protestantism ; and their struggle against it was a struggle on the part of the dynasties for existence.

We ask, how was it that Protestantism failed in South Germany when it was backed up by the North, and had so little real strength set against it? the answer to this question should be supplied by the study of the period of sixty years that intervened between the death of Charles V. and the outbreak of the Thirty Years' War. It was caused, first, by the divisions of the Protestants themselves, the disputes between the Lutherans and the Calvinists, between the Saxon and Palatine Electors, and between the two branches of the house

1 These words were said before the events of 1871 . 
of Saxony ; secondly by the enormous exertions of the Jesuits, who by every means in their power or in the power of man, by preaching, by educating, by intriguing, by persecution, by persuasion, by bribing, by taxing, by force and fraud, threw their great and intricate organisation against the advancing tide of Protestantism and effectually stayed it; thirdly, by the material power and assistance which the German Hapsburgs and other Catholic princes could invariably look for from Spain under Philip II.- - a power which the Jesuits directly or indirectly could bring to bear where and when they pleased. By these three causes the victory of Protestantism was cut short, the interests of the Bavarian and Austrian dynasties thoroughly consolidated with those of the Papacy, and the South enabled to present a strong, united, and in the main a victorious opposition to the North.

Among the secondary causes were the retention of the imperial power by the house of Hapsburg, and the constantly available implement which was thus put in their hands for interfering with the chronic quarrels and jealousies of their rivals. So long as the machinery of the Empire, election and jurisdiction, was kept up, so long as the three ecclesiastical electorates continued Catholic, and the King of Bohemia's vote gave the Austrians a majority in the electoral college, so long it was in the power of the Austrian house to play off their opponents at their discretion. This had been early apparent when Charles V. broke the power of the Smalkaldic league, by setting up Maurice as competitor to his cousin in the Saxon Electorate; and as long as the Empire lasted this weapon remained effective. It was unquestionably a great fulcrum, by which Austria stopped the progress of Protestantism : Protestantism which it hated no doubt for its own sake sufficiently, but scarcely less because in the political programme of the Protestant North the first article was its own humiliation.

With these points in our minds let us recall the train of events that connects the religious peace which terminates the reign of Charles V. with the state of affairs at the accession of Ferdinand II. The two great principles laid down at the peace of Augsburg for a compromise between the two religious parties were, first, that called the Ecclesiastical Reservation, intended to restrain the Protestants from any further appropriation of the property of the Church, and secondly, the Imperial Declaration of Toleration, which was intended to preserve to the Protestants the toleration of their religious freedom. It cannot be said that either party honestly or sincerely accepted the compromise. But the guilt of breaking it first belongs to the Protestant princes, who were unchecked by any scruple in their attempts to appropriate the abbeys and bishoprics, at a moment 
when the Catholic party was far too much humiliated to attempt open persecution. During the reigns of Ferdinand and Maximilian the imperial power was but little exerted to compel the parties to keep the compromise: bishops renounced Popery and retained their sees in spite of the Ecclesiastical Reservation; and, by means of indults from the Empire, Protestant princes were elected to, and retained all their lives, the government of ecclesiastical states without taking orders. On the other hand, the Catholic party, as it revived from the severe shock it had experienced, stirred up by the Jesuits and by the restored life and discipline that flowed from the Council of Trent, began largely to proselytise, more largely to repress religious freedom, and, where there was room, to persecute.

The later years of Maximilian II., during which he fell more completely under the influence of Philip II., saw him less and less inclined to oppose the restoration of Popery. The Catholic reaction set in strongly both in Germany and France; and very considerable portions of Central Germany, which had been regarded as lost to the Church, were effectually and permanently reclaimed : Franconia especially, under the influence of the bishops of Bamberg and Würzburg, returned in large proportion to the faith. The Emperor Rudolf, who succeeded Maximilian, went in far more completely than his father had done for the reaction. Maximilian had simply allowed both parties to take their own course, but Rudolf and several others of the imperial family determined to give a firm support to orthodoxy. And the field for their action in this respect was principally their own immediate states: Bohemia, which had long before Luther been leavened by Huss with tenets opposed to the doctrine of Rome, and Austria, where the whole of the nobles and large portions of the country population had embraced Protestantism. The character of the policy of repression which was adopted in the Austrian states was not the same as that which had been exercised so cruelly and so unsuccessfully in France and the Netherlands. The Protestants were not burned, but their teachers were forbidden to hold services for more than a limited number of worshippers; they were next imprisoned and banished; then the professors of Protestantism were compelled to emigrate, and their places were filled by strangers, who both religiously and politically were bound to be faithful to their patrons.

Such was the line taken by the Catholic reaction in Germany: a more humane and also far more effective policy than that of Philip II., and one which, administered by the Austrian princes who were generous and humane by character, although determined in their pursuit of their great object, perhaps caused as little acute suffering as any religious persecution has ever done. Rudolf him- 
self, however, had no energy of any sort, and whilst his influence was supreme in his own states, men went very much their own way.

The great start of the reaction in the Austrian states dates from 1597, when Ferdinand of Styria, the archduke who ultimately became Ferdinand II., set his shoulder to the wheel and rapidly succeeded in turning back the tide of the Reformation in that country. The zeal of Ferdinand revived the zeal of Rudolf, who also began to proscribe and banish Protestants in Austria; and, wherever the imperial jurisdiction gave him any power, to throw his weight into the Catholic scale. The able man of the party was, however, Maximilian of Bavaria, whose long reign covers a great part of the Catholic counter-reformation and the Thirty Years' War also.

Well, the success of the reaction at last awoke the fears of the Protestant princes. As early as 1594 at Heilbronn, several of them had formed a confederation for mutual defence, and resistance to the imperial claims. In 1597 they renewed this league at Frankfort, with additional provisoes bearing on religious points : thus united they had concluded at Heidelberg in 1603 an alliance with Henry IV. of France, the object of which was the destruction of the house of Hapsburg and the remodelling of the state system of Europe; and in $\mathbf{1 6 0 8}$ they had formed themselves into a league, at Aschhausen, called the Protestant Union, which was to keep together for ten years, under the presidency of the Elector Palatine, who was a Calvinist. The formation of the Protestant Union was regarded as a challenge by the Catholics, who in reply formed themselves into the Catholic League under Maximilian of Bavaria. Thus, under the two rival princes of the house of Wittelsbach, the two parties stood face to face nearly ten years before actual hostilities began.

Many circumstances contributed to delay the general outbreak for which all things seemed now ready; the first and most important was undoubtedly the death of Henry IV. at the moment that he was going to march into Germany to adjust the succession to the Berg-Juliers inheritance, as it was said, but in reality to attempt the overthrow of the Hapsburgs, in consequence of which the war was smothered in its beginning. Another was the split in the imperial house itself, and the result from that split, that each of the parties attempted to win the Protestants by concessions. Rudolf, by his negligence and eccentric conduct, had lost the affections of the Austrians, and by his repressive policy had provoked the populations of Bohemia and Hungary-for Hungary was largely. Protestant and always discontented-to throw off his yoke.

Advantage was taken of this state of things by his younger brother, the Archduke Matthias, who had led an adventurous life, 
and had been the nominee of William of Orange as Governor of the Netherlands at the time when there seemed a probability of their succeeding in shaking off the yoke of Spain, and who had, in 1607, succeeded in wresting the Hungarian crown from Rudolf. Matthias was a not less strong Catholic than Rudolf, but he had more suppleness and more power of intrigue. The only justification of his conduct is to be found in the fact that, had he not stepped in, Rudolf would have lost the richest part of the family inheritance in circumstances which rendered it very improbable that it could ever be recovered. By intriguing with the malcontents in Bohemia, he got himself called in to mediate between them and the Emperor, who was trying to obtain the succession for Leopold, his cousin, and Matthias's rival. Leopold had brought into Bohemia the army which Rudolf had collected to oppose Henry IV. and the Evangelical Union, and had frightened the Bohemians with an alarm of persecution. Matthias then succeeded in supplanting Rudolf on the Bohemian throne as he had done on the Hungarian. This was in 1611.

In 1612 Rudolf died, and the Empire was open to election. The choice of the electors seemed practically confined to the Austrian archdukes, for, except Maximilian of Bavaria, all the princes who were of rank sufficient to allow them to be competitors were Protestants, and the idea of electing a Protestant Emperor was never broached. The Protestant electors would, however, gladly have had either the Archduke Albert of the Netherlands or the Archduke Maximilian, the grand master of the Teutonic knights. They, true to the family tradition, refused to be put in nomination, and Matthias, who was trusted by neither party, became Emperor. But he found his power, when he got it, nothing but labour and sorrow. $\mathrm{He}$ had intrigued with the Protestants against Rudolf, and could not expect the Catholics to trust him. The Protestants were not likely to trust a Catholic who had so clearly only used them for his own ends. In vain he attempted to hold the balance between them. He saw a successor in Ferdinand of Styria, gradually gaining upon him in the support of the whole Catholic interest of Germany. As he had edged out Rudolf, he was now edged out by Ferdinand.

But this time all was done decently. Neither Matthias nor any of his brothers had children, and the result of the succession being left open on his death would be probably a redivision of the estates of the house, in which no one would be strong enough to attempt to hold the old family position in the Empire. I need hardly remind you how strong the family feeling has always been in the great ruling houses of Germany. The Archduke Maximilian, in the interest of the family, proposed in 1617 that the surviving members 
should yield their claims on the succession to the Archduke Ferdinand of Styria. Matthias saw no help but to agree. Contrary to the advice of his minister, Klessel, and unwarned by the example of his brother Rudolf, he obtained for Ferdinand the succession to Bohemia in 1617, and in the following year the Archduke secured the crown of Hungary. He did not wait for the death of Matthias to undertake the administration of his estates. He began to attack the Bohemian Protestants at once; and, to prevent any attempt on the part of Matthias to recover power, carried off and imprisoned Klessel.

It was the persecution by Ferdinand, begun before the death of Matthias, that kindled the flames of the Thirty Years' War. The materials were all ready long before. The Protestant Union was ready for the struggle, and intriguing for the imperial succession. Ferdinand was known to be an able and determined Catholic: such a one as had never yet sat on the throne of Charles V. Ferdinand I. had been a fair and honourable mediator; Maximilian II. more than half a Protestant; Rudolf had been a nobody; Matthias was incapacitated by his own engagements, and was already shelved. But Ferdinand was able and determined. If it were possible to prevent his accession to the imperial throne, the fate of Catholicism in Germany would be sealed. It would not be possible to elect a Protestant Emperor, but the gift of the Empire might be made a bribe to secure the adhesion of some prominent Catholic to the anti-Austrian scheme. Maximilian of Bavaria, it was thought, might be detached; on his refusal, the Duke of Savoy was sounded in vain. But before an attempt could be made to secure the imperial crown, the Bohemian vote must be made safe. A change of dynasty in Bohemia would have the effect of altering the balance in the electoral college. Bohemia was in a state of discontent and rebellion. Matthias once out of the way, the election of Ferdinand might be set aside as unlawful, and a Protestant King substituted. The Protestant party would then have four out of the seven votes in the election.

But no one was anxious to seize on the succession. The battle would have to be fought by the Protestant Union, and the head of the Protestant Union was the Elector Palatine. The Elector Palatine was not a wise man nor a bold man: but he was wise enough not to covet either of the dangerous crowns. Moreover, he was a Calvinist, whilst far the greater proportion of Protestant Germany was properly Protestant: that is, Lutheran after the Confession of Augsburg. But the Electress Palatine Elizabeth Stewart, daughter of James I. of England, was ambitious, and strong-minded, and romantic at the same time, and she would be a 
queen. Under her persuasion Frederick began to regard himself as King of Bohemia soon to be. But the crown was not yet within his reach. So long as Matthias lived no successful attempt could be made legally to set aside Ferdinand.

Ferdinand's own intolerance made the opening that was waited for. His chief ministers in Bohemia were Slavata and Martinitz, two very determined enemies of the Protestants, and active persecutors. The leader of the Protestant party was Matthew Henry, Count of Thurn. The council of regency consisted of ten members, seven Catholic, of whom Slavata and Martinitz were two, and three Protestants. The religious toleration of Protestantism in Bohemia had been secured in 1611 at the accession of Matthias. This, then, was the situation of affairs. The accession of Ferdinand was viewed with horror by the Bohemians ; Martinitz and Slavata would be ready instruments, and had already shown that they knew how to persecute. Count Thurn was the natural leader.

To look back a little further, the exact circumstances that led the way to the revolt were these: By the royal edict of toleration (the letter of Majesty, July 5, 1609, wrested from Rudolf by the Protestants when they revolted before the election of Matthias), the towns which were members of the Bohemian estates were enabled to build churches and schools for Protestant worship; but this did not extend to those towns which were in the demesne of lords, only to those which were immediately under the crown, members of the states. Two towns in demesne, Brunau, which was subject to the Abbot of Brunau, and Klostergraben, which was subject to the Archbishop of Prague, built themselves churches, under a mistaken interpretation of the edict. Ferdinand, soon after his coronation, directed the demolition of the churches. Count Thurn, anxious, it would seem, for a pretext against the government, declared this a breach of the edict; and, in his capacity as one of the defenders of religion, called a meeting of delegates to Prague to protest. The delegates protested violently, demanding the expulsion of Martinitz and Slavata from the council of regency, and, having obtained admission to the council, threw the two out of the window, May 23, 1618. Thus the revolt broke out before the death of Maximilian, before the imprisonment of Klessel, which did not take place until July 20, 1618. It was the spark that set the whole mass ultimately on fire. We have, however, some further generalisations to make before we can begin the war. 


\section{LECTURE II}

\section{THE BOHEMIAN STRUGGLE}

THe first act or episode of the Thirty Years' War is this Bohemian struggle, some sketch of which I began to give in the last lecture. This act has a certain completeness of its own; it is concluded without bringing any of the other European powers outside of Germany openly into the arena. I shall then in the present lecture, after recapitulating in chronological order the train of events that I grouped together in the last lecture, proceed to detail the remaining particulars of importance of the years 1619 and 1620.

Our train of events begins with the accession of Ferdinand to the Bohemian throne. His coronation took place on June 29, 1617. He promised then and there not to interfere with the government of Bohemia during the life of Matthias. Matthias's chief minister, Cardinal Klessel, was opposed to his master's resignation, and was more anxious to maintain the peace of the country and the tenure of it by the house of Austria than to persecute the Bohemians into Catholicism and lodge the supreme power in the hands of Ferdinand in particular. Besides the opposition of Klessel, the Protestant princes of Germany viewed Ferdinand's promotion with great dislike, and, as we said, began to contemplate a countermovement even before the opening for their interference was made. The events at Klostergraben and Brunau took place soon after Ferdinand's coronation, and the appeal to Matthias on the subject showed Ferdinand the irreconcilable opposition between his views and those of Klessel.

The assembly of delegates called together by Count Thurn to petition the Emperor for redress took place on March 6, 1618. Matthias's answer was that he would not interfere between the vassals and their lords, who, acting on an imperial prohibition, had closed the heretical churches. This closing of the churches may seem to us an act of religious persecution, but there is, I think, no doubt that it was warranted by the law, and neither is there any doubt, I think, that the action taken on the occasion by Count Thurn was the result of a deeply laid plan to throw off the Austrian yoke: the Protestant powers watched the progress of events, and on May 14, 1618, renewed the Union for three years. It was, no doubt, the knowledge of some ready help to come from this quarter that emboldened the delegates to execute, on May 23, the famous defenestration of Slavata and Martinitz, and to effect the institution of a provisional government in Prague. 
The rebellion in Bohemia accelerated the action of the Union. Now it seems to have been that they determined to offer the imperial crown to the Duke of Savoy, and to place Frederick, the Elector Palatine, on the Bohemian throne. But neither party had much of an army at command. Matthias was very reluctant to come to blows with the Bohemians. He sent an army, under his two generals, Dampierre and Bucquoy, into the country, but he spoke fairly to the provisional government, and really hoped, it would seem, to settle the matter pacifically. Two parties, however, were concerned, besides the Bohemians and Matthias, who were determinedly set against compromise: Ferdinand, who was prepared to risk everything for the Church, and the Evangelical Union, who were determined not to tolerate Ferdinand. In order to get rid of the moderate counsels of Klessel, Ferdinand, on July 20, kidnapped him away from Vienna; and the Union about the same time took up arms in support of the Bohemian government. It sounds curious to hear that just at this time-July 7, 1618-Ferdinand succeeded in acquiring the Hungarian crown.

The interference of the Union in Bohemia was preceded by a meeting at Rothenburg, which addressed to Matthias a strong remonstrance on his treatment of the Protestants; and then an army under Mansfeld was sent into the country. The date of Mansfeld's attack on Pilsen is November 1618. Whilst he and Dampierre and Bucquoy were maintaining an attitude of mutual defiance and neutralising one another's influence, the Bohemians, under Count Thurn, were rapidly revolutionising Bohemia, and even ravaging the Austrian states. The weight of power and force was conclusive against Matthias for the moment. He had no other army than that under Dampierre and Bucquoy, and Ferdinand had none at all. As the winter approached he proposed peace, and an arbitration between himself and his subjects, to be made by the Duke of Bavaria and Elector of Mentz on one side, and by the Electors Palatine and of Saxony on the other. The day was fixed for a conference to adjust preliminaries, April 14, at Egra; but before that Matthias was dead, March 20, 1619.

The position of Ferdinand was anything but promising; nothing but great luck or great ability could have saved him. The German Protestants were determined to be rid of him; Bohemia was in a state of revolution; he had no strong support in Europe, although, no doubt, England, France, and Spain viewed the rebellion with aversion; and it was absolutely vital to him to obtain the election to the Empire. But he had very considerable ability, very great luck, and above all, enemies to deal with who were strong neither in principle nor in union. The death of Matthias seems to have put an 
end to the idea of a conference. Ferdinand was not likely to compromise matters, even if he were without resources. He addressed the Bohemians with pacific professions, but did not recognise their new government, and directed, without any power of enforcing his orders, the restoration of the unpopular council of regency. On the other hand, the provisional government would not recognise him. Thurn proceeded in May to revolutionise Moravia as he had already done Bohemia, and prepared the Bohemian estates to elect a new King. In the following month he entered Austria, and on June 6 blockaded Ferdinand in Vienna.

Ferdinand had no other force than that opposed to Mansfeld in Bohemia. The people of Vienna were disaffected and excitable. Almost alone he held out against his vindictive antagonist; he sent away his family into Tyrol, refused to listen either to Thurn or to the revolted Viennese, and awaited his fate with intrepidity. Just at the desperate moment, with the townspeople clamouring for surrender and Count Thurn thundering at the gates, he was relieved by the arrival of 500 brave men, whom Dampierre had detached to his assistance. This little band penetrated the town by the only gate that the Bohemians had been unable to close, and their presence restored order in the city. It is suggestive of the vast difference between ancient and modern warfare to read of 500 men in such circumstances saving an empire. What little force Ferdinand had was far away; Thurn, at the head of the Bohemians, was unable completely to beleaguer Vienna; and the arrival of 500 men turned the scale. Vienna has always been famous for hairbreadth escapes, and this was a signal one. The $\mathbf{5 0 0}$ disciplined soldiers got the city into order, revived the spirit of the loyal and intimidated the traitorous, organised a defensive force, and successfully held the city against Thurn, until news arrived of the defeat of Mansfeld by Bucquoy at Tein on June 8, in consequence of which the besieging army was suddenly withdrawn.

The raising of the siege enabled Ferdinand to set to work at once to secure his election to the Empire. He placed the defence of the estates in the hands of the Archduke Leopold, and went into Germany. The meeting of the electors was called for July 20 at Frankfort. For a short time there is a lull in the war and fighting gives place to intrigue, until this affair is finished. The business of the election is curious as well as important. During the vacancy of the imperial throne, the office of Vicar of the Empire was discharged by the Elector of Saxony and the Elector Palatine, the latter of whom, as president of the Protestant Union and intending to be King of Bohemia, was anxious to thwart Ferdinand, whilst the former, as a Lutheran, had to choose between the Catholics and the Calvinists. 
The object of the Elector Palatine was, as his overtures to Bavaria and Savoy were ineffectual, to prolong the interregnum until some arrangement could be made for transferring the Bohemian vote from Ferdinand to himself. $\mathrm{He}$ urged delay. Ferdinand urged the importance of promptness, and, although none of the electoral body seems to have been enthusiastic in support of Ferdinand, he triumphed.

The ecclesiastical electors and Maximilian of Bavaria, who, although not himself an elector, was the most important man of the Catholic party and directed the policy of the archbishops, inclined to peace at any price. They had seen the progress made by the Counter-Reformation in the way of quiet repression, and although fully determined not to yield an inch, but to maintain an attitude of armed resistance, still felt averse to the actively aggressive policy to which Ferdinand was considered to be attached. Of the three ecclesiastical electors, Ferdinand of Cologne was brother to Maximilian and brother-in-law to Ferdinand; John Suicard, the Elector of Mentz, was an earnest and politic churchman; the Elector of Treves, Lothar von Metternich, was a prominent man in the reaction, and, with the Elector of Mentz, was the founder of the Catholic League. Of the lay electors, Frederick himself was one; John Sigismund of Brandenburg, who had embraced Calvinism in 1613, and was likely to act in concert with him, was another; and the third was John George of Saxony, who at once represented the Lutheran religion and maintained the imperialist tendencies of his house. In this combination there was not much material to work upon; the ecclesiastical party, though not enthusiastic for Ferdinand, accepted him as the only safe candidate; and the Elector of Saxony had no great objection to him. The Palatine and Brandenburg electors were in a hopeless minority.

But if the Empire was unassailable, the Bohemian crown was within reach. An earnest appeal for delay was listened to, and the day of election deferred till August 28. The Bohemian estates were then immediately summoned; a list of grievances against Ferdinand was exhibited, and his election annulled. A new election followed. and the estates of Moravia, Silesia, and Lusatia admitted to take part. On August 27 Frederick, at Prague, was elected King of Bohemia ; and the next day at Frankfort, Ferdinand was elected Emperor. Frederick was crowned on October 25 by the administrator of the Calixtines: Ferdinand on September $\mathbf{9}$ by the Archbishops of Mentz and Cologne.

As for the constitutional aspect of all this, there is no doubt that the Bohemians had strong grounds of complaint against Ferdinand. $\mathrm{He}$ had, contrary to his undertaking, interfered in Bohemian affairs 
during the life of Matthias, he had sent or continued the employment of foreign troops in Bohemia, and had, by undertaking to procure the succession for the Spanish branch of the family on the failure of the German one, infringed the right of the Bohemians to elect their own king. But it is very questionable whether these grievances could have constituted a legal argument for his deposition, and it should be remembered that the opposition to him in Bohemia dated much earlier than any of his transgressions. It is not enough to show that Ferdinand was guilty without showing that he was not forced deliberately into his false position : the defenestration and its consequences amply justified his interference and the mission of such troops as he had to send. This, however, matters little. Whichever side was right and whichever wrong, the plan of Count Thurn and the designs of Frederick on the kingdom are more than enough to show that Ferdinand's sins were a mere pretext of aggressive enmity, an enmity which might have been perfectly just in itself, but was not justified by these pleas.

The failure of the Protestant opposition at Frankfort to impede Ferdinand's election had the effect of making it an easier matter than it would have otherwise been: instead of a strict capitulation with new safeguards, as was usual, the only two new articles were of merely technical import, touching the right of the Vicariate and the machinery of the Aulic Council. Thus, then, on August 27 and 28, the two great parties saw placed at their heads two Kings of Bohemia, a Catholic and a Protestant one, adding to their religious differences the hatred of personal rivals, the vindictive bitterness of personal wrongs.

No formal truce had been made to facilitate these proceedings; but the occupation of the principal actors had caused a momentary lull. It was broken by Bethlen Gabor, the Prince of Transylvania, who represented the anti-Austrian feeling in Hungary, although he had personally supplanted, a few years before, the recognised head of the Transylvanian party. He was one of the determined Protestants who had urged Frederick to set aside his scruples about accepting the Bohemian crown; and, seeing that that stroke had succeeded, he determined to play the same part in Hungary. He marched into that kingdom, raising all the malcontents as he went, and on October 20 took Presburg. From Presburg he advanced into Austria at the head of a huge horde, and drove Bucquoy, upon whom the defence of the country against Count Thurn had been imposed by Leopold, and who had been brought from Bohemia where he was rapidly gaining on Mansfeld, to take refuge in Vienna.

Ferdinand, on his return from Germany early in November, found himself, from a military point of view, little better off than he 
had been when he undertook the journey. The withdrawal of Bucquoy from Bohemia had enabled Mansfeld to recover his lost ground. He had retaken the towns that had been compelled to submission. Budweis was the only place in the Bohemian kingdom that remained to the Emperor. But the worst was now come. The approach of winter put a stop to hostilities. Bethlen Gabor was unable to support his great army at such a distance from home and withdrew from Austria, styling himself, however, King of Hungary.

Both parties devoted the season to an attempt at obtaining new and efficient allies; that is, to make the war, which was as yet confined to the Austrian states, and was nominally between Ferdinand and his rebellious subjects, a German if not also a European war. It was not yet even a German war. The two great organisations had not yet drawn swords against each other, although both were armed, and saw probably that the end was not far off.

Before the end of November the Protestant Union met at Nuremberg. The meeting was attended by the Count Palatine, the Duke of Saxony of the Ernestine house, the Margrave of Brandenburg, the Duke of Würtemberg; the Landgrave of Hesse, and the Margrave of Baden. Every house that had accepted the Reformation in either of its two great phases was represented. Frederick, the new King of Bohemia, the president, appeared in person, and even the Emperor sent envoys to represent his interests and watch the proceedings, the discontented Austrian states also being present by deputy. Ferdinand's envoys were received: on his part they promised peace and remedial legislation, and exhorted the confederates not to break up the peace of the Empire. Frederick pleaded his own cause more effectually; but his personal influence was enough to secure his success. In reply to the imperial envoys the Union answered that no credit could be attached to the Emperor's promises. They presented a long schedule of real and formal gravamina touching the constitution and action of the Aulic Council. They insisted that the Emperor should procure the disarmament of the Catholic League, in which case they would themselves disarm. As for Bohemia, they were bound both by religion and by self-preservation to see that no wrong was done there, and certainly would not allow the new King to be molested in his own hereditary states.

The Catholic League was not less on the alert. Ferdinand on his way home from the coronation betook himself to his brother-inlaw, Maximilian, and agreed with him on the plan to be pursued. Allies were to be sought for everywhere, and the Emperor must even submit to a small diminution of territory, if it were necessary, to secure ultimate victory. A meeting of the League was called at Würzburg, at which new resolutions were taken for the support of 
the Catholic faith ; new members, especially the Duke of Lorraine, were taken into the confederation, and it was determined to seek succour for the faith from the Pope and the King of Spain.

The winter was devoted by both parties to the formation of alliances and the collection of forces. The Protestants looked with confidence to England and Holland and the North ; but they relaxed nothing in their efforts to bring together a thoroughly German army. The Catholics applied to France, where the Duke de Luynes was now prime minister, having just succeeded in supplanting Anne of Austria and the Concinis; to Spain, where Philip III. was getting into his last years, and to Rome. The request for aid was only partially successful on either side. James I.-divided between the desire of pleasing his people, who were enthusiastic on the side of the Count Palatine, and the fear of a quarrel with Spain; between the wish to preserve the inheritance of his grandchildren and the dislike to encourage the Bohemians in their deposition of their lawful sovereign - at length decided on sending 4,000 men to Holland, who were to set free 3,000 Dutchmen for the assistance of Frederick. $\mathrm{He}$ sanctioned also the assembling of 2,400 volunteers to aid the Count Palatine. The 3,000 was the contribution of the United Provinces towards the defence of religion. Hungary, under Bethlen Gabor, might be relied upon, and, although the Northern powers were slow to move, the German princes showed so much energy as might safely be expected to maintain the struggle until they should be able to assist them.

The cause of Ferdinand was not less well supported: Philip III. was prevailed upon by the threats and remonstrances of the Austrian ambassador Khevenhüller, and in opposition to the advice of the Duke of Uzeda, his prime minister, to furnish 24,000 men under Spinola (Ambrosio) to invade the Palatinate from the Netherlands. The Pope granted a tenth of all Church revenue in Spain, Italy, and the Netherlands, and a monthly subsidy of 20,000 zecchins. France would not furnish either money or soldiers, but would urge peace and attempt mediation. Immense forces were in the meantime collected in Germany itself, and the crisis was looked for early in the spring.

Before the crisis came the fortunes of Ferdinand began to look up. In January 1620 he felt strong enough to issue a formal document declaring the election of Frederick to be null and void; the next month he obtained from Saxony the assurance of neutrality, soon to be followed up by active assistance; and, what was even more important, he concluded a truce with Bethlen Gabor, which relieved him from pressure on the side of Hungary. These were the beginnings of a change. 
Whilst Frederick was making a royal progress in the Bohemian States, Ferdinand was intriguing might and main. In March the Lutheran party, Saxony and Hesse, at Mülhausen, joined the ecclesiastical electors in a demand on the Union to abstain from interference, and in a request to Frederick to resign the crown. It was only by the strenuous opposition of the Electors of Mentz and Saxony that they were prevented from putting him under the ban of the Empire. At the same time they declared to the Union that the dispute was not a religious dispute, and ought not to be treated as if liberty of religion were at stake. The Union was perfectly aware of this; its object was avowed, not only to secure religious liberty, but to limit the ambition of the house of Austria, to which it attributed the design of establishing a supremacy in Europe, and consequently a crusade against all the forms of Protestantism.

These mutual threats, however, of the great parties did not expedite the war. Fighting was still going on in Bohemia, but not a blow was struck in Germany. Only the two great armies drew nearer and nearer, and at last encamped over against one another, the host of the Union under the margrave of Anspach, Joachim Ernest of Brandenburg, at Ulm ; and that of the League, under Maximilian, at Günzburg. Large as the army of the Union was, the confident spirit that pervaded the Catholic army was wanting, and they had no leader like Maximilian.

As they were waiting for battle and Europe watching them, the French envoys, the Duke of Angoulême at their head, arrived, and, instead of a battle, negotiations took place, the result of which was an agreement between the Union and the League, arrived at on July 3. By this it was determined that the attitude of hostility between the two great parties should cease; the League undertook not to attack the Palatinate, and the Union to abstain from interference in Bohemia. Nothing but the certainty of failure or internal treason could have moved the Union to submit to such terms as these. The League was left free to fight Ferdinand's battles in Austria and Bohemia; the Union undertook to maintain the integrity of the Palatinate against Spain and Austria: a most unequal division of responsibility in reality, although in words it appears plausible. Virtually it was a surrender of Frederick to Ferdinand, as the consequences rapidly showed. No doubt there were both internal dissension and something like treason among the Protestants ; the Margrave Joachim Ernest of Brandenburg was strongly suspected of corruption and jealous of the exaltation of Frederick; but the most powerful solvent was, no question, want of sympathy and despair of success. The Lutheran party, Saxony, Denmark, and Hesse were on the Emperor's side, and the remainder 
of the Protestants were not even united by a common Calvinism. Further, as I said before, there was no leader who inspired confidence.

As soon as the treaty was concluded the armies separated; that of the Union marched into the Lower Palatinate, and that of the League into Upper Austria. Spinola, with 20,000 veterans, was already occupying the former country, and against him the army of the Union, under the Margrave George Frederick of Baden, was perfectly powerless. Spinola marched to the Rhine without opposition; his enemies did nothing before the winter compelled them to return home; and before the winter the fate of Frederick was decided. The attack on Bohemia was managed with the utmost ability and crowned with complete success. Maximilian of Bavaria undertook the reduction of Upper Austria. The King of Poland, Sigismund III., an energetic Catholic (who had been also King of Sweden, and had tried hard to restore the Church of Rome there, losing his kingdom for that reason in 1604), poured a horde of Cossacks into Silesia ; and the Elector of Saxony invaded Lusatia, persuaded by the promises of Ferdinand and by his jealousy of the Calvinist predominance in his immediate neighbourhood. The imperial forces were thus at liberty to concentrate upon Frederick; and Bucquoy, at the head of them, was able to agree on a project of campaign with Maximilian, whose work in Upper Austria was soon accomplished.

Against these the only ally on whom Frederick could depend was Bethlen Gabor, who at the expiration of the truce had declared himself King of Hungary and renewed the war. The third imperial army, under Dampierre, was sent against him. The odds in Bohemia were very uneven. Frederick had not more than 20,000 men, and an auxiliary force of 8,000 Hungarians; he had many brave friends, but few generals. Christian of Anhalt, John George of Jägerndorf, the Count Hohenlohe, and Ernest of Mansfeld, the last of whom supported his army by plunder, were all. Even the affection of the Bohemians and Moravians was alienated by his Puritanism, and Count Thurn, who had made him king, was offended by being displaced to make way for the Duke of Anhalt. In every respect Frederick showed himself at once without capacity, tact, or personal courage. His Calvinism and his wife were the two strong points about him, and they did him fully as much harm as they did good. Steadily the Germans under Maximilian, the Italians and Spanish forces under Bucquoy, advanced upon him, the united forces amounting to 50,000 men.

Count Tilly, John Tserclaes, one of the two great names of the Thirty Years' War, a Netherlander by birth, of Brussels ; a devoted 
and unscrupulous Catholic, and an almost invincible soldier, was Maximilian's chief adviser. Under his arrangements the two armies entered Bohemia by different routes, from the south, and joined at Pisek on September 30. The army of Frederick was at Presnitz, in the north-western corner of Bohemia, inferior vastly in numbers, and with divided counsels. Frederick himself was hovering between Presnitz and Prague. Pisek was one of the most important fortresses in Bohemia ; there was nothing fit to present an obstacle to the enemy between it and Prague. It was summoned to surrender; but before the terms were agreed upon it was taken by escalade by the Walloons and Cossacks, and, notwithstanding the efforts of Maximilian and Bucquoy, cruelly sacked. The terror of the example was so great that all the strong towns of Western and Southern Bohemia at once gave in their adhesion to the Emperor as King of Bohemia.

The next town to be besieged was Pilsen, where Count Mansfeld commanded, and towards which Frederick was gradually bringing up his forces. The season was, however, now far advanced, and the commanders were averse to undertaking a regular siege. They moved off in the direction of Prague. Constant skirmishes took place between the advanced posts of the two armies, but no general battle; Frederick being gradually driven back on the city of Prague itself. After a vain attempt at negotiation, Frederick encamped the remains of his divided, discontented, and demoralised army on the Weisserberg, close to the south-west side of Prague; there they attempted to raise defences, whilst he himself took refuge in the city itself. On November 8, 1620, was fought the battle of the Weisserberg or of Prague. The Moravians under Christian of Anhalt and the younger Count Thurn fought bravely, but the Hungarians fled at once, and the Bohemians made no effort. The battle was over in an hour. Frederick at the time was giving a banquet in the city, and although the alarm of the engagement reached him, his good manners prevented him from leaving the table. When he at last rose, he found the gates of the city closed and the fugitives demanding admittance.

Frederick showed the spirit of a mouse. He demanded a truce of twenty-four hours. Maximilian offered him eight on condition of his renouncing his claims on the crown. Frederick purchased the eight hours' truce by resignation, and decamped at once. His friends were heartily ashamed of him. They tried to show him that the struggle was far from lost; that Pilsen was still untaken; that a large Hungarian force was at Brandeis; that he was behaving treacherously and cowardly; that his position was no worse than that of Ferdinand had been when, but a year before, he was besieged 
in Vienna. It was all in vain. Panic fear had seized the unlucky prince, and off he went. With his wife and family, Anhalt, Hohenlohe, and Thurn, he escaped to Breslau in Silesia, and thence to Berlin. The people of Prague, seeing themselves deserted and their defenders dispersed, surrendered at once; the States consented to acknowledge the Emperor as King on November 13. Mansfeld only continued to hold out at Pilsen and Tabor with the remains of the army, and he was obliged to confine himself to defensive warfare.

Bohemia was thus, before winter, at the feet of Ferdinand, and the first act of the drama was closed. The characters of the two competitors are well shown by their conduct at Vienna and Prague, and the difference of their characters is almost by itself enough to account for the result of the war. Ferdinand was a man of invincible spirit and determined perseverance. He was a pupil of the Jesuits in their best days ; accomplished, vigilant, politic, and brave ; narrowly and devotedly Catholic, but in all other respects a man who, had he been a Protestant, would have been a first-rate Protestant hero. He was a good husband and father, pure in life, temperate, religious to fanaticism, and with the fanaticism unscrupulous in word or deed such as might defend the great cause. On the other side was Frederick, the Calvinistic champion, vain, presumptuous, and cowardly; as intolerant as Ferdinand, but without any of his great or good qualities; unable to command, unable to deliberate, an intriguer without craft, and ambitious without either courage or perseverance. The facts of his having a beautiful wife and of being an uncompromising Puritanical Calvinist are scarcely enough to warrant us in making a hero of him. Far worthier and greater men are now to take up the part that he has so signally failed to play. As for himself, his failure is complete, but the punishment has yet to be paid.

The end, then, of 1620 saw the Emperor completely triumphant, the only misfortune of the war being the loss of Dampierre, who was killed in Hungary and his army routed by Bethlen Gabor. We have next to see how the victorious party used their triumph, and how the war which seemed to be thus rapidly extinguished came to be a Thirty Years' and European war.

\section{LECTURE III}

\section{THE DEVELOPMENT OF THE WAR}

Never, probably, in European history had been a reverse so sudden and so entire as that of Frederick of Bohemia : the victory of the Weisserberg made him in a moment a beggar and an exile. But it 
did not follow immediately that Ferdinand's position became correspondingly strong, or strong enough to enable him to be merciful. He determined to hold no terms with either the usurper or his supporters, and he was not the man at any time to temporise or to make any secret of his intentions.

Within the limits of Germany the state of affairs was this during the winter of 1620 :-Mansfeld was yet in possession of Pilsen, Tabor, and the neighbouring places in Bohemia; and in the Palatinate, Heidelberg, Mannheim, and Frankenthal had been able, under English commanders and officers, to hold out against Spinola. Within the territories that he had or claimed, these few towns were all that were left to Frederick. Ferdinand, on the other hand, was hampered everywhere by the smallness of his forces and by the variety of his enemies. The loss of Dampierre, who had fallen at Presburg in October, had to be replaced by the mission of Bucquoy into Hungary, and the mission of Bucquoy involved the employment of Maximilian and Tilly to watch Mansfeld. At the same time Silesia was anything but quiet, and indeed it was nearly a year before that province was brought to submission. He was further deep in debt; Upper Austria was pledged to Maximilian for the expense of the war ; and Lusatia was promised or given to the Elector of Saxony in consideration of his support. Nor was the imperial position strong in Germany. It never indeed was strong, and the mere collapse of the opposition, by the self-stultification of the Evangelical Union at Ulm, was not enough to throw life into the system which had been for the moment victorious. The Evangelical Union still existed; among the Protestant princes who were not in the Union there were many who would be ready to oppose to the death any attempt, either to limit the extension of Protestantism or to recover the lost endowments of the Roman Church. Even amongst the Catholics there was a strong feeling against any measure which should destroy so great and ancient a member of the Empire as the Elector Palatine.

Outside Germany, the world had enough to do to mind its own business just now. James I. was deep in the plans of the Spanish marriage. France was just beginning a religious war waged by the Court against the Protestants under Rohan and Soubise. The truce of twelve years, made between the United Provinces and Spain, was on the point of expiring (April 10, 1621), and, as soon as hostilities should recommence, Spinola would have to be recalled from the Palatinate. In Spain Philip III. was approaching the end of his reign, and although he was well disposed, as he had shown, towards the Austrian branch of his house, any attempt at common action was viewed with the greatest jealousy by both France and the 
Italian powers; it was at this moment proved by the resistance opposed by France and Venice to the attempt made by the Spanish and Austrian armies to seize the Valtelline and so establish a communication between Milan and the Tyrol.

Ferdinand, in view of these complications, seeing that any moment might so alter the state of affairs as to throw the forces that were now keeping one another in suspension into energetic action, determined that on his part no time should be lost. He could not afford to be merciful; he might as well push his severities to the point of vindictiveness. The Union had had in November a meeting at Heilbronn at which nothing was done. The imperial policy was to strike such terror into it that it should fall to pieces. On January 22, 1621, Ferdinand took a first and most decided step. He published from Vienna the ban of the Empire against Frederick the Count Palatine, John George of Brandenburg-Jägerndorf, the Count of Hohenlohe, and Christian of Anhalt: the execution of the ban in the Upper Palatinate was entrusted to Maximilian of Bavaria, and in the Lower to the Archduke Albert, sovereign of the Netherlands. At the same time the Emperor prepared to take savage revenge on the Bohemians ; forty of the leaders of the insurgents were arrested, and after four months' imprisonment twenty-three of them were put to death: Count Thurn and twenty-seven others who had fled were proscribed and their estates forfeited : a proclamation was issued directing all landholders who had been implicated in the rebellion to sue for pardon, or to suffer entire confiscation in case of subsequent information. Over seven hundred nobles submitted and had their lives spared, but their estates were seized, and their families beggared. The whole fabric of society in Bohemia was subverted, and since that period the country has until the present century been either quietly submissive to Austrian rule or devoid altogether of political life.

These proceedings of Ferdinand are in themselves indefensible. They were impolitic as well as unjust. It may be true that the Bohemians had no constitutional standing-ground, for they had prosecuted internecine war against their king and could have no claim to the mercies of a constitution which they not less than their oppressor had set at nought, but the ruthless relentless character of the revenge was more likely to inspire the remaining enemies of Austria with a desperate spirit of resistance than to frighten them into hopeless submission. And the proceedings against Frederick were carried out in defiance of the constitution of the Empire, without the consent, against the wish, of the electoral body, and in breach of the capitulation made at the election of a new Emperor. All this Ferdinand overlooked in his anxiety to make an end of Frederick 
and out of his estates to find means for repaying the services of Bavaria and Saxony, getting his own dominions out of pawn.

At the moment these severities were successful. A meeting of the Catholic League in February alarmed the Union into the expectation of a general attack; and on April 12, at Mentz, peace between the League and the Union was concluded. Peace was made also between Spinola and the Union, who could not wait even for the week that intervened before the truce between Spain and Holland expired; and almost immediately after the Evangelical Union broke up, having done no work except the production of the Thirty Years' War, in which on every occasion it shirked fighting. The Palatinate was thus left in the hands of Spinola, save the three towns that held out for Frederick, and these were besieged in execution of the ban.

Now, however, there is again a turn in the tide. The King of Spain died on March 31,1621; the truce between Holland and Spain expired on April 21; and on July 13 the Archduke Albert died at Brussels. Spinola was recalled from the Palatinate, the forces being placed under Gonzalvo de Cordova; and at the other side of the Empire, the force of Bethlen Gabor was increased by the arrival of the Bohemian refugees, with whose aid he defeated Bucquoy at Neuhäusel, the imperial commander falling in the battle. Just now for the first time we find Christian of Denmark beginning to move, calling together the estates of Lower Saxony and giving signs of the action that he took two years later.

But all interest now centres in Mansfeld, whom we left at Pilsen in November, and who still kept the standard of Frederick hoisted in Bohemia. Tilly was the general pitted against him by Ferdinand, and they were well matched; both were brilliant generals, strong religious partisans, and unscrupulous men. Mansfeld is known chiefly as a plunderer and ravager, Tilly as a sacker of cities; both of them have had their admirers, Mansfeld among the Puritans, Tilly among the Jesuits. Both of them may have had redeeming points : but they do not come out in history. For many months they watched one another with very inferior forces. Mansfeld had about 8,000 men, Tilly had not many more ; the imperial army in Hungary had sunk to 8,000 men too. At length the Elector of Saxony came into the field with 5,000 men, and Tilly got some other reinforcements. Mansfeld had exhausted the resources of the country and the patience of the people. Pilsen was surrendered by his men against his will, and he was compelled to leave Bohemia; by a forced march of singular daring he struck across the Upper Palatinate, what is now the north-eastern part of Bavaria, and encamped at Rosskopf, near Nuremberg. Tilly was hot in pursuit, 
and Mansfeld made proposals to surrender. Whilst these were in consideration, on October 4, he broke out of his entrenchments in the night and marched at full speed into the Lower Palatinate, where he was joined by the English contingent, making up an army of 20,000 men. With these he expelled Gonzalvo and the Spaniards, relieved Mannheim, Heidelberg, and Frankenthal, and revived the hopes of Frederick. Tilly failed to prevent the union of the forces, and as the winter approached hostilities, as usual, ceased.

Mansfeld took his army to Alsace, where they could find subsistence by exactions from the Emperor's subjects, and there he was joined by Frederick. The Margrave of Baden put his army in preparation ; the Duke of Würtemberg also moved, and Christian of Brunswick set to work on the Protestants of Lower Saxony-in pursuance of the line taken by the King of Denmark early in the year. But before these successful proceedings of Mansfeld and his allies gained anything like completeness, the luck of Ferdinand on the Hungarian and Silesian frontiers had put him in a condition to make Western Germany the chief seat of the war. Silesia had made complete submission in October. In January 1622, by the peace of Niklasburg, Bethlen Gabor reconciled himself with Ferdinand, resigned the title of King and surrendered the regalia, receiving from Ferdinand in return large endowments in lands, titles, and treasure. Thus effectually disarmed, although he rebelled again in 1625, and in 1629 made preparations just before his death to invade Hungary, he drops permanently out of our story. At this time also Ferdinand married his second wife, Eleanora Gonzaga, and on the occasion granted an amnesty in Hungary on the most liberal terms, granting even the election of a Protestant Palatine.

The interest of the year 1622 depends on the military movements of Tilly against Mansfeld, the Margrave George Frederick of Baden Durlach, and Christian of Brunswick. The margrave was an unlucky man; he had been one of the supporters of Frederick's election to Bohemia, and by his consent to let the Austrian troops cross from Alsace through his territories towards Bohemia had acted, unfortunately and against his own will, in a manner fatal to the elector's interest. Now he determined to devote himself entirely to the cause ; going so far as to divest himself of his dominions in favour of his son lest the house should suffer, by his incurring the imperial ban. Christian of Brunswick was a different sort of man, much more of the selfish adventurer: he was a young man, a violent and cruel persecutor. As Bishop of Halberstadt he had a stake in the Protestant cause which made him an irreconcilable foe to the Catholics; his atrocities on the priests were such that it was said they believed 
him to be Antichrist in person. He, however, was a much more able general than the margrave.

These three armies, then, supported the Palatine or Protestant cause against Tilly, and together they would have been too much for him. At Mingolsheim, on April 29, 1622, he was beaten by Mansfeld and the margrave; and took care not to meet them together again. The separation between the two, caused by an attempt of the margrave to penetrate into Bavaria, gave him his opportunity: he met and defeated the army of Baden at Wimpfen on the Neckar on May 6 ; left Mansfeld to tire himself at the siege of Ladenburg, and marched to meet Christian. Him he met at Höchst on the Main on June 20, and beat him, pursued him until he joined Mansfeld, and then drove them both into Alsace. They were still far from discouraged; the Protestant feeling of Germany was but half roused, when all at once Frederick let them down and left them without a legal standing-ground.

James I. of England was hard at work at statecraft. He knew that his people were enthusiastic on the side of Frederick. $\mathrm{He}$ had not yet discovered the illusory character of Spanish engagements. $\mathrm{He}$ persuaded himself that he could by his influence with Spain prevail on the Emperor to restore the Elector Palatine, and, in conjunction with Denmark and the Archduchess Isabella, who wanted to maintain peace in the Netherlands, to restore peace to Europe. His self-deception imposed on his son-in-law : he withdrew himself from Mansfeld and his other friends, and, although they were ready to fight for him even only for the name, and were besieging Saverne on his behalf, retired into Holland.

Christian and Mansfeld, finding themselves forsaken, looked out for an escape. Mansfeld even entered into negotiations for taking service with the Emperor, whose most dangerous enemy he had been so long. At length, however, they determined to join Maurice in the Netherlands. They pushed accordingly from Alsace, through to Verdun; there they parted, Mansfeld passing through Champagne, to the terror of the French, and Christian through Bouillon and Luxemburg. They met again at Breda, and there strengthened Maurice so thoroughly that he was able to raise the siege of Bergenop-Zoom. At Fleury in Hainault Mansfeld met Cordova on August 29, and a severe engagement followed, but he succeeded in making his way to Breda.

The Margrave of Baden submitted to the Emperor and disbanded his forces. Tilly was now free to repossess himself of the Palatinate, and to anticipate the claims which the Spaniards by whose armies it had been overrun might make upon it. This was speedily done. On September 6, Heidelberg was taken by assault : Mannheim capitu- 
lated; and with the exception of Frankenthal, Frederick had no longer a spot of ground that acknowledged him.

Ferdinand was contemplating a measure that would seal his deprivation; the transfer of the electoral dignity to the other branch of the Wittelsbachs, in the person of Maximilian of Bavaria, whose claims on Upper Austria he intended to buy off by a gift of the Upper Palatinate. His preparations for this severe act were completed in the winter ; and a Diet was called at Ratisbon. This Diet had originally been summoned for Midsummer 1621 ; it met at Ratisbon on November 24,1622 , and had business enough to arrange. The Landgraves of Hesse-Darmstadt and Hesse-Cassel had a quarrel about Marpurg; the Margraves of Baden about the Upper Mark of Baden; the Elector of Saxony was discontented at the treatment of the Lutherans in Bohemia ; and endless other quarrels were on hand, looking to be settled now. And the Emperor had some difficulty in getting the estates round to his own way of thinking. Even Spain remonstrated at the entire destitution of the Elector Palatine. The other members of the Palatine House, the Count of Neuburg particularly, who was a Catholic, protested against the diversion of the electorate from his family as contrary to the Golden Bull. Brandenburg and Saxony remonstrated in the Protestant interest. But Brandenburg was very weak and Saxony only half zealous ; and Ferdinand managed, by playing off the smaller princes against one another, as their family disputes very generally enabled him to do, to get his own way at last.

The question was considered from January 7 to February 25, 1623, and on the latter day the Emperor formally declared the electoral vote transferred from the elder to the younger branch of the Wittelsbachs, as Charles V. had transferred that of Saxony from the Ernestine to the Albertine line of Wettin. The new elector was recognised by all his fellows, Brandenburg alone objecting; and by the ambassadors of France. The Elector of Saxony was put in possession of Lusatia: Lewis of Darmstadt was reconciled by the investiture of Marpurg; Christian of Anhalt was admitted to favour: John George of Hohenzollern was made a Prince of the Empire. But although the Diet had been thus easily managed, Mansfeld and Christian were far too active and determined to allow this to be a settlement of all claims. Mansfeld during the winter had led his forces into East Friesland, the Count of which country was friendly to the Emperor, and had there, as usual, maintained them by pillage. Christian had again stirred up the princes of Lower Saxony; they had formed a league, of which the King of Denmark, the Elector of Brandenburg, the Dukes of Brunswick, Holstein, and Mecklenburg were members : which avowed as its object the defence 
of the country against Tilly on one side and Mansfeld on the other, but which Christian intended to use for the recovery of the Palatinate. Before the Diet of Ratisbon separated, which was in March, the Emperor found it necessary to send Tilly to break up this combination. The princes urged Christian to make his submission to Ferdinand ; and he found it necessary to evacuate Westphalia. On his way to join Mansfeld in East Friesland, Tilly overtook him at Stadtlohn on August 6, and thoroughly routed him. After some months, manœurring, they found themselves helpless and the country they were occupying exhausted: and in January 1624 these two renowned adventurers broke up their forces; they both took refuge in Holland, to reappear again for a short space. But their great game was played, and their place is taken by new though not more famous actors.

The year 1624 was a little interval of peace : that is, of intrigue. Poor Frederick had gone quite out of sight. Mansfeld and Christian were beggared and their armies dispersed. The imperial forces under Tilly occupied the Palatinate, the Duke of Bavaria kept South Germany in order. Bethlen Gabor made an attempt with Turkish aid to recover what he had resigned at Niklasburg, but he was brought to terms again by May. Ferdinand devoted the breathing time to persecution and repression : everywhere within his States he enforced the restitution of the property of the Church and proscribed the worship of the heretics. Everywhere he showed the determined pertinacity of his policy, and made it too plain to the hostile or halfreconciled princes what they would have to undergo if he should ever succeed in making himself Emperor in deed as well as name. A long list of restitutions enforced in Franconia and other territories where the imperial power was strong and the petty princes could be taken in detail, warned the North German powers which had grown strong on the plunder of the Church of what would befall them. The King of Denmark trembled for his tenure of the archbishoprics of Bremen, Lübeck, and Verden ; Christian could not hope to retain Halberstadt, or the Brandenburgers Magdeburg. And the germ of an organisation there was already : the princes formed a new league, and this time with promises of alliance and aid from a far wider circle than ever before. The treaty of Paris, concluded August 8, 1624, united the Kings of England, France, Denmark, the Duke of Savoy, and the republics of Holland and Venice, in an agreement to recover the Palatinate for Frederick and to resist the further aggrandisement of the Emperor. Sweden also joined the confederation.

It is important, by the way, to observe that each of these confederates was induced by different reasons to pursue this end. James I. had awakened from his dream of the Spanish marriage and 
was concluding a French one for his son; he would fain be revenged on the Spaniards and at last strike a blow for his son-in-law. France was now at peace, comparatively speaking, under the growing influence of Richelieu, jealous, moreover, of the Italian intrigues of Spain and Austria exemplified in the attack on the Valtelline and an attempt to partition the estates of Genoa between Spain and Savoy. The Duke of Savoy, who had missed the acquisition he hoped to make, was, like the Venetians, in dread of the same policy, which was to unite the Milanese with the Tyrol by the annexation of the Valtelline. Denmark was especially hostile at this moment because the Emperor had enabled the Counts of Schaumburg to renew their claims on Holstein, and the King now remembered that he was uncle to the Elector Palatine's wife and bound in honour to look after his interests. Gustavus Adolphus was not only an earnest Protestant hero, but he had a revenge to wreak on Ferdinand, who supported Sigismund of Poland in the claims he still made to the Swedish throne, from which Charles of Sudermania, the father of Gustavus Adolphus, had ejected him in 1604. It was true Gustavus had no reasonable pretext for going to war. His possessions nowhere even approached those of the Emperor, and his power was in no real danger from him ; but by the gift of part of Pomerania which might any day become an imperial escheat, by the dropping in of the life of the childless duke, he might have a standing-ground given him; and, if this could be done, he in character and ability stood so high that he might fairly claim to be head of the league.

The year 1624 passed before it was determined who should take the lead. It fell at last to Christian, King of Denmark, and he was accepted by the Lower Saxon States as their head also in lieu of the Duke of Brunswick, Christian of Lüneburg, who had been director of the circle for eleven years, withdrawing in his favour. This conclusion was come to on March 25, 1625 ; and war almost immediately followed : a branch or department of the Thirty Years' War which lasted exactly four years; and which brought on the stage new persons and a new policy on the part of the Emperor which are memorable for ever. In the name of Wallenstein these new principles are centred. It was to resist the Northern League that Ferdinand availed himself of the services of Wallenstein, whose name marks this epoch of the war as distinctly as those of Frederick and Maximilian did the first; those of Mansfeld, Christian, and Tilly, the second ; and those of Gustavus Adolphus and Bernard of Weimar the period that follows.

The employment of Wallenstein marks an independent line of action on the part of the Emperor. All through his policy there were two lines of design : one the restoration of the Roman Catholic 
religion, the other the restoration of the imperial power. Up to this time, however, the main direction of his efforts and those of his supporters had been towards the recovery of his hereditary dominions and the punishment of those who, in the purpose of establishing Protestantism, had attacked him in Bohemia. No doubt whatever, the Protestant princes were intent on curbing the imperial power as well as on stopping the Counter-Reformation: in both points they regarded the overthrow and humiliation of Ferdinand as the great object of war and policy, and there were many powers in Europe that looked kindly on their efforts in one or both designs.

England, in the person of her king, might stand aloof and desire the continuance of the old state of things that had existed under Ferdinand I. and Maximilian, when the Empire as such exerted no influence on the politics of Europe, and religious matters were, after a period of great excitement, almost at a standstill ; but the English people and Parliament were enthusiastically earnest in support of the cause of the Elector Palatine, and disliked, as far as they understood it, the predominant position of Austria, which they looked on as a dependency of Spain.

France, on the other hand, whilst she hated and dreaded Protestantism, hated and dreaded quite as much the revival of the power of her old antagonist. To her the cause of Germany, of the Empire, of the Austrian Hapsburg, was still the cause of Charles V., although the territory that made Charles V. so terrible to France had altogether run off into the other line, with which the present rulers of France were closely allied. We might expect the action of France in a struggle like that which was progressing to be neutralised by these motives. If her hatred of the Reformation drew her one way, her hereditary policy with regard to the German princes and her attitude towards the Austrian house drew her the other.

Whilst, then, to France and states like her the designs of Ferdinand were only partially dangerous, he was on both points opposed tooth and nail by the German Protestant princes. But further than this : the German Catholic princes were zealous enough for the restoration of the faith; but far less zealous, nay occasionally jealous, of the aggrandisement of the imperial power. The Catholic League was formed for the defence of the Catholic religion; not for the increase of the imperial power, still less for the purpose of securing or enlarging the Hapsburg inheritance. As for this third motive, liberally as it is attributed to the Austrian house in general, I confess that I do not see much in Ferdinand's policy that seems directed to the securing of it, independently of his design of increasing the imperial power. He seems to have regarded the 
imperial power as the inheritance, and working for the former he worked effectually but subordinately for the latter. But the Catholic League fought for neither, only for the restoration of religion. The Catholic League was strong in the support of France, which had concluded the pacification of Ulm and had never countenanced the programme of Frederick, but which still held Toul, Verdun, and Metz, standing proofs of her strength and of her enmity to the Empire.

And what is the point? The battle had been hitherto fought by the Catholic League : the director of all the armies was Maximilian of Bavaria, Ferdinand's friend and brother-in-law, but not one of his own house-a man if not superior, certainly not inferior to himself in ability, as honest, as religious, as experienced, and more popular, because more thoroughly trusted. In all points touching religion Maximilian might be thoroughly confided in; but the League of which he was the head was not likely to go further than it had done. To Ferdinand, but not to the League, were the triumph of religion and the restoration of the Empire one and the same thing. The leaguers had not looked kindly on the deposition and proscription of Frederick; as members of the Empire they could not but see that the precedent was dangerous to themselves, and an example that might, when the tide of fortune turned, be most fatal. If it ever came to a struggle between the Empire and the princes on purely secular grounds, the Lutherans and Catholics and Calvinists might make head together. It was high time, then, for the Emperor to take the war into his own hands, to take the Catholic League for an ally or an instrument, instead of being an instrument of the Catholic League. Tilly was the general, and the forces were the forces of the League. The Emperor himself had no standing army to speak of, only a few thousand mercenaries, who would be needed for the defence of Bohemia and Hungary : nothing like the standing army which Charles V. had had; and which even he had drawn from Spain and Italy, rather than from his own German lands.

Ferdinand had neither men nor money, and his mind was not one which could complacently contemplate a system of warfare such as was carried on by Mansfeld, which paid the wages of its mercenaries by promises of pillage from friend as well as foe. But, although he could not contemplate it as directly his own action, he could prevail on himself to use men who would act on the same principle. If he could not pay an army he might attach to his service some leader who would be able to find means of paying one. To reward the leader out of the spoils of the Bohemian traitors, or with prospective grants from the forfeitures of imperial vassals, would not be so difficult or so repulsive. So the Emperor looked round for a general after his own heart and found Wallenstein. 
Wallenstein was a nobleman, of German descent, of a family settled in Bohemia. His name was Albert Wenceslas Eusebius von Waldstein, lord of Waldstein and Hermenetz: he was born in 1583, and now therefore was forty-two. He had been brought up a Protestant, but converted to Romanism in consequence of an escape which he regarded as miraculous. He was educated in the family of Charles, Margrave of Burgau, son of the Archduke Ferdinand and Philippina Welser, at Innsbruck. He had travelled over Europe, studied languages, history, and mathematics, and gone deeply into astrology. After his marriage to an old rich Moravian lady, he took to the practice of arms, and had made the acquaintance of the Emperor when he was Duke of Styria, by raising a small body of cavalry at his own expense and fighting on his side against the Venetians in Friuli. His second wife was the daughter of Count Harrach, one of the Emperor's ministers. He had lost his estates in Bohemia as a Catholic and imperialist, during the revolutionary period, and had been, when Ferdinand triumphed, rewarded in proportion to his losses, so that he was already a rich man, and high in the Emperor's confidence. He had raised a force of 1,000 cuirassiers at his own expense, had shown signal ability, and had fought with signal success.

Whilst Ferdinand was looking for a general, Wallenstein was looking for his opportunity. He saw the state of matters and proposed to the Emperor that he should at his own expense raise a force of 50,000 men, in the Emperor's name; provided he should have himself the supreme command and appoint his own officers. Here was the exact thing that Ferdinand wanted; by accepting the offer he would avoid the repulsive system of mercenary or adventurer forces, and have an instrument after his own way of thinking. Other men looked on Wallenstein as an extravagant, ambitious visionary. But Ferdinand had watched him and seen his ability, ability that was none the worse in his eyes for being accompanied by a lofty enthusiasm. Historians differ, and probably always will differ, as to the character of Wallenstein: as to the question whether he inspired Ferdinand with his own designs, or Ferdinand chose him for his adaptability to his. The genius of the men suggests the former theory; the situation of affairs countenances the latter : but it is even more probable that the complication of religious and imperial interests called into play the genius of the man so wonderfully adapted to meet both. 


\section{LECTURE IV}

\section{THE INTERVENTION OF DENMARK--WALLENSTEIN'S SUCCESSES}

WhETHER the policy which Ferdinand II. adopted in taking Wallenstein for the leader of his armies was suggested to him by Wallenstein himself, or was, as I showed in the last lecture, the natural result of the circumstances in which he found himself, Wallenstein being the instrument ready to his hand, I shall not venture to decide. It is clear that Wallenstein was ready, and wonderfully well suited to the post in which his master placed him. He received the imperial commission to raise 50,000 men, and was elevated, by a very unusual exercise of imperial authority, to the rank of a duke-Duke of Friedland in Bohemia. It was from particular districts of Bohemia that his force was to be levied, and it was very speedily made up to 22,000 men; before it reached Lower Saxony it numbered 30,000. With these the policy of the imperial general was to join Tilly, the general of the League, and to overwhelm in detail the armies of Christian of Denmark, Ernest of Mansfeld, and Christian of Brunswick.

Of the latter two we have heard a good deal before. Christian of Denmark was brother of Anne of Denmark, wife of our James I. He was king for sixty years, from 1588 to 1648 . $\mathrm{He}$ was an experienced soldier and a man of a good deal of ambition, but not of high character in any respect, and far from a good king. Nor was he in policy a match for either the friends who would use him, or the foes who would thwart him. It was his fear for his ecclesiastical acquisitions in North Germany and for his Holstein duchy that led him, more than any interest for the Count Palatine or the Lutheran religion.

The election of Christian to the headship of the new confederation took place on March 25, 1625, at Segerburg in Holstein. Other meetings were held in the course of a few months at Brunswick, at which larger promises and engagements were entered into ; Tilly, on behalf of the League, protesting against the organisation as a breach of the constitutional law of Germany. The war opened formally by a declaration from King Christian that the object of the confederation was the securing the peace of the circle of Lower Saxony. The circle of Lower Saxony included the duchies of Holstein, Lauenburg, Mecklenburg, and Brunswick, in all their branches, and the bishoprics of Bremen, Hamburg, Lübeck, Magdeburg, Halberstadt, and Hildesheim, the larger part of which was in the hands of Protestant pseudo- 
bishops ; and formed a compact bundle of spoil, more to be coveted and easier to be handled than any other ecclesiastical plunder except perhaps the Franconian, which were in safe Catholic keeping. It was not unfair that Lower Saxony should be the battle-field of such a contest.

Well, the watchful eye of Tilly was upon all the arrangements of the new confederation. He marched upon the Weser, sending the Count John Jacob of Anhalt into the territory of Cologne to oppose the march of Christian and Mansfeld, who had been collecting forces in England and France. Tilly rapidly occupied Hamelen and Minden before the King of Denmark got his reinforcements; and pushed on into the Brunswick territories, and the states of Lower Saxony, already frightened, opened negotiations with him for peace. Already at Brunswick, in August, these negotiations were in progress, and as Wallenstein with the imperial army approached the scene of action they were renewed. By November, however, both parties were ready for the contest, and the news from the allies abroad was encouraging. Tilly's force was not indeed large enough to hold all the territory that he overran; he had been indeed obliged to withdraw from the siege of Nienburg, after a sharp struggle; but Wallenstein's army was approaching in full strength, enriched with the spoils of the Magdeburg and Halberstadt countries. On the other hand, Mansfeld occupied the duchy of Lüneburg, Christian of Brunswick was collecting a new force in the bishoprics, and the united armies under the King of Denmark reached the number of 60,000 men. With these the struggle was to begin as soon as the season permitted. In the meanwhile a series of truces was made to give Christian time to visit Denmark, and to allow the other princes who were not in the Lower Saxon league to try their hands at negotiating. But the efforts for peace made by the Electors of Brandenburg and Saxony counted for nothing with men like Mansfeld; and the alliance between England, Holland, and Denmark, made in December at the Hague, the object of which was to assist the confederation, was far more effectual for mischief.

Early in the spring of $\mathbf{1 6 2 6}$ hostilities began in earnest. King Christian arranged a plan of campaign, dividing his forces between himself and his two great leaders. To Christian of Brunswick he committed the task of raising men and supplies in the bishoprics of Lower Saxony and Westphalia, and of keeping order in the duchy of Brunswick. He himself took the field against Tilly, and Wallenstein he hoped to thwart by the skill and experience of Mansfeld. King Christian's field was the country on the Weser; Mansfeld's, that on the Elbe; the sphere of Christian of Brunswick's labours lay between the two. But Christian's work was very nearly done by 
this time. He was only twenty-nine years old, but a veteran in war; unrivalled in daring; oppressive, unscrupulous, an adventurer of the extremest cast. But he was dying of an internal complaint which was incapacitating him for work even when he took the command, and was probably the reason why the easiest part of the campaign was allotted to him. After making a short invasion of Hesse, chiefly to levy men, money, and provisions, and fortifying Göttingen and one or two other places against sudden attacks, he retired to Wolfenbüttel, where he died on June 6. He had resigned his bishopric of Halberstadt in 1624, and as he had no territory of his own, nor any descendants, his name has had none to defend it. His brother, Frederick Ulric, who was the reigning Duke of Wolfenbüttel, took the opposite side in politics ; whence, perhaps, arose Christian's prominence in the Protestant councils. He was the last of the house, and on his death, in 1634, the duchy fell to the Lüneburg branch.

The interest is concentrated on the other two commanders. The decline and death of Christian of Brunswick threw the chief burden of the fighting on the King of Denmark, who now had double work. His plan was to prevent if possible any meeting between Wallenstein and Tilly; and to do this he despatched the Duke of Saxe-Weimar to make a diversion in Westphalia. If Tilly could be drawn from the Weser, he himself might advance southwards and occupy Hesse, and so reach the Palatinate. The design, however, was too transparent : the Duke of Weimar was successful as far as he went, for he met no army, no resistance ; the people bought him off with presents and elected the son of King Christian coadjutor of Osnabrïck, but he did not draw Tilly away from his chosen ground, and King Christian did not venture as yet to attack him. Tilly took Göttingen notwithstanding poor Duke Christian's precautions. Then he attacked Nordheim, but, finding it well provisioned, he determined to compel King Christian to a general engagement. This was fought at Lütter, in the duchy of Wolfenbüttel, on August 27. Tilly was completely victorious. Christian with difficulty escaped into Holstein ; five thousand of his men perished on the field, two thousand were taken prisoners. The whole of the duchy of Lüneburg thus fell into Tilly's hands; the Count of Anbalt occupied Osnabrück and the other Westphalian towns that were reduced early in the year ; and so far as the circle of Lower Saxony was concerned, it was infinitely worse off than when it began the struggle.

The other branch of the campaign was before now removed into a very remote region. Wallenstein had wintered at Dessau, the capital of one of the Anhalt duchies, lying close on the borders of the circle of Lower Saxony, and had intrenched his camp at the bridge there over the Elbe. So threatening was his position 
that as early as February Christian William of Brandenburg, the administrator of Magdeburg, had made an energetic attempt to dislodge him, which was defeated with very great loss. A month later Mansfeld was sent against him, rather perhaps with the intention of diverting him than of fighting a pitched battle. He moved through Brandenburg upon Anhalt, and, having taken Zerbst, attacked the intrenched camp at Dessau. Wallenstein, however, came down on him in force on April 25, and inflicted a very severe defeat. Mansfeld was the last man to recognise a beating: he retired into Brandenburg again, and, having levied another force, in conjunction with the five thousand Danes under John Ernest of Weimar, who had returned from Westphalia, made a bold stroke at the imperial states. Before Wallenstein could stop him he was in Silesia, carrying all before him, Bethlen Gabor waiting for him on the Hungarian frontier. With their forces joined they awaited the attack of Wallenstein, who reached Hungary soon after with thirty thousand men.

But the season was more advanced, and pestilence appeared in both armies. John Ernest of Weimar was left behind in Silesia; and, although this placed an active enemy in the rear of Wallenstein's army, Mansfeld's was proportionately diminished. Disease and desertion were rapidly weakening Mansfeld, when Bethlen Gabor, who invariably did the wrong thing at the wrong time, made a truce with Wallenstein to April 1627, and withdrew into winter quarters. Mansfeld saw that the game was up: he disbanded his men, sold his artillery at Buda, and started through Bosnia on his way to Venice. At Zara, however, in Dalmatia, he was overtaken by the last enemy, and there he died on November 30. John Ernest of Weimar, who was keeping the joint conquests in Silesia in the rear of Wallenstein's army, survived Mansfeld only a week, and so escaped defeat; for Wallenstein, on concluding the truce, had turned back to meet him.

Thus much for Wallenstein's first campaign. The report of the year's warfare was very much in favour of Ferdinand: the King of Denmark beaten at Lütter; Christian of Brunswick, Mansfeld, and John Ernest of Weimar dead and their armies dispersed; Lower Saxony in the hands of Tilly; the Dukes of Brunswick petitioning for reconciliation; and Silesia re-occupied by Wallenstein.

The history of the year 1627 is the supplement of that of 1626 : it is marked by no great battle or by the appearance of any new hero. But the successes of the imperialists were steadily followed up; and the places which still held out against them, throughout the whole area of the war, were one by one taken, and Christian was driven step by step into Denmark. The war was still confined to Lower Saxony 
and Silesia ; the only attempt at a diversion in the south being made by the Margrave George Frederick of Baden-Durlach, who quitted his retirement at Basel and levied forces in Alsace on behalf of the Count Palatine. He was soon dislodged by the Archduke Leopold, and retired with his little force to join the King of Denmark; but he was beaten by Tilly, as was to be expected, and did nothing to redeem his usual character for ill-luck. The details of the year are briefly these :

Wallenstein first completed the subjugation of Silesia, which, after the death of the Duke of Weimar, had been committed by King Christian to the younger Count Thurn, and to Christian William of Brandenburg. He took Ratibor, Jägerndorf, and Troppau; and, having pacified the country, marched to join Tilly. During this time King Christian was strengthening the garrisons of the places that still held out, and establishing a series of forts between the Weser and the Elbe, so as to save at least Holstein and the Mecklenburgs in the general ruin. The submission of the Brunswick dukes rendered the Lüneburg territory untenable, but Wolfenbüttel still held out, and Wallenstein indemnified himself by ravaging the northern duchy.

Tilly left the western division of the work, as usual, to the Count of Anhalt, who undertook the country lying between the Weser and the Elbe; then, when Wallenstein had finished in Silesia, he advanced to meet him. Whilst the Administrator of Magdeburg was preparing to hinder his crossing the Elbe at Dessau, he crossed it at Tangermünde, considerably lower down; and then, passing the Havel, took Havelberg, and joined Wallenstein; the conjoint armies made little trouble of Brandenburg, compelled the Elector to withdraw his protest against the transfer of the Palatinate, and then marched northwards. Lauenburg and Boitzeburg fell before them. At last Tilly reached Holstein, took Rendsburg, and compelled King Christian to fly to the islands. The news of these successes caused the surrender of the few fortresses that were still defending themselves. Nordheim was taken by Fürstenburg; Nienburg and every strong place in the bishopric of Bremen except Stade by the Count of Anhalt; Wolfenbüttel by Pappenheim. The poor Dukes of Mecklenburg, who had been compelled to do homage to the King of Denmark, were despoiled of their territories, and Pomerania and Brandenburg were compelled to submit to heavy exactions. Stade, Glückstadt, and Krempe were the only places that resisted the imperialists in the whole circle of Lower Saxony.

The complete humiliation of an enemy gave time for discussing conditions of peace; and the Emperor was meanwhile making the 
most of his advantages in another way. The utter prostration of the Protestant cause had already inspired the sterner Catholics with the idea of the Edict of Restitution, which was issued a year later, directing the restoration of all secularised ecclesiastical property. The Emperor seems to have been anticipating the idea by obtaining the election to the northern sees for the Archduke Leopold, his younger son. Leopold was already bishop of Strassburg and Passau. The Emperor now took advantage of the state of things in Lower Saxony to obtain for him the succession to Halberstadt, and prepared to lay claim for him to Magdeburg and Bremen. But before this was accomplished the tide of war had turned. The thrones of Bohemia and Hungary were about the same time secured by the usual preliminary election and coronation for his eldest son Ferdinand; and a negotiation for peace with the Turks was completed in September 1627.

The proposals for peace between the King of Denmark and the Emperor were also passing freely: Tilly, on behalf of the League, attempting to soften, Wallenstein, in pursuit of his own and the imperial objects, to harden, the rigour of the terms offered. But the year ended without any feasible plan being devised, and Christian had recourse to the last resources of a Danish king, by equipping a small fleet and preparing to attack the coasts of the Baltic where Wallenstein was in possession.

There can be no doubt that the League was content with the measure of success that it had already attained, and was sincerely desirous of peace. At Würzburg, in the summer, a great meeting of the Catholic princes had bitterly complained of the exhaustion of the country by the war, and of the great miseries caused by the pecuniary exactions and quartering of the troops during the winter on their oppressed subjects; and at Mühlhausen, in September, earnest pleadings for peace and loud complaints made themselves distinctly heard. Still, it is not to be wondered at that no common terms of peace could be arranged. The Emperor, in his great triumph, thought no humiliation too great for his foes. Christian and Frederick were not disposed to acquiesce formally in their own annihilation. Matters could not be worse. Miserable as matters were, they could be made more miserable still by perpetuation.

The proposals made to Christian were that he should renounce his claims to all territory outside of Denmark, should surrender Glückstadt, the only place in Holstein that he still possessed, and should pay to the Emperor the expenses of the war. To Frederick, who made his suit by the Dukes of Lorraine and Würtemberg, the conqueror prescribed the renunciation, not only of the Bohemian crown, but of the electoral vote; the restoration of the Catholic 
religion throughout the Palatinate, and the confiscation of as much of his dominions as would remunerate the Emperor for his expenses. Such terms carried their own rejection with them; the victims had nothing to gain by such submission. So at the close of $\mathbf{1 6 2 7}$ peace was not made; and since actual resistance was almost impossible Ferdinand and Wallenstein determined to push their advantages and carry out some of the schemes which they entertained in common for completing the imperial supremacy.

Early in 1628, the Upper Palatinate was made over to Maximilian instead of Upper Austria, which he still retained for the expenses of the war of 1621. He and the League as impersonated in him were thus for the moment propitiated; and the Emperor could give his entire attention to the North. On March 4, 1628, he bestowed on Wallenstein the title of Duke of Mecklenburg, confiscating to him the duchies as forfeitures, in consequence of the compulsory oath of allegiance which the dukes had taken to Denmark. He conferred on him also the title of Admiral of the Baltic. Wallenstein's adventurous spirit was roused as much by the new commission probably as by the accession of dignity and territory; he entered warmly into the imperial scheme and betook himself to the task of besieging Stralsund, which was the key of the Baltic, and had received in 1626 a Danish garrison by way of precaution.

The siege of Stralsund began on May 16, 1628, and lasted to July 22, when it was relieved by the Swedes, and Wallenstein, having reached the limit of his conquests, retired in disgust. The exact design of Ferdinand in taking this line is not certainly known. The old view is that he intended to attack Sweden, and restore King Sigismund of Poland; but this, although it may have been put forward at the time, seems too far-fetched an idea. It was twenty-four years since Sigismund had been dethroned, and the Swedes were all strong Protestants; their King Gustavus, moreover, was one of the most popular and accomplished princes of the time. On the other hand, it is regarded by modern writers as a still deeper but more practicable scheme, to destroy the English and Dutch commerce and throw all the mercantile traffic of the world into the hands of Spain.

As yet Wallenstein was an admiral without ships; the imperial towns of the Hanseatic League were well furnished with ships and sailors; the first step to be taken, whatever the ulterior design was to be, must be to get the ships of the Hanse Towns into the hands of Wallenstein. To effect this the Emperor made a formal proposition to the Hanseatic League. If they would consent to give up their neutrality, to renounce their connexion with Sweden and Denmark, and the freedom of trade, the Emperor would incorporate them under his own protectorship, and let them have the monopoly 
of trade with Spain and the Indies. They rejected the offer with contempt; contempt, perhaps, hardly warranted by their position, but gaining much in force by the effectual resistance of Stralsund. Stralsund Wallenstein had sworn to take, even if it were bound by chains to heaven. Stralsund he failed to take, failed even to prevent her from receiving a Swedish garrison and renewing the alliance between the Hanseatic League and Sweden.

It may, I think, be questioned whether the imperial design were so exclusively a mercantile one. I confess that I think that the plan for the acquisition of the fleet was rather more likely to be dictated by military than by economical considerations; and that it was to complete the subjugation of Denmark and to prevent any attempt on the part of Gustavus Adolphus to renew the war. Wallenstein may, like Alexander, have sighed for new worlds to win, and dreamed of further conquests north and east; and there were doubtless in the imperial councils men capable of forming an ulterior design for the creation of a great mercantile Germany under the imperial guidance and in strict alliance with Spain; but the reason that lies nearest the surface was the one that I have stated. This design was confounded by the resistance of Stralsund and by the refusal of the towns to listen to Ferdinand's propositions.

The siege of Stralsund wore out the summer. Christian was able to sweep the Baltic, plunder some of the towns in the imperial interest, and cut off the supplies of others. Tilly took Stade, but managed no other success, Glückstadt and Krempe he could not take without a fleet. Some few places in Holstein and Schleswig were recovered by the Danes with English help; but the transactions were not brisk, the Emperor had to send a considerable force into Italy, where war was going on between him and the Duke of Nevers for Mantua, which the latter claimed as heir, as against the Duke of Guastalla, whilst the Emperor insisted that it was an imperial fief and should be placed in his hands until a judicial examination showed to which of the claimants it should be adjudged. Many considerations tended towards the pacification and to obtain somewhat easier terms for Christian ; and at last, in May 1629, by the mediation of the Elector of Brandenburg, and through the allprevailing influence of Wallenstein, peace (the peace of Lübeck) was made. Christian was allowed to receive back all his lost dominions, but bound to interfere no more in the affairs of Germany than when and where his interests as Duke of Holstein authorised him, thus tacitly renouncing the cause of the Count Palatine and the Dukes of Mecklenburg, and to give up all claims to the great ecclesiastical possessions in Lower Saxony on which he had set his heart, as the provision for his children. The Swedish ambassadors were not 
admitted to this congress : and Ferdinand would not even allow Gustavus Adolphus to be named King of Sweden, a piece of folly of which we should hardly have thought him capable.

So ended the four years' act of the Thirty Years' War-the Lower Saxon or Danish episode. Before we proceed with the remaining incidents of this great struggle-and we have now only run through ten of the thirty years-it is necessary to ask what were the causes of the collapse of the European confederation which had promised so great things in 1625, and where were the succours of England, Holland, and France. The anti-Catholic and anti-Austrian policy that was so dear to the Protestant heart of Europe had as yet only ruined every prince who had gone heart and soul into it. Frederick the Count Palatine is an exile and a beggar; Christian of Denmark a fugitive in his own dominions; the Margrave of Baden, the Dukes of Mecklenburg, not to speak of the hundreds disinherited in Bohemia, totally wrecked ; and every great general who had yet taken up the Protestant leadership beaten or dead. Why have England, France, and Holland been wanting, or, if they have not, where is the result of their goodwill?

We will take England first. We have had occasion to note already the position taken up by James I. in regard to the Palatinate. Although that policy was dictated by a comparatively unworthy motive, and James was deceived by the power to which he was sacrificing his people's confidence, it must be allowed that it was in itself wise and sensible. England's interests were not great in Germany, and her influence has never been admitted by German statesmen except when and where capital could be made by it. It was different with Holland, in the working out of whose independence, both as against Spain and in behalf of liberty generally, the English rulers might wisely have shown more, and more disinterested, zeal than they did. If Elizabeth's policy was prudent in letting the United Provinces fight their battle alone, or at least only helping them where they could afford to give substantial securities, it was not to be ascribed to James as a folly that he declined to join in a crusade for the propagation of Protestantism, of that especial description of Protestantism that he knew best and hated most. From almost every point of view, save and except the religious, the Spanish connexion was more valuable to England than the German if the German could not be had without alienating the Spanish. It is impossible to read with patience much of what were once regarded as the great exploits of the Elizabethan age; the piratic and buccaneering work of men whose only excuse was that their enemies were more inhuman than themselves and could not be attacked according to the rules of civilised warfare. 
When the nation cried out for a crusade on behalf of Frederick, it was as well that the helm of state was guided by a king who hated war and was bent on being friends with Frederick's enemies. As the failure, however, of the design for the Spanish marriage freed James from any politic scruples he might have had about offending Spain, he was unable at the time, 1623 , to do more than continue the liberal allowance he had made of $18,000 l$. a year to his daughter and her husband, and to attempt a negotiation for peace, the only result of which was the desertion by Frederick of the cause for which Mansfeld and Christian were fighting. It was the unhappy influence of Buckingham that brought England into the war. He knew how popular the cause of the Count Palatine was with the Puritans, and that for a war in his cause the Parliament would not begrudge a vote of money. Under his influence James laid the state of affairs before the Parliament in February 1624 and received from the two houses, on March 5, a unanimous advice that the transactions existing with Spain and the Emperor should be broken off, with a promise that should war follow they would grant liberal supplies. James, in answer, declared his reluctance, and insisted on his poverty. The Parliament made a large grant, and James prepared for war.

The marriage of Charles with Henrietta Maria gave the opportunity of bringing France into the plan. Mansfeld himself negotiated the details of the English alliance and drew up a plan of the campaign to be fought with English money and by English men. But the opening of the struggle was unfortunate, large numbers of men were lost by disease long before the fighting began ; and before the Lower Saxon circle had elected Christian of Denmark as its general, James I. was dead (March 27), Maurice of Nassau died also on April 13, and the loss of the two sovereigns was fatal at the time to the united enterprise. Charles I. was probably more sincerely desirous to rescue his brother-in-law than James had been; but he succeeded to 700,000l. of debt, and was never able to do more than contribute money: the grants of the Parliament to James were quite inadequate even to start effective warfare.

I do not propose to go further into the troubles of Charles's reign, which were unquestionably caused by the conduct of the Parliament in respect to the war with Spain and in behalf of Frederick. The warlike enthusiasm of the Puritans was exhausted before the war began, and quite quenched by its ill success. Negotiation succeeded negotiation, and expedient expedient. Charles was impoverished at home, and the money he contributed was wasted abroad. The relations with the French were hampered by the religious quarrels in France also. Charles was distrusted, and the Parliament unreasonable. The war with France which broke out early in 1627, and the 
dissolution of the Parliament, in February 1629, put a stop to any possible efforts on behalf of Frederick. The Puritan party had forced the war, had stopped the supplies by which alone it could be maintained, and, involving the King in difficulties, forcing him into unconstitutional ways of conducting the government, made those unconstitional proceedings the plea for overthrowing the throne.

So ended the share of England in that war. Much was done by English money, and much by English men, but the money was contributed as subsidies, and the men fought under a foreign flag. England as England did nothing. France, however, did even less than this. If England's policy was foolish and useless, that of France was careful and selfish. She had mediated and negotiated, and the result was the desertion of Frederick by the Union in 1620 . She had confined her efforts to negotiation during the frantic struggles of Mansfeld and Christian in 1622. She joined England in the league of 1624, but never attempted anything overt in support of the Protestants. Richelieu simply contented himself as yet with defeating the plans for increasing the imperial influence in Italy. His designs had not yet ripened; Ferdinand's power had not yet reached its height, nor had either realised the notion that France must adopt the principles of Henry IV. if Ferdinand was going to revive the claims and the policy of Charles V.

As for Holland, the death of Maurice of Nassau in 1625, hastened as it was by the failure of his attempt to relieve Breda, left the republic with more than enough on its hands. War with Spain, with Spinola that is, followed, and although from time to time we find the Dutch able to divert Tilly and Anhalt from the war in Westphalia and occasionally suffering at their hands, they had enough to do to maintain their own position; and probably did as much as could be done in this way for the Protestant cause, preventing the archduchess from joining in overwhelming the remaining forces still struggling. That Sweden should stand aloof from the contest in which at so short an interval it was to take so great and decisive a part is much more to be wondered at; the reasons of this we must discuss by and by.

We close our view of this part of the struggle with the reflexion that Austria has now reached the pinnacle of power, and that any change must be a change for the better for the Protestant side. We may question, and I think very reasonably, whether the designs of Ferdinand did not grow wider as his success became greater, and the difficulties which at the beginning of his reign seemed overwhelming melted one by one like snow before him. At first they were probably limited to the proscription of Protestantism in his own states, a measure which he had long contemplated and to the furtherance of which he devoted himself with all the earnestness of his strong

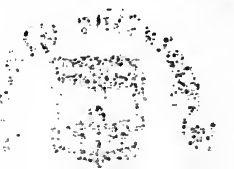


nature. The aid of the League and the speedy collapse of the Bohemian opposition opened up the possibility of rehabilitating the imperial authority; and the successes in Lower Saxony having completed that, opened in turn the prospect of extinguishing dissent in the length and breadth of the Empire, strangling the Reformation in its native seats, and making the authority he wore again an Empire, Holy and Roman.

\section{LECTURE V}

\section{THE SWEDISH INTERVENTION}

The next great point we reach is the Edict of Restitution, March 6, 1629 : a date preceding the Peace of Lübeck by a couple of months, but leading to a train of events entirely distinct from that which was closed by that treaty. This edict was partly the result of the action of the League, which had already discussed the matter with the Emperor, partly a consequence of the two lines of Catholic and imperial policy which we have seen were held by Ferdinand and Wallenstein in common. The restoration of all ecclesiastical property which had been alienated since the religious peace at the close of the reign of Charles V. was a measure in strict accordance with the terms of that peace, the Ecclesiastical Reservation in particular. But the peace was a compromise : on the one side the Ecclesiastical Reservation, on the other the Declaration of Toleration. Systematically the Protestants had disregarded the former. As systematically the Catholics had disregarded the latter. We have seen in former lectures how the Ecclesiastical Reservation was evaded, and how the imperial declaration was defied : how the imperial power connived at the invasion and threw its whole weight into the scale of the Catholic reaction.

The triumph of the Catholic party naturally suggested the formal resuscitation of the Ecclesiastical Reservation, and the annulment of everything that had been done in defiance of it. The party that should have insisted on the concession of religious toleration was now, to all appearance, bound hand and foot. It was in Lower Saxony in particular that the ecclesiastical endowments had been most shamelessly perverted. Two archbishoprics, Bremen and Magdeburg, and twelve bishoprics had been permanently alienated from the Catholic Church: the chapters were filled with Protestant canons, and the sees administered either by laymen under the title of administrators, or by bishops who were not less laymen and

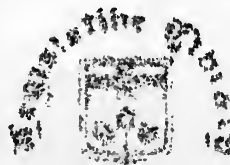


Protestants, allowed by imperial indults to enjoy their position until their visit to Rome, which visit they never intended to pay. The great houses of North Germany, Brunswick, Saxony, and Brandenburg, had grown rich in this way. The cupidity of the Catholic princes in South Germany was not less marked, but it was gratified in a way some degrees less uncanonical. The younger sons were educated for holy orders and received immense endowments in the way of pluralities, as we saw in the case of the Archduke Leopold.

So long as the struggle was undecided, and the armies of the League were fighting heart and soul on the same side with the Emperor, there seems to have been but one opinion among the Catholics as to the propriety of issuing such an edict. But when the Emperor and Wallenstein struck out their newer and bolder line, when the princes saw that the object of their policy was not merely to restore the faith, but to make the Empire a powerful reality, they began to reconsider the wisdom of the measure; and their reconsideration was quickened no doubt by the fact that the edict was issued, without their consent having even been asked, by the Emperor on his own authority, and that its execution was committed to the hands of Wallenstein. Ferdinand's policy in his own states was such as to strike terror into his friends as well as his foes. Bohemia was given up to military tyranny. The Jesuits preached, and the soldiers massacred and plundered those who would not comply. The whole social fabric was overturned, and the people, one might say, outlawed. The Emperor forsook all the characteristic features of the repressive policy of Austria, and took up for the time that of Spain: not, indeed, the Inquisition and the stake, but the not less effective weapons of the sword and famine.

The example of Bohemia roused the terrors of Germany. The Lutheran princes, represented by the Elector of Saxony, who had throughout been faithful to Ferdinand, remonstrated bitterly against the Edict of Restitution; against the act itself, the way in which it was carried out, and the policy which it too plainly indicated. The party of the League began to fear that the constitution of the Empire would be in danger from the exaltation of the Emperor; they also resented the military occupation of their estates on the pretext of the execution of the edict. Maximilian of Bavaria was jealous, as he might well be, of Wallenstein, and, much as he desired the destruction of Protestantism, had a stronger feeling in his dread of the destruction of Germany.

The property of the convents recovered under the edict was not given to the bodies that had formerly possessed it, but was heaped on the Jesuits, whose influence was regarded as supreme with the Emperor. Already, since the appointment of Wallenstein, the zeal of 
the League had begun to cool : now he was all-powerful, they were insignificant. This feeling was intelligible enough abroad. Although Ferdinand shut his eyes to it, neither Richelieu nor Gustavus Adolphus, the hero of the coming epoch, was wilfully blind; out of this alienation they saw their way to work the humiliation of the great foe. Nothing like resistance, however, was yet possible: the princes stood by and saw the edict ruthlessly executed in Swabia and Franconia, where the chief offenders were the imperial cities. These, as they had been under Charles V., were the first to lose their liberty of religion : especially hard it was on Augsburg; and so complaints multiplied.

Ferdinand showed his hand too plainly. At the very moment that he issued the edict he was trying to prevail on the League to dismiss its forces and leave the defence of religion and the peace of Germany to him. The answer of the leaguers assembled at Heidelberg in March 1629 was emphatic. They would not be dismissed as in disgrace : they had won the triumph of religion and set up the house of Austria again; until they were indemnified for all they had done they would not yield an inch of territory ecclesiastical or secular, or dismiss a single soldier. For more than a year the mass of Germany was seething in discontent, from the Edict of Restitution in March 1629 to the Diet of Ratisbon in July 1630. In that assembly the mischief reached its head, but before that assembly met Gustavus Adolphus had begun his wonderful career of conquest.

Whilst the thunder-cloud was gathering, Ferdinand's forces were largely drawn off to Italy. There also he was beginning to revive the designs of Charles V., and there the old weapons of French hostility were being sharpened to defeat him. Italy had been very little on the German mind since the death of Charles. The Spanish branch had inherited all the Italian possessions of the house, and they were strong enough to sway the country without imperial interference, though without the imperial title. Ferdinand I. and Maximilian were thoroughly German: Rudolf and Matthias had far too much to do at home to think of interfering. But Ferdinand II., in this as in all other matters, was a different man. He thought more of the Spanish connexion than any of his predecessors; and he wished both to play into the hands of Spain, to strengthen the family interest-that is, to extend the imperial power-and to cut off the rising hopes of France.

The design on the Valtelline, the design on Genoa, had been foiled by the French. Now the duchy of Mantua and Montferrat was in danger of becoming an outpost of France. The last duke of the Gonzaga line died in 1627; the duchy fell into debate, as I mentioned in the last lecture, between the Duke of Nevers, a 
Gonzaga by birth but a Frenchman by allegiance, and the Duke of Guastalla, whose line had branched off from the main stem of the Gonzagas a generation earlier than that of Nevers. The Duke of Savoy took the opportunity of claiming Montferrat. Naturally enough, France supported Nevers; as naturally, Spain supported Guastalla and Savoy; the Emperor demanded possession of the whole inheritance as a deposit until it should be shown to whom it legitimately would fall. The French supported their claimant energetically, Lewis XIII. himself taking the field, and compelled the Spaniards and Savoyards to abandon the siege of Casale, and give up Susa and some other territories to themselves. This was in the spring of 1629. Ferdinand thereupon sent a large force $(30,000)$ into Italy, which, co-operating with the Spaniards, overran the unfortunate territory, and, in July 1630, took Mantua by storm and sent the Duke of Nevers into exile.

This was the state of affairs and of the imperial relations with France when the Diet of Ratisbon opened. The Diet was called for several reasons : first to organise the defence of Germany, by settling the complaints of the League and of the sufferers under the execution of the edict, and so secure a unanimous effort against the King of Sweden, whose attitude and ability were threatening, although, from his poverty and the distance of his dominions, both parties in Germany had hitherto treated him with little respect, and Ferdinand had no cause to fear him. A second great object with the Emperor was to secure the election of his eldest son as King of the Romans.

The Diet met on July 9. The Electors of Saxony and Brandenburg absented themselves, not liking to vote against the election; all the other electors were present. After some preliminary discussions, a protest on behalf of Saxony against the edict, and an attempt on the Emperor's part to stifle the complaints against the maintenance of so large a force in the territories of the princes, the business of the Diet became nothing more or less than a violent attack upon Wallenstein. In this both Protestant and Catholic joined. The Emperor had clothed him in far too great authority; his pride and arrogance rendered him the disgust of the whole human race. The oppressions and exactions of which he and his army had been guilty, the devastation of Mecklenburg and Pomerania, the miseries of the distressed dukes, miseries which they had certainly not deserved, and which were inflicted against equity and the law of the Empire, were grounds of accusation that told almost as much against the Emperor as against his faithful servant. They were pressed by the envoys of Saxony and Brandenburg, Mecklenburg and Würtemberg. Then Maximilian took up his parable. The deliberations of the Empire were not free whilst Ferdinand main- 
tained an army of 150,000 men; the army must be reduced; Wallenstein must be dismissed; the execution of the edict must be put off for fifty years if it necessitated such armies and such men; and when the complaints of Germany were satisfied it would be time to think about electing a King of the Romans. The electors, who would gladly have chosen Maximilian himself, re-echoed the sentiment. Ferdinand was very angry - furious. He had been successful in the north, successful in the south; Bethlen Gabor was dead; the Church was restored in Bohemia; all the mischief that had been done in the last seventy years was remedied; and now he was to be thwarted like this. Rather he would turn his armies on Bavaria and be avenged on that treacherous friend.

There was a French ambassador at Ratisbon, the Capuchin Joseph, Richelieu's confidant; come to prevent the election of the King of the Romans, to obtain the dismissal of Wallenstein, the cession of Mantua, and to do whatever harm he could do besides to Germany and the imperial house. Father Joseph stirred up Maximilian on the one side, and soothed down the Emperor on the other. Let him prevail on Wallenstein to resign; he could be easily reappointed on an emergency; a small reduction of the great army would satisfy the elector; the King of Sweden was not a man to be feared; and the alliance of Lewis XIII. might be to all intents and purposes secured by the decision of the Mantuan controversy in favour of the Duke of Nevers. Doubtless Father Joseph was deceiving all parties, he never intended to ally France with Germany. He was, if not in actual conference with Gustavus Adolphus, conniving at his expedition and anxious for its success; he wanted to set Bavaria against Austria, but he cared no more for the one than the other.

Ferdinand, determined to sacrifice all to the prospects of his son, after a long struggle with himself, yielded. He dismissed 18,000 of his best cavalry, and reduced his army nominally to 39,000 men. The League fixed theirs at 30,300 . He asked Wallenstein to resign his command; and Wallenstein, to the astonishment of the world, complied. He had been warned by the stars that he would be dis. missed for a time but restored shortly with greater glory than ever. And next the Emperor consented to give up Mantua to the French on the understanding that they should cease to give any countenance to the Protestant party in Germany or to the enemies of the Empire outside. The treaty, which was repudiated by the Spanish ambassadors, was concluded on October 13. The cause of the Elector Palatine was pleaded at the Diet by the English ambassadors in vain. The solemnities closed by the coronation, on November 7, of the Empress Eleanora. 
Ferdinand had scarcely to wait for the end of the Diet to discover how he had been deceived. Gustavus Adolphus was carrying all before him, and was unquestionably in league with Richelieu. The veteran troops whom he had disbanded were enlisting under the banner of Gustavus. He had dismissed and probably mortally offended his best general, the man whose designs were his own only made more splendid by his exploits and glorified by his enthusiasm. And the Archduke Ferdinand was not elected King of the Romans. Richelieu had checkmated him in his full career. The contempt with which the Germans on both sides regarded Gustavus Adolphus is sufficiently shown by the fact that they went on deliberating at Ratisbon, and that Ferdinand disbanded so large a part of his army, after the Swedish expedition had begun to move; nay, after it had actually occupied a part of the soil of Germany. Yet they must have known well that Gustavus was a man of power and ability, or it would hardly have been such an object with the Emperor to replace Sigismund on the Swedish throne or with Wallenstein to take Stralsund and to acquire the command of the Baltic. It is probable that both sides regarded the Protestant cause as so far lost that nothing that Gustarus could do would save or resuscitate it. They may be pardoned for not foreseeing how great things he would do.

We have to inquire who Gustavus Adolphus was. Gustavus Vasa, King of Sweden, who rescued that kingdom from the sway of Denmark in 1523 and was one of the first kings in Europe who became Protestant, left three sons : Eric XIV., who reigned from 1560 to 1568 and was a mad Protestant; John, who reigned from 1568 to 1592 and was a strong Roman Catholic ; and Charles, Duke of Sudermania, who was a wise and moderate Protestant. On the death of John his son Sigismund succeeded him; he was a Catholic like his father, and was elected King of Poland in 1587. His uncle Charles, who, as leader of the National or Protestant party, had wrung from John a sort of religious equality for the Protestants, finding that Sigismund was determined on restoring Romanism, dethroned him in 1604 and reigned seven years as Charles IX. Gustavus Adolphus was his son; he succeeded him in 1611 at the age of sixteen. Gustavus was a prince of very great promise, and had already before his father's death been declared of age, an honour which his personal bravery and skill in arms had earned him. He possessed in Axel Oxenstiern, the Chancellor of Sweden, who both in his early years and after his death directed the government of the country, an able, honest adviser. His reign began with a series of struggles, in each of which he was victorious. By the advice of Oxenstiern he attached himself to the nobles of Sweden, with whom his father had been on bad terms, and so secured himself against 
internal troubles. The wars with Denmark and Poland he had inherited, and in them he got good training. The war with Denmark was a chronic state of things with Sweden; that with Poland was owing of course to the religious and family relations of the two monarchs.

From the beginning of his reign he had been strongly inclined to assist the Protestant party in Germany; he had offered help at different times and been rather snubbed than thanked. The Germans did not want foreign interference in their internal affairs ; they were not inclined to take as leader one whose very existence as a king was ignored by the Emperor, nor one whose deadly enemy was so high in the Emperor's favour as the King of Poland was; but even more strongly the jealousy of Christian of Denmark interfered to keep him in the background. In $\mathbf{1 6 2 4}$ he had offered aid to the Lower Saxon League, and had even entered into competition with Christian for the leadership ; but as this leadership involved the surrender to him of some Baltic towns, it was objected to and Christian preferred, with the luck which we reviewed in the last lecture. Gustavus was chagrined at the repulse, but he saved his forces whilst Christian was losing his, and generously assisted at the end of the war in 1628 in helping the Stralsunders to hold out successfully against Wallenstein. I need not go into detail as to his contests with Denmark, Russia, and Poland ; it is sufficient to say that he made in 1613 a treaty of peace with Christian; that in 1617 he obtained a truce of forty years with the Czar of Muscovy, with large cessions of territory on the east of the Baltic; and that having beaten his cousin Sigismund out of Livonia and Prussian Poland, he had made in September 1629 a truce of six years with him also, thus rendering himself, at the head of an attached people and well-disciplined army, able to take on himself the burden of the defence of the Protestant cause.

This truce with Sigismund was contrived by the French minister; by Richelieu himself, no doubt, who a year later, at the Diet of Ratisbon, contrived to rob Ferdinand of the fruit of his Italian victory and to make him disarm in the presence of his most dangerous enemy. Although Richelieu saw that Gustavus would be a very useful thorn in the side of Germany, he had by no means fathomed the greatness of the man : he would use him, but be shy of supporting him, and by his treatment of him showed it. Gustavus, who was a proud man as well as a wise one, did not care about being patronised, and accordingly made no bargain with the French until his assistance became of sterling value to them.

$\mathrm{He}$ began his crusade very much on his own responsibility, although he had assurances of goodwill from England, Holland, and 
the Hanseatic League. Protestant Germany did not welcome him. Catholic Germany did not fear him. He wrote to the electors complaining of the ignominy with which the Emperor had treated him in refusing him the title of King, and explaining the reasons for the war. Before he left home, he assembled the States of Sweden and obtained from them their consent to accept his little daughter Christina as his successor. Then, with an army of 15,000 men, he set sail at Elfsnabben, and on June 4, 1630, landed on Ruden, a small island between Rügen and Usedom, not far from the mouth of the Oder, in what was then Pomerania. The Germans were at this time, you will remember, on their way to the Diet of Ratisbon. The imperial general in those parts was Conti, who had with him an army of 17,000 men. On July 20 Gustavus occupied Stettin, the capital of Pomerania. The old Duke Bogislaff was the last of his race: and the succession was claimed by Brandenburg. But Bogislaff had no love for Brandenburg, and, although in great fear and dread of the Emperor, concluded an alliance with Gustavas which placed Pomerania, land and army, under the command of the King of Sweden as long as the war lasted. As soon as he had got into Stettin, Conti advanced to meet him; but neither party was anxious for a battle: Conti garrisoned the fortresses inland, and Gustavus, having waited for reinforcements, expelled the garrisons from most of the strongholds on the coast and blockaded Demmin, Greifswald, and Colberg. He then threatened Mecklenburg and harassed Conti with superior force until, in disgust at not being properly supported by the Emperor, he resigned.

Count Schaumburg, Conti's successor, was still more unlucky. The winter was approaching before he took the command, and his first measure was to withdraw a large part of his army into winter quarters. Gustavus, whose men regarded a German winter as a very mild season indeed, used the opportunity afforded him of securing his hold on Pomerania still more certainly. He drove back the imperial army at every point, turned the garrisons out of the cities, and advanced southwards nearly as far as Frankfort-on-the-Oder, which he would have occupied had he been able to secure his retreat in case of the Emperor bringing an overwhelming force against him. The Elector of Brandenburg, however, who was angry at his occupation of Pomerania, refused to allow him to enter and garrison Küstrin, which would have enabled him to do this, and Gustavus in consequence seized the town of Brandenburg and levied heavy contributions.

His successes during the winter were so great that Richelieu had no longer any reluctance in making alliance with him. A treaty was signed at Bärwalde, Gustavus's camp near the Oder, on January 13, 
the object of which was stated to be the defence of the common friends of France and Sweden, the liberty of trade, the security of the Baltic and the Ocean; and the demolition of the forts erected on the coasts and in the territory of the Grisons. France was to pay to Sweden an annual subsidy of 1,200,000 francs; Gustavus to maintain an army of 60,000 foot and 6,000 cavalry. No change was to be made in the state of religion if the allied cause triumphed; Maximilian and the other leaguers who might wish were to be allowed to be neutral; and the alliance was to be for six years. The month after this treaty was concluded, Tilly took the field in Brandenburg and the real fighting began.

Again, however, we must turn to the question of Gustavus's reception in Germany, and the further point how far he was legally and morally justified in taking the position that he did. I have mentioned several times that both parties very unduly despised Gustavus Adolphus. The Emperor had, indeed, on hearing of his arrival, issued (August 8, 1630) a threatening letter against him, insisting on his withdrawing from German soil, and menacing him with the whole vengeance of the Empire if he persisted; but Gustavus could afford to smile at that; and in spite of his threats the Emperor was so bent on the purpose for which he had called the Diet that he weakened himself most materially, and continued to do so after the successes of Gustavus became formidable. Wallenstein was recalled from the north, and dismissed from command, and the 18,000 cavalry were disbanded, whilst Gustavus was driving Conti before him and steadily occupying Pomerania as the basis of future operations.

On the other hand, the Protestants were quite as cool. The Electors of Saxony and Brandenburg showed no sign of welcome; their attitude was in fact rather hostile than otherwise. Brandenburg wanted Pomerania; his ministers were in the imperial pay, he was jealous of Gustavus personally; he might use him, and he would wait for his opportunity. Saxony was faithful to the Emperor and to the policy of the Albertine line, which was to keep up their own Lutheranism, but to depress everyone else's ; to hold fast by the Empire, and as a reward for their fidelity to purchase toleration; to keep their own house safe, and let the rest of the world fare as it might. Both the electors, too, had the idea that by keeping aloof from the contest they might pluck advantage out of the strife; wait until it was clear who would win and then throw their force on to the victorious side. If the Protestants won, they would thus secure the lead amongst their fellow-religionists; if the Emperor won they might make a merit of abstention from the war, and by adhesion to him purchase continued toleration. Doubtless they saw that abstention on their part made the victory far more difficult to 
the winning party which they were waiting to join : and that such duplicity was certain to damage them with both sides, but they would not honestly risk their independence on the single issue. They were not strong enough, as they were not generous enough, to stake that on the success of either party.

The attitude of Brandenburg and Saxony determined that of the rest, the shattered remnant of the Protestant states. Hesse declared for Gustavus, but Hesse lay too far from the scene of action to help, and had not strength to stir alone. The only two princes who. attempted anything before the spring of 1631 were Francis Charles of Saxe-Lauenburg, who with a small force occupied Ratzeburg and for a moment threatened the duchy of Mecklenburg; but was speedily defeated and taken prisoner by Count Pappenheim; and Christian William of Brandenburg, the ex-administrator of Magdeburg, who, having got entrance into his old city, roused the burghers to renewed resistance. The Magdeburgers had never acquiesced in the supremacy of Wallenstein in the north; they had paid him money and bought him ships, but they would not receive his garrisons, and had successfully held out against his execution of the Edict of Restitution. Now they openly declared for Gustavus, and by their position on the Elbe presented a most formidable obstacle to any attempt on the part of the imperialists to dislodge the Swedes. They were, as we shall see, the first victims in the struggle.

Thus much, then, was all that Germany did, nearly all she could do, to welcome her deliverer. What with despair and ruin on one side, apathy and jealousy on the other side of the Protestant party, Gustavus seemed likely to have the war to himself, and Gustavus behaved as if he thought so. As a consummate general, he made sure of his ground at every step; he knew his dangers, he did not overestimate his powers; he knew his enemies, their skill, experience, and resources; he had counted the cost before he went down to the battle. He was one of the greatest masters of the art of war that ever existed. $\mathrm{He}$ introduced into warfare the two great changes that mark the difference between medieval and modern tactics. He gave up fighting in great masses, which the cannon-balls cut through and demolished at once, substituting light columns and shallow lines of soldiery, who could re-form immediately after receiving the enemy's fire; and he introduced the practice of flying artillery. Before his time the guns, in preparation for battle, were set in permanent position, and as the complexion of the struggle varied, or the attitudes of the parties changed, became useless. With these two principles he won his great battles.

But we were to ask-How can the invasion of Gustavus Adolphus be justified on legal and moral grounds? We must answer, I think, 
that the case is an exceptional one, a very exceptional one in all history, in which the result alone could justify the undertaking. Gustavus had, as against the Emperor, only the barest legal excuse for an attack. His territories were not in real danger. Sweden was in no peril now from the machinations of Sigismund, and might rest safely on her own powers of defence, so well proved in the wars of Russia, Poland, and Denmark, even were the Emperor to lend his forces to the King of Poland for the recovery of his inheritance. It was, then, only because the Emperor had refused him the title of King, and otherwise treated him contemptuously, that he had ground, of a legal character, of complaint against him.

What is to be said on the other head? Gustavus Adolphus was an earnest and intelligent Protestant; not a blind bigoted Puritan making mountains out of molehills, straining at gnats and swallowing camels, covering his own rabid hatred of his adversaries with the cloak of hypocritical zeal; but a Protestant who firmly believed in the truth of God's revelation, and as truly believed that he saw in the purpose and policy of the Jesuits a conspiracy to blot vital Christianity out of the world. Had Gustavus in this belief been unsuccessful, the world would have regarded him as a mad enthusiast; higher and nobler minds would have admired and wondered at him as a hero and a martyr, but would not have called him a wise man. It is only our knowledge of the transcendent ability and perfect honesty of Gustavus that leads us to allow him moral justification. Had he been ever so enthusiastic, ever so hopeful, he would not have been justified in going to war, if he had not seen that he had a fair chance of being successful; had he not trusted, humanly speaking, to his own skill and resources. He left nothing to the chapter of accidents; he left nothing to luck; he did not reckon, more than an experienced general is justified in doing, on the mistakes of his enemies.

This being so, we contemplate his purpose. He saw Germany prostrate at the feet of the Jesuits, the enemies-as he thought, and as, unhappily, too many of their acts justified him in thinking them, -of God and man. If the liberty of religion were extinguished in Germany, it would scarcely be able to exist elsewhere : the Church of which he was a living member was perishing; in time the storm must destroy his own native Church as well. So he undertook the part of a deliverer, ready to lay down his life, not in vain, not for mere sentiment, not from blind enthusiasm, but with the determination to save Germany and the Protestant faith.

We cannot, I think, refuse him justification; not the very highest meed of praise. At the same time we cannot but see that he succeeded where nine hundred and ninety-nine out of every thousand 
kings or generals would have failed, and would have condemned themselves in the failure. Whatever we may think of the Jesuitism that he turned back in its full tide, or of the Protestantism for which he fought and died, whether it were worth the sacrifice or not, we cannot read his character and story without seeing that he is one of those men whose acts have wrested round the course of this world; that he was a champion and a deliverer, true, wise, pure, and noble, such as the world has never seen before and may never see again.

\section{LECTURE VI}

THE VICTORIES AND DEATH OF GUSTAVUS ADOLPHUS

We have now reached the winter of $\mathbf{1 6 3 0}$. We have seen Gustavus employed in securing Pomerania, and laying a basis for future operations; his army increasing and his enemies melting before him, and himself now bound by alliance to France. We have now to take up and connect the two strings of his very wonderful history, the story of his successes against the armies of the League and of the Empire, and of the way in which he by compulsion or persuasion roused the Protestant princes to energetic action. The whole story of the remainder of his life lies between January 1631 and November 1632 : a little less than two crowdedly eventful years.

In January 1631, Gustavus was encamped near the Oder; Pomerania was not entirely secured; Magdeburg was the only city in Germany that held for him. The Elector of Brandenburg refused to allow him to occupy Spandau or Küstrin, and until that was done he could not march upon Frankfort. The Elector of Saxony would not let him cross the Elbe at Dessau, and therefore he could not join the Magdeburgers, or, if it were necessary, join in their defence. The force of Schaumburg, however, was diminished to less than half of what it had been, and, that disposed of, he might despise the selfish neutrality of the princes. It was under these circumstances that Tilly undertook the command of the imperialists. Maximilian of Bavaria and the Catholic League had not accepted Gustavus's offer of neutrality. Maximilian would have undertaken the chief command if he had been suffered. But the Emperor wanted it for his son; and the election was decidedly compromise, Tilly being chosen so that the victory might fall to neither of the rivals.

In February Tilly began his march northwards. By February also the Protestant princes were roused up to do something on their own account. They met at Leipsic on the 8th, and after forming a 
new confederation which was to be neutral in the present warfare between Sweden and Austria, after resisting the entreaties of Gustavus that they would act like men and cast in their lot with his, they sent a petition and list of gravamina to the Emperor. Ferdinand temporised with them for a time, and nothing came of the negotiation. The progress of Gustavus was, on the whole, too rapid to fall in with the steady movements of the imperial chancery. It is curious to read how one set of the princes, the most interested one would have thought, were debating, whilst the others were fighting; the Calvinist and Lutheran theologians disputing at Leipsic; the League in solemn conclave at Dinkelsbühl; and Maximilian of Bavaria making up a treaty for eight years for himself with France: of neutrality, if France should go to war with the Empire. This treaty was signed on May 30, five months after Richelieu had thrown over the Emperor and allied himself with Gustavus. On April 6 also the treaty of Cherasco was signed between Ferdinand and the Duke of Mantua, which enabled the Emperor to recall 24,000 men from Italy.

Whilst this was being done, Tilly was persuaded that he saw an opportunity. He had under him 20,000 men. $\mathrm{He}$ heard that Gustavus had started on an expedition to Mecklenburg and that he might overwhelm him whilst his forces were divided. Gustavus was indeed gone off in the Mecklenburg direction and was besieging Demmin, on the frontier of Pomerania and Mecklenburg; but the movement was but a feigned one, intended to draw Tilly into a disadvantage. The old general left 8,000 men in Frankfort, stormed New Brandenburg, which Gustavus had occupied early in the winter, and hastened to the defence of Mecklenburg. Before he reached the frontier he learned that Demmin had surrendered and that Gustavus was in full march on Frankfort. A race to Frankfort followed, in which Gustavus won: took the city by assault and massacred the garrison.

Tilly, seeing that his forces could not be maintained on the Oder, retired before him and threw himself on Magdeburg. At the end of March, Tilly besieged Magdeburg, and on May 10 he took it. Gustavus Adolphus did not relieve it. He could not do so. It was impossible for him to sacrifice his whole plan of the war to save the unfortunate city; but he did his best. To secure his base it was necessary that the Elector of Brandenburg should entrust him with Spandau and Küstrin, and that the Elector of Saxony should let him cross the Elbe at Dessau. The two Electors were in their dream of the new neutral confederation, and they refused. By threatening to march upon Berlin, Gustavus compelled Brandenburg to put Spandau in his charge until the siege of Magdeburg was raised, and 
on May 4 he received it. But Saxony still held out, and on the 10th Magdeburg surrendered. The place was sacked with every circumstance of the most barbarous and most appalling cruelty. Tilly refused to prevent his men from glutting their lust and desire of vengeance ; and the most flourishing city of North Germany was left a desert; help being within reach, but hindered by the selfish policy of the men who should have been the first to rise in its defence.

From Magdeburg, Tilly marched, threatening the same treatment, against the Landgrave of Hesse. Ferdinand regarded the capture of the unhappy city as a triumph ; sent orders to Leipsic to insist on the princes breaking up their wretched confederation; and summoned a meeting of deputies to assemble at Frankfort-on-theMain in August to arrange for the execution of the Edict of Restitution. Pappenheim was left by Tilly as his lieutenant in Magdeburg. Gustavus was not yet quite in a condition to avenge it. No sooner was the siege over than the Elector George William demanded the restoration of Spandau. Gustavus humoured him; he fixed June 11 for the surrender; but on that day he appeared with his army at Berlin: George William was glad to purchase mercy by the surrender of Spandau, Brandenburg, and Rathenow, a free passage through the electorate, and a contribution of 30,000 crowns a month. Gustavus then rushed back to Pomerania to take Greifswald, but it surrendered before he reached it. He had thus Pomerania and Brandenburg safe, and could now approach the Elbe: this he did with rapidity, took Havelberg and threatened the imperialists at Magdeburg. But the boldness of this move brought Tilly back ; and Gustavus retired to Werben, where he encamped. There he protected Mecklenburg from attack; restored the dukes whom Wallenstein had dispossessed and whom Ferdinand had put under the ban of the Empire. At Werben also, on August 12, he concluded a treaty with the Landgrave William of Hesse by which he took charge of his forces and fortresses, and promised him security and reparation. Whilst he was there he received very large reinforcements from Sweden under his queen Eleanora, and from England under the Marquis of Hamilton.

Gustavus was now waiting for the return of Tilly: Count Fugger was sent against Hesse, and Tilly encamped at Wolmerstadt. There he was attacked by Gustavus and suffered a severe check. $\mathrm{He}$ retaliated by attacking the camp at Werben, but here he was checked also, and began to discover that for the first time in his life he had met his equal in the art of war. Intensely exasperated, he determined to wreak his vengeance on Saxony, or at least to compel the Elector to take up arms against the Swedes. But John George 
was so thoroughly frightened by his threats that he threw himself into the arms of Gustavus, entreated his protection, and offered whatever terms he chose. Tilly was besieging Leipsic. Gustavus prescribed to the unworthy Saxon the same terms that he had offered to the faithful Hessian, and the treaty was made on September 1. Immediately after Gustavus crossed the Elbe at Wittenberg, united his army with the Saxon one, and proceeded to the relief of Leipsic.

The battle of Breitenfeld, a German mile from Leipsic, was fought on September 7. Tilly fought on the old principles, great masses and fixed artillery, with new men, raw recruits many of them. Gustavus fought on the new principle, with veteran soldiers; lines six men deep, and field artillery. Tilly advanced from the south from Leipsic, himself commanding the centre; Pappenheim led the left wing, and Fürstenberg the right. Gustavus approached from the north, himself opposed to Tilly, and the Saxon army to Fürstenberg. The whole wing under Pappenheim outflanked the Swedish army. Gustavus had nine thousand horse and 13,000 foot: Tilly had about 40,000 altogether. Fürstenberg beat the Saxons: Gustavus beat Pappenheim, sent a large detachment to help the Saxons, and then turned the fixed guns of Pappenheim's wing upon Tilly. The reserves of Gustavus's army then attacked. Tilly had no reserves; he was terribly beaten; narrowly escaped capture, and was wounded in three places. He was rescued by Rudolf Maximilian of Lauenburg, who shot the giant Swede, Frederick the Long, when he had nearly overpowered him, and carried him off to Halle. In this battle, on the imperial side 7,000 were slain, 5,000 prisoners and all the guns were taken; only 2,000 men out of the 40,000 could be brought together after it. The Swedes lost 700; and the Saxons 2,000 .

This was the first pitched battle fought by Gustavus since he landed, and it is memorable both in political and military history. It brought Germany to its senses, and taught Europe that it had at last come to possess a great king. France was frightened at the triumph of its friend and ally. Ferdinand, always greater in adversity than in prosperity, was nerved to new efforts. The Protestants saw that their time was come; the leaguers, that there must be no holding back.

Gustavus had now succeeded in consolidating the territory that wasleft behind him. Pomerania, Saxony, Mecklenburg, and Brandenburg were all bound to him by treaties that secured to him communications with the Baltic and the way home to Sweden. He had succeeded in turning jealous and selfish neutrals into the instruments, if not the supporters, of his policy. The smaller princes were crowding round him for protection. But the further he got from 
Sweden the more difficult it was to maintain his own army : he had to make the Germans fight for themselves. Before he left Saxony he settled the plan of further proceedings. The Elector John George he sent at the head of the Saxon army into Bohemia, Lusatia, and Silesia, to hold for the Protestants what he had once held for the Emperor, to atone for his treacherous selfishness, perhaps to place an impassable barrier from henceforth between himself and Ferdinand.

This done and his own authority established in Merseburg and Halle, he set out for the Main ; receiving at every step of his journey petitions for new alliances and protection, and embodying in a new force the armies of the little States he passed through, giving to each its sphere of action and charge to keep. At Erfurt he met the Duke of Weimar and incorporated him. From Erfurt he passed into Thuringia, carrying all before him without any real resistance. Schweinfurt submitted as he passed. Würzburg surrendered at once, and the citadel a few days after, before Tilly, who was raising forces for its defence, had time to succour it. Thence Gustavus advanced along the Main to Aschaffenburg. On November 1, Hanau submitted. On the 16th, Gustavus entered Frankfort, and the Emperor's Diet of deputies, which had assembled there in August to treat of the execution of the edict, vanished before him. Here he received the submission of the Landgrave George of Hesse-Darmstadt, the head of the house opposed to the faithful William of Cassel, and obtained from him a guarantee for the safe passage of his army across the Main in the possession of Rüsselsheim, which he garrisoned (November 19).

He now approached the Palatinate, which was still held by the Spaniards. At Oppenheim he crossed the Rhine ; Mentz surrendered on December 13; Mannheim on the 29th. The ecclesiastical princes of the Main and Rhine fled everywhere before him, and everywhere he received new petitions for protection from the free cities and small Protestant states in every part of Germany. Not less successful were the generals whom he left behind him in the execution of his plans. John George of Saxony occupied Prague and restored Protestantism in Bohemia before the winter ; Tott, in Mecklenburg, secured Rostock and all else that was not yet taken; Baner, the Magdeburg country ; Bernard of Weimar, the Brunswick territory; the Archbishop of Bremen and the Duke of Horn, Franconia. Brunswick made alliance with him. The vast imperial armies of which a year before the leaguers had been complaining were nowhere.

Tilly seems never to have recovered the battle of Leipsic. After his vain attempt to relieve Würzburg, and another as vain to attack Nuremberg, he posted himself at Rothemburg, and retired thence 
upon the Danube. The Spanish army, having garrisoned Heidelberg and Frankenthal, evacuated the Palatinate. The Duke of Lorraine, who was leading 12,000 men to join Tilly (he had determined to throw off the burden of French protection and side with the Emperor), saw his forces disperse without a battle. Rapidly and steadily Gustavus pushed on: he had secured the passage of the Neckar by taking Wimpfen; then he went along the Rhine to Worms. During the short winter holiday that he gave his army he stayed about Mentz and Frankfort. At Mentz he received the English ambassadors, who congratulated him on his victories; at Frankfort in February 1632 he had a visit from the Elector Palatine Frederick, now in the twelfth year of his exile.

The whole Catholic world was now in alarm. It was not merely the success of Gustavus, but the utter and entire collapse of their own triumphant armies that terrified them; the failure of the invincible Tilly; the loss of Bohemia before the tipsy old John George; the defection everywhere of the cities and people of the states whose rulers continued faithful to the League. The ground that had been won by the Counter-Reformation was lost, although, as the result showed, not permanently. The Bishop of Würzburg betook himself with his story to the French court and told it so well that, if it had not been for Richelieu, Lewis XIII. would have thrown over his alliance with Gustavus. As it was, Richelieu had some difficulty in arranging terms; he compromised, however, by offering to mediate, to prevail on Gustavus to grant neutrality to the League, as the French on their part had done to Maximilian of Bavaria, and to content himself with the protection of his allies and the humiliation of Ferdinand.

The leaguers were too wide awake now to think of this. Maximilian saw that he must either stand or fall for the present with the house of Austria, and joined in the deliberations that were taking place at Vienna for a new confederation against the Swedes. The great question to be deliberated was the appointment of a new general. Tilly, it was said, was worn out and a failure: he had been great in handling an army, but a man was wanted who could make one. And men's thoughts at once centred on Wallenstein. But Wallenstein had many enemies : although amongst his own creatures he had some faithful and adoring friends, his enemies were the men in power. Maximilian, at the head of them all, was jealous of Wallenstein's fame, unwilling to serve under him, and diametrically opposed to everything that was characteristic in Wallenstein's policy. Ferdinand himself saw that it would be dangerous to trust one whom he had so completely sacrificed; and he wished, as before, that his son the King of Hungary should have 
the command as the likeliest way to secure his election to the Empire. In this plan he was supported by the envoys of Philip IV. But the majority of the German counsellors would have no one but Wallenstein, if Wallenstein could be had. And Wallenstein would condescend to no terms beneath the dignity of a sovereign prince. He held back for a time; at last, when the Emperor had shown himself sufficiently submissive, he relented.

The conditions of the engagement were at first that he should raise an army, and then the Emperor should determine who should lead it. Under this arrangement he raised within three months a disciplined force of 40,000 men. Then Ferdinand agreed on a further treaty. Wallenstein was to be declared general-in-chief of the imperial and Spanish armies, with no limit to his authority; Ferdinand and his son were not even to set foot in his camp; he was to have absolute power in nominating officers, in exacting contributions, in disposing of the confiscated estates of the enemy; no safe-conduct was to be granted, no project of peace considered without his knowledge or consent.. When the war was over he was to be rewarded either out of the imperial estates or out of the confiscations, to be reimbursed for his expenses and to be secured in Mecklenburg ; whilst Ferdinand was to bind himself to make Prague his chief residence as soon as Bohemia was conquered.

Whilst these arrangements were being completed, and Wallenstein was directing his first blows against the Saxons in Bohemia, the season for war began and Gustavus was proceeding southwards. The proposition for neutrality having failed, Gustavus determined to attack Bavaria, and to attack it before Wallenstein could effect a junction with Tilly, as he was sure to do as soon as his force was large enough to leave Bohemia safe in charge. Tilly was at Nördlingen; he too, as soon as March came, began to stir. His army now numbered 20,000 men, and they were well furnished, as they had not been in the preceding year, with ammunition and provisions. He advanced on Schweinfurt, to cut off, if possible, Gustavus's communications. But the King was prepared for this. He sent Oxenstiern to the Rhine to stop the Spaniards, and centred his own force at Aschaffenburg, under Baner, Horn, and Bernard of Weimar. Whilst he was at Aschaffenburg, Tilly could not get to Schweinfurt; he was obliged to fall back, after threatening Nuremberg, towards the Danube again ; he crossed the Danube to join the Elector on Bavarian soil and encamped on the Lech.

It was there that Gustavus saw he must take him before Wallenstein could join him. He proceeded as rapidly as possible from Aschaffenburg to Nuremberg, and from Nuremberg to Donauwerth which he stormed. From Donauwerth he marched on Ingolstadt, 
which he besieged, but, finding the resistance stronger than he expected, he returned to Donauwerth, crossed the Danube there, and passed to the Lech, on the other side of which Tilly was posted. $\mathrm{He}$ was fortunately able to command the passage of the Lech by the aid of his artillery. After a terrible struggle he effected it. Tilly made every effort to prevent it, but he was mortally wounded in the fray, and Aldringer, the second in command, was also disabled. Maximilian, left to himself, saw that the struggle was unequal, and led back the army to the protection of Ingolstadt. Thither Tilly was carried, and there he died of his wounds, reiterating with his last breath that Ratisbon must be secured or all was over. All was over in fact in Bavaria; Ratisbon commanded the entrance into Austria.

This is the end of Tilly. He was seventy-three years old; a wonderful warrior ; an honest, temperate, unselfish old man ; but an unrelenting, unscrupulous persecutor, and a general without fear and without remorse. That he was a Jesuit and the instrument of Jesuits is scarcely a fair reason for exaggerating his faults, although it may account for their being more mischievous in their effects upon the world. But as a man he should not be judged on those grounds. Great as was the harm that he did, wrong as you may believe his principles, and cruel his whole system of warfare, he was not exactly an enemy of the human race. He was a man of strong convictions, and of a hard sort of religion, more like Puritanism than Popery; and, bad as he may have been, he had some good points which men more praised and admired have been without. He was faithful, and unselfish.

The defeat of Tilly on the Lech was not, as a success, to be compared with the victory of Breitenfeld, but it was a signal triumph, most especially as it laid Bavaria at the feet of Gustavus ; and he saw himself the conqueror of the estates of the prince who, of all the German potentates, had done most harm to the Protestant cause. In triumphal procession he passed on to Augsburg; Landshut and Freising opened their gates to his army, but he went on direct to Munich, the southern limit of his conquests. His treatment of Bavaria was different from his treatment of the other States he had passed through : he does not seem to have contemplated a permanent occupation, or to have tried to secure the country behind him as he had done before. Ingolstadt was still holding out, and Ratisbon, which he as well as Tilly saw should rightly be the next object of attack, held out successfully against Horn, his general whom he had sent to besiege it. On May 7, he entered Munich with the Elector Palatine in his company. The Swedes would fain have revenged on Munich the sack of Magdeburg, but Gustavus forbade it: 
he allowed the citizens to ransom their town for 300,000 thalers, and suffered no plunder or outrage to take place.

$\mathrm{He}$ did not stay long in Munich. Maximilian was invading Franconia, and the defence of Nuremberg was a more important object than the devastation of Bavaria; Gustavus accordingly.retraced his steps and took up his position again in Franconia.

By this time Wallenstein was able to devote himself to the attack on Gustavus. Up to this moment he had been employed in Bohemia, where John George and his minister and General Arnheim were getting tired of war, and were not perhaps altogether indisposed to treat with Wallenstein. By keeping them in play and increasing and disciplining his army, Wallenstein let the time run on until Gustavus had conquered or at least overrun Bavaria. He had no particular wish to save Maximilian's territory, and did not hurry to join Tilly. But when Tilly was dead and Bavaria occupied, and Gustavus on his way back to consolidate his hold on Franconia, Wallenstein bestirred himself, drove the Saxons out of Bohemia, and followed them into Lusatia; retook Prague and took Egra also-a very strong position at the point where the Upper Palatinate, Bohemia, Saxony, and Franconia meet. From Egra he threatened Nuremberg. At Lutitz, near Egra, he met the Elector Maximilian, and joined his forces with his own.

The army under his command amounted to sixty thousand men, and with these he marched on Nuremberg. But Nuremberg was ready for him, and finding that he had no chance of taking it he removed to Zorndorf, where he entrenched his camp and watched the proceedings of Gustavus. For nearly two months, from June 30 to August 21, the two great generals watched one another, both anxious to draw the adversary out of his strong position, but both determined not to be drawn. During this time Gustavus collected forces from all the provinces where his armies were scattered; and his generals went on taking place after place on the Rhine and in Thuringia.

At last, on August 24, Gustavus attacked Wallenstein's camp, leaving his own in the charge of the Nurembergers. The attack was long and pertinacious, but Wallenstein was neither to be drawn nor to be driven; after every regiment in the army had assaulted in turn, Gustavus had to withdraw without a victory and with very considerable loss. He kept his ground for a fortnight longer, and then removed from Nuremberg, leaving a strong garrison. This state of things had lasted seventy-two days; and both parties had endured what was more like the horrors of a siege than the dangers of ordinary warfare in the field.

When Gustavus broke up his camp to go again into Bavaria, 
Wallenstein went northwards to punish the Electors of Saxony and Brandenburg on their own ground. The intention of Gustavus in leaving Nuremberg for Bavaria seems to have been to try to draw off Wallenstein from the exhausted country, which was mainly Protestant also, and to remove the theatre of war into the neighbourhood of the hereditary States of the Emperor. It certainly seems a change from the plan hitherto adopted, so full of purpose and so brilliantly executed; but it must be remembered that Gustavus had not yet met either such an army or such a general as Wallenstein, and that the only struggle in which they did encounter one another was a drawn game. Both had been cautious about attempting a pitched battle. It may be that both saw the issues were too great to be risked for the sake of a speedy decision; that neither could afford to give the other the slightest advantage in the way of beginning.

The two great armies then broke up. Gustavus went to Bavaria, and sent Bernard of Weimar to defend Franconia and the line of the Main. Wallenstein undertook Franconia previously to attacking Saxony, and sent Maximilian to defend his own dominions, and Clam-Gallas to Bohemia. His first object was to prevent the Saxons from joining Duke Bernard, and to drive out the Swedish garrisons.

Gustavus's second inroad into Bavaria failed of its purpose; it might be too bold to say that it was a mistake. He again crossed the Danube at Donauwerth, having taken Rothenburg, Dinkelsbuhl, and Nördlingen on the way, and on September 27 recovered Rain on the Bavarian side of the Lech. Thence he was recalled by the urgent entreaties of John George of Saxony.

Wallenstein would not be drawn off into Bavaria. After ravaging Culmbach and attacking Coburg, he hastened into Meissen. At Altenburg he met Clam-Gallas and Holck, who had done their work on the Elbe: thence he marched on Merseburg, where he met Pappenheim returning from the ravaging of Lower Saxony and Thuringia with 40,000 men; together they besieged Leipsic, and took it on October 22. Wallenstein now knew that Gustavus was returning northwards; he determined if possible to prevent him from joining the Saxons, and hastened, after the capture of Leipsic, to send Pappenheim to Halle.

Gustavus was now very near. He had left a part of his army to occupy Maximilian, and joined Duke Bernard at Arnstadt; thence, following the course of the Saale, they marched towards Leipsic, and approached the imperialist army, which was moving from Weissenfels towards the Elster, from the direction of Naumburg.

At Lützen the two armies came in sight of one another; and 
both knew that a battle was inevitable. But the Swedes were tired after a long day's march, and evening was come; they rested opposite to one another all night. Wallenstein, reluctant to the last to fight, although very considerably outnumbering his adversary, consulted his astrologers, and, finding the stars hostile to Gustavus, determined to give battle. The battle of Lützen was fought on November 6. There Gustavus fell and Wallenstein was defeated. The King of Sweden again drew up his army on the new plan; two thin lines, one of them to act as reserve; plenty of field guns and those arranged scientifically in order with the fighting men. Wallenstein stuck, as Tilly had done, to the old system : four compact masses in the centre, and the cavalry on the wings ; but he had in a measure intrenched his position in the night, with ditches and redoubts, and threw on the Swedes the burden of attack. The Swedish infantry, in the thick fog of a specially foggy November morning, attacked the intrenchments and were cruelly driven back by a strong fire from the musketeers. When they were giving way, Gustavus came in person to the rescue, brought up his cavalry on the right wing and passed the ditch, driving in the enemy upon their own cavalry. In the midst of the victory he learned that the left wing was being overwhelmed by Pappenheim, who was coming up from Halle; riding hurriedly to the rescue with Duke Francis Charles of Lauenburg and three attendants, he got into the fog, and found himself close upon a party of Austrian cavalry. There he was shot in the arm and breast, mortally. Duke Bernard of Weimar had presence of mind to conceal the fact, and told the Swedes that their king was taken prisoner. They determined to rescue him, threw themselves on the imperialists and drove them back with an irresistible charge. Pappenheim arrived with new forces, but the Swedes, exhausted as they were, received them, and a panic followed. Pappenheim was mortally wounded; his army believed him to be slain and fled in dismay. In spite of Wallenstein's efforts, he recognised the fact that he was beaten; and left the field in the night.

So Gustavus fell ; the victory he won in his death being nearly as great as any he won in his life. I shall not favour you with any more moral reflexions about him. I stated my opinion of him in my last lecture. He had done a very great work. Much still remained to be done; and not a little of what he had done had to be done again, but it was his first doing of it that made the second possible. And now he had laid down his life for the cause. He had counted the cost before he began the war, and always had in view a death on the battlefield as the likely end of his career. He knew that he had not lived, and would not die, in vain. His death, however, was far 
from the end of the strife: of the Thirty Years' War we have not yet reached the central year. But the heroes are quickly dropping off. Another lecture must bring us to the end of Wallenstein : thenceforward we shall, I fear, have more of politics, less of adventure.

\section{LECTURE VII}

THE WAR FROM THE BATTLE OF LÜTZEN, 1632, TO THE DEATH OF WALLENSTEIN, 1634

ONE of the most convincing proofs of the great warlike abilities of Gustavus Adolphus is found in the fact that, short as his career as a conqueror was, he had trained up a school of generals who were able to fill up his place as soon as it was vacant. Many of these, moreover, were German princes of whom it cannot be said that they had learned their lesson whilst he was learning his. Baner and Horn and some of the others may have served under him in his earlier wars, but Bernard of Weimar, the Counts of Salm, the Palatine of Birkenfeld, and a great number of others who come prominently forward as we proceed with our story, were Germans, who may indeed have fought and studied the art during the early stages of the war which has now reached the middle of its course, but cannot be said to have had a chance of learning the virtues of generals until they came to be associated with him.

The supply of generals, and the wonderful gift of warlike skill which they seemed to have exemplified, are indeed characteristic features of this war in common with some of the other great military periods of the history of Europe. Alexander the Great trained a school of great generals, and so did Napoleon Bonaparte: Gustavus stands, in ability though not in power, at a very short distance behind these. Notwithstanding the frequency of wars, there had not been during the preceding century anything like these men. Charles V. was a great warrior, and in the early part of his reign he had two or three brilliant generals in Italy; but for the greater part of it he stands almost alone. After him comes Maurice of Saxony; in the next generation there are Maurice of Nassau and Spinola ; but then we come to Tilly, Wallenstein, and Gustavus, with their many pupils.

It is seldom indeed that, on the sudden fall of a great leader, his place is instantly supplied. This was done in the case of Gustavus, at least in some respects. Bernard of Weimar, on whom the command devolved at Gustavus's death, was never for a moment 
wanting to his position; whilst Oxenstiern, Gustavus's chancellor, who had been his prime minister since he came to the Swedish throne, took upon himself to keep together the reins of the Protestant and anti-Austrian policy which he had helped his master to devise. Bernard won the battle of Lützen on the day of Gustavus's death; and Oxenstiern, as soon as he had made safe the crown on the head of the little Christina, came down from Sweden into Germany to re-create the Protestant confederation. Greatly dismayed as the whole party was at the loss of the prince who had embodied the hopes of one half in his brilliant successes and had led the other half so much further than they ever had intended to go in opposition to the Emperor, such was Oxenstiern's adroit management that he kept them for the time at least up to the mark, and shamed those who would have flinched into something like resolution.

If we look back now for a moment on the state of things in Germany at the time of Gustavus's death, we shall see, I think, that his position was by no means what it was when he had beaten Tilly at Leipsic. He was still a victorious leader of an army, a host of armies that had never been beaten, but he had passed the zenith of his triumphs when he first met Wallenstein. Wallenstein had not beaten him, but had distinctly foiled him, and, evading defeat, had raised the Catholic powers again from the prostration in which the battle of Leipsic had laid them. The period of Gustavus's success was the period of Wallenstein's retirement: the time when the mighty army, before which all the other leaders of the Protestants had gone down, had dissolved in the mysterious way which left Tilly without a reserve to fall back upon at Leipsic, and laid Bavaria open to Gustavus after the crossing of the Lech.

Whether Gustavus, if he had lived, would have proved in the end too strong for Wallenstein may well be questioned. On the one side you have the most perfect skill, the most enthusiastic spirit of daring, and the most carefully constructed plan of campaign ; on the other, scarcely less skill, scarcely less daring, and, instead of the constructive power, the most consummate faculty of handling an army in the field. Whilst Gustavus gives each of his great disciples a share in the management of the plan which his own genius devises, and so makes them realise most fully the unity of the combination and their own responsibility for the result, Wallenstein's armies seem to act as one man under his yet more marvellous power of impressing his own will upon the masses of soldiers. Although both Gustavus and Wallenstein seem to have been worshipped by their common soldiers, Wallenstein is, more than Gustavus, the soldier's general ; and none of Wallenstein's disciples came accordingly so near their master's fame as did those of Gustavus. Further, however, Wallen- 
stein was, during the greater part of his career, supreme ruler of his army, whilst Gustavus had to create an army from among the subjects of a great number of princes who were jealous of him and begrudged him everything. He had in this respect greater difficulties to contend with than Wallenstein had. The comparison of the two leads to the conclusion that, in point of military skill, the palm cannot safely be awarded to one as against the other, as on all the occasions when they came in contact it was a drawn game between them ; save at Lützen, where Bernard had really, after Gustavus's fall, to fight a new battle against Pappenheim, in which chance, if we may so speak, seems largely to have befriended him.

Germany, then, had seemed at the opening of the year 1632 as completely prostrate before Gustavus as it had been some years previously before Ferdinand. As then the appearance of Gustavus had altered the aspect of affairs, so now did the recall of Wallenstein; but before the struggle could be fought out both Gustavus and Wallenstein disappear. At the moment of Gustavus's death Germany was by no means under his control. He had overrun nearly the whole of it, but had not attempted to hold what he had won; he had not succeeded in taking Ingolstadt or Ratisbon, so that his conquest of Bavaria could not be secured by the occupation of the fortresses. Franconia he was holding with his armies, but Alsace lay open to the hostility of the Duke of Lorraine, the Palatinate was indifferently defended against the Spaniards; and, further north than that, Lower Saxony lay open to them through Westphalia and the archbishopric of Cologne. Saxony and Brandenburg were felt to be insecure supporters behind; both of them jealous of the supremacy of the Swedish king, Saxony as the head of the Lutheran interest, and Brandenburg as the claimant of Pomerania. In Bohemia, Wallenstein at his first movement had driven the Saxons-who were perhaps half willing to be driven, and seem never to have fought heartily except in Saxony and for Saxony-out of Bohemia.

The battle of Lützen was so far decisive that Wallenstein quitted the field of war immediately after and retired again into Bohemia, leaving the Protestant armies, which could fight in winter as well as in summer, to divide again and return to the tasks they had been occupied with when the alarm of Wallenstein's advance on Franconia had brought Gustavus Adolphus back from his second invasion of Bavaria. The battle of Lützen was fought on the 6th of November, Wallenstein during the night left the position which he had so stoutly defended, and all his artillery on the field, and retired upon Leipsic, whence, having left a small garrison in the citadel, he returned to Bohemia, where he passed the winter; and 
where, after his retreat was secured, he punished very severely the officers to whose cowardice he attributed the defeat at Lützen, and munificently rewarded those who had signalised themselves by valour or address. He remained in Bohemia until May 1633, when he again threatened the Upper Palatinate and Saxony.

The Protestant leaders proceeded, as soon as they were assured of their enemies' retreat, to return each to the field of work from which he had been summoned, or to undertake a new one whilst the victory was yet before men's minds. Horn marched into Alsace; the Saxons quickly recovered Leipsic, and then, with the army of Duke Bernard, compelled the remainder of the imperial army, which was occupying Chemnitz, to surrender. Two or three other places in the electorate which were still in the hands of the enemy were subsequently taken, and by Christmas the whole of the country was free from them. As soon as this was done, Bernard with the Swedish army returned to Franconia; Baner went to Swabia, and other generals into the Lower Palatinate, Westphalia, and the Rhine country.

It is a somewhat dreary task to pursue the movements of these generals into detail, especially after we have accustomed ourselves to gather the interest of the war round a single person or in the unity of a single campaign ; but as the year 1633 was a most eventful one we must try to do something of the kind; taking the more insignificant persons first and falling back upon Bernard and Waillenstein last.

Horn, I said, was sent to Alsace ; Baner into Swabia against the Bavarian forces. The successes of the Bavarians against Baner quickly caused Horn to leave Alsace and assist his fellow general. $\mathrm{He}$ crossed the Rhine and took Kenzingen and Freiburg in Breisgau; at Rothweil he received 2,000 Würtembergers as a reinforcement; at Geckingen he joined Baner, and together they marched on the Bavarians, who had entered Swabia from the southeast and had occupied Memmingen and Kempten. At Kempten they routed the Bavarians, and immediately after freed the duchy of Würtemberg from invasion.

It was now March, and Horn joined Bernard at Augsburg on the 12th of that month. After a few joint operations against Bavaria, Horn was again detached into the Upper Palatinate, where he spent most of the summer. In the autumn he returned westward, and, having in vain besieged Constance, re-entered Alsace, which had been reoccupied by the imperial army in January, after Horn's march into Swabia, and where Otto Lewis, the Count of Salm, generally called the Rhinegrave, had been since June waging a somewhat unequal warfare against them. Horn, having crossed the 
Rhine at Strassburg, joined the Rhinegrave at Colmar. The news, however, of an imperial army advancing under the Duke of Feria from Italy prevented much more being done in Alsace; the whole force was summoned to meet Bernard at Stockach on September 25, and the remainder of Horn's proceedings for the year falls in with those of the general-in-chief.

The two Rhinegraves, Otto Lewis and Philip, had occupied themselves all the summer with a small force, but with considerable success, in holding the strongholds of the margraviate of Baden and shutting in the imperial garrison at Breisach.

Into the Lower Palatinate Christian, Count Palatine of Birkenfeld, was sent early in the year. The unhappy Frederick, ex-Elector Palatine and ex-King of Bohemia, had, as I should have mentioned before, died at Mentz on November 29, 1632 ; he had long been ill, but the news from Lützen is said to have broken his heart. We take leave of him as one of the most mistaken men in all history. Christian of Birkenfeld was a member of a junior branch of the house which had split up into an unusual number of fragments; he was a pupil of Gustavus, who had made him a general of cavalry. His campaign is signalised by the capture of Heidelberg, which he took by capitulation on May 24 : this terminated the hold of the Catholic League on the Palatinate. The Bavarian and Spanish garrisons were ejected, and the Duke of Lorraine alone threatened, but the Duke was beaten at Pfaffenhof by the Count Palatine on August 1.

In Westphalia George of Lüneburg and the Landgrave William of Hesse occupied, during the spring and summer, most of the towns of the bishoprics of Osnabrïck and Paderborn; and the imperialists under Beninghausen were severely beaten at Oldendorp on June 28. Kniphausen, another general of the Protestants, took Osnabrück in September, and Duke George besieged Hildesheim, which, however, held out until July 12, 1634.

These are, I think, the most important movements of the year, except those of Duke Bernard and Wallenstein. During the whole of the time Oxenstiern, moreover, was attempting to strengthen the confederation in a series of congresses, to which we must return by and by.

Duke Bernard's proceedings were not very complicated. Having, as we saw, rid the electorate of Saxony from the invaders, he returned to Franconia ; Bamberg was surrendered to him without a blow, and Hochstadt followed the example. From Hochstadt he advanced towards the Danube; Horn joined him on March 12 at Augsburg, and they took measures together for securing the Upper Palatinate. After Horn was detached for this service, a conspiracy was discovered amongst the troops in Franconia, which was quelled 
by Bernard with great ability, and partly in consequence he claimed for himself the fulfilment of a promise made him by Gustavus that he should receive the investiture of the duchy of Franconia, with the bishoprics of Würzburg and Bamberg. The claim was admitted on June 12. On July 18 the Swedish ambassador released the estates of Franconia from the oath taken to Gustavus, and handed over the ducal authority to Bernard, who on the 19th, at Würzburg, received the homages.

Thus dignified as Duke of Franconia, Bernard prepared to invade Bavaria; took Eichstädt, and attempted, in the hope of being seconded by internal treason, to seize Ingoldstadt. In this, however, he failed: and the approach of the Duke of Feria to the aid of Aldringer, the Bavarian general, led him to concentrate all his available forces near the Lake of Constance. This march of the Duke of Feria, who was coming up through the Valtelline with 12,000 foot and 2,000 horse, was a part of the design which Ferdinand, under the pressure of Maximilian, had formed, of conducting at least a portion of the military transactions of the Catholic party independently of Wallenstein. Informed of the advance of this formidable force, but unable to see that it would be the interest of the Catholic powers to avoid a struggle, Bernard collected his forces at Stockach, near the north-eastern horn of the Lake of Constance. Horn and the Palatine of Birkenfeld met him there on September 25. But the Duke of Feria, instead of approaching them, turned off towards the Danube; and when they had given him time to make his way towards the hereditary estates of Austria, Bernard felt himself strong enough to attempt his long-postponed march on Ratisbon. Advancing cautiously through Swabia, he took Neuburg, Ingolstadt, and at last Ratisbon, on November 5. Straubing fell three days later, and then he crossed the Isar into Southern Bavaria, hoping to meet Wallenstein. But Wallenstein, as usual, was unwilling to help Bavaria, and advanced no nearer than the Upper Palatinate, where he had defeated the Swedes at Steinau on October 18. Bernard, hearing that he had retired, regarded the campaign as at an end, and took up his winter quarters, as usual, in Franconia.

What, we next ask, had Wallenstein been doing since the battle of Lützen? He took the field in May : determined, apparently, to ensure his hold on Bohemia before attempting anything further. He assembled his army between Pilsen and Egra, on the Saxon and Palatinate frontier, and began that extraordinary game which, as we shall soon see, proved fatal to himself. Having a very insufficient force, and little artillery, he found it necessary to avoid an engagement, and endeavoured to gain time by negotiating with Arnheim, the Saxon general, for armistices, and even for peace. 
Arnheim, who, we saw before, was not enthusiastically faithful to the Swedish cause as he regarded it, and who had served under Wallenstein, was imposed on by these propositions, and only found out that they were feigned when Wallenstein's object was gained. Having been so often deceived, all he could do was to determine to be imposed upon no more, which he did. When Wallenstein's purpose was answered and his forces increased and equipped, he sent Holck, a Dane and one of his best lieutenants, with 7,000 men to watch Duke Bernard; then dashed into Silesia, where Arnheim was waiting for him. To get rid of Arnheim, he detached Count Gallas to attack or feign to attack Saxony with 10,000 men. Arnheim quitted Silesia to defend Saxony, and Wallenstein seized his opportunity, overwhelmed the force of Swedes under Count Thurn at Steinau, on October 18, and compelled them to surrender all the strongholds of that province, Great Glogau, Liegnitz, and Wohlau. Thence he occupied Lusatia, took Frankfort and Landsberg in Brandenburg, and prepared to strike a blow at Pomerania which would cut the power of the Swedish confederation at its base, and might recover Mecklenburg for himself.

It was in the midst of this design that he heard of Bernard's successful doings in Bavaria and received the orders of the Emperor to hasten to the relief of Ratisbon. Determined, however, on his own line of action, he contented himself with sending Count Gallas with 10,000 men, and these to act only on the defensive. Another imperative command compelled him to march south in person, but he simply made a show of trying to recover Cham, which Bernard had taken, and, before he had succeeded in taking it, was recalled by the news that the Saxons had besieged Frankfort and were going to invade Silesia. He immediately returned to Pilsen, and, as the winter was close at hand, sent his troops into quarters. The wisdom of his proceedings we must examine when we come, as we shall directly, to his fall.

So, however, the year 1633 closes, and we have yet to look at the political movements going on amongst the allies. Of these movements Axel Oxenstiern is the presiding genius: he takes up the political as Duke Bernard does the military place of Gustavus Adolphus. He had lost no time after the battle of Lützen in endeavouring to supply that place. As soon as he saw Sweden prepared to accept the succession of the little Christina, knowing that the battle with Denmark and Poland, if it must be fought at all, must be won on the soil of Germany, he came to Germany, and, as the head of the Swedes, called together at Heilbronn, on February 28, 1633 , a congress of the four circles which had become most devoted to Gustavus, those of the Upper and Lower Rhine, Franconia, and 
Swabia. The estates met on March 3, and in a series of conferences which lasted through the spring, the old relations were thoroughly reconstructed. Notwithstanding the intrigues of the Elector of Saxony, who was partly deluded by Wallenstein's diplomatic mancuvres and partly by his own jealousy of the Swedes, Oxenstiern succeeded in binding the four circles in a league for carrying on the war in alliance with Sweden until the Elector Palatine and the Dukes of Mecklenburg should be restored, the liberty of religion and the rights of the princes secured, and the expenses incurred by Sweden in the Protestant cause reimbursed. The confederates bound themselves further to make no several or special agreements with the enemy, and to place the direction of their movements in the hands of Oxenstiern himself as the representative of Sweden. This arrangement was completed on April 13.

On the 9th a treaty had been made with France continuing the alliance until the close of the war. In this France showed herself even more ready than before to take part with the Protestant princes, the successes and enthusiastic spirit of Gustavus having proved rather alarming to Richelieu. In February the alliance between France, Saxony, and Brandenburg had been renewed. Christian of Denmark stood aloof from this league and tried hard to make peace with Ferdinand. He was, however, now too much impoverished to make his assistance worth having, and the negotiations came to nothing: the Danish estates opposed his change of politics, although the Emperor was willing to bribe him with a promise, which could never have been intended to be kept, of the Lower Saxon bishoprics.

The confederation of Heilbronn was renewed and confirmed in September 1633. The Swiss were invited to join it, but they wisely declined. The Elector of Brandenburg, after thinking long about it and seeing that Wallenstein would not be likely to spare him whether he joined it or not, acceded at length, and several small princes in Westphalia and Lower Saxony also gradually came in. The Elector of Saxony was the chief Protestant who stood aloof.

On the imperial side there was less harmony and much more intrigue. To Maximilian and the Catholic princes the present supremacy of Wallenstein was intensely exasperating: he claimed the supreme command and collected round himself all the warlike material that Catholic Germany could supply; and he neither attempted anything decisive nor would even strike a blow for the deliverance of Bavaria. His own plan of campaign he was far too proud to lay before them, and his conduct gave ground even for suspicions of his honesty. $\mathrm{He}$ had become far too powerful to continue to be a subject, and his attitude in Bohemia, if he were unfaithful to the Emperor, was such as to ruin the imperial cause 
altogether in that kingdom and so to wreck the cause of the League in Germany : he was acting there as a sovereign prince, in constant communication with Arnheim and the Saxons, who only lately had been occupying Bohemia as enemies and were still in arms against the Emperor, and one subject of discussion between them was the preservation or restoration of the rights of the Bohemian kingdom. His tolerance and liberality, moreover, were in direct opposition to the persecuting policy and poverty, not to say meanness, of Ferdinand.

The complaints of Wallenstein's haughty demeanour, his contempt for the Catholic princes, and his mysterious conduct were carried to Ferdinand constantly, almost from the moment at which Wallenstein was prevailed on to resume the command and re-create the imperial army. And Ferdinand, although he could have no real ground even for suspicion against Wallenstein, was disposed to listen to any plan that promised to place his son, the King of Hungary, at the head of the army. The desire of doing this and the constant attempts of Maximilian to rouse him from mere dependence on Wallenstein, were the cause of his summoning the Duke of Feria with his large army from Italy in September, and probably also of the Duke of Feria's avoidance of a battle with Bernard, Horn, and Berkenfeld and his rapid movement into Austria.

Wallenstein responded to this act of distrust by one of disobedience or what looked like it, for it must be remembered that it was an infringement of the terms on which he had been reappointed. He refused to come to the help of Ratisbon, and, having advanced to Cham, retired without punishing the foe. A better motive than mere sulky obstinacy did, however, certainly actuate Wallenstein during all this, and might, if he had condescended to explain, have made all things straight with the Emperor, if not with the leaguers. Wallenstein saw that the power of the Swedes must be struck at its root. Pomerania and Mecklenburg seized and made sure of, the supplies of men and provisions that came by the Baltic would be cut off, and the war, thrown upon the internal resources of Germany, must end as all such wars had ended before.

It was unfortunate that his own stake in confiscated Mecklenburg suggested to his enemies the idea that his movements in that direction were caused by his mere greed of dominion. We may be very certain from the pains which we saw Gustavus Adolphus take to secure his base in the North, before he would move even into Saxony, that Wallenstein's idea of cutting off that base was the wisest that could have been formed, whether or not it were suggested by his longing for an independent sovereignty for himself. He had been kept in Bohemia all the spring by want of artillery and of soldiers, 
and to gain time had entered into delusive negotiations with the Saxons; nay, it is even possible that he had hopes of persuading them to a neutrality which would have enabled him to leave Bohemia safe whilst he marched northwards.

When he had at length made his preparations and was victoriously reclaiming all that the Saxons and Swedes had won, he was recalled to defend Bavaria; and he not unreasonably regarded this order as an act of distrust and an infringement of his rights, and as a fatal check to his great plan. When he found that Bernard, instead of staying in Bavaria, had gone back to Franconia to watch him, his disgust at the Emperor's conduct was no longer restrained, and his words and even his acts became such as to render him still more excusably than before an object of suspicion at Vienna. Ferdinand seems to have thought that he might be worried into resigning, and accordingly communicated to him in a roundabout way the design for superseding him. But Wallenstein did not take the hint; and the Emperor found that he must give a more direct indication of his wish. He sent him orders to break up his army, to send 6,000 horse into the Netherlands, another large body of troops to Passau to defend Bavaria, and himself to march on Ratisbon, and, having recovered it, to spend the winter on the enemies' soil: that is, in Swabia or Franconia.

It was already winter and Wallenstein was at Pilsen, his soldiers in their quarters. It is now, I think, that Wallenstein first begins to treat in sincerity with the Protestants. Unfortunately, his former diplomacy had disposed them to regard all such overtures with the greatest suspicion; and they declined to listen to them. At the same time he laid the state of affairs before the colonels of his army, and tried to withdraw them not so much from their allegiance to Ferdinand, as into his own design of resisting dismissal. The colonels, believing that his dismissal was aimed against them, and would have the effect of robbing them of all the rewards they had earned, signed, to the number of fifty-two, a formal requisition to him not to resign his command, and bound themselves to remain faithful to him, even to shed the last drop of their blood in his service. This was done on February 12, 1634.

Although, however, the colonels and the soldiery in general seemed to enter into his design of resistance, Gallas and Aldringer, knowing that his disgrace was determined on, took measures of their own. Octavio Piccolomini, who had been one of his most intimate friends, carried the news of the requisition to Vienna, and Ferdinand, under the joint pressure of Maximilian of Bavaria, the Spaniards, and the Jesuits, alarmed, moreover, by the falsehoods that Piccolomini liberally introduced into his report, ordered that Wallenstein should 
be arrested and deprived of his command. Gallas was nominated in his place, and Piccolomini was ordered to seize him, dead or alive.

He immediately returned with his instructions ; Gallas took the command and made himself sure of Prague, Budweis, Leitmeritz, and Tabor; Pilsen and Egra were still in the hands of Wallenstein. But Wallenstein was now almost helpless : he had sent to Vienna to explain the requisition of the colonels, and learned from thence how fatal a weapon he had placed in the enemy's hands. He sent Tersky, his most intimate friend, to seize Prague, which Gallas had already occupied, and himself hastily proceeded to Egra, where he renewed his proposals, through Duke Francis Albert of Lauenburg, to Bernard of Weimar, offering to surrender both Egra and Pilsen and to join the Protestants with the army which he still trusted. Bernard was afraid to believe him ; he sent to Frankfort to Oxenstiern with the same offers; but before an answer could come his fate was decided. On February 25, 1634, Wallenstein was assassinated at Egra by several Scottish and Irish officers, whom Gordon, the governor of Egra, had persuaded to join his plot. Tersky and Kinsky, his two faithful friends, were killed before the assassins could reach Wallenstein's chamber. The man who murdered him was an Irishman named Devereux.

So Wallenstein died, and another of the great heroes of the time leaves the stage-a man of transcendent ability, but of character so wayward and peculiar that his successes are even more wonderful than his powers. Of the guilt, the foul dishonour, of his murder there can be no doubt. The chief blame falls, of course, on Gordon and the conspirators; the next on Piccolomini, and the next on Ferdinand. We must believe that the Emperor both misunderstood Wallenstein and was deceived by Piccolomini ; but the commission to seize him, alive or dead, was a cruel reward for all that Wallenstein had done for the Catholic cause and for the house of Austria.

\section{LECTURE VIII}

THE INTERVENTION OF FRANCE IN THE WAR

THE only political result of the death of Wallenstein was the drawing more closely together the Catholic powers, to whom his supremacy in the imperial armies had been a subject of disgust and contention. It enabled the Emperor to place his son, the King of Hungary, in command; it satisfied the Pope, as well as he could be satisfied with anything that he hated so much as the Empire; it pleased 
Spain, which was now ready to take an active part in support of the common honours of the two branches of the house of Hapsburg, and it put it in the power of the Emperor to satisfy Maximilian and his allies of the old party of the League who wanted to have Bavaria and the territories of the other Catholic princes properly defended, or who did not understand Wallenstein's counter-scheme to Gustavus's military policy, and thought South Germany wantonly or wilfully sacrificed to the North. In a more ulterior way it possibly served to prevent the Emperor from getting that entire autocracy in Germany which Wallenstein probably contemplated obtaining for him, and with it the extinction of Protestant opinions in central Europe.

It is impossible, of course, to speak with any certainty on a design so visionary as it seems now, and the very authenticity of which is problematical; but it is manifest from many reasons that the Protestant party was becoming exhausted, and that a victorious campaign under Wallenstein would have laid them more completely prostrate than ever. Wallenstein's successors were able generals, but did not entertain his far-seeing political designs ; had he lived to carry them out, it is even possible that the radical difference between himself and the Emperor on religious toleration might have undone them when at the point of fulfilment, and that the Jesuits, seeing this, conspired with his other enemies for his downfall.

At the moment of his death the situation was simply this: the army which he had commanded had gained great successes in Bohemia, Lusatia, Silesia, and the Mark of Brandenburg, and was threatening at no great distance Pomerania and Mecklenburg. Duke Bernard, on the other side, had taken the strongholds that protected Bavaria and Upper Austria, and had quartered a large force in Ratisbon as well as occupied his former quarters in Franconia. The position was somewhat critical, for a decided defeat on either side would have laid the centre of the enemy's strength open to immediate attack. Bernard might at any moment advance upon Vienna. Wallenstein doubtless, as soon as he was ready, would have cut off the Swedish base of operations in Pomerania. His death, however, opened the door to new and very different counsels.

The Protestant armies were at the opening of 1634 thus posted:-Bernard was at Ratisbon with 10,000 men : Horn was in Swabia, holding all the country to the west of Augsburg. Baner, with the Saxons, was threatening the recovery of Lusatia; the Rhinegrave was active in Alsace, the larger part of which also was occupied by the Swedes; and in Westphalia a struggle on a small scale was proceeding between the imperial forces and the Hessians. Almost immediately after Wallenstein's death the estates of the 
circle of Lower Saxony joined Oxenstiern's confederation at Heilbronn.

The action of the war begins in March, and it was at first very much in favour of the Protestants. In Swabia Horn advanced from Ravensburg, took Biberach, Kempten, and Memmingen, and defeated the imperialists at Wangen before the end of March. In Alsace, the Rhinegrave, on March 2, defeated the Austrians at Warweil, and on April 1 took Freiburg in the Breisgau; Philippsburg also surrendered to him. In Bavaria the reverse was the case; the Bavarians recovered Straubing on March 22. In Silesia, Lesley took Landsberg and defeated the Swedes under Götz in their attack upon Oppeln. Baner, however, further north succeeded soon after in recovering Frankfort on the Oder, and would have done more if the Saxons had not mistrusted him. Arnheim, with the Saxons, recovered Glogau; Baner, with the Swedes, entered Bohemia and threatened Prague.

Sufficient activity was being shown in all quarters of the field of war. On the Catholic side, the Cardinal Infant, Ferdinand of Spain, son of Philip III. and Archbishop of Toledo, now twenty-five years old and the man of the family, had collected a force of Milanese, which on his way through Germany he was to utilise in favour of the Emperor before he took it to the Netherlands ; and the King of Hungary, with the aid of Wallenstein's old officers-who, having lost their master, had determined to do the best they could for the Emperor-having put down the momentary dissatisfaction among the soldiers that was caused by Wallenstein's assassination, had got his large army into fighting order.

To King Ferdinand the recovery of Ratisbon was the first great object to be gained. The King of Hungary was not afraid of the loss of Bohemia, which Baner and Arnheim were threatening. $\mathrm{He}$ knew the difficulty which Oxenstiern was now experiencing in keeping the Protestants together, and trusted to the jealousy between Baner and Arnheim to neutralise any strong measures that might be taken in Bohemia. Unfortunately, the jealousies were not confined to these two. The Elector of Brandenburg had got a new cause of offence in Oxenstiern's refusal to betroth the little Queen Christina to his son; the Elector of Saxony was again half Austrian, now that Oxenstiern had restored the Calvinistic Count Palatine; nay, worst of all, Horn and Bernard of Weimar were contending about the command of the army in the South. Ferdinand acted as if he knew all this; left 10,000 men under Colloredo to defend Prague (a very insufficient force indeed, if he had not something not far removed from treachery to depend on); and with the Cardinal Infant marched on Ratisbon. 
They left Bohemia by Egra, crossed the Danube at Straubing, which the Bavarians had retaken, as we saw, in March, and advanced to the siege of this most important city. Bernard had left it strongly garrisoned ; but in the event of a siege it must of necessity fall, before a force so much superior as that which was brought against it, unless it could be relieved in time. The principal man in the defence was Count Thurn, our old friend of the Bohemian revolution, who had his own luck and now disappears from history. The besieging army numbered 30,000: the King of Hungary was aided by the counsels of Gallas and Piccolomini ; and the Duke of Lorraine was there with the forces of the League. After seven assaults and an enormous loss of life on the part of the besiegers, Ratisbon was taken on July 26. Bernard and Horn were not in time to save it: their competition for command and their variance of opinion on the plan to be followed during the campaign kept them asunder. When at last they had joined at Augsburg, and had attacked Landshut on the way to Ratisbon, the news of the capture reached them.

This was the loss of the greatest advantage that had been gained since the death of Gustavus. But it was far from being the worst blow that fortune had in store for the confederates. Bernard and Horn retired upon Augsburg, to arrest the progress of the enemy by guarding Donauwerth : the imperial army advanced on Nördlingen. The intelligence of an invasion of Bohemia did not distract them from the end in view. Ten thousand men were detached to keep the Saxons in play, but the vacuum was more than supplied by the arrival of the Spaniards under the Cardinal Infant. Ferdinand marched on Nördlingen with 40,000 men. Before Bernard reached Donauwerth he had crossed the river and stormed the town; on August 16, he was before Nördlingen, the great stronghold of the Protestants in Swabia. For the relief of this town, they had to strain every nerve; the Rhinegrave was summoned from Alsace, Bernard and Horn reconciled their differences and prepared for a decisive battle. But the Rhinegrave lost time on the way: he had just taken Rheinfelden and was on the point of taking Breisach; he had to stay to destroy his own works for fear they should be seized by the enemy, and he arrived too late.

The battle was fought on September 6, 1634. Ferdinand was ready for the attack: he drew off his force from the siege, set his guns in order for battle, and stood on his defence. Bernard appears, in opposition to Horn's advice, to have urged the immediate engage ment before the Rhinegrave arrived. The Protestants attacked, and at first with appearance of success: but they met with a very stout resistance, and fell back with enormous loss. Then the Imperialists 
took their turn. Eight thousand Swedes and Germans had fallen in the struggle, two thousand in the flight, and four thousand were taken prisoners. Horn, after performing miracles of valour, was taken, Bernard escaped but very narrowly. The imperial army triumphed with a loss of but two thousand men, and they took all the baggage, stores, and artillery of the allies. The town surrendered the next day.

The battle of Nördlingen is one of the great battles of the war ; it was to the Protestants what the battle of Leipsic had been to the League, and its political results were hardly less important in a contrary way. The Protestant armies could bear defeat as little as the imperialist armies could sustain their triumph: the same rule appears throughout the contest. The Catholic party comes out strong in adversity, the Protestant party in prosperity : defeat rouses and unites the former, whilst it paralyses and divides the latter.

If it had not been for France, the battle of Nördlingen would probably have ended the war, for the Emperor was heartily tired of it, and was willing, by concessions to the Lutherans, to pacify the larger part of the Protestants ; the Calvinist element might then be demolished in detail. As usual, however, Germany's extremity was France's opportunity. The imperial generals were not slow in following up their advantage. The confederates were so completely beaten that it was no longer necessary for the enemy to keep his forces together. The Cardinal Infant proceeded by Aschaffenburg and Cologne on his march to the Netherlands ; the Duke of Lorraine by the Breisgau, to his own country. The army of the League, under Werth, occupied the Upper Palatinate; and a part of the Bavarian force the line of the Main. The King of Hungary pursued the Rhinegrave and drove him across the Rhine, then took possession of the cities of Swabia and Franconia, and Heilbronn, the seat of the confederate Diet, amongst them. The stronger places held out. Heidelberg was twice besieged and twice relieved in the course of the winter, once by Bernard and once by the French. The confederate council took refuge in Frankfort; and Nuremberg and Augsburg prepared for resistance.

But the action of the Protestants was paralysed, and their losses in men and material were not easy to make up. Ferdinand wintered in Swabia, in the duchy of Würtemberg, the stronghold last year of the Protestants in South Germany. A very few isolated successes only can be set against these reverses: these were chiefly in the north of Germany; in Lower Saxony, the princes who had been the last to join the confederation were wavering in their allegiance under the treacherous dealing of John George of Saxony ; the neutrality of Brandenburg; the earnest pacific efforts of 
Christian of Denmark, and the wavering disposition of the Dukes of Brunswick. Nothing could be more hopeless than Oxenstiern's view of affairs when he called the allies to Frankfort. The force that still remained was the army of Baner in Lusatia; that of the Rhinegrave in Alsace ; the remnant of the cavalry under Bernard, and what little force was kept in the field by William of Hesse and George of Lüneburg.

The confederates laid on Sweden the blame of all their troubles : as after the battle of Mühlberg, as after the battle of Prague, they sought each the easiest way of escaping from an alliance which was now certain to destroy them. Still Oxenstiern maintained a bold spirit ; bitter as it must be to let France reap the benefits of Gustavus's victories, that must be the next move in the game. Philippsburg was at once handed over to Louis XIII., and an engagement was proposed by which, if France would enter heart and soul into the struggle, Alsace should follow. But before France had made up her mind, the great defection of Saxony had robbed the anti-imperial party of one more great chance. John George of Saxony had been early in 1634 intriguing with Wallenstein, and ever since Wallenstein's death had been growing more and more lukewarm. Again Lusatia was set before him as a reward of his complaisance, and his conscience as the head of the Lutheran party was propitiated by the hint that the Edict of Restitution should not be executed in his dominions. The King of Denmark pressed him to make peace; the battle of Nördlingen had a still more conclusive influence. Before the end of November 1634 a project of treaty was drawn up at Pirna, which in the following January was laid before the Saxon estates. The next month an armistice was effected, and on May 30, 1635, the peace of Prague was concluded. The peace of Prague was negotiated by John George not merely for himself, but for the whole of the Lutheran powers of Germany if they would accept it ; the Calvinist houses, especially the Elector Palatine's, having no more share in the advantages of it than they had had eighty years before under the peace of Passau. The terms are worth study. The most important are these: the abandonment of the Edict of Restitution so far as the Lutherans are concerned, and with it, of course, the abandonment of the principle of the Ecclesiastical Reservation; all mediate ecclesiastical property appropriated since the peace of Passau-that is, all Church estates which had been feudally held of the princes, as was frequently the case with monastic property-was to remain to the possessors, and all immediate property - that is, Church estates feudally held of the Emperor, which had been seized since November 11, 1627-was likewise so secured, subject to rearrangement, however, within the following forty years. The worship of the Confession of 
Augsburg was to be allowed in the Empire generally, save in Bohemia and the hereditary estates of Austria. A general amnesty was to be issued, and all conquests made since the landing of Gustavus Adolphus were to be restored, but the Dukes of Würtemberg, William of Hesse, and the Margrave of Baden were excluded from the amnesty. Thus reconciled, the Germans were to unite in expelling foreigners from the German soil. Lusatia was to be held by the Elector as a fief of Bohemia; Magdeburg was given to his second son; Halberstadt was left to the Archduke Leopold. If the Elector of Brandenburg would join, he was to be secured in the Pomeranian succession.

By this treaty it will be seen that Ferdinand resigned a great deal ; all, in fact, that he had claimed in 1628, and that had brought down Gustavus Adolphus on the Empire. An acceptance of the treaty on a large scale would isolate the Swedes and give to the war henceforth the character of a war between France and the Hapsburg house, provided that France would openly go to war with the Empire. What was quite as dear to the Emperor's heart, it would enable him doubtless to secure the election of his son as his successor.

Whilst the imperial counsellors were intriguing for and negotiating this arrangement, the armies were not relaxing their efforts against the Palatinate and the remaining allies of the Swedes on the French frontier. No battle of any importance was fought, but the strongholds changed hands or were besieged and relieved. On March 26 the Spanish army seized Trèves and carried off the Elector, who had placed himself under French protection, a prisoner. Philippsburg, so lately handed over to the French, had fallen into the imperial power in January. But the seizure of Trèves was the starting-point of a new phase in the struggle : war to the death between France, with all the allies she could procure, and the house of Hapsburg in Spain, the Netherlands, and Austria.

The alliance of Oxenstiern with Louis XIII. had never been interrupted, and it was therefore unnecessary that it should be renewed; but the battle of Nördlingen did necessitate new efforts on behalf of the confederates, from which Richelieu did not shrink. A new arrangement was accordingly negotiated during the time that the Emperor and the Elector of Saxony were debating the peace of Prague, and, by a treaty between Oxenstiern and Richelieu, the French agreed to declare war against Spain, to subsidise the Swedes with 500,000 livres, and to furnish a force of 12,000 men to assist the confederates in Germany. The Swedes on their part were to surrender Alsace, except Benfeld, with Philippsburg and Speyer, to assist in recovering the towns in Alsace which were now in Austrian hands, for the French, and to grant the privileges of a neutral to any Catholic 
power in Germany that should claim the protection of France. These terms, which had been in the process of settlement since November, were set before the allies at Frankfort by Oxenstiern on March 11, 1635 , and only accepted by them under his most earnest entreaty. Bernard was at the same time made general-in-chief of the German army.

On comparing the terms of the treaty of Paris with those of the peace of Prague, we cannot, I think, look without astonishment at the condition to which Germany was reduced. On the one hand, the Emperor, the most bigoted Catholic, was agreeing with the protector of the Lutheran party to drive the foreigners, Catholic and Protestant, out of Germany ; and on the other, Louis XIII., as great a Catholic, as great an oppressor of the Calvinists in his own dominions as Ferdinand was of the Lutherans and Utraquists in his, joining with the Swedes and the Calvinists of Germany in an attack on the Catholic house in its three great seats of dominion on condition of receiving as reward a great slice of German territory. The national party, for such we may fairly regard the Protestants as being, was divided between an emperor sworn to destroy Protestantism and a king whose services were to be purchased by the alienation of a German country. Out of such combinations, or from men capable of such combinations, what good end could be expected? In the view of such want of principle, such hypocritical selfishness, it is a relief to look at even uncompromising bigots like Ferdinand and Maximilian, men who never lost sight of their purpose, mistaken as it might be, who were capable even of sacrifice for their religion such as it was, and were above the mere greed of territory in comparison. We could not look for two Gustavus Adolphuses in a generation.

The war now changes its character very much; it loses most of the features which the policy of Gustavus had impressed upon it, and becomes what it had been in the earlier stages-a struggle in which, besides the religious interest, the imperial and national German interests were largely and confusingly intermingled.

France was not prevailed on thus ostensibly to enter the field until she had spun her web of alliances very close. On February 8 , 1635, Richelieu had concluded a treaty with Holland for the conquest and partition of the Spanish Netherlands. On July 11 at Rivoli the Dukes of Savoy and Parma joined in a design for the conquest of the Milanese. The vast resources which the great minister had been labouring to create for France were all now utilised : two fleets and four armies. One army was for the Notherlands, 26,000 men; another for Italy, of 14,000; a third, under the Duke of Rohan, of 4,000, to secure the Valtelline, that Austrian and 
Spanish troops might not pass to and fro to each other's assistance; and a fourth, under La Force, to help Bernard and the confederates on the Rhine.

Of the two competing claims on the adhesion of Germany, the peace of Prague, although not the most promising, drew in the larger number of the smaller powers. The imperial cities were weary of the war which exhausted their resources, destroyed their trade, laid them open to exactions from both sides, and to dangers for which their constitutions did not afford any real remedy. Although they were hot for the Reformation, and probably more sincerely so than any of the princes, although they had tasted less of the plunder, and really cared more for the liberty of conscience, still they were bodies of men to whom peace was more natural than war, and who would be justified in placing themselves, upon adequate conditions, on the side of that one of the two powers which proved itself most able to guarantee peace. This, for many reasons, was the imperial side.

The conclusion of the peace of Prague between Saxony and the Empire was followed, therefore, at no great length of time, by the adhesion of some of the greatest cities. Frankfort, the first, joined on July 14. Nuremberg seems to have held back until June 1636. The Elector of Brandenburg had already embraced it: the princes of Anhalt and most of the members of the States of Lower Saxony followed. The confederation of Heilbronn was finally dissolved in the month of September; and one by one all the princes who were not formally excluded by the treaty itself gradually came in. The war thus became one, not between the Emperor and League against the Swedes and the confederation, but between France and Sweden assisted by the excluded princes on the one side, and the Emperor and King of Spain assisted by the princes who had taken advantage of the treaty and the remainder of the League.

The peace of Prague and the treaty of Paris thus mark one of the chief changes in the character of the war, and one of the epochs at which the memory may rest in accumulating details. The military details of 1635 are sufficiently intricate: everywhere and continually fighting appears to be going on, and without much to impress the memory. We may divide it according to the locality of the struggle.

(1) In Italy, where the Duke of Rohan was to occupy the Valtelline, and Créqui and the Duke of Savoy to operate against the Milanese, little was done, and that little was unfavourable to France. The Duke of Rohan, with the assistance of the Grisons, occupied the Valtelline and so prevented any attempt on the part of the Austrians to succour the Spaniards; but the Spaniards were 
strong enough to fight their own battle. The Duke of Savoy and Créqui had continual misunderstandings with one another, and so laid themselves open to the enemy. And the Spaniards not only were able to hinder them from doing anything decisive, but actually succeeded in compelling the Duke of Parma to relinquish the French alliance and to give up Sabionetta. This little episode runs into the year 1636.

(2) In the Netherlands the French had greater success, but the evils of the unnatural alliance between Richelieu and the Prince of Orange prevented their being carried so far as they might. After taking Tirlemont and Diest the allies besieged Louvain; but the brave little eity held out so pertinaciously that it wearied both the patience and the unanimity of the besiegers : a diversion by the Spaniards on their own soil called off the Dutch, and the French, who had suffered heavily, had to retire without capturing the place ; followed by a Spanish expedition which ravaged Picardy and threatened the still more formidable invasion which was effected in the next year.

(3) In Germany itself the struggle was now chiefly confined to the Rhine and the Palatinate. There, on the imperial side, Gallas and the Duke of Lorraine were opposed to Duke Bernard and the Swedes, Cardinal de la Valette, and the French. By the recovery of Philippsburg in January 1635 and the capture of Worms they were able to make their way into Lorraine, where the Duke had still some adherents and was able to maintain himself. They took Heidelberg and Dilsburg, swept the Palatinate, and blockaded Mentz, which, notwithstanding the efforts of the allies to relieve it, was taken on October 24. Frankenthal fell in October ; Königshof, the last place held by the Swedes in Franconia, early in December. Louis XIII. put himself again at the head of his army and called out a feudal levy throughout France. In the meantime Baner was defending the Swedish acquisitions in North-Eastern Germany against the Saxons with but scanty success. He defeated them with a loss of 7,000 men at Diemitz in October, and afterwards took Havelberg; but the imperialists took Stargard, and in the obscurity of the petty struggles of that remote region it is not easy to discern that either side had much advantage. The army of Gallas, on its return from Lorraine, established itself at Worms.

In the midst of all this confusion, it is somewhat puzzling to be told that Duke Bernard, who had lost all his treasure at Kaiserslautern, was in treaty with the Emperor for reconciliation, and had actually to be bought off by the French by the promise of Alsace as an hereditary state and a large subsidy. This transaction 
is dated in October, and a treaty arranging for a truce of twenty-six years between Sweden and Poland was made in September. These seem to consolidate the Swedish chances a little more; but the latter was purchased by the surrender of the conquests which Gustavus had made in Prussia.

The frequent negotiations between France and the Swedes seem, however, to show that Richelieu was awaking to the great importance of the alliance, and that it was now courted on the French side rather than on the Swedish. Oxenstiern himself was weary of war, and inclined to despair of success; Baner alone, of the Swedish generals, maintained the spirit and skill of Gustavus ; Bernard was wavering. The three treaties to which I refer especially are two already mentioned, that of Compiègne, between Louis XIII. and Christina, on April 28, 1635, and that with Bernard October 26 ; and a third, the actual conclusion of which falls in 1636, the treaty of Wismar, March 20, involving a confederation to last three years, on the old terms of France subsidising the Swedes.

The warfare of $\mathbf{1 6 3 6}$ is, so far as Germany is concerned, not less puzzling than that of 1635 . The attack on France engrossed the attention of the world, and probably most of the force that was available on the Austrian and Spanish side. Three armies attacked France ; one in Picardy, which was led by Thomas of Savoy, took La Capelle and St. Léger-le-Catelet in July, and Corbie in August, advancing so near Paris that the Court fled to Orleans and Richelieu even talked of resigning. To meet this Louis XIII. again took up arms, and as usual with effect; he recovered Corbie in November, and drove the enemy out of the country before the winter. A second army, under Gallas, passed the Rhine at Breisach, and, joining the Duke of Lorraine, invaded Burgundy, where they besieged St. Jean de Losne a little half-fortified place at the confluence of the Ouche and the Saône, but were forced to retire without taking it, after a siege of three weeks, by the weather, famine, and pestilence. A third Spanish army made an ineffectual attack on Guienne. So much is tolerably clear.

In Germany, Baner in the autumn did some great things. With a little army of 12,000 men he recovered the Swedish supremacy in Brandenburg and Pomerania; defeated the Saxons and imperialists at Wittstock on September 24; drove them through Hesse, took Erfurt, entered Meissen and besieged Leipsic. Wrangel, co-operating with him, scoured the March of Brandenburg, took Frankfort, and besieged Küstrin. The Saxons had, however, taken Magdeburg, in spite of Baner's efforts to save it, on July 3.

Duke Bernard was in Alsace, which he now regarded as his own, just as he had before regarded Franconia ; the Cardinal of La 
Valette, son of the Duke of Epernon, having joined him. Together they took Saverne, and helped to drive Gallas out of Burgundy. In Westphalia Lesley recovered Minden, April 26 ; and the Landgrave William of Hesse compelled Lambri to raise the siege of Hanau. This is pretty nearly all.

More important civil transactions were, however, going on. The Pope was attempting a mediation; he sent Cardinal Ghinetti to Cologne to propose terms of peace. The French showed some signs of acquiescence, but now the Swedes held back: and this particular negotiation, like that former one which had been held at Cologne in the war of emancipation of the Netherlands, dragged on for several years. On September 5, 1636, the Emperor called a Diet at Ratisbon, partly to deliberate on the mediation of the Pope and the King of Denmark, principally to secure the election of his son as King of the Romans. This was accomplished at last. The votes of Saxony and Brandenburg had been secured by the peace of Prague; the Elector of Trèves was in prison at Vienna ; Bavaria and Cologne were safe, as was also the Elector of Mentz. The election was completed, the Palatine house alone protesting, on December 22.

Ferdinand II. survived the attainment of this, one of his great political aims, only six weeks ; dying at Vienna on February $15,1637$. His death, as we shall see, marks another stage. As for his character, we have, I think, seen as much as we need of it already. We have, I trust, done ample justice to his great ability, his thorough honesty of purpose, and his firmness in adversity: we have re-echoed the sentiments of all historians as to the misdirection of his aims, his bigotry, his unscrupulous intolerance, his subservience to the Jesuits. If we were Jesuits we should probably say that he was a good man and a good king. As we are not, we will content ourselves with saying that if it had not been for the Jesuits he would have been a good man and a good king. He was a man of pure life, kind and gentle in every private relation, and inflexibly just everywhere but where his religion was concerned. There we must allow he was a tyrant. Judged by his own principles-and I question whether we as men have a right to judge a man morally by any other than those which he himself maintains-the balance is considerably in his favour. 


\section{LECTURE IX}

\section{NINE YEARS OF WAR, 1637-1645}

We have still before us eleven years of the thirty over which the war extends; and it is very desirable that the present course of lectures, of which only four now remain, should cover the whole ground. This can only be done by confining ourselves to the chronological statement of the events of the war as closely as possible until we can bring them to a conclusion, and then turn back to comment on their general bearing, and on the politics of the states engaged in them. And this, I think, we shall be enabled to do without much crowding, for, so far as the political combinations go, we have now-with the exception of one change, that which placed the Lutheran party again in opposition to the Emperor-exhausted them. The principal characters soon die off, and, although the war continues with little flagging and little more energy than before, it presents us with no grand events or sudden revolutions of fortune until we approach the close.

Ferdinand II. died, not at the point at which his successes had reached their maximum, but before that decline began, gradual and scarcely intermitted, which compelled his son to conclude the peace of Westphalia. During the whole period that follows, negotiations for peace were proceeding, under the mediation of Denmark at Hamburg, and under that of the Pope at Cologne; and yet there is no real intermission of fighting. The battles and sieges are nearly as wearisome as the negotiations. Ferdinand III. was in some respects a wiser man than his father: that is, he was more tolerant religiously and less ambitious ; but he was not in any respect, except so far as his ability as a general goes, so strong a man as Ferdinand II., and he had, moreover, to contend with the exhaustion of power which his father's pertinacious policy had involved. He was, like his father, a good and honest Catholic, but he was not so great a man by any means. At the beginning of his reign, in the opening of 1637, we find that Baner is the great and leading spirit in the Swedish host, and Duke Bernard has rather sunk his character of a German hero in his desire to found an hereditary state, under the auspices of France, in Alsace. In Germany generally the peace of Prague has caught the Lutheran princes, William of Hesse being the chief exception; and the Palatine family are unable to make themselves heard except by feeble protests, the Papal negotiators at Cologne being unwilling to admit their envoys to learn the terms, of peace. 
The Swedish generals in the North, Wrangel in Pomerania and Banerin Lower Saxony, Brandenburg, and Lusatia, begin the year with some conspicuous successes: Baner, in January 1637, had made his way so far south as to besiege Deipsic. In March, however, the death of poor Duke Bogislas of Pomerania necessitated the settlement of the question that had been so long moved. The Elector of Brandenburg made his claim as heir; Baner responded by producing the treaty by which the possession of the duchy had been secured to Sweden at all events to the end of the war. He accordingly refused to vacate his position. The Elector at last heartily joined the Emperor, and Gallas was sent with the imperial force to compel the surrender. Hatzfeld and Görtz, who had been acting with considerable success on the Elbe, joined Gallas and succeeded in driving Baner out of the Mark into Pomerania itself. In June the Saxons with the imperial forces cleared Lusatia of the Swedes, drove Wrangel across the Wartha, took Landsberg, and prepared to drive Baner to extremities. In spite of a brilliant diversion by an attack on Silesia, Gallas overwhelmed Wrangel and got possession of all Pomerania to the west of the Oder, except Anclam, Stettin, and Stralsund. The autumn was now come, and having garrisoned the forts that were in his hands, he retired into Saxony for the winter.

In the West, Bernard, having in April renewed his treaty about Alsace with France, joined his forces with the French under $\mathrm{Du}$ Hallier and crossed the Rhine. The imperialists under Werth attacked him in his camp unsuccessfully; but after a few skirmishes which are not worth the name of battles he retired into Lorraine.

The great gain of the imperialists in this season was the capture of Ehrenbreitstein, which was starved into surrender in June. The other event of the year was the death of William the Faithful, landgrave of Hesse-Cassel, on September 24. His heir was a child; the guardianship was disputed by his mother and the head of the rival branch, the Landgrave of Hesse Darmstadt, who was imperialist ; the dispute paralysed the action of the little state for a long time, but the mother at last succeeded in vindicating her right and carried out to the end of the war the principles and policy of her husband.

So far for Germany. Outside of Germany, the French were successful in recovering from the Spaniards the conquests they had made the previous year in Picardy, and in repelling the invasion on the south. They, moreover, beat the Duke of Modena, who was commanding in Italy for the Spaniards; and their ally, Duke Bernard, kept a tight hold on Lorraine. On the other hand, they lost the adhesion of the Duke of Parma, who was obliged to renounce the treaty of alliance; they lost their possession of the Valtelline, the Duke of Rohan being ordered out by the Grisons, and the com- 
munication between the Spanish and Austrian territory reopened. The Elector of Trèves was released from imprisonment on condition of renouncing his league with France ; and the Duke of Savoy, dying, left a disputed guardianship of his son, in which the imperial party represented by Prince Thomas of Carignan and the Cardinal of Savoy were able to neutralise the efforts made by the Duchess Christina, who was Louis XIII.'s sister, to assist France. On the whole, although the French had some brilliant successes, the balance of gain on the year is in favour of Ferdinand.

The following year, 1638, may be distributed in much the same way but with a different result. Again we have Baner and Gallas in the north-east, Bernard and Werth on the Rhine, and the French fighting on the Pyrenees and in the Netherlands. In February, in Pomerania, the imperialists are successful. Gartz and Warnemünde fall into their hands, and Mecklenburg is seriously imperilled. In July Baner recovers all that had been lost, and after retaking Wolgast in September drives Gallas into the Magdeburg territory and thence into Silesia and Bohemia.

(2) Duke Bernard had some wonderful successes. He began the year by the siege of Rheinfeld; after one reverse at the hands of Werth and Savelli, he won a great victory over them on March 5, taking them both prisoners. After the battle he captured the town, and after it Röteln and Freiburg in Breisgau. In July he beat the Bavarians at Witteweir; and he crowned his successes by the capture, in December, of Breisach, which had so long formed the strength of the imperial position on the Upper Rhine. This done, he wintered in Burgundy.

(3) The success of France against the Spaniards continued. The Prince of Condé won battles in Navarre; the Archbishop of Bordeaux burned the Spanish fleet (August 22). The Capuchin Joseph, Richelieu's confidant, died. A new school of French generals was springing up, whose exploits are as confusing as their effects are evanescent. The interesting scenes of the war are on the same ground as those of last year, Pomerania and Alsace; but the victories that were won in 1637 correspond to defeats in 1638 : the attackers and defenders change places, and the luck is reversed. I should not omit a bold attempt of the heir of the Palatinate, Charles Lewis, to recover his inheritance in February 1638. $\mathrm{He}$ invaded Westphalia with Swedish and English succours, but was beaten by Hatzfeld at Lemgo in October.

In 1639 we have at least a definite and rememberable course of events. Baner and Bernard seem to have hit upon a plan for cooperation on the old principles : Baner to invade Bohemia, Bernard Bavaria; and so to advance in concert on the hereditary states. 
With this intention Baner marched out of Saxony in April, entered Bohemia, driving the Austrians before him; defeated them at Brandeis on May 20, and approached Prague ; finding, however, that the people did not rise as he had expected them to do, he withdrew into Moravia to wait for the movement of Bernard. Poor Bernard, however, was near his end. His one exploit of the year was the siege of Thann, which held out until late in the spring. His fatigues and anxieties seem to have worn him out. He fell sick of a fever at Neuburg, and died there on July 8 ; at the zenith of his chances, perhaps, although not of his successes. The French were sparing no pains to make him entirely their own; they wanted Bernard, but still more they wanted Breisach. Invitations to Paris poured in upon him, and even offers of marriage if he would ally himself with the great cardinal. His illness compelled him to send an agent with excuses; Richelieu tampered with the agent for the betrayal of Alsace; and the knowledge of this treachery probably aggravated Bernard's complaint.

On his death-bed he left Alsace to his brothers, of whom William, the reigning Duke of Weimar, was reconciled with the Emperor. But the French, whose subsidies had contributed largely to the conquest of the country, refused to recognise the claim. The dukes could not of course rely on imperial aid for the recovery of a territory conquered from the imperial house. So, by hook or by crook, France succeeded in getting the whole of Alsace into her power.

In Bernard the anti-Austrian cause lost its greatest enemy. Henceforth Baner remains, for the little time he lives, the great general of the party; but Baner is a very different man from Bernard, whom his admirers would place but a little below the rank of Gustavus Adolphus. In him, then, the war loses one more of the few objects of interest that light up this generally dreary portion of it.

The French employed this year six armies : La Meilleraye in the Netherlands ; De Feuquières on the Luxemburg frontier; Marshal Châtillon in Champagne; Condé in Languedoc; Longueville in Italy ; La Valette in Piedmont. On the death of Bernard, Longueville took up his standing-ground in Alsace, but his victories belong to the next year. Piccolomini defeated Feuquières; La Valette and Prince Thomas played a drawn game in Piedmont, but the town of Turin fell into the hands of the prince in August, the citadel remaining to the French. Little else was really done. Poor Charles Lewis, on whose behalf nominally the war was raging, put in a foolish claim to the succession of Duke Bernard, but the French were not going to stand that; they arrested him and sent him to Vincennes; and he was not released until he had surrendered his pretensions to Alsace. 
We thus come to the year 1640, marked by the death of the old Elector of Brandenburg and by a marked change of management in that part of Germany under his successor Frederick William, the Great Elector and founder of the Prussian monarchy. Another thing that makes the year generally important is the successful attempt of Portugal to emancipate itself from the rule of Spain, and the revolt of Catalonia, which the exhaustion of the Spanish treasury had compelled the king to tax, contrary to the privileges of the country. These events materially weakened the imperial alliance, and opened the way for advantages of which Richelieu lost no time in availing himself.

The year generally was one of conferences. The congress for the Danish mediation was working at Hamburg, the Papal one at Cologne: the Emperor was holding Diets, at Nuremberg and at Ratisbon, and negotiating with the Landgravine of Hesse on one side and Baner on the other. The raising of funds was now becoming to the Emperor a greater difficulty than ever. The fighting, however, although slackened, was not intermitted. Early in the year Baner was driven out of his conquests in Bohemia and Moravia, and retired upon Meissen. The Duke of Longueville came down the Rhine and not only took possession of Bernard's place in Alsace but drove the Bavarians into the duchy of Würtemberg, and, taking towns all along as he descended, carried war into Westphalia. But the negotiations that were in progress rather tied the hands of the German princes. On the side of Italy and France, the siege of Turin occupied a good part of the year; it surrendered to the French in September. The Spaniards were, moreover, beaten at sea.

The political mark of the year is made by the signs of an approaching break-up of the status established after the treaty of Prague. The Landgravine of Hesse-Cassel, finding it impossible to get what she thought justice from the Emperor, determined to throw herself on the side of the Swedes, and the Dukes of Brunswick, unable to get the security they wanted for their hold on the bishopric of Hildesheim, followed the example. The conduct of the Diet at Ratisbon, which was the first general Diet held since the war broke out, did not mend the Emperor's position. The estates were loud in their professions of a desire for peace. Ferdinand represented, soundly enough, that the only way towards peace was an alliance of all Germany against France and Sweden, which the peace of Prague also involved. They accepted the peace of Prague as the basis of a settlement, but they begrudged money for the providing an army; only Bavaria and Austria consented to make anything like an adequate grant. The seats of the peace conferences were brought nearer : the papal one moved from Cologne to Münster, 
the Danish from Hamburg to Osnabrück; contrary to the Emperor's wish, for this move placed them nearer and more under the influence of France than they had been. He was compelled also to allow deputies from all the states of the Empire to attend on their deliberations.

The historians mention further as a sign of the times the publication of a work by Chemnitz, the Chancellor of Stettin, on the constitution of the Empire, in which the authority of the Holy Roman Cæsar is treated with little ceremony, and the theory advanced that Germany is rather an aristocratic confederation than a basis or remnant of universal empire. The book was probably inspired by the Swedes, but the doctrine gained ground among the jurists of the Protestant states, and produced, no doubt, some important effects on the form which the peace ultimately took.

The year 1641 opens with a rousing incident. The Diet was still sitting at Ratisbon, the Emperor there in person, when Baner pounced down upon it and scattered it in the wildest confusion. He had collected men in Saxony, where we left him, 15,000 altogether ; had added a French contingent under Guébriant, of 6,000; and started at Christmas for the South. From Erfurt he marched by Hof right down upon Ratisbon; the Danube was frozen, and so the walls of the city could be reached on all sides; Ferdinand had a very narrow escape from capture; and but for an opportune thaw the place would have been taken. On the arrival of the imperial forces, the Swedes and French retired. Guebriant went back to the Rhine; Baner to Bohemia, closely pursued by Piccolomini ; through Bohemia to Saxony, and so into the bishopric of Halberstadt. At Halberstadt Baner died; his illness was produced by intemperance: the date of his death is May 10.

Torstenson, another pupil of Gustavus, whose reputation is not inferior to Baner's own, succeeded him in command. A little before Duke George of Lüneburg, who was besieging the imperial garrison at Wolfenbüttel, also died : his brother and successor, Augustus, went over to the Emperor. Before the siege of Wolfenbüttel was raised the Bavarians and Austrians sustained a severe defeat from the Swedes on June 19. After the appointment of Torstenson to the command of the Swedes there was a great deal of fighting in Northern Germany, in which, with a few exceptions, the imperialists had the advantage. Torstenson wintered in Lüneburg, Piccolomini in Hesse and Southern Brunswick. I may here remark again that some of the greatest successes of the Swedes were obtained by their practice of commencing operations in the depth of winter, whilst the imperial forces were safe in winter quarters. In January 1642 Torstenson left his winter resting-place and came down like a thunder- 
bolt on Bohemia, Silesia, Moravia, carrying all before him. The imperial generals, Piccolomini and the Archduke Leopold, who were diverted for the moment by an irruption of the French under Guebriant into Westphalia, hastily mustered their forces for the defence of Austria, for Vienna itself was threatened, and, but for the sturdy defence of Brieg in Silesia, must have fallen before it could be relieved.

Before these two generals with superior force Torstenson fell back through Silesia into Saxony, and, having at the beginning of November reached Leipsic, awaited the attack on the plain of Breitenfeld, where Tilly had experienced his first great defeat. Again the ground was lucky for the Swedes: on November 2 the Austrian force was completely beaten ; 10,000 men on that side were killed or taken prisoners. Leipsic was taken and the Archduke conducted his shattered force back to Bohemia.

This is the great feature of the year. It is marked in France by the busy continuation of the war in Navarre, the discovery of the plot of Cinq-Mars with Orleans and the Spaniards, for the deposition of Richelieu ; and by the death of Richelieu himself. The successes of Guebriant in North-west Germany, which I mentioned as dividing the attention of the Austrian commanders during Torstenson's march on Silesia, were also considerable. On January 17, he beat the army under Lamboy and Mercy at Kempen; took both the generals and 5,000 of their troops prisoners, and gained possession in consequence of the whole Electorate of Cologne.

The events of 1642 go thus sadly against Austria. The year 1643 opened, as usual, by a rapid movement of the Swedes into Silesia; followed by their retreat before the imperial army, with a sudden change of tactics. Here we again touch on tenable ground. The Emperor had been long negotiating with Christian of Denmark, who was beginning to recover strength and loved the Swedes as little as ever; an alliance was accordingly made. Christian was to attack the Swedes in their own land and so, if possible, draw them away from Germany. But the Swedes were more than a match for Christian both in war and diplomacy; instead of waiting for news from Sweden, Torstenson marched from Silesia into Holstein and absolutely conquered Denmark at a blow; only Glückstadt and Krempen held out against him ; whilst Horn, who had been exchanged after the battle of Rheinfeld for Werth, devastated the islands.

Christian, having once ruined himself and his kingdom for the Protestant ascendency, did it a second time for the Catholic. The Emperor felt bound to do what he could for his ally, and, whilst Torstenson was in Denmark, sent his army to cut off his return; but he was unfortunately weakened by his change of commanders. The 
Cardinal Infant, Governor of the Netherlands, died in 1641; the Archduke Leopold was called away from the Austrian army to succeed him ; and in his place as generalissimo the Emperor appointed Gallas, whose conduct and successes up to this time certainly seemed to warrant the nomination. Unfortunately, it was offensive to the two next best leaders, Piccolomini and Hatzfeld, who resigned their commissions and entered the service of Spain and Bavaria. With them apparently Gallas's luck deserted him, for he never did anything great again; and he was especially unfortunate in this expedition. It reached Holstein in the winter, and advanced early in 1644 to shut up Torstenson in Jutland. But Torstenson was too quick for him; he seized Rendsburg, thereby preventing Gallas from entering Denmark at all ; and then, taking the offensive, promptly drove him back into Lower Saxony, where, at Magdeburg, he reduced him to the most wretched condition.

The army of Gallas, worn out by unusual exertions, demoralised by constant repulses and disappointments covering the whole of the year 1644, was scarcely any longer worth Torstenson's consideration. He left the management of it to his lieutenant Königsmark, and marched off with the bulk of his army into Silesia again. Poor Gallas in November made an attempt to get his forces past Königsmark into Austria again, but he was beaten at Yutterbuck, on the Saxon and Brandenburg frontier, a few miles north of Wittenberg, and only scattered detachments ever reached home.

During this time the French undertook the conduct of the war on the Rhine, wisely confining their attention to that frontier, and, under the more cautious policy of Mazarin, keeping their forces within reach of Paris. Guebriant, after his victory at Kempen early in 1643, found himself chiefly opposed by the Bavarian army. After moving and countermoving through Franconia, he attempted to penetrate the duchy of Würtemberg, and besieged Rothweil, but he was killed in the siege, and his army, under Rantzau, after capturing the place, was beaten at Düttlingen by Mercy, the Bavarian general, with a loss of 6,000 men and all the artillery, on November 25, 1643 . The battle of Rocroi, won by the Duke of Enghien, afterwards the great Condé, over the Spaniards under Francisco de Mello, on May 19, 1643, had struck a fatal blow at the already declining power of Spain, which far more than balanced these occasional victories. As Rantzau was regarded as incompetent, the Viscount of Turenne was called from Italy to command the French army in Germany, and with Enghien and Grammont to consolidate the results of the battle of Rocroi.

Although the victory at Düttlingen had somewhat refreshed the spirits of the Austrians, the condition of affairs at the opening of 1644 was very discouraging. The great and already famous French 
generals were on the Rhine; Gallas was losing army and fame in the unhappy expedition to Denmark ; and now another old influence hostile to the Hapsburg house all at once rose to life on the side of Hungary. Torstenson and the French diplomatists had negotiated an alliance with George Ragotzki, the Prince of Transylvania, which threatened to renew the terrors of the days of Bethlen Gabor. For the moment Ferdinand thwarted him ; concluded a truce for twenty years with the Turks, on whose assistance Ragotzki had reckoned, and drove back with a handful of veterans the inroads of the Transylvanian cavalry. But the evil was only put off for a time; and the next year Ragotzki contributed in no small measure towards the imminent ruin of Austria.

Thus distracted, Ferdinand had little chance of assisting the Bavarians against Enghien and Turenne in 1644. The former fought bravely as long as they could ; in May they besieged Freiburg in Breisgau, and, in spite of an attempt of Turenne to raise the siege, they took it on July 28. But a few days after Mercy was attacked in his intrenched camp near the same city by the united French army, and. completely beaten. In the strength of this victory the French took Philippsburg and Mentz, Mannheim and Speyer. At one moment, then, Gallas's army was perishing in Saxony; Mercy escaping at full speed from Enghien, in Swabia; and the very existence of Austria proper was threatened by Ragotzki. So ends the year 1644 .

The next year seems almost to extinguish hope. On all three sides Austria was beaten or helpless. Take the French first. Enghien left Turenne in command after the conquest of the Palatinate, and his forces were held together with difficulty, badly paid and badly provisioned. $\mathrm{He}$ was obliged by Mercy to retire from the vicinity of the Neckar and wait for reinforcements. These were brought up by Enghien in person, and with them he fell on Mercy at Nördlingen on August 3,1645. This was one of the greatest battles of the war ; but, unlike the first battle of Nördlingen in 1634, it was a great defeat of the Catholics. Mercy, after an heroic defence, was killed, and Turenne remained master of Franconia; a vast number of prisoners were taken, and Bavaria permanently disabled.

The French general, agreeable to the policy of the last year, did not advance any further into Germany, but devoted himself to the recovery of the electorate of Trèves. That city was taken and restored to its Elector on November 19. The same month that the battle of Nördlingen was fought, and Bavaria, the oldest ally of the Emperor, paralysed, Christian of Denmark was compelled by the successes of Königsmark to renounce the imperial alliance. This general, after scattering the army of Gallas at Yutterbuck, had 
returned to the task of humiliating Denmark, seized all the cities of Lower Saxony, Bremen and Verden for instance, where Danish authority had been so studiously established; he had then taken Leipsic, Torgau, and Meissen, and compelled the Elector of Saxony to sue for an armistice, and then joined Torstenson in Moravia. Christian's peace with Sweden was concluded on August 13, 1645, and on the most humiliating conditions.

Worst of all Ferdinand's misfortunes, however, now was his position at home ; where, without more than the remains of an army, he lay open to the attacks of Torstenson and Königsmark on the north and Ragotzki on the east. His scanty force, the remains of Gallas's army, had been placed under Hatzfeld, Gallas being disgraced, and with a Bavarian contingent had fought a battle at Jankow (February 24, 1645) between Tabor and Prague, in which the imperial army was quite destroyed and Hatzfeld captured. The victorious Swedes occupied all Moravia and came down on the Danube above Vienna. Ferdinand rushed back from Prague to defend Vienna, but found the enemy in possession of the approaches : he had to go to Ratisbon, the Empress and the court fled to Grätz, and a siege of Vienna was imminent. Ragotzki was now overrunning Hungary (May), and, by contributing large reinforcements to Torstenson, enabling the Swedes to make the most effectual use of their veteran forces.

All things looking so hopeless, it is somewhat astonishing to find how very easily the tables were turned. Ferdinand did anything but despair. Fortunately he had time to collect, under the Archduke Leopold and Gallas, forces enough to keep the Swedes north of the Danube. On May 20 he recovers the bridge at Vienna. He patched up a peace with Ragotzki (July 26,1645 ), who was already tired of his allies and ready to play the part of Bethlen Gabor. Thus relieved from fear of Turks and Transylvanians, Ferdinand was able to levy a considerable force in Hungary; with this he relieved Bavaria; and was actually able to take the offensive against Torstenson, who had been besieging Brunn when he might have taken Vienna. Torstenson retired before the Archduke, and, after passing into Bohemia, was obliged by illness to resign his command (December 4 ) in the course of the winter to Wrangel, whom we have seen already commanding with Baner in Mecklenburg and Pomerania.

This extraordinary effort of Austria, seeming to be in extremis, oppressed on every side, is certainly one of the most curious effects of the war. Unlike her condition in 1618, when, although for a moment powerless, her resources were unexhausted and her allies fresh, she was now impoverished, depopulated, weakened in every respect, and saw her allies either ruined for her sake, like Bavaria 
and Denmark, or preparing to desert her. No doubt the illness of Torstenson helped to save her; but Torstenson was always an invalid, and yet in spite of his infirmities had exhibited a power and energy during the last two years in no wise inferior to what Gustavus and Bernard had shown before him. Next to this we must place the exhaustion of the powers of the other combatants ; for, although France was in the field and strong, her purpose was now not so much to drive the Hapsburgs to despair as to secure the frontier of the Rhine for herself and to compact her conquests; and in the interior of Germany the long war and disorganisation consequent upon it had produced their natural effects.

It was not that the Thirty Years' War was an especially bloody one; its armies were never very large; the largest of them would scarcely be called an army at the present day or in the nomenclature of nineteenth-century warfare; and often they were very small. The battles were fought far more by tactics and skill of handling than by numbers. Yet the result of what was now twenty-seven years' disturbance of every relation of society had had its natural effects. The land, where it was not thinned of its inhabitants, was overrun and devastated by the mercenaries who fought on both sides and plundered alike friend and foe. On the side of Hungary, which since the death of Bethlen Gabor had enjoyed comparative peace, matters were not quite so bad : and Ferdinand was able thus, as his successors have so often done, to use Hungary for the salvation of Austria.

I think we may say that in this lecture we have imitated Ferdinand's example. 'We have cut through an enormous mass of afflicting details and at last begin to see daylight. The back of the work is fairly broken; and we may, fully recognising that we are not out of the wood, reckon on finishing the fighting part of the war in another lecture. If we can do this we may yet redeem our promise of getting a glimpse at least of the political aspects of the period, and of the contemporaneous condition of the other States which have a history of their own outside and independent of this great and engrossing struggle.

\section{LECTURE X}

THE CLOSING SCENES OF THE WAR, 1646-1648

We have brought down our survey now to the end of 1645 . We remember that peace negotiations have been going on at Münster and Osnabrïck for several years; that the Emperor has gradually lost 
some of the most important allies that he made by the treaty of Prague-the Elector of Brandenburg, already long intriguing against him, and John George of Saxony and Christian of Denmark, compelled by the successes of Torstenson and Königsmark to make separate treaties of peace; that the last ally of any importance left to the Emperor is Maximilian of Bavaria ; that Wrangel has just succeeded Torstenson in command of the Swedes, and that Turenne is the general to whom France now confides her interests in the protracted struggle; that the Archduke Leopold and Gallas are again at the head of the imperial armies; that Wrangel and the Swedes are wintering in Bohemia, Leopold and the imperialists watching them on the Danube.

Fortunately for us, the campaign of 1646 is an intelligible one. Wrangel's design is to join the French near Mentz, and then concert action with Turenne. His own army is diminished and worn out with the fatigues of the last year, whilst the imperial one is being rapidly recruited. It is necessary for his own preservation to effect a union with the French. The Archduke's purpose is to prevent the junction and to take the two foes separately. Accordingly, very early in the year, Wrangel left Bohemia and proceeded through Meissen in the direction of Westphalia to meet Königsmark first, then to descend to Bacharach, where Turenne was expected to cross the Rhine. After occupying Höxter on April 24, and Paderborn on May 5, he effected at Wetzlar the junction with Königsmark, who had also entered Westphalia, taking Lemgo and some other towns, and thence he turned south into Hesse, where the Archduke was waiting to intercept him on the way to Bacharach.

The Swedes were not strong enough to risk a battle; they accordingly took up their position at Amöneburg and waited for news. The Archduke posted himself with his army in the neighbourhood of Wetzlar. Turenne, however, seeing that a junction with the Swedes from the side of Mentz would be impracticable, had crossed the Rhine at Wesel, north of Cologne, and was marching round into Hesse from the north. The move was successful, and the junction was at last effected at Giessen on July 31. It was now the turn of the imperialists to avoid a battle: they withdrew to Ilmenstadt, and let the joint armies pass southwards.

The allies now descended on the Main, took Aschaffenburg, ravaged Franconia and Eastern Swabia, crossed the Lech at Rain September 11, and entered Bavaria, besieging Augsburg and taking everything else by the way. The Archduke, who was equal on this occasion to his reputation, saw that no time was to be lost. He cut across from Hesse to the Upper Palatinate in order to save Ratisbon. This he succeeded in doing, aided partly by the reluctance of the 
French to depart too ar from the Rhine; be also raised the siege of Augsburg on October 12. The disagreement between Wrangel and Turenne as to further operations soon afterwards closed the campaign, earlier than usual.

Wrangel wintered in Swabia. The imperial army spent the rest of the year in recovering the places in Bohemia, Silesia, and Moravia which Torstenson had occupied in $\mathbf{1 6 4 5}$; in spite of Wittenberg, the lieutenant of Wrangel, who was sent with a strong detachment to prevent them. During this year Enghien was employed in the Netherlands, where he took Dunkirk on August 10. The war in Spain and Tuscany was less favourable to the French than before. In August this year the Emperor had his eldest son Ferdinand crowned at Prague king of Bohemia.

The year 1647 opens with some new and important events : the first and most serious to the Emperor being the defection of his uncle Maximilian of Bavaria. We have had a good deal to say about Maximilian already; we have given him, I think, always his just credit as an able, sincere, moderate, and honest, though to a great extent a mistaken man. We have seen how he represents the religious element on the Catholic side, in contrast to the dynastic element, which was so largely mixed with the religious in the Austrian family. He was the head of the League ; never a thoroughgoing imperialist, thoroughly German, as well as faithfully Catholic. $\mathrm{He}$ had, in spite of the divergence of opinion, adhered steadily to Ferdinand II. Even when in 1631 he had set himself to obtain the dismissal of Wallenstein, and so laid Germany open to Gustavus Adolphus, it was not that he was led by treachery towards Austria, but because he feared the subjugation of Germany; and he did his best to supply, where it could be supplied, the place of Wallenstein. He had made great sacrifices on the Catholic side, had seen his capital in the hands of the Swedes and his country three or four times ravaged. He also stood to win largely if the imperial side should be victorious; the confirmation of the transfer of the electoral dignity and the territory of the Upper Palatinate was what he looked for as but a portion of his due. This being so, we may be sure that nothing but weariness and despair compelled him to enter into terms with the French, as he did in January 1647.

The negotiations for peace went on for two months, and it was agreed upon at Ulm in March. By this pacification, Maximilian recovered Rain, Donauwerth, and some other important places; surrendered to the Swedes Ueberlingen and Memmingen in Swabia, and to the French several important towns in the Würtemberg and Baden countries; he also bound himself to recall his troops from the imperial service. This defection was a very serious blow to 
Ferdinand, who could not afford to dispense with his last ally or with his best soldiers; and he had other losses at the same time. Gallas, who was his most experienced general, died at Vienna in April, and the Archduke Leopold, his brother and best adviser, was summoned to take the governorship of the Netherlands and save the Spanish inheritance there from the attacks of Condé. Ferdinand supplied as well as he could the place of Gallas by the appointment of Melander, a Hessian convert, a Calvinist by religion ; and himself prepared to take an active part in the coming campaign.

This year the war begins earlier than usual. Wrangel, after wintering in Swabia, began to take the towns that were still held by imperial garrisons ; and Turenne in March began to ravage Würtemberg. The pacification of Ulm only saved, of course, the places that were claimed by Bavaria ; and both generals, without transgressing that agreement, found abundance of employment. Turenne took Tübingen, then marched north and took Aschaffenburg and Hochstadt; next he approached Mentz and put the city to ransom. The Elector, who alone of the three was now on the Emperor's sideTrèves being thoroughly French and Cologne included in the Bavarian pacification-paid an enormous sum to save the town. Turenne next attacked Darmstadt. The Landgrave was driven on both sides : on one by Turenne, at Darmstadt; on the other by Wrangel at Schweinfurt. He also had to give in, when he had no more chance of resisting.

By this time, however, the Emperor was ready for action. The loss of the Bavarian soldiery he replaced as well as he could by large levies of recruits whom he trained himself. Unfortunately, in attempting to retain the services of the Bavarians contrary to their master's obligations, he further offended Maximilian; but the diffculty on that score was only a short one, for Maximilian found his new patrons altogether unmanageable. The Emperor took the field in July. Then Wrangel, having taken Schweinfurt, was besieging Egra. The Emperor did what he could to save it, but it was taken on July 7, almost in his sight, he being posted at Falkenau. After the capture he marched to attack the Swedes; but Wrangel by a hasty move surprised him, and he had to fly for his life, the sentinels who were on guard before his tent being taken prisoners. As soon, however, as the force was rallied, he made head with some success against them, and fought two or three small battles with his ancient good fortune.

It may be questioned how long he could have maintained the struggle alone. Just at this moment Maximilian returned to his side. The demands of the French and the Swedes had proved too much for him. Not content with the terms, scarcely less than 
ignominious, of the treaty of Ulm, they demanded of him the surrender of his claims on the Upper Palatinate, and this he determined to resist. $\mathrm{He}$ proposed a reconciliation with Ferdinand : he was to have the electorate and his endowment in the Palatine inheritance secured to him, and he would return to his old party. The agreement was not long in transaction; on September 7 it was signed at Munich, and Wrangel retired before the united armies into the north of Germany. He there occupied the bishoprics of Halberstadt, Minden, and Hildesheim, and quartered for the winter in Brunswick. Melander followed him as far as Hesse and occupied Marpurg; but the Swedes were strong enough to leave the landgraviate of Cassel in the hands of its proper owners, Königsmark being detached to the assistance of the Landgravine.

This year Ferdinand obtained for his son the succession to Hungary; he was crowned as Ferdinand IV. on June 16 . The Archduke Leopold was successful in the Netherlands, recovering Armentières in May and Landrecies in July, against Marshal Gassion. Gassion was killed at Lenz on September 27, and his death, necessitating the recall of Turenne from Franconia just at the same time that Maximilian changed sides, contributed to shorten the campaign in Germany. In Spain the Prince of Conde found himself unable to pass Lerida, the usual limit of French conquest; and in Italy the revolution at Naples, part of the programme of which was to place the Duke of Guise on the throne, turned out a fiasco.

And thus we come at last to 1648 , and the war seems no nearer its end than at any given point in the last eleven years. All parties very much weakened, but by this time so much accustomed to war that it is more trouble to give it up than to continue it; none, moreover, really satisfied with affairs as they are; no one having succeeded in getting what he wanted when he began; all having suffered so much that none cared to avoid suffering a little more; all having seen so many changes that it seemed no great exercise of patience to await another turn of the wheel. Spain and the United Provinces were, however, anxious, for peace with one another: ${ }^{1}$ war between them had been going on, with but a twelve years' truce, ever since the revolt after Alva's administration, above seventy years; and peace was arranged between them on January 30, 1648. But this peace promised rather to be a help towards the continuance of war in Germany, as the Dutch armies and treasure, liberated from their constant employment in defence of their liberties, might naturally be expected to become a serious obstacle to French plans with regard to the north-east frontier.

1 The Dutch wished to preserve the integrity of the Spanish Netherlands and feared their annexation by France.-A. H. 
Exhausted, however, as all parties are, the year 1648 is full of incident. The Thirty Years' War, we may say, is game to the last ; fighting goes on until after the peace is signed, and by a singular coincidence the struggle ends where it began, within the walls of Prague, thirty years before. We left Wrangel wintering in Brunswick. Early in the spring he marches south: he must have marched south so often that we wonder how he ever found a new place to march to. This time he comes down, as he had done in 1646, upon the Main, takes Windsheim on March 2, and joins Turenne. The imperialists awaited them on the Danube between Neuburg and Ingolstadt; but they were obliged to retire as the Swedes advanced, and to fall back upon Augsburg. On the march Königsmark and Wrangel fell upon Melander at Zusmarshausen and defeated him. He himself was killed. The army was saved by Montecuculi and Duke Ulric of Würtemberg. The battle of Zusmarshausen was fought on May 17. After the victory the allies crossed he Lech into Bavaria, drove the imperialists across the Isar and the Inn, and ravaged the country cruelly. Piccolomini, however, speedily redressed the balance; collected the remains of the army, and beat the Swedes at Dachau on September 15. They then retired into Swabia, Turenne towards the Palatinate.

Whilst these things were doing, Königsmark was executing the brilliant move that gives distinctness and memorability to the last year of the war. He was moving on Prague : not with a large force, but with one formed of the veterans who had learned speed and success under Gustavus, Bernard, Baner, Torstenson, and Wrangel. Whilst Wrangel was approaching the Danube Königsmark turned through the Upper Palatinate into Bohemia, and, although he took places enough on his way to make retreat possible if it were necessary, he arrived at:Prague on July 15. At Prague there was, as usual, suffcient political disaffection to make his arrival welcome to at least one party. Ernest Odowalski was the person whose overtures had induced Königsmark to make the attempt; he had met him at Rakonitz and undertook to act as guide. In the night Odowalski led the attack on the walls of the little town in which the arsenal and citadel were. As the arrival of the Swedes was entirely unexpected, for Königsmark had given out that Pilsen was the object of his attack, intending to put the garrison of Prague off their guard, the victory was won with little bloodshed. The bridge between the Little Town and old Prague was seized and one tower on the further side was also secured, but the force within the city was too large for Königsmark to attack, and for the time he satisfied himself with the possession of the citadel and arsenal.

The defence of Old Prague was conducted by Count Colloredo, 
the governor, who had escaped across the river during the night attack. He mustered the troops, drilled the citizens, brought in additional troops, and made the best use he could of the little artillery that he had.

Wittenberg arrived early in August to help the besiegers ; and he undertook the attack on the New Town of Prague from the Ziskaberg; but as he was not much better supplied with artillery than the defenders, he postponed his attack until Charles Gustavus, the Palatine of Deuxponts, nephew of Gustavus Adolphus and generalissimo of the Swedish army, should arrive to help him. Charles Gustavus brought with him an army of 10,000 men; but the more brisk the assault, the more brilliant the resistance. Conti, the engineer of the imperialists, managed to foil every attempt of the Swedes to avail themselves of the breaches which their cannon made in the wall. At last, after a long series of failures, Charles Gustavus determined to take the place by storm. Four thousand men entered a huge breach made and kept clear by the Swedish guns; when a mine was sprung by which 500 of them perished. The garrison chose this moment for attack, and the assailants were terribly mauled. After five hours' fighting they effected their retreat. Charles Gustavus soon after gave up the siege; and on October 25, the day after he drew off his forces, the news arrived of the signing of the terms of the peace of Westphalia. ${ }^{1}$

Thus suddenly, in the midst of a war which promised to all appearance to go on as long as it had done already, peace came: not the least startling of the phænomena of the struggle. The parties to the peace had been negotiating for at least five years, and, if they had chosen, might, so far as the balance of successes affected the matter. have made peace on much the same terms as those on which they did it at last, at any point of the negotiations. It is therefore unnecessary to look in the immediate circumstances of the war for the causes of its closing at this particular time. The generals had got into a habit of fighting which made war easier than peace; the diplomatists had got tired of arguing, and at last agreed to a settlement that did not exactly satisfy any single party to the war.

We must now turn back and mark the principal dates connected with these negotiations. The proposals for peace began to be mooted as early as the year 1636, when Christian of Denmark offered himself as negotiator between Sweden and the Emperor, and Pope Urban VIII. offered to act as mediator between France and Spain. The seat of the King of Denmark's negotiations was, as we have seen, Hamburg ; that of the Pope's was Cologne.

1 The French had meanwhile taken Tortosa on July 13, and had won the battle of Lens on August 20.-A. H. 
But it was several years before even the preliminaries of the transactions could be agreed upon. Neither of the great parties was really anxious for peace. In 1638 the arrangements for safe-conduct of the ambassadors, and even the choice of the place of meeting, were yet undetermined. The French and Swedes annually renewed their alliance and agreed neither to make peace without the other; the machinery of the double mediation was thus rendered useless. The constant shifting of the chief German powers left the world in doubt as to which of the two principal parties they belonged to, and by which their interests were to be provided for. The princes in the assembly of Nuremberg in 1640 were unable to settle amongst themselves their differences in such a way as to give the faintest hope of an agreement. The Diet held at Ratisbon the same year was equally undecided : it was only in its adjourned meeting in 1641 that the Emperor was compelled to consent to the choice of Münster and Osnabrück as the places of meeting, and not until Christmas Day 1641 that the preliminaries were signed.

These preliminaries were not what is understood by the term in modern diplomacy, in which it means some statement of the general principles, if not also a project of the details of the peace which is to follow; but simply the necessary steps for holding the congresses in which both the principles and details of the pacification will have to be debated $a b$ initio. These preliminaries then consisted of little more than a provision that Osnabrïck and Münster should be the places: Münster for the negotiations between France, Spain, the Catholic princes, and the Empire; Osnabrück for those between Sweden, the Protestant princes, and the Empire; the securing of the neutrality of the two cities during the progress of negotiations; and the arrangement for free intercourse and common deliberation, so that the pacification when complete might be embraced in a single treaty.

The day of meeting was to be March 26, 1642. Although the Emperor had consented, or had been compelled by the Diet to authorise his envoys to assent, to these terms, he did not like them and tried to evade them; this attempt causing a still further delay. It was not in his mind to stay his hand until he had punished Sweden and got the recalcitrant princes at his mercy. It was his policy to make peace with France and to isolate Sweden; or if that could not be done, to make peace with Sweden and to isolate France. This object was defeated by the article that determined that there should be but one treaty : accordingly he disavowed his ambassador, applied at Hamburg, where the preliminaries had been signed, for a revision of them, and showed every symptom of an intention to break up the transaction. However, the great defeat of the Archduke 
and Piccolomini at Breitenfeld in November 1642 brought him to a better mind. On April 28, 1643, the preliminaries were at last ratified, and the meeting called for June 11 in the same year. In the course of July the imperial representatives arrived at Münster; the French did not appear until March 19, 1644, delayed by the changes which took place in the French government after the deaths of Richelieu and Louis XIII.

During the whole of these seven or eight years during which the subject was broached, there are, if possible, three distinct sets of negotiations to be followed: those between the parties to the peace which I have been tracing ; those between France, Sweden, and their partisans in Germany; and those between the Emperor and the princes with whom he was trying to come to an agreement preparatory to the general peace. No memory is capable of containing the dates and other minutiæ of these dealings, nor have I attempted to note the greater part of them. Of the negotiations of France we may take the bargaining with Bernard of Weimar for Alsace as a specimen, and of those of Germany the negotiations by which one after another the Lutheran States were brought to acquiesce in the peace of Prague, or in which the Emperor tried to satisfy the Dukes of Brunswick for the possession of Wolfenbüttel or the bishopric of Hildesheim, or declared the terms on which he would listen to intercession for the Palatine family, a general amnesty to offenders, or the relaxation of the Edict of Restitution and such like. These must not be left unnoticed, because, in reading the authorities, they are apt to come in confusedly and as if they were a part of the preliminaries for the general pacification, with which they were not really in any direct way connected. We put them, then, altogether on one side; let the man who can remember them all and put them in their places do so; they have their true importance in local and personal history only.

An exception must be made, however, in behalf of an assembly held under imperial auspices at Frankfort in 1643 and 1644, in which it was attempted to determine the status of the smaller German states during the congress. Of course the Emperor claimed to represent the Empire; of course also the Protestant states were well aware of what their fate must be if the Emperor were entrusted with their interests as against the Swedes and French. The electors might treat as parties to the peace, but how about the princes who were not electors? Were they to be left out altogether, or to be represented severally ; if not severally, could they be represented curiatim, with a joint vote, as they were sometimes in the assemblies of the Diet? In January 1645 the Emperor at last consented that the princes should be represented 'ad formam 
collegii,' but only as counsellors and advisers, not as principals in the treaty. This difficulty arose again as soon as the congress met.

But in the meantime other difficulties arose. In 1643 the King of Denmark, one of the mediators, had thrown himself on the imperial side, and had his country ravaged, and been reduced to sue for peace on condition of surrendering large portions of his dominions to Sweden. When on June 11, 1645, the congress actually met, this quarrel was yet undecided, and only on August 13, 1645, by the peace of Brömsbro was he admitted to terms.

On June 11, then, the congress began its business. At Osnabrück the imperial envoys were Maximilian of Trautmannsdorf, Maximilian of Lamberg, and John von Crane. The Swedish were Oxenstiern himself and another Swedish lawyer. At Münster the imperial representatives were, besides Trautmannsdorf, who went between both places, Count John of Nassau and Isaac Volmar : all three converts from Lutheranism. The French plenipotentiaries at Münster were the Duke of Longueville, the Count d'Avaux, and Abel Servien. The mediation was really transacted by the republic of Venice, which was represented by Aloysio Contarini. The King of Denmark had disqualified himself by going to war, and the Pope disavowed any connexion with the treaty as soon as he knew what the terms were likely to be. The ambassadors of Rome were, however, constantly present, first Ghinetti, then Machiavelli, Rosetti, and Chigi, who became himself Pope in 1655 as Alexander VII. Pope Urban VIII., who had lived through nearly all the war, died in 1644. The interests of the League were managed by Schönborn, bishop of Würzburg; those of the Protestants who refused to be represented by the Elector of Saxony, by Wolfgang Conrad von Thumbshirn, the ambassador of the Duke of Saxe-Altenburg, assisted by the envoys of Celle, Brunswick, and Magdeburg.

The first thing to be done was to present the propositions of the powers ; and Mylonius, the Swedish envoy, presented his proposition on June 11, with the approval of France. Sweden demanded Pomerania notwithstanding the claims of Brandenburg, and, besides, three bishoprics in Westphalia and two in Lower Saxony. France demanded the absolute cession of the territories of Metz, Verdun, and Toul, the three bishoprics that had been stolen nearly a century ago by Henry II., as defender of the liberties of Germany ; Alsace also, and Lorraine; and the conquests which had been made in Italy, Spain, and the Netherlands. The ambassadors of Spain were overbearing, those of the Emperor temporising. The Catholic and Protestant States of Germany made proposals diametrically opposed to one another: especially as touching the future of the Palatinate. The Pope himself was of opinion that the Palatinate must be 
restored, although in a Roman Catholic family; but Maximilian of Bavaria, the steadiest Catholic in Germany, would thus have to forgo the reward of all his labours and the compensation for his sufferings. On all sides there was holding back, or the assertion of claims so large that the very statement of them was sufficient to show that they were either insincerely put forward or were an absolute prohibition of peace.

The first proposition of the Swedes, touching the integrity of the Empire, raised the question how the several states were to take part in the negotiations: and upon this the Catholic princes differed of course from the Protestant, and the Protestants differed not less among themselves. When this was at last adjusted, the assemblies at Osnabrück and Münster were found to have adopted a variety of rule about admission of the representatives of the states, and that occasioned still further delay; then the ambassadors of the Electors insisted on being called 'excellency ;' and so on.

At last, on December 11, the Protestants exhibited their gravamina, and on January 29, 1646, the Catholics handed in theirs. The discussion of these occupied the congresses for two years; during which, as we saw in the first half of the lecture, some of the most startling revulsions and vicissitudes of fortune took place: the change of attitude on the part of Bavaria, and the rapid decline of Spanish arms being the most notable. Spain, from being the most opposed to a pacification, now became most anxious to complete one ; and although, when the peace of Westphalia was drawn up, Spain refused to join or even recognise the provisions of it, her real anxiety for such peace as might be had was shown by the treaty with Holland, which was concluded on January 30, 1648, at Münster. The good example was followed by the other powers; the time spent on the discussion of claims was found to be not wholly wasted.

The Osnabrück negotiations closed first, and, having been submitted to the authorities of Münster, the treaty was signed on August 6, 1648. The Münster Congress continued for a month later, a good deal of discussion being held on the point whether the King of France as ruler of Alsace should be allowed a place among the estates of the Empire. When that point was decided in a way that made sure of a resumption of the dispute on a future occasion, the treaty of Münster also was signed, on September 8; the formal signatures of the plenipotentiaries were attached to the two documents on October 24, and the peace was proclaimed, with great blowing of trumpets, firing of cannon, and beating of drums, on the following day at both Münster and Osnabrück. The same day the plenipotentiary of Burgundy-that is to say, the Spanish am. bassador-protested solemnly against the treaty of Münster; as 
Chigi, the Papal Nuncio, did the day before against the peace of Osnabrück: a protest preliminary to the declaration of the nullity of the two issued by Pope Innocent X. in December. The ratifications were exchanged in February 1649 ; but the Swedes were disinclined to leave Germany until all the provisions of the treaty of Osnabrück had been rigidly carried out.

To arrange the execution of the special terms, a new conference was opened at Nuremberg, in which Sweden was represented by Wrangel, and the Emperor by Piccolomini. This began to sit in May 1649, and continued its sessions until June 1650, issuing its recesses for the removal of the imperial and Bavarian garrisons from the towns occupied in the body of Germany in September 1649, and for the dismissal of the Swedes in June 1650. This done, the Emperor declared all persons who should attempt anything contrary to the peace to be under the ban of the Empire, a sentence which was actually issued against Bremen in 1652 for a breach of one of the provisions of the treaties.

I shall reserve to another lecture a review of the terms of the two treaties, and such general reflexions as I may have to make on the war itself. I cannot say that I regret, for my part, the fact that this course of lectures has not answered exactly to the title I gave it when I first planned it; and that, whilst we have given a good deal of attention to the drum and trumpet part of the story we have been obliged rather to cut short the political commentary. I am not sorry for this, because on the whole $I$ think that the way in which we have worked through the details will have been more useful to you than any general views set forth and accepted without adequate knowledge. But if any of you thinks otherwise, and that we had better have stuck to the political aspects of the Thirty Years' War, I will try to satisfy him in the next two lectures. 


\section{TWO LECTURES SUPPLEMENTARY TO THE COURSE ON THE THIRTY YEARS' WAR}

\section{LECTURE I}

SURVEY OF THE REIGNS OF LOUIS XIII. AND PHILIP IV.

IN the present lecture I propose, by way of supplement to the course, to run as briefly as possible through the reigns of Louis XIII. and Philip IV. so far as they are contemporaneous with the Thirty Years' War, and point out in them the principal facts that have a bearing on the progress of that war. Very many of these we have discussed already, but it is necessary just to remind ourselves of their natural sequence and of their relations to other aspects of the history besides the great war, in order to see how it was that at one moment France held back and at another maintained the burden of the whole, or at another forced on the combatants without being herself able to take part in the fighting work.

Louis XIII. came to the throne of his father when a child, and he never so far outgrew the habits of his minority as to originate anything like national policy or to be his own minister. He was brave and just and goodnatured; but idle and devoid of moral courage, always swayed by favourites or by ministers who felt themselves strong enough to be independent of his favour. His reign falls into three epochs: the minority, the ministry of the Duke de Luynes, and the ministry of Cardinal Richelieu. The first lasted from 1609 to 1617 ; the second from 1617 to 1621 ; and the third from 1621 to 1642 . Louis survived his master for six months only. The remaining years of the war saw Mazarin the prime minister of France.

As for the first of these three periods, as it falls outside our present subject, I shall not say much : but this much is necessary. Marie de Médicis, undertaking the regency, found that it was quite impossible for her to attempt to carry out the policy which had tasked to the utmost the power of Henry IV. His three great designs were first the humiliation of Spain and Austria; secondly, the keeping of the Protestants and Catholics of France in peace 
together; and thirdly, the securing of his position as King against the anarchical tendencies of the feudal or princely party, which had by more than one conspiracy contrived his overthrow, plotted with his enemies regardless of the claims of either religion or patriotism, and presented the most formidable obstacle to the career of administrative reform which under the influence of Sully he had originated, and without which he saw the position that he coveted and had partly earned for France would be untenable. Marie de Médicis could not attempt to carry out the three lines of policy together; her great object must be to preserve the royal power for her son, and for this purpose to secure peace abroad as affording the best chance of quietness at home.

So, as soon as Henry was cold in his grave, the French army was recalled from Germany, and a close alliance with Spain set on foot, and this was cemented in 1612 by a double marriage. Louis XIII. was betrothed to Anne of Austria, the daughter of Philip III., and his son, afterwards Philip IV., to Elizabeth or Isabella, Louis's sister. The other two branches of policy soon afforded work enough to the Queen Mother. The Protestants and the princes united to give trouble. The princes rose in indignation against Concini, the Queen's Italian minister; the Protestants required further guarantees and a greater independence in the administration of their own affairs. At first the princes were bribed to submission. Conde, in 1610, received a pension of 200,000 francs. But their appetite grew by being indulged, and in 1614 a large party of them, comprising mon of both religions, at the instigation of the Duke of Bouillon, a Protestant, withdrew from court and demanded the convocation of the States General.

The States General assembled for the last time before the great Revolution. They proved more inclined to the King than to the party of the nobles. The prince of Conde, in 1615, showed symptoms of rebelling and was disgraced. In 1616, just after concluding a treaty on equal terms with the King, he was arrested, and his friends prepared for war. But, before the war was well begun, the fall of Concini put an end to one of the chief ostensible grounds of complaint. Louis and his companion de Luynes had conspired against the minister, and his arrest issued in his death. The power thus wrested from the Queen Mother was wielded by Louis and Luynes; but they had neither of them genius to devise a better policy than that which he had carried out, and which indeed was the only one possible to such weak hands.

In 1618, the year of the outbreak of the Bohemian struggle, Luynes was the ruler of France. He, in 1619, released Condé and by his advice put down the rising of the nobility which his own 
sudden exaltation had provoked, and a short period of quiet followed. But a struggle with the Protestants, who had acted contrary to the royal prohibition in assembling at Rochelle, followed : provoked, it was believed, by the Papal Nuncio, and connected in some obscure way with a design to restore the supremacy of the Queen Mother. Louis and his minister marched into the south, overthrew the religious liberty and the constitution founded upon it of the Béarnese, and drove the whole Protestant party to desperation. In this war de Luynes died of a fever at Montauban. The following year, the most influential of their nobles were bribed to conversion, and the King began a series of counter-reformation measures on the German plan; forbidding religious services and flooding the land with Capuchin missionaries.

During this little time Marie de Médicis recovered some influence with her son; and by her introduction Richelieu, already bishop of Luçon and a cardinal, made his way into the authoritative and confidential place that de Luynes had occupied. Richelieu became a member of the royal council April 1624; and immediately unfolded his plan for reviving the political programme of Henry IV. humiliating the Hapsburgs, demolishing the nobility, and reducing the Protestant imperium in imperio to a nullity. Up to this time clearly there was no likelihood of France being able to take part in a religious war, although both before and after, under comparatively strong princes, she might be found persecuting at home what she was nurturing abroad.

Richelieu's first move, in accordance with the treaty made by Louis in January 1623 with Savoy and Venice, was to compel the Papal garrison which had in the imperial and Spanish interest occupied the Valtelline to retire, and restore the country to the Grisons. The Huguenot rising under Soubise in 1625 prevented any overt action on behalf of the German princes who were in arms against Ferdinand ; but the marriage of Charles I. of England with the Princess Henrietta Maria detached the English interest from the Spanish side and led the way to what would have been, but for Charles's own troubles, a united action against the Empire. Unhappily for all parties, England next undertook the support of the Huguenots at $\mathrm{La}$ Rochelle, drawing down on it especially the vengeance which it was powerless to avert, and preventing any concert in favour of the Elector Palatine until his chances were quite gone. In 1628 Rochelle was taken, and Richelieu showed that he had no intention of sparing any of his enemies, religious or political, who fell into his hands. This religious struggle, which lasted from 1625 to 1628 , coincides nearly in time with the ill-fated attempt of Christian of Denmark to undertake the religious emancipation of 
Germany. In 1629 Louis XIII. saw the Huguenots completely humbled, and Ferdinand II. saw himself by Wallenstein's aid supreme over both Princes and Protestants.

In 1630 Richelieu had made up his mind, if the successes of Gustavus Adolphus should answer in any way to his pretensions, to use him as an instrument for the darling designs of France. As soon as he saw him in possession of Pomerania he entered into the closest relations with him, and, through his confidant Joseph, completely hoodwinked the Emperor. The treaty of Bärwalde in January 1631 is the starting-point of the share taken by France in the Thirty Years' War. It was not at first an overt share. Sweden was subsidised, but a show of peace with both Austria and Spain was preserved. The troubles of Lorraine, which the Duke was anxious to deliver from French control, and the intrigues of the Duke of Orleans, whose incorrigible restlessness and ignominious betrayal of his friends placed in Richelieu's hands a store of weapons for the demolition of the nobles, afforded employment for the two or three years during which France played this shy game. Oxenstiern was inclined to use France; Richelieu was intent on using Sweden; neither trusted the other, but increasing necessities brought the two continually closer. After the death of Gustavus, Oxenstiern saw that French assistance was indispensable: after the battle of Nördlingen, he was obliged to entrust the French minister with the direction of proceedings, and to consent to a dismemberment to a certain extent of the country that he had come to deliver.

In 1635 begins the leadership of France in the great war ; a period of whose wearisome sameness and unvarying uncertainty we have in the former lectures had sufficient experience. Year after year the alliance with Sweden is renewed, war is carried on in the Netherlands and in Navarre against Spain, in Lorraine and Alsace against the Empire, and in Italy and Savoy against both together. Great French armies ravage interior Germany ; Bernard of Weimar is brought by French promises and disappointed by Richelieu's manœuvres ; and meanwhile a grand school of French Marshals is trained, under whom the great conquests of Louis XIV.'s reign are to be made. In 1640 the revolt of Catalonia, provoked by Spanish misgovernment and fostered by French intrigue and the emancipation of Portugal, made the partition of the Spanish heritage a much more feasible design than it had seemed when in 1635 the Cardinal confederated with Holland for the purpose. On all sides, however, the French arms steadily advanced and the imperial fortune sank.

The year 1642, the last of Richelieu's life, witnessed the contrivance and defeat of the conspiracy of Cinq-Mars. Louis, whilst besieging Perpignan, discovered a secret treaty, to which his brother the Duke 
of Orleans and the Count Duke Olivares were parties, for the overthrow of Richelieu and the nominal emancipation, but real setting aside, of the King himself. In this treaty were named the Duke of Bouillon, son of the old intriguer who bore the title at the beginning of the reign, and Cinq-Mars, Louis's personal and most confidential friend. It was dated on March 13, and signed by Olivares himself on the part of Spain, and on the part of the Duke by Fontrailles, his agent. On June 13, Cinq-Mars was arrested at Narbonne, where he was in actual attendance on the King, and on the 23rd the Duke of Bouillon also was arrested at Casale, where he was in command, with the army destined for Italy. The Duke of Orleans, as on the previous occasions when he had been found conspiring, betrayed his associates, and Richelieu saw that the King could not afford to be merciful. The Duke was condemned to lose his estates and honours; Bouillon to surrender Sedan as the ransom for his liberation; Cinq-Mars was beheaded, and with him his friend de Thou, whose only offence was that he had not revealed the conspiracy in which he refused to join.

It is said, probably with truth, that Cinq-Mars, who was very young, had taken the idea of the conspiracy as against Richelieu from some incautious words of the King himself, and that his offence accordingly was that merely of a politician, not of a traitor. But if this is true, it is not the less true that Orleans had conspired against Louis long before, and that neither he nor Bouillon would have been satisfied with the mere resignation of the Cardinal. Louis was extremely weak and ought to have saved Cinq-Mars; but the crime could not be allowed to go unpunished : at its lowest estimate it was an attempt to sacrifice the welfare of the nation for the aggrandisement of a faithless and incapable individual. It is this conspiracy and its punishment which perhaps more than anything else have made the name of Richelieu disliked. I confess that is difficult to see how, for his master's sake, he could have acted otherwise.

This is an episode in the history of the war with Spain, and indeed in the siege of Perpignan. That city was taken on August 29. Richelieu died, aged 58, on December 4. Mazarin succeeded to his place in the royal council and was made a cardinal before the end of the year. Marie de Médicis died in 1642 also ; and in May 1643 Louis XIII. followed them, leaving his kingdom in a position of far greater importance than it had been at his accession, the royal power more firmly consolidated, the territory increased by the acquisition of Alsace, the frontier strengthened materially by the possession of Sedan on the one side and Perpignan on the other; Spain humiliated in the Netherlands, and threatened with disintegration in the peninsula itself; a school of great generals springing up, trained under the heroes of the Thirty Years' War. And all this he owed 
to Richelieu. Fertile indeed is the period in great men ; scarcely any age has seen three such as Oxenstiern, Richelieu, and Wallenstein alive at the same time : altogether, the mischief that they worked in Europe has never been exceeded until the advent of Napoleon Bonaparte.

Louis XIV. was five years old when he began to reign, and only ten when the peace of Westphalia settled the system of Europe for a century and a half. Any speculations on the part he played in the world would therefore be out of place in this course. His mother, Anne of Austria, sister to Philip IV., governed France as regent, and Cardinal Mazarin, who has been said to be her second husband, governed her. The policy of Mazarin bore to that of Richelieu, in one sense, the same relation that Richelieu's had borne to that of Henry IV. It was the traditionary policy of France, as strong at the present day as it was then, but modified by the character of the administrator. In itself a thoroughly selfish and ungenerous one, it had, as moved by Henry IV., something of the glory and grace which his early career as an emancipator and deliverer had shed upon everything that he took in hand. As moved by Richelieu it exchanged that show of heroism and sentiment, which indeed was very hollow and unreal, for the strong, ruthless, thoroughly prosaic and businesslike precision which marked the Cardinal, and which, in spite of all his intrigues, comes out so clearly on the face of history as to make the reign of Louis XIII. comparatively easy reading. In the hands of Mazarin it becomes meaner, pettier, and more timid, more scrupulous of appearance, less of principle; a cruel, selfish, aggressive policy, but still a strong one, formidable both from the address of the minister and also, and more really so by the skill and resources of the country which internally he misgoverned.

So long as the Thirty Years' War lasted, Mazarin, treading in Richelieu's footsteps, got into no great difficulties. The troops who fought under Enghien and Turenne were badly paid and equipped, and corruption reigned in many quarters where Richelieu had put it down with the strong hand ; but the work of war was enough to employ men's minds, and the complaints accumulated without overwhelming the minister. The policy of Mazarin in Germany I have already characterised as leading him to hug the Rhine and endeavour to strengthen the hold of France on the German side, rather than to penetrate into the vitals of the Empire and destroy the Hapsburgs, as Henry IV. or Richelieu would have tried to do. Perhaps one might conclude that Mazarin's ambition was a more entirely selfish one than that of Richelieu, who, although he certainly clung to and loved power for its own sake, had great views for France, which he felt himself able, and to be the only man who was able, to carry out. The year 1643 saw, five days after the young King's accession, in 
the victory of Rocroi, an omen of the reign that was to last for seventy-two years, and to contain more of the favourite French glory than any other before or after: to contain but also to survive it. It witnessed also the great defeat of Düttlingen. In 1644 Enghien beat Mercy in Alsace and got possession of Philippsburg in consequence; in 1645 the same great leader made an end of the Bavarian army at Nördlingen. 1646 was marked by constant victories in the Netherlands, where the power of Spain was at a very low ebb; and on the other frontiers with equal continuity Enghien (now called Conde), Turenne, and Gassion repelled the efforts of the imperialists and of the Spaniards. In 1647 the revolt of Naples gave the Guises one more chance of attaining the throne for which they had offered themselves as candidates for nearly two centuries; but then the tide turned. The Duke was taken prisoner. The Archduke Leopold raised the Spanish fortunes again in the Netherlands, but only to add glory to the victory won over him at Lens by Condé.

In January 1648 the Dutch concluded peace with Spain, and in October the peace of Westphalia settled the quarrels of Europe; all, at least, except those of France and Spain. This war lasted eleven years longer, in all twenty-five, and closed in 1659 at the peace of the Pyrenees. This peace secured Perpignan, Roussillon, and Conflans to France, on the Spanish side; and Gravelines, Montmedy, Landrecies, and Thionville on the side of the Netherlands ; confirming, or rather recognising, also the provisions of the peace of Westphalia, by the renunciation of Spanish claims on Artois and Alsace. The peace of the Pyrenees is a sort of supplement to that of Westphalia, but the period that intervenes is one into which we cannot now venture even to glance.

So much, then, for the general history of France, as it sheds light on the great struggle. Before we turn to Spain, in which we shall have little more to do than to repeat what we have said already, we should just note the varying attitudes, during our period, of the Republic of Holland. Holland was the natural enemy of the Spanish Hapsburgs, and consequently the natural ally of France: it was, except some of the Swiss Cantons, the only state in Europe which professed and established the religion for which the Elector Palatine risked and lost his inheritance; it was from a military point of view powerful and beginning also to be rich. It was therefore reasonably to be expected that Holland would take a large part in a war in which the interests of Spain and Calvinism were so large ingredients. And certainly the Dutch did a great deal, though not so much as they might; they afforded asylums for the uncrowned potentates and for the generals whose resources were exhausted, and they fought a handto-hand fight for their own liberties. But I think their history shows 
that they had no real interest in Germany, and that their love for France was merely the result of their hatred of Spain. It is to be remembered, however, always that they were in a chronic state of politico-religious sedition.

The treaty of the Hague, which in 1609, April 9, established a truce for twelve years between the Spanish and the Dutch provinces, was the first recognition in diplomacy of the existence of the United Provinces on the part of Spain. It did not recognise their independence, but simply their existence, and it was a mere armistice. It expired in 1621. The Archduke Albert, who had governed for Spain during its continuance, died the same year, and the recall of Spinola from the Palatinate to continue the war with Holland marks one of the earlier stages of the Thirty Years' War. In 1624 Spinola besieged Breda, and Maurice, who had been Stadtholder for forty years, died partly of disgust at not being able to relieve it. It was taken in 1625. Frederick Henry of Nassau succeeded Maurice as Stadtholder. $\mathrm{He}$, in 1625, joined the alliance of the Hague between England and Denmark against Spain: a project which was to Holland but the continuance of the natural state of things, but which led to the ruin, at no long interval, of both the monarchs who took part in it.

In 1631 Holland joined the confederation formed by Gustavus against the Empire, but its efforts were still mainly directed against Spain ; and only assisted the Swedish or Protestant cause by finding constant employment for the Spanish forces within their own territory. Frederick Henry had as his opponent in the Netherlandsafter the death of the Infanta Isabella, the daughter of Philip II. and widow of the Archduke Albert, which occurred in 1633-the Cardinal Infant Ferdinand of Toledo, who helped to beat Bernard of Weimar at Nördlingen and was altogether an able and successful administratcr. In 1635 Frederick Henry joined a third confederation, that of the treaty of Paris, with France and Sweden, as against Spain; really against Austria. In August 1637 he retook Breda. In 1641 the Cardinal Infant died, and Don Francisco de Mello, who was beaten at Rocroi, succeeded him. Frederick Henry died in 1647. The same year the Archduke Leopold was at last able to undertake the government of the Spanish provinces, which had been waiting for him since 1641. The peace between Holland and Spain, in January 1648, at last recognised the independence of the United Provinces as a sovereign state and a free country.

The reign of Philip IV. lasted forty-four years, during one half of which the Count Duke Olivares was his prime minister and the real ruler of the vast dominions of the Spanish crown. If Olivares were really the despicably dishonest and selfish minister that his 
enemies describe, Spain must indeed have descended very rapidly the plane of decline in which she had been going since the death of Philip II. Her power in Europe must have rested on the reputation for wealth and strength the real sources of which had long been exhausted. Philip IV. was sixteen years old when he began to reign; on March 31, 1621. The few events in which his father, Philip III., and his minister, the Duke of Uzeda, influenced the opening scenes of the great war, I mentioned in the early lectures of this course: they consisted chiefly in his support of the views of Maximilian of Bavaria, in his conduct with respect to the family claims of Spain on the Bohemian succession in case of the extinction of the descendants of Ferdinand I., and in the attempt made through the agency of the Duke of Feria to seize the Valtelline in the Hapsburg interest. I am not sure that this amount of interference is not as much as was exercised by his son in the whole of his long reign.

Philip IV. was a most indolent and pitiful person. He was not without ability, but he never put it to use; he had neither the industry of his grandfather nor the personal virtues of his father; he was vicious and extravagant and his reign is on the whole one of the most wretched in the annals of Spain. His first act was to appoint Olivares, who had been a gentleman of his bed-chamber, prime minister in the place of the Duke of Uzeda, who, with his whole clan, friends and enemies, was at once disgraced. Olivares was simply corrupt and unprincipled. $\mathrm{He}$ had certain business talents which enabled him to take the trouble of governing off his master's hands; he was sharp-sighted to detect corruption where the detection could be made to minister funds for the royal extravagance; he also was extravagant and profligate: he could form designs whose very greatness, considering the state of Spain at that time, is a proof of his incapacity for real political government, and the result of which was in almost every instance failure.

The situation of Spain was peculiar: her nobles had been corrupted by long prosperity, and her commerce overfed by the newly discovered lands in America. When the sudden glut and momentary excitement of gain and conquest were over, the Spaniards found themselves to a great extent disabled from playing their proper national part in Europe. Extravagance, pride, and the honour to arms had been carried to a length far greater than their permanent resources would at all justify; the nation, or the political forces of it, became, like the ruling dynasty, effete, whilst the prestige of wealth and empire was still dazzling the eyes of monarchs like James I. and supplying a false basis for the hopes of men like Ferdinand II. and Maximilian of Bavaria. 
How little Spain as Spain was able to do in aid of the German Catholics we have seen already: except an occasional diversion in the Milanese, the King of Spain and Naples could help his cousin in no material way. The Netherland provinces supported for the most part their own wars : indeed, until the death of the Infanta Isabella, in 1633, these states could be scarcely said to be more than nominally attached to Spain ; and it was during these years that, by the mission of Spinola into the Palatinate, most of what was done or pretended to be done by Spain was done.

The first event of importance to our history in the reign is the negotiation for the Spanish marriage of Charles, Prince of Wales : a negotiation which was broken off in 1623, and which ought never to have been begun. The political importance of it is the fact that as long as it lasted it prevented James I. from interfering in Germany in favour of the Palatine Elector his son-in-law, and when it was broken off provoked the English people into a war for which they were not prepared, the ultimate result of which was fatal to the King. The next is the resumption of the war with Holland in 1621 on the expiration of the twelve years' truce of which we have said enough : this also went rather against the imperial and Catholic interests by withdrawing the Spanish forces from the Palatinate when they were most wanted. A third memorable affair is the war of Mantua, into which Olivares forced his master, and the result of which was the overreaching of Ferdinand II. by Richelieu in the peace of Cherasco.

Up to this moment, although Olivares's schemes had been injurious to his allies, they had a sort of success ; the English war had been anything but creditable to the English arms ; Spinola had taken Breda, notwithstanding the desperate efforts of Maurice of Nassau to hinder it ; and, in negotiation with Richelieu, Olivares had even obtained a slight advantage over that most astute statesman. But from the year 1628, by the time that his impudent and aggressive policy had turned the arms of nearly all Europe against him, fortune seems to have deserted him : and in $\mathbf{1 6 3 0}$ he lost in Spinola, whom he had treated with signal ingratitude, the person to whom Spain owed all the reality that underlay the semblance of successes.

The beginning of the great war with France in 1635 forced Spain into the position which she was loth to take, of one of the principals in the great war. It was a Spanish force that arrested the Elector of Trèves whilst under French protection, and afforded Richelieu the opportunity of bringing his schemes to their issue. I have mentioned from time to time the contemporaneous campaigns in which Enghien carried his laurels in Spain whilst Turenne and the other rising generals were training in the Netherlands and in Alsace. Much of the good fortune that attended the Spanish arms in their resistance 
to French invasion must be attributed to the difficulties of the ground on which the battle was fought.

In the year 1646 began a train of events, one of the least of the consequences of which was the disgrace of Olivares. This was the revolt of Catalonia. The expenses of government had been so great that Philip, under Olivares's advice, suspended the fueros or charters of several of the Spanish provinces in order to tax them for his immediate wants. In the spirit of this act he imposed on the Catalans the sustentation of a large body of mercenaries who had been fighting for him against France. The provocation was of the same sort as we have seen in Germany ten years before this, when it was one of the formal grounds of the complaints of the League against Wallenstein.

The Catalans had extremely large privileges by their charter, and they refused to provide the soldiers with more than shelter, beds, fire, salt, and water, and that only when they were actually on service, on the march. The Viceroy, the Count of San Coloma, was murdered in the attempt to enforce obedience. First the Duke of Cardona, then the Marquis of Los Velez were sent to Barcelona to put down the revolt; but the death of the former and the severity of the latter caused the mission to be ineffectual.

The Catalans asked the help of France in their despair. The French were long in sending it, and the Catalans proclaimed a republic; but the republic went down soon before the arms of the Marquis, and the province in February 1641 handed itself over to Louis XIII. as the elected Count of Barcelona. It was by the aid of the revolted Catalans that Louis was enabled to possess himself of Roussillon.

The loss of Roussillon was almost forgotten in the loss of P.ortugal, where Olivares's policy in $\mathbf{1 6 4 0}$ produced the same result that it produced in Catalonia. The attempt to override the Portuguese constitution, to reduce the kingdom to the rank of a province, was, according to the Portuguese, the occasion of the outbreak ; and it may well have been that Olivares was foolhardy enough to attempt a measure which would have been too great for Charles V. or Philip II. At this period of her history a united Spain was an idea repulsive to every section of the peninsula-to every one of the kingdoms that rejoiced in a history, laws, and privileges of its own.

The Portuguese revolt was headed by the Duke of Braganza, whose success vindicated his attempt from the charge of insanity. He achieved the independence of his country. Spain had no partisans in Portugal, but her national pride would not submit to the loss of the kingdom. The war, which was begun in 1640, although from the beginning a hopeless one for Spain, went on for twenty-eight 
years: it was not until 1668 that the King of Spain recognised the independence of the King of Portugal. Long before this the connexion of the subject with our present one ceases.

The loss of Roussillon and Portugal together caused the disgrace of Olivares in 1643 , just at the moment when the abilities which had failed to thwart Richelien might have had a chance against Mazarin. As soon as he began to lose the royal favour, complaints poured in on every side against him-the injured nobility on one side, the King's nurse on another; the outcries of the people, which might have been unheard but for these more penetrating agencies. $\mathrm{He}$ was coolly dismissed by Philip, who appointed in his place Don Luis de Haro de Guzman, his nephew, who changed the tactics but failed to restore the fortunes of Spain.

The year 1647 is marked by the revolt of Naples under Masaniello in July and a second in October, to the aid of which the French were invited. The influence of Spain, however, on our war was becoming smaller and smaller : the peace with the United Provinces in January 1648 is the last of her contributions to the interest of it. We close this scanty review of the part she played with contempt rather than pity. Philip IV. reigned until 1665 , but he did nothing more memorable in his later than in his early years, and in his son Charles II. the line of the Spanish Hapsburgs, than which no house except the Bourbons ever became so rapidly and totally effète, came to an end.

\section{LECTURE II}

\section{THE PEACE OF WESTPHALIA}

It is impossible for me, in a lecture which is to sum up a long series of events of great importance, and at the same time most difficult to retain in anything like order, in an ordinary memory, to attempt anything like an analysis of a document which, like the treaties of Westphalia, runs into the smallest minutiæ on particulars which, when stated generally, are so puzzling. These treaties have been the subject-matter of a course of lectures given by the Professor of International Law, ${ }^{1}$ one of which he has published, and I shall make use of it in the present lecture for all that we can now take in hand of the technicalities of the subject. In that course, I believe, he went historically through the treaties; this, of course, in a single

1 Professor Montagu Bernard. 
lecture I cannot pretend to do. We will, however, first accept his analysis of the treaties as containing four distinct elements :

First, the declaration of peace and clauses of amnesty, which implies the restitution of such conquests as are not to be retained, the revival of rights which the state of war has interrupted, and the release of prisoners.

Secondly, the provisions necessary for removing the causes that led to the war, for redress of grievances, and for the prevention of their recurrence.

Thirdly, the satisfaction exacted by the stronger party for injury sustained and for the compensation of the costs of war.

Fourthly, there are the provisions for the execution of the foregoing.

All these elements are in both the treaties; not arranged, of course, in this analytical way, but digested into a large number of clauses. The Osnabrück treaty contains seventeen articles; the Münster one thirteen. The following is a brief recension of the order in which they come :

The Osnabrück treaty has (1) a declaration of peace; (2) an article of amnesty; (3) an enunciation of rights restored; (4) an enumeration of the special places to be restored; $(5)$ a redress of religious grievances; (6) a recognition of the independence of the Swiss Cantons; (7) the admission of Calvinism as a lawful religion on a par with Lutheranism; (8) a statement of the constitution of the Empire and the relations of the various members of the Diet to the imperial Crown; (9) a provision for the restoration of commercial relations; (10) the provision of satisfaction to the Swedes; (11) the securing of Pomerania to Brandenburg; (12) the restoration of the Dukes of Mecklenburg; (13) the satisfaction of Brunswick; (14) the restoration of the Palatine family; (15) the satisfaction of the princes of Hesse and the ecclesiastical principalities; (16) the securing the laying down of arms ; and (17) the provision for executing the treaty. Of these seventeen it will be seen that the first, second, and third answer to Professor Bernard's first element; his second includes the fourth to the ninth; his third, the tenth to the fifteenth ; and his fourth the two remaining.

The treaty of Münster agrees nearly with this, varying in the omission of four articles and the consequent disturbance of order. The first four clauses are identical with the corresponding ones in the Swedish treaty; the fifth and seventh articles of Osnabrück are included in the fifth of Münster; the sixth of Münster provides for the Hessians ; the seventh of Münster answers to the sixth of Osnabrück; the eighth and ninth are the same in both; the tenth of Münster provides satisfaction for the French; the eleventh includes 
Italian states in the peace; the twelfth and thirteenth are the sixteenth and seventeenth of the other.

So much for the form. The most important portions of the matter of the pacification are the alterations of territorial arrangements implied in the satisfactions of the several powers that have to be satisfied; the remedy of the religious grievances to which, in theory at least, the war was traced; and the arrangement of the relations between the Emperor and the states of the Empire. The first of these includes, in primary importance, the satisfaction of the crowns of Sweden and France; the restoration of the Palatinate and of Mecklenburg; the bestowal of Pomerania on Brandenburg, and many subordinate particulars besides. The second, the adjustment of religious rights and the provision for the future, and the division, moreover, of the spoil of the Church under those provisions. The third speaks for itself.

Now take first the satisfaction of France. France is to have:

(1) Her claim fully recognised to the territory of the three bishoprics; this is to be incorporated into France as it was formerly in the Empire, reserving, however, the metropolitan jurisdiction of Treves.

(2) France is to have Alsace and all its dependencies united to the crown of France, including Breisach.

(3) The house of Austria, which had possessed the landgraviate of Alsace, renounces all right to it in favour of France, provided, however, that the Catholic religion as established in the rest of the hereditary dominions of Austria, without toleration of religious freedom, shall continue to be maintained.

(4) France is to have the right of putting a limited garrison in the fortress of Philippsburg: the fortress itself continuing to be the property of the see of Speyer. A variety of other articles provide for the restitution to the house of Austria of the possessions held by France on the Rhine not included in this surrender, and for the conservation of the bishoprics of Basel and Strassburg, as well as of the imperial towns and immediate vassals of the Empire in Alsace, to the Empire. The Archduke Ferdinand Charles, the nephew of Ferdinand II., the chief loser by this cession, is to receive a money indemnity from France.

Sweden is to receive the archbishopric of Bremen and the bishopric of Verden and the rights of the Chapter of Hamburg, 'secularised' into a principality conferring seat and vote in the Diet: she is to have also Upper Pomerania and Rügen, Wismar in Mecklenburg, and some places annexed to these.

Brandenburg is to have the rest of Pomerania and the bishoprics of Halberstadt, Minden, and Magdeburg after the death of the present administrator. 
The Dukes of Brunswick, who lose their claims on these bishoprics, are to have an alternate possession of that of Osnabrück and the monastery of Walkenried. The Dukes of Mecklenburg are restored, and have the bishoprics of Ratzeburg and Schwerin as compensation for the loss of Wismar and its dependencies.

Bavaria retains the Upper Palatinate and the electoral vote. The Palatine house recovers the Lower Palatinate and has an eighth electorate instituted for it; also a sum of money in indemnification and the reversion of the lost territory in case of the extinction of the Bavarian branch.

Hesse-Cassel is to have the abbey of Hersfeld as a princely fief, a great part of the county of Schaumburg and an indemnity in money. All the other states, the ecclesiastical principalities, Baden, Würtemberg, and others, are to be replaced in their old rights.

So much, then, for territorial arrangements. In the second place we take the redress of religious grievances. In this respect the provisions of the peace of Passau are revived; and, so far as the Edict of Restitution was concerned, a provision like that in the peace of Prague, for the maintenance of the Ecclesiastical Reservation, was made. Church property that was secularised on January 1,1624 , was to remain so for ever, and likewise that which was then in the hands of the Catholic Church: on that basis the Ecclesiastical Reservation was to continue. As for the Declaration of Toleration, the freedom of religion was established on the same principle as before, save that Calvinism was recognised as a lawful religion as well as Lutheranism, and that no provision of toleration should be regarded as extending to the hereditary states of Austria.

I have mentioned several of the appropriations of ecclesiastical estates that resulted from these arrangements; to go more into detail would only be puzzling. As for the further provisions for establishing religious equality in the imperial machinery, the 'Itionsrecht,' the 'jus eundi in partes,' dividing the whole Diet into two bodies, one Catholic and the other Protestant, who, without reference to a majority, were to settle disputed matters by arrangement, seems to be a lame sort of expedient, but, I suppose, answered the purpose of a compromise.

In the third place, the Swiss Confederation is declared to be out of the limits of the Empire: and the circle of Burgundy is to be included in the Empire as soon as France and Spain have agreed on terms of peace. But most important on this head are the two following provisions, which seem almost to abolish the imperiad jurisdiction altogether: "that the electors, princes, and states of the Roman Empire shall enjoy without contradiction the right of voting in all deliberations touching the affairs of the Empire, especially 
when they turn upon the declaration of war, the imposition of a tribute, the levies of troops, treaties of peace and alliance; and they shall treat of other such affairs, which henceforth shall not be settled without the privity and free concurrence of all the states of the Empire.' This leaves the Emperor, of course, even less power than usually belongs to a constitutional monarch. The next gives to each of the states political independence: "that each of the states shall freely and for ever enjoy the right of making alliances among themselves or with strangers, for their own preservation and security, provided that these alliances shall not be formed against the Emperor and the Empire or contrary to the public peace.'

These clauses were not all that were proposed for the further limitation of the imperial authority on the new theory of the character of the Empire. Amongst the projects broached was one for establishing regular sessions of the Diets; one to forbid the election of a King of the Romans during the lifetime of the Emperor, or, if it were necessary, to forbid his being chosen from the same family; another to introduce a permanent capitulation or convention between the Emperor and the Empire, to be signed on election; another to forbid the issuing of the ban of the Empire against any prince or state without the consent of the Diet. Fortunately for himself, Ferdinand managed to get these points referred to a future Diet; as was also the disposition of the town of Donauwerth and its restoration to its rights and privileges, the legal difficulties of which were so overwhelming that nothing more was ever done in the matter. A few other miscellaneous transactions, such as the ratification of the peace of Cherasco and the provision for the inclusion of allies, complete the important portions of the pacification. And so we will leave it. I mentioned briefly, in the last lecture but one, the transactions that completed the execution of the negotiations.

We have thus made such a survey of the sequence of events in this famous and important struggle as the limits of a term's lectures would allow, or the proper proportion of the period to the necessary complete cycle of your work here. We have found it, compressed into this small space, sufficiently tough reading, and difficult to carry in anything like order in the memory. It is possible that in attempting to trace too minutely the exact links of cause and consequence I have not set before you in sufficient clearness the leading influences of the war. If so, it is too late now to attempt to repair the mistake, but we may first recapitulate once for all the stages of the war in their order and in the process of their development.

Taking the history of the war as a whole, and not as a portion only of the great struggle of the Reformation, in which aspect I will return to it directly, it may be divided nearly as we have done from 
lecture to lecture. The first stage is that of the Bohemian war, from the accession of Ferdinand to the capture of Prague. The second includes the struggles of Christian of Brunswick and Mansfeld, in which the interest spreads from Bohemia to Germany at large. The third is the stage at which Denmark takes the lead, and struggles at the head of the Protestant party until it is entirely broken up and Wallenstein's policy and principles are triumphant. The fourth is the period of Gustavus Adolphus and Wallenstein, and reaches from the Edict of Restitution to the peace of Prague. The fifth reaches from the peace of Prague to the peace of Westphalia; it may be regarded as broken into two, the few years preceding the opening of negotiations, and the remainder in which the war and the negotiations went on side by side; but it is perhaps as convenient to regard the whole thirteen years as substantially a single portion of the great struggle.

In the first, then, of these stages the war is Bohemian or Austrian; in the second it is German; in the third it becomes a struggle of the whole of the Protestant Continent against the Empire, under the leadership of Denmark; in the fourth it is the same under Sweden, but assisted by France ; in the fifth it is a European contest, in which all other causes of war are mingled, in which all the nations of Europe are engaged, in which neither religion nor nationality determines the portion of any one of the combatants.

It is on the lines of this arrangement that $I$ have tried to draw the sketch that we have attempted in this course of lectures. It may, however, be done, perhaps, with equal effect upon the memory, by grouping the events round some of the chief characters of the struggle. Ferdinand II., Maximilian, and Tilly, Frederick the Count Palatine, Count Thurn, Mansfeld, and Christian of Brunswick, form one group ; a second is made by Wallenstein and Tilly, Christian of Denmark, Christian of Brunswick, and Mansfeld; a third by Gustavus Adolphus, Bernard of Weimar, and Wallenstein; a fourth by the successive generals on each side, after the passing away of Gustavus and Wallenstein; on the Protestant side, Bernard, Horn, Baner, Torstenson, Wrangel, and Königsmark ; on the Catholic side, Ferdinand III., the Archduke Leopold, the Cardinal Infant, Gallas, Piccolomini, Hatzfeld, and Mercy. But in fact it is not very wise in me to recommend to you such artificial methods of arrangement; if the time could be afforded, the Thirty Years' War might easily be made a period of study in and for itself, like the Peloponnesian war in ancient bistory. As matters are at present, the best we can do is to get as complete a view as we can of its parts, variations, and general tendencies. The minutiæ of either places or persons cannot be retained in the mind with due regard to the proportion of history. 
But I said that we ought to look at the war, not merely as a whole in itself, capable of minute division, and illustrated by the political changes of the states whose actions affect it directly or indirectly and are so affected by it. It may be regarded as the third act of a great series, of which the reign of Charles V. is the first, and the period of the Catholic reaction, between the peace of Passau and the battle of Prague, the second. Throughout the whole of this there is one idea, or rather two distinct ideas, in progress which may be regarded as giving a unity to the long period. The Reformation is one, the claims of the house of Hapsburg the other. On the whole, the history of the house of Hapsburg is the string on which most certainly the unity of the history arranges itself. The reign of Charles V. witnesses the growth of the Reformation; the intervening period the growth of the anti-Reformation ; the Thirty Years' War the struggle between the two: a struggle out of which the Reformation party, partially victorious, emerges with the loss of almost everything that gave it a real and lasting interest; and the anti-Reformation party, technically defeated and having failed to compass the ends for which all along it has struggled, carries off the solid fruits of victory.

But I am not sure that it is wise, or even convenient, to read the history exclusively from this point of view. The bundle of influences which we regard in common talk as the Reformation, and the association of parties that we group together as the Reformation interest, vary so much at different periods of the long struggle that it is difficult to realise any real identity of them. The spiritual outbreak of emancipated thought, the rise against the political supremacy of one great Catholic house, the desire of plunder to be obtained from the division of the great ecclesiastical estates, the jealousies of the several powers, the Catholic and Protestant or imperial and antiimperial tendencies of the branches of the same family, cannot be reduced and arranged so as to give an identity to the Reformation throughout; and much less can they be arranged so as to give a personal identity of presentment to the party. The sole fixed element is the house of Hapsburg; and even this varies as its plans vary in their object, for the assertion of the imperial dignity, the reformation of the Church on Papal principles, or the consolidation and aggrandisement of the family power.

It is easy, of course, to adopt the ordinary solution of political historians of the present day, and conclude that the selfishness of Austria is a constant quantity, although its object may for the time be any one or all of the three that I have mentioned. There are great conveniences in such a view, although it is apt to divert the mind from regarding the many different influences and phases of influence 
which produced and modified the Hapsburg selfishness. But insist on it as you may, it does not enable you to impersonate the counterinfluences. It is only in France, under the influence of the selfish policy of the dynasties of Valois and Bourbon, that the exact antithesis to Austria, the one unfailing, persistent, irreconcilable antagonist, can be found. France armed and excited against Austria the influences that she was repressing on her own soil, and it was France that made the Thirty Years' War possible and that made it last the thirty years it did last.

But it cannot be denied that to regard the whole period mainly as a struggle between two great dynastic policies is unworthy in the last degree of a philosophical historian. And to my mind it is scarcely less unworthy to hang the interest of the whole on the selfishness, the dynastic policy of the house of Hapsburg, as is the modern fashion: a view which of course is largely suggested by the political and philosophic adherents of the Prussian policy in Germany. This view may be simply stated. The whole period was a struggle waged by the dynastic policy of Austria against the spirit of the German people. The German people had declared emphatically against Rome, the house of Hapsburg determined to force Romanism upon them; the German people had cast off the last shadow of imperialism, the house of Hapsburg determined to revive the obsolete claims of the Empire ; the German people had a multiplicity of interests opposed to the dynastic interests of the Hapsburgs, but the house of Hapsburg determined to sacrifice everything to its own dynastic ends, even at the risk of quenching all that was living and patriotic in Germany at large. And next to this deliberate purpose of Austrian selfishness, the great source of German miseries was the multitudinous array of rival principalities marshalling against one another the forces of a nation that was not consulted, destroying the life of the nation by such treatment, and flourishing on that destruction.

There is much truth in this picture; but it is not the whole truth; and it is so far from being the whole truth that it amounts in many respects to thorough misrepresentation. It is true that Austria had a selfish policy, and it is true that the princes were greedy and unprincipled: it is true that the sovereigns were mad, and the people perished; but it is not true to suppose that it was done with a conscious disregard of right or without an honest purpose, in many respects, on each side : and still less is it true that the sacrifice was a conscious one. It is impossible to read such a view without seeing that it is drawn from a modern and ex-parte standpoint. Distinctly the Evangelical Union was the most pronounced and definite impersonation of anti-Austrian principles, 
regarded as religious, dynastic, or national; yet the Evangelical Union was a union of princes and burghers, who neither loved nor trusted one another, who were not prepared to risk anything, and who did look to win largely in the coarsest material way. It was not a national rising, such as that of the Bohemians certainly was; it was only in pretence based on solid grounds of action, and its ignominious failure testified to the little faith or self-sacrifice that was mixed up with it.

It is only on the principles of Protestant dogmatism, and of that German Liberal dogmatism that is so largely, even if unconsciously, leavened with it, that we can shut our eyes to the fact that there was on the other side an array of Catholic princes, infinitely superior in political and moral energy to the Protestant ones ; with as strong a hold on the faith, and a much more fervent, self-sacrificing, persevering spirit of resistance. If we are to look at the struggle from the religious standing-point, well, let us do it, but let us acknowledge that we do it. But we cannot say that we believe that the men who fought the battles did so. We cannot say that the Saxons and Brandenburgers regarded the struggle as one of truth and enlightenment against darkness and error. They called themselves Protestant, they were Protestant enough when they wanted a reason for secularising an abbey or a bishopric, or when they saw a Protestant kinsman in danger, yet they fought with very little intermission on the Catholic side, and they certainly made the fight an impossible one on the Protestant side.

We may disavow inclination for either side, and say: 'Little as I like the policy and principles of Rome, I like as little the policy and principles of German Protestantism. I am not concerned to defend the fair fame or justify the interference of Gustavus Adolphus ; but yet the spirit of the house of Austria is repulsive to me; on the whole I cannot help seeing that the result of Austrian success would have been to retard progress, and the result of Austrian failure would have been more thoroughly to secure liberty.' The answer to this is simply: Show me that you mean by liberty and progress anything whatever but the advancement of your own opinions, and then I will begin to consider the validity of your plea.

I do not think that we need necessarily rise from the study of the period, then, with a definite impression that either party was exclusively wise and good, or that the result of the struggle was decisively good or decisively bad. Nay, I think that we should be guilty of a great sin against conviction if we did so. I believe myself that as with the men so also with the measures, and so very clearly in the results, good and evil were very much mixed. I hold 
that it must have been a very great evil to have had Germany subjugated by the Jesuits; that the propagation of religion by persecution is at once the most futile and about the most wicked of all political objects; yet I hold that Ferdinand II. and Maximilian of Bavaria were, according to their light, wise and conscientious men : as surely so as the great majority of the princes on the other side were profligate politicians and selfish, aggressive, greedy tyrants. I hold it certain that the best of these men struggled on very mixed motives, and that in the worst of them the batred of oppression was the sole redeeming trait. Further than this I withhold personal acquittal or condemnation. If a man is to be judged by the unforeseen effects of his most deliberately careful and conscientious acts, there is no one who can be acquitted of blame in all history. Happily we are not obliged to judge. The result is not to condemn the purpose; so neither can the cause justify the champion, or the end justify the means.

As for the results, however, the peace of Westphalia was in itself a compromise: the Thirty Years' War contains much that is dramatic, but it has no pretensions to the character of a drama itself. Its results were what neither party was struggling for ; they are decisive for neither side; but they are marked and lasting. The peace drew a decided and permanent line between Protestant and Catholic Germany. What was left Protestant continues so, and what was left Catholic continues Catholic ; it stopped the process of robbery on the Protestant side; what was secularised then remained secular, and what was kept ecclesiastical then remained ecclesiastical to the end of the Empire. It settled the boundaries of Germany from that day to the same period; for Lorraine, the only subsequent addition to France, had long been French to all intents and purposes, and the seizure of Strassburg remains the only considerable infringement of the rule. But, further, it settled the constitution of the Empire to be but primus inter pares : the chief state of a confederation in which the pre-eminence was but nominal, and the reality of the power due to the possessions of the reigning house outside Germany.

That this much was an advantage to Austria, that the position of the imperial authority in 1648 was better than it was in 1448 , is no diminution from the importance of this truth. Austria was stronger, but the Empire was relatively weaker. The old theory went the way of all theories in 1648, and Austria was content to let it be so. Henceforth the imperial dynasty is Austrian; Austria does not sacrifice her imperial position to her dynastic interests, simply because there is nothing to sacrifice. The Empire under the later Hapsburgs is as much the Empire of Austria as it was when Francis II. exchanged the title of Emperor of the Romans for that 
of Emperor of Austria. The disruption of the old system was so far completed; what it wanted of completion was left undone because the exhaustion was too great to suffer more to be done then; but it soon bore results in the creation of the Prussian kingdom and in the entire break-up that followed a century after. The parts so broken up have now, after a season of trouble, begun to reunite: with what result we dare not anticipate now, but certainly with a great result for good or for evil throughout the whole world. 


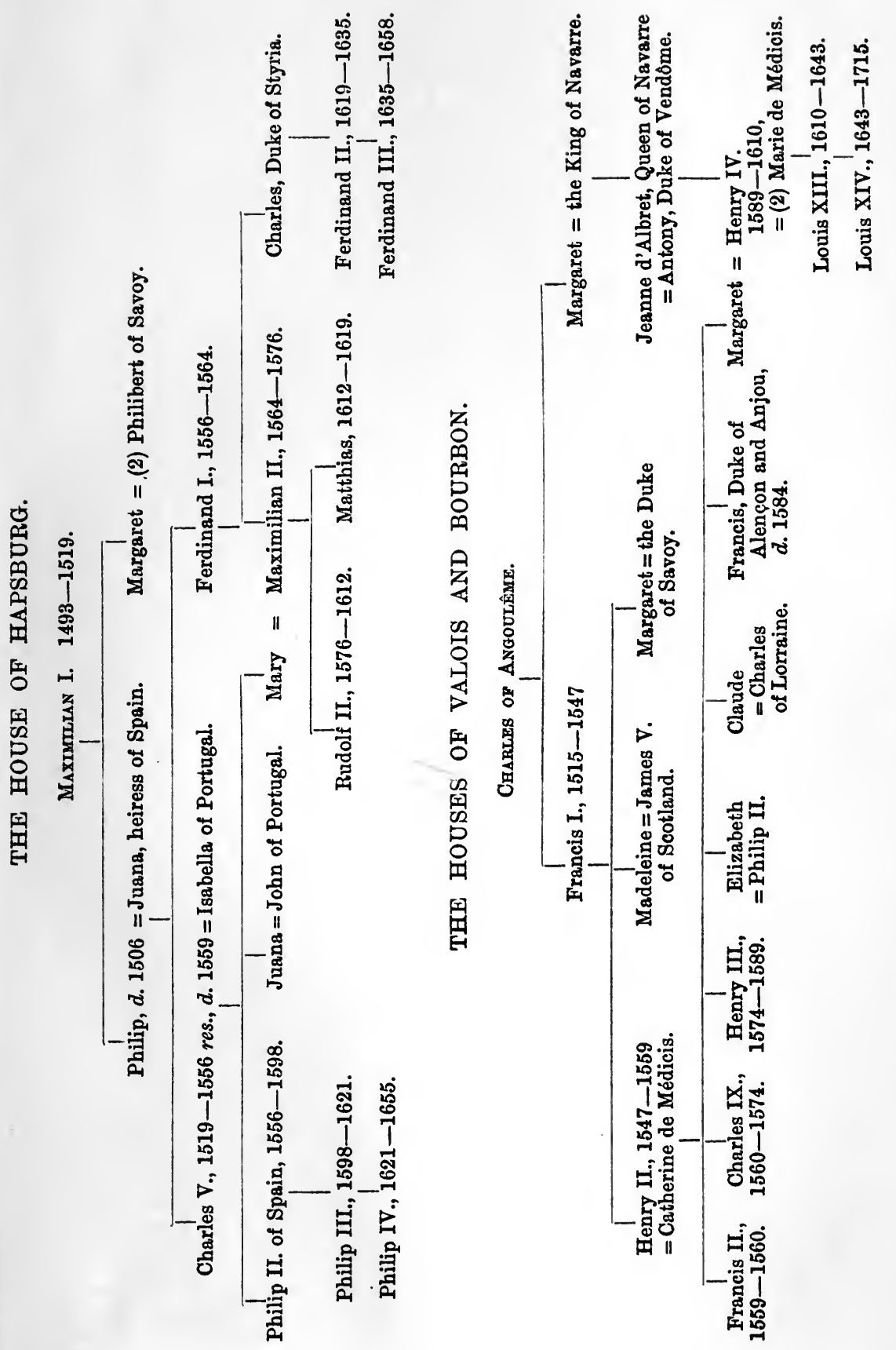





\section{INDEX}

Anow of Guelders, 30

Adrian VI., Pope (Adrian of Utrecht), $18,36,54,55,69$

Adrian, Cardinal, sent to receive homage in Valencia, 20

Adrian Florenz, Canon of Louvain, 28

Aerschot, Duke of, 212

Agnes of Mansfeld, 164

Agricola, John, 108

Aguila occupies Kinsale, 267

Aix, capture of, by Bourbon and Pescara, 56

Aix-la-Chapelle put under the ban of the Empire, 260

Alava, Spanish Minister at Paris, 201

Alava, 204

Albert Alcibiades, 117

Albert, Archduke, of Austria, 161, 163, $220,221,224,268,301,394$

Albert III. (the Magnanimous) of Bavaria, 163

Albert V., Duke of Bavaria, 178

Albert of Brandenburg, Archbishop of Mentz, 42, 47, 68, 99, 115

Aldobrandi, Hippolito. See Clement VIII.

Alençon, Francis, Duke of, 191, 210, 229, 230, 232. See also Anjou

Alexander VI., Pope, 74

Alexander, the Grand Prior, 252

Alexander of Parma. See Parma

Alkmaar, siege of, 207

Alva, Duke of, $89,124,152,156,186$, $188,199,200,202,203,204,205$, 207, 221, 229

Amboise, conspiracy of, 184 ; Edict of, 185

Amiens captured and re-taken, 224

Anabaptists, the, 35, 101

Ancre, Marshal d', 221, 252

Andreas, Cardinal, of Anstria, 268

Anjou, Duke of, 188; projected marriage with Elizabeth of England, 190 ; elected sovereign of the Central States, 215; his death, 216. See also Alençon
Anna Maria, queen of Philip II., 160

Anna of Saxony, wife of William the Silent, 210

Anne of Austria marries Lewis XIII. of France, 252, 388; Regent of France, 392

Anne of Germany, 163

Annebaut, General, 89

Antonio, prior of Crato, 221, 222

Antony, King of Navarre, 159, 182, 184, 185

Antwerp, 200, 201, 212, 215

Aragon, kingdom of, 14; Cortes, 15, 20 ; Don John de Lanuza, Regent of, 21

Archange, Father, 248

Ardres, Henry VIII. of Engl.nd visits Francis I. at, 53

Aremberg, Count of, 202

Armada, Spanish, 219

Arnold, Duke of Guelders, 30

Arques, Henry of Navarre beats the Duke of Mayenne at, 235

Arras, bishopric of, 33

Artois, 25

Aschaffenburg taken by Turenne, 378

Aschhausen, Protestant Union formed at, 260

Asturias, Charles's landing in, 23

Augsburg, Confession of, 72, 98, 359

Augsburg, Diet of, 9, 97, 149

Augustus the Pious of Saxony, 163

Aulic Council, 43, 45

Auvergne, Count of, 247, 248

Avaux, Count d', 384

Avila, Don Sancho d', 208

Avila, Junta meet at, 22

Azevedo, Peter Henriquez d', 161

BADEN, Margrave of, 261, 303

Bamberg surrenders to Bernard of Weimar, 347

Baner defeats the Saxons at Diemitz, 362 ; captures Erfurt and Meissen, and besieges Leipsic, 363 ; driven into Pomerania, 366 ; victorious at 
Brandeis, 368 ; retires on Meissen, 369 ; disperses the Diet of Ratisbon, 370 ; his death, 370

Barbarossa, Hayraddin, 83, 124

Barcelona, Charles at, 20 ; Treaty of, 61; Peace of, 71, 74

Barlaimont. See Berlaymont

Barneveldt, 270

Barricades, Day of the, 233

Bärwalde, treaty signed at, between Gustavus Adolphus and Richelieu, 328, 390

Basel, Council of, 100

Bathory, Stephen, King of Poland, 175

Bayard, death of, 56

Béarn, Prince of (Henry IV.), 188

Beaufort, Gabrielle d'Estrées, Duchess of, 246

Beghards, 35

Beguins, 35

Bergen-op-Zoom, Maurice raises the siege of, 303

Berlaymont, 198, 199

Bernard, Duke of Weimar, 336, 341, 344, 347; becomes Duke of Franconia, 348; captures Eichstädt, Neuburg, Ingolstadt, Ratisbon, and Straubing, 348; refuses Wallenstein's offer of service, 353 ; contention with Horn, 355 ; defeated by Ferdinand II. at Nördlingen, 357 ; becomes general-in-chief of the German army, 360 ; offered the territory of Alsace by Ferdinand, 362 ; captures Saverne, 365 ; retires into Lorraine, 366 ; takes Rheinfeld, Röteln, and Freiburg, beats the Bavarians at Witteweir, and captures Breisach, 367 ; his death, 368

Bethlen Gabor, Prince of Transylvania, 292; proclaims himself King of Hungary, 293 ; defeats Bucquoy at Neuhäusel, 301 ; abandons his pretensions to the crown, 302

Biberach taken by Horn, 355

Bible, the, translated, 100

Biron, Marshal, 237, 239, 247

Blois, States General meet at, 231

Blood, Council of, 202, 208

Boisot, Admiral, 208, 210

Boitzeburg captured by Tilly and Wallenstein, 314

Bologna, Charles V. enters, 77

Bonnivet sent into Navarre by Francis I., 53 ; captures Fontarabia, 54

Bordeaux, convention of, 215 ; Archbishop of, burns the Spanish fleet, 367

Borghese, Camillo, Pope, 159

Borgia, Cæsar, 74
Bossu, Admiral, 206, 207

Bouillon, Duke of, 248, 250, 252, 388

Bourbon, Cardinal Charles of, 159, 229, 232, 234, 235

Bourbon, Duke of, Constable of France, 54

Bourg, Anne du, 183

Bourges visited by Charles, 32

Brabant, Duke of, Anjou elected, 215

Braganza, Duke of, 397

Brandeis, Baner's victory at, 368

Brandenburg, Elector of, 249

Breda, 209, 219, 396

Brederode, 200, 201, 270

Breissach captured by Bernard of Weimar, 367

Bremen, archbishopric of, 177

Brill, capture of, 206; handed to England as security for debt, 218

Brömsbro, Peace of, 384

Bruges, Duke of Anjou elected Count of Flanders at, 215

Brunau, Protestant church demolished at, 287

Brussels, Treaty of, 52 ; the Union of, 211 ; the New Union of, 213

Brussol, Treaty of, 249

Bucquoy, General, 289, 290, 292, 296, 301

Buda burned by Solyman, 123

Buoncompagno, Hugo, Pope, 159

Burgundy, House of, 26

Cajetan, Cardinal, 68, 235, 236

Calderon, Rodrigo, 265

Calemburg, Count, 200

Cambrai, bishopric of, 33 ; League of, 28,51 ; peace of, $8,29,31,60$

Campeggio, Cardinal, 70

Caraffa, Cardinal, elected Pope, 149

Cardona, Duke of, 397

Carignan besieged by the Count of Enghien, 91

Carlstadt supports Luther, 69

Carranza, Bartholomew, Archbishop of Toledo, 84, 195

Casimir, John, 214

Castaldo, Ferdinand's Minister, 126

Castile, kingdom of, 14; Ximenes appointed regent, 18

Castilian Cortes, 15, 21

Catalonia, Cortes of, 15; Charles V. at, 20 ; revolt of, 397

Cateau-Cambrésis, Treaty of, 130, 155

Catherine of Aragon, 78, 100

Catherine of England a possible claimant to the Spanish erowns, 17

Catherine de' Medici, 230, 231; her death, 234. See also Médicis

Catholic League meets at Würzburg, 293 
Cercamps, peace nego tiations at, 155 Cérisoles, Battle of, 91

Champagny (brother of Granvelle), 209,214

Charité, La, 189, 191

Charles I. of England, 319, 389

Charles V., Emperor, 8, 9, 13, 17 ; crowned at Valladolid, 19 ; his ingratitude to Ximenes, 19 ; acknowledged as joint sovereign of Aragon with Johanna, 20 ; overtures to the Castilian rebels, 22 ; terms dictated by the Junta, 23; lands in Asturias, 23; marries Isabella of Portugal, 23; crushes the revolt of the Moriscoes, 24 ; offends the Castilian nobles by his taxation proposals, 24; dismisses the nobles from the Cortes, 24 ; received by Francis I. at Bourges, 32 ; visits Paris, 32; triumphal entry into Ghent, 32 ; introduces the Inquisition into the Netherlands, 34 ; elected Emperor of Germany, 43 ; meets Henry VIII. of England and Cardinal Wolsey, 43 ; crowned Emperor by Pope Clement VII., 48, 77 ; appoints his brother Ferdinand King of Germany, 48 ; lands at Genoa, 73, 76; makes his wife his regent in Spain, 76 ; receives the crown of Lombardy, 77 ; protests against Francis to the Papal Assembly, 80; besieges Marseilles, 81 ; accused of treason by Francis, 82 ; his treatment of Ghent, 86; puts the Duke of Cleves to the ban of the Empire, 88; defeats the Duke of Cleves, 89 ; summons the Diet at Augsburg, 97; calls the Diet to Cologne, 98; makes peace with the Smalkaldic League, 99 ; annuls the Edicts of Worms and Augsburg, 100; attacked by the Smalkaldic League, 104 ; propounds the Interim, 108; fails in besieging Metz, 116; resigns the Netherlands to Philip, 120; his character, 132-144; abdicates, 150

Charles IX. of France, 158, 185; at Bayonne, 186; ordinance at Moulins, 187; marries Elizabeth of Austria, 189; jealous of his brother, 189, 190; saves the King of Navarre, 190 ; arrests the Duke of Alençon and the King of Navarre, 191 ; his death, 192 ; negotiations with the Prince of Orange, 203

Charles IX. of Sweden, 159

Charles X. of France, Cardinal of Bourbon proclaimed as, 235

Charles, Margrave of Austria, 261
Charles the Bold, 26

Charles of Egmont, 29, 30

Charles of Lorraine, Cardinal Archbishop of Rheims, 182, 258

Charles Emmanuel of Savoy, 164, 165, 264

Charles Gustavus, Palatine of Deuxponts, 381

Charles Lewis defeated by Hatzfeld, 367

Charlotte of Bourbon marries William of Orange, 209 ; death of, 215

Charolais retained by Philip II., 225, 240

Chartres besieged by Condé, 187 ; Henry III. retires to, 233 ; secured by Henry of Navarre, 236

Château Thierry, Duke of Anjou dies at, 216

Châtillons, the, 182

Chemnitz, Chancellor of Stettin, 370

Chemnitz, Martin, 256

Cherasco, Peace of, 396

Chièvres, Charles's prime minister, 20

Chimay, Prince of, 216

Christian I. of Saxony, 163

Christian II. of Saxony, 163

Christian III. of Denmark declares war against Charles V., 89

Christian IV. of Denmark, 159 ; opposes Ferdinand, 301 ; elected head of the Lower Saxon Confederation, 306, 310; negotiates with Ferdinand, 350, 371; renounces his alliance with Ferdinand, 373; his offer of mediation, 381

Christian of Anhalt, 296, 297, 300, 304

Christian, Count Palatine of Birkenfeld, 347

Christian of Brunswick, 302, 312

Christian Ernest of Brandenburg, 261

Christian William of Brandenburg, $177,313,314,330$

Chytræus, David, 256

Cinq-Mars, conspiracy of, 390

Clara Isabella, Infanta, 161

Claude of Chalon, 161

Clement VII., Pope, $8,55,58,60,70$, 74,100

Clement VIII., Pope, 159

Clément, Jacques, assassinates Henry III. of France, 235

Cochlæus opposes the Reformers, 98

Cocqueville, General, 202

Cognac, treaty of, 58

Coignac, 189

Coligny, Admiral, 154, 182, 184, 187, $188,189,190,203$

Collateral Council of Naples, 74 
Cologne, archbishopric of, 34

Colonna, Pompeo, 74

Colonna, Vittoria, 84

Colonnas, the, deprived of their duchy, 152

Commendone, Papal legate, 176

Compiègne, Treaty of, 363

Compli pillaged by the Duke of Guise, 153

Compostella, Castilian Cortes meet at, 21

Concini, Minister of Marie de' Medici, 251, 388

Condé, Prince of, 191, 229, 252, 367, 379, 388. See also Enghien

Condé, Princess of, and Henry IV., 249

Confession of Augsburg, 9, 72, 98, 149, 358

Conspiracy of Amboise, 184

Constitutions of the Spanish kingdoms, 14

Contarini, Aloysio, 384

Corbie taken by Thomas of Savoy, and recaptured by Louis XIII., 363

Cortes, the Spanish, 14, 16, 20, 227

Cortez, Hernando, 132

Corunna, Castilian Cortes at, 21

Cosmo (Duke of Florence) Grand Duke of Tuscany, 165

Cossé, Marshal, 189

Council of Basel, 100

Council of Blood, 202, 208

Council of Mechlin, 26, 27

Council of Trent, 9,102

Council of Troubles, 202

Crane, John von, 384

Cranmer, Archbishop of Canterbury, 100

Cremona, 54

Crespy, peace of, 8, 85, 92, 93

Cromwell, Thomas, 100

Croy, William de, Archbishop of Toledo, 20

Culmbach ravaged by Wallenstein, 341

Cyprus, Venetians lose, 196

DAupierre, General, 289, 296

Dancing Heretics, 35

Dandelot, 182

Day of the Barricades, 233

Declaration of Independence of the United Provinces, 215

Declaration of Toleration, 176, 177, 179

Demmin surrenders to Gustavus Adolphus, 333

Dendermonde, conference at, 201

Deventer, Brethren of the Common Life founded at, 36
Devereux assassinates Wallenstein, 353

Diana of Poictiers, 183

Diemitz, Baner defeats the Saxons at, 362

Diet of Augsburg, 9

Dinkelsbuhl taken by Gustarus Adolphus, 341

D'O, intendant of the finances, 238

Donauwerth occupied by Charles V., 105 ; put under the ban of the Empire, 260

Doria, Andrea, 73, 81, 124, 126, 130

Doria, Filippino, 60, 74

Drake, Sir Francis, 221, 222

Dreux, Francis of Alençon flies to, 230

Dreux, Battle of, 185

Duiveland, Requesens marches to, 209

Dunham's, Dr., criticism of Robertson, 12

Dunkirk captured by Marshal de Termes, 155 ; taken by the Duke of Enghien, 377

Düttlingen, Battle of, 372,393

EberhaRd of Lübeck, 177

Eboli, Princess, 224

Ecclesiastical Reservation, 149, 176, 179,358

Eck, Johann, 68, 98, 101

Edict of Amboise, 185

Edict of Nantes, 240

Edict of Restitution, the, 315, 321, 358

Edict of Roussillon, 186

Edward VI., England under, 150

Egmont, Charles of, 29, 30

Egmont, Count, 155, 187, 198, 199 , $200,201,202$

Egra, Wallenstein assassinated at, 353 ; captured by Wrangel, 378

Ehrenbreitstein, surrender of, 366

Eichstädt captured by Bernard of Weimar, 348

Eleanor, Queen of France, 82

Eleanora, Empress, coronation of, 325

Electors of Germany, 42

Elfsnabben, Gustavus Adolphus embarks at, 328

Elizabeth of Austria, 189

Elizabeth of England, 157, 190, 203, $218,221,222,223,229$

Elizabeth of France, queen of Philip II., 160

Elizabeth, Queen of France, 163

Elizabeth, Queen of Spain, 186

Elizabeth Stewart, Electress Palatine, 286 
Emmanuel Philibert of Savoy, 164, 221

Enghien, Count of, 91

Enghien, Duke of, victories of, 372, 377, 393. See also Condé

England, condition of, under Edward VI., 150

England's entry into European politics, 52

Entragues, Madame d', 247

Entragues, Mademoiselle d', 246

Epernon, Duke of, 233, 235, 239

Erfurt, Luther enters University of, 67 ; captured by Baner, 363

Eric XIV. of Sweden, 159

Ernest, Archduke, Governor of the Netherlands, 161, 163

Ernest of Bavaria, Archbishop of Cologne, 163

Ernest of Lüneburg, 72, 103

Ernest of Mansfeld, 219

Escovedo (Don John's secretary) assassinated, 213, 223

Escurial built by Philip II., 225

Essex, Earl of, 222

Estrées, Gabrielle d', Duchess of Beaufort, 246

European politics, Papal influence on, 8

Faber opposes the Reformers, 98

Farnese, Alexander, Duke of Parma, 161, 213. See also Parma

Farnese, Ottavio, 109, 161, 165

Ferdinand I. of the House of Hapsburg, 71, 158; his election as King of the Romans, 99 ; at the Diet of Augsburg, 148; becomes Emperor, 150; his family, 162; at Passau, 169 ; at Augsburg, 169, 171; his complicity in Martinuzzi's assassination, 169; elected Emperor, 170 ; his coronation refused by Paul IV., 170; negotiations with Pius IV., 172 ; his death, 172

Ferdinand II. of the House of Hapsburg, 162; crowned King of Bohemia, 264,288 ; receives the crown of Hungary, 289; holds Vienna against Count Thurn, 290 ; elected Emperor 291 ; acknowledged King of Bohemia, 298 ; his character, 298; his reprisals on the Bohemians, 300 ; marries Eleanora Gonzaga, 302 ; deprives Frederick of his electorate, 304 ; endeavours to supersede Wallenstein, 352; orders Wallenstein's arrest, 353 ; captures Ratisbon, 356 ; defeats Duke Bernard at Nördlingen, 357 ; secures the kingdom of the Romans for his son, 364 ; his death, 364
Ferdinand III. of the House of Hapsburg, 365 ; driven to Ratisbon, 374 ; has his eldest son crowned as King of Bohemia, 377; narrowly escapes capture by Wrangel, 378 ; his son crowned King of Hungary, 379

Ferdinand IV. of Hungary, 379

Ferdinand of Aragon becomes king of Naples, 73

Ferdinand of Carinthia, 163

Ferdinand, Elector of Cologne, 291

Ferdinand of Styria crowned King of Bohemia, 264

Ferdinand of Toledo, Cardinal Infant of Spain, 355, 372, 394

Ferdinand of Tuscany, 165

Feria, Duke of, 237, 347, 348

Ferrara added to the Papal States, 74

Field of Cloth of Gold, 43

Flacius Illyricus, 170

Flagellants, 35

Flanders, 25

Flanders, Count of, Anjou elected, 215

Florence, Francis, Duke of, 246

Flushing, revolution at, 206 ; taken as a surety by Elizabeth of England, 218

Fonseca, Antonio de, 22

Fontarabia captured by Bonnivet, 54

Foreign influence at Charles's court, 17 ; hated by Spaniards, 18

Formula Concordiø, 256

Fox, Bishop of Hereford, 100

France in the sixteenth century, 180

Francesco Maria of Tuscany, 165

Francis I. of France, Protestant distrust of, 10 ; and the Ghent burghers, 32 ; a candidate for the crown of Germany, 41 ; rivalry with Charles V., 49; seizes Milan, 56; besieges Pavia, 57; defeated and taken prisoner by Pescara, 57 ; liberated, 58; intrigues with Sultan Solyman, 78; allies himself with the Smalkaldic League, 78 ; occupies Savoy, 79; accuses Charles V. of treason, 82 ; proclaims war against Charles, 89; occupies Landrecy, $90 ;$ his death and character, 95

Francis II. of France, 158, 182, 184

Francis of Alençon, 229, 230

Francis Prince of Conti, 159

Francis of Florence, 246

Francis of Guise, 182, 185

Francis Charles of Saxe-Lauenburg, 330

Frankenthal, 302, 337

Frankfort, German Electors meet at, 42

Frederick II. of Denmark, 159 
Frederick the Wise, Count Palatine, 102

Frederick, Elector Palatine, elected King of Bohemia, 264, 291; his incapacity, 296 ; resigns the crown, 297 ; visits Gustavus Adolphus, 337 ; his death, 347

Frederick (the Wise) of Saxony, 42, 68,70

Frederick of Toledo, 207

Frederick the Long, 335

Frederick Augustus the Strong, 47

Frederick Henry of Nassau, 394

Frederick Ulric, Duke of Wolfenbüttel, 312

Frederick William III. of Prussia, 163

Fregoso, Cæsar, 88

Freiburg taken by the Rhinegrave, 355 ; captured by Bernard of Weimar, 367

'Freiherren,' or German barons, 44

Friesland joins the League of Utrecht, 214

Friesland, West, province of, 25

Fuentes, Pedro Henriquez d'Azovedo, Count of, 220, 239

Fuggers, Charles V.'s bankers, 97

Gamas defeats Wrangel, 366; defeated at Yutterbuck, 373; his death, 378

Gassion, Marshal, 379

Gemblours, Don John's victory at, 213

George of Brandenburg-Anspach, 70 72,98

George, Landgrave of Hesse-Darmstadt, 336

George Frederick, Margrave of Baden, 296, 302

Gerard, Balthazar, assassinates William of Orange, 216

Germaine of Foix married to Ferdinand, 16

German kingdom, historical survey of the, 37 et seq.

Germany in the sixteenth century, 253

Gertruydenberg surrendered to the Spaniards, 219; captured by Maurice, 219

Ghent, 31; burghers' invitation to Francis I., 32 ; Charles's triumphal entry into, 32 ; his treatment of, 86 ; congress of the States at, 210 , 211 ; submits to Alexander of Parma, 217

Ghinetto, Cardinal, 364

Ghislieri, Michael, Pope, 159

Giron, Pedro, Duke of Ossuna, 160

Goignies, De, 213

Golden Bull of Charles IV., 97

Gomez, Ruy, $224 n$.
Gonzaga, Eleanora, wife of Emperor Ferdinand, 302

Gonzaga, Ottavio, 213

Gonzalvo of Cordova, 74, 301

Gotha, war of, 174

Göttingen taken by Tilly, 312

Granvelle, Cardinal, 156, 160, 161, $198,199,202,204$

Gravelines, meeting at, between Charles and Henry VIII. of England, 53; Battle of, 155

'Great Privilege' of the Netherlands provinces, 27

Gregory XIII., Pope, 159 ; condemns Archbishop Carranza, 195

Gregory XIV., Pope, 159 ; declares against Henry IV. of France, 236

Greiffenklau, Richard von, Archbishop of Treves, 42

Grenoble taken by Lesdiguières, 236

Gröningen, province of, 25

Gröningen besieged by Philip of Hohenlohe, 214

Groote, Gerhard, 36

Grumbach, William, 171, 174, 175

Guastalla, Duke of, 317, 324

Guasto, Marquis del, 88

Guébriant killed while besieging Rothweil, 372

Guelders, duchy of, rival claimants for, 29

Guelders joins the League of Utrecht, 214

Guelders and Friesland, Duke of, Anjou elected, 215

' Gueux, les,' 200

Guienne and Languedoc, Catholic confederation, 187

Guines captured by the Duke of Guise, 155

Guise, Claude Dake of, 159

Guise, Francis Duke of, 153, 154, 159, 185

Guise, Henry Duke of, 116, 159, 188, $232,233,234,236,252$

Guise, Mary of, 159

Guise, René II. Duke of, 159

Gustavus Adolphus, King of Sweden, 326 ; sails from Elfsnabben and occupies Stettin, 328; modernises the mode of warfare, 330 ; takes possession of Spandau, 333 ; defeats Tilly at Wolmerstadt and Werben, 334 ; overwhelms Tilly at Breitenfeld, 335; captures Schweinfurt and Würzburg and garrisons Rüsselsheim, 336; Oppenheim, Mentz, and Mannheim surrender, 336 ; captures Wimpfen, 337 ; finally defeats Tilly and enters Bavaria, 339; prevents the sacking of Munich, 339; unsuccessfully at 
tacks Wallenstein, 340 ; his second inroad into Bavaria, 341 ; killed at the Battle of Lützen, 342

Guzman, Lewis de Haro de, 398

HAARLEM captured by Alva, 207

Hague, Treaty of the, 394

Hainault, county of, 25

Halberstadt, bishopric of, 177

Hamelen occupied by Tilly, 311

Hammes, Duke of Guise seizes, 155

Hanseatic League, the, 316

Harlai, Achille de, 234

Hatzfeld defeats Charles Lewis at Lemgo, 367 ; resigns his commission, 372

Heidelberg, 302, 303, 337, 347

Heilbronn, confederation of, 350

Heiligerlee, Battle of, 202

Henry II. of France declares war against Charles V., 113

Henry III. of France, becomes King of Poland, 229; crowned at Rheims, 230 ; marries Louise of Vaudemont, 230 ; alarmed by Guise's popularity, 232 ; retires to Chartres, 233; issues an edict of reunion at Rouen, 233 ; procures the assassination of Guise, 234; joins Henry of Navarre, 234 ; assassinated by Jacques Clément, 235

Henry IV. of France. See Henry of Navarre

Henry VIII. of England meets Charles V., 43 ; receives Charles in London, 53; visits Francis I. at Ardres, 53 ; meets Charles at Gravelines, 53; renounces his alliance with Charles, 58 ; death of, 95

Henry, King of Poland, 229

Henry, Cardinal King of Portugal, 215,221

Henry of Anjou besieges La Rochelle, 191 ; elected King of Poland, 191

Henry of Guise. See Guise

Henry of Nassau, 81, 161

Henry of Navarre, marriage arranged with Margaret of France, 189 ; captures Cahors, 231; beats the Duke of Joyeuse at Coutras, 233 ; joins Henry III. at Tours, 234 ; victory over the Duke of Mayenne at Arques, 235; wins the Battle of Ivry, 235; besieges Paris, 235; Pope Gregory XIV. declares against him, 236; captures Epernay, 237; takes Dreux, 237; recantation at St. Denis, 238; crowned as Henry IV., 238; receives Papal absolution, 239; negotiates with Philip II.,
240 ; issues the Edict of Nantes, 240 ; his character, 241; divorces Margaret of Valois, 246; marries Marie de Médicis, 246; makes an alliance with Holland, 249; his court scandals, 249; assassinated by Francis Ravaillac, 250

Henry of Saxe-Lauenburg, 177, 257

Henry of Wolfenbüttel, 103

Hermann of Cologne deposed by the Pope, 104

Hermann of Minden, 177

Hermann of Wied, Archbishop of Cologne, 42

Hertford, Earl of, 91

Hildesheim besieged by George of Lüneburg, 347

History, modern and medieval, contrasted, 1, 2

Höchst-on-the-Main, Battle of, 303

Hochstadt surrenders to Bernard of Weimar, 347 ; taken by Turenne, 378

Hochstraten opposes Luther, 68

Hohenlohe, Count, 296, 300

Holland, county of, 25

Holland joins the League of Utrecht, 214 ; and Zeeland renounce allegiance to Philip II., 210

Holy League, formation of the, 58

Holy Union, the, 231

Hoogstraten, 202

Hôpital, Chancellor, 184

Horn, Count, 187, 199, 200, 201, 202

Horn, Duke of, 336, 355

Horuc Barbarossa, 19

Huguenots, the $185,187,188,189,191$, $192,200,210,389$

Hulst, Francis Van der, 36

Hulst captured by Archduke Albert, 220

Ingolstadt occupied by Charles V., 105 ; by Bernard of Weimar, 348

Innocent IX., Pope, 159

Inquisition, Spanish, 24, 34, 195

Interim, the, 108

Inter-State jealousy, Spanish, 14

Irish rebellion discouraged by Philip II., 194 ; encouraged by Philip III., 267

Isabella of Castille, death of, 16

Isabella of France married to Philip of Spain, 388

Isabella of Portugal, 23, 76

Isabelle, Infanta of Spain, 236

Italy, territorial state of, in the sixteenth century, 73

Irry, Battle of, 235 
JÄGERNDORF taken by Wallenstein, 314

James I. of England, 158, 223, 318

James (or Jacob), Margrave of Baden, 258

Jarnac, Battle of, 159, 188

Joachim of Brandenburg, 42, 102, 261

Joachim II., Elector of Brandenburg, 163

Joachim Ernest of Brandenburg, Margrave of Anspach, 295

Joachim Frederick, Elector of Brandenburg, 163, 176

Joam, Duke of Braganza, 221

Johanna seized and proclaimed queen by Castilian Junta, 22; re-taken by nobles, 23

John III. of Sweden, 159

John of Aragon, 74

John of Austria, Governor of the Netherlands, 161,211 ; his victory at Lepanto, 196; aims at securing the throne of England, 212; seizes Namur, 212; deposed by the States, 213 ; his death, 213

John of Chalon, 161

John of Nassau, 214, 384

John Casimir, Count Palatine, 230, 257

John Ernest of Weimar, 313

John the Constant of Saxony, 70, 71, 72,99

John Frederick the Magnanimous of Saxony, 99

John Frederick of Gotha, 174

John George of Brandenburg, 163, 258, 296,300

John George of Hohenzollern, 304

John George of Saxony, 163, 291, 358

John Jacob of Anhalt, 311

John Sigismund of Brandenburg, 163, 291

Joseph, Father (Richelieu's confidant), 325,367

Juliers and Cleves, duchy of, seized by Rudolf II., 262

Julius of Brunswick, 177, 256

Julius II., Pope, 67, 74

Julius III., Pope, 109, 119, 149, 151

Julius, Bishop, of Würtzburg, 257

Junta meet at Avila, 22

KarLing Empire, extent of the, 37

Kempten captured by Horn, 355

Khevenhüller, Austrian Ambassador, 294

Kinsale occupied by Aguila, 267

Klesel, Bishop of Vienna, 264

Klessel, Cardinal, 288

Klostergraben, Protestant church demolished at, 287
Knights of St. John, 122, 128

Knights of St. Michael, 183

Kniphausen captures Osnabrück, 347

Königsmark overruns Lower Saxony, 374 ; with Wrangel wins the Battle of Tusmarshausen, 380 ; besieges Prague, 381

La Capelle captured by Thomas of Savoy, 363

Landrecy occupied by Francis I., 90

Landsberg taken by Lesley, 355

Landshut, Papal forces join Charles $\nabla$. at, 104

Languedoc and Guienne, Catholic confederation, 187

Lannoy, Charles de, 57, 74

Lanuza, John de, Regent of Aragon, 21,224

Latimer, Bishop of Worcester, 100

Lauenburg captured by Tilly and Wallenstein, 314

Lautrec, 54,60

League, formation of the, 231

League of Cambrai, 28, 51

League of the Sixteen, 232

League of Venice, $82 n$.

Leclerc, Bussy, 234, 236

Leicester, Earl of, 218

Leipsic taken by Wallenstein, 341; besieged by Baner, 363

Lemgo, Hatzfeld defeats Charles Lewis at, 367

Leo X.'s intervention in European politics, 8; supports Francis I.'s candidature for the German kingdom, 41 ; changes of views, 53 ; death of, 54

Leo XI., Pope, 159

Leoninus, Dr., 209

Leopold, Archduke, Bishop of Passau, 262

Leopold, Archduke, son of Ferdinand II., 315, 376, 378, 379

Lepanto, Battle of, 174, 196, 204

Lerma, Duke of, 265, 270

Lesdiguières captures Grenoble, 236 ; Governor of Dauphiné, 237; beats the Duke of Savoy, 240

Lesley recovers Minden, 364

L'Esparre sent into Navarre by Francis I., 53

Lewis, king of Hungary, 29, 123

Lewis V., Count Palatine, 42

Lewis VI.. Elector Palatine, 163

Lewis of Darmstadt, 304

Lewis of Nassau, 200, 201, 202, 207, 208

Leyden, siege of, 208

Leyva, Antonio de, 78, 81 
Liège, province of, 25

Lisbon taken by Philip II., 221

Lisle, Lord, 91

London, Charles visits Henry VIII. at, 53

Longjumeau, Peace of, 187

Longueville, Duke of, 252, 369, 384

Lorraine, Cardinal of, 187, 188

Lorraine, Duke of, 347

Los Velez, Marquis of, 397

Lotharingia, 26

Loudun, Peace of, 252

Louis XIII. of France, 251, 362, 387 ; betrothed to Anne of Austria, 388; marries Anne of Austria, 252; declares himself of age, 252; CinqMars' conspiracy against, 390 ; death of, 391

Louis XIV. of France, 162, 392

Louis of Condé, 159, 182,184, 187, 188

Louis, Count Palatine, 99

Louise of Savoy, 54, 60

Louise of Vaudemont, wife of Henry III. of France, 230

Lowestein, Castle of, 203

Lübeck, Peace of, 317

Ludovico, Pietro, 107

Luther, Martin, enters Erfurt University, 67 ; professor of philosophy at Wittenberg, 67; visits Rome, 67 ; appears before the Diet of Worms, 69 ; Pope Adrian's. VI.'s action against, 69 ; undertakes the composition of Catechisms, 71; draws up the reformers' declaration, 72 ; his death, 95, 102

Lütter, Tilly defeats King Christian at, 312

Lux, Baron de, 247

Luxemburg, Duke of, 252

Luxemburg, meeting at, between Don John and the States conference, 211

Luynes, de, Minister to Lewis XIII., 252,388

MADRID, treaty of, 58

Maestricht captured by Alexander of Parma, 214

Magdeburg sacked by Tilly, 334

Magdedurg, archbishopric of, 176

'Magna Carta' extorted from Mary of Burgundy, 28

Mahomet, Sultan, 256

Mannheim relieved by Mansfeld, 302 ; capitulation of, 303 ; taken by Gustavus Adolphus, 336

Mansfeld, Peter Ernest, Count of, 161, 264, 289, 296, 301, 313

Mantua, War of, 396

Marcellus II., Pope, 119

Marck, William de la, 206
Margaret of Anjou, Queen, 159

Margaret of France, 189

Margaret of Navarre, 229

Margaret of Parma, 161, 165

Margaret of Savoy, 28, 60

Margaret of Valois, 212

Maria of Portugal, 17, 160

Marie de Médicis, 158, 246, 251, 387 391

Marseilles, siege of, 56,81

Martinitz, Bohemian Minister, 287

Martinuzzi, George, 124, 126

Martyr, Peter, 84

Mary of Austria, 29

Mary of Burgundy, 27, 28

Mary of England, 119, 151, 155, 160

Mary of Hungary, 31, 82, 160

Mary Stuart, 157, 183, 212, 218, 219

Masaniello's revolt, 398

Massacre of St. Bartholomew, 184, 229

Matthias, Emperor, 158, 162, 213, 215 ; crowned King of Hungary, 261 ; elected King of Bohemia, 262

Maurice of Nassau, 161, 162, 218, 219, $220,268,269,303,319,394,396$

Maurice of Saxony, 9, 105, 110, 111, 163

Maximilian I., Emperor, 40, 68

Maximilian II., Emperor, 157, 158, 162 ; elected King of the Romans, 171; King of Bohemia, 171; crowned King of Hungary, 171; becomes Emperor, 172; his character, 172 ; at a Diet at Augsburg, 174 ; concludes peace with the Turks and with Transylvania, 174; his religious policy, 178; aims at his son's election as King of the Romans, 179; his death, 180

Maximilian, Archduke, 256

Maximilian of Bavaria, 163, 256, 262, 264, 291, 377

Maximilian of Burgundy, 26, 30

Maximilian of Lamberg, 384

Maximilian of Trautmannsdorf, 384

Mayenne, Charles Duke of, 159, 234, $235,236,237,239,240$

Mazarin, Cardinal, 392

Mechlin sacked by Alva, 207 ; taken and re-taken, 214; Council of, 26, 27, 197

Medici, the, 74

Medici, Alexander de', 77

Medici, Alexander de', Pope, 159

Medici, John de', Pope, 158

Medici, Marie de'. See Marie

Médicis, Catherine de, 182, 183, 184 ; becomes Regent of France, 185; her court, 186 ; at Bayonne, 186, 200 ; intrigues, 187, 188; and the Massacre of St. Bartholomew, 190 
Medina-Celi, Duke of, 204, 207

Medina del Campo, burning of, 22

Meissen captured by Baner, 363

Melanchthon, Philip, 69, 71, 72, 98, $101,111,112,170$

Melander appointed to command Ferdinand III.'s army, 378; occupies Marpurg, 379 ; defeated and killed at Zusmarshausen, 380

Melito, Conde de, regent of Valencia, 21

Mello, Francisco de, 394

Memmingen taken by Horn, 355

Mendoza, Inigo Lopez de, Marquis of Mondejar, 160

Mendoza, admiral and general, 268

Mentz surrenders to Gustavus Adolphus, 336; put to ransom by Turenne, 378

Mercœur, Duke of, 239

Mercy, Bavarian general, 371, 372

Merveille (Maraviglia) assassinated, 79

Metternich, Lothar von, Elector of Treves, 291

Metz resists Charles V., 116

Milan, Francis I. and Pescara at, 56

Miltitz, Charles von, 69

Minard, President, 183

Minden occupied by Tilly, 311 ; recovered by Lesley, 364

Mingolsheim, Battle of, 303

Miranda, Don Juan de Zuniga, Count of, 160

Modena, Duke of, 366

Modern and medieval history contrasted, 1, 2

Moncada, Hugh de, 59, 74

Moncontour, Battle of, 188

Mons captured by Lewis of Nassau, 207

Montauban, 189

Montferrat claimed by the Duke of Savoy, 324

Montgomery, Count of, 192

Montigny, 198; assassinated in prison, 203

Montmorency, Duke of, constable of France, 32, 113, 151, 154, 156, 182, $183,185,187,230$

Montpensier, Duchess of, 233, 236

Moriscoes, revolt of the, 24, 195

Morone, Cardinal, 119, 177

Morone, Chancellor of Milan, 58

Moulins, Charles IX.'s ordinance at, 187

Muley Hassan, King of Tunis, 124

Mülhausen, Battle of, 70

Münster, Anabaptists in, 101 ; Treaty of, 399
Narror seized by Don John, 212

Nancy, heads of the League meet at, 233

Nantes, Edict of, 240

Naples, revolt of, 398

Navarre, fortress dismantled by Ximenes, 19

Navarre, Antony of, 172, 184, 185, 229

Navarre, Henry of. See Henry IV.

Navarre, Margaret of, 186, 187, 188, 190,229

Nemours, Duke of, 236

Nérac, seat of Henry of Navarre, 231

Netherlands, the, 25, 27, 33, 34, 196

Neuburg captured by Bernard of Weimar, 348

Neuburg, Count Palatine of, 261, 304

Neuhäusel, Bucquoy defeated at, 301

Nevers, Duke of, 317, 324

New or Nearer Union of Brussels, 213

New Triumvirate, the, 185

Nice, Truce of, $8,32,84$

Nienburg taken by the Count of Anbalt, 314

Nieuport invested by Maurice of Nassau, 269

Niklasburg, Peace of, 302

Nojars, projected arrest of Condé at, 188

Nordheim taken by Fürstenburg, 314

Nördlingen, 105, 341, 356, 373, 394

Noyon, Peace of, 19,51

Nuremberg, Peace of, 99 ; Protestant Union meets at, 293

Ochrno, Bernard, 83, 84

Odowalski, Ernest, 380

Olivares, Count Duke, 391, 394

Olivarez, Don Henriquez Guzman, Count of, 160

Olivier, Chancellor, 184

Opitz, Protestant preacher, 255

Oppeln, Lesley defeats Götz at, 355

Oppenheim, Gustavus Adolphus at, 336

Orange, William of, 156, 198, 199, 200 , 201, 202, 206, 207, 362

Orleans surprised by the Huguenots, 187

Orleans, Duke of, 391

Osiander's theological disputations, 170

Osnabrück, bishopric of, 177 ; captnred by Kniphausen, 347 ; Treaty of, 399

Ostend taken by Spinola, 269

Otto Lewis, Count of Salm, 346

Oudenarde taken by Parma, 216

Oudewater sacked by Requesens, 209

Overyssel joins the League of Utrecht, 214

Oxenstiern, Axel, 326, 344, 347, 349, $358,359,363,390$ 
Pacheco hanged by the people of Flushing, 206

Pacheco, Doña Maria de, 22, 23

Padillo, Don John de, 22, 23

'Paix boiteuse, la,' 189

'Paix fourrée, la,' 188

'Paix Malassise, la,' 189

Paleario, Aonio, 84

Papal indulgences, Luther's action regarding, 68 ; influence on European politics, 8,9

Pappenheim, Count, 330

Paris visited by Charles, 32 ; besieged by Henry of Navarre, 236 ; Treaty of, 305,394

Parma, Alexander Farnese, Duke of, viceroy of the Netherlands, 165; captures Tournay, 215; takes Oudenarde, 216 ; compels submission of Ghent, 217; besieges Antwerp, 217; takes Sluys, 218; relieves Paris, 236 ; raises the siege of Rouen, 237 ; his death, 219

Parma, Duke of, 362,366

Parma, Duchess of, governante of the Netherlands, 186, 198, 201, 202, 204

Passau, Peace of, 110, 126, 147

Paul III., Pope, 74, 79, 100, 109

Paul IV., Pope, 119, 151, 152, 154

Paul V., Pope, 159

Pavia, Battle of, 29, 55, 57

Peasants' War, 70

Pembroke, Earl of, 153

Peretti, Felix, Pope, 159

Perez, Antonio, 223

Perpetual Edict, the, 212

Perpignan, siege of, 391

Perrenot, Antony, 156, 160 . See also Granvelle

Pescara refuses the kingdom of Naples, 58

'Petite Paix, la,' 188

Pfaffenhof, Christian of Birkenfeld defeats the Duke of Lorraine at, 347

Pflug, Julius, 108

Philibert of Chalon, 161

Philibert of Orange, 74, 77

Philibert, Emmanuel, of Savoy, 153, 160

Philip II. of Spain institutes a Council of government for Italy, 74; marries Mary of England, 151; his four marriages, 160 ; his character, 193; supports Elizabeth of England, 194; Moriscoes revolt against him, 195; his son's death, 195; joins Venice and the Pope against the Turks, 196; his intrigues, 199; his Segovia despatch, 200; his complicity in Montigny's assassination, 203 ; claims Portugal, 215 ; offers reward for the head of William of Orange,
215 ; secures the Portuguese crown, 221 ; his death, 225

Philip III. of Spain, 158, 163, 265, 267,271

Philip IV. of Spain, 252, 388, 394

Philip I. of Portugal. See Philip II. of Spain

Philip of Burgundy, bishop of Utrecht, 29

Philip the Handsome, 26

Philip of Hesse, 47, 72, 99

Philip of Hohenlohe besieges Groningen, 214

Philip of Lüneburg, 72

Philip the Magnanimous, 70, 71

Philip the Rhinegrave, 347

Philip William of Orange, 161

Philippsburg, surrenders to the Rhinegrave, 355

Piacenza ceded by Philip, 155

Picardy invaded by Henry of Nassau, 81

Piccolomini, Octavio, 352, 353, 370, 372,380

Pilsen, siege of, 264, 301

Pisek sacked, 297

Pius IV., Pope, 158, 177

Pius V., Pope, 159, 177, 223

Pizarro, Francisco, 132

Plessis-les-Tours, treaty at, 215

Poictiers besieged by Coligny, 188

Poissy, religious disputation at, 185

Poland, Duke of Anjou chosen King of, 175

Poland, Henry of. See Henry III. of France

Pole, Cardinal, 119, 151

'Politiques,' the, 191, 230

Portugal claimed by Philip II., 215

Prague, Matthias elected King at, 262 ; Battle of, 297; Peace of, 358

Prejudice in the study of modern history, 3

Presburg taken by Bethlen Gabor, 292

Prierias opposes Luther, 68

Protestant distrust of Francis, 10

Protestant Union, the, 293

Protestants, massacre of, at Vassy, 185

Provence invaded by Bourbon and Pescara, 55

Puritanism and political freedom, traditional connection between, 62

Pyrenees, Peace of the, 393

Ragotzkr, George, Prince of Transylvania, 373

Raimond de Cardona, 74

Rainucci, Duke of Parma, 221

Rammekens taken by Elizabeth of England as surety, 218 
Rantzau defeated by Mercy, 372

Ranuzzo of Parma, 165

Ratibor taken by Wallenstein, 314

Ratisbon, Diet of, 260, 304, 324; taken by Bernard of Weimar, 348

Ravaillac, Francis, assassinates Henry IV. of France, 250

Ravenna seized by the Venetians, 60

Recess of Augsburg, 120

Reformation, the, aided by inadequate episcopal superintendence, 33 ; causes of the, 62 et seq.

Renaudie, 183

Rendsburg taken by Tilly, 314

René of Nassau, 161

Renneberg, Count, 214

Requesens y Cuniga, Don Luiz de, $161,207,208,209,210$

Reservation, Ecclesiastical, 149, 358

Restitution, the Edict of, 315, 321,358

Rheims, archbishopric of, 34

Rheinfeld captured by Bernard of Weimar, 367

Rhinegrave, the, 346, 355

Richelieu, Cardinal, 320, 328, 337, 359, $363,368,389,391,396$

Ridolfi plot, the, 203, 223

Rinçon, Antonio, 88

Riviera, Don Parafan de, Duke of Alcala, 160

Robert de la Marck, 53; proclaims war against Charles, 54

Roche Abeille, battle at, 188

Rochelle, La, 188, 189, 191

Rocroi, Battle of, 372, 393

Rohan, Duke of, 252, 361

Rome captured by Bourbon, 60; Luther visits, 67

Rosny. See Sully

Rossem, van, Marshal of Guelders, 89

Röteln taken by Bernard of Weimar, 367

Rothenburg taken by Gustavus Adolphus, 341

Rothweil besieged by Guébriant, 372

Rotterdam sacked by Bossu, 206

Rouen, Henry III. issues edict at, 233 ; secured by Henry of Navarre, 236

Roussillon, Edict of, 186

Rovere, Francesco Maria della, 74

Rudolf II., Emperor, 158, 162; secluded life of, 354 ; his truce with Amurath, 256 ; his inactivity, 258; Tycho Brahé's prediction, 261; relinquishes Hungary, Austria, and Moravia, 261; annuls the Treaty of Dortmund, 262 ; his death, 262

Rudolf Maximilian of Lauenburg, 335

Rüsselsheim garrisoned by Gustavus Adolphus, 336

Ruyter, De, blows up the Castle of Lowestein, 203
ST. AldDEgonde, lord of, 200, 209

St. André, Marshal, 185

St. Bartholomew, Massacre of, 184, 190, 191, 229

St. Cloud, Henry III. assassinated at, 235

St. Denis, Battle of, 187

St. Germain, Peace of, 189

St. Jean d'Angelly besieged by the Duke of Anjou, 188

St. John, Knights of, 122, 128

St. Léger-le-Catelet taken by Thomas of Savoy, 363

St. Ménehould, treaty of peace at, 252

St. Michael, Knights of, 183

St. Pol, Count of, 60,61

St. Quentin, Battle of, 153

Salamanca, Treaty of, (1505), 16

Salentin of Ysemburg, Archbishop of Cologne, 257

San Coloma, Count of, 397

Saragossa, Charles meets the Cortes of Aragon at, 20

Sarrasin, John, prior of St. Vaast, 214

Sauvage, Charles's Chancellor, 20

Savoy, Duke of, 240, 247, 324, 362

Saxony, Maurice, Elector of, 161

Schaumburg, Count, 328

Schönborn, Bishop of Würzburg, 384

Schoonhoven taken by Requesens, 209

Schouwen taken by Requesens, 209

Schweinfurt, negotíations at, 99 ; taken by Gustavus Adolphus, 336; captured by Wrangel, 378

Sebastian, Dorn, of Portugal, 221

Segovia revolts against Charles, 22 ; murder of Tordesillas the deputy, 22 ; Philip II.'s despatch from, 200

Serin, Count, 256

Servien, Abel, 384

Seven United Provinces, republic of the, 33, 220

Sforza, Francesco Maria, 77

Sidney, Sir Philip, 218

Sidney, Sir Robert, 250

Sidonius, Michael, 108

Siena ceded by Philip, 155

Sievershausen, Maurice of Saxony killed at, 163

Sigismund of Brandenburg, Archbishop of Magdeburg, 176

Sigismund III. of Poland, 296

Sigismund of Sweden, 159

Sigismund Bathory, Prince of Transylvania, 256

Simancas, archives of, 193

Sismondi, John, historian, 77

Sittard, Battle of, 89

Sixtus V., Pope, 159

Slavata, Bohemian Minister, 287

Sluys taken by Alexander of Parma, 218 
Smalkaldic League, the, 72, 78, 99, 100,169

Solyman, Sultan, 78, 122, 174

Spain, condition of, at Charles's accession, 13; decline of, in the early seventeenth century, 265

Spanish fleet burned by the Archbishop of Bordeaux, 367

Speyer, Diet of, 70, 71

Spinola, Ambrosio, 269, 296

Spinola, Frederic, 267

Stade taken by Tilly, 317

Stadtlohn, Tilly beats Cbristian at, 305

Stettin occupied by Gustavus Adolphus, 328

Stralsund besieged by Wallenstein, 316

Straubing captured by Bernard of Weimar, 348

Strozzi, Leo, 129

Study of modern history approached with prejudice, 3 ; necessity of critical judgment, 4

Suicard, John, Elector of Mentz, 291

Sully, Duke of, 238, 246, 251, 388

Sybilla, Electress of Cleves, 106

Szigeth besieged by Solyman, 174

Tangeruïnde, Tilly crosses the Elbe at, 314

Tavannes, Marshal, 188

Tein, Bucquoy defeats Mansfeld at, 290

Teligny, Mrs., marries William the Silent, 216

Termes, Marshal de, 155

Tetzel, John, 68

Thionville taken by the Duke of Guise, 155

Thirty Years' War, the, 163

Tholen, isle of, 209

Thomas à Kempis, 36

Thomas of Savoy, 363

Throgmorton's plot, 223

Thumbshirn, Wolfgang Conrad von, 384

Thurn, Matthew Henry, Count, 264, 288, 290

Tilly, Count, 296, 301 ; occupies Hamelen and Minden, 311; takes Göttingen, 312; defeats King Christian at Lütter, 312 ; captures Stade, 317; opposes Gustavus Adolphus of Sweden, 332 ; sacks Magdeburg, 334; defeated by Gustarus Adolphus, 334 ; besieges Leipsic and is overwhelmed by Gustavus, 335 ; goes to Rothemburg, 336 ; defeated and killed on the Lech, 339 ; his character, 339
Toledan deputies expelled from Cortes by Charles, 21 ; magistrates arrested, 21

Toledo revolts against Charles, 22

Toledo, Ferdinand Alvarez de, Duke of Alva, 161

Toledo, Pedro de, 74, 84, 126

Toledo, William de Croy, Archbishop of, 20

Toleration, Declaration of, 177

Tordesillas, deputy for Segovia, murdered, 22

Torstenson takes Leipsic, 371 ; defeats Lamboy and Mercy at Kempen, 371 ; conquers Denmark, 371 ; resigns his command to Wrangel, 374

Tournay, bishopric of, 33 ; captured by the Duke of Parma, 215

Tours, Henry III. of France and Henry of Navarre at, 234

Trent, Council of, 9, 102

Treslong, Admiral, 206

Triumvirate, the New, 185

Troppau taken by Wallenstein, 314

Troubles, Council of, 202

Truchsess, Gebhard, Elector of Bavaria, 164, 257

Tserclaes, John, Count Tilly, 296

Tübingen captured by Turenne, 378

Tuileries building commenced, 186

Turenne, Viscount of, 372 ; defeats Mercy at Nördlingen, 373; his successes in Würtemberg and Darmstadt, 378; recalled to the Netherlands, 379

Turks, European treaty against the, 53

Tycho Brahé, 254, 261

ULRIC, Duke of Würtemberg, 380

Union of Brussels, the, 211

United Provinces, 394; Declaration of Independence, 215

Urban VII., Pope, 159, 381, 384

Urbino, principality of, 165 ; added to the Papal States, 74

Utrecht, bishopric of, 25, 33 ; League of, 214; Union of, renewed, 218; Bishop of, a prince of the Empire, 34

Uzeda, Duke of, 270, 395 .

Valdes, Archbishop of Seville, 195

Valencia, Cortes of, 15; Cardinal Adrian in, 20; Conde de Melito regent of, 21 ; revolt in, 23

Valenciennes, siege of, 201

Valesco, Constable of Castile, 239

Valladolid, Charles V. crowned at, 19 ; Cortes of, 228 
Vassy, massacre of Protestants at, 185

Vaucelles, truce of, 152

Vehmgericht, Westphalian, 71

Vendôme, Duke of, 159, 252

Venice, League of, $82 n$.

Verdun, Peace of, 37

Vervins, Peace of, 220, 224, 240

Viglius, 191, 203

Villalar, Padilla taken prisoner at, 23 Vitri, 252

Volmar, Isaac, 384

WALLENSTER, his birth and education, 309; created Duke of Friedland, 310; subjugates Silesia, 314 ; becomes Duke of Mecklenburg and Admiral of the Baltic, 316 ; attacked by the Diet of Ratisbon, 324 ; resigns his command, 325 ; raises a new army, 338 ; resists Gustavus's attack at Zorndorf, 340 ; ravages Culmbach and besieges Leipsic, 341 ; defeated by Gustavus at Lützen, 342; negotiates with Arnheim, 348; invades Silesia, 349 ; a cause of jealousy, 350 ; his arrest ordered by Ferdinand, 352 ; assassinated by Devereux, 353

Wangen, Ferdinand's troops defeated by Horn at, 355

War of the Three Henries, 232

Warweil, Austrians defeated by the Rhinegrave at, 355

Weisserberg, Battle of the, 297

Welser, Philippina, 261

Werten, treaty of, between Gustavus Adolphus and William of Hesse, 334

Westphalia, Peace of, 381, 393, 398

Wied, Hermann von, Archbishop of Cologne, 102

William II. of Bavaria, 163

William of Chièvres, 28,53

William of Cleves, 30, 88, 162

William the Faithful, Landgrave of Hesse Cassel, 366

William of Nassau, 270

William the Silent, Prince of Orange, 161 ; negotiates with Requesens, 209; appointed Governor by the States, 209 ; marries Charlotte of Bourbon, 209; his peace proposals rejected, 213 ; negotiations with the Duke of Anjou, 215; his head valued by Philip II., 215; attempted assassination, 215; death of his wife, 215; marries Mrs. Teligny, 216 ; his assassination, 216
Wimpfen, Battle of, 303, 337

Winter King of Bohemia, the, 163

Wismar, Treaty of, 363

Wittenberg, Luther becomes professor of philosophy at, 67 ; surrendered by the Electress of Cleves, 106

Witteweir, Duke Bernard defeats the Bavarians at, 367

Wolfenbüttel captured by Pappenheim, 314

Wolfgang of Anhalt, 72

Wolfgang of Zweibrücken, 188

Wolmerstadt, Gustavus Adolphus defeats Tilly at, 334

Wolsey's, Cardinal, aims, 52

Worms, Luther before the Diet of, 69

Wrangel defeated by Gallas, 366; enters Bavaria, 376 ; disagrees with Turenne, 377; captures Schweinfurt and Egra, 378; retires into North Germany, 379; captures Windsheim, 380

Würtemberg, Duke of, 261, 302

Würzburg, Catholic League meets at, 293 ; surrendered to Gustavus Adolphus, 336

$X_{\text {Anten, }}$ Peace of, 264

Ximenes, Cardinal, appointed Regent of Castile, 18; death of, 19

YUTTERBdCK, Königsmark's victory at, 373

ZAPOLSKI, John, 123, 174

Zara, Mansfeld dies at, 313

Zeeland renounces allegiance to Philip II., 210; joins the League of Utrecht, 214

Zerbst taken by Mansfeld, 313

Zierikzee besieged by Requesens, 209, 210

Zorndorf, Gustavus Adolphus attacks Wallenstein at, 340

Zriny, Count Nicolas, 174

Zuniga, Juan de, 160

Zusmarshausen, Melander defeated and killed at, 380

Zutphen surrendered to Frederick, 30 ; sacked by Alva, 207

Zweibrücken, Wolfgang Duke of, 188, 261

Zwingli and the Holy Eucharist, 170 


\section{PLEASE DO NOT REMOVE}

CARDS OR SLIPS FROM THIS POCKET

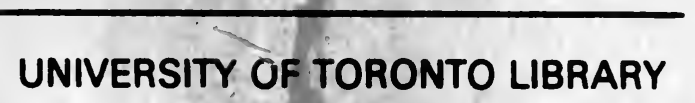

UNIVERSITY OF TORONTO LIBRARY

D

228

S93
Stubos, Nilliam

Lectures on Furopean history 

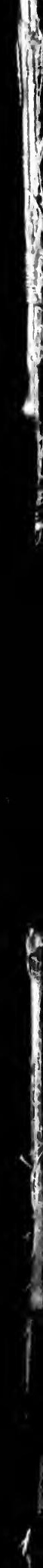